Bibliothèque d'Archéologie Méditerranéenne et Africaine - 17

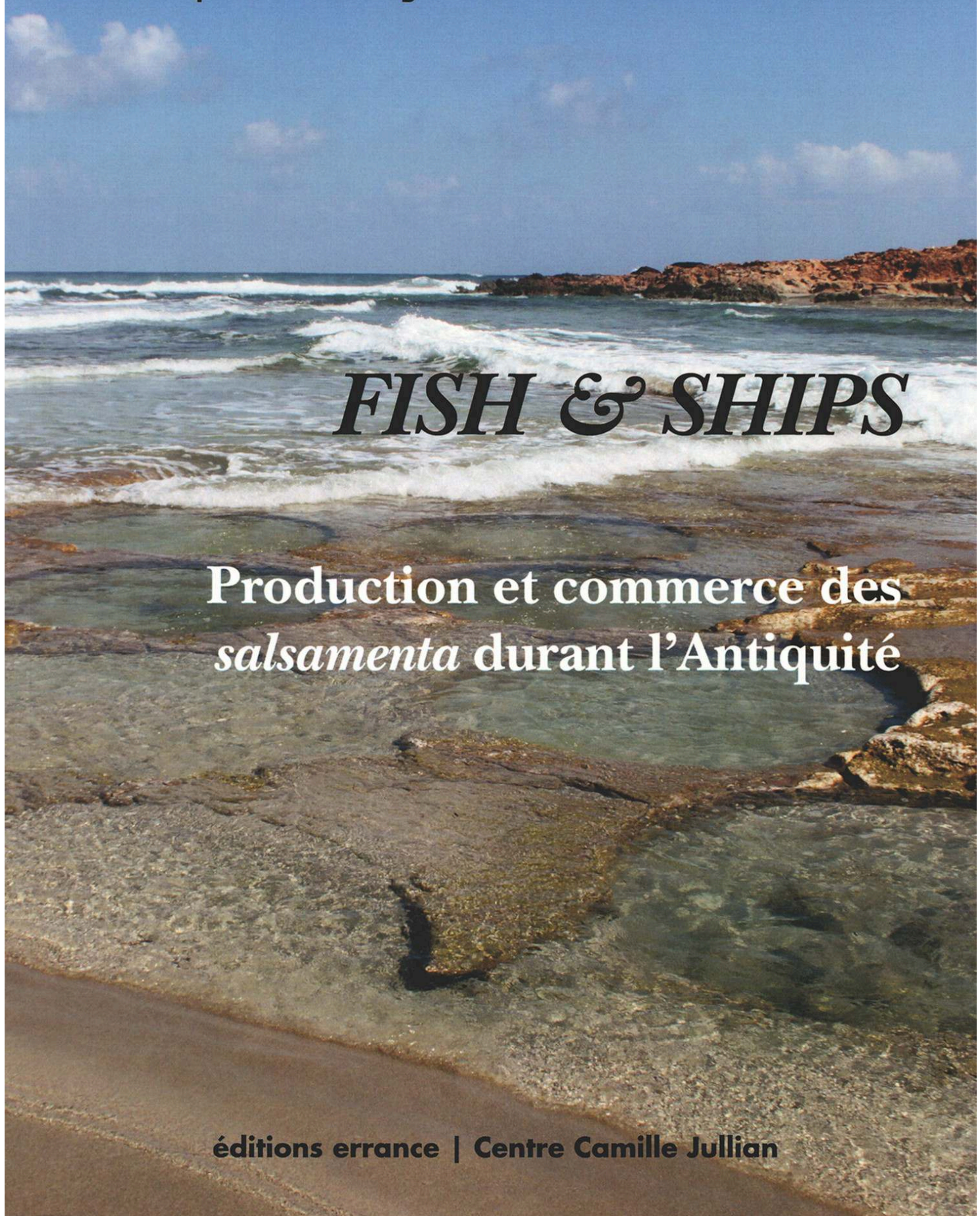




\section{Fish \& Ships}

Production et commerce des salsamenta durant l'Antiquité

Production and commerce of salsamenta during Antiquity

\section{Emmanuel Botte et Victoria Leitch (dir.)}

DOI : 10.4000/books.pccj. 1507

Éditeur: Publications du Centre Camille Jullian

Lieu d'édition : Aix-en-Provence

Année d'édition : 2014

Date de mise en ligne : 6 avril 2020

Collection : Bibliothèque d'archéologie méditerranéenne et africaine

ISBN électronique : 9782491788063

\section{Sbooks}

http://books.openedition.org

Édition imprimée

Date de publication : 1 janvier 2014

ISBN : 9782877725798

Nombre de pages : 239

\section{Référence électronique}

BOTTE, Emmanuel (dir.) ; LEITCH, Victoria (dir.). Fish \& Ships : Production et commerce des salsamenta durant l'Antiquité. Nouvelle édition [en ligne]. Aix-en-Provence: Publications du Centre Camille Jullian, 2014 (généré le 08 avril 2020). Disponible sur Internet : <http://books.openedition.org/pccj/1507> ISBN : 9782491788063. DOI : https://doi.org/10.4000/books.pccj.1507. 


\section{$\mathrm{B}$ ibliothèque d'Archéologie \\ Méditerranéenne et Africaine \\ 17}


Dans la lignée des anciens Travaux du Centre Camille Jullian, la Bibliothèque d'Archéologie Méditerranéenne et Africaine (BiAMA) regroupe des travaux (monographies, actes de colloques, ouvrages collectifs) en relation avec les programmes scientifiques du Centre Camille Jullian, sur l'histoire et l'archéologie de la Gaule méridionale, de l'Afrique du Nord et du bassin méditerranéen. La BiAMA peut comprendre des sous-séries, comme la collection Études massaliètes (EtMassa).

\section{Responsable légal :}

Marie-Brigitte Carre, Directrice du CCJ

Directeurs de la publication :

Sophie Bouffier et Henri Tréziny

Comité de pilotage :

S. Bouffier, M.-Br. Carre, X. Delestre, H. Tréziny

Conception graphique et contrôle :

Véronique Gémonet

Mise en page :

Emmanuel Botte, Véronique Gémonet

\section{Comité de lecture :}

S. Bouffier (CCJ, Aix-Marseille Université), J.-P. Brun (Collège de France), M-Br. Carre (CCJ, CNRS), X. Delestre (CCJ, DRAC PACA), D. Garcia (CCJ, AMU, Inst. Univ. de France), M. Griesheimer (CCJ, AMU), A. Hermary (CCJ, AMU), Ph. Jockey (CCJ, AMU), M. Lombardo (Professeur à l'Université de Lecce), T. S. Loseby (Professeur à l'Université de Sheffield), J.-M. Mignon (Service archéologique départemental du Vaucluse), P. Pomey (CCJ,CNRS), L. Rivet (CCJ, CNRS), J. Sanmarti (Professeur à l'Université de Barcelone), J.-Chr. Sourisseau (CCJ, AMU), H. Tréziny (CCJ, CNRS), C. Virlouvet (École française de Rome), E. Voutiras (Professeur à l’Université de Thessalonique).

(C) 2014 pour tous pays,

Édition Errance, éditeur du groupe Actes Sud, BP 9003813633 Arles Cédex Tel. 04-88-65-92-05 / 06-99-30-70-87

Fax : 0143293488

Courriel : contact@editions-errance.fr

http://www.libairie-epona.fr

Centre Camille Jullian

Maison Méditerranéenne des Sciences de l'Homme

5 rue du Château de l'Horloge. BP 647, 13094 Aix-en-Provence Cedex 2

ISBN : 978-2-87772-579-8

ISSN BiAMA : 2101-2849

Illustrations de couverture :

Vasques sur la côte à Al-Agla (C) Mohamed A Hesein).

Illustration $4^{\text {ème }}$ de couverture :

Image théorique d'un poisson (C) T. Theodoropoulou).

Arles-Rhône 3, pot du Latium $\mathrm{n}^{\circ} 22$ contenant des restes de cordage

(C) Arc-Nucléart).

\section{Publications du Centre Camille Jullian}

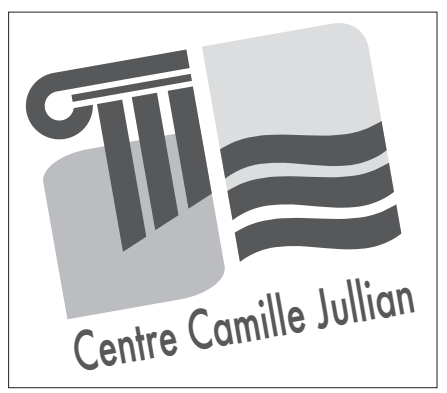

Ouvrage financé par

le Centre Camille Jullian, l'Ecole française de Rome, l'Institut Européen d'Histoire et des Cultures de l'Alimentation, et le LabexMed
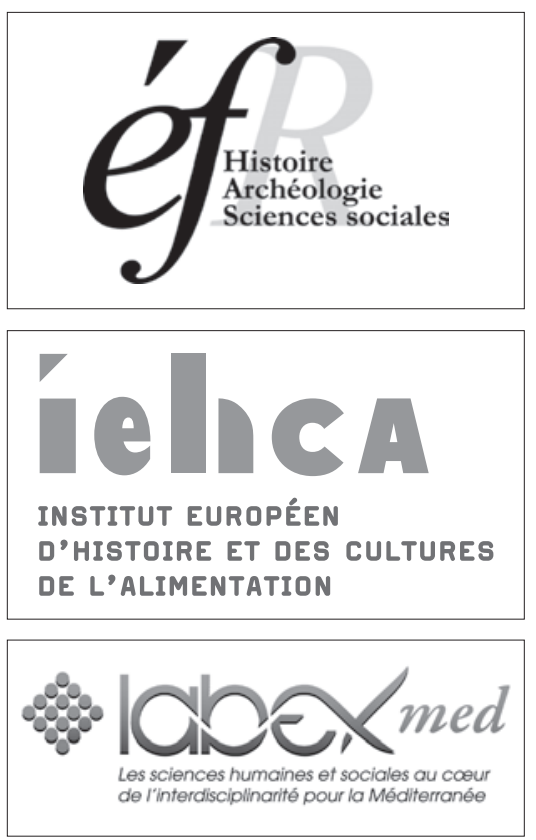

Envoyer les manuscrits à :

Bibliothèque d'Archéologie Méditerranéenne et Africaine Centre Camille Jullian

Maison Méditerranéenne des Sciences de l'Homme

5 rue du Château de l'Horloge. BP 647,

13094 Aix-en-Provence Cedex 2 


\section{FISH \& SHIPS}

\section{Production and commerce of salsamenta during Antiquity \\ Production et commerce des salsamenta durant l'Antiquité}

Actes de l'atelier doctoral, Rome 18-22 juin 2012, édités par Emmanuel Botte et Victoria Leitch

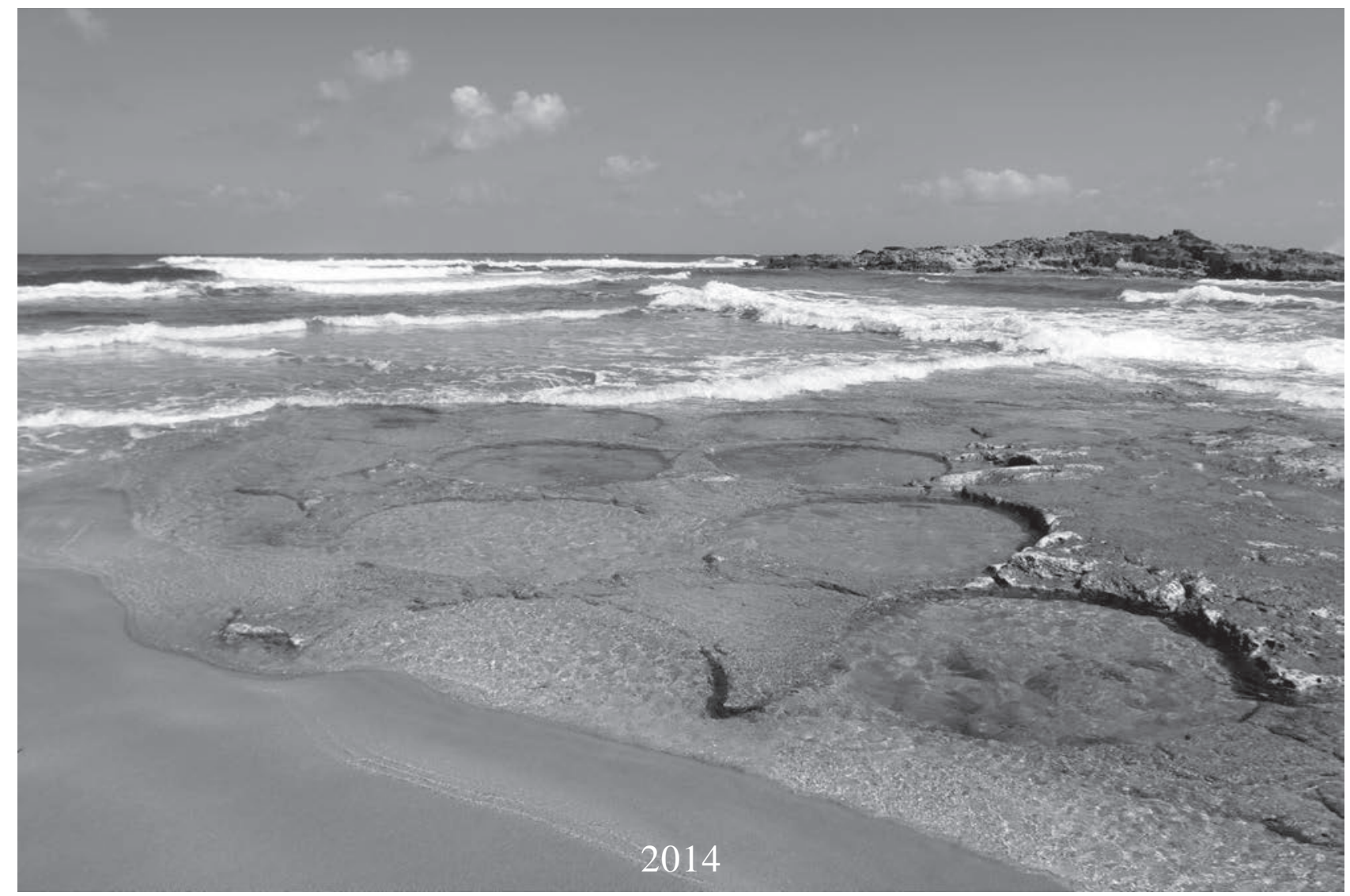




\section{Sommaire}

Liste des auteurs

Introduction

(Emmanuel BOTTE et Victoria LEITCH)

Les installations de traitement du poisson : aperçu historiographique

(André TCHERNIA)

Analyse chimique des sauces et des conserves de poissons : un état de la question

(Nicolas GARNIER)

Garum, Liquamen and Muria: A new approach to the problem of definition

(Sally GRAINGER)

Les sauces de poisson dans l'ouest de la province romaine de Lyonnaise : réflexions sur l'élaboration et la nature des produits (Cyril DRIARD)

The fish remains from the Cardo V sewer: New insights into consumption and the fishing economy of Herculaneum (Erica ROWAN)

Le commerce des coquillages marins en Gaule romaine : animaux « en coquille » et chair décoquillée

(Anne BARDOT-CAMBOT)

La production urbaine de salaisons en Algérie à l'époque romaine : l'exemple de Tipasa (Maurétanie Césarienne)

(Touatia AMRAOUI)

Exploitation et commercialisation des ressources maritimes de la Petite Syrte : témoignages archéologiques et spécificités régionales (Ali DRINE et Elyssa JERRAY)

Fish and Ships in the desert? The evidence for Trans-Saharan trade in fish products

(Victoria LEITCH)

Ancient marine resource exploitation in the coastal strip of Cyrenaica: Some evidence of fish-related industry in Cyrenaica? (Mohamed A. HESEIN) 
An overview of the fish-salting production centre at Tróia (Portugal)

(Inês VAZ PINTO, Ana Patrícia MAGALHÃES, Patrícia BRUM)

Fish processing and salted-fish trade in the Punic West: New archaeological data and historical evolution

(Antonio M. SÁEZ ROMERO)

Nouvelles données sur les pots dits « à garum » du Latium, d'après les découvertes subaquatiques du Rhône (Arles)

(David DJAOUI, Gaël PIQUÈS, Emmanuel BOTTE)

La Sardinia tra Penisola Iberica e Africa immersa in un mare di « sale » I d.C.-VII d.C.

(Cristina NERVI)

Salting the East: Evidence for salted fish and fish products from the Aegean sea in Roman times

(Tatiana THEODOROPOULOU)

Fish products and their trade in Tauric Chersonesos/Byzantine Cherson: The development of a traditional craft from Antiquity to the Middle Ages

(Martina ČECHOVÁ)

Conclusions

(Emmanuel BOTTE et Victoria LEITCH) 


\section{Liste des auteurs}

\section{Touatia Amraoui}

Docteur en archéologie

Université de Lyon 2

touamraoui@yahoo.fr

\section{Anne Bardot-Cambot}

Docteur en Histoire, Langues et Littérature anciennes

Post-doctorat : programme « Investissement d'Avenir »

ANR-11-LABX-0032-01 - Labex ARCHIMEDE

UMR 5140 - Archéologie des Sociétés Méditerranéennes

390, avenue de Pérols

F - 34970 Lattes

annebardot@wanadoo.fr

\section{Emmanuel Botte}

Docteur en Archéologie

ATER au Collège de France

Chaire des Techniques et économies de la Méditerranée antique

11, place Marcelin-Berthelot

F - 75005 Paris

emmanuel.botte@college-de-france.fr

\section{Patrícia Brum}

Troia Resort

Edifício Administrativo - Banda C

P - Tróia. 7570-789 Carvalhal GDL

psbrum@troiaresort.pt

\section{Martina Čechová}

Slovanský ústav AV, v.v.i.

Valentinská 91/1

CZ - 11000 Praha 1

cechmata@gmail.com

\section{David Djaoui}

Musée départemental Arles antique

Presqu'île du cirque romain

BP 205

F - 13635 Arles Cedex

david.djaoui@cg13.fr

\section{Cyril Driard}

Bureau d'études Eveha

44, rue Proudhon

F - 63000 Clermont-Ferrand

cyril.driard@eveha.fr

\section{Ali Drine}

Institut National du Patrimoine de Tunis

4 Place du Château

TN - 1008 Tunis

ali_drine@yahoo.fr

\section{Nicolas Garnier}

Laboratoire Nicolas Garnier

32 , rue de la Porte Robin

F - 63270 Vic-le-Comte

labo.nicolasgarnier@free.fr

\section{Sally Grainger}

Independent scholar

Timberua Glen road

Grayshott

Hindhead GU266NB, UK

sallygrain@aol.com

\section{Mohamed A. Hesein}

Department of Archaeology and ancient History

University of Leicester. UK

Department of Archaeology

University of Omar Al-Mukhtar, Al-Bayda, Libya

medhesein@hotmail.com

\section{Elyssa Jerray}

Université d'Aix-Marseille 1 - IRAA (USR 3155 - CNRS)

Maison Méditerranéenne des Sciences de l'Homme

5, rue du Château de l'Horloge BP 647

F-13094 Aix-en-Provence Cedex 2

ejerray@yahoo.fr 


\section{Victoria Leitch}

School of Archaeology and Ancient History

University of Leicester

University Road

Leicester LE1 7RH, UK

vl46@le.ac.uk

\section{Ana Patrícia Magalhães}

Troia Resort

Edifício Administrativo - Banda C

P - Tróia. 7570-789 Carvalhal GDL

apmagalhaes@troiaresort.pt

\section{Cristina Nervi}

MIUR, Ministero dell'Istruzione, dell'Università e della

Ricerca

Via Boidi 2

I - 15073 Castellazzo Bormida (AL)

cristinanervi@libero.it

\section{Gaël Piquès}

ASM - Archéologie des Sociétés Méditerranéennes

UMR5140, Univ. Montpellier 3, CNRS, MCC

F - 34000 Montpellier

gael.piques@cnrs.fr

\section{Erica Rowan}

St. Cross College

St. Giles'

Oxford, UK

OX1 3LZ

ericaskrowan@gmail.com

\section{Antonio M.Sáez Romero}

Grupo de Investigación HUM-440

Área de Arqueología (Universidad de Cádiz)

Facultad de Filosofía y Letras

Avda. Dr. Gómez Ulla, s/n

E - 11003 - Cádiz

antonio.saez@uca.es

\section{André Tchernia}

Directeur d'études émérite de l'E.H.E.S.S. Marseille

Centre Camille Jullian (UMR 7299)

MMSH - 5, rue du Château de l'Horloge BP647

F - 13094 Aix-en-Provence cedex 2

archeocom@mmsh.univ-aix.fr

\section{Tatiana Theodoropoulou}

Wiener Laboratory

The American School of Classical Studies at Athens

43, Souidias st.

GR - 10676 Athens

tatheod@hotmail.com

\section{Inês Vaz Pinto}

Centro de Estudos em Arqueologia, Artes e Ciências do Património (CEAACP)

Troia Resort

Edifício Administrativo - Banda C

P - Tróia. 7570-789 Carvalhal GDL

ivpinto@troiaresort.pt 


\section{Introduction}

es travaux qui composent cette publication sont issus de l'atelier doctoral Fish \& Ships. Production et commerce des salsamenta durant l'Antiquité, qui s'est tenu à Rome du 18 au 22 juin 2012, à l'École française de Rome et à la British School at Rome.

Il a impliqué quatre partenaires scientifiques principaux : l’École française de Rome, la British School at Rome, le centre Camille Jullian et l'université d'Oxford à travers le programme Oxford Roman Economy Project. Nous remercions les directeurs respectifs de ces institutions, qui ont soutenu le projet dès le début : Catherine Virlouvet, Christopher Smith, Marie-Brigitte Carre et Andrew Wilson.

Cet atelier a également bénéficié du soutien financier du LabexMed de la Maison Méditerranéenne des Sciences de l'Homme à Aix-en-Provence, et notre projet de publication a été retenu par l'Institut Européen d'Histoire et des Cultures de l'Alimentation.

L'objectif de cette rencontre était de réunir sur une longue durée des spécialistes de la recherche sur la conservation du poisson et sur son commerce durant l'Antiquité, des spécialistes de céramique, mais également des chercheurs travaillant sur l'économie, tout cela dans un double objectif : à la fois faire le point sur des zones qui désormais sont les vitrines de nos disciplines : l'Afrique et la péninsule Ibérique pour ne pas les citer, mais également mettre l'accent sur des zones ou des périodes qui sont encore trop peu connues ou étudiées.

Nous avons choisi d'organiser un atelier doctoral plutôt que de tomber dans le piège de la « colloquite » selon l'expression de Jacques le Goff. L'avantage en était évident : plutôt que de réunir les maîtres de la discipline pour les faire discuter entre eux, ils allaient aussi servir d'encadrants à des doctorants et jeunes chercheurs internationaux travaillant sur le sujet. À notre connaissance, parmi tous les travaux que l'on recense sur ce thème, aucun atelier doctoral n'avait encore été organisé.

Durant cette rencontre, 14 intervenants et 14 participants - doctorants ou jeunes docteurs - se sont retrouvés pour présenter leurs travaux et échanger leurs idées et points de vue. Ainsi autour des participants les discussions ont été riches, notamment grâce à R. Auriemma, T. Bekker-Nielsen, D. Bernal, M. Bonifay, M.-B. Carre, N. Garnier, S. Grainger, A. Marzano, S. Pesavento Mattioli, M. Sternberg, A. Tchernia, I. Vaz Pinto, A. Wilson.Nous remercions ceux parmi eux qui ont accepté d'êtres les examinateurs des contributions qui composent ce volume.

Les travaux synthétiques sur ce domaine ne sont pas nombreux, et il faut saluer celui qui vient de paraître d'A. Marzano ${ }^{1}$. Auparavant, et hormis des publications ciblées sur des ateliers ou des zones géographiques plus restreintes, peu de travaux avaient vu le jour ${ }^{2}$. Il faut néanmoins rappeler la publication dans les MEFRA d'une série de séminaires qui portaient le nom de la cultura del mare 3 . À l'intérieur de ces séminaires, on voyait déjà se profiler les zones d'étude privilégiées de nos disciplines, mais aussi y apparaître les lacunes. Parmi les grandes lignes, on pouvait déjà voir que la péninsule Ibérique occupait la première place, et cela n'a pas véritablement changé depuis, mais il faut souligner que depuis cette publication, on a vu l'intérêt porté sur d'autres régions, et notamment sur la

1. A. Marzano, Harvesting the Sea, Oxford, 2013.

2. Nous ne les citons pas ici car ils apparaitront dans les bibliographies respectives des articles qui composent ce volume.

3. MEFRA 110-1, $1998 ; 111-1,1999$ et 112-1, 2000. 
mer Noire, l'Afrique, mais aussi sur l'Italie qui, bien que l'hôte de cet atelier doctoral, n'avait pas grand chose de synthétique à offrir.

André Tchernia, dans ses conclusions au séminaire la cultura del mare 4 , écrivait : « un des objectifs de la réunion était de mettre en lumière les lignes de possibles travaux futurs », et nous pensons que les travaux qui composent ce volume illustrent cet objectif espéré, mais qu'ils constituent également non pas un état de la question définitif, mais bien un pas en avant vers une meilleure connaissance de l'artisanat et du commerce des produits de la mer durant l'Antiquité.

L'ouvrage est composé en trois chapitres, respectivement dédiés à des approches historiographiques et technologiques, aux études archéologiques sur l'Afrique et enfin à celles dédiées au reste de la Méditerranée. Plutôt que de faire un classement relatif à la chronologie évoquée dans chacune des contributions, nous avons pris le parti de les classer selon un ordre géographique d'ouest en est, plus aisé à suivre pour le lecteur.

Enfin, nous tenons à remercier Henri Tréziny d'avoir accepté de recevoir ce manuscrit dans la collection BiAMA.

Emmanuel BOTTE et Victoria LEITCH

4. A. Tchernia, Conclusions de la 3e journée Cultura del Mare, MEFRA, 112-1, 2000, p. 169-171. 

Première Partie

Approches historiographiques et technologiques

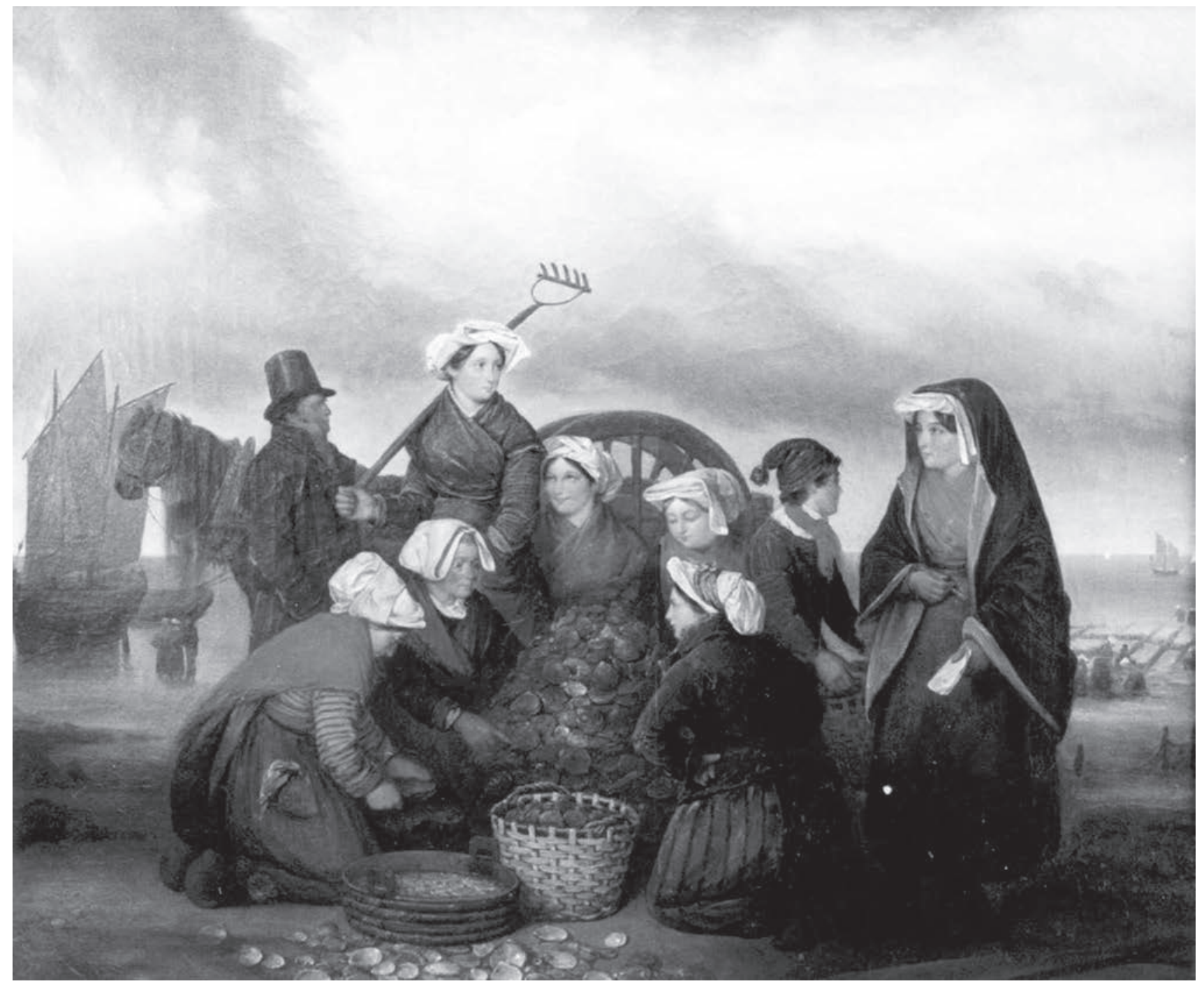





\section{Les installations de traitement du poisson : aperçu historiographique}

\section{André Tchernia}

$\mathrm{N}$ otre connaissance des pêcheries et des installations de traitement du poisson repose actuellement sur des sources diverses : textes grecs et latins, repérés depuis longtemps, de rares inscriptions lapidaires, quelques monnaies portant des images de poissons, les vestiges archéologiques des ateliers d'amphores destinées à contenir les produits de la mer et enfin ceux des établissements qui les traitaient. On peut mettre au crédit du livre de M. Ponsich et M. Tarradell paru en 1965, Garum et industries antiques de salaisons dans la Méditerranée occidentale, d'avoir éveillé l'attention générale sur l'importance de cette dernière source, quoiqu'il fût presque exclusivement consacré aux fabriques marocaines ${ }^{1}$. Michel Ponsich et Miguel Tarradell avaient pourtant été précédés bien avant par d'autres auteurs dont les travaux n'ont pas eu le bonheur d'avoir en leur temps suscité la même attention.

\section{La découverte des pêcheries par Rostovtzeff}

Quiconque se demande ce qu'on savait dans le second quart et au milieu du $\mathrm{XX}^{\mathrm{e}} \mathrm{s}$. de la production d'un bien commercialisé dans le monde romain se tourne naturellement vers Rostovtzeff. L'érudition fabuleuse du savant russe impressionne encore, même si l'on rejette les conclusions qu'il a tirées de cette masse de documents (je dirais plutôt adjointes à cette masse de documents). Le cas des pêcheries est une surprise. $\mathrm{Si}$ l'on se reporte aux passages indiqués dans l'index de la Social and Economic History of the Roman Empire sous le terme "Fisheries », on ne les trouve jamais citées seules et pour elles-mêmes. Elles font partie d'une série de quatre termes qui les associe avec les mines, les carrières et les forêts. Il faut attendre la dernière mention de pêcheries, au chapitre VII, pour comprendre que l'association s'explique par la conception d'une catégorie « ressources naturelles ne relevant pas de l'agriculture ». La note 100 de ce chapitre, longue d'une page et demie, et dont l'appel manque curieusement dans le texte, mais

1. Botte 2009, p. 12-14, où l'on trouvera une vue d'ensemble de l'historiographie. se situe certainement du côté de ce passage, offre une bibliographie sur ces ressources. La première partie est consacrée aux mines, la seconde aux pêcheries. Cette partie commence par « Relatively plentiful information exists regarding fishing...», remarque qui contredit celle qu' on trouve dans le texte "Our information on the exploitation of the natural resources of the Empire, apart from agriculture, is very scanty indeed $»^{2}$.

C'est que, dans l'édition initiale de $1926^{3}$, la note, beaucoup plus courte (comme c'est le cas pour beaucoup des notes de la Social and Economic History) ne portait que sur les mines et les carrières. Dans l'édition allemande de 1931, une longue adjonction traite du poisson, mais sans mentionner les pêcheries. Celles-ci font leur apparition dans l'édition italienne de 1933, qui a été reprise en anglais par Fraser en 1957. C'est donc entre 1931 et 1933 que Rostovtzeff a découvert l'archéologie de pêcheries. Le texte principal a lui aussi subi à ce moment une légère modification : dans la phrase de 1926 « The organization of fisheries and of the exploitation of forests and the industries connected with it and the method of extraction of salt remains almost a blank in our knowledge », les mots "organization of fisheries" ont été supprimés ${ }^{4}$.

\section{Le travail des savants portugais dès la fin du $\mathrm{XIX}^{\mathrm{e}} \mathrm{s}$.}

Le mérite d'avoir ouvert les yeux de Rostovtzeff doit revenir aux deux articles généraux datés de 1931 qu'il cite dans sa note : une chronique de Raymond Lantier qui mentionnait l'atelier de Fréjus en Gaule romaine, et, pour le Portugal, un bref panorama rédigé par Francesco Pellati, I monumenti del Portogallo romano, paru dans la revue dirigée par Ettore Pais, Historia. Après dix-neuf pages consacrées aux villes, aux villas, aux ponts et aux aqueducs, Pellati souligne en une page et demie l'intérêt

2. Rostovtzeff 1957, p. 340.

3. Où elle occupe le $n^{\circ} 85$.

4. p. 294 et 940 . 
des vestiges d'ateliers de salaisons. Il s'appuie sur les travaux menés dans l'Algarve à partir de 1878 par le grand archéologue du XIX ${ }^{\mathrm{e}}$ s., Estacio da Veiga, qui entreprit de faire dresser un inventaire des vestiges archéologiques de sa province. Pellati énumère une dizaine des sites repérés par Estacio da Veiga. Il en ajoute quelquesuns au nord de l'Algarve, en particulier celui de Troia de Setubal, devenu depuis célèbre.

La source essentielle de Pellati était, dans ces pages, un article beaucoup plus ancien, paru en 1906 dans le Bulletin Hispanique. L'auteur, Mesquita de Figueiredo, y faisait connaître les résultats d'Estacio da Veiga, mort avant d'avoir publié tout son inventaire. Il fournissait la carte des sites repérés d'ateliers, les plans sommaires de trois d'entre eux, et décrivait les bassins avec leurs mensurations. Ponsich et Tarradell reproduiront un des plans. La photo d'un bassin de salaison publiée par Pellati a été prise par Mesquita de Figueiredo. D'après de brèves notices de $O$ Arqueólogo Português, il a ajouté la mention de sites plus au nord, et celle des ateliers d'Espagne d'après une lettre de Hubner.

La description des bassins de salaison donnée par Mesquita de Figueiredo a été reprise de façon très proche dans l'article salsamentum du Daremberg et Saglio, rédigé par Maurice Besnier et paru en 1911. Un long et riche article, qui ne consacre qu'une colonne à l' archéologie, entièrement fondée sur Mesquita de Figueiredo. C'est la seule référence mentionnée par Rostovtzeff qui ne soit pas tirée de l'article de Pellati. Il ne connaît pas les installations de Belo, pourtant attentivement décrites dès 1918 par Bonsor et Paris, et de nouveau dans la publication finale du site en $1926^{5}$.

\section{Quatre-vingt-cinq ans de perdus}

On voit que pendant soixante ans beaucoup d'informations, dont certaines avaient été recueillies vingt ans plus tôt, ont été publiées sans recevoir grand écho. Le livre de Ponsich et Tarradell a eu la chance de paraître un an seulement avant que Fausto Zevi, reprenant lui aussi des travaux de Dressel vieux de plus de quatrevingts ans, n'invente les amphores Dr. 7-13 et ne suscite enfin de l'intérêt pour la production et le commerce des produits de la mer ${ }^{6}$. La conjoncture intellectuelle était moins favorable au temps de Mesquita de Figueiredo. La quasi-absence dans les ouvrages de Rostovtzeff et de Tenney Frank des installations de production connues laisse cependant des regrets.

Il faut ajouter que le Bulletin Hispanique, une revue généraliste d'aire culturelle, n'était pas le lieu le plus adapté pour parler aux archéologues d'autres pays et aux historiens de l'économie antique. La note de Rostovtzeff et même le passage de l'article du Daremberg et Saglio étaient pour leur part enfouis parmi une foule de références de tous ordres. Cela a limité leur impact sur les chercheurs spécialisés. Une politique scientifique ne peut se contenter de sacraliser l'idée de publication, en oubliant qu'un texte imprimé ne prend de véritable existence que dans l'acte d'être lu. Le souci de trouver la solution appropriée pour transmettre de nouvelles connaissances à ceux qui sont disposés à en tirer profit, plutôt que de les déposer où que ce soit, en espérant qu'elles irrigueront en pluie fine toute une communauté où chacun est censé faire ses choix et reconnaître les siens dans l'infini de la littérature, devrait habiter les auteurs et les institutions ${ }^{7}$.

Les travaux sur les implantations d'ateliers de traitement du poisson et sur les ateliers d'amphores se sont beaucoup multipliés depuis. Sans toutefois qu'on ait suffisamment progressé par rapport à la formule de Zevi «l'esportazione del garum e delle analoghe salse a base di pesce ». On s'est certes aperçu que les amphores ne contenaient pas que des sauces, mais aussi des poissons entiers et sans doute des quartiers de gros poissons. Mais la répartition de ces différents produits dans les différents types d'amphores, la typologie des installations selon l'objet de leur production ne sont pas des questions résolues. On utilise encore souvent, comme je le fais moi-même, l'expression facile « salaisons et sauces de poisson ».

Considérons pourtant que cela équivaudrait dans le monde actuel à parler de la morue et du nuoc-man comme de produits homogènes, dont on étudierait le commerce en bloc et sans les distinguer. Voilà sans doute un élément majeur à inclure dans un projet qui pourrait être avancé à l'occasion de cette école d'été.
6. Zevi 1966.

7. Gardin 1977. 


\section{Bibliographie}

Besnier 1911 : BESNIER (M.) - article Salsamentum. In : Daremberg (C. V.) et Saglio (E.), Dictionnaire des antiquités grecques et romaines, tome IV, 2, 1911, p. 1022-1035.

Bonsor, Paris 1918 : BONSOR (G.), PARIS (P.) - Exploration archéologique de Bolonia (province de Cadix), Bulletin Hispanique, XX, 2, 1918, p. 77-127.

Botte 2009 : BOTTE (E.) - Salaisons et sauces de poisson en Italie méridionale et en Sicile durant l'Antiquité, Naples, Centre Jean Bérard (CCJB, 31 ; Archéologie de l'artisanat antique, 1), 2009.

Gardin 1977 : GARDIN (J.-Cl.) - Conclusion. In : Méthodes classiques et méthodes formelles dans l'étude typologique des amphores : actes du colloque de Rome (17-19 mai 1974), Rome, (CEFR, 32), 1977, p. 313-318.

Lantier 1931 : LANTIER (R.) - Ausgrabungen und neue Funde in Frankreich aus der Zeit von 1915 bis 1930 (Paläolithikum bis Römerzeit), Frankfurt am Main, Bericht der römisch-germanischen Kommission, 20, p. 77-146 (p. 125).

Mesquita de Figueiredo 1906: MESQUITA DE FIGUEIREDO (A.) Ruines d'antiques établissements à salaisons sur le littoral sud du Portugal, Bulletin Hispanique, tome 8, $\mathrm{n}^{\circ} 2$, 1906, p. 109-121.

Paris et al. 1926: PARIS (P.), BONSOR (G.), LAUMONIER (A.), RICARD (R.), DE MERGELINA (C.) - Fouilles de Belo (Bolonia, province de Cadiz (1917-1921), tome I : la ville et ses dépendances, Bordeaux-Paris (Bibliothèque de l'école des hautes études hispaniques, VI), 1923-1926.

Pellati 1931 : PELLATI (F.) - I monumenti del Portogallo romano, Historia, $5, \mathrm{n}^{\circ} 2,1931$, p. 195-217.

Ponsich, Tarradell 1965 : PONSICH (M.), TARRADELL (M.) - Garum et industries antiques de salaison dans la Méditerranée occidentale, Paris, PUF (Université de Bordeaux et Casa de Velázquez), 1965.

Rostovtzeff 1926 : ROSTOVTZEFF (M. I.) - Social and Economic History of the Roman Empire, Oxford, Clarendon Press, 1926.

Rostovtzeff 1931 : ROSTOVTZEFF (M. I.) - Gesellschaft und Wirtschaft im römischen Kaiserreich, 2 vol., Leipzig, Quelle \& Meyer, 1931.

Rostovtzeff 1933 : ROSTOVTZEFF (M. I.) - Storia economica e sociale dell'impero romano, Firenze, La Nuova Italia, 1933.

Rostovtzeff 1957 : ROSTOVTZEFF (M. I.) - Social and Economic History of the Roman Empire, Oxford, Clarendon Press (2nd edition revised by P. M. Fraser), 1957.

Zevi 1966 : ZEVI (F.) - Appunti sulle anfore romane, Archeologia Classica, XVIII, 1966, p. 208-247. 



\section{Analyse chimique des sauces et des conserves de poissons : un état de la question}

\section{Nicolas Garnier}

\section{Introduction}

$\mathrm{A}$ lors que les recherches menées en archéologie biomoléculaire depuis quelques années et les derniers développements technologiques permettent de mieux identifier les huiles végétales ${ }^{1}$ dont l'huile d'olive ${ }^{2}$ ou encore le $\operatorname{vin}^{3}$, les équipes d'analystes chimistes se trouvent confrontés à un réel défi pour définir et détecter des marqueurs de sauces de poissons potentiellement conservés dans des récipients en céramique, sous forme d'imprégnations des parois poreuses ou même de dépôts visibles au fond des vases. L'approche moléculaire est devenue incontournable car rares sont les découvertes de macro-restes identifiables par examen visuel ou par microscopie optique, par des ichtyologues principalement. C'est le cas notamment d'épaisses couches d'arêtes et d'écailles retrouvées au fond de bassins de préparation du garum à Nabeul en Tunisie ${ }^{4}$, à Troia au Portugal ${ }^{5}$ ou encore à Pompéi dans la «Bottega del Garum » (I, 12,8) où furent identifiées des arêtes desséchées et désarticulées d'anchois contenus dans un sac (Engraulis encrasicholus) ${ }^{6}$ ou au fond d'une jarre ${ }^{7}$. Il s'agit généralement de thon, de sardine, de bonite ou de maquereau. Récemment, des restes d'arêtes ont permis de reconstituer deux maquereaux conservés dans un pot du Latium retrouvé dans l'épave d'Arles $3^{8}$. Mais, malgré un grand nombre d'amphores à sauces et à salaisons de poissons retrouvées lors des fouilles archéologiques et identifiées par leur type, ces découvertes sont rares. Notre objectif est de développer une méthodologie d'analyse chimique qui permettrait d'identifier la nature des contenus même en l'absence de macro-restes.

1. Garnier 2009.

2. Garnier 2011.

3. Pecci 2013.

4. Sternberg 2000.

5. Voir la contribution d'I. Vaz Pinto dans ce volume.

6. Reese 2002.

7. Smriga 2010.

8. Étude G. Piquès pour D. Djaoui. Voir la contribution de D. Djaoui, G. Piquès et E. Botte dans ce volume.
À ce jour, aucune étude chimique n'a réellement porté sur la détection et l'identification des sauces et des conserves de poissons en contexte archéologique. La complexité du sujet explique en grande partie le retard par rapport à l'étude d'autres produits biologiques comme les huiles et les produits laitiers par exemple. Cependant, un grand intérêt est porté pour tous les dérivés du poisson actuels, car dans de nombreuses régions, notamment dans la zone tropicale, l'accès au poisson frais est impossible en raison de la dégradation microbienne et autolytique durant sa préparation ou son stockage ${ }^{9}$. Traditionnellement, les sauces de poissons sont fabriquées à partir d'un mélange de poisson et de sel, stocké pendant 6 à 12 mois à température ambiante tropicale, dans de larges bassins habituellement creusés et maçonnés dans le sol et à l'ombre. Le liquide brun formé, dit «fraction riche en protéines solubles », est appelé «sauce de poissons » et prend différents noms suivant les pays: nampla en Thailande, patis aux Philippines et nuoc-mam au Camboge et au Vietnam. Aussi, les sauces de poissons actuelles ont été largement décrites en chimie alimentaire, notamment pour le contrôle de la qualité des produits de type nuоc-mam par exemple ${ }^{\mathbf{1 0}}$.

Bien que les profils chimiques varient, les sauces sont caractérisées par une forte teneur en sel et une concentration importante en acide glutamique libre pouvant atteindre $10 \mathrm{~g} / \mathrm{L}$ pour certaines sauces japonaises ${ }^{11}$. Les teneurs élevées en acides aminés libres sont comparables à celles d'autres condiments fermentés comme les sauces soja ou Worcesterchire, le parmesan ${ }^{12}$ ou encore les bouillons cubes ${ }^{13}$ et sont dues à l'autolyse des protéines musculaires et la liquéfaction des chairs sous l'action d'enzymes endogènes au poisson, i.e. acide-protéases, endo- et exo-peptidases.

\footnotetext{
9. Gram, Huss 2000.

10. Yoshida 1998 ; Tsuji et al. 1994 ; Ijong, Ohta 1995.

11. Yoshida 1998.

12. Sinesio 2009.

13. Yoshida 1998.
} 
Les études publiées ne portent généralement que sur une classe spécifique de composés souvent liés aux propriétés organoleptiques du produit. Qui plus est, ces molécules souvent labiles, polaires voire ionisées, et donc facilement perdues en contexte archéologique; leur chance d'être conservées est très minime, en faisant des marqueurs peu fiables pour l'identification des dérivés du poisson anciens, soumis à plus de 2000 ans de dégradations physicochimiques et biologiques. Une autre approche est alors indispensable, fondée sur l'évaluation de la pertinence de chaque marqueur en fonction de sa conservation. Les composés neutres et apolaires, donc insolubles dans l'eau et non hydrolysables, sont les meilleurs candidats car généralement les mieux conservés lors de l'enfouissement; à l'opposé, la plupart des composés chimiques majoritaires dans le poisson frais, polaires, n'ont que de très faibles chances d'être conservés. Dans cet article, nous dresserons un bilan des analyses de sauces de poissons actuelles et de leurs matières premières, puis exposerons les pistes de recherche lancées depuis quelques années pour l'identification du garum et leurs résultats obtenus à ce jour.

\section{Les produits à base de poisson fermenté}

Plusieurs produits peuvent être obtenus à partir du poisson, soit par hydrolyse enzymatique ou acide des protéines, soit par fermentation bactérienne. Ils peuvent être classés en quatre catégories :

- les produits à base de poisson fermenté traditionnels de l'Asie du Sud-Est et orientale,

- les produits à base de poisson en semi-conserve traditionnels d'Europe,

- le poisson ensilé,

- les hydrolysats de protéines de poisson.

Seuls les deux premiers types nous intéressent. Les premiers correspondent au garum et à l'allec romains, les seconds aux conserves de poisson réalisées dans le sel, la saumure ou parfois aussi le miel...

\subsection{Les sauces de poisson fermenté d'Asie}

Les produits à base de poisson fermenté sont une des bases de la cuisine traditionnelle asiatique. On distingue deux grandes régions : à l'ouest du golfe du Bengale où les épices sont abondamment utilisés pour stimuler l'appétit ; à l'est où l'on recherche le goût umami (bon goût) et le goût salé des produits fermentés (poisson, soja...).
La part de ces produits dans l'apport nutritionnel en protéines est souvent exagérée et ils sont souvent utilisés comme condiments pour faciliter la consommation de produits basiques comme le riz.

La préparation est simple : les poissons d'eau douce, d'eau de mer, les coquillages et les crustacés sont mélangés à du sel pour donner une large gamme de produits fermentés qui n'existent pas à l'état naturel (d'où la dénomination de «produits»). Le sel, en grandes quantités, évite la putréfaction des chairs, qui se décomposent suivant des processus chimiques d'hydrolyse uniquement (appelés protéolyse ou autolyse). Les produits fermentés obtenus, riches en sel, sont consommés filtrés ou non, sous forme de sauces ou de pâtes. Le procédé diffère des conserves par salage où le sel permet de conserver le poisson, notamment son aspect, en évitant la protéolyse.

\begin{tabular}{|l|l|l|}
\hline Pays & Sauce & Pâte \\
\hline Burma & ngapi & ngapi \\
\hline Indonésie & ketjap-ikan & trassi (crevettes) \\
\hline Cambodge & nuoc-mam gau-ca & prahoc \\
\hline Laos & nam-pla & padrec \\
\hline Malaisie & budu* & belachan (crevettes) \\
\hline Philippines & patis & bagoong* \\
\hline Thaïlande & nam-pla & kapi \\
\hline Vietnam & nuoc-mam & $\begin{array}{l}\text { mam-ca (poisson) } \\
\text { mam-tom (crevettes) }\end{array}$ \\
\hline
\end{tabular}

Tableau 1. Sauces et pâtes de poisson fermenté d'Asie du Sud-Est.

( ${ }^{\star}$ Bagoong et budu sont des sauces de poissons non filtrées, pour lesquelles l'hydrolyse enzymatique n'a pas été menée à terme jusqu'au produit liquide. Les protéines et peptides résiduels donnent un aspect colloïdal, intermédiaire entre la sauce et la pâte.)

Le poisson se décompose naturellement par action des enzymes protéolytiques présentes dans l'intestin. Le phénomène de décomposition, appelé autolyse ou chimiquement protéolyse (hydrolyse des protéines), se produit très rapidement. Cependant, dans certaines régions du Vietnam, le nuоc-mam est fabriqué à partir de poisson éviscéré. Pour remplacer les enzymes du poisson et initier la protéolyse, du jus d'ananas ou de papaye est ajouté. La sauce a un goût différent des sauces traditionnelles obtenues par autolyse. 
Les produits de type shiokara sont préparés à partir de poisson séché et de sel, mais en plus faible proportion que pour les sauces, évitant l'autolyse rapide. Les poissons ou crevettes mélangés au sel sont séchés au soleil $(5-8 \mathrm{~h})$, écrasés, laissés au repos 7 jours à l'abri de l'air, puis encore séchés au soleil $(5-8 \mathrm{~h})$ avant d'être laissés 7 à 90 jours. Ces produits peuvent constituer des plats comme le ngapi à Burma, le prahoc cambodgien, ou le belachan, pâte de crevette traditionnelle de Malaisie.

Les narezushi sont obtenus par fermentation de chair de poisson mélangée à des glucides cuits (généralement du riz) et du sel. D'autres ingrédients peuvent être ajoutés, chaire animale, oiseaux entiers, autres légumes, etc. Les glucides provoquent une fermentation lactique, permettant une plus longue conservation du produit. Ces produits proviennent principalement de Chine et du Japon, mais on trouve aussi le pla-ra thaillandais et le burong-isda des Philippines.

Sur la côte de l'Inde, on trouve quelques produits à base de poisson fermenté utilisant des petits poissons d'eau douce qui ne sont pas consommables directement. Le hentak est un mélange d'Esomus dandricus (Barbus indien volant) et d'une Araceae, l'Alocasia macrorrhizos, réduit en poudre, séché au soleil puis laissés fermenter 7 jours en pot de terre. Le mélange est prêt à consommer. Pour le ngari, le Puntius sophore est lavé, séché, bouilli à l'eau puis fortement pressé et conservé dans un pot de terre, sans air, pendant 4 mois. Il entre dans la composition des currys.

\subsection{Les produits de conserve européens}

En Scandinavie, mais aussi en Hollande, Allemagne, Belgique et France, des produits traditionnels à base de poissons de semi-conserve sont élaborés dans du sel, du sucre, des épices, des agents conservateurs ou des acides organiques. Pendant la production la chair du poisson « mûrit » (en anglais, ripening) i.e. les protéines subissent une protéolyse partielle jusqu'à un certain stade correspondant à une saveur, un goût et une texture typiques du produit recherché. Les poissons à chaire grasse sont les plus utilisés, anchois de Scandinavie (sprats, Clupea sprattus), harengs tidbits et marinés (Clupea harengus harengus). L'addition d'épices, d'acides (acides citrique, lactique ou benzoïque) permet de retarder l'apparition de micro-organismes.

Pour des proportions de sel supérieures à $10 \%$ dans la chair, les protéines musculaires sont dénaturées. Le mûrissement commence alors, pour environ 12 semaines; les protéines, et précisément l'actomyosine musculaire, subissent une protéolyse et se transforment en protéines à plus courte chaîne, en peptides (hydrolyse partielle), voire en acides aminés (hydrolyse totale). De là une solubilisation progressive de la matière protéique initiale. L'hydrolyse enzymatique est le principal phénomène du « ripening » et se traduit, pour les sprats de Scandinavie, par la formation d'acides aminés solubles.

De cette diversité de matières premières et de recettes, il ressort que les produits à base de poissons fermentés actuels, produits traditionnels de la cuisine asiatique ou européenne, peuvent être utilisés comme références pour aborder les sauces et les conserves de poissons de l'Antiquité. Le garum, la fleur de garum et l'allec se rapprochent des sauces produites en Asie du Sud-Est, alors que les conserves de poissons sont à mettre en rapport avec les semi-conserves d'Europe du Nord.

\section{Composition chimique des poissons}

La composition chimique des poissons dépend de nombreux facteurs. Les muscles (les chairs, constituant environ $50 \%$ du poids de l'animal) ont une composition différente de la peau et des arêtes. Aussi, les proportions relatives d'eau, de graisses, de protéines et de matière minérale varient pour les chairs d'espèces différentes, mais aussi au sein d'une même espèce suivant le milieu dans lequel vit le poisson (eau douce ou milieu marin ; eau froide, tempérée ou tropicale) et suivant la période de l'année. Il n'existe donc pas de composition chimique propre au poisson et l'on ne peut que définir des lignes générales.

Les poissons, les crustacés et les coquillages se distinguent des animaux terrestres par leur nature poïkilotherme, une forte teneur en composés azotés nonprotéiques ${ }^{14}$ qui leur confère une odeur caractéristique, des teneurs variables en lipides mais avec un fort degré d'insaturation et des acides $\omega-3$ abondants, et une faible proportion de glucides. Leurs chairs sont particulièrement vulnérables aux dégradations bactériennes et se détériorent facilement. Depuis 50 ans, le développement des techniques analytiques a permis de connaître peu à peu la composition chimique de différentes parties des poissons et des coquillages vivant dans les eaux froides, tempérées ou équatoriales. Cependant, nos connaissances et les méthodologies évoluent et bon nombre de données anciennes ne sont plus assez pertinentes, en raison de protocoles ou de techniques manquant de précision. La priorité doit être donnée aux recherches récentes mettant en œuvre des protocoles précis de purification des familles chimiques et des nouvelles techniques analytiques beaucoup plus pertinentes.

14. Notés NPN, non-protein nitrogen. 


\subsection{Composition globale}

Les chairs des poissons, coquillages et crustacés renferment principalement de l'eau, des protéines, des graisses (lipides) et des matières minérales (cendres). Une des caractéristiques est la très grande variabilité de la composition lipidique. Parmi les composés secondaires on trouve du glycogène, des sucres, des sucres phosphorylés, des nucléotides, des vitamines hydro- et liposolubles, du cholestérol et autres stérols (cf lipides), des pigments dont l'hémoglobine et la myoglobine, des substances azotées non protéiques (NPN : acides aminés, urée principalement dans les cartilages, l'oxyde de triméthylamine chez les poissons de mer et les crustacés), des enzymes (protéines), des hormones, des phospholipides et parfois d'autres substances comme des hydrocarbures. Nous nous intéresserons ici aux deux familles majoritaires, les lipides (acides gras constitutifs, triglycérides et phospholipides, stérols) et les composés azotés dont les protéines principalement.

Globalement, pour les poissons d'eau douce ou marins et les coquillages, le taux d'humidité varie de 60 à $80 \%$ et le taux de protéines de 18 à $20 \%$. Le taux de lipides est très variable, de 0.5 à $19 \%$ au sein d'une même espèce. Les compositions varient aussi suivant les organes. La peau est beaucoup plus grasse que la chair et contient surtout des lipides neutres, les triglycérides (Tableau 2). Les chutes (tête et viscères) sont souvent plus grasses que les parties habituellement consommées. Le foie et les viscères sont les organes les plus gras. Aussi pour les chairs, les muscles dorsaux et caudaux sont plus riches en protéines et moins gras que les muscles ventraux et ceux proches de la tête.

Les poissons se caractérisent aussi par des muscles rouges se présentant sous la forme d'une couche souscutanée brune à rougeâtre. Ces muscles servent aux mouvements continus et lents de l'animal, contrairement aux muscles blancs, plus spécifiques aux mouvements rapides. Les poissons de fond n'ont donc que très peu de muscles rouges contrairement aux autres qui nagent continuellement. Les muscles rouges contiennent 5 fois plus de pigments (myoglobine et hémoglobine), lipides (2 à 5 fois), vitamines, glycogène, sucres et acides nucléiques, alors que les muscles blancs contiennent plus d'eau, protéines, phosphates minéraux, acide lactique, enzymes liées à l'activité glycolytique permettant le fonctionnement rapide des muscles. Les muscles blancs utilisent le glycogène comme source d'énergie, les muscles rouges les lipides (Tableau 3). Chez les poissons gras comme les scombridés, les muscles rouges représentant 9 à $24 \%$ des muscles, contre $2-3 \%$ pour les poissons maigres. Les petits poissons montrent plus de muscles rouges (37\% chez la sardine) que les gros poissons $(10-12 \%$ pour le thon).

\begin{tabular}{|l|c|c|c|}
\hline & Peau & Muscle & $\begin{array}{c}\text { Poisson } \\
\text { entier }\end{array}$ \\
\hline $\begin{array}{l}\text { Poids relatif par rapport } \\
\text { au poisson étêté, } \\
\text { éviscéré et désossé }\end{array}$ & 5 & 95 & 100 \\
\hline Humidité & 63.0 & 75.0 & 74.6 \\
\hline Protéines extractibles totales & 1.8 & 15.8 & 15.1 \\
- Protéines sarcoplamiques & 0.6 & 3.7 & 3.5 \\
- Protéines fibrillaires & 1.2 & 12.2 & 11.6 \\
\hline Lipides totaux extractibles & 16.2 & 4.3 & 4.9 \\
- Phospholipides & 2.5 & 1.0 & 1.0 \\
- Lipides neutres & 11.0 & 2.4 & 2.8 \\
- Acides gras libres & 0.4 & 0.1 & 0.1 \\
\hline
\end{tabular}

Tableau 2. Composition chimique de la peau et des muscles de Stromateus cinereus (d'après Kamat et Kumta, p. 8). Les données sont exprimées en \%.

\begin{tabular}{|c|c|c|c|c|}
\hline & \multicolumn{2}{|c|}{$\begin{array}{c}\text { Thon } \\
\text { (Euthynmus affinis) }\end{array}$} & \multicolumn{2}{|c|}{$\begin{array}{c}\text { Sardine } \\
\text { (Sardinella longiceps) }\end{array}$} \\
\hline & $\begin{array}{l}\text { Muscle } \\
\text { rouge }\end{array}$ & $\begin{array}{l}\text { Muscle } \\
\text { blanc }\end{array}$ & $\begin{array}{l}\text { Muscle } \\
\text { rouge }\end{array}$ & $\begin{array}{r}\text { Muscle } \\
\text { blanc }\end{array}$ \\
\hline Humidité & 69.4 & 70.9 & 64.6 & 72.8 \\
\hline $\begin{array}{l}\text { Protéines } \\
(\mathrm{N} \text { total } \times 6.25)\end{array}$ & 18.3 & 18.9 & 19.1 & 20.7 \\
\hline Graisses & 4.6 & 3.1 & 14.1 & 4.8 \\
\hline Cendres & 1.2 & 1.7 & 1.4 & 1.7 \\
\hline Sucres & 0.8 & 0.3 & 0.9 & 0.5 \\
\hline
\end{tabular}

Tableau 3. Composition chimique des muscles rouges et blancs du thon et de la sardine (d'après Kamat et Kumta).

Les données sont exprimées en \%.

L'âge et le sexe influe aussi sur les compositions globales : la teneur en lipides augmente avec l'âge, et les poissons mâles sont généralement plus gras que les poissons femelles. Mais le facteur le plus important est la saison. Pour la sardine, la proportion de graisse est maximale de septembre à janvier; les triglycérides suivent cette évolution. En revanche, les phospholipides sont toujours présents à $1 \%$ environ. L'augmentation globale des graisses est donc due aux triglycérides. Pour le maquereau d'Inde, la période « grasse » est observée en septembre - novembre, pour le requin en octobre mai (d'après la composition du foie). Pour les poissons à chair blanche, les variations sont moins nettes. 


\subsection{L'eau}

L'eau est le constituant largement majoritaire du poisson. Elle est présente soit sous forme libre, non liée dans les pores interstitiels, soit sous forme «liée », retenue par les molécules polaires et ioniques (protéines principalement) par liaison hydrogène ou ionique. Seule $4-5 \%$ de l'eau des muscles se trouve sous forme liée. L'eau libre est sensible aux actions extérieures (congélation, changement de $\mathrm{pH}$, osmose, cuisson, séchage, pressurage) et peut facilement sortir des muscles, comme c'est le cas lorsque le poisson est mélangé au sel lors de la préparation du garum $^{15}$.

La proportion d'eau libre (et disponible) peut être mesurée par l'activité de l'eau, $a_{w}$. Elle permet aussi d'évaluer la viabilité des micro-organismes dans tel ou tel milieu. Ainsi, la chair des poissons frais a une activité de 0.99. Comme les bactéries et les levures ont besoin d'une humidité $a_{w}$ supérieure à $0.88^{16}$, les tissus musculaires du poisson leur offrent un milieu idéal pour leur développement. Ainsi, les chairs des poissons sont microbiologiquement instables et facilement dégradées par les bactéries et les levures.

\subsection{Les composés azotés}

\subsubsection{Protéines des poissons et crustacés}

Dans le poisson, tous les organes renferment une part de tissus musculaires et de protéines.

Les muscles striés du corps, appelés muscles squelettiques et chair, représentent l'essentiel des protéines du poisson et se composent de deux protéines principales, la myosine et l'actine ${ }^{17}$, mais aussi la tropomyosine et la troponine. Ces protéines structurales (ou myofibrillaires) représentent $65-75 \%$ des protéines musculaires. Elles sont solubles dans les solutions neutres peu salines. La myosine est insoluble sauf dans des solutions fortement ioniques; lors de l'élaboration de la sauce de poisson, il est essentiel d'optimiser la concentration en

15. Lors de l'expérience réalisée par Emmanuel Botte, les sardines rejettent une grande part de leur eau pendant les 24 premières heures. Il s'agit d'un phénomène d'osmose où l'eau quitte les muscles pour diluer le milieu extérieur riche en sel, i.e. plus concentré en ions $\mathrm{Na}^{+}$ et $\mathrm{Cl}^{-}$que le milieu musculaire, afin d'aller vers un équilibre des concentrations entre les deux milieux.

16. Les seuils d'activité de l'eau en dessous desquels les micro-organismes ne sont pas viables sont : 0.91 pour la plupart des bactéries, 0.88 pour les levures, 0.80 pour les mousses, 0.75 pour les bactéries halophiles, 0.65 pour les moisissures xérophiles et 0.60 pour les moisissures osmophiles.

17. Protéines associées et souvent appelées actomyosine. sel afin de maximiser la proportion de protéines dissoutes. La dégradation des protéines myofibrillaires au niveau moléculaire provoque un changement physique et visible de la chair. Les mollusques et invertébrés se caractérisent par la paramyosine $(3 \%$ pour la coquille Saint-Jacques, $14 \%$ pour le calamar, $19 \%$ pour l'huître des protéines musculaires), protéine impliquée dans la contraction et la fermeture des bivalves.

Les protéines sarcoplasmiques $(20-30 \%$ des protéines musculaires) regroupent l'albumine, la globuline, l'hémoglobine et la myoglobine. De faible poids moléculaire $(40-70 \mathrm{kDa})$, elles sont solubles dans l'eau à faible force ionique et $\mathrm{pH} 7.5$-8.0. Elles sont plus abondantes chez les poissons de mer (sardine, maquereau) que pour les poissons de profondeur.

Les protéines du stroma comprennent le collagène, l'élastine et la connectine. Le collagène représente $3 \%$ des protéines totales chez les téléostéens, $7 \%$ des cartilages des poissons ${ }^{\mathbf{1 8}}$. Le collagène des poissons est différent de celui des animaux terrestres car il contient plus d'acides aminés essentiels et moins d'hydroxyproline. Le collagène de crevette est riche en tryptophane et est insoluble dans les solutions salines.

Enfin les poissons renferment des nucléoprotéines mais plus faiblement que les animaux terrestres, incluant les protéines simples, l'acide phosphorique, les sucres (ribose, déoxyribose) et les bases puriques et pyrimidiques.

\begin{tabular}{|c|c|c|c|}
\hline Force ionique & $\begin{array}{l}\text { Groupe de } \\
\text { protéines }\end{array}$ & Localisation & $\begin{array}{l}\% \text { des protéines } \\
\text { totales du poisson }\end{array}$ \\
\hline $\begin{array}{l}\text { Solubles dans } \\
\text { l'eau et solu- } \\
\text { tion peu saline } \\
\text { (f.i. } 0.05), \mathrm{pH} \\
7.5-8.0\end{array}$ & $\begin{array}{l}\text { Protéines sar- } \\
\text { coplasmiques } \\
\text { (albumine, } \\
\text { globuline, } \\
\text { hémoglobine, } \\
\text { myoglobine, }\end{array}$ & Sarcoplasme & $\begin{array}{l}\text { Poissons : } 10-20 \% \\
\text { Crustacés : } 30 \%\end{array}$ \\
\hline $\begin{array}{l}\text { Solubles en } \\
\text { solution saline } \\
\text { (f.i. } 0.3-0.6 \text {, } \\
5 \% \mathrm{NaCl})\end{array}$ & $\begin{array}{l}\text { Protéines } \\
\text { structurales } \\
\text { (myosine, } \\
\text { actine, tro- } \\
\text { pomyosine, } \\
\text { troponine) }\end{array}$ & $\begin{array}{l}\text { Myofibirilles } \\
\text { (éléments } \\
\text { contractiles } \\
\text { des muscles) }\end{array}$ & $\begin{array}{l}\text { Poissons : } 75 \text { - } 80 \% \\
\text { Crustacés : moins }\end{array}$ \\
\hline $\begin{array}{l}\text { Insolubles en } \\
\text { solution saline }\end{array}$ & $\begin{array}{l}\text { Collagène, } \\
\text { élastine }\end{array}$ & $\begin{array}{l}\text { Sarcolemme } \\
\text { et stroma } \\
\text { (tissus } \\
\text { connectifs, } \\
\text { myocom- } \\
\text { mata) }\end{array}$ & $\begin{array}{l}\text { Poissons : } 3 \text { \% } \\
\text { Invertébrés : + }\end{array}$ \\
\hline
\end{tabular}

Tableau 4. Solubilité des différentes protéines présentes dans les poissons et crustacés (d'après D.P. Sen, Advances in fish processing and technologies, Allied publishers LTV, Mumbai, 2005).

18. Les muscles des animaux terrestres sont beaucoup plus riches en collagène que ne le sont les cartilages des poissons : $8-20 \%$ pour les ruminants, $15 \%$ pour le lapin. 


\begin{tabular}{|l|l|l|l|l|l|l|l|l|l|l|}
\hline Espèce & Arg & His & Ile & Leu & Lys & Met & Phe & Thr & Trp & Val \\
\hline $\begin{array}{l}\text { Cynoglossus } \\
\text { arei (sole) }\end{array}$ & 3.0 & 2.6 & 3.0 & 5.0 & 7.4 & 1.3 & 2.3 & 3.7 & - & 2.9 \\
\hline $\begin{array}{l}\text { Euthynnus } \\
\text { affinis (thon) }\end{array}$ & 6.3 & 8.1 & 4.4 & 5.8 & 8.2 & 1.0 & 2.4 & 3.1 & - & 3.5 \\
\hline $\begin{array}{l}\text { Rastrelliger } \\
\text { kanagurta } \\
\text { (maquereau } \\
\text { d'Inde) }\end{array}$ & 6.8 & 1.9 & - & 11.0 & 6.5 & 4.3 & 4.2 & 5.5 & 1.1 & 6.0 \\
\hline $\begin{array}{l}\text { Sardinella } \\
\text { longiceps } \\
\text { (sardine) }\end{array}$ & 7.0 & 1.7 & - & 13.4 & 8.0 & 3.8 & 6.1 & 4.7 & Tr. & 5.9 \\
\hline $\begin{array}{l}\text { Metapenaeus } \\
\text { monoceros } \\
\text { (crevette } \\
\text { mouchetée) }\end{array}$ & 6.0 & 2.0 & 2.0 & 4.5 & 11.7 & 1.6 & 3.2 & 3.9 & - & 2.0 \\
\hline $\begin{array}{l}\text { Penaeus } \\
\text { monodon } \\
\text { (crevette } \\
\text { géante } \\
\text { tigrée) }\end{array}$ & 6.4 & 2.5 & 4.9 & 10.5 & 10.0 & 2.1 & 4.3 & 5.5 & - & 4.3 \\
\hline $\begin{array}{l}\text { Sepia spp. } \\
\text { (seiche) }\end{array}$ & - & - & 5.2 & 7.0 & 7.1 & 3.6 & 7.3 & 3.2 & 0.8 & 5.0 \\
\hline $\begin{array}{l}\text { Perna varidis } \\
\text { (moule) }\end{array}$ & 7.3 & 4.5 & 5.9 & 7.9 & 10.5 & 1.8 & 4.7 & 4.0 & - & 4.7 \\
\hline $\begin{array}{l}\text { Crassostrea } \\
\text { spp. (huitre) }\end{array}$ & 7.1 & 2.0 & 1.2 & 3.1 & 9.1 & 0.9 & 1.2 & 2.0 & - & 4.5 \\
\hline
\end{tabular}

Tableau 5. Composition globale en acides aminés des parties consommées de poissons et crustacés (d'après D.P. Sen, Advances in fish processing and technologies, Allied publishers LTV, Mumbai, 2005).
Les protéines de poissons sont une source riche en acides aminés pour l'homme, notamment en acides aminés essentiels. Elles se caractérisent par une forte proportion de lysine et de méthionine. La composition globale en acides aminés de la chair dépend surtout de la proportion et de la composition de la myosine, l'actine et le collagène.

Le collagène est pauvre en acides aminés essentiels sauf la phénylalanine, et contient plus d'arginine, de glycine et de proline que la myosine et l'actine. Il contient aussi l'hydroxyproline et l'hydroxylysine absentes des autres protéines.

La myosine présente une composition quasi identique pour les poissons d'eau douce, de mer et les animaux terrestres.

\subsubsection{Autres composés azotés}

Le plasma et le fluide intercellulaire regorgent de composés solubles autres que les protéines. Ils sont beaucoup plus sensibles à l'action des bactéries que ces dernières et sont responsables de l'odeur caractéristique des poissons et crustacés. Il s'agit principalement de composés dérivés de la triméthylamine (oxyde de triméthylamine TMAO, cholines, bétaïnes), l'urée, les acides aminés libres, des peptides (ansérine, méthyl carnosine, glutathione), des dérivés de la guanidine (adénosinetriphosphate ATP, inosine monophosphate, hypoxanthine).

Les composés azotés non protéiques (NPN) constituent $10 \%$ environ des composés azotés chez les téléostéens, $25 \%$ chez les crustacés et $30 \%$ chez les élasmobranches, expliquant leur odeur plus prononcée. Ces derniers se caractérisent par des taux d'urée très importants, suivi de la TMAO. Les poissons d'eau douce ont une teneur en NPN très faible comparativement, notamment en TMAO. Les crustacés ont des chairs riches en acides aminés libres $(300 \mathrm{mg} / 100 \mathrm{~g}$; poissons de mer $30 \mathrm{mg}$, poissons d'eau douce $50 \mathrm{mg}$, élasmobranches $75 \mathrm{mg}$ ).

Concernant les acides aminés libres, les chairs d'animaux marins se caractérisent par un fort taux d'histidine libre, surtout pour les poissons à chair sombre. Le crabe est riche en $\alpha$-alanine et glycine libres, les crevettes en tyrosine et phénylalanine.

Concernant les produits fermentés, une étude générale portant sur 61 sauces de poissons fabriquées à partir de sardines et d'anchois en Asie a montré que les produits du Vietnam, du Japon et de Thaïlande sont riches en NPN, pauvres en acides organiques et présentent un profil d'acides aminés similaire, alors que les sauces de Myanmar et du Laos présentent peu d'acides aminés, 
avec un profil très différent ; quant aux produits chinois et coréens, ils montrent des teneurs intermédiaires ${ }^{19}$. À Myanmar et en Chine, la fermentation acétique fait de l'acide acétique le marqueur acide principal, alors que le pyroglutamate et le lactate dominent pour les autres pays. La créatinine, provenant de la créatine dans le cas d'une fermentation bactérienne faible, montre des taux variables, suivant la qualité de la fermentation.

Les acides nucléiques sont présents sous forme d'ARN (42-142 mg/100 g muscle pour les poissons des mers tempérées et arctiques), d'ADN ( $0.2-2.5 \mathrm{mg} / 100$ $\mathrm{g}$; très variable suivant la partie du corps et l'âge) ou d'inosine phosphate. Enfin, une large variété de composés non azotés est aussi présente dans les muscles : glycogène, glucose, ribose et acide lactique, tous liés à l'activité musculaire. Leur proportion est très dépendante de l'état physiologique de l'animal à sa mort.

Les études comparatives montrent donc qu'il est difficile d'établir une composition générale pour l'ensemble des sauces de poissons, et même pour des sauces élaborées à partir des mêmes espèces. Les protéines musculaires semblent les meilleurs marqueurs, mais la fermentation provoque leur hydrolyse quasi-totale et donc leur perte. Les acides aminés formés et les autres marqueurs azotés étant très solubles dans l'eau, rares seront les contextes archéologiques où ils pourront être conservés. L'étude de la fraction de composés moins polaires tels les lipides est une autre piste pour la détection des résidus de sauces de poissons.

\subsection{Les lipides}

Les lipides sont des composés apolaires (hydrophobes) qui regroupent : les acides gras, unités de base servant à former les lipides hydrolysables, à savoir les triglycérides et les phospholipides. Dans un sens plus large, les stérols (molécules non hydrolysables) sont aussi inclus dans la famille des lipides, ainsi que leurs esters. Les vitamines liposolubles, les alcoxyglycérides, les hydrocarbures (squalène, pristane, zamène), les cérides et certains pigments (astacènes, caroténoïdes) rentrent dans la famille des lipides.

On considère généralement comme gras les poissons comportant plus de $5 \%$ en masse de lipides (hareng, maquereau, saumon), les semi-gras de 2 à $5 \%$ (sole, flétan, mulet; moules), et les maigres moins de $2 \%$ (morue, haddock, thon, seiche, crevette). La teneur en graisse varie fortement en fonction de la saison pour une même espèce.

19. Park et al., 2001.

\subsubsection{Les lipides polaires hydrolysables : phospholipides et cholines}

Les acides gras, souvent considérés comme les constituants des corps gras ${ }^{20}$, se trouvent en faible proportion à l'état libre dans le poisson et plutôt sous forme estérifiée, soit de lipides polaires (phospholipides et lécithines), soit apolaires (triglycérides).

Les phospholipides présents dans les membranes cellulaires des muscles des poissons, des crustacés et des mollusques, sont soit libres, soit liés à des protéines (complexes lipo-protéiques). Ils constituent 5 à $10 \%$ du phosphore total contenu dans le poisson. Contrairement aux triglycérides, les phospholipides sont des constituants basiques de la cellule et leur proportion reste constante. La partie phosphate des phospholipides est généralement estérifiée par une choline ou un sucre, définissant ainsi plusieurs sous-classes: les phosphatidyl-cholines (ou lécithines) et -éthanolamines (céphalines) par exemple, ou les sphingomyélines. Pour la sardine, les lipides représentent au total $6.0 \%$ massiques du muscle hydraté dont $0.8 \%$ de phospholipides (soit $13 \%$ ). Les lécithines et les céphalines constituent $62 \%$ et $16 \%$ de ces phospholipides. Pour les crevettes Metapenaus sp., les lipides représentent $0.7-1.2 \%$ du muscle, parmi lesquels $49-65 \%$ de phospholipides. Lécithines et céphalines constituent respectivement 47 $-52 \%$ et $23-30 \%$ des phospholipides, part beaucoup plus importante que pour les viandes de bœuf, de mouton ou la volaille.

La composition en acides gras des phospholipides est très différente de celle des triglycérides. Les phospholipides sont riches en acides gras polyinsaturés et à longue chaîne, notamment les acides caractéristiques EPA (20:5) et DHA (22:6). Les triglycérides sont plus riches en acides à plus courte chaîne, saturée ou monoinsaturée (fig. 1).

\subsubsection{Les triglycérides (lipides apolaires)}

Les triglycérides, lipides de réserve, sont stockés sous forme de dépôt adipeux sous la peau des poissons. L'huile de poisson, extraite du poisson et des déchets, contient au moins $97 \%$ de triglycérides. Certaines huiles de foie de poisson et d'Elasmobranchii contiennent 8

20. Jusqu'à récemment, les techniques analytiques ne permettaient pas d'accéder aux lipides de haut poids moléculaire comme les triglycérides et les phospholipides. Ils étaient donc hydrolysés en acides gras. La plupart des normes européennes utilisent l'analyse des acides gras comme seule caractérisation des poissons, notamment en chimie alimentaire, rendant donc peu à peu obsolète la littérature de ce domaine. 
(a) anchois

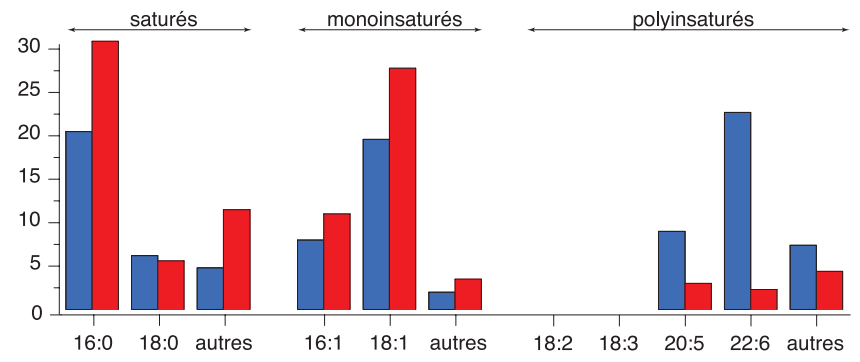

(b) maquereau

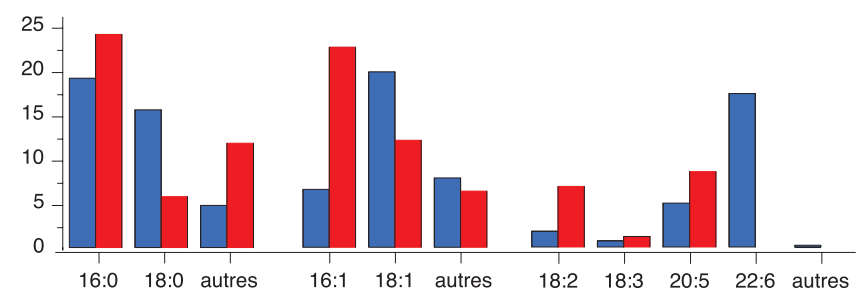

(c) sardine

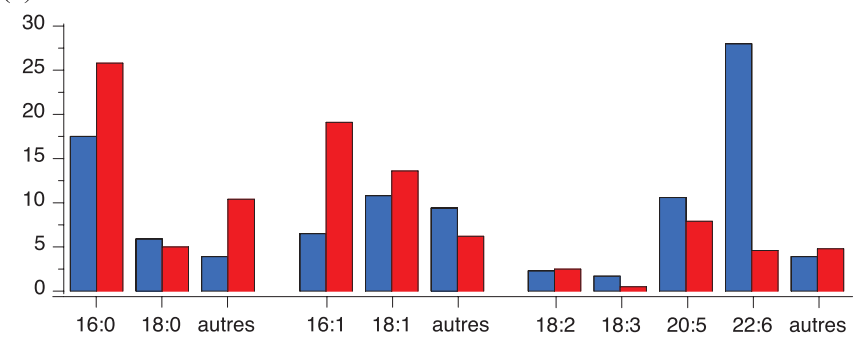

Fig. 1. Composition en acides gras saturés, monoinsaturés et polyinsaturés des phospholipides ( $P L$ ) et des triglycérides (TAG) d'anchois, de maquereau et de sardine (16:0 acide palmitique, 18:0 acide stéarique, 16:1 acide palmitoléique, 18:1 acide oléique, 20:5 acide eicosapentaénoique EPA, 22:6 acide docosanohexaènoique DHA).

- $14 \%$ d'insaponifiables, parfois pouvant aller jusqu'à $80 \%$.

La composition en acides gras des triglycérides est souvent considérée comme la composition en acides gras du poisson, négligeant ainsi les contributions des autres lipides, phospholipides et esters dont ceux de stérols ${ }^{\mathbf{2 1}}$.

Les acides gras des triglycérides présentent une distribution large, $\mathrm{du} \mathrm{C}_{14}$ au $\mathrm{C}_{22}$, pour les poissons de mers froides ou tropicales. Les acides polyinsaturés EPA et DHA, acides $\omega-3$, sont spécifiques aux poissons. Les poissons de mers chaudes contiennent plus d'acides saturés que ceux de mers froides, et moins d'acide 20:122. Les poissons des mers froides et tempérées sont

21. Étant donnée la forte proportion de phospholipides dans les poissons maigres, les compositions en acides gras sont donc à bien différencier, ce qui n'est pas le cas dans la littérature.

22. Pour le maquereau d'Atlantique nord $12 \%$ (Scomber scombrus), celui de Nouvelle-Zélande $6.2 \%$ (Trachurus declivis) et le flétan d'Inde $0.8 \%$ (Psettodes scombrus). généralement plus riches en EPA qu'en DHA dans un rapport EPA / DHA parfois supérieur à 30. L'acide arachidonique 20:4 est plus présent dans les espèces des mers chaudes. Enfin, les poissons d'eau douce ont une plus forte teneur en acides $\mathrm{C}_{16}$ et $\mathrm{C}_{18}$, et plus faible en $\mathrm{C}_{20}$ et $\mathrm{C}_{22}$ que les poissons d'eau de mer.

\subsubsection{Les stérols et leurs esters}

Comme pour tous les animaux, le cholestérol, libre ou estérifié, est le stérol très majoritaire des poissons et des coquillages. Dans les muscles des poissons, il représente 93 - $99 \%$ de l'insaponifiable, contre $26-96 \%$ pour les huîtres, crabes et crevettes (mais généralement en dessous de $50 \%$ ). Les poissons des mers tempérées contiennent 20 à $73 \mathrm{mg}$ de cholestérol / $100 \mathrm{~g}$ de chair fraîche, 20 à $110 \mathrm{mg}$ pour les poissons de rivière, et 90 à $170 \mathrm{mg}$ pour les crevettes. Les coquillages et les crustacés présentent des concentrations plus élevées, de 140 à $190 \mathrm{mg}$, alors que les plus fortes concentrations se trouvent dans la laitance $(790-1500 \mathrm{mg}$ ) et le foie (1 250 - $4250 \mathrm{mg} / 100 \mathrm{~g}$ ). Pour les poissons, les chairs dorsales blanches montrent une plus faible teneur en cholestérol que les muscles blancs ventraux, eux-mêmes que les muscles rouges.

\subsubsection{Autres lipides}

Les chairs des poissons contiennent des vitamines hydrosolubles de la famille des vitamines $\mathrm{B}^{23}$, et des vitamines liposolubles. La riboflavine et la niacine sont les plus abondantes, à des teneurs respectives de 0.22 $4.30 \mathrm{mg}$ et $0.15-5.97 \mathrm{mg} / 100 \mathrm{~g}$ chair fraîche pour les poissons de mer, $3.93-4.58 \mathrm{mg}$ et $5.71-6.12 \mathrm{mg} / 100 \mathrm{~g}$ pour les mollusques.

Les poissons contiennent aussi des vitamines liposolubles, A, D et E. Les foies de certains poissons, morue, flétan, thon, sont des sources essentielles de vitamine D (de 550 I.U. à 250000 I.U./g) et de vitamine E (18 - $45 \mathrm{mg} / 100 \mathrm{~g}$ huile de foie de morue). La vitamine $\mathrm{E}$ (tocophérols) est présente dans les chairs et l'huile de foie $(100-200 \mathrm{mg} / 100 \mathrm{~g} ; 6.3 \mathrm{mg} / 100 \mathrm{~g}$ dans la chair de thon).

Deux types de pigments sont présents : des pigments rouges caroténoïdes (astaxanthine et son dérivé d'oxydation l'astacine) présents dans les algues, le plancton et les organismes de la chaîne alimentaire, crevettes, crustacés, ou des poissons comme le saumon ou la truite arc-en-ciel. L'hémoglobine et la myoglobine

23. Les vitamines du groupe $B$ sont la thiamine $\left(B_{1}\right)$, la riboflavine $\left(\mathrm{B}_{2}\right)$, la niacine $\left(\mathrm{B}_{3}\right)$, la pyridoxine $\left(\mathrm{B}_{6}\right)$, l'acide pantothénique $\left(\mathrm{B}_{5}\right)$, la biotine $\left(\mathrm{H}\right.$ ou $\left.\mathrm{B}_{8}\right)$, l' acide folique $\left(\mathrm{B}_{9}\right)$, la cyanocobalamine $\left(\mathrm{B}_{12}\right)^{5}$. 
sont responsables de la couleur sombre de certaines chairs de poisson, atteignant des concentrations de 390 et $580 \mathrm{mg} / 100 \mathrm{~g}$ pour les muscles sombres du maquereau. La myoglobine de poisson est une protéine dont la structure est différente de celle que l'on trouve chez les mammifères. Elle est assez sensible aux dégradations, et réagit notamment avec la TMAO pour former un composé vert, observé lorsque les chairs de poisson se dégradent. Hémoglobine et myoglobine catalysent fortement les réactions d'oxydation, même si les poissons sont congelés.

Les crustacés et les mollusques ne contiennent ni hémoglobine ni myoglobine, mais l'hémocyanine, protéine cuivrée présente dans le sang des invertébrés qui joue un rôle similaire à l'hémoglobine.

Les acides biliaires, synthétisés par les organismes à partir du cholestérol, sont présents surtout chez les poissons d'eau douce, concentrés dans la vésicule biliaire. Lorsqu'un poisson entier est conservé sans être éviscéré, la vésicule finit par se rompre et rend impropre à la consommation toute la partie ventrale de l'animal. Ce phénomène ne se rencontre pas chez les poissons marins, notamment sardine, maquereau et thon, pour lesquels la vésicule est minuscule.

Parmi les hydrocarbures, le squalène est un composé particulièrement abondant dans les huiles de foie, notamment de requin. D'autres hydrocarbures comme le pristane $\mathrm{C}_{18} \mathrm{H}_{38}$ et le zamène $\mathrm{C}_{18} \mathrm{H}_{36}$ ont été identifiés pour les requins et les élasmobranches. Ces huiles peuvent renfermer jusqu'à $80 \%$ d'insaponifiable constitué de 7 à $90 \%$ de squalène suivant les espèces, et de $2-7 \%$ de pristane. Les huiles de foie et les viscères d'élasmobranches contiennent aussi des alcoxydiglycérides.

Les cérides constituent aussi une part importante des lipides du foie de certains poissons, notamment les mulets contenant $20-35 \%$ de lipides dont $90 \%$ de cérides. Ils proviennent de l'estérification d'alcools saturés à longue chaîne par des acides gras peu insaturés et constituent des marqueurs particulièrement stables dans le temps.

$\mathrm{Au}$ vu de ces résultats, il est impossible de définir le profil moléculaire d'un poisson. Chaque espèce montre des marqueurs en proportions différentes, mais variant aussi en fonction du sexe, de l'âge, de la saison. Cependant, on note que les protéines sont les principaux composants des muscles, associés aux lipides, triglycérides, phospholipides, stérols et hydrocarbures. Les muscles blancs se distinguent aussi des muscles sombres, et les viscères, notamment le foie, présentent des marqueurs chimiques mais aussi une flore bactérienne qui influe sur la décomposition du poisson.

\section{Analyse des poissons actuels}

\subsection{Méthodologie d'analyse pour les substances azotées}

Les protéines sont les secondes substances en importance dans le poisson, après l'eau. Ce sont des polymères organiques constitués d'un enchaînement d'acides aminés, les unités de base ou unités monomères. Ceux-ci sont au nombre de 22 et leur enchaînement constitue la séquence protéique, au même titre que le code génétique pour l'ADN. L'enchaînement de plusieurs acides aminés prend le nom de peptide, polypeptides pour quelques dizaines, puis de protéines pour des séquences plus longues. L'étude des protéines est une science très récente, la protéomique, qui a pour but ultime de déterminer la séquence entière d'une protéine. Cependant, les techniques analytiques ne permettaient pas, jusqu'à peu, d'obtenir un tel résultat. Aussi, mis à part les laboratoires spécialisés en spectrométrie de masse, on doit souvent se contenter d'informations partielles qui nécessitent des moyens bien moindres. L'information peut être obtenue à différents niveaux :

- la mesure de la teneur en azote, car chaque acide aminé comporte 1 à 3 atomes d'azote. Cependant l'azote peut provenir d'autres sources.

- des tests colorimétriques permettant de détecter la présence de protéines ${ }^{24}$.

- des analyses de la composition générale en acides aminés : l'échantillon est hydrolysé en totalité, transformant toutes les protéines et peptides en acides aminés. Le résultat est la composition globale en acides aminés mais aucune information n'est obtenue sur la séquence protéique. On peut discriminer certains matériaux protéiques mais la méthode ne permet d'en identifier aucun assurément. C'est la méthode la plus répandue en chimie alimentaire et les données publiées dans la littérature donnent principalement ces résultats.

- la détermination partielle d'une séquence protéique, par la méthode (ou dégradation) d'Edman. La méthode est limitée car elle demande une protéine purifiée, en quantité non négligeable, et ne peut permettre d'aller audelà de 8 acides aminés environ.

24. S'ils ont été développés pour la détection de protéines dans des couches picturales de peintures, les tests colorimétriques ne sont pas applicables aux échantillons archéologiques. Seul l'usage de réactifs fluorescents, plus sélectifs et sensibles et surtout qui permettent de s'abstraire de la couleur du prélèvement (généralement sombre et marron pour les matériaux organiques anciens), permettrait une détection efficace des protéines et des peptides. Nos recherches sont en cours. 
- les méthodes de protéomique, réalisées sur une protéine ou des mélanges de protéines, dégradées ou non, permettant $(i)$ d'obtenir un spectre de masse global par spectrométrie de masse MALDI-TOFMS, (ii) de caractériser plus précisément peptides et protéines digérées en les séparant un à un par chromatographie en phase liquide à l'échelle nano (nanoLC) et en caractérisant chaque entité préalablement séparée par son spectre de masse obtenu par spectrométrie de masse tandem MS/ MS. En déterminant la séquence de chaque fragment digéré, la séquence protéique totale d'une protéine peut être reconstituée. La confrontation des séquences avec les bases de données internationales disponibles on line permet d'identifier la protéine en question et l'espèce dont elle provient.

\subsection{Les analyses élémentaires : la teneur en azote}

Pour tous les matériaux azotés, il est de coutume de mesurer le taux d'azote total par la méthode de Kjeldahl ${ }^{25}$. La méthode consiste à minéraliser tout l'azote présent dans l'échantillon et à le doser sous forme d'ammoniac. Conventionnellement, on admet que toutes les protéines renferment $16 \%$ d'azote, permettant ainsi de remonter au taux de protéines du milieu. La méthode a deux limites : d'une part la teneur en azote des protéines varie de 14 à $18 \%{ }^{26}$; d'autre part, l'azote peut provenir de sources non protéiques, soit organiques (amides, nitriles, amines biogènes...) soit minérales (ammonium, nitrates, nitrites, etc.). Dans une étude plus complète, Aqueretta et al. ont pu déterminer les taux d'azote total (méthode Kjeldahl), d'azote non protéique (méthode Kjeldahl après précipitation des protéines), d'azote provenant d'acides aminés libres (méthode de Massi) et d'azote basique volatil (méthode de Malle et Tao) pour différentes sauces de poissons.

Etant donné la complexité des échantillons archéologiques et notamment la part totalement aléatoire de fraction minérale (dépendant tant du milieu d'enfouissement que des méthodes de prélèvement), il est illusoire de vouloir appliquer la simple méthode de Kjeldahl à

\section{Kjeldahl 1883.}

26. Le taux de protéines est déduit du taux d'azote total en multipliant le résultat par 6.25. Or les différentes protéines musculaires ont des compositions différentes, des propriétés chimiques et biochimiques différentes, mais leur taux d'azote est assez proche, entre 15 et $17.6 \%$, avec une moyenne de $16 \%$ (d'où le facteur 6.25). Cependant pour la myosine, principale protéine musculaire, ce facteur est de 6.0. Le collagène, principale protéine de la peau mais présent aussi dans les chairs, le taux d'azote est le plus haut, $18 \%$ (soit un facteur de 5.5). En moyennant les rapports, on admet qu'un facteur 6.25 est un bon compromis mais le résultat doit être considéré comme un indice approximatif. ce type d'échantillons anciens, résidus ou imprégnations de céramique. L'analyse élémentaire et la détermination du taux d'azote total d'un échantillon n'ont que peu de valeur informative et tout usage n'en est que surinterprétation, pour l'identification des matériaux organiques anciens. Les protocoles mis en œuvre par Aqueretta et al. donnent des renseignements plus sûrs mais ne sauraient remplacer l'analyse structurale, i.e. l'identification certaine des marqueurs conservés, un à un.

\subsection{Les analyses structurales de composés azotés}

\subsubsection{Les acides aminés}

Jusqu'à peu, les protéines ne pouvaient être analysées directement et devaient être hydrolysées totalement en leurs unités constitutives, les acides aminés, par un traitement en milieu acide fort. Les acides aminés ainsi libérés sont ensuite purifiés et analysés généralement par chromatographie en phase liquide. Un premier cas d'étude d'acides aminés provenant d'un objet archéologique était l'analyse d'une concrétion calcitique conservée au fond d'un vase en verre d'une tombe d'Axum ${ }^{27}$, permettant d'identifier des résidus de peau et de poils d'animaux; les résultats ont cependant été surinterprétés en allant jusqu'à l'identification de poils de glandes de civette, car les compositions en acides aminés des tissus kératinisés sont trop proches les unes des autres pour les différents animaux.

Différent poissons fermentés traditionnellement préparés en Asie du Sud-Est et en Afrique ont été analysés, en comparaison avec les produits végétaux similaires à base de soja ${ }^{28}$. Les composés trouvés dans les sauces de poissons et les pâtes de crevettes sont très proches de ceux identifiés dans les sauces soja et la pâte de soja fermentée, le miso. Toutes sont riches en sel (chlorure de sodium) et en acides aminés. Dans une reconstitution de garum $^{29}$, Aquerreta et al. déterminèrent que la protéolyse avait lieu surtout pendant les 24 premières heures, en présence d'enzymes. Hjalmarsson et al. n'ont pu analyser que la pêche d'hiver de capelans (Mallotus villosus) et non celle d'été, car les poissons d'été, abondamment nourris de plancton, sont beaucoup plus riches

27. Éthiopie, VIe s. ap. J.-C. ; von Endt 1976.

28. Mizutani et al., 1992.

29. Le « garum » est fabriqué à partir de foie et de viscères de thon (Tunnus thynnus) et de maquereau (Scomber scombrus), d'origan, de coriandre et de thym, auxquels sont ajoutées des enzymes protéolytiques commerciales (Fungal Protease P31000, Alcalse 2.4L, Kojizyme MG, Trypsin PTN 3.0 ou Neutrase 0.5L), ainsi que des antioxydants (acide citrique, butyl-hydroxyanisole = E320 et butylhydroxytoluène $=\mathrm{E} 321)$ et du sel (14\% en valeur optimisée). 
en enzymes protéolytiques; le poisson à peine pêché commence déjà à se décomposer ${ }^{30}$. Les enzymes protéases comme les cathepsines sont surtout actives au début de la fermentation ${ }^{31}$ avant que les enzymes exogènes prennent le relai. Ainsi, les poissons dont les entrailles sont riches en enzymes, à savoir ceux péchés l'été, sont plus adaptés à la production de garum. Ijong et Ohta observaient que le même phénomène d'hydrolyse des protéines se produisait pendant 40 jours pour la fermentation du bakasang (sauce de poisson traditionnelle d'Indonésie, non ensemencée par des enzymes exogènes). A la fin du processus, la quasi-totalité des protéines sont hydrolysées en acides aminés. Les acides aminés majoritaires sont :

- l'acide glutamique, la leucine, la lysine, l'arginine, l'alanine, la valine et la taurine pour la sauce de thon skipjack $^{32}$,

- l'alanine, l'isoleucine, l'acide glutamique et la lysine pour le bakasang indonésien ${ }^{33}$,

- l'acide glutamique / glutamine, l'acide aspartique, l'arginine, la lysine, le leucine, l'isoleucine, la valine et la tyrosine pour le « garum » d'Aquerreta ${ }^{34}$,

- les acides aspartique et glutamique, la leucine, l'isoleucine, et la lysine, la sérine, la glycine, la thréonine, la valine pour la sauce de capelan d'été (72.9 mg d'acides aminés / $g$ de sauce) ${ }^{35}$.

Contrairement aux dérivés de soja fermentés, les produits à base de poissons ne contiennent de substances ni aigres ni douces. L'acide glutamique, principal responsable du goût umami, se retrouve dans tous les produits du poisson ; produit d'hydrolyse des protéines, il est suffisamment stable pour ne subir aucune réaction de dégradation secondaire lors de la fermentation. En revanche, la proline, l'arginine et la sérine, constitutives en partie des protéines de poisson, sont souvent absentes des sauces commerciales. Enfin, les acides aminés libérés lors de l'hydrolyse des protéines musculaires du poisson peuvent aussi subir des dégradations partielles comme c'est le cas de l'histidine partiellement transformée en histamine. La réaction se produit dès que le poisson est pêché, même conservé dans la glace, et surtout lors de la fermentation (sauce d'anchois Stolephorus sp. appelée nampla en Thaïlande, Brillantes et al., 2002). De grandes concentrations de sel peuvent cependant inhiber la croissance des micro-organismes responsables de la

30. Hjalmarsson et al., 2007.

31. Tungkawachara et al., 2003.

32. Cha, Cadwallader 1998.

33. Ijong, Ohta, 1996.

34. Aquerreta et al. 2002.

35. Hjalmarsson et al. 2007. décarboxylation de l'histidine en histamine ${ }^{36}$, mais audelà de 2 mois de fermentation, la concentration en sel est stable $(28-30 \%$ pour les sauces de viscères de thon Thai $\left.{ }^{37}\right)$.

\subsubsection{Protéines et peptides}

Durant la fermentation du poisson et sa transformation en garum, les protéines musculaires se dissolvent au fur et à mesure de leur hydrolyse progressive en peptides puis en acides aminés. Appeler les sauces de poissons des «fractions riches en protéines solubles ${ }^{38}$ n'est donc pas totalement exact, car en fin de fabrication, les protéines sont en grande partie hydrolysées. À la fin du processus, les composés azotés sont surtout des acides aminés libres et quelques peptides résiduels ${ }^{39}$ qui interagissent avec les sucres réducteurs du milieu pour donner des composés de couleur brune, par réaction de Maillard. Une petite quantité de sucres suffit à initier la réaction qui se propage ensuite ${ }^{40}$. Certains acides aminés se dégradent, notamment pour donner des pyrazines, qui réagissent à leur tour, accentuant la coloration brune du mélange par un procédé non-enzymatique mais chimique ${ }^{41}$.

La réaction de protéolyse peut aussi être suivie en mesurant l'activité des bactéries protéolytiques et des bactéries halophiles. Elle décroît tout au long de la fermentation, atteignant un seuil de non détection au-delà de 20 jours pour les sauces à base de poissons blancs du Pacifique ${ }^{42}$, et de 5 mois pour une sauce à base de viscères de thon de Thailande ${ }^{43}$. Le taux d'azote total indiquerait que la fermentation est achevée en 4 mois ; le taux d'azote aminé mesuré par titrage au formol, traduit que l'hydrolyse des protéines est assurée à la fois par des enzymes endogènes et des protéinases bactériennes qui se développent dans le milieu ${ }^{44}$. Étant donné que la concentration en sel est constante ${ }^{45}$ au bout de 2 mois puis que l'activité des bactéries protéolytiques et halophiles devient indétectable après 5 mois, l'on pourrait déduire que la concentration en protéines et en peptides, substrats des bactéries, est devenue nulle. Aucune mesure

\footnotetext{
36. Sanceda et al. 1999.

37. Dissaraphong et al. 2006.

38. Hjalmarsson et al. 2007.

39. Dissaraphong et al. 2006.

40. Kawashima, Yamanaka 1996.

41. Hjalmarsson et al. 2007.

42. Lopetcharat, Park 2002.

43. Dissaraphong et al. 2006.

44. Lopetcharat, Park, 2002.

45. Écartant ainsi l'hypothèse que la baisse d'activité des enzymes est due à une concentration en sel devenue trop forte.
} 
directe de la concentration en protéines n'a été réalisée, et ne peut l'être réellement car le résultat obtenu traduit à la fois la teneur en protéines non hydrolysées du poisson mais aussi en celles de tous les micro-organismes qui se sont développés pendant la fermentation - comme d'ailleurs le montre le taux d'azote total, toujours croissant. Dans une sauce de poisson préparée à partir de capelan pêché en Arctique (Mallotus villosus, poisson réputé pour ne pas se décomposer facilement et donc ne pas pouvoir donner de sauce de poisson) ensemencé par du foie de morue riche en enzymes protéases comme la trypsine, le taux d'hydrolyse des protéines atteint $60-70 \%$ au bout de 6 mois ${ }^{46}$. Autant dire que pour des poissons qui s'autolysent facilement, l'hydrolyse est quasi-totale. La probabilité de retrouver un peptide est très faible, un fragment conséquent de protéine quasi nul. ${ }^{47}$

De récentes études ont porté sur la caractérisation des entités peptidiques non totalement hydrolysées (peptides et protéines). Plusieurs peptides ont été isolés à partir de sauces d'anchois, de sardine et de bonito : 14 dipeptides (de 1 à $42 \mu \mathrm{mol} / \mathrm{L}$ ) et seulement 1 tripeptide $(4 \mu \mathrm{mol} / \mathrm{l})^{48}$. Récemment, nous avons développé une méthodologie fondée sur l'analyse protéomique, qui permet de caractériser des polypeptides sans hydrolyser totalement les protéines en acides aminés. La méthode a fait ses preuves pour l'identification d'espèces à partir de colles de poissons utilisées pour la polychromie de sculptures anciennes ${ }^{49}$. Afin d'évaluer son potentiel pour des échantillons archéologiques de type amphore, nous avons étudié (1) de filets de poisson frais ou séché, (2) et des imprégnations de ces mêmes chairs en début de décomposition sur des céramiques ${ }^{50}$. L'extraction couplée à une digestion sélective permet d'extraire des peptides qui sont ensuite séparés et identifiés par nanoLCnanoESI MS. La méthode a ainsi permis d'identifier des peptides génériques des poissons (fragments de myosine), mais aussi des séquences spécifiques à la bonite et à la sardine. Si la méthode a montré tout son potentiel pour des poissons pris séparément ou en mélange, il semble que le processus de fermentation du poisson et l'hydrolyse quasi totale des liaisons peptidiques soient un obstacle à toute identification de peptides dans des sauces de poissons modernes ou anciennes.

46. Gildberg 2001.

47. Pour un taux d'hydrolyse des protéines (donc des liaisons peptidiques) de $70 \%$, la probabilité de retrouver un dipeptide est de $30 \%$, un tripeptide $0.3^{2}=9 \%$, un tétrapeptide $0.3^{3}=2.7 \%$... un peptide à 10 acides aminés $0.3^{9}=0.0019 \%$.

48. Ichimura et al. 2003.

49. Dallongeville et al. 2012.

50. Dallongeville et al. 2011.

\subsection{Méthodologie d'analyse pour les lipides}

Les protocoles d'extraction et d'analyse des fractions lipidiques provenant d'échantillons archéologiques (résidus ou imprégnations invisibles de supports poreux minéraux) sont largement décrits dans la littérature et notamment résumés dans la revue Regert, 2010. Ils sont appliqués aux matériaux biologiques modernes afin de les valider pour la recherche de tel ou tel marqueur, et de construire des bases de données de composition chimique, profils chromatographiques et spectres de masse des marqueurs d'intérêt. La figure 2 montre par exemple l'analyse de la fraction de lipides solubles extraits de filets de saumon frais, où l'on identifie les marqueurs cités précédemment: le cholestérol, phosphate et glycérophosphate, et les acides gras présents en faible quantité sous forme libre, de monoglycérides (MAG) ou d'éthanolamines acétylées. La composition globale en acides gras ne s'obtient qu'après saponification ou transestérification, directement de la chair, telle qu'elle a été obtenue pour un filet de bonite séché suivant les méthodes traditionnelles du nord du Maroc (Ceuta, fig. 3). On remarque que les acides isoprénoïdes ${ }^{51}$ utilisés comme marqueurs des espèces marines sont absents des deux extraits lipidiques. Des travaux récents que nous avons menés récemment au sein du LNG sur les huiles végétales et sur les produits laitiers ont révélé la présence de ces acides, principalement l'acide phytanique. Un autre acide isoprénoïque, l'acide 5,9,13-triméthyltétradécanoique (TMTD) a été identifié dans les éponges marines (comme les deux autres cités précédemment), mais aussi dans le lait humain et des sédiments contenant un Mycobacterium ${ }^{52}$. Aussi l'acide phytanique est présent non seulement chez les poissons et les mammifères marins, mais aussi chez le mouton, le bœuf, les matières grasses (nous préciserons de ruminants), les bactéries halophiles ; et l'acide 4,8,12-TMTD chez le hareng, la graisse de phoque, la graisse de mouton et des échantillons géologiques ${ }^{53}$. C'est dire que l'interprétation des acides isoprénoïdes est plus délicate qu'elle n'a été présentée jusqu'à présent. La présence des acides phytanique, 4,8,12-TMTD et 5,9,13-TMTD comme marqueurs des espèces marines serait à prendre avec précaution et à reconsidérer.

51. Les deux acides phytanique (ou 3,7,11,15-tetraméthylpalmitique) et 4,8,12-TMDT (ou 4,8,12-triméthyltridécanoïque). Références citées dans Regert 2010.

52. Barnathan et al. 1992.

53. Carballeira et al. 1987. 

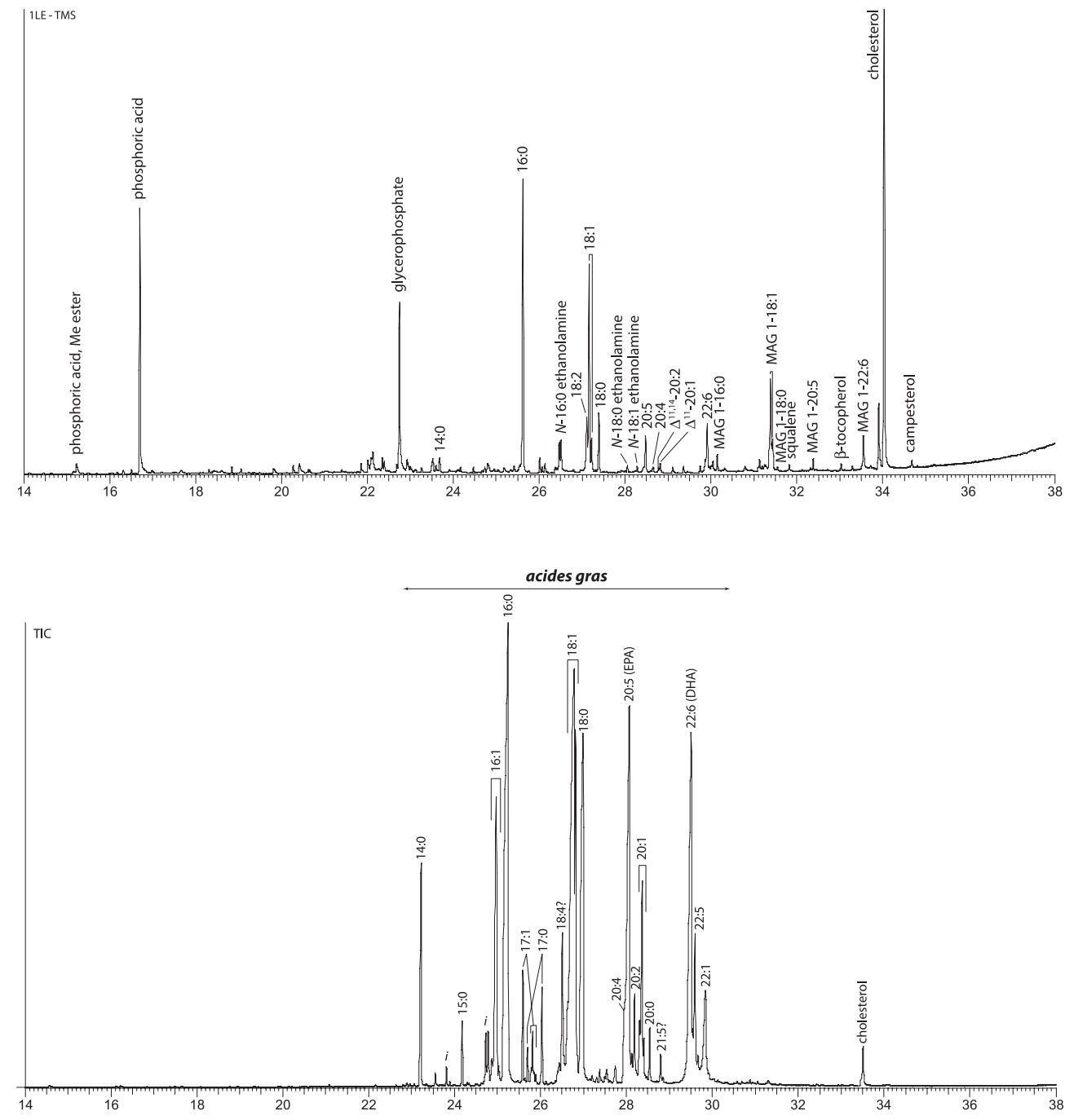

Fig. 2. Exemple d'analyse de la fraction lipidique soluble telle qu'utilisée pour les échantillons archéologiques, et appliquée à un filet de saumon actuel.
Fig. 3. Exemple d'analyse de la fraction lipidique soluble telle qu'utilisée pour les échantillons archéologiques, et appliquée à un filet de bonite à dos rayé (Sarda sarda séché et consommé traditionnellement à Ceuta).
L'analyse des triglycérides sous leur forme native est beaucoup plus délicate. En effet, la large distribution des acides gras (de 30 à 60 acides gras différents) et notamment leur degré d'insaturation très variable rendent le profil des triglycérides très complexe, conduisant jusqu'à plus de 5000 structures de triglycérides possibles. Les triglycérides ne peuvent pas être analysés par les méthodes classiques d'analyse par chromatographie en phase gazeuse couplée à la spectrométrie de masse (GC-MS, gas chromatography - mass spectrometry) en raison de leur haut poids moléculaire, et donc de leur faible volatilité. Les molécules doivent être séparées à l'état de solution par chromatographie en phase liquide (LC, liquid chromatography), couplée à la spectrométrie de masse (LC-MS). La chromatographie liquide sur colonne d'ions $\mathrm{Ag}^{+}$est souvent utilisée pour séparer les molécules suivant leur degré d'insaturation ${ }^{54}$. Les longs temps de séparation par chromatographie, l'usage de solvants souvent incompatibles avec la spectrométrie de masse (ex. hexane), et le relargage progressif des ions $\mathrm{Ag}^{+}$rendent le couplage LC-MS difficile. Récemment, nous avons développé des méthodes d'analyses n'utilisant que la spectrométrie de masse ${ }^{55}$. La spectrométrie de masse tandem, ou MS/MS, permet de séparer les molécules par leur masse dans une première expérience MS, au lieu de les séparer par chromatographie ; dans une seconde étape, les ions sélectionnés par leur masse sont fragmentés et analysés en spectrométrie de masse (mode MS/MS). Plusieurs modes d'ionisation douce sont utilisés: l'APCI (atmospheric pressure chemical ionization) ou l'electrospray (ESI) soit en solution acidifiée donnant les ions $[\mathrm{M}+\mathrm{H}]^{+}$et les adduits avec les ion sodium $[\mathrm{M}+\mathrm{Na}]^{+}$, soit par cationisation en rajoutant des ions comme le lithium notamment. Les ions $[\mathrm{M}+$ 


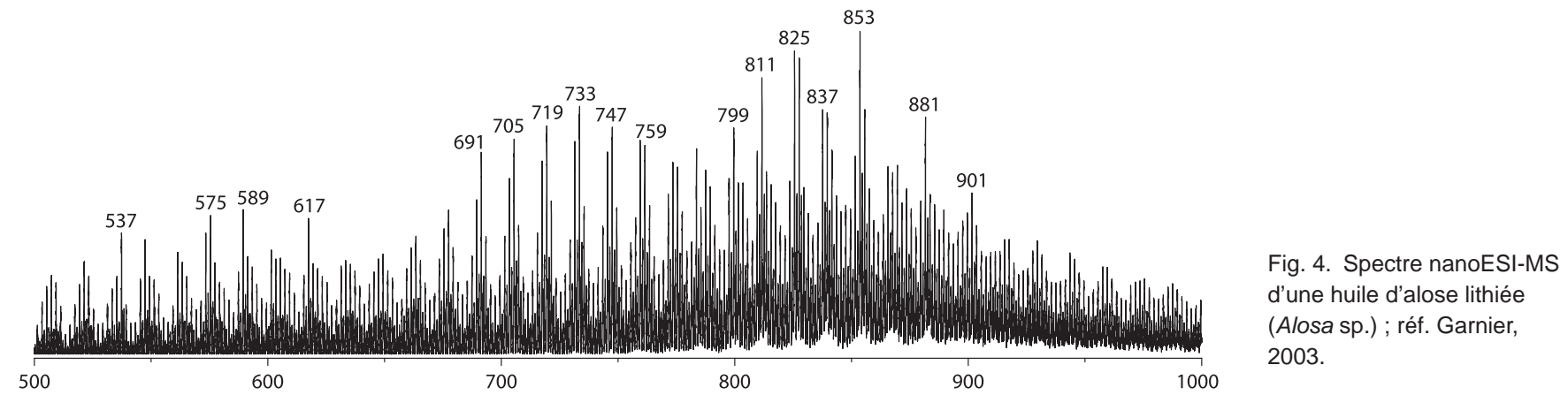

Li] ${ }^{+}$formés sont très stables et donnent des fragmentations simples, démarche très utile pour des mélanges très complexes comment c'est le cas des huiles de poissons. (fig. 4)

Malheureusement, ces approches qui livrent des informations très riches et précises pour les huiles de poissons actuelles ne peuvent pas être appliquées aux échantillons archéologiques car les triglycérides sont très rapidement hydrolysés en acides gras lors de l'enfouissement. En effet, nous avons effectué des tests sur un poisson frais (bonite, Sarda sarda) laissé quelques jours à température ambiante. L'extraction de la peau et de la chair du poisson laissée 2 semaines à température ambiante a montré que tous les triglycérides avaient déjà disparu, alors que le poisson avait encore conservé tout son aspect. Il semble donc que les triglycérides fortement insaturés des poissons soient très sensibles aux réactions d'hydrolyse. Cette observation a été confirmée par l'analyse de différents produits actuels : sauce nuoc-mâm commerciale, colatura di alici de Cetara et garum préparé à partir de sardines (recette préparée par Emmanuel Botte, inédite). Aucun de ces produits n'a révélé la présence de triglycérides. Aussi, Ohshima et $a l$. ont comparé la dégradation de différents mélanges de cholestérol, de triglycéride pur (trioléine utilisée comme modèle, marqueur majoritaire de l'olive) et d'huile de foie de morue fraîchement extraite et purifiée. Le cholestérol et la trioléine, ainsi que le mélange des deux, s'oxydent assez lentement. En revanche, l'huile de poisson s'oxyde très rapidement car les acides polyinsaturés constitutifs nécessitent des temps d'induction de la réaction d'oxydation radicalaire très courts par rapport aux acides di- et triinsaturés (acides linoléique et linoléique respectivement). Au bout de 37 jours à $25^{\circ} \mathrm{C}$, les acides polyinsaturés ont totalement disparu, que ce soit sous forme estérifiée (glycérides) ou libre; aussi, ils présentent un degré d'oxydation très élevé, correspondant à la formation de leurs produits de dégradation. Seul le « garum » préparé par Aquerreta et al. en 48 h en ensemençant les déchets de poissons avec des enzymes protéolytiques montre une forte teneur en acides gras polyinsaturés, et plus généralement en matière grasse (10.2\% pour le « garum » d'Aquerreta $; 6-11 \%$ pour la sauce de viscères de thon coréenne skipjack ${ }^{56} ; 0.06 \%$ pour le Nuoc-mam commercial). L'hypothèse formulée par Aquerreta d'utilisation de poissons non gras ou encore une étape de délipidification de la sauce obtenue serait probablement à revoir au profit du mode de fabrication : un processus rapide en $48 \mathrm{~h}$ évite l'oxydation des lipides, alors que le processus lent par fermentation naturelle et autolyse du poisson en plusieurs semaines conduit inévitablement en parallèle à l'oxydation naturelle des lipides insaturés.

Une autre étude a montré la conservation d'une série d'acides gras aromatiques dits $\omega$-(o-alkylphényl)alcanoïques dans des résidus carbonisés sur plusieurs sites ${ }^{57}$. Ces acides, absents des poissons, sont des marqueurs de dégradation des acides polyinsaturés. Ils ne seraient pas formés par isomérisation des acides polyinsaturés au contact de la céramique ${ }^{58}$ mais par isomérisation lors du chauffage intense de résidus alimentaires (au-delà de $270^{\circ} \mathrm{C}$ ), sans influence de la céramique ${ }^{59}$. En l'occurrence, ces acides ont peu de chance d'être retrouvés dans les sauces de poissons car le poisson n'est jamais chauffé pour obtenir le garum, tout au moins jamais au point d'être carbonisé. Il pourrait l'être dans le cas de l'allex, si le mélange a « accroché » au fond du récipient de chauffe.

Compte tenu de l'oxydation rapide des acides gras polyinsaturés et de leur solubilité dans l'eau, favorisant leur perte par lessivage du milieu d'enfouissement depuis la déposition de l'objet, nous avons orienté nos recherches vers d'autres marqueurs plus pertinents et

56. Cha, Cadwallader 1998.

57. Craig et al. 2007.

58. Hansel et al. 2004.

59. Craig et al. 2007. 
surtout plus stables dans le temps pour être retrouvés malgré la décomposition du poisson et l'enfouissement dans le sol, en milieu humide notamment. Les travaux récents menés sur l'huile d'olive conservée dans les amphores «à huile » des épaves gallo-romaines d'Arles 3 et de Lyon-Parc Saint-Georges ont montré aussi que la conservation des acides gras était assez aléatoire suivant les conditions de milieu ${ }^{60}$. En revanche, les stérols, molécules neutres et non-ionisables au contraire des acides gras, sont systématiquement conservés et constituent des marqueurs beaucoup plus fiables que les acides gras. Cet axe de recherche a été privilégié pour les échantillons archéologiques de référence ( $\mathrm{cf} 4$.).

\subsection{Les analyses isotopiques}

En complément de l'analyse structurale, les rapports isotopiques du carbone et de l'azote, notés respectivement $\delta{ }^{13} \mathrm{C}$ et $\delta{ }^{15} \mathrm{~N}$, peuvent être mesurés soit sur l'échantillon global (ou l'extrait lipidique total), soit par couplage à la chromatographie en phase gazeuse (couplage GC-CIRMS) pour chaque acide gras. Cependant l'analyse par couplage demande une quantité suffisante de matière et une préparation assez fastidieuse des échantillons. Par conséquent, seuls les rapports isotopiques des acides gras majoritaires, à savoir les acides palmitique (16:0) et stéarique (18:0), sont habituellement mesurés. Comme pour la mesure de la teneur en azote (cf 1.3), les rapports $\delta{ }^{13} \mathrm{C}$ et $\delta{ }^{15} \mathrm{~N}$ peuvent être grandement faussés par des pollutions environnementales ou encore la diagenèse de la matière organique sédimentaire. Pour cela, l'échantillonnage et les prélèvements doivent être conduits avec beaucoup de rigueur; seul le cœur des prélèvements est analysé. L'analyse globale du $\delta{ }^{13} \mathrm{C}$ permet cependant de classer les échantillons avant une analyse par GC-CIRMS plus précise, de repérer des sources pélagiques, et par couplage aux données de l'analyse globale du $\delta{ }^{15} \mathrm{~N}$, de distinguer parfois des sources de poissons d'eau douce ${ }^{61}$.

Dans un second temps, l' analyse $\delta{ }^{13} \mathrm{C}$ des acides palmitique et stéarique permet non seulement de distinguer les sources animales et végétales, mais aussi au sein du règne animal par exemple, de distinguer les animaux ruminants, les non ruminants et les poissons ${ }^{62}$. Aussi les poissons d'eau douce présentent un rapport $\delta{ }^{13} \mathrm{C}$ de -31 à $-32 \%$ pour l'acide palmitique, alors que les poissons

60. Garnier 2011.

61. Craig et al. 2007.

62. Id. d'eau de mer ont un rapport $\delta{ }^{13} \mathrm{C}$ de -24 à $-25 \%$ pour le même acide.

Bien que très informatives, les analyses isotopiques de GC-C-IRMS sont assez peu souvent mises en œuvre car la matière organique conservée sous forme d'imprégnations des parois des vases en céramique est souvent insuffisante pour effectuer l'analyse, la technique GC-CIRMS étant beaucoup moins sensible que les techniques de GC-MS ou de nanoESI-MS. Aussi les résultats ne sont pertinents que pour des dépôts uniques ou des mono usages de récipients, car si plusieurs sources sont mélangées ou leurs dépôts superposés, les rapports isotopiques mesurés sont moyennés et difficiles à interpréter.

\section{Analyses d'échantillons archéologiques}

Les exemples d'étude d'échantillons de sauces de poisson anciens sont encore rares. Les analyses élémentaires d'azote n'ont jamais été employées à cette fin. Seules les analyses structurales ou isotopiques par couplage GC-C-IRMS plus pertinentes ont permis d'apporter des arguments convaincants pour l'identification du garum.

\subsection{Les analyses structurales des composés azotés}

\subsubsection{Les analyses d'acides aminés}

Partant du principe que le collagène est bien conservé dans les échantillons anciens et sert en analyse de routine pour la datation au ${ }^{14} \mathrm{C}$ ou la détermination des rapports isotopiques de $\delta{ }^{13} \mathrm{C}$ et de $\delta{ }^{14} \mathrm{~N}$, Evershed et al. ont étudié une série des céramiques culinaires médiévales (site de West Cotton à Raunds, U.K. ${ }^{63}$ ). Ils concluent que les protéines semblent s'adsorber beaucoup moins bien que les lipides dans les parois des vases, et que les acides aminés sont moins bien conservés que leurs marqueurs lipidiques du fait de leur solubilité dans l'eau et de leur sensibilité vis-à-vis du chauffage.

Plus récemment, dans le péristyle de la «boutique du garum » de Pompéi (I, 12,8), au-moins deux des six dolia en place contenant des ossements séchés et désarticulés d'anchois ont été prélevés. Seules les analyses élémentaires (teneurs $\mathrm{Na}, \mathrm{K}, \mathrm{P}$ et $\mathrm{Ca}$ ) et des acides aminés libres ont été menées sur le dépôt, montrant que 7 des 22 acides aminés sont conservés, l'acide glutamique et la glycine étant les plus abondants ${ }^{64}$. Excepté

63. Evershed, Tuross 1996.

64. Smriga et al. 2010. 
la lysine, tous sont aussi majoritaires dans les sauces de poissons actuelles. Malgré le chauffage des dépôts lors de l'éruption du Vésuve (vers $300-400{ }^{\circ} \mathrm{C}$ environ), la dissolution partielle des acides aminés solubles postfouilles et l'activité microbienne, les auteurs concluent à un condiment au goût umami, probablement une sauce de poisson. Les acides aminés sous forme de peptides ou de protéines n'ont pas été recherchés, limitant ainsi la portée de l'étude.

\subsubsection{Les analyses protéomiques}

La protéomique étant un domaine de recherche très récent et maîtrisé par de rares laboratoires, seule une étude concluante a été menée sur des échantillons archéologiques, à savoir des céramiques Punuk du XIII ${ }^{e}$ - XIV ${ }^{\mathrm{e}}$ s. provenant de Point Barrow en Alaska. Un peptide provenant de la myoglobine de phoque a pu être identifié, et plusieurs fragments protéiques spécifiques aux cétacés et pinnipèdes. Cependant, les conditions d'enfouissement (permafrost, précipitations très faibles) étaient idéales pour la conservation des biomatériaux et sont loin de correspondre aux résidus imprégnés dans des parois d'amphores ou de dolia, parfois entiers comme à Pompéi mais le plus souvent retrouvés fragmentaires et exposés aux dégradations microbiennes.

\subsection{Les analyses structurales de lipides}

Les études conduisant à l'identification des espèces pélagiques sont peu nombreuses car les critères d'identification des poissons et de leurs dérivés sont encore assez mal établis. L'étude de caramels alimentaires adhérant à des tessons de céramiques du $\mathrm{I}^{\mathrm{er}}-\mathrm{II}^{\mathrm{e}}$ s. ap. J.-C. provenant d'un établissement rural de la Roche-sur-Yon ${ }^{65}$ a révélé la présence d'acides isoprénoïdes associés au phytol (fig. 5). L'absence de phytostérols permet d'éliminer toute source végétale et conforte l'hypothèse d'une matière grasse d'origine animale. L'absence des séries d'acides impairs en $\mathrm{C}_{15}$ et $\mathrm{C}_{17}$, linéaires et ramifiés, permet d'écarter les produits laitiers. L'acide phytanique est associé au phytol, à l'acide TMTD à l'état de traces, et au cholestérol, allant dans le sens de dérivés de poissons d'après les données fournies par la littérature ${ }^{66}$. Cependant, d'après nos observations et études comparatives des poissons, des huiles végétales et des produits laitiers, ces arguments sont à prendre avec prudence.

65. Fouilles du site «Maisons neuves des Landes 3 » et rapport: ArchéoLoire, 2012, resp. Yann Bière, analyses organiques N. Garnier. 66. Craig et al. 2007 ; Regert 2010.
D'autres marqueurs de poissons ont été identifiés dans un entonnoir associé à une amphore à poissons provenant des fouilles de San Fernando dans la baie de Cadix (resp. D. Bernal Casasola) : les acides polyinsaturés EPA (20:5) et DHA (22:6) révèlent que les parois de l'entonnoir ont été imprégnées par un fluide à base de poisson ${ }^{67}$, dont la composition en acides gras, notamment en acides polyinsaturés, est assez proche du garum de thon préparé et analysé par Aqueretta et al. ${ }^{68}$ Les deux acides gras EPA et DHA associés sont assez spécifiques pour permettre une identification sûre dans ce cas.

Afin de tenter de définir une signature des sauces de poissons, nous avons analysé une série d'échantillons de référence : résidus au fond de cuves ayant servi à la fabrication du garum de Nabeul ${ }^{69}$, des amphores à poissons Dr. $7 / 11$ provenant de Pompéi ${ }^{70}$. Alors que les profils chromatographiques de ces échantillons sont assez différents, notamment quant à la distribution mais aussi la présence ou non des acides gras, tous présentaient un massif de stérols assez similaire. Le cholestérol domine souvent, associé à des marqueurs de dégradation, cholestènes, cholestadiènes et cholestatriènes (fig. 6). Le cholestérol subit une première déhydratation pour donner principalement le cholest-3-ène et le cholest-4-ène. Ce premier, le plus stable, est peu observé alors que le cholest-2-ène, beaucoup moins stable thermodynamiquement, se trouve en proportions plus importantes. Ce profil typique semble être caractéristique des sauces de poissons fermentées et se distingue des profils des graisses chauffées. En plus du profil de stérols identique pour tous les échantillons, on retrouve aussi les acides phytaniques à l'état de traces. Ce faisceau d'informations confirme la présence de dérivés de poissons. Le référentiel a été enrichi par l'étude de pots du Latium provenant de l'épave Arles 2. L'identification de marqueurs de poissons a été confirmée par l'étude ichtyologique menée par $\mathrm{G}$. Piquès qui a révélé du maquereau, dont le décompte précis des vertèbres démantelées a permis d'identifier deux individus ${ }^{71}$. La méthode proposée ici permet donc de détecter des traces de sauces de poissons dans des récipients poissés, les constituants de la poix ne perturbant ni l'extraction ni l'identification des marqueurs de poissons.

67. Garnier 2006.

68. Aqueretta et al. 2002.

69. Fouilles de M. Bonifay. Étude du contenu des cuves étudié et publié par Sternberg 2000.

70. Matériel étudié par E. Botte.

71. Voir la contribution de Djaoui et al. dans ce volume. 


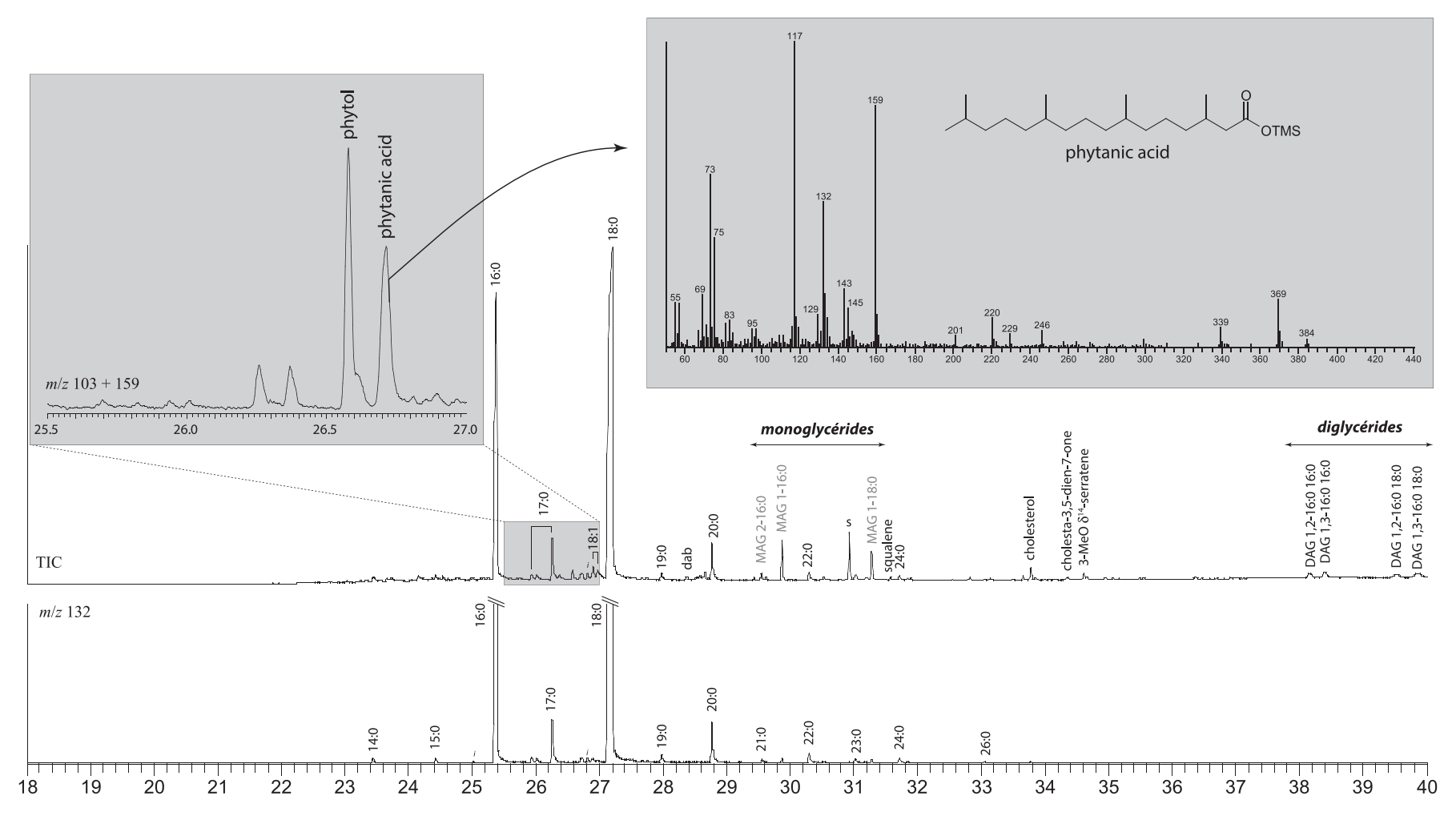

Fig. 5. Chromatogramme de l'extrait lipidique d'un caramel alimentaire conservé dans une céramique culinaire (Maisons Neuves des Landes 3 , La Roche-sur-Yon, fouilles ArchéoLoire, ler - Ile s. ap. J.-C.).

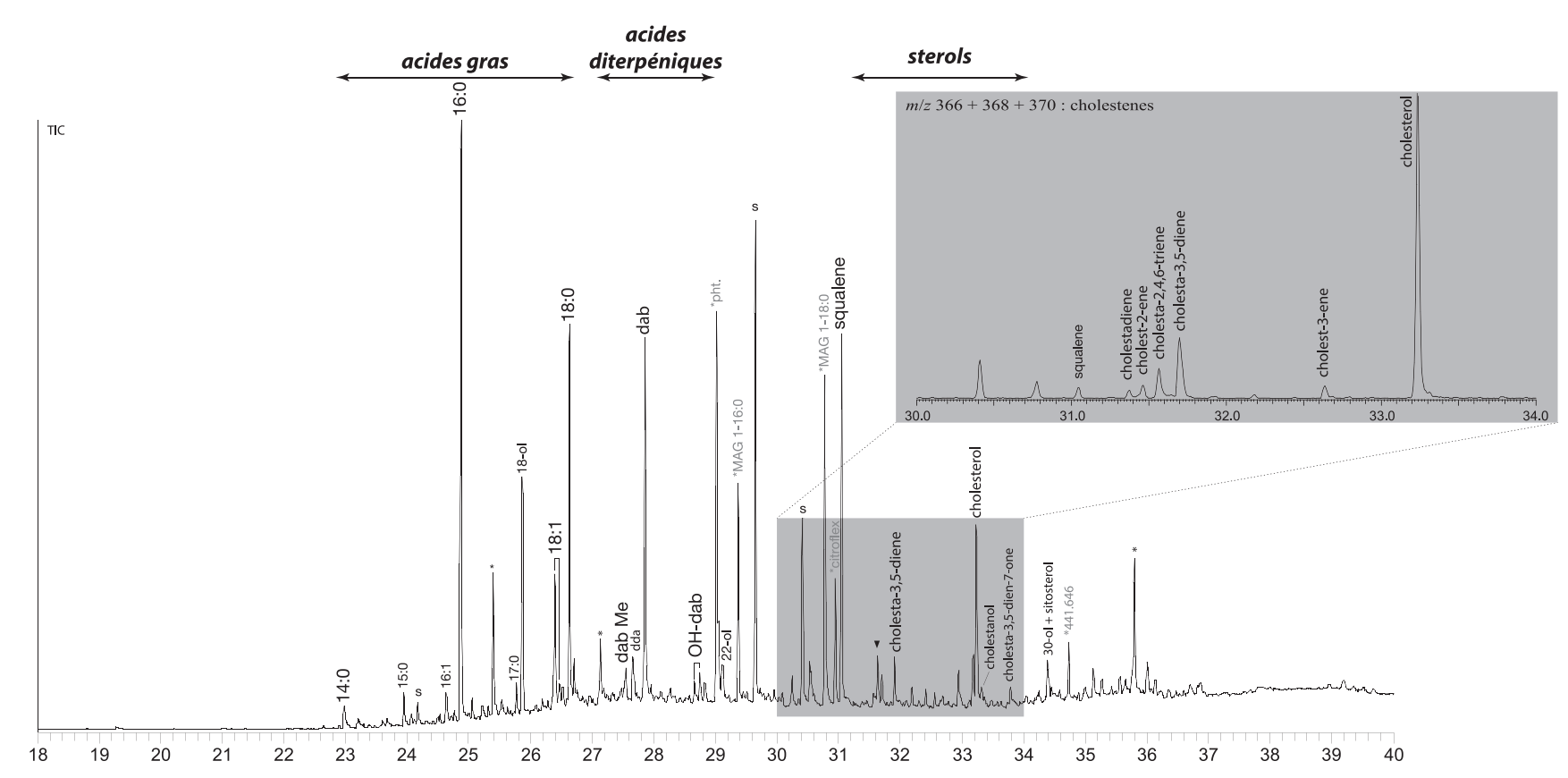

Fig. 6. Chromatogramme de l'extrait lipidique d'une amphore Dr. $7 / 11$ (Inv. 70029, imprégnations des parois, Pompéi, 79 ap. J.-C.). 


\section{Conclusion}

L'identification des sauces de poissons dans des céramiques ou les bassins de préparation est encore un défi que les analystes chimistes n'ont pas su, à ce jour, totalement relever. Les pistes de recherche des marqueurs sont nombreuses: acides gras polyinsaturés, acides isoprénoiques, protéines, acides aminés, stérols, mais la stabilité de nombre d'entre eux ou leur transformation lors de la fermentation du poisson limite leur conservation et donc leur chance d'être un jour identifiés. Ainsi les protéines semblent totalement hydrolysées en acides aminés lors de la décomposition du poisson en garum. Ceux-ci, ionisés et donc très solubles dans l'eau, sont facilement perdus lors de l'enfouissement, ce qui en fait des marqueurs peu fiables. Aussi ils peuvent provenir d'autres sources protéiques, viande, os, légumineuses, etc. Spécifiques des poissons, les acides gras polyinsaturés sont facilement oxydés; leur découverte est assez exceptionnelle, mais indéniable. Les acides isoprénoïdes, qualifiés de marqueurs du poisson dans la littérature, ne se retrouvent pas dans tous les poissons et peuvent provenir d'autres sources (huiles végétales, produits laitiers). Leur pertinence devra être évaluée, en les recherchant systématiquement dans tous les corps gras actuels. Enfin les acides $\omega$-(o-alkylphényl) alcanoïques sont formés par dégradation thermique des acides gras polyinsaturés, et ne peuvent donc pas être retrouvés dans le garum qui n'est pas chauffé.

Afin de définir quels pouvaient être les marqueurs réellement conservés, nous avons analysé un corpus d'amphores à garum et de bassins de préparation des sauces de poisson. Les marqueurs généralement recherchés (protéines, acides aminés, acides polyinsaturés et acides $\omega$-(o-alkylphényl)alcanoïques) n'ont jamais été détectés. La piste la plus fiable semble celle des stérols. Composés neutres, ils sont systématiquement conservés. En revanche, initialement présents en faibles quantités dans le poisson, ils obligent à développer un protocole précis et sensible. Parmi les amphores et vases analysés, chaque imprégnation de paroi présentait le même profil : le cholestérol (biomarqueur) associé à ses marqueurs de dégradation qui diffèrent de ceux observés lors d'une dégradation thermique. À ce jour, l'association de ces composés semble être la piste la plus sûre pour rechercher des traces de garum dans des objets archéologiques.

\section{Bibliographie}

Adlof, List 2004 : ADLOF (R.), LIST (G.) - Analysis of triglyceride isomers by silver-ion high-performance liquid chromatography: Effect of column temperature on retention times, Journal of Chromatography A, 1046, 2004, p. 109-113.

Aquerreta et al. 2002 : AQUERRETA (Y.), ASTIASARÁN (I.), BELLO (J.) - Use of exogenous enzymes to elaborate the Roman fish sauce "garum", Journal of the Science of Food and Agriculture, 82 (1), 2002, p. 107-112.

Barnathan et al. 1992: BARNATHAN (G.), MIRALLÈS (J.), GAYDOU (E.M.), BOURY-ESNAULT (N.), KORNPROBST (J.-M.) - New phospholipid fatty acids from the marine sponge Cinachyrella alloclada uliczka, Lipids, 27 (10), 1992, p. 779-784.

Brillantes et al. 2002 : BRILLANTES (S.), PAKNOI (S.), TOTAKIEN (A.) - Histamine Formation in Fish Sauce Production, Journal of Food Science, 67 (6), 2002, p. 2090-2094

Carballeira et al. 1987 : CARBALLEIRA (N.M.), MALDONADO (L.), PORRAS (B.) - Isoprenoid fatty acids from marine sponges. Are sponges selective?, Lipids, 22(10), 1987, p. 767-769.

Cha, Cadwallader 1998 : CHA (Y. J.), CADWALLADER (K. R.) - AromaActive Compounds in Skipjack Tuna Sauce, Journal of Agricultural and Food Chemistry, 46 (3), 1998, p. 1123-1128.

Craig et al. 2007 : CRAIG (O.E.), FORSTER (M.), ANDERSEN (S.H.), KOCH (E.), CROMBÉ (P.), MILNER (N.J.), STERN (B.), BAILEY (G.N.), HERON (C.P.) - Molecular and isotopic demonstration of the processing of aquatic products in Norhtern European Prehistoric pottery, Archaeometry, 49, 2007, p. 135-152.
Dallongeville et al. 2011: DALLONGEVILLE (S.), GARNIER (N.), BERNAL CASASOLA (D.), BONIFAY (M.), ROLANDO (C.), TOKARSKI (C.) - Dealing with the identification of protein species in ancient amphorae, Analytical and Bioanalytical Chemistry, 399, 2011, p. 3053-3063.

Dallongeville et al. 2013 : DALLONGEVILLE (S.), RICHTER (M.), SCHÄFER (S.), KÜHLENTHAL (M.), GARNIER (N.), ROLANDO (C.), TOKARSKI (C.) - Proteomics applied to the authentication of fish glue: application to a 17th century artwork sample, Analyst, 138 (18), 2013, p. 5357-5364. doi: 10.1039/c3an00786c.

Dissaraphong et al. 2006 : DISSARAPHONG (S.), BENJAKUL (S.), VISESSANGUAN (W.), KISHIMURA (H.) - The influence of storage conditions of tuna viscera before fermentation on the chemical, physical and microbiological changes in fish sauce during fermentation, Bioresource Technology, 97, 2006, p. 2032-2040.

Evershed, Tuross 1996 : EVERSHED (R.P.), TUROSS (N.) - Proteinaceous material from potsherds and associated soils, Journal of Archaeological Science, 23, 1996, p. 429-436.

Garnier 2003: GARNIER (N.) - Analyse structurale de matériaux organiques conservés dans des céramiques antiques. Apports de la chromatographie et de la spectrométrie de masse, Chimie, Université Pierre et Marie Curie (Paris VI), 2003, 405 p.

Garnier 2006 :GARNIER (N.) (2006) - Preliminary analysis of the organic content of two ceramic vessels. In: Bernal Casasola (D.) y Saez Romero (A. M.), Infundibula gaditana. Acerca de los vasos troncoconicos perforados para filtrar garum y otros usos industriales en la Bahia de Cadiz, ROMULA, 5, 2006, p. 210-218 
Garnier et al. 2002 : GARNIER (N.), CREN-OLIVÉ (C.), ROLANDO (C.), REGERT (M.) - Characterization of Archaeological Beeswax by Electron Ionization and Electrospray Ionization Mass Spectrometry, Analytical Chemistry, 74, 2002, p. 4868-4877.

Garnier et al. 2009 : GARNIER (N.), ROLANDO (C.), HØTJE (J.M.), TOKARSKI (C.) (2009) - Analysis of archaeological triacylglycerols by high resolution nanoESI, FT-ICR MS and IRMPD MS/MS: Application to 5th century BC-4th century AD oil lamps from Olbia (Ukraine), International Journal of Mass Spectrometry, 284, 2009, p. 47-56.

Garnier et al. 2011: GARNIER (N.), SILVINO (T.), BERNAL CASASOLA (D.) - L'identification du contenu des amphores: huile, conserves de poissons et poissage, SFECAG, (Actes du congrès d'Arles, juin 2011), 2011, p. 397-416

Gildberg 2001 : GILDBERG (A.) - Utilisation of male Arctic capelin and Atlantic cod intestines for fish sauce production - evaluation of fermentation conditions, Bioresource Technology, 76, 2001, p. 119-123.

Gram, Huss 2000 : GRAM (L.), HUSS (H.H.) - Fresh and processed fish and shellfish. In: Lund (B.M.), Baird-Parker (T.C.), Gould (G.W.) (Eds.), The Microbiological Safety and Quality of Foods, Aspen Publishers Inc., Gaitherburg, Maryland, USA, 2000, p. 472-506.

Hansel et al. 2004 : HANSEL (F.A.), COPLEY (M.S.), MADUREIRA (L.A.S.), EVERSHED (R.P.) - Thermally produced $\omega$-(o-alkylphenyl) alkanoic acids provide evidence for the processing of marine products in archaeological pottery vessels, Tetrahedron Letters, 45, 2004, p. 2999-3002.

Hjalmarsson et al. 2007: HJALMARSSON (G.H.), PARK (J.W.), KRISTBERGSSON (K.) - Seasonal effects on the physicochemical characteristics of fish sauce made from capelin (Mallotus villosus), Food Chemistry, 103, 2007, p. 495-504.

Holcapek et al. 2010 : HOLCAPEK (M.), DVORÁKOVÁ (H.), LÍSA (M.), GIRÓN (A.J.), SANDRA (P.), CVACKA (J.) - Regioisomeric analysis of triacylglycerols using silver-ion liquid chromatography-atmospheric pressure chemical ionization mass spectrometry: Comparison of five different mass analyzers, Journal of Chromatography A, 1217, 2010, p. 8186-8194.

Ichimura 2003 : ICHIMURA (T.Hu J.), QUA AITA (D.), MARUYAMA (S.) - Angiotensin I-converting enzyme inhibitory activity and insulin secretion stimulative activity of fermented fish sauce, Journal of bioscience and bioengineering, 96 (5), 2003, p. 496-499.

Ijong, Ohta 1995 : IJONG (F.), OHTA (Y.) - Microflora and chemical assessment of an Indonesian traditional fermented fish sauce "Bakasang", Journal of Faculty of Applied Biogical Sciences, 34, 1995, p. 95-100.

Kamat, Kumta 1972 : KAMAT (S.V.), KUMTA (U.S.) - Studies on radiation pasteurisation of medium fatty fish, Fishery Technol., 9 (1), 1972.

Kawashima, Yamanaka 1996 : KAWASHIMA (K.), YAMANAKA (H.) Free amino acids responsible for the browning of cooked scallop adductor muscle, Fish. Sci., 62, 1996, p. 293-296.

Kjeldahl 1883 : KJELDAHL (J.) - Neue Methode zur Bestimmung des Stickstoffs in organischen Körpern, Z. Anal. Chem., 22, 1883, p. 366-382

Lísa et al. 2009 : LÍSA (M.), HOLCAPEK (M.), SOVOVA (H.) (2009) - Comparison of various types of stationary phases in non-aqueous reversed-phase high-performance liquid chromatography-mass spectrometry of glycerolipids in blackcurrent oil and its enzymatic hydrolysis mixture, Journal of Chromatography A, 1216, 2009, p. 8371-8378.
Lopetcharat, Park 2002: LOPETCHARAT (K.), PARK (J.W.) Characteristic of fish sauce made from Pacific whiting and surimi by products during fermentation stage, J. Food Sci., 67, 2002, p. 511-516.

Mizutani et al. 1992 : MIZUTANI (T.), KIMIZUKA (A.), RUDDLE (K.), ISHIGE (N.) - Chemical components of fermented fish products, Journal of Food Composition and Analysis, 5 (2), 1992, p. 152-159, http://dx.doi. org/10.1016/0889-1575(92)90031-E.

Ohshima et al. 2001 : OHSHIMA (T.), LI (N), KOIZUMI (C.) - Oxidative Decomposition of Cholesterol in Fish Products, JAOCS, 70 (6), 2001, p. 595 -600 .

Pecci et al. 2013 : PECCI (A.), CAU ONTIVEROS (M.A.), GARNIER (N.) - Identifying wine and oil production: analysis of residues from Roman and Late Antique plastered vats, Journal of Archaeological Science, 40, 2013, p. 4491-4498.

Reese 2002 : REESE (D.) - Fish: Evidence for specimens, mosaics, wall paintings and Roman authors. In : Jashemski (W.F.), Meyer (F.G.) (eds.), The Natural History of Pompeii, Cambridge University Press, 2002, p. 274-291.

Regert 2011 : REGERT (M.) - Analytical strategies for discriminating archaeological fatty substances from animal origin, Mass Spectrometry Reviews, 30 (2), 2011, p. 177-220.

Sanceda et al. 2001 : SANCEDA (N.G.), SUZUKI (E.), KURATA (T.) Development of normal and branched chain volatile fatty acids during the fermentation process in the manufacture of fish sauce, Journal of the Science of Food and Agriculture, 81, 2001, p. 1013-1018.

Sen 2005 : SEN (D.P.) - Advances in fish processing and technologies, Allied publishers LTV, Mumbai, 2005.

Sinesio et al. 2009 : SINESIO (F.), COMENDADOR (F.J.), PEPARAIO (M.), MONETA (E.) - Taste perception of umami rich dishes in Italian culinary tradition, Journal of Sensory Studies, 24, 2009, p. 554-580.

Smriga et al. 2010 : SMRIGA (M.), MIZUKOSHI (T.), IWAHATA (D.), ETO (S.), MIYANO (H.), KIMURA (T.), CURTIS (R.I.) - Amino acids and minerals in ancient remnants of fish sauce (garum) sampled in the "Garum Shop" of Pompeii, Italy, Journal of Food Composition and Analysis, 23 (5), 2010, p. 442-446.

Solazzo et al. 2008 : SOLAZZO (C.), FITZHUGH (W.), ROLANDO (C.), TOKARSKI (C.) - Identification of protein remains in archaeological potsherds by proteomics, Analytical Chemistry, 80, 2008, p. 4590-4597.

Sternberg 2000 : STERNBERG (M.) - Données sur les produits fabriqués dans une officine de Neapolis (Nabeul, Tunisie), MEFRA, 112, 2000, p. 135-153.

Tungkawachara et al. 2003 : TUNGKAWACHARA (S.), PARK (J.W.), CHOI (Y.J.) - Biochemical Properties and Consumer Acceptance of Pacific Whiting Fish Sauce, Journal of Food Science, 68 (3), 2003, p. 855-860.

Tsuji et al. 1994 : TSUJI (K.), KANEKO (K.), KIM (C.H.), OTAGURO (C.), KANEDA (T.) - Composition of free sugars, organic acids, free amino acids and oligopeptides of kochujang seasoning made in Korea, Nippon Shokuhin Kogyo Gakkaishi, 41, 1994, p. 568-573.

Von Endt 1977 : VON ENDT (D.W.) - Amino-acid analysis of the contents of a vial excavated at Axum, Ethiopia, Journal of Archaeological Science, 4 (4), 1977, p. 367-376

Yoshida 1998 : YOSHIDA (Y.) - Umami taste and traditional seasonings, Food Reviews International, 14, 1998, p. 213-246. 



\section{Garum, Liquamen, and Muria: A new approach to the problem of definition}

\section{Sally Grainger}

\section{Introduction}

$\mathrm{T}$ The picture of fish sauce that emerges from the ancient literature is complex. The ancient writers who discuss these products do so without the precision we need and often contradict each other so that a precise understanding of which sauce corresponds to which recipe, production process or name is less than clear. The ancient literary evidence is largely provided by two quite distinct kinds of text: on the one hand 1 st $\mathrm{c}$. AD elite Roman consumer perspectives from letters, Natural Histories, poetry and particularly satire, and on the other texts that are perceived as late-Roman from users such as cooks, doctors, and vets. These texts often derive from much earlier Greek sources so the evidence appears to be polarised both by time and by culture.

The early elite consumer tells us only of the exclusive and expensive types of garum which may have had quite a narrow culinary role and appear as the primary product, while the everyday cooking fish sauces used by millions of ordinary Romans and Greeks around the empire are hardly comprehended at all in the literature ${ }^{1}$. In zooarchaeology we have the reverse situation, as the only recognised evidence for fish sauce is the bone fragments from small clupeidae and sparidae, which are identified as part of the apparently bony fish paste known as allec, the consumption of which is viewed as low status ${ }^{2}$. This stark contrast in the perceived status of the consumer of each kind of evidence makes for confusing conclusions, such as the tendency for fish bone specialists to consider certain forms of this fish paste as an elite product with reference to the discussion in Pliny ${ }^{3}$.

1. Corcoran 1962, p. 205.

2. Van Neer 2002, p. 208.

3. Cotton 1996, p. 223-238. Pliny The Elder HN 31.96. "Allec is the sediment of garum, the dregs neither strained nor whole. It has, however begun to be made separately from tiny fish, otherwise of no use. The Romans call it apua, the Greeks aphye, because this tiny fish is bred out of rain... Then allex became a luxury and its various kinds have come to be innumerable... Thus allex has come to be made from oysters, sea urchins, sea anemones, and mullet's liver,
In the course of this study it will become clear that many ancient elite consumers of fish sauce did not actually understand the products at all well and it is their confusion that is directly responsible for ours. At the heart of this ancient and modern confusion is the failure on the part of modern researchers to comprehend fully that there were multiple varieties and qualities of fish sauce, some for cooking, some for the table, just as there are today in south east Asia. We can and must attempt to differentiate between them through a synthesis of the archaeological and literary sources. Only with this level of analysis can we hope to disentangle the complex problem of nomenclature. The ultimate aim is to gain a greater understanding of the relative value of the different fish sauces within the ancient economy, and not least within Roman cuisine. In what follows I will offer a radically new way to approach the dilemma of how to differentiate between the various fish sauces which takes account of the opinions of those who made, traded and used these products.

\section{The single sauce hypothesis}

Within ancient historical and archaeological research there is currently an assumption that there was only one type of Roman fish sauce. This sauce was called garum; all the varieties of fish, different components of fish, recipes and qualities were all defined within the generic term garum. The distinction between the fish sauce made from small and medium whole-fish with extra viscera and that made from just fish viscera and blood is acknowledged by the leading scholars in the field but they are all considered forms of garum $^{4}$. This belief stems largely from the statements on fish sauce by Pliny the Elder. Pliny's garum is the luxury product made from fermented viscera

and salt to be corrupted in numberless ways so as to suit all palates". The Geoponica is very clear that the residue makes allec not that the entire residue is allec.

4. Corcoran 1963, p. 204-209; Curtis 1991, p. 13; Curtis 2009, p. 713; Studer 1994, p. 195; Etienne 2007, p. 7; Van Neer 2002, p. 208. 
and "other parts that would otherwise be considered refuse" (31.93). Pliny has stressed the viscera which is associated with the expensive sociorum garum and not directly referred to whole fish but his "other parts" have nonetheless been taken to mean small fish otherwise of no value: thus he seems to be referring to a whole-fish sauce not a blood/viscera sauce. As he subsequently suggests that the residue of this garum makes allec and that this is a fish paste derived from whole fish, he must not comprehend that there were two types. The surviving Greek recipes for fish sauce also affirm the importance of the distinction between blood/viscera sauce and one made from whole fish. It is clear from the Geoponica too that the term garon, with an additional adjective to designate the blood/viscera sauce, did function generically in Greek ${ }^{5}$. To make matters worse some ancient commentators, largely elite consumers, also seem to use the Latin term garum in a generic sense; however it will be my contention that garum, for those who manufactured and traded these products, was a specific term in Latin referring to the blood/viscera sauce rather than a general term and that for most of the Roman period the word liquamen actually represented the primary product: a fish sauce made from whole-fish ${ }^{6}$.

Manufacturer, trader and user didn't use the word garum, as the elite writers seem to, as a term for the general idea of fish sauce in Latin, they employed a far more specific and technical terminology, which we may suppose involved precise use of all the terms at their disposal and which survives in ancient texts and on amphorae - in both Greek and Latin ${ }^{7}$. There are a number of instances where fish sauce is described in term of colour. The blood/viscera sauce will necessarily be darker because of the blood and in fact we do find "black" and "bloody" adjectives being used in Greek texts ${ }^{8}$. However in Latin the literary sources do not use specific adjectives with garum referring to colour. Instead we only find the singular garum, garum sociorum or liquamen. The use of the word sociorum "of our

5. Geoponica 46. Dalby 2011, p. 348-349. The difference between the two sauces concerns the fish blood rather than viscera which, from my experiments, provide additional digestive enzymes rather than distinctive characteristics. The flavour of a liquamen made with and without extra viscera is indistinguishable and dominated by fish flavours while the blood sauce taste and smells quite distinctly of iron and is not fishy at all.

6. Curtis 1991,p. 7.

7. In Greek: garon, garou melanos (black): Galen, Kuhn 1965, p. 637. garon haimation (bloody): Geoponica 20.46.6, Dalby 2011, p. 348-349; P. Anst. inv. no 44. In Latin garum, garum sociorum, gari nigri, garum flos, liquamen, liquamen flos, muria and allec.

8. For other ref. to gari nigri: Aetius 3,83 and Latin translations of Galen, see note 37. Pliny talks of garum blended to look like "aged honey wine": Pliny $H N 31.93$. allies" we are told by Pliny refers to the luxury mackerel garum made in New Carthage in Spain. Martial describes this sauce being "made from the blood of a still breathing mackerel" and it therefore implies this black and bloody sauce ${ }^{9}$. Whether we can say that all the sauce made by this company of allies in New Carthage was the luxury blood/viscera sauce is unclear and probably quite unlikely. The terminology used in the dining rooms of Rome may well have been different to those used by the manufacturer. Crucially we cannot know which sauce is being referred to when garum occurs singularly in Latin texts. Writers may not actually know or care which one they are referring to, especially in satire.

The meaning in Latin of liquamen has always remained obscure and has long been assumed to be a Late Latin equivalent for garum $^{\mathbf{1 0}}$. Garum only appears in the early period, liquamen in the late and it is generally assumed that the word garum fell out of favour and liquamen simply became the more popular word. Not only has no one thought to question why this should be the case but no one has considered that multiple varieties of fish sauce require multiple terms in Latin and they do not seem to exist ${ }^{11}$. If one looks closer at the literary evidence it becomes apparent that all the early elite Latin consumers refer to garum and there is no reference to liquamen at all. Liquamen is not a term used by elite/ educated Romans ${ }^{\mathbf{1 2}}$. Liquamen exists only in apparently late and vulgar Latin didactic literature such as veterinary and cookery books, which though considered to be written in the Late Empire, often can be seen to derive from much earlier Greek material ${ }^{13}$. The situation is clearly more complex than a simple switch in terminology. It is admittedly clear that Latin garum is hardly mentioned in any forms of elite Latin literature after the mid 3rd c. AD, though the term does not disappear entirely as Ausonius makes an obscure reference to it in the early 4th c. ${ }^{14}$ We can also see parallel use of garum and liquamen in their occurrence on amphorae tituli picti from Rome and Pompeii in the 1st c. AD. That garum always meant something different to liquamen can be seen in its presence along side liquamen in the medicinal

9. Pliny HN 31.94; Martial 13.102, Curtis 1991 p. 8, n.11.

10. In Greek liquamen is a hapax legominon appearing only in the Geoponica where it appears to be a direct translation of garon. For the standard view Etienne 2007, p. 7.

11. Curtis 2009, p. 713; Cotton et al. 1996, p. 231.

12. It is cited in Columella three times at 6.2.7; 9.14.3 and 9.14.17 but each time liquid generally are meant.

13. Grocock, Grainger 2006, p. 13-23, 61; Adams 1995, p. 663. Much of Pelagonius and Vegetius is derived from writers such as Celsius, Columella and Apsyrtus: the Greek horse doctor.

14. Ausonius Epist 25. 21. 
and veterinary and culinary texts ${ }^{15}$. The employment of both terms suggests that garum had a meaning distinct from liquamen in the early period which was still current when the later fish sauce had apparently been renamed liquamen. Curtis acknowledges that liquamen must have had a separate meaning to garum in the first century $\mathrm{AD}$ but he maintains that it was the 2 nd and subsequent washings of the residue of garum which is the only way to explain the later convergence of the terms ${ }^{\mathbf{1 6}}$. I would disagree here as the tituli picti do not suggest this and there is no evidence at all to this effect.

\section{Studies on fish sauces}

\subsection{The origins of fish sauce in the Mediterranean}

Garum was clearly derived from the original Greek word garos and seems to have been the name of a fish used to make the sauce in Greece according to Pliny. This fish is unknown but we may reliably assume that it was small clupeidae and sparidae. We know that 5 th $\mathrm{c}$. BC Greek comedy refers to garos from the Black Sea and by the 4th c. Cadiz was shipping garos to Athens ${ }^{17}$. We know very little about this early fish sauce apart from the fact that it was considered rotten. Crucially the image of fish sauce use from the early Greek sources never appeared to have a luxury tag: the foods it was associated with were simple poor man's vegetables and pulses and it formed a very basic dressing or dipping liquid with oil and vinegar or wine ${ }^{18}$. The formal Greek cuisine that emerged during the Hellenistic period seems to have been defined around the use of this garos and it is this cuisine that arrived in Rome in the 2nd century $\mathrm{BC}$ when the Roman elite fell under the spell of Greek dinning culture ${ }^{19}$. At this point we must assume that this garos was made from small fish, otherwise of no value, and the term simply became latinised into garum. At this early period we seem to be dealing with a single sauce of the whole fish garos type.

However the cuisine associated with elite dining as described by Archestratus in the late 4th c. BC in Sicily does not appear to use a garos fish sauce, despite its

15. For Apicius see below. Pelagonius liquamen: 9; 11.2; 13; 98; 455; 457, garum: 428;13. Vegetius liquamen: 1.10.1; 1.17.10, 16; $2.91 .2 ; 2.108 .2 ; 2.132 .4 ; 4.6 .1$, garum: $2.28 .8 ; 3.28 .10$. Marcellus Empiricus, 5th c. medical writer from Gaul "Medicinae" liquamen 30.52; garum 30.41 .

16. Curtis 2009, p. 713. Ausonius Epist 21.

17. Pliny $H N$ 31.93. Dalby 1996, p. 75-76 ; Athenaeus, II, 67.b-c.

18. Dalby 1996, p. 25 Galen On the properties of food 1.25.2.

19. Grocock, Grainger 2006, p. 17. apparent importation into Athens at this time, but does make use of a similar dipping sauce blended with vinegar and oil made with a salted fish "brine" called ö $\lambda \mu \eta$ $(\mathrm{alm} \overline{\mathrm{e}})^{20}$. If Archestratus reflects elite practices a century before the Romans acquired a liking for Greek dining practices then the use of halme and its Latin counterpart muria would seem to be the more elite product and the knowledge and use of it would also be widespread. There was clearly more than one type of fish sauce at the end of the Hellenistic period. Garos and muria were sufficiently different to require separate names though whether the blood/viscera garum had yet been developed is not clear.

\subsection{Apicius: the Roman recipe collection}

The text where we find fish sauce in use most often is the recipes collection known simply as Apicius. In 2006 I along with Dr Christopher Grocock published a new edition of this text ${ }^{21}$. The text had been interpreted by Brandt to be a collection of recipes written down if not actually compiled by an elite gourmet in the late Empire $^{22}$. This was due to the use of vulgar Latin which is the literary register most common in the late Empire among the elite as well as the rest of society. However it was clear to us that the individual recipes had actually been written by the slave cooks who would speak and write their own "blue collar" Latin. The Latin was grammatically inferior and displayed no literary merit of any kind. Brandt's imaginary compiler is also absolutely silent: there is no authorial voice in the text at all and one would expect an author/compiler to make himself known. The silent compiler suggested to us that this text was actually a functional collection designed by and for the cooks who devised and used the recipes. This conclusion has repercussions for dating the text too as it may be concluded that any vulgar/late Latin written by an elite gourmet would date the text to the late 4/5th c. $\mathrm{AD}$ but vulgar Latin from cooks cannot be so precisely dated: "Vulgar Latin...is just a collective label to refer to all those features of the Latin language that are known to have existed from textual attestations and incontrovertible reconstructions, but that were not recommended by the grammarians" ${ }^{23}$. It is quite clear that a grammatically inferior written Latin co-existed with the more learned registers in 1 st century imperial Rome and there is no

20. Olson, Sens 2000, p. 159 (fr. 38). Athenaeus VII, 329b: where the brine is identified as from pilchard.

21. Grocock, Grainger 2006.

22. Brandt 1927, p. 30, 36, 130-3.

23. Herman 2000, foreward; Grocock, Grainger 2006, p. 95 and note 1. 
reason why many of the recipes could not have been written down at that time. In fact some of the recipes contain internal evidence to suggest that they were originally written down as early as the 1 st c. $\mathrm{AD}^{24}$. We may also suppose therefore that many of these recipe collections, of which Apicius is just one surviving version, began the process of compilation in the early empire and under particular Greek influence as the surviving recipe collection retains its Greek chapter headings and contains numerous technical culinary terms which are hybrid Greek/Latin terms ${ }^{25}$.

In relation to the issue of fish sauce terminology these conclusions have profound consequences. There is very little garum qua blood garum in Apicius: in these recipes the cook does not appear to use this sauce and in fact we have no reference to cooking with the blood/ viscera sauce anywhere in the literary evidence. This would seem entirely logical too, as an expensive and intensely- flavoured blood sauce would be lost in the cooking process and wasted, while an expensive sauce needed to be seen by the gourmet to be experienced, valued and discussed. In Apicius, liquamen is the universal term for the primary fish sauce and even when we find garum, with two exceptions, it is part of a compound term directly transliterated from the Greek: oivóy $\alpha \rho v$ $($ oenogaron $=$ oenogarum $)$ and therefore referring to the original whole fish sauce. In Apicius oenogarum is a slightly more complex version of the Greek wine/ vinegar, oil and fish sauce dressing ${ }^{26}$. These sauces are widespread throughout the text and represents a hot or cold, thin or thickened sauce used both within a cooked dish and served as a dip ${ }^{27}$. When the recipes themselves were firmly dated to the late empire, the use of liquamen to designate the "single" fish sauce was at least rational. Now the recipes do not necessarily fit neatly into that early/late pattern, the lack of black garum in Apicius is striking. Apicius is supposed to be the epitome of high status cooking and black garum is the luxury sauce par excellence, so why is it barely mentioned?

24. Grocock, Grainger 2006, p. 13-23; 369-372.

25. Oenogarum, oxygarum, hypotrimma, tisane, thermospodium, oxyporium, melizomum: Grocock, Grainger 2006, p. 27.

26. Dalby 1996, p. 25. Other compound sauce were oxygarum with vinegar; hydrogarum which is a cooking liquor not a sauce per se; garelaeum with oil (Orebasius 4.28).

27. A sauce poured over a dish $(4.5 .3 ; 8.8 .7)$; a salad dressing for vegetables (passim book 4); a sauce used within a dish (4.5.1; $4.2 .31 ; 4.2 .5)$ and a dressing for fish or meat $(7.3 .1 ; 10.3 .11,12)$. A translation for the word oenogaron is found in a late gloss to the Gargilius Martialis text. This text provides the other important recipe for fish sauce manufacture and the sauce is entitled "Confectio liquaminis, quod oenogarum vocant" "a liquamen sauce which is called an oenogarum".
From modern South East Asian cuisine we learn of a fermented squid blood viscera (and ink) sauce that is used today in Japanese cuisine. It is known as ishiri and is used as a finishing sauce for sushi as well as cooked food. Its taste neither fishy nor salty, and smells of the iron compounds from the blood. Japanese cuisine also has a whole-fish sauce called ishiru and many dishes are prepared with both i.e. the whole fish sauce is used for cooking and the blood/viscera sauce finishes the dish ${ }^{28}$.

I would suggest that black garum was never part of the cooking process and its absence perfectly natural in both early and late recipes. It was too strong for cooking and was designed to be used at table by slaves or diners as a "finishing" sauce. It became popular among the elite to blend oenogarum sauces with black garum in the 1 st c., but by the time the recipe collections had been finalised in the 4/5th c. its use in this way was limited. In Apicius garum occurs just twice: as a non compounded word, it is found at 7.13.1 where mushroom are served with garum and pepper: "Ash tree fungi: boil and serve while hot and dry in garum and pepper, as long as you pound the pepper with liquamen". The recipe is of course ambiguous and we might use it to retain the current belief in the "single sauce". However taken literarily the pepper is pounded into a mash with liquamen and then the mushroom are served with this mash and blood garum $^{29}$.

\subsection{Garum and Diocletian's Price Edict}

The single sauce hypothesis is reinforced by the wording for fish sauce on Diocletian's price edict. The inscription is a controversial source for many reasons which are not of concern here ${ }^{30}$. Dated to AD 301 it lists the prices, in Greek for the eastern Empire and Latin for the west, of common commodities and services available when inflation was very high throughout the empire. We find that in Latin 1st and 2nd quality liquamen is rendered as 1 st and 2nd quality garos in the Greek inscriptions ${ }^{31}$. This is however what we should expect: the primary product of trade and commerce

28. http://www.ishiri.jp/en/ This sauce is truly fermented with bacteria and low salt. It is quite remarkable that the Japanese word for viscera is gari!

29. For a similar pepper mash: Apicius 2.2.8. Vegetarian version of these fish sauces existed it seems and the terminology used is indicative of the primacy of liquamen/garos. Pseudo-Pollux Quotid. 112v: a text with Greek and Latin has "with a garos of turnip" is equivalent to "with a liquamine"; Palladius Opus Agri. 3.25.12 "Liquamine ex piris"; Pseudo-Galen De Remediis vol 14, p. 546m.

30. Lauffer 1971, p. 124.

31. Id., p. 104. 
was liquamen and it corresponds to the original primary product from Greece. It is more surprising to find that a separate blood/viscera sauce or a muria is not listed. I would argue that the rarity of black garum in texts in the late empire, particularly in Apicius, reflects a rarity in commerce too and that it was not sufficiently popular at the time of the edict to warrant its own price. It was clearly commercially available as Ausonius' letter confirms but may simply have been such a small percentage of the overall market that it didn't warrant its own listing. It is possible that black garum always had a relatively small market in comparison to liquamen and lost what popularity it had in the late empire. I believe black garum was made to appear more important because of the unusually close view we get of the elite at table in the early empire through satire. The obsession in luxury foods in dining was largely concentrated in the early empire and later Romans looked on their ancestors with some scorn for their obsession with exclusivity ${ }^{32}$.

\subsection{The uses of black garum}

If we look elsewhere at the references to garum in satire it becomes clear that the sauce being discussed is a visible thing as opposed to being hidden away in the kitchen. That the term liquamen is unrecognised by the gourmet is not surprising given that the "cooking sauce" would never be visible. We find garum poured onto oysters; Ausonius when discussing the garum he has received says he will "fill my patina" with it: a patina is a thick set frittata delivered cooked from the kitchen; fish is served as if floating in garum; a garum piperatum pepper sauce is poured on to fish in a dish from a wine skin; a garum sociorum made from mullet viscera is used to drown and serve with mullets while an allec is made from their livers; a cook is expected to blend Falernian wine with aged garum and pepper to serve with a roasted boar; a cheap mistress begs her lover for a small amount of garum; Garum and in fact muria too is used to make special oenogarum sauces and the host discusses the ingredients being used in such detail that we may be able to say that these sauces were blended at table ${ }^{33}$. Certainly finely decorated Samian ware mortaria are often found with wear pattern of use and this is difficult for

32. Ausonius' text is discussed in detail below. While living in Southern Gaul in the 4th c. he had to have his garum specially delivered. Macrobius a century or so later "not that I am saying we should be though superior to the ancients... but I am just stating the facts: people were keener on luxuries in those days than they are now" (Macrobius Saturnalia 111.13.16).

33. Martial Epi 13.82; Ausonius Epist 21; Seneca 3.17.2; Petronius Satiricon 36.3; Pliny HN 9. 66; Martial 7.27.8; 11.27. archaeologists to comprehend as they are assumed to be table ware. Most mortaria are coarse kitchen ware vessels and the labour involved in their use would normally be hidden ${ }^{34}$. It may be said that there are too few references indicating that blood garum was always used in different ways to liquamen. It is also apparent that all three types of sauce (muria, garum, liquamen) could be blended with wine and oil to make the dipping sauce oenogarum which was a visible component of ancient cuisine yet it seems clear from the recipes that the black sauce was not used in cooking. It may be possible to determine the quantities of garum to liquamen consumed through analysis of amphora size. The urceii or table top jugs that fish sauce was sold in at Pompeii came in many sizes (fig. 1).

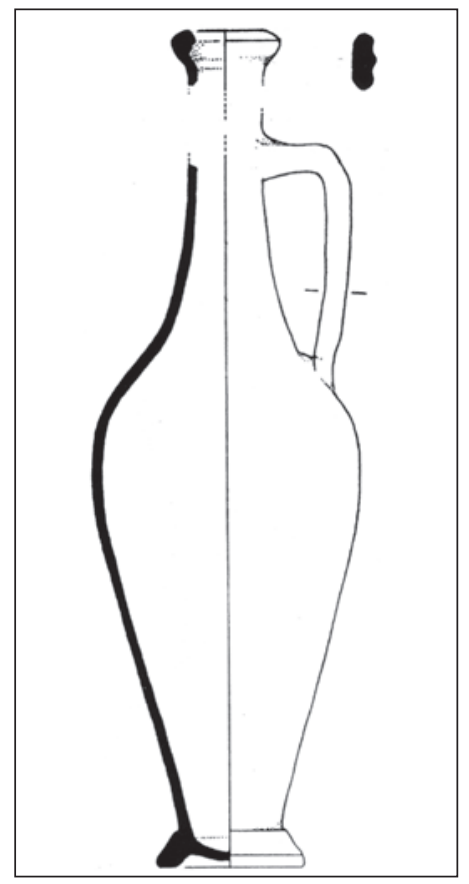

Fig. 1. Urceus found in Terzigno near Pompeii (from Cicirelli 1996, fig. 10-41 p. 166).

All are very much smaller then the average fish sauce amphorae which can stand up to $90 \mathrm{~cm}$. From published tituli picti in CIL, the majority of liquamen labels are on amphorae, while named and exclusive garum is largely found on the much smaller urceii. Curtis has also noted that these urceii labelled simply garum have been found in Pompeii in relatively modest dwellings and bars and, though he was at the time using garum to mean fish sauce generally, this must mean that black garum was also consumed among the sub-elites probably as a table sauce in the bars $^{35}$.

34. Horace Sat 2.8; 2.4.63-9; Willis 2005, p. 8.4.4; Biddulf 2008 p. $91-100$.

35. Curtis 1991, p. 159-175; The difference in volume sold can not be calculated as capacity of amphorae are rarely recorded but it does seem as though by volume more liquamen was sold than garum. 


\subsection{Fish sauce in Galen}

Galen's use of fish sauce in his treaties on food and diet is valuable as there are numerous references to what we now know is a simple whole-fish garos which is blended with wine/vinegar and oil as a simple dressing for vegetables as we have come to expect. Lettuce for instance is boiled in the winter and served with olive oil, garos and vinegar while mallow and cabbage are served with olive oil and garos in order to ease their passage through the body. Galen also lists many pot herbs such as celery, hyacinth and rocket which are all served in a similar way ${ }^{36}$. There is just one reference to black garos in Galen and it requires more consideration. The text is not that on food and diet which makes no reference to the black sauce at all which also supports the view that it was not used in the preparation of food, but one called "Medical compounds according to places" ${ }^{37}$. The remedy is apparently called an oxyporium and considered a Spanish digestive and later versions of the text reference the idea that black garum was also called sociorum after the Spanish traders ${ }^{38}$. Other medicinal recipes for oxyporium also make use of garum. In Apicius this remedy is mixed with vinegar and garum and this is in fact the only other direct reference to garum in Apicius that is not combined in a compound term and subsequently listed as a liquamen. This source indicates that black garum had a continuing medicinal role throughout the period even if it appears to be used less at table ${ }^{39}$.

We cannot know when the blood viscera sauce was introduced into ancient cuisine. It certainly does not seem to be part of the early Greek evidence and its introduction may have been instigated by influence from Rome as the knowledge of these sauces spread. As a theory I offer the following: as fish sauces became generally more popular in Rome the elite would have been concerned with differentiating their foods from everybody else's. If the consumption of liquamen fish sauces made from small fish was widespread then the elite would create

36. Grant 2000, p. 138; $141 ; 146$.

37. Galen Opera Omnia ed. C.G. Kuhn (1965 reprint of 1823 edition Hildesheim George Olms) Bk 12.637. (comp. med.sec.loc) "For the stench of wounds that (remedy) which is called 'of the Spanish'. Take: black garos, called oxyporum by the Romans, 1 sextarius, squill vinegar, 1 sextarius, Attic honey, 11/2; boil until it binds, and put it away in a glass vessel and use". Translation with gratitude: Justin Mansfield.

38. A Latin translation of this remedy made in the Renaissance, gives the following translation of the 2nd line "gari nigri quod Romani sociorum appellant." (black garum which the Romans call "of our allies"). Galeno 1537, p. 361.

39. Apicius 1.32; Columella 12.59.4. Garum in a remedy: Columella 6.9.1 to treat fever in ox; 6.34.2 to treat horses; 7.10.3 to treat scrofulous pigs. Liquamen is used in veterinary remedies c.f. note 17 . a demand for a luxury version. The manufacturer may have instigated new developments in fish sauce types to meet this demand. One of these would have been the blood and viscera sauce, though how they thought of it is quite bizarre to comprehend. Its expense meant that it functioned as a table condiment and the gourmet could control the bottle and discuss its merits to demonstrate his culinary knowledge. Other developments at this time may have been the use of much larger fish, that did have a market value as salted fish, such as mackerel, tuna and larger clupeidae and sparidae. We may surmise that the fashion for Greek culinary culture at this time would mean that the original term was retained to designate the new luxury black table sauce forcing the merchants and traders to coin a new term; liquamen to designate the original small whole-fish sauce ${ }^{40}$. Liquamen remained in the kitchen and invisible to the diner who only saw and valued expensive sauces at table. In the later Roman period as black garum was not as visible either in commerce or at the table, it was naturally taken for granted among some commentators, as it has been today, that garum was just the Latin for garos and it began to be used to designate the single primary product. Only this seems to explain the group of late and early medieval references that claim that garum was equivalent to liqua$m e n^{41}$. They must have genuinely believed at the time that it was and simply did not comprehend the complexity behind these products.

\subsection{Muria and Ausonius' letter 21}

The letter sent by Ausonius to his friend Paulinus in the early 4th century is quite intriguing and deserves to be quoted in full.

"Fearing that the oil you sent me was not pleasing, you repeated your gift and distinguished yourself more fully by adding a condiment (of muria $^{42}$ ) from

40. The term liquamen is cognate with liquere/liquescere meaning "to be liquid" and "liquefy". Isidore of Seville in the 6th c. defines liquamen as "little fish dissolved during salting produce the liquid of that name" and defines garum as the "juice of fish" Etymologiae 20.3.20. Corcoran 1962, p. 205 was the first to be confused by the Isidore definition and combine the liquor from salted fish (muria) with the sauce derived from dissolved fish.

41. Caelius Aurelianus 5th c. medical writer Chron 2.3.70 "ex garo quod vulgo liquamen appellant"; 2.1 .40 "vel garum quod appellamus liquamen" See partic. Beda Gramm. 7.279,10 "muria id est garos" which in the 7th c. may refer to the fact that in Roman Palastine muria/ies seems to have been the term for the primary product i.e. liquamen (Weingarten 2005).

42. This first muria is out of place and is not needed in the sentence. It seems strange that he used it at all having subsequently declared 
Barcelona. But you know that I have neither the custom nor the ability to say the word muria, which is in use of the common folk, although the most learned of our ancestors and those who shun Greek expressions do not have a Latin expressions for the appellation garum. But I, by what ever name that liquor of our allies is called,

'now will soon fill my patinas so that that juice (sucus), more sparingly used on our ancestors' tables, will flood the spoons' ...." 43

The issue of the difference between garum and liquamen can be dealt with quite easily: if he believes that there is no Latin expression that he can use to replace garum then liquamen clearly cannot be equivalent to it. That he associates it with sociorum suggests he has received a blood/viscera sauce and there is no term in Latin for this. What requires explanation is his apparent use of muria to designate the sauce he has received.

Muria is primarily a brine; that is, salt and water. It is also defined as the brine that salted fish are stored in (muria salsamenti) ${ }^{44}$. Muria appears very rarely in Apicius and seems not to have been a regular part of the cook's seasonings in the preserved recipes. This product is seen as a lower status form of seasoning but we have seen that a form of fish-brine was used in elite 4th c. Greek cuisine as an ingredient in dipping sauces and this combination is also found in references to food in Roman satire, so muria could potentially be desirable and especially if aged ${ }^{45}$. Muria may have been valued because it was a "clean" sauce i.e. free of fermenting viscera, which was perceived as putrefaction ${ }^{46}$.

Martial's epigram on muria that follows the one for garum sociorum has often been seen as evidence that muria could in fact designate another garum made from tuna blood and viscera ${ }^{47}$.

that he doesn't like the term. Andrew Dalby (per. com.) has suggested that this first muria is a gloss and I am inclined to agree.

43. Ausonius Ep. 21 (Translation C. Grocock) That he claims this sauce was "more sparingly used on our ancestors tables" is difficult to comprehend as noted by Corcoran (1963, p. 205).

44. Cato RR 7; Columella 12.55.4; Gargilius Martialis, Curae boum ex corpore. 4; Pliny, HN. 31.83-92 For its low status image c.f. Isidore of Seville Etym. 20.3.20.

45. Horace 2.4.63-9. An amphora tituli picti from London suggest that young tuna could be aged for 2 years. This cannot be whole fish as it would not be fit for consumption at that age and therefore muria is likely though un-named. Tituli picti also suggest muria could be aged Curtis 1991,p. 197. http://www.museumoflondon.org. uk/Collections-Research/Research/Your-Research/Londinium/Lite/ classifieds/sauce.htm (19/10/2012).

46. Seneca. Epist 95.25 "A costly extract of poisonous fish which burns up the stomach with its salted putrefaction".

47. From the use of tuna viscera to make the haimation or bloody sauce in the Geoponica. Martial Epigrams 13.103; Corcoran 1963 p. 206 ; Studer 1994, p. 195.

\section{"Amphora Muriae}

I am the daughter, I admit it, of Antipolitan tunny. Had I been of mackerel, I should not have been sent to you".

It is fair to say that it is not logical, to have another term to designate the blood/viscera sauce which can also mean a completely different less valued product entirely. However the perception of muria as low status is deceptive as we must ask for whom is it inferior and where it fits in the sliding scale of fish sauce quality. Martial has, I think, juxtaposed garum with muria here because they represented the two different types of sauce that could be valued in Roman cuisine rather than offering two that were virtually the same. After all what can be said of the differences between one lot of fish viscera and another!

We do not know the volume of tuna caught in the Mediterranean but given the potential size of this fish it is likely to be large and the volume of muria generated clearly had a market. However I suspect that tuna was not used to make a liquamen but only made garum or muria as a secondary product to the salted fish ${ }^{48}$. It is apparent that tuna muria could be aged and would mature in flavour and value ${ }^{49}$. Tuna would also generate vast quantities of viscera and blood which would make tuna garum just as the Geoponica advocates and archaeological evidence confirms the use of tuna blood in the production of garum haimation ${ }^{50}$. This poem and amphorae tituli picti suggest that mackerel actually served as the best fish to use both for muria and garum. The elite therefore would consider tuna muria a product for everyone else to consume. Everyone else actually represents the thriving middle in Roman society, not the poor. We may also propose that garum could be made from a mixture of many types of fish blood and viscera and this would ultimately represent the lowest quality garum. Horace has one gourmet tell his guests that their oenogarum was made with muria and another who makes it with garum $^{\mathbf{5 1}}$. I had considered that this muria consuming gourmet was being ridiculed by the poet but clearly it is not that simple. The choice of

48. Curtis 1991 p. 6. One may imagine the non-viscera waste matter from such a large fish generating a cheap muria too.

49. See above note 45 . There is a modern fish sauce called colatura di Alici tradizionale made in Salerno Italy which involves very time consuming evisceration of tiny anchovy. The absence of viscera which provides digestive enzymes makes this sauce unusual. The sauce takes a year to completion and the tradition may go back ancient times and derive from a desire to make a "clean" fish sauce. It claims to be a garum, but has more in common with a muria. http://www.youtube.com/watch?v=GVGaz5yT67E.

50. Tiny gill bones from tuna have been found in a storage vessel in Aila Aqaba Jordon (Van Neer 2008).

51. Horace Sat 2.4.63-9;2.8. 


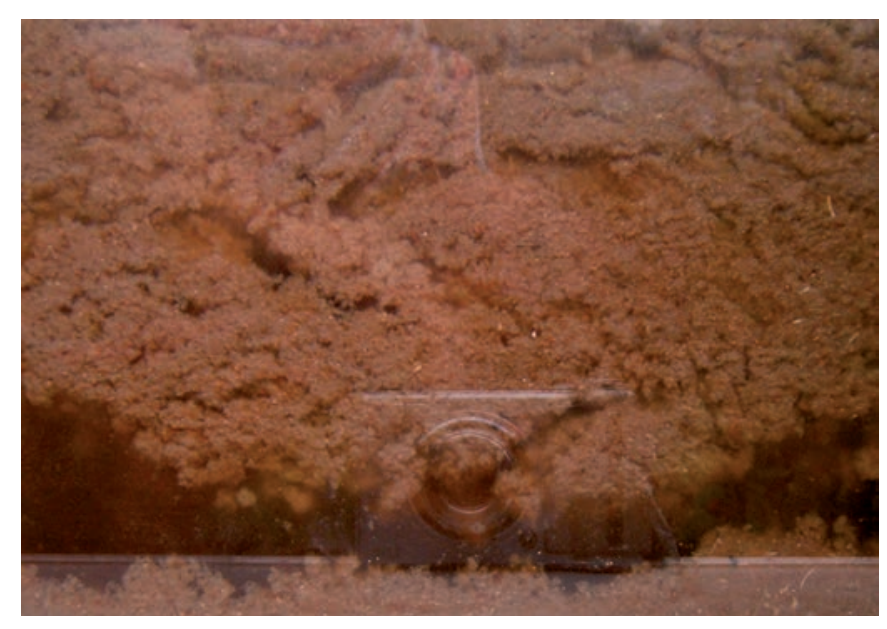

Fig. 2. Image of an unfiltered liquamen fish sauce (Grainger 2010).

which sauce to use in a given circumstance will depend on factors we do not necessarily understand. In the late empire liquamen is also described as a vulgar term in contrast to garum, but this does not mean that liquamen "per se" was necessarily lower class or cheaper; this would depend on its origin, variety, manufacturer and recipe used ${ }^{52}$. I have conducted many experiments to manufacture liquamen fish sauce and though they cannot be dealt with here in any detail it has been possible to demonstrate that long term storage of the unfiltered sauce results in exceptional nutrition ${ }^{53}$. An image of an unfiltered mackerel liquamen sauce can be seen in fig. 2 where the residue or allec is floating on the top of the clear enriched sauce. When this bone-free residue was re-brined and left for a few months, a relatively good quality second sauce was generated and which we find described on the price edict ${ }^{54}$.

Returning to Ausonius' letter, these discussions have allowed us to see that he strikes a lofty pose and looks down on muria which he suggest is a vulgar term and we therefore assume it is a cheap and commonplace ingredient but vulgar is clearly a relative cultural idiom and from his lofty position is clearly the term that everybody else uses. He appears to be discussing the very idea of fish sauce seasonings generally and, as he does not want to use garum and as he has not received liquamen, he is using the only other term at his disposal: muria, which is only slightly lower quality than the garum sociorum that he values. At the same time he acknowledges that it is inadequate and expresses some frustration over the issue of what to call whatever he has received: "by what ever name that liquor of our allies is called." That he has received a black garum is fairly clear but this letter also demonstrates that in the late empire fish sauce terminology had become a complicated issue.

\section{Conclusion}

It has been possible to see that each type of fish sauce could have had different roles within Roman cuisine. The sauce made just from blood and viscera is clearly sufficiently different in taste and flavour from the wholefish sauces and fish brines to warrant the development of specific and sophisticated roles for all three sauces, which may have been instigated by apparently proactive Roman gourmets.

There is a complex social order behind the consumption of these multiple varieties and qualities of fish sauce which would benefit from further study. When talking of fish sauces in archaeology and history it is now necessary to be much more precise and stipulate if possible which kind of fish sauce is being referred too. One could buy aged elite black mackerel garum, ordinary black tuna garum, elite liquamen cooking sauces made from mackerel or cheaper cooking sauces made with a mixture of clupeidae and sparidae, or a tuna or mackerel muria, both of which could also be aged or new. All of these products could also come in second or even third grade versions. Distinguishing between them will not always be possible in the archaeological record but a recognition of the diversity is essential. It is also no longer adequate to simply refer to a single product called garum as the term cannot convey the complexity of these products and its use actually confuses more than it aids our understanding of the fish sauce trade. It is clear that the perception of the quality of these products depends on many factors : the particular taste of the consumer, the particular role the sauce will have in the meal and whether that meal is everyday or a rite of passage feast as well as the purchasing power of the consumer and where the consumer is placed and places himself in the social order.

52. See note 8 above. Curtis 1991, p. 195 where he sites many tituli picti of named manufacturers.

53. Grainger forthcoming; Grainger 2010.

54. See note 3 with ref to the bone free allec. 


\section{Bibliography}

Adams 1995 : ADAMS (J.N.) - Pelagonius and Latin Veterinary terminology in the Roman empire, Studies in Ancient Medicine, Vol. 11, E.J. Brill, Leiden, 1995.

Biddulph 2008 : BIDDULPH (E.) - Form and function: the experimental use of Roman Samian ware cups, Oxford Journal of Archaeology, 27 (1), 2008, p. 91-100.

Brandt 1927 : BRANDT (E.) - Untersuchungen zum Römischen Kochbuch, Leipzig, Philologus, Supplement band XIX, Heft III, 1927.

Corcoran 1962 : CORCORAN (T.H.) - Roman fish sauces, Classical Journal, 58, 1962, p. 204-210.

Cotton et al. 1996 : COTTON (H.), LERNAU (O.), GOREN (Y.) - Fish sauce from Herodian Masada, Journal of Roman Archaeology, 9, 1996, p. 223-238.

Curtis 1984 : CURTIS (R.) - Negotiatores allecarii and the herring, Phoenix, $38.2,1984$, p. $147-158$.

Curtis 1991: CURTIS (R.) - Garum and Salsamenta. Production and Commerce in Materia Medica, Leiden, Brill, 1991.

Curtis 2009 : CURTIS (R.) - Umami and the foods of classical antiquity, American Journal of Clinical Nutrition, 90 (suppl): American Society for Nutrition, 2009, p. 712-718.

Dalby 1996 : DALBY (A.) - Siren Feasts: a history of food and gastronomy in Greece, London, Routledge, 1996.

Dalby 2006 : DALBY (A.) - Food in the ancient world from A to Z, London, Routledge, 2006.

Dalby 2011 : DALBY (A.) - The Geoponica, Totnes, Prospect Books, 2011.

Etienne 2007 : ETIENNE (R.), MAYET (F.) - L'industrie des salaisons et sauces de poisson dans la péninsule Iberique : état de la question. In : Lagóstena (L.), Bernal (D.), Arévalo (A.) (eds), Cetariae 2005. Salsas y salazones de pescado en Occidente durante la Antigüedad (Cádiz, 7-9 de noviembre de 2005), BAR International Series 1686, Oxford, 2007, p. $5-20$.

Grainger 2007 : GRAINGER (S.) - A new approach to Roman fish sauce. In : Petits Propos Culinaires. Essays and notes on food, cookery and cookery books, 83, Prospect books, Totness, 2007, p. 92-112.
Grainger 2010 : GRAINGER (S.) - Roman fish sauce: an experiment in archaeology, unpublished MA dissertation, Reading university, 2010.

Grainger forthcoming : GRAINGER (S.) - Roman fish sauce: fish bone residues and the practicalities of supply. In : Zohar (I.), Fradkin (A.), Morales (A.) (eds), Fish and fishing; Archaeological, Anthropological, Taphonomical, and Ecological perspectives, Special volume of Archaeofauna: International Journal of Archaeology.

Grant 2000 : GRANT (M.) - Galen, On food and diet, London, Routledge, 2000.

Grocock, Grainger 2006 : GROCOCK (C.), GRAINGER (S.) - Apicius: a Critical edition with introduction and English translation, Prospect book, Totness, 2006.

Herman 1975/2000 : HERMAN (J.) - Le Latin Vulgaire, Collection Que sais je ? 1247, $3^{\mathrm{e}}$ éd. rev. et corr., Paris (Vulgar Latin translated R Wright, University park PA, 2000).

Lauffer 1971 : LAUFFER (S.) - Diokletians Preisedikt, Berlin, de Gruyter, 1971.

Olson, Sens 2000 : OLSON (S.), SENS (A.) - Archestratos of Gela: Greek culture and cuisine in the fourth century BCE, Oxford university Press, 2000.

Studer 1994 : STUDER (J.S.) - Roman fish sauce in Petra, Jordan. In :Van Neer (W.) (ed.), Fish exploitation in the past, Proceedings of the 7th meeting of the ICAZ Fish Remains Working Group, Annales du musée Royal de l'Afrique Centrale, Sciences Zoologiques 274, Tervuren, 1994.

Van Neer 2002 : VAN NEER (W.), ERVYNCK (A.) - Remains of traded fish in archaeological sites: indicators of status or bulk food? In: Jones O'Day (S.) et al. (eds.), Behaviour behind bones, Proceedings of the 9th ICAZ conference, Durham, 2002, p. 203-14.

Van Neer 2008 : VAN NEER (W.), PARKER (S.) - First archaeological evidence for haimation, the invisible garum, Journal of Archaeological Science, 35,2008 , p. 1821-1827.

Willis 2005 : WILLIS (S.) - Samian pottery, a Resource for the study of roman Britain and beyond: the results of the English Heritage funded Samian Project. An e-monograph. http://intarch.ac.uk/journal/issue17/1

Weingarten 2005 : WEINGARTEN (S.) - Mouldy Bread and Rotten Fish: Delicacies in the Ancient World, Food \& History, vol. 3.1, 2005, p. 61-71. 



\section{Les sauces de poisson dans l'ouest de la province romaine de Lyonnaise : réflexions sur l'élaboration et la nature des produits}

\section{Cyril Driard}

\section{Introduction}

$\mathrm{L}$ a production des sauces et des salaisons de poisson sur le littoral de la province romaine de Lyonnaise est attestée mais il s'agit d'une activité économique difficile à cerner et ce pour plusieurs raisons: d'une part, contrairement au bassin méditerranéen, aucun texte ou inscription concernant cet artisanat n'a été recensé dans l'ouest de la Gaule. D'autre part, aucun contenant spécifique pouvant avoir servi au transport ou à la diffusion de ce produit n'a été retrouvé. Ces deux sources documentaires, qui font défaut en Lyonnaise occidentale, sont à l'origine des principales connaissances concernant cet artisanat dans l'Empire romain ; les fouilles archéologiques sur ce type d'établissement restant encore assez rares.

Une trentaine de sites antiques, ayant pour caractéristique commune la présence de cuves quadrangulaires maçonnées, ont été identifiés sur le littoral de la péninsule armoricaine. Ils se situent presque tous sur le territoire des Osismes, à l'exception de deux établissements reconnus dans la cité des Vénètes et d'un site incertain chez les Coriosolites. Pendant longtemps, la fonction de ces constructions a fait l'objet d'interrogations. À défaut de connaître la réelle utilisation de ces structures, différentes interprétations ont été proposées : balnéaire ${ }^{1}$, caves ${ }^{2}$, fours à briques, magasins à $\operatorname{sel}^{3} \mathrm{ou}$ postes de guet. Il faut attendre les fouilles du site des Plomarc'h à Douarnenez, réalisées par M.-L. Fleuriot à partir de 1955, pour que l'hypothèse de cuves destinées à la production de salaisons de poisson soit envisagée ${ }^{4}$. Cette interprétation est confortée suite à la publication d'une étude sur les ateliers de garum et de salaison de poisson identifiés au Maroc et en Espagne méridionale ${ }^{5}$. Les bassins maçonnés littoraux découverts dans l'ouest de la Gaule sont alors systématiquement interprétés comme des installations destinées à l'élaboration

1. Fréminville 1837, p. 186-187.

2. Borrely de Kervelegan 1899, p. 304-306.

3. Abgrall 1895, p. 183-190.

4. Merlat 1957, p. $186-190 ; 1958$, p. 94 ; 1959, p. 342-343.

5. Ponsich, Tarradell 1965 des salaisons et des sauces de poisson ${ }^{6}$. La fonction du site des Plomarc'h a été confirmée dans les années 1990, grâce aux fouilles réalisées par J.P. Bardel ${ }^{7}$. Des dépôts bruns de 1 à $2 \mathrm{~mm}$ d'épaisseur et dégageant une odeur de poisson ont été observés sur les parois des cuves mises au jour dans cet établissement ${ }^{8}$, sans pour autant faire l'objet de description détaillée.

Les fouilles réalisées en 2007 et 2008 sur deux autres ateliers, situés à Etel (Morbihan) et Kerlaz (Finistère), ont permis de découvrir des dépôts semblables. Ces nouvelles observations, associées aux différentes données recueillies lors de ces deux fouilles récentes, ont été confrontées à l'archéologie expérimentale. L'objectif de cette démarche était de tenter de reproduire les différents dépôts observés afin de mener des réflexions sur les produits élaborés au sein de ces ateliers et surtout d'essayer de comprendre la fonction des différentes cuves mises au jour.

\section{Bilan des connaissances acquises avant 2007 sur les ateliers de salaisons et de sauces de poisson dans l'ouest de la Lyonnaise}

La majorité des observations effectuées sur les ensembles de cuves maçonnées sont anciennes et peu détaillées. La plupart de ces vestiges archéologiques sont aujourd'hui inaccessibles ou détruits, ce qui limite les possibilités de réexaminer leur fonction.

La présence de restes de poisson, intéressant peu les explorateurs du $\mathrm{XIX}^{\mathrm{e}}$ et du début du $\mathrm{XX}^{\mathrm{e}}$ s., n'a été signalée que sur trois sites. Une couche constituée exclusivement de déchets de poisson, épaisse d'environ $30 \mathrm{~cm}$, a été retrouvée au fond de l'une des cuves mise au jour au lieu-dit Kerobistin à Combrit. Il s'agirait de restes de sardines si l'on en croit l'expertise des marins contactés suite à la découverte ${ }^{9}$. Une couche similaire a été mise en évidence lors de la fouille de l'établissement

6. Galliou, Sanquer 1972, p. 199-223.

7. Bardel 2007, p. 101-116.

8. Sanquer 1977, p. 359.

9. Borrely de Kervelegan 1899, p. 304-306. 
de la rue du Guet à Douarnenez ${ }^{10}$. Enfin, dans cette même commune, lors des différentes campagnes de fouille du site des Plomarc'h, plusieurs amas de restes de poissons ont été découverts. Il s'agissait de couches de 4 à $10 \mathrm{~cm}$ d'épaisseur, constituées de «millions de vertèbres, d'écailles, de têtes de poisson ». L'étude ichtyologique ${ }^{11}$ a permis d'identifier des petites sardines dont la taille n'excédait pas 3 à $4 \mathrm{~cm}$, quelques sprats et un merlu. Le fond de l'une des cuves était recouvert d'un dépôt brun de 1 à $2 \mathrm{~mm}$ d'épaisseur avec une odeur de poisson, " comme si à la suite d'une forte chaleur, le contenu de la cuve s'était caramélisé ${ }^{12}$. La reprise des fouilles en 1994 a permis de retrouver de nombreux restes de poisson, ainsi qu'un dépôt brun semblable, décrit comme une « cristallisation » d'un millimètre d'épaisseur ${ }^{13}$.

Du matériel de pêche a été découvert lors de fouilles d'ateliers, sans pour autant que l'on puisse établir de lien entre ces outils et l'approvisionnement en poissons des unités de production. Une navette en alliage cuivreux a été découverte lors des fouilles du site de Kervel à Plonevez-Porzay ${ }^{14}$, une navette en alliage cuivreux et une série de huit pesons taillés dans des éléments architecturaux en terre cuite ont été mis au jour dans celui de Lanévry à Kerlaz ${ }^{15}$, enfin, des aiguilles « de filet » en os et des pesons en terre cuite ont été découverts sur le site du Resto à Lanester ${ }^{\mathbf{1 6}}$.

Les ateliers identifiés (fig. 1) se situent tous en milieu rural, à proximité de bâtiments pouvant présenter des caractéristiques résidentielles. Il pourrait s'agir de complexes artisanaux situés dans les zones d'exploitation de villae ou de fermes. Aucun plan complet n'est disponible, le site des Plomarc'h est l'établissement le mieux documenté, bien qu'une seule des trois unités de travail connues ait fait l'objet de fouilles et de relevés précis. Quelques plans partiels permettent d'observer plusieurs répartitions possibles des cuves au sein des ateliers (fig. 2). Elles peuvent être disposée en $U$, formant une enclave bordant un espace de circulation (exemple : atelier de la rue du Guet à Dournenez). D'autres ont été disposées en une rangée, avec un bassin situé perpendiculairement à l'une des extrémités. L'ensemble forme un L, s'articulant autour d'une cour (exemple: unités a et c des Plomarc'h à Douarnenez). L'atelier de PortRhu à Douarnenez semble constitué de deux rangées de cuves parallèles, situées de part et d'autre d'un couloir

10. Peuziat 1981, p. 15-16 ; Sanquer 1981, p. 54-55.

11. Desse 1958, p. XII.

12. Sanquer 1977 , p. 359.

13. Bardel 2007, p. 101-116.

14. Sanquer 1969, p. 36-37.

15. Driard 2011, p. 351, fig. 54.

16. André 1992, p. 42. de circulation. Les ateliers les plus imposants (unité b des Plomarc'h à Douarnenez et Lanévry à Kerlaz) sont caractérisés par des séries de cuves accolées les unes aux autres, s'adossant à un important mur de soutènement.

Les modalités de construction des cuves semblent avoir répondu à des critères architecturaux précis, seules les dimensions et la profondeur varient d'un atelier à un autre. Elles ont été installées dans une excavation ayant pour limite le plan du bâtiment. Les murs sont construits avec des moellons de petit appareil en granit, joints au mortier de chaux. Leur épaisseur est comprise entre 0,50 et $0,60 \mathrm{~m}$. Le fond des cuves est souvent constitué d'un radier de cailloux, sur lequel plusieurs couches de mortiers de chaux et de tuileau ont été coulées. Le revêtement des parois est constitué, dans la majorité des cas, de deux à trois couches de mortier de tuileau et d'un enduit. Des solins d'étanchéité ont été aménagés dans les angles, aux jonctions entre les différentes parois et entre les parois et le fond des bassins. Il existe plusieurs cuves où aucun enduit et aucun solin n'a été mis en évidence. Aux Plomarc'h à Douarnenez, sur les seize cuves observées, cinq ne sont pas enduites. Elles sont plus profondes, regroupées dans la même zone et leur fond est constitué du substrat ${ }^{17}$. À Lanester, sur les quatre cuves fouillées, deux ne sont pas enduites. Il s'agit également des structures les plus profondes ${ }^{18}$. Ces bassins ont souvent été interprétés comme des zones de stockage, soit du produit fini, soit d'une des matières premières comme le sel par exemple. Il ne faut pas exclure aussi la possibilité qu'il s'agisse de cuves inachevées. D'ailleurs, un des bassins des Plomarc'h occupe l'emplacement de deux cuves. Il n'est pas revêtu de mortier de tuileau et des aménagements laissent supposer que la partition de ce bassin en deux cuves faisait partie du projet architectural initial ${ }^{19}$. Ces ateliers étaient couverts. Sur le site des Plomarc'h à Douarnenez, des emplacements de poteaux encastrés dans la maçonnerie et des piliers de soutènement ont été retrouvés. Ils étaient probablement destinés à maintenir la toiture ${ }^{20}$.

Le comblement des cuves comporte très souvent des éléments architecturaux et décoratifs. Lors de l'exploration du site de Kerobistin à Combrit, un socle en granit, un pilier avec moulures et une section de sphère en marbre blanc ont été découverts ${ }^{21}$. Une base de colonne en granit a été mise au jour dans l'une des cuves de l'Anse de Morgat à Crozon ${ }^{22}$, deux fragments d'une

17. Bardel 2007, p. 101-116.

18. André 1992, p. 41-47.

19. Bardel 2007, p. 101-116.

20. Id.

21. Borrely de Kervelegan 1899, p. 304-306.

22. Pape 1978, p. A-91. 


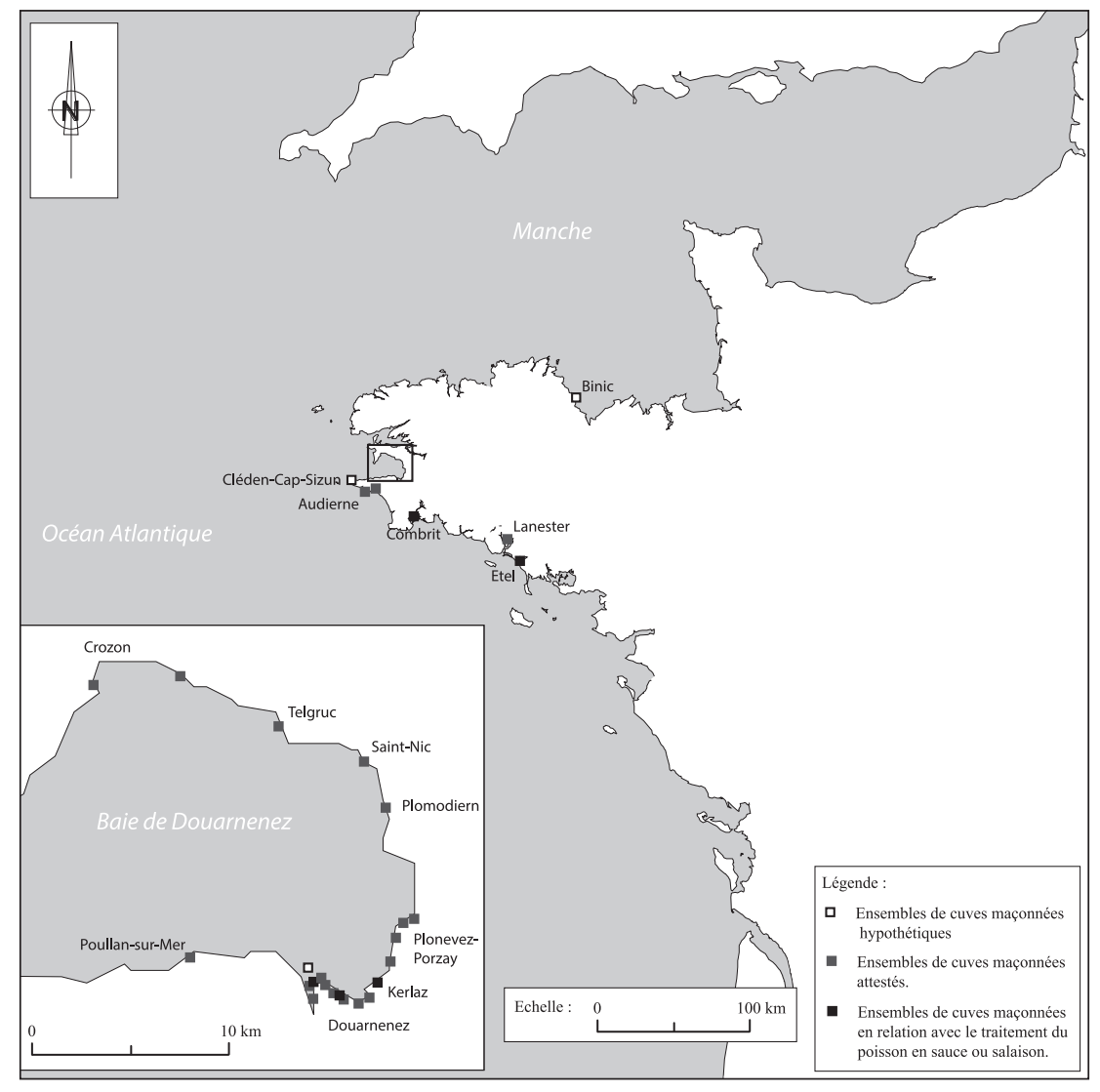

Fig. 1. Carte des ensembles de cuves maçonnées identifiés sur le littoral de la Lyonnaise (réalisation : C. Driard).

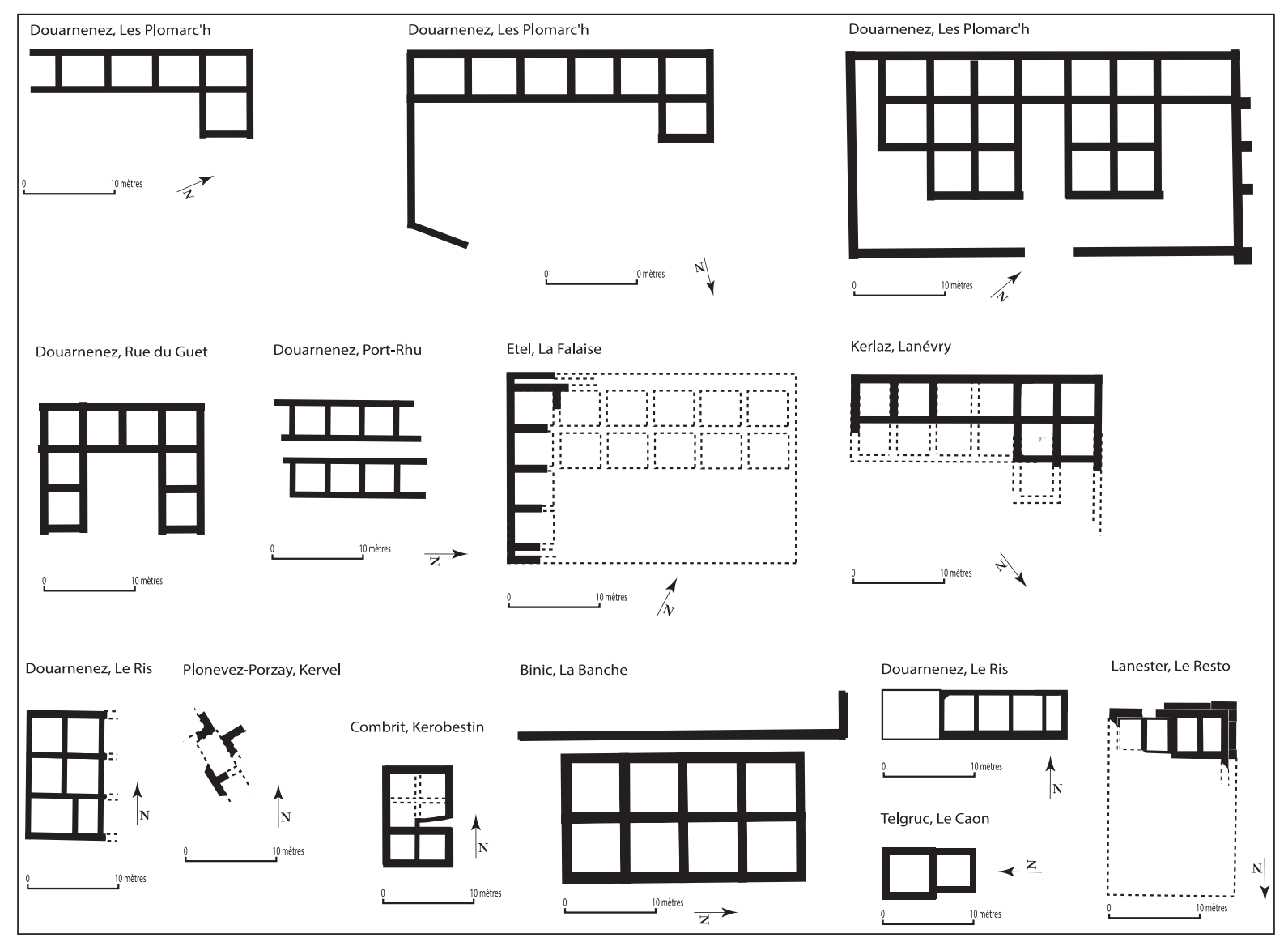

Fig. 2. Les plans d'ateliers équipés de cuves maçonnées en Lyonnaise (réalisation : C. Driard). 
base de colonne moulurée en granit ont été trouvés dans l'atelier de Porz ar Vag à Plomodiern et un fragment de pilastre en marbre a été découvert au fond de l'une des cuves de Lanévry à Kerlaz ${ }^{23}$. La provenance de ces éléments est très souvent indéterminée. Il pourrait s'agir de blocs rapportés pour combler les cuves ou d'éléments provenant du démantèlement d'édifices voisins. Ces éléments architectoniques peuvent également provenir de la destruction des ateliers. Aux Plomarc'h à Douarnenez, une colonne en calcaire à base attique et un fragment de haut-relief ont été découverts ${ }^{24}$. Une autre colonne avec base moulurée en granit, provient du porche d'entrée de 1'atelier ${ }^{25}$. Celui-ci se situe en face du mur constituant le fond de l'édifice, dans lequel sont aménagées des niches. C'est en contrebas de la niche centrale qu'une statue d'Hercule en marbre a été trouvée. D'autres sculptures de cette même divinité ont été découvertes dans les cuves de quatre autres établissements de la Baie de Douarnenez ${ }^{26}$. L'embellissement des ateliers pourrait s'expliquer par la présence de représentations divines en leurs murs.

Sur le conditionnement des produits issus des cuves, l'utilisation de vases en céramique commune a été proposée $^{27}$, suite à la découverte de poteries contenant des restes de poisson dans l'une des cuves des Plomarc'h à Douarnenez. L'utilisation de contenants en bois semble être une bonne alternative, confortée suite à la découverte de Fos-sur-Mer ${ }^{28}$. Pour les ateliers du sud de la Gaule, l'hypothèse d'un transport des sauces de poisson en dolia ou en tonneaux et d'un reconditionnement en amphores à Lyon a été évoquée pour expliquer les différentes inscriptions de Antipolitanum sur des amphores produites à Lyon ${ }^{29}$. Un dispositif commercial semblable pourrait avoir été mis en place dans l'ouest de la Lyonnaise. Enfin, il ne faut pas exclure l'éventualité de contenants en verre.

Enfin, concernant la chronologie de ces ateliers, très peu de données archéologiques sont disponibles. Les différentes découvertes de mobilier archéologique permettent de situer leur fonctionnement au cours des $\mathrm{II}^{\mathrm{e}}$ et $\mathrm{III}^{\mathrm{e}} \mathrm{s}$. de notre ère.

23. Driard 2011, p. 335-336.

24. Bardel 2007, p. 101-116.

25. Sanquer 1979 , p. 359.

26. Maligorne 1998, p. 87-93 ; Driard 2011, p. 379-380.

27. Galliou 1971, p. 229-230.

28. Découverte d'un fût en bois contenant des arêtes de sardines prises dans de la résine et interprétées comme des restes de salaisons de poisson (Desse-Berset, Desse 2000, p. 93).

29. Martin-Kilcher 1990, p. 37-44.
2. Les fouilles archéologiques des ateliers d'Etel (Morbihan) et de Kerlaz (Finistère)

Deux édifices équipés de cuves maçonnées ont fait l'objet de sondages archéologiques en 2007 et 2008. Le premier établissement étudié est celui de Lanévry à Kerlaz ${ }^{30}$. Il se trouve dans la baie de Douarnenez, là où se concentrent les principales découvertes de batteries de cuves maçonnées. Le second, localisé à l'écart de cette concentration remarquable, se situe au lieu-dit La Falaise à Etel $^{31}$. Le choix de ces deux sites pour y réaliser des sondages archéologiques a été effectué en fonction de l'accessibilité du terrain et surtout, de l'urgence à étudier ces gisements, détruits progressivement par l'érosion maritime.

L'établissement de Lanévry s'est développé sur des terrasses artificielles surplombant la mer et aménagées sur le versant d'un vallon au fond duquel coule un petit cours d'eau. Le sommet du promontoire était vraisemblablement occupé par un complexe résidentiel, jamais étudié et en grande partie détruit. En contrebas du versant du vallon, plusieurs bâtiments dont la fonction est indéterminée ont été observés ${ }^{32}$. Les sondages ont été réalisés sur deux terrasses situées dans la partie médiane du site archéologique où quelques cuves avaient été mises au jour. Les objectifs des recherches étaient de délimiter l'atelier et d'étudier son environnement immédiat. Le bâtiment abritant les cuves est situé à l'écart des autres constructions, seuls les restes d'un foyer et quelques fosses ont été mis au jour à proximité. Il se présente sous la forme d'un édifice rectangulaire mesurant $20 \mathrm{~m}$ de long et au moins $8 \mathrm{~m}$ de large. Le mur constituant le fond du bâtiment sert également de mur de soutènement à la terrasse située à l'arrière du bâtiment. Au moins 13 cuves ont été identifiées ; deux d'entre elles mesurent $3 \mathrm{~m}$ de côté, cinq mesurent 3,20 $\mathrm{m}$ de long et $3 \mathrm{~m}$ de large. La profondeur des cuves dont le fond a été atteint était de $3 \mathrm{~m}$, la plus creuse atteignant $4,30 \mathrm{~m}$.

L'atelier de la Falaise à Etel a été implanté sur un promontoire dominant l'embouchure de la ria d'Etel. Il s'agit d'un bâtiment rectangulaire mesurant $22 \mathrm{~m}$ de largeur et probablement $30 \mathrm{~m}$ de longueur. Seule l'extrémité ouest de l'édifice, située sous le sentier côtier, a été sondée. Il abriterait 14 cuves, observées lors des travaux d'aménagement du camping. Les sondages archéologiques ont permis de mettre en évidence au moins cinq

\footnotetext{
30. Driard 2011, p. 172-177.

31. Driard 2007, p. 55-62 ; 2008, p. 237-344 ; 2011, p. 171.

32. Bousquet 1969, p. 253-254; Sanquer 1970, p. 49 ; Galliou, Sanquer 1972, p. 211-213.
} 
cuves, dont quatre mesurant 3,80 $\mathrm{m}$ de long, 3,65 $\mathrm{m}$ de large et au moins $2,20 \mathrm{~m}$ de profondeur.

Lors de ces deux fouilles, différentes informations apportant des renseignements sur la fonction des cuves et le type de production ont été recueillies. Elles se répartissent en trois catégories : les outils, les amas de restes osseux (essentiellement de poissons) et les dépôts, ainsi que les traces d'altérations observées au fond et sur les parois des cuves.

Seule la fouille du site de la Falaise a permis de découvrir deux outils. Le premier est un fragment de rouleau tronconique en granit, similaire à celui trouvé lors des fouilles de l'atelier des Plomarc'h à Douarnenez ${ }^{33}$. Ce dernier a été interprété, lors de sa découverte, comme un rouleau provenant d'une machine « destinée à presser le garum ${ }^{34}$. Ces rouleaux présentent des similarités avec ceux utilisés dans les moulins à sel à l'époque moderne, toutefois, leur fonction dans les ateliers de la Falaise et des Plomarc'h demeure indéterminée. Un fond de vase percé ${ }^{35}$ rempli de restes osseux de poisson agglomérés et tassés a été retrouvé. Il a été utilisé au moins deux fois, comme en atteste un amas de déchets de poissons compressés dont la forme coïncide avec le négatif du fond de vase percé. La compression de restes de poissons correspond donc à un geste pratiqué dans les ateliers, bien que la majorité des déchets retrouvés n'aient pas subi cette opération.

Les restes osseux découverts correspondent essentiellement à du poisson. Ils ont été retrouvés sous la forme de couches de plusieurs centimètres d'épaisseur, contenant des milliers de pièces osseuses. Ils se trouvaient en position de rejet, précipités dans les cuves lors de leur comblement. Concernant l'établissement de la Falaise, à Étel, quatre cuves ont été sondées, mais seulement trois l'ont été jusqu'au fond. Sur ces trois dernières, deux ont livré des restes de poissons. Sur le site de Lanévry à Kerlaz, trois des neuf cuves mises en évidence ont été sondées jusqu'au fond. Parmi ces trois cuves, une seule n'avait pas fait l'objet d'explorations postérieures à leur premier comblement. Il s'agit de l'unique structure ayant livré des restes de poissons. Les autres bassins mis au jour étaient scellés par des portions de murs effondrés. Leur contenu a été préservé dans l'optique de fouilles archéologiques ultérieures.

33. Bardel 2007, p. 101-116.

34. Id., p.106-107.

35. Cet objet peut être comparé aux découvertes effectuées dans l'un des puits de Lattes (Piquès 2005) qui contenait un amas de restes de poissons comparable à ceux d'Étel et de Kerlaz, ainsi que quatre fonds d'amphores gauloises, percés, remplis d'ossements de poissons et interprétés comme de possibles filtres.
Les couches de déchets de poisson ont été partiellement prélevées, le volume total des échantillons atteint 96 litres pour un poids total de $97,92 \mathrm{~kg}$ à Etel et 22 litres pour un poids total de $22,44 \mathrm{~kg}$ à Kerlaz. Ces dépôts de restes osseux ont évolué en milieu clos. En effet, les cuves sont des structures avec un fond et des parois étanches et épaisses. De plus, leur comblement a été scellé par une couche de mortier de tuileau détritique tassée dont l'épaisseur varie de 0,05 à $0,20 \mathrm{~m}$. Ce niveau correspond à l'enduit d'étanchéité des parties supérieures des cuves, qui ont été burinées par les récupérateurs de matériaux afin d'accéder aux moellons de la maçonnerie. La densité de déchets de poisson était si importante que le cœur du dépôt a probablement peu évolué depuis son rejet au cours de l'Antiquité. L'odeur de poisson était encore présente lors de la fouille. La couche de restes osseux de poissons issue de la cuve 1 du site de la Falaise à Étel comprenait des écailles, des nageoires, des os céphaliques (operculaire, frontal, hyomandibulaire et dentaire), des rachis, des vertèbres, et des côtes. Certains éléments étaient complets, d'autres fragmentés. Des connexions anatomiques comprenant trois à huit vertèbres avec leurs côtes ont été observées lors de la fouille mais ces restes se sont désolidarisés lors du séchage. Le dépôt de la cuve 2 était similaire. Enfin, le dépôt de la cuve 7 du site de Lanévry était principalement constitué de vertèbres complètes et d'épines très fragmentées.

Les restes osseux appartiennent essentiellement à des poissons (à plus $99 \%$ ). D'autres animaux ont été identifiés (rongeurs et batraciens), leur présence est anecdotique (inférieure à 0,5\%). L'ensemble des ossements avaient une teinte jaunâtre à orangé. Les ossements d'animaux et les coquillages retrouvés dans les couches situées dans les niveaux inférieurs et supérieurs, au contact de ces dépôts de restes de poissons ne possédaient pas cette teinte. Une telle modification de couleur serait donc antérieure à l'enfouissement de ces déchets et pourrait résulter d'une opération particulière du traitement du poisson. Des restes osseux appartenant à de petits animaux, comme les rongeurs ou les batraciens, ont été retrouvés avec les déchets de poisson. Ils possèdent aussi cette teinte jaunâtre à orangé, à l'instar des restes de poissons. Cela laisse supposer que la présence de ces animaux au sein de la couche de restes de poisson n'est probablement pas liée à des intrusions postérieures à l'enfouissement du dépôt. Ils pourraient avoir participé, accidentellement ou parce qu'ils faisaient partie des ingrédients nécessaires à la recette, à une même action, qui a conduit à la formation de ces déchets.

La majorité des restes de poissons proviennent de la famille des clupéidés. Il s'agit essentiellement de 


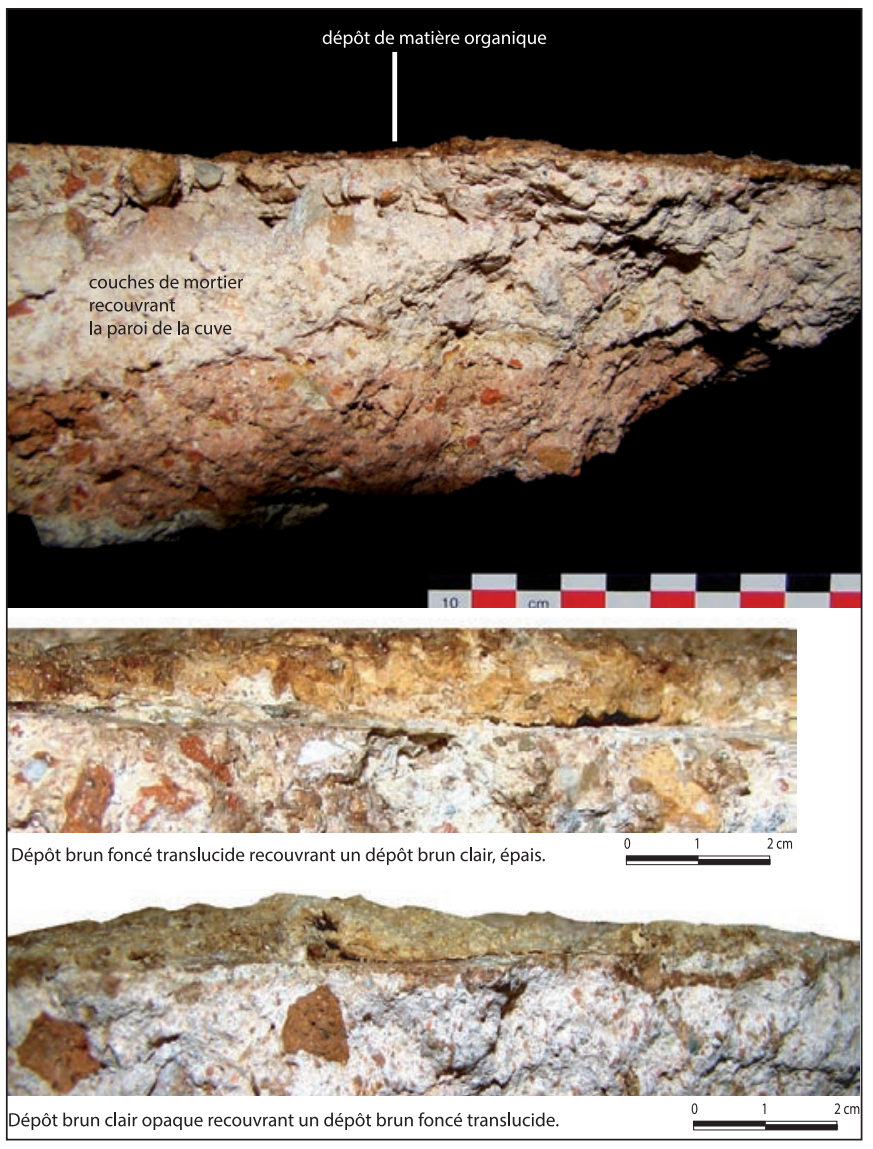

Fig. 3. Les dépôts de matière organiques sur les parois des cuves maçonnées du site de La Falaise à Etel (réalisation : C. Driard).

sardines Sardina pilchardus: cette espèce représente plus de $99 \%$ des restes de poissons provenant des cuves d'Étel. On note également la présence anecdotique de harengs (Clupea harengus), de scombridés, identifiés à des maquereaux (Scomber scombrus) et les restes d'au moins deux gadidès, identifiés à des merlans (Merlangius merlangus). À Kerlaz, la seule espèce identifiée est la sardine (Sardina pilchardus). La majorité des sardines retrouvées dans ces dépôts mesurent entre 10 et $12 \mathrm{~cm}$. Les poissons les plus courts mesurent environ $8 \mathrm{~cm}$ et les plus longs n'excèdent pas $13 \mathrm{~cm}^{36}$.

Les données obtenues à partir de cette première analyse confirment donc l'importance de la sardine, qui semble être l'ingrédient principal des spécialités à base de poissons et de sel produites dans les cuves littorales de la province de Lyonnaise ${ }^{37}$. Cependant, il convient de

36. Évaluées d'après des ossements provenant de spécimens actuels mesurés et au moyen d'une droite de régression entre les tailles des individus, à partir de mesures effectuées sur le hyomandibulaire (Desse 1984 ; Desse, Desse-Berset 1996 ; Piquès 2005, p. 294-295).

37. Les restes de poisson découverts dans les cuves des Plomarc'h à Douarnenez (Sanquer 1977, p. 359), dans celles de Kerobistin à

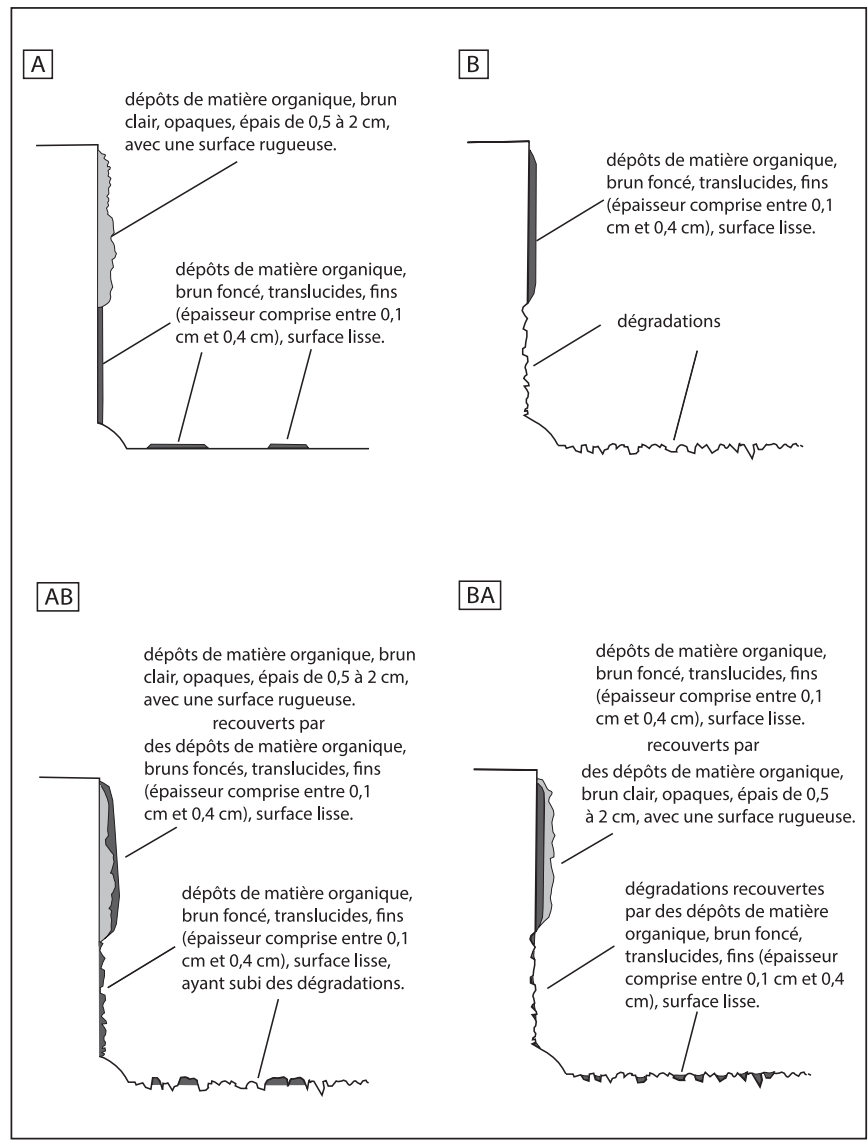

Fig. 4. Les différents types de dépôts et de traces observés sur les parois et au fond des cuves d'Etel et de Kerlaz (réalisation : C. Driard).

rester prudent sur la représentativité de ces échantillons de restes osseux. Seuls les poissons entiers ou les parties de poisson utilisées avec un fragment de leur squelette sont identifiables. Si les résidus retrouvés appartiennent à une préparation du type garum, il est possible que des viscères ou des chairs provenant d'autres espèces étaient associés aux poissons entiers, sans qu'il soit possible de le détecter. De plus, la présence d'une couche de coquilles d'huître au fond de la cuve 1 de l'atelier d'Etel soulève la question de l'emploi de ce coquillage dans les productions de l'atelier.

Les dépôts de matière organique, jamais signalés en dehors des ateliers de la péninsule armoricaine, se présentent sous la forme d'une couche brune, translucide ou opaque, lisse ou rugueuse, d'une épaisseur moyenne de $2 \mathrm{~mm}$ (fig. 3). Lors de leur mise au jour, une très forte odeur de poisson s'en dégage (phénomène déjà décrit lors des fouilles des Plomarc'h à Douarnenez). Le mortier de chaux constituant les parois et le fond de la

Combrit (Borrely de Kervelegan 1899, p. 304-306) et dans celles de la rue du Guet à Douarnenez (Peuziat 1981, p. 15-16 ; Sanquer 1981, p. 54-55) appartiendraient essentiellement à des sardines. 
cuve prend parfois une coloration brunâtre, ce qui laisse supposer que les dépôts de matière organique sont liés à une solution liquide qui tend à s'imprégner dans les maçonneries. Cette observation a été faite sur le site de Lanévry à Kerlaz. À Étel, c'est beaucoup moins évident. Cela pourrait être dû à la qualité des maçonneries ${ }^{38}$.

Les dépôts de matière organique et les altérations observés sur les parois et au fond des cuves ont été classés en cinq catégories (A, B, AB, BA et C) (fig. 4).

A : au niveau supérieur de la cuve, les parois comportent des dépôts de matière brun clair, opaques, épais de 0,5 à $2 \mathrm{~cm}$, avec une surface rugueuse. Au niveau inférieur, les parois comportent des dépôts brun foncé, translucides, fins (épaisseur comprise entre $0,1 \mathrm{~cm}$ et $0,4 \mathrm{~cm}$ ), et dont la surface est assez lisse.

B : au niveau supérieur de la cuve, les parois comportent des dépôts brun foncé, translucides, fins (épaisseur comprise entre $0,1 \mathrm{~cm}$ et $0,4 \mathrm{~cm}$ ), et dont la surface est lisse ou légèrement rugueuse. Au niveau inférieur, on observe une dégradation de l'enduit et des couches de mortier des parois, du solin et du fond de la cuve.

AB : Les dépôts observés semblent être la superposition d'un dépôt de type $\mathrm{A}$, puis d'un dépôt et de traces d'usure de type B.

BA : Les dépôts observés semblent être la superposition d'un dépôt et de traces d'usure de type $\mathrm{B}$, puis d'un dépôt de type A.

$\mathrm{C}$ : les parois des cuves ne comportent aucun des dépôts de matière décrits précédemment, ni altération importante. L'enduit est lisse et bien conservé. On remarque à sa surface des zones recouvertes par une multitude de petits trous dont le diamètre est de quelques micromètres. Il s'agit d'une corrosion par piqûres, généralement produite par certains anions (en particulier, les chlorures).

Le type $A B$ semble résulter du type $A$, auquel succède le type $\mathrm{B}$. Le type $\mathrm{BA}$ semble résulter du type $\mathrm{B}$, auquel succède le type $A$. En partant de l'hypothèse selon laquelle les traces de type $\mathrm{A}, \mathrm{B}$, et $\mathrm{C}$ résulteraient de trois types d'activités ou d'étapes de préparation différentes réalisées dans les cuves mises au jour sur les sites de Lanévry à Kerlaz et de la Falaise à Étel, on peut en déduire que le type $\mathrm{AB}$ correspond à une activité ou à une phase de préparation à l'origine des traces de type A, la même cuve est utilisée ensuite pour une activité ou une phase de préparation à l'origine des traces de type $\mathrm{B}$. Ainsi, les traces de type $\mathrm{B}$, laissées lors de la dernière

38. Les analyses de mortier de tuileau prélevés dans les parois et les solins d'étanchéité des cuves ont permis de démontrer qu'ils présentaient une matrice partiellement hydraulique (Driard, Coutelas 2007), ce qui n'est pas forcément le cas de tous les mortiers de tuileau. utilisation de la cuve, se superposent aux traces de type A, laissées lors de l'une des utilisations précédentes de la cuve.

Le type BA correspond à une activité ou à une phase de préparation à l'origine des traces de type $\mathrm{B}$, la même cuve est utilisée ensuite pour une activité ou une phase de préparation à l'origine des traces de type A. Ainsi, les traces de type A, laissées lors de la dernière utilisation de la cuve, se superposent aux traces de type B, laissées lors de l'une des utilisations précédentes de la cuve.

Le type $\mathrm{C}$ correspond à des traces laissées par un contenu de nature différente des quatre cas précédents. Il semblerait que les cuves caractérisées par ce type de trace aient été préservées pour une activité en particulier, moins salissante et moins destructrice que celles ayant eu lieu dans les autres cuves. Les soupçons concernant le produit à l'origine de ces dégradations se portent sur le sel. Si cette hypothèse était confirmée, deux solutions pourraient être évoquées : l'utilisation de la cuve soit en tant que réserve de sel, soit pour y faire des salaisons de poissons. Les données archéologiques disponibles ne permettent pas de favoriser l'une ou l'autre de ces deux hypothèses. Étant donné les besoins en sel que requiert la salaison ou la production de garum, il est aisément envisageable qu'une ou plusieurs cuves aient été réservées au stockage de cette denrée, à proximité immédiate des structures à alimenter.

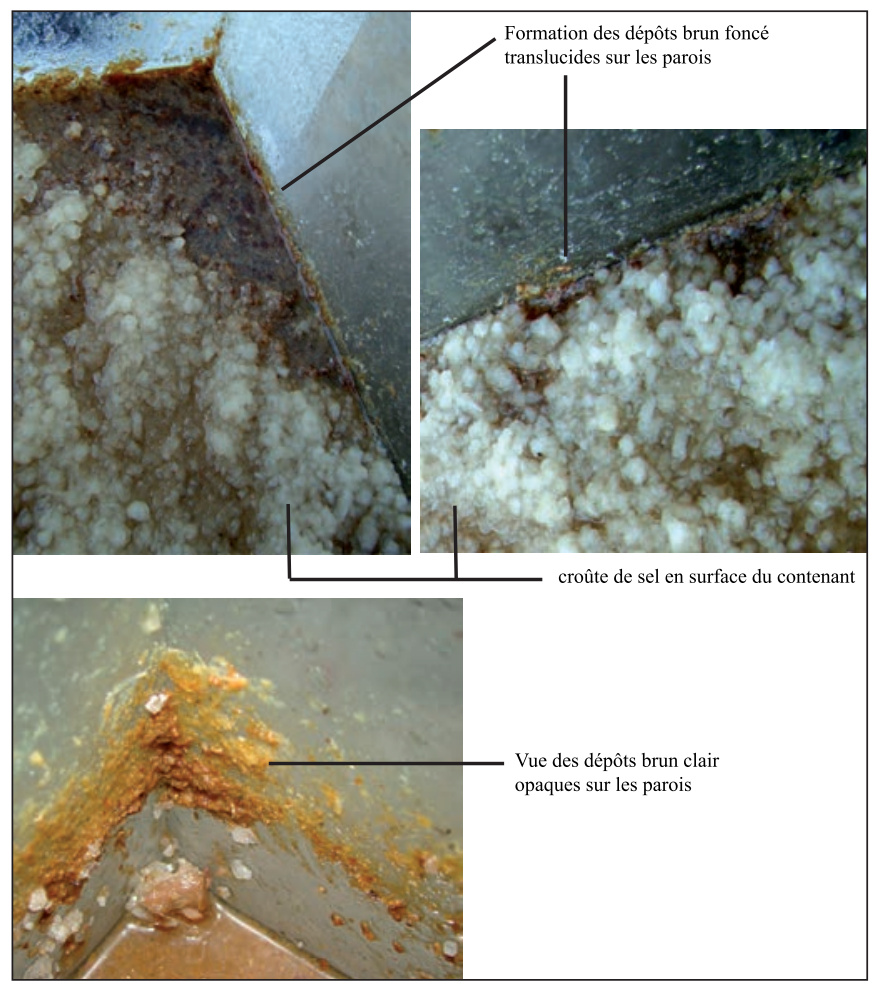

Fig. 5. Expérimentation archéologique : création des dépôts brun foncé translucides et brun clair opaques (réalisation : C. Driard). 


\section{Archéologie expérimentale}

Différents essais de fabrication de sauces de poisson ont été effectués afin de recréer les dépôts de matière organiques et les traces observés sur les parois des cuves. Cet objectif explique les libertés prises lors des différentes expérimentations, par rapport aux recettes et aux techniques rapportées dans les textes antiques.

Les expérimentations ont été réalisées avec des conditions climatiques proches de celles du sud-ouest de la Bretagne et le contenant a été placé en extérieur, sous un abri. Les ingrédients utilisés se sont limités aux sardines, au sel et à de l'eau. La première expérimentation a été effectuée avec du sel ignigène, obtenu par la cuisson d'une saumure. Les autres expériences ont été réalisées avec du sel non raffiné provenant des marais salants de Guérande. Les expériences ont été effectuées dans des bacs de 301 en plastique, dont l'une des faces internes avait été préalablement recouverte d'une paroi en plâtre destinée à recueillir les dépôts. L'une des expérimentations a été réalisée dans un aquarium, afin de pouvoir photographier le processus tout au long de l'expérience. La durée moyenne d'une expérimentation est de 4 à 6 mois.

La première expérience, réalisée avec un tiers de sel ignigène et deux tiers de poisson, a été un échec. Elle n'a pas été renouvelée en raison du temps nécessaire à l'obtention de ce type de sel. La deuxième expérience, réalisée avec un tiers de sel issu de marais salant et deux tiers de poisson, a permis d'obtenir un produit de type garum de bonne qualité mais sans les dépôts brun foncé translucides et les traces d'altérations observés lors des fouilles des cuves. Toutefois, quelques dépôts brun clair opaque ont commencé à se former. Pour la troisième expérience, la quantité de sel a été augmentée, atteignant $50 \%$ du volume de la préparation. Les poissons se sont alors asséchés et aucun liquide n'a été produit. La quatrième expérience a été effectuée avec les mêmes proportions de poisson et de sel que la précédente tentative, mais en rajoutant de l'eau régulièrement. Cette option a permis d'atteindre les objectifs fixés (fig. 5).

Le processus permettant l'obtention de l'hydrolysat a duré environ quatre mois (fig. 6 et 7). La température et le niveau d'humidité ambiant sous l'abri protégeant le contenant ont été relevés trois fois par jour et deux fois par nuit (fig. 8).

- 14 juillet 2008 (début de la quatrième expérimentation) : les couches de sardines ont été déposées dans le contenant en alternance avec des couches de sel. Le volume disponible était de 251 . L'expérience a permis de remplir 201 du contenant, avec $50 \%$ de poisson et $50 \%$ de sel. À l'issue du remplissage de l'aquarium,
0,501 d'eau a été ajouté afin de maintenir l'humidité nécessaire au bon déroulement du processus.

- 17 juillet 2008 : au bout de trois jours seulement, le processus de liquéfaction des chairs des poissons est visible. Des tâches brunes apparaissent autour des poissons. Une épaisse croûte de sel se forme à la surface du contenant. Le processus se poursuit désormais dans un milieu clos, où l'homme n'a pas à intervenir, sauf pour ajouter de l'eau (environ 0,2 litre par semaine) afin de contrer les effets de l'évaporation. Il ne faut pas en rajouter de façon excessive, sinon le garum n'est pas assez concentré. L'eau s'infiltre sous la croûte sans la détruire.

- 18 août 2008 : les poches de liquide brun autour des poissons n'ont cessé d'augmenter en volume. Après 38 jours de macération, on observe la migration du liquide brun vers la surface, mais cette remontée est stoppée par la croûte de sel. Le liquide remonte de façon privilégiée le long des parois et il commence à s'infiltrer entre les parois du contenant et la bordure de la croûte de sel. Le liquide brun parvenant en surface est bloqué entre la croûte de sel et les parois du contenant, il s'assèche, constituant alors un dépôt de matière organique brun foncé, lisse et translucide, recouvrant les parois du contenant dans leur partie supérieure.

- 10 novembre 2008 : après avoir macéré dans la saumure pendant 133 jours, les chairs des sardines sont totalement dissoutes. Il ne reste plus que les parties osseuses, les écailles et les nageoires des poissons. Le liquide brun est stocké sous la croûte de sel qui est désormais flottante. Nous procédons donc à son percement. Le liquide brun et translucide remonte alors en surface, accompagné de différents déchets. La croûte de sel est totalement retirée et le contenu de l'aquarium est laissé au repos. La décantation permet de mettre en évidence 4 niveaux différents : le fond du contenant est occupé par la couche de sel ; au-dessus, on observe un liquide brun clair plus épais et opaque, puis un liquide brun foncé translucide et enfin, les déchets de poisson (restes osseux, écailles...), flottant à la surface de l'aquarium. L'étape suivante consiste à retirer la couche de déchets flottants en surface . La méthode la plus simple s'avère l'utilisation de pots percés de trous de différentes tailles. Ces outils permettent de récupérer un maximum de déchets tout en laissant passer le liquide, une partie du produit étant toutefois prélevée lors de cette opération. Le pressage des déchets peut permettre de le récupérer. Les différents restes osseux prélevés conservent une coloration jaunâtre à brunâtre liés à leur séjour dans la solution issue de la macération des poissons.

Une fois que les déchets sont retirés, la décantation se poursuit. Le liquide brun clair plus épais et opaque remonte en surface. Il se dépose sur la partie supérieure 

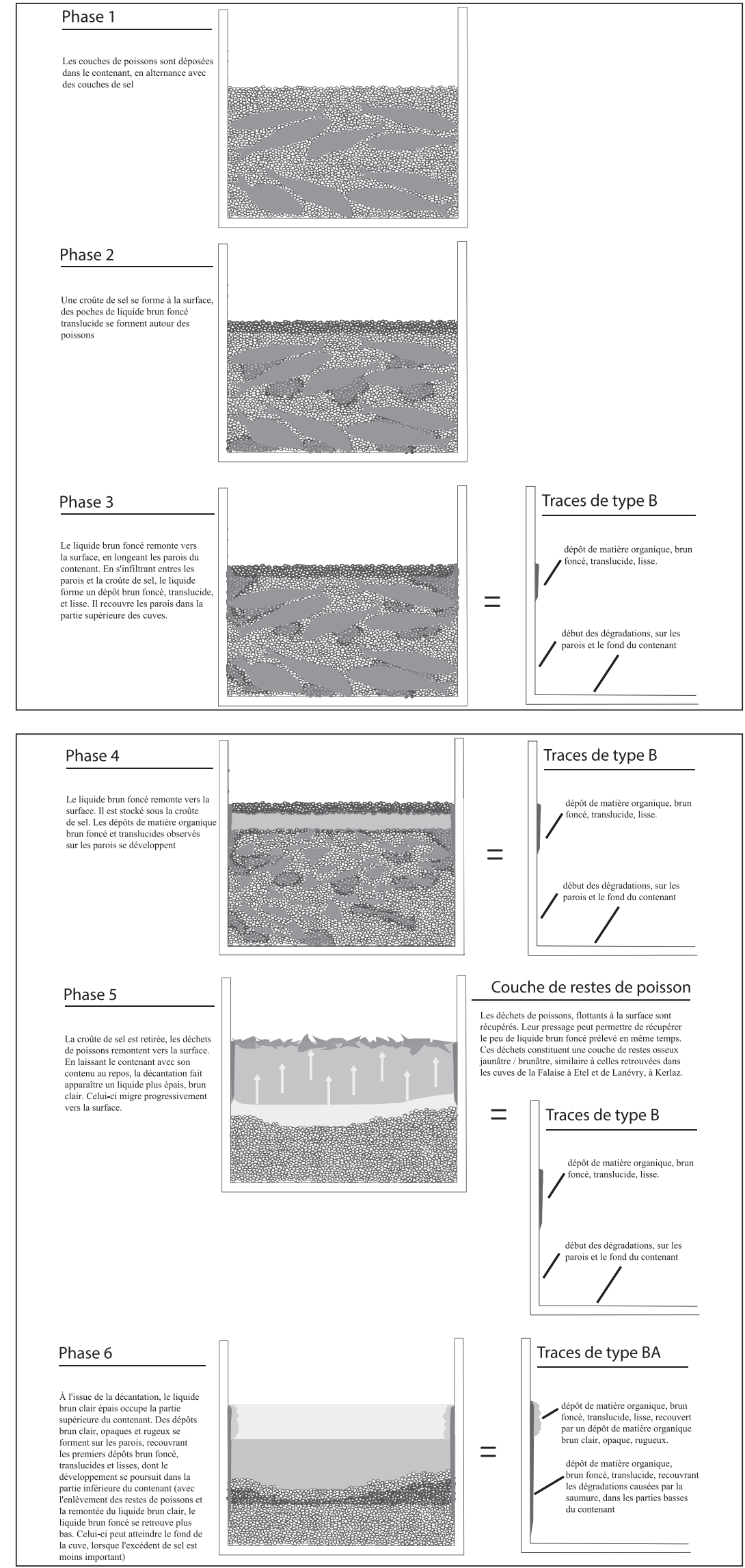

Fig. 6. Expérimentation archéologique, phases 1 à 3 (réalisation : C. Driard).
Fig. 7. Expérimentation archéologique, phases 4 à 6 (réalisation : C. Driard). 


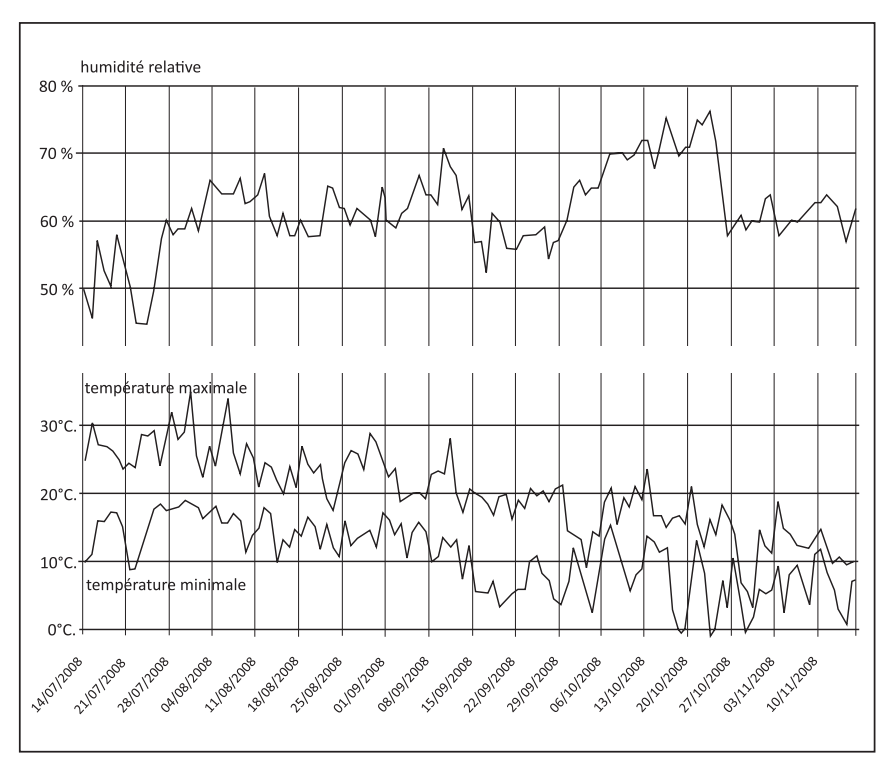

Fig. 8. Relevé quotidien toutes les 12 heures de la température et de l'humidité relative dans le contenantlors de la quatrième expérimentation (réalisation : C. Driard).

des parois du contenant, créant une couche de matière organique brun clair, opaque et rugueuse, recouvrant le premier dépôt brun foncé, translucide et lisse. Cette couche opaque se prélève assez facilement et constitue une «bouillie » ou une «pâte» savoureuse et fine. Il pourrait s'agir de l'hallec. Enfin, le contenant est vidé du liquide brun foncé et translucide. Le goût et la couleur de ce produit expliquent facilement l'engouement suscité par ces sauces dans l'Antiquité. L'excédent de sel restant au fond du contenant peut être réutilisé pour une prochaine préparation. Les parties basses des parois et le fond du contenant ont été endommagés. Les parties supérieures du contenant ont été protégées par les dépôts bruns foncés.

Les différentes traces observées dans les cuves sont comparables à celles mises en évidence lors de ces expérimentations. Lorsque toutes les étapes de l'élaboration de l'hydrolysat sont réalisées dans le même contenant, alors il est possible d'observer sur les parois et le fond, tout d'abord des traces de type $\mathrm{B}$, puis des traces de type BA. Les autres types de traces (A et $A B)$ ne peuvent pas être reproduites lors de l'expérimentation, si tout le processus de fabrication du l'hydrolysat se fait dans le même contenant. Afin de reproduire les dépôts de type A, il est nécessaire, à l'issue de la phase 6 , de récupérer tout le liquide et de le laisser décanter dans un nouveau contenant. C'est la seule solution que nous avons trouvé pour créer des dépôts de matière organique brun clair, épais et rugueux, sur la partie supérieure des parois du contenant, et des dépôts de matière organique brun foncé, fins, translucides et lisses, sur la partie inférieure et au fond du contenant. Ainsi, l'hypothèse d'une décantation

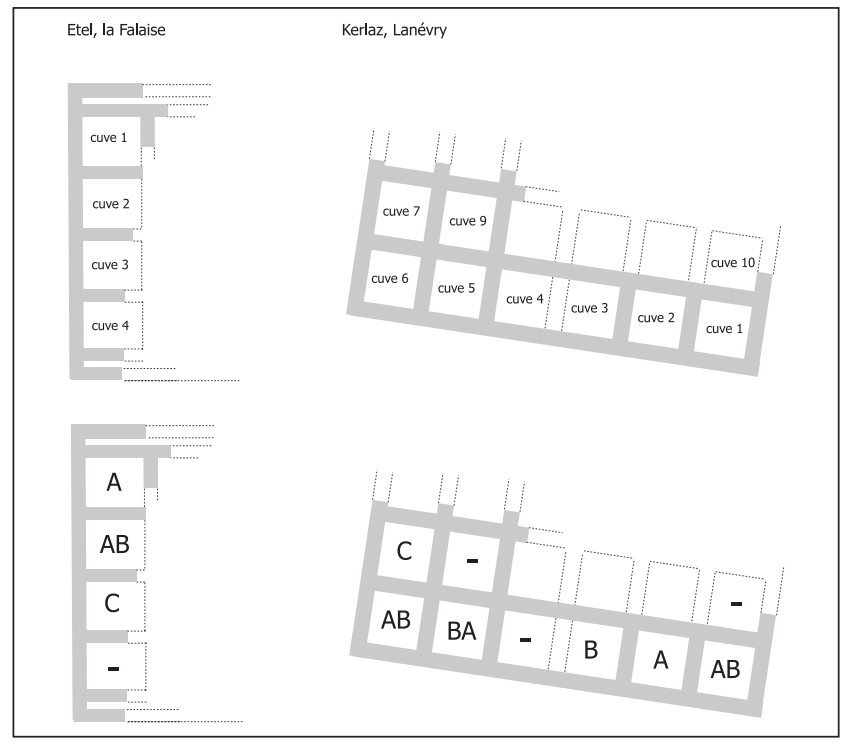

Fig. 9. Localisation des cuves étudiées avec identification du type de traces relevées sur les parois et au fond des cuves (réalisation : C. Driard).

de l'hydrolysat dans une cuve spécifiquement réservée à cette utilisation peut être avancée en présence de dépôts de type A. Les traces de type $\mathrm{AB}$ peuvent être obtenues dans une cuve ayant préalablement servi à la décantation de l'hydrolysat et réutilisée pour la macération dans un second temps.

Par conséquent, les deux sites fouillés, la Falaise à Étel et Lanévry à Kerlaz (fig. 9), pourraient avoir disposé tous les deux d'au moins une cuve réservée à la décantation, qui aurait servi, après le prélèvement du liquide brun clair, à un éventuel stockage provisoire du liquide restant (que l'on peut qualifier de garum). Ces cuves sont identifiables en raison de la présence de traces de type A. Sur le site de la Falaise, à Étel, il s'agit de la cuve 1, et à Kerlaz, sur le site de Lanévry, il s'agit de la cuve 2. Les deux sites disposaient également chacun d'au moins une cuve conservée en bon état, qui pouvait être réservée au stockage du sel (traces de type C). À Kerlaz, il s'agit de la cuve la plus profonde, la 7 et à Étel, il s'agit de la cuve 3. Enfin, grâce aux traces de type $A B$, on peut mettre en évidence des cuves ayant été utilisées dans un premier temps pour la décantation de l'hydrolysat, puis réutilisées dans un second temps, pour la macération d'un nouveau chargement de poissons et de saumure. C'est le cas de la cuve 2 à Étel et des cuves 1 et 6 à Kerlaz. Sur ce site, la cuve 3 présentait uniquement des traces de type $\mathrm{B}$, elle aurait donc été utilisée uniquement pour la macération (jusqu'à la phase 5 , avec un retrait rapide des liquides produits, déplacés dans un autre endroit). Est-ce un hasard, si cette structure est située juste à côté de la cuve 2 qui a servi uniquement à la décantation et éventuellement au stockage ? Enfin, la 


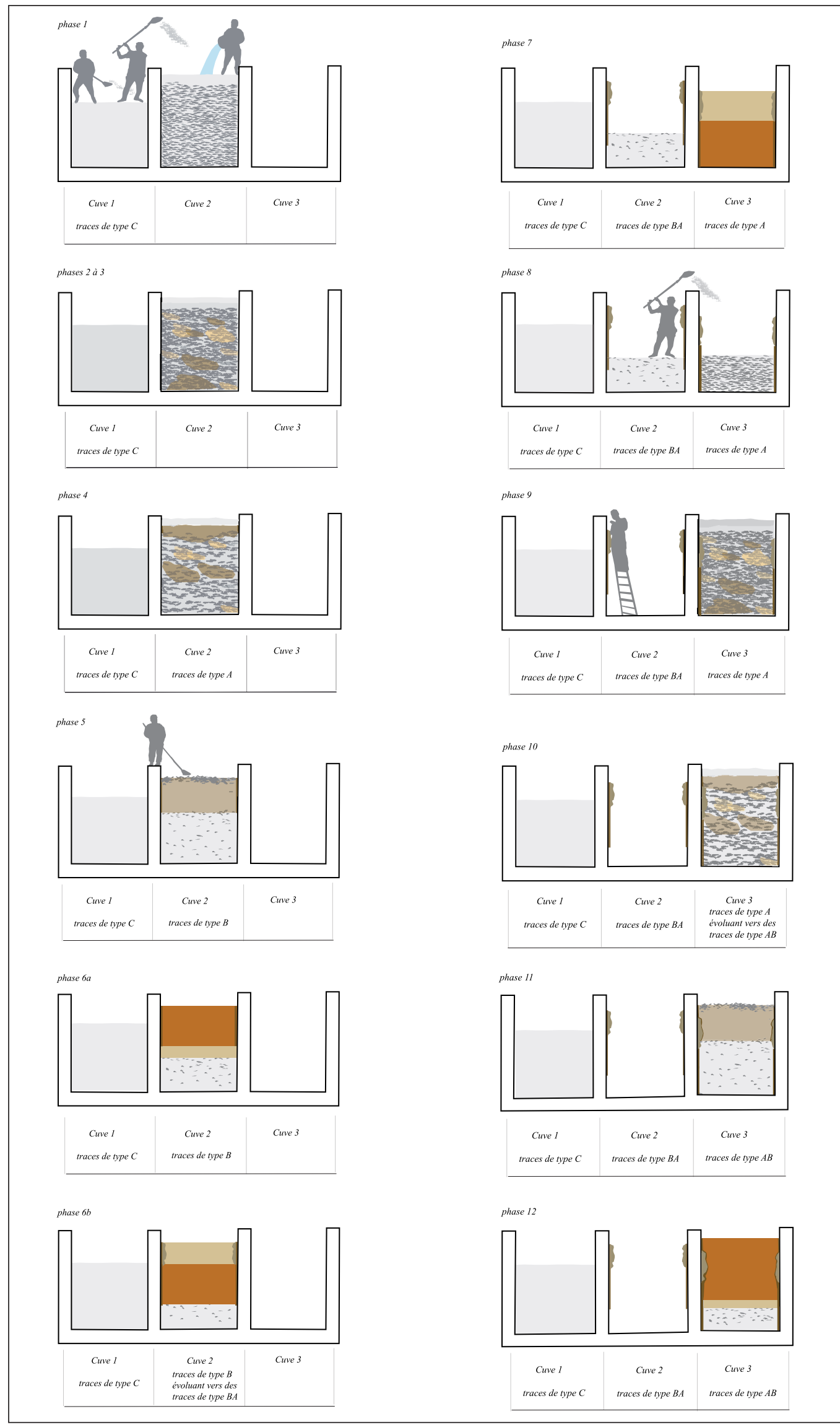

Fig. 10. Hypothèse de fonctionnement des cuves : phases 1 à 12 . (réalisation : C. Driard). 
cuve 5, à Kerlaz, semble avoir servi pour la macération et la décantation (traces de type BA).

Ces observations se limitent probablement aux dernières utilisations des cuves. La question de l'entretien des cuves et plus particulièrement, de la fréquence des réparations, demeure. En effet, aucun rechapage destiné à réparer les parois endommagées n'a été observé. L'ensemble des revêtements de la cuve était-il détruit, afin de le refaire intégralement à neuf ? À moins que la présence des dépôts de matière organique ne fût suffisante pour colmater les traces d'usure. Il pourrait d'ailleurs être envisagé que les dépôts (difficiles à enlever sans endommager la cuve) aient été volontairement laissés en place afin de renforcer l'étanchéité des structures, à l'instar de ce qui a parfois été proposé pour certaines concrétions dans les aqueducs.

\section{Restitution hypothétique du fonctionnement d'un atelier : fonction des cuves et produits obtenus}

Les données archéologiques recueillies lors des fouilles des ateliers d'Etel et Kerlaz mises en perspective avec l'archéologie expérimentale permettent de proposer une hypothèse de restitution des étapes d'utilisation des cuves qui peut être résumée en 12 phases (fig. 10). Le modèle proposé s'applique à un ensemble de trois cuves et il permet de proposer une explication à toutes les observations réalisées lors des fouilles.

Phase 1 : la cuve 1 sert uniquement au stockage du sel, à l'origine des traces de type $\mathrm{C}$. La cuve 2 est remplie de poissons et de sel (avec adjonction d'eau douce), afin de produire des hydrolysats. La cuve 3 n'est pas utilisée à ce stade.

C'est obligatoirement lors de la première étape (remplissage de la cuve) que les batraciens et les rongeurs, éventuellement d'autres animaux, peuvent être pris au piège (à moins qu'ils ne fassent partie de la recette). Même si leur présence est accidentelle et connue des artisans, ces derniers n'ont peut-être pas pris le soin de descendre au fond de la cuve pour aller les chercher. La présence des restes de ces animaux lors du pressage des restes de poisson laisse supposer qu'ils ont eu le temps de macérer dans la cuve, à l'instar des poissons.

Phases 2 à 3 : les poches de liquide brun, issues de la macération des sardines, apparaissent autour des poissons. Une croûte de sel se forme en surface de la cuve. Celle-ci isole le processus de fabrication du produit et évite que d'autres animaux indésirables tombent dans le contenant, au cours des quatre mois que peut durer la macération des poissons.
Phase 4 : le liquide brun remonte vers la surface et s'accumule sous la croûte de sel. Les traces de type B (dépôts brun foncé translucides) se forment sur la partie supérieure de la cuve et endommagent l'enduit dans sa partie inférieure.

Phase 5 : la croûte de sel est détruite, le liquide brun occupe la partie supérieure de la cuve. Les déchets de poissons remontent à la surface et ils sont prélevés. Les traces de type B se développent.

Phase 6: après une période de repos, deux liquides se distinguent: un liquide brun clair et épais, au-dessus duquel se trouve un liquide brun foncé. La phase de décantation commence, le liquide brun clair, épais (bouillie), remonte dans la partie supérieure de la cuve, alors que le liquide brun foncé se retrouve dans la partie inférieure du contenant. Ce phénomène est à l'origine du développement de dépôts brun clair opaques et rugueux recouvrant les dépôts brun foncé, translucides et lisses. Dans la partie inférieure de la cuve, la présence du liquide brun foncé est à l'origine de dépôts brun foncé, translucides et lisses, colmatant les dégradations occasionnées par la saumure (traces de type BA). Ces traces se développent largement si la décantation se prolonge dans cette cuve. Dans cet exemple, le liquide est transféré dans la cuve 3 , réservée à cette étape du processus.

Phase 7 : le liquide brun a été reversé dans la cuve 3 où la phase de décantation se déroule. Des dépôts brun clair, opaques et rugueux se forment dans la partie supérieure de la cuve, alors que des dépôts brun foncé translucides et lisses apparaissent dans sa partie inférieure. Il s'agit de traces de type A. Si cette cuve est réservée uniquement à la phase de décantation, les traces observées resteront de type A. Cependant, dans cet exemple, une fois que la cuve a été vidée de ses produits en vue de leur commercialisation, celle-ci est remplie de sel et de poissons pour une nouvelle phase de macération.

Enfin, cette hypothèse nécessite le transvasement du produit d'une cuve à une autre et pose inévitablement des problèmes techniques. L'utilisation de dispositifs de pompage est envisageable pour récupérer le liquide le plus fluide, mais aucune trace archéologique de tels procédés n'a été mise en évidence au sein des ateliers de salaison. Les différences de niveau du fond de certaines cuves et les aménagements permettant une communication entre les bassins soulèvent la question d'un transvasement par écoulement d'une cuve à une autre ${ }^{39}$.

39. Lors de la fouille de l'atelier de la rue du Guet à Douarnenez, deux cuves présentaient la particularité d'être reliées par un tuyau en plomb. Par ailleurs, le fond de certaines cuves semblait avoir été réhaussé par rapport au fond initial (Peuziat 1981, p. 15-16 ; Sanquer 1981, p. 54-55). Des conduits reliant plusieurs cuves de profondeur différente entre elles ont été mis en évidence dans l'un des ateliers de Nabeul (Slim et al. 1999 ; Sternberg 2000). 
Phase 8 : l'excédent de sel situé dans la cuve 2 est reversé dans la cuve 3 , en cours de remplissage.

Phase 9 : le processus de macération débute dans la cuve 3 (comme aux phases 2 et 3 pour la cuve 2 ).

Phase 10: des dépôts brun foncé commencent à apparaître dans la partie supérieure de la cuve 3. Ils recouvrent les dépôts brun clair issus de l'opération précédente de décantation.

Phases 11 et 12 : au fur et à mesure du processus conduisant à l'obtention des hydrolysats, les dépôts se développent dans la partie inférieure la cuve, la saumure endommage le dépôt de matière organique brun foncé qui s'était formé également au moment de la décantation précédente. Ces traces correspondent au type $\mathrm{AB}$.

Ces premières analyses sont des hypothèses de travail et il serait intéressant de pouvoir procéder à d'autres observations sur des sites du même type. Il serait également nécessaire de pouvoir fouiller un atelier de façon exhaustive afin de compléter ces informations.

\section{Conclusion}

Les fouilles réalisées sur les ateliers de Kerlaz et d'Etel permettent de faire progresser les connaissances sur les ateliers de salaison et de sauces de poisson en Lyonnaise occidentale, limitées jusque là à de simples inventaires des établissements littoraux présentant des batteries de cuves maçonnées, ainsi que quelques observations architecturales.

L'archéologie expérimentale a démontré qu'il était possible d'élaborer un produit de très bonne qualité, tant d'un point de vue gustatif qu'au niveau de la texture, sans intervention humaine avant l'extraction du produit. Il suffit de laisser le processus se dérouler en milieu clos et d'alimenter régulièrement la cuve en eau.
La méthode de production retenue diffère des recettes évoquées dans les textes antiques et notamment celui des Géoponiques ${ }^{40}$, dans lequel est décrite la fabrication du liquamen. Bien que riche en informations, ce texte décrit la réalisation d'une sauce de poisson dans une poterie et non dans des cuves de grandes dimensions. La plupart des gestes décrits ne sont pas compatibles avec ces profonds bassins, mesurant de 2 à $4 \mathrm{~m}$ de côté et autant de profondeur. Il est par exemple impossible de remuer une telle quantité de poissons et de sel quelque soit l'outil utilisé.

Les dépôts de matière organique et les différentes traces observés lors des fouilles n'ont été reproduits qu' avec une quantité importante de sel représentant $50 \%$ ou plus du volume total de la préparation. Utiliser une telle quantité de sel pour réaliser une sauce de poisson peut paraître absurde, notamment en milieu méditerranéen où l'on peut produire du garum en quelques semaines seulement. Il semblerait d'ailleurs qu'un excès de sel ralentisse le processus ${ }^{41}$. Cependant, dans la péninsule armoricaine où se trouvent les ateliers équipés de cuves maçonnées les plus septentrionaux de l'Empire romain, le climat est différent et la production de sauces de poisson peut prendre plusieurs mois. Une telle quantité de sel permet de former une croûte protectrice recouvrant la production, l'isolant du climat défavorable et évitant les intrusions d'indésirables au cours des mois de macération.

Ainsi, il est probable que la présence exclusive de dépôts de matière organique brun foncé translucide sur les parois des cuves dans l'ouest de la Lyonnaise soit liée à la grande quantité de sel utilisée pour produire des sauces de poisson. Cette particularité pourrait résulter d'une adaptation de la production de garum à des régions moins propices à l'élaboration de ce condiment.

40. Geoponica, XX, 46.

41. Communication orale de S. Grainger, Roman fish sauce: an experiment in archaeology, durant l'atelier doctoral Fish \& Ships en juin 2012. 


\section{Bibliographie}

Abgrall 1895 : ABGRALL (J.-M.) - À propos des découvertes récentes du Grand-Ris, $B A A B$, 1895, p. 183-190.

André 1992 : ANDRÉ (P.) - Un atelier de salaisons chez les Vénètes d'Armorique, $R E A, 94,1-2,1992$, p. 41-47.

Bardel 2007 : BARDEL (J.-P.) - L'établissement antique de Plomarc'h Pella à Douarnenez (Finistère) : un ensemble représentatif des établissements de salaisons romains de la baie, Aremorica, Études sur l'Ouest de la Gaule romaine, 2007, p. 101-116.

Borrely de Kervelegan 1899: BORRELY DE KERVELEGAN - Ruines gallo-romaine en Combrit, BSAF, 26, 1899, p. 304-306.

Bousquet 1969 : BOUSQUET (J.) - Informations archéologiques, Gallia, 27,1969, p. 241-258.

Desse 1958 : DESSE (G.) - communication, BSAF, 94, 1958, p. XII.

Desse 1984 : DESSE (J.) - Propositions pour une réalisation collective d'un corpus : fiches d'identification et d'exploitation métrique du squelette des poissons. In: Desse-Berset (N.) (éd.), Deuxièmes Rencontres d'ArchéoIchthyologie (second Fisch-Osteo-Archaeozoology meeting), Paris, 1984, p. 67-86.

Desse, Desse-Berset 1996 : DESSE (J.), DESSE-BERSET (N.) - On the boundaries of osteometry applied to Fish. In : Morales (A.) (éd.), Fisches and Archaeological Record, 1996, (Archaeofauna, 5), p. 169-177.

Desse-Berset, Desse 2000 : DESSE-BERSET (N.), DESSE (J.) - Salaisons de poissons marins aux marges orientales du monde gréco-romain : contributions de l'archéozoologie, MEFRA, 112, 1, 2000, p. 119-134.

Driard 2007 : DRIARD (C.) - L'établissement romain de la Falaise à Étel, Bulletin de la Société Archéologique et d'Histoire du Pays de Lorient, 33, 2007, p. 55-62.

Driard 2007 : DRIARD (C.) - Un établissement romain spécialisé dans les productions de salaisons et sauces de poisson à Étel (Morbihan, France). In : Béarez (P.), Grouard (S.), Clavel (B.) (éds), Archéologie du Poisson, 30 ans d'archéo-ichtyologie au CNRS, Hommage aux travaux de Jean Desse et Nathalie Desse-Berset, Antibes, XXVIII ${ }^{\mathrm{e}}$ rencontres internationales d'archéologie et d'histoire d'Antibes, XIVth ICAZ Fish remains working group meeting, APDCA, 2007, p. 237-344.

Driard 2011 : DRIARD (C.) - Les établissements littoraux de la province romaine de Lyonnaise, Contribution à l'étude de l'habitat dispersé et de l'exploitation des ressources maritimes sur les côtes de l'Atlantique et de la Manche dans l'Antiquité, mémoire de thèse, Tours, 2011, 3 vol., 715 p., $102 \mathrm{pl}$.

Driard, Coutelas 2007: DRIARD (C.), COUTELAS (A.) - Étel «la Falaise » Morbihan, sondage d'évaluation d'un atelier de salaisons de poissons romain, campagne 2007, Etude de l'extrémité ouest de l'établissement, rapport de sondages archéologiques, SRA Bretagne, Rennes, 2007, 120 p.

Fréminville 1837 : FRÉMINVILLE (Ch. de) - Antiquités de Bretagne, Côtes du nord, Brest, 1837, p. 186-187.
Galliou 1971: GALLIOU (P.) - La céramique des Plomarc'h en PloaréDouarnenez (Finistère), Annales de Bretagne, 1, 1971, p. 229-230.

Galliou, Sanquer 1972 : GALLIOU (P.), SANQUER (R.) - Garum, sel et salaisons en Armorique romaine, Gallia, 30-1, 1972, p. 199-223.

Maligorne 1998 : MALIGORNE (Y.) - Hercule et la production du garum en baie de Douarnenez, BSAF, CXXVII, 1998, p. 87-93.

Martin-Kilcher 1990: MARTIN-KILCHER (S.) - Fischsaucen und Fishkonserven aus dem römischen Gallien, Archéologie Suisse, 13, 1990, p. 37-44.

Merlat 1957 : MERLAT (P.) - Informations archéologiques, Gallia, 15, 1957, p. 186-190.

Merlat 1958 : MERLAT (P.) - Informations archéologiques, Gallia, 16, 1958, p. 94 .

Merlat 1959 : MERLAT (P.) - Informations archéologiques, Gallia, 17, 1959, p. 342-343.

Pape 1978 : PAPE (L.) - La civitas des Osismes à l'époque gallo-romaine, Klincksieck, Paris, 1978.

Peuziat 1981 : PEUZIAT (J.) - Une nouvelle usine de salaisons découverte dans le quartier du Guet, $A B, 32,1981$, p. 15-16.

Piquès 2005 : PIQUÈS (G.) - Les déchets de fabrication de sauce de poisson dans le comblement d'un puits gallo-romain et la question du sel à Lattes. In : Piquès (G.) et Buxó (B.) (dir), Onze puits gallo-romains de Lattara (I ${ }^{e r} s$. av. n. è. - II ${ }^{e}$ s. de n. è), Lattara, 18, Lattes, 2005, p. 293-306.

Ponsich, Tarradell 1965 : PONSICH (M.), TARRADELL (M.) - Garum et industries antiques de salaisons dans la Méditerranée Occidentale, Paris, 1965.

Sanquer 1969 : SANQUER (R.) - Chronique d'archéologie antique et médiévale, $B S A F, 95,1969$, p. 21-60.

Sanquer 1970 : SANQUER (R.) - Chronique d'archéologie antique et médiévale, $B S A F, 96,1970$, p. 25-74.

Sanquer 1977 : SANQUER (R.) - Douarnenez, Plomarc'h Pella, Gallia, 35, 1977, p. 355-360.

Sanquer 1979 : SANQUER (R.) - Douarnenez, Plomarc'h Pella, Gallia, 37, 1979 , p. 359-360.

Sanquer 1981 : SANQUER (R.) - Chronique des fouilles archéologiques en Bretagne, année 1981, $A B, 32,1981$, p. 7-49.

Slim et al. 1999 : SLIM (L.), BONIFAY (M.), TROUSSET (P.) - L'usine de salaison de Neapolis (Nabeul). Premiers résultats des fouilles 1995-1998, Africa, XVI, 1999, p. 153-197.

Sternberg 2000 : STERNBERG (M.) - Données sur les produits fabriqués dans une officine de Neapolis (Nabeul, Tunisie), MEFRA, 112, 1, 2000, p. $135-153$ 


\section{The fish remains from the Cardo V sewer: New insights into consumption and the fishing economy of Herculaneum}

\section{Erica Rowan}

\section{Introduction}

$\mathrm{T}$

The role of fish consumption and fishing in the Roman world as an important part of the diet and food economy has, until recently, been underplayed ${ }^{1}$. However, during the past decade, renewed scholarly interest in the use and acquisition of fish during the Roman period, and in particular the production and transport of salted fish products, has demonstrated the falsity of that view ${ }^{2}$. The fish economy is much larger than was previously thought and although fish did not feature prominently in the diets of all the inhabitants of the Roman Empire, those living by the coast benefited from access to both salted and fresh fish. Wealthy individuals were prepared to pay for its transportation inland. Current debates also ask who was consuming fish and how far down the social scale they went.

Fish salting factories have the advantage of leaving behind very visible archaeological traces, including large concrete vats and occasionally enormous collections of fish bones. Consequently, some of these factories are well studied and much is known about the species of fish being processed and the volume of production. Amphora studies also tell us about the distribution of fish products ${ }^{3}$. However, very little is known about the consumption of fresh fish in the Roman world. Multiple types of fishing equipment have been found at sites around the Empire, including different sized hooks and fragments of net, attesting to the widespread practice of fishing throughout the Mediterranean ${ }^{4}$. The ancient sources, including Pliny, Athenaios, Oppian, Galen and Apicius shed some light on the types of fish that were consumed, although the validity of their statements may be questioned and matching ancient terms to specific

1. Gallant 1985, p. 31-44.

2. Curtis 2005, p. 31-34; Marzano 2013.

3. Trakadas 2005; Curtis 1991, 2001; Desse-Berset, Desse 2000; Wilson 2006; Slim et al. 2007; Botte 2009.

4. Giner 2010, p. 66-75; Bernal Casasola 2010, p. 87-95 ; Kron 2008, p. 205; Marzano 2013, p. 30-33. taxa problematic ${ }^{5}$. Thus while our physical evidence is widespread, it is also extremely fragmentary and our data from the ancient sources is biased towards the elite. This has made it difficult to assess the economic impact of fishing on towns and the organization of fishing in a regional sense, as well as the cost of fresh fish and the buying power of the consumer.

This chapter utilizes fish data from the Cardo V sewer in Herculaneum to discuss the fishing economy in the Bay of Naples with a particular focus on the acquisition, purchase and consumption of fresh fish. This assemblage contained fish bones and otoliths ${ }^{6}$ and is one of the largest urban domestic collections of fish remains from the Roman world.

\section{The Cardo V assemblage}

The Cardo V sewer in Herculaneum is located beneath Insula Orientalis II in the north-eastern corner of the site. During the first quarter of the $1^{\text {st }} \mathrm{c} . \mathrm{AD}$, the insula, with its combination of commercial and domestic spaces, was built to subsidize the construction of the adjacent palaestra/religious complex ${ }^{7}$. The ground floor shops of Ins. Or. II contained a bakery, a wine shop and a gem shop, amongst others ${ }^{8}$. The domestic spaces consisted of ground and upper floor apartments where people lived either above or behind their shops or in independent

5. Pliny $H N$ 9, 32; Oppian Halieutika; Athen. Deipnosophistae, Galen Alim. Fac. 3,6-8; Apicius De re coquinaria 9-10; Wilkins 2005, p. 27-28.

6. Otoliths or 'earstones' are calcium carbonate structures in the form of aragonite located in the skull of bony fish. Each fish has three pairs of otoliths, the sagittae, asteriscus and the lapillus that function together to provide the fish with a sense of orientation in the water. In most bony fish, the sagittae are far larger than the asteriscus and lapillus and thus are the type most frequently used for identification, sizing and aging (Harvey et al. 2000). The shape of an otolith is highly species specific with the left and right sides often acting as mirror images of each other (except in the case of the flatfish) (Campana 2004).

7. Monteix 2010, p. 288; Wallace-Hadrill 1994, p. 117.

8. Maiuri 1958, p. 462-466; Monteix 2010, p. 411-420. 
units. These commercial/domestic units varied in size from $57.7 \mathrm{~m}^{2}$ to $848 \mathrm{~m}^{2}$. The sewer was fed by the ground and upper floor latrine shafts of the shops and apartments above with only three small rooftop drains to allow fresh water into the tunnel ${ }^{9}$. The biological material from the sewer consequently consists almost entirely of human and kitchen waste. The absence of an exit point at the southern end of the sewer, combined with the absence of a source of running water, turned the sewer into a long cesspit that needed to be cleaned out periodically ${ }^{10}$.

In 2007 the entire contents of the north-south branch of the Cardo V sewer were systematically excavated by the Herculaneum Conservation Project using a system of one meter square quadrants ${ }^{11}$. Approximately, $10 \%$ or $1140 \mathrm{~L}$ of organic material was processed through the use of sieving and flotation ${ }^{12}$. Microscopic analysis of the samples revealed that there had been excellent biological preservation of carbonized and mineralized seeds as well as eggshell, seashell and bone. Hundreds of fish otoliths and fish bones were recovered as well. The flot was sieved to $0.5 \mathrm{~mm}$ and the residue to $2 \mathrm{~mm}$ to ensure the recovery of extremely small fish bones.

\subsection{Identification and characteristics of the Cardo V fish remains}

The author sorted material from four sewer quadrants for otoliths and any remaining fish bones (13 otolith samples and 9 fish bone samples) that had not been sorted on-site. (fig. 1, Table 1) ${ }^{13}$. Combined with material sorted on-site by other members of the excavation team, the samples produced over 300 hundred otoliths and several hundred fish bones. There were 170 otoliths (56\% of the total number recovered) identified using the AFORO online database and reference material provided by

9. Andrews 2012.

10. Camardo 2006-2007.

11. The material from Herculaneum was provided by the Herculaneum Conservation Project (HCP), a Packard Humanities Institute initiative in collaboration with the Soprintendenza Speciale per i Beni Archeologici di Napoli e Pompei and the British School at Rome. For further information see: Stanley-Price, 2007; Herculaneum Conservation Project 2009- 2010. For the excavation of the Cardo V sewer by HCP, see: Wallace-Hadrill et al. 2008.

12. Robinson 2007a; Robinson 2007b. Recognizing the valuable nature of this material, the entire contents of the sewer were retained and the remaining $90 \%$ is currently in storage in Herculaneum.

13. The otoliths from a fifth quadrant, Q5-6, were briefly studied. In the interests of time only one otolith from the sample was identified as it belong to a taxa (Merluccius merluccius L.) that had not been previously identified in the other four quadrants.
Rebecca Nicholson at Oxford Archaeology ${ }^{\mathbf{1 4}}$. Including Nicholson's initial examination of the fish bones, a total of 43 different fish taxa have been identified. There are 13 taxa unique to the otoliths, 21 to the fish bones and nine which have been recovered as both otoliths and bones (Table 2). This was the first instance of the use of an online tool for the identification of ancient otolith specimens. The ability of the database to allow identification of otoliths down to species level proved to be extremely beneficial since, with certain fish families, it is difficult to differentiate between species of the same family based only on the skeletal remains. This is particularly true of the Sparidae or sea bream family, and thus the database was invaluable as the Cardo V assemblage is dominated by sea breams. MNI calculations based on the otolith material resulted in 84 Sparidae individuals which comprised $63 \%$ of the total number of fish from the four quadrants. In addition to those that could only be identified to family, the sea bream otoliths were represented by five species and three genera. The remaining 34 taxa are generally small coastal fish such as anchovies and mackerel with a few examples of larger fish such as sea bass. All of the taxa can be found in the Mediterranean and live in either shallow coastal waters or estuaries ${ }^{15}$. None of the taxa lives exclusively in fresh water and thus the assemblage represents the results of estuary and coastal fishing.

\section{Consumption of fish in Herculaneum}

The presence of both the otoliths and fish bones within the Cardo $\mathrm{V}$ sewer puts us in the unique position of being able to differentiate fish consumption habits. Broadly speaking, in Ins. Or. II, fish were eaten either whole, in pieces or as fish sauce.

Whole fish are represented by the otoliths or by the otoliths and the bones (See Table 2). These fish were not only brought back to the apartment whole, but were also consumed whole. The passage of the bones and otoliths through the human digestive tract is observable in the flattening and smoothing of some of the vertebrae and otoliths respectively (fig. 2) ${ }^{16}$. Unsurprisingly,

14. Lombarte et al. 2006; Rowan forthcoming.

15. Froese, Pauly 2013.

16. While it is possible that some of the otoliths had smoothed edges due to degradation in the sewer, degradation due to digestion is the more likely cause. Otoliths will not survive in acidic conditions, instead requiring alkaline conditions for their long term survival in the archaeological record. The otoliths would have spent far more time in the sewer than they did passing through the human digestive tract and if there had been acidic conditions in the sewer then the otoliths would probably have broken down entirely. Jones 1986; Jones 1990, p. 143. 
all of these taxa are small fish, often less than $20 \mathrm{~cm}$ in length ${ }^{17}$. This category includes the many varieties of sea bream as well as the damsel fish, greater weever and anchovies. These species, except for the damsel fish, are still eaten whole in the Bay of Naples today.

Fish that are larger than $20 \mathrm{~cm}$ and represented exclusively by skeletal remains were probably eaten as pieces of fish ${ }^{18}$. Since there is such excellent otolith preservation, in some cases the absence of an otolith suggests the absence of the head of the fish ${ }^{19}$. This category includes taxa such as eels, seabass, garfish, wrasse and mullet.

Finally, the quantity of anchovy, sardine, blotched picarel and mackerel bones suggests fish sauce consumption by the inhabitants of Ins. Or. $\mathrm{II}^{20}$. Not only were these four species the most commonly used varieties in the production of fish sauce in the Roman world, but they are the only small fish, under $20 \mathrm{~cm}$, from the sewer represented by a significantly large number of bones but relatively few otoliths, or in some cases, as with the blotched picarel, are represented only by the bones ${ }^{21}$. Thus, while on occasion anchovies and varieties of picarel were consumed fresh, they were most often eaten in the form of fish sauce.

\section{Economic implications of the Cardo V assemblage}

The sewer, as a closed context, represents waste generated almost exclusively by those working and living in the shops and apartments of Ins. Or. II. It is possible that customers could have used the latrines located in the ground floor tabernae. However, none of the shops contains seating or appears to sell goods that would have promoted extended stays in the building, thus reducing customer use of the latrines ${ }^{22}$. Therefore, when we discuss fish consumption in Ins. Or. II, we are speaking about a limited

17. Froese, Pauly 2013.

18. At the moment, distinguishing fresh from salted fish from the faunal remains alone is not possible and it is likely that some of the fish recovered only as bones were originally salted.

19. The bones of the eels and garfish recovered from the sewer were from undersized specimens and as these taxa already have small otoliths the absence of eel and garfish otoliths in the sewer may have been due to preservation issues.

20. The mosaics from the House of Aulus Umbricius Scaurus in Pompeii, the primary producer of fish sauce in the region, specifically mention the use of mackerel in his garum (Cooley, Cooley 2004; Curtis 1984). In Portugal, at the fish salting factories of Quinta do Marim, Travessa de Frei Gaspar and Troia, sardines and anchovies dominated the faunal remains. Desse-Berset, Desse 2000, p. 86-91.

21. Carannante 2008-2009, p. 44.

22. Monteix 2010, p. 255-288. number of people. By using evidence from the sizes of the various shops and apartments, we can begin to infer the socioeconomic status of the residents of Ins. Or. II and, by proxy, the fishing economy in the Bay of Naples.

The shops and apartments situated above the excavated portion of the sewer, Ins. Or. II.6 to II.14, range in size from $57.7 \mathrm{~m}^{2}$ at II.10 to a possible $848 \mathrm{~m}^{2}$ at II. $7^{23}$. In addition to significant variations in size, these spaces also differed in function, room sizes and amount of living space. For example, the wine shop at II.9 consisted of two ground floor rooms and an upper floor room that was reached by a wooden staircase ${ }^{24}$. Despite having a front room entirely dedicated to wine sales, it is likely that the owners of the shop lived in this unit, using either the backroom or upper floor room as domestic space. On the other hand, II.7 consists of an upper floor apartment, stretching over two storeys with views over the palaestra/religious space below, a second floor latrine and a kitchen ${ }^{25}$. Moreover, at $848 \mathrm{~m}^{2}$ this apartment was larger than some of Herculaneum's atrium houses ${ }^{26}$. Despite the fact that most of the habitation space in Ins. Or. II was on upper floors, the socioeconomic range of the inhabitants was likely similar to many of the other insula blocks in Herculaneum and Pompeii with its mix of small to medium sized shops and homes in addition to a wealthier house. How does this architectural data relate to the fish remains?

Patterns of fish consumption in the insula can be understood through an analysis of the ubiquity and diversity of the fish assemblage from the Cardo V sewer. The material in the sewer was deposited vertically through the latrine shafts, but the downward slope of the sewer and gentle flushing by waste water caused the material to shift slowly in a horizontal direction towards the south ${ }^{27}$. Consequently, the material situated below a latrine shaft does not directly correspond to the apartment above. Nevertheless, accounting for an increase in the density of material at the southern end of the sewer, the excavation of the assemblage, stratigraphically quadrant by quadrant, has provided both a spatial and chronological view of the material.

\footnotetext{
23. Andrews 2006.

24. Id., vol 2, p. 357.

25. Giornali dei Nuovi Scavi di Ercolano, 1933 ; Andrews 2006, vol. 2, p. 101-109.

26. The second floor of the insula is not well preserved and it is also possible that this area was divided into smaller units. Nevertheless, these units were probably owned by slightly wealthier residents since all the space would be dedicated to living quarters unlike the commercial/domestic units below.

27. Camardo 2006-2007.
} 


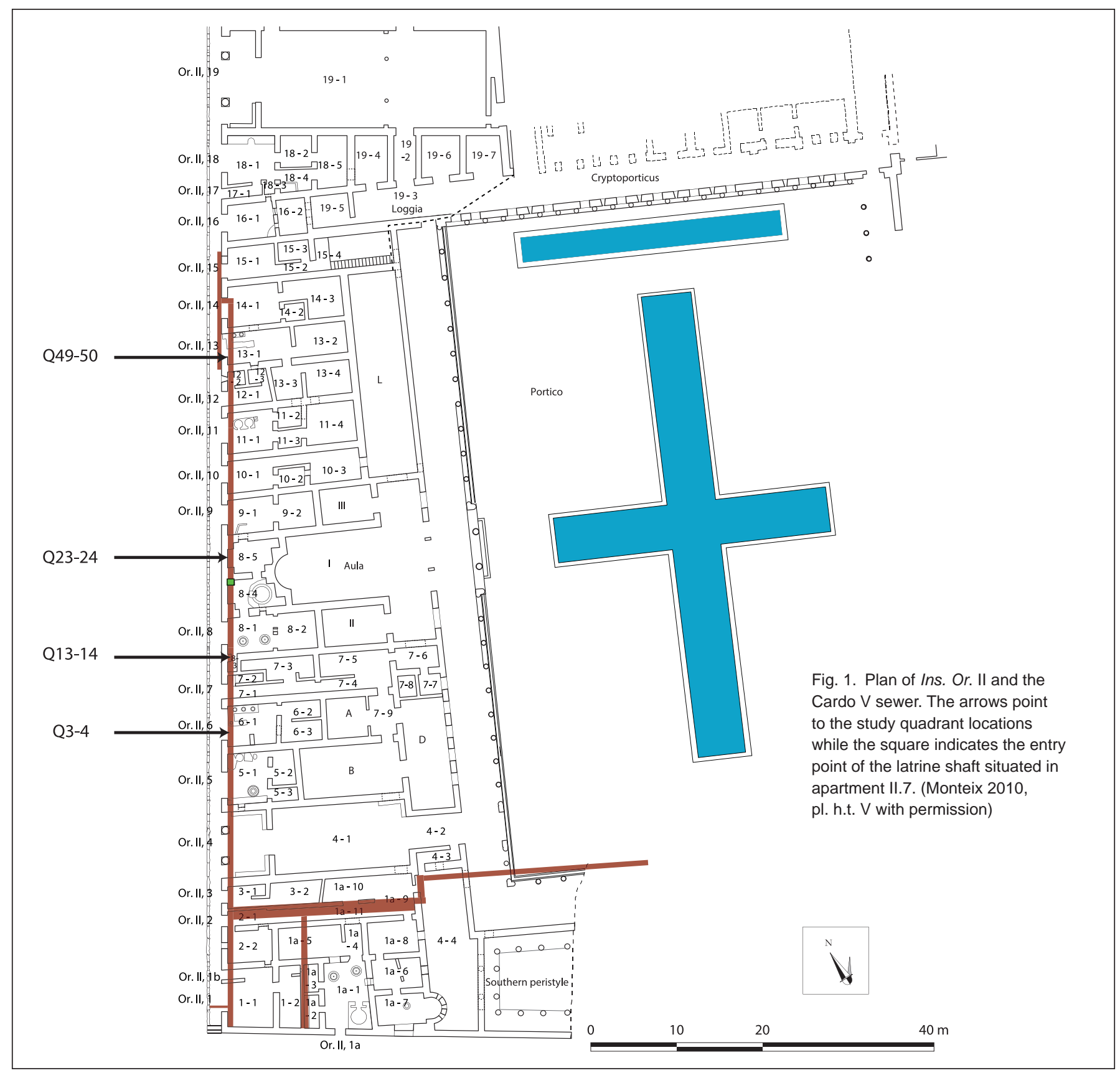

\begin{tabular}{|c|c|c|c|}
\hline Quadrant & $\begin{array}{c}\text { Stratigraphic } \\
\text { layer }\end{array}$ & $\begin{array}{c}\text { Identified } \\
\text { otolith sample }\end{array}$ & $\begin{array}{c}\text { Identifie d fish } \\
\text { sample }\end{array}$ \\
\hline \multirow{4}{*}{$3-4$} & 38 & $\checkmark$ & $\checkmark$ \\
\hline & 39 & $\checkmark$ & $\checkmark$ \\
\hline & 40 & $\checkmark$ & $\checkmark$ \\
\hline & 41 & $\checkmark$ & $\checkmark$ \\
\hline \multirow{3}{*}{$13-14$} & 38 & $\checkmark$ & \\
\hline & 39 & $\checkmark$ & $\checkmark$ \\
\hline & 40 & $\checkmark$ & $\checkmark$ \\
\hline \multirow{2}{*}{ 23-24 } & 38 & $\checkmark$ & \\
\hline & 40 & $\checkmark$ & $\checkmark$ \\
\hline \multirow{3}{*}{$49-50$} & 39 & $\checkmark$ & \\
\hline & 42 & $\checkmark$ & $\checkmark$ \\
\hline & 52 & $\checkmark$ & $\checkmark$ \\
\hline $5-6^{*}$ & 40 & $\checkmark$ & \\
\hline
\end{tabular}

Table 1. Identified otolith and fish samples from the Cardo $\mathrm{V}$ sewer * Only a single otolith from quadrant 5-6 was photographed and identified 
Ubiquity scores simply count the presence or absence of an item in a sample, in this case fish bones and otoliths. Thus if there is a high degree of ubiquity in both the quadrants and strata, then we can conclude that fish was widely consumed across both space and time. The four quadrants (Q3-4, 13-14, 23-24, 49-50) that were analysed for their fish remains span the length of the sewer (fig. 1). Out of the 30 taxa identified from the fish bones, $59 \%$ were found in multiple quadrants and $100 \%$ were found in multiple strata. Out of the 22 taxa identified through the otoliths, $60 \%$ were found in more than one quadrant and $71 \%$ were recovered from multiple strata. Together the high quadrant and strata ubiquity scores for both the fish bones and the otoliths indicate that fish were eaten by multiple inhabitants living along the length of Ins. Or. II for the entire span of time it required the biological assemblage to accumulate, approximately 10 years.

However, while fish remains were recovered from multiple quadrants and strata, the low range of taxa per sample, 2-15, clearly demonstrates that only particular species were consumed on a regular basis. Sea breams, picarels and damsel fish had the highest ubiquity scores indicating that they were the most frequently eaten varieties of fish and in the largest quantities ${ }^{28}$. The remaining types, such as sea bass and eels were eaten on a less frequent basis, for reasons which will be explained in the following section.

Although the sewer material shifted during deposition, the unidirectional nature of the shift means that material from the quadrants can be roughly associated with a particular portion of the insula (fig. 1). As can be seen in fig. 3, Q13-14 contains both the largest range of fish species and almost twice the amount of fish as any of the other three quadrants. Q13-14 is situated six quadrants (or $6 \mathrm{~m}$ ) downstream from the latrine drain of the large apartment at Ins. Or. II.7. The six intervening quadrants are situated beneath the bakery. Since the bakery did not contain living space is it likely that the majority of the fish material in this quadrant came from II.7. Although in theory Q13-14 could represent material deposited at any point north of this quadrant, the absence of a source of forced water to flush out the sewer means that the deposit moved slowly. It is unsurprising that the inhabitants of the largest apartment were consuming more fish and a wider range of fish than the other residents of the insula.

28. It is possible that boneless fillets of fish were also eaten, which would not survive in the archaeological record. However, boneless fillets could only come from larger fish, which would be more difficult to catch and therefore more expensive.

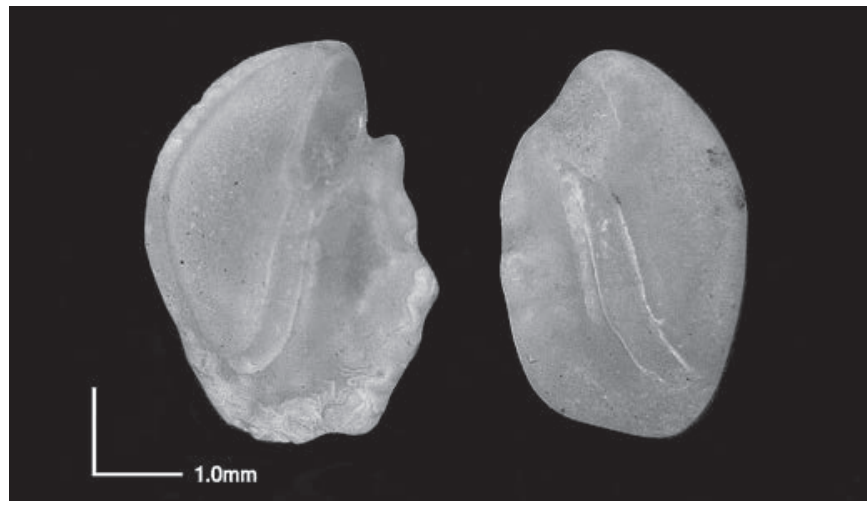

Fig. 2. Left and right Sparidae otoliths (sagittae) from Q13-14 in the Cardo V sewer showing varying signs of degradation and smoothing due to digestion.

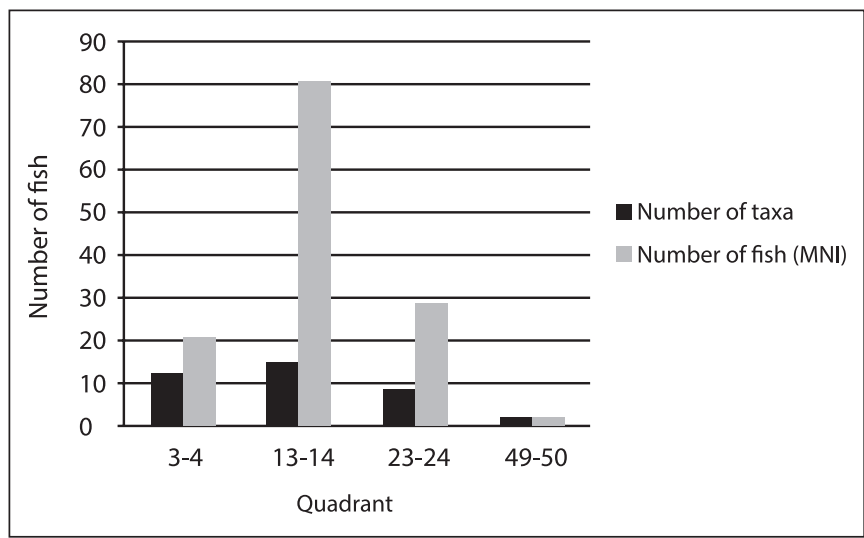

Fig. 3. Number of taxa and the number of fish per quadrant based on the otolith results.

Taking into account the various sizes of the shops and apartments, we find that fresh fish are consumed by people of varying financial means. Economically, this suggests that particular species of fish, usually the smaller types, were both inexpensive and habitually available for purchase in Herculaneum. The ancient sources and even modern scholars have suggested that fresh fish must have been extremely expensive, unlike the inexpensive and widely available garum $^{29}$. However, fresh fish in Herculaneum must have been relatively affordable, otherwise the Cardo V otoliths would be restricted to the southern end of the sewer in quadrants downstream from II.7. This is clearly not the case (fig. 3).

29. Athenaios focuses on the rare and expensive fish, at one point complaining that the fishermen in Roman sold tiny fish for a high price $(6.244 \mathrm{c})$. Apicius' recipes are directed towards the middle to upper classes. In many cases, the sale and consumption of fish is only noted in the sources when the prices are exceptionally high. For example, Macrobius tells the story that a mullus was purchased for 7000 sesterces (Sat 3.16.9). Corcoran 1963, p. 99-102; Gallant 1985, p. 39-44; Déry 1998, p. 94-97; Wilkins 2005, p. 30; Bekker-Nielsen 2010, p. 198-199. 


\section{Herculaneum fish market}

The composition of the fish market was dictated by financial and ecological pressures. Firstly, fishermen focused on catching fish that the market demanded. Market demands in turn were dictated by preference and cost. People preferred to eat particular species of fish due to a combination of personal taste and social expectations ${ }^{30}$. However, in a cyclical fashion, personal taste and social expectations were probably dictated by the environment of the Bay of Naples. The fish that were the closest and easiest to catch were probably the least expensive, and thus the most popular, at least amongst the middle and lower classes.

\section{1. Fishing in the Bay of Naples}

It is this combination of species habitat requirements, fishing techniques and market pressures that enable us to reconstruct fishing in the Bay of Naples. Since the habitat requirements of the 43 fish taxa, including migratory patterns, spawning grounds and feeding patterns are dictated by nature and not by man, fisherman had to operate within certain parameters. In reconstructing fishing patterns in the Bay, we must firstly recognize and subsequently also adhere to these parameters in our analyses.

The fish recovered from the sewer inhabit two broad ecological areas, coastal marine waters or brackish/estuary waters (Table 2). As the Bay is fed by only a single large river, the Sarno, the estuary zone in the Bay was restricted to the marshy area south of Pompeii where the fresh water from the Sarno mixed with the salt water of the Mediterranean ${ }^{31}$. There are only three taxa that live primarily in freshwater while the remaining 40 taxa can be found in marine waters. Eleven of these taxa are migratory and thus would have been in the Bay of Naples only during particular times of the year. Excluding these migratory taxa, 29 taxa were non-migratory and thus were available in the Bay of Naples throughout most of the year.

\footnotetext{
30. Marzano 2013, p. 273.
}

31. Vogel, Märker 2010; Pescatore et al. 2001. Herculaneum was situated on a tufo terrace surrounded to the east and the west by two small rivers. (Jansen 1991, p. 146). Although both rivers drained into the Bay they were probably too small to act as suitable habitats for estuary water fish.
Table 2. Identified taxa from the fish bone and otolith samples recovered from the Cardo V sewer

*Information from Whitehead 1986 and Froese, Pauly 2013

** $\mathrm{GN}=$ gill net. Method of capture is based on archaeological and modern data. See Bekker-Nielsen (2002), Thomas (2010) and Muñiz (2010) for good discussions of fishing gear in the ancient world and Sassu et al. (2001), Colloca et al. (2004), Stergiou, Karpouzi (2002) for discussions of modern fishing methods in the Mediterraneanand Tyrrhenian sea.

\subsubsection{Fishing in the Sarno Estuary}

Estuary waters are used by many fish species as a spawning ground. Consequently, at particular times of the year the number of species and the number of individuals that can be found in a river estuary will increase dramatically ${ }^{32}$. The environmental data for the fish assemblage recovered from the Cardo V sewer, including migratory patterns and spawning times, indicates that fishing in the Sarno estuary was a seasonal activity (Table 2). The summer would have been the peak fishing season as many valuable migratory species include anchovy, Mediterranean horse mackerel and sea bass entered the Bay of Naples and the Sarno at that time ${ }^{33}$. The other peak season would have been the winter when the pilchard arrived and the Anguillidae made their journey from the river to the sea ${ }^{34}$. None of the non-migratory taxa recovered from the Cardo V sewer lives exclusively in an estuary habitat and thus there was no need for large scale fishing to take place in the estuary outside of the two peak seasons. Young Sardinella live in estuaries, but the adults live in coastal areas. Since Sardinella live in schools it is more likely that they were caught along the coast using casting or draw nets ${ }^{35}$. The mullets and drums are families of bottom dwelling fish that can live either in coastal or brackish waters ${ }^{36}$. While they could be caught with a simple line and hook, the easiest way to catch bottom dwelling fish is to use drag or seine nets ${ }^{37}$. It was probably easier to use drag and seine nets along

32. Koutrakis, Tsikliras 2002.

33. Froese, Pauly 2013; Olivar et al. 2001, p. 111; Ragonese et al. 2003, p. 100.

34. Somarakis et al. 2006, p. 282; Vøllestad 2011.

35. Whitehead 1986, vol. 1.

36. Stergiou, Karpouzi 2002, p. 222; Froese, Pauly 2013 ; Whitehead 1986, vol. 2.

37. Muñiz 2010, p. 42. 


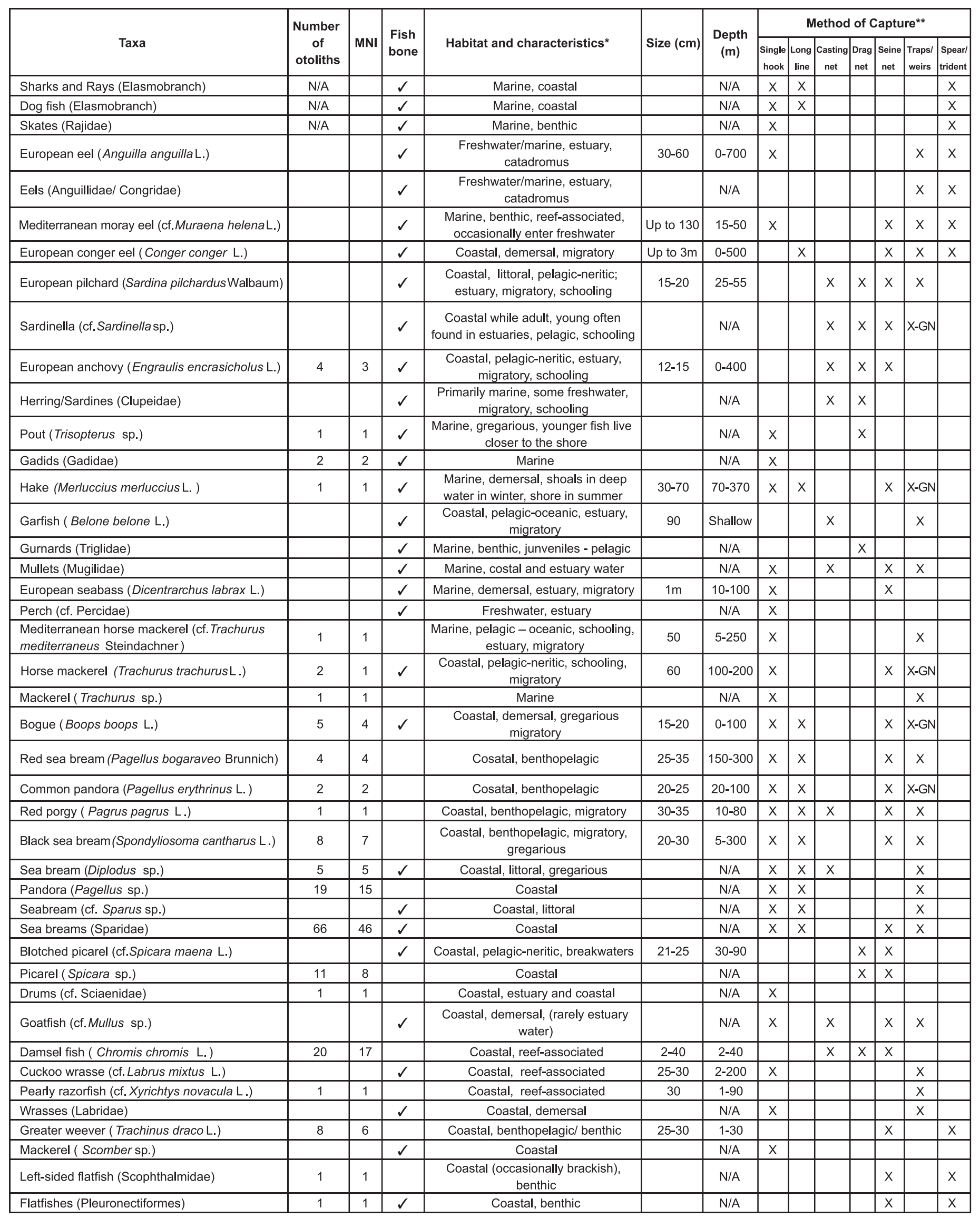


the coast than in the muddy estuary waters and thus mullets and drums were also likely caught along the coast.

In Herculaneum, the price of fish gathered from the Sarno estuary depended both on the season and the characteristics of the species. For example, the European anchovy, the European pilchard and the Mediterranean horse mackerel are all schooling species and therefore would have been caught in large numbers using casting or seine nets ${ }^{38}$. The majority of the catches were probably used for the production of fish sauce but as the otolith evidence from the sewer has shown, some were obviously sold fresh in the markets of the Bay of Naples. The abundance of these shoaling species during their spawning season would have made them inexpensive despite the need to transport them approximately $16 \mathrm{~km}$ from the Sarno to Herculaneum.

Sea bass, on the other hand, especially fresh, would have been a far more rare and expensive item than mackerels and anchovies. The ecological characteristics of this species would have driven up the cost, further enhancing the Roman belief that it was a prized item ${ }^{39}$. Sea bass are solitary creatures and can grow up to $1 \mathrm{~m}$ in length, which meant that could only be caught using either a single line and hook or a seine net ${ }^{40}$. The use of a line and hook is a very time consuming activity while the operation of a seine net requires the participation of multiple people. Although sea bass spend the summer months in coastal water or in river mouths they do not come right up to the shore and would probably have had to have been caught from boats. The presence of sea bass bones in only one sample from the Cardo V sewer suggests that the majority of the inhabitants of Ins. Or. II could not afford this type of fish. The absence of sea bass otoliths further suggests that only a portion of a sea bass was purchased and not a whole fish (though we must remember that only $10 \%$ of the excavated material was sampled). Thus unlike anchovies and sardine that could be quickly caught in their hundreds from the shore, the effort and equipment required to catch a single sea bass was considerably higher, making them an extremely expensive foodstuff.

\subsubsection{Coastal Fishing}

The Mediterranean Sea is characterized as having a narrow coastal shelf that descends into deep basins. The coastal shelf of the western coast of Italy is particular

38. Froese, Pauly 2013; Muñiz 2010, p. 41-44.

39. Martial 2.37.4.

40. Gallant 1985, p. 67; Whitehead 1986, vol. 2.; Nicholson 1997 ; Froese, Pauly 2013. narrow, extending only $10-20 \mathrm{~km}$ from the shore before the sea level reaches depths of more than $200 \mathrm{~m}^{41}$. All the taxa, except for the Anguillidae and Percidae, inhabit the coastal shelf for at least a portion of the year. As regards fishing, even fishing from boats did not need to be done far from the shore nor in deep waters ${ }^{42}$. Again, similar to the estuary fish, the price of fish caught in coastal waters depended on migratory patterns and species characteristics.

Eight of the coastal fish are migratory including three species of Sparidae, the horse mackerel and the European conger eel ${ }^{43}$. Adult horse mackerel live in large schools, coming closer to the coast and the surface during the summer but moving out into deeper waters, up to depths of $600 \mathrm{~m}$, in the winter ${ }^{44}$. As a schooling species they were caught in large volumes using seine or gillnets and sold fresh as well as for fish sauce and salting ${ }^{45}$. Bogue and black sea bream are characterized as gregarious species and, similar to horse mackerel, were also probably caught using seine nets, gillnets and even long lines ${ }^{46}$. Red porgy, like bogue and black sea bream, live in inshore waters for most of the year ${ }^{47}$. However, there are solitary species and thus could not be caught in large numbers in nets, but instead were probably caught using either a single line and hook, long lines, or occasionally in seine nets ${ }^{48}$. These four taxa were probably inexpensive when in season, especially as they could be fished right from the Herculaneum shore. Ecologically, the conger eels are very different, living near the coast during their juvenile stage but moving out to deeper waters as adults ${ }^{49}$. It is probably for this reason that all the conger eel bones found in the sewer were from small individuals.

The remaining 21 taxa are all non-migratory coastal fish. This does not necessarily mean that all the taxa were available throughout the year, simply, that they

41. Pinardi et al. 2004, p. 1244-1246.

42. In Italy today, the majority of small coastal fish are still caught on the continental shelf by independent fishermen using small boats. Colloca et al. 2004.

43. Froese, Pauly 2013.

44. Froese, Pauly 2013; Ragonese 2003, p. 101.

45. Sbrana et al. 2007; Desse-Berset, Desse 2000.

46. Whitehead 1986, vol. 2; Froese, Pauly 2013.

47. Whitehead 1986, vol. 2; Stergiou, Karpouzi 2002, p. 223.

48. It should be noted that seine and gillnets are not designed to catch a single species and many of the taxa recovered from the Cardo V sewer would have been caught at the same time during a single fishing event. Modern studies of gillnets have shown that, in attempts to catch hake, horse mackerel, bogue and common Pandora were caught as well. Sbrana et al. 2007.

49. Froese, Pauly 2013. 
were present in the Bay of Naples in steady numbers for multiple seasons. Winter, particularly January, would have been the time of least availability as some of the species, including hake and the pearly razorfish spend the winter in deeper waters ${ }^{\mathbf{5 0}}$.

During the warmer months these non-migratory fish can be found in three broad environmental habitats, which, in turn, determined fishing methods and cost. Seven of the taxa can be found in benthic environments; living primarily on the sea floor ${ }^{51}$. All seven types could be caught using tridents or spears (although with the exception of skates, that was probably not the preferred method) ${ }^{52}$. Using drag nets or seine nets from the shore was a more effective and efficient way of capturing these fish as many could be caught at once. However, unlike using a casting net from the shore to catch small anchovies, the use of these drag and seine nets would have required the cooperation of multiple people and much larger nets. The increase in equipment and manpower no doubt increased the cost of these taxa and it is not surprising that the majority of the bones of these benthic species recovered from the sewer are from small specimens. The greater weever, the smallest of the seven, is the only taxon found in significant quantities, with otoliths recovered from four samples.

There are 9 taxa which live in a demersal or benthopelagic habitat, just above the sea floor ${ }^{53}$. This group includes the majority of the Sparidae and thus most of the fish found in the Cardo $\mathrm{V}$ assemblage. Long lines and seine nets would have been efficient and effective ways to catch the Sparidae. Since they are all approximately the same size and live above rocky or sandy bottoms in inshore waters they were likely caught at the same time, especially if casting nets were used ${ }^{54}$. Their abundance and ease of capture right off the Herculaneum shore no doubt drove down the cost, making them one of the most frequently available and inexpensive types of fresh fish for sale. Hake are larger than the Sparidae and live in deeper waters, often between $70-370 \mathrm{~m}^{55}$. They too could be caught using long lines, seine and gillnets but since they lived farther from the shore more effort was required to catch them or they were a more rare catch if fisherman had to wait until they swam into shallower waters. Today they are caught primarily by trawling

50. Whitehead 1986, vol. 2.

51. Whitehead, vol. 2. 1986; Froese, Pauly 2013.

52. Muñiz 2010, p. 34-36.

53. Whitehead 1986, vol 2; Froese, Pauly 2013.

54. Froese, Pauly 2013.

55. Id. in the Mediterranean although gillnets are used in the Tyrrhenian Sea ${ }^{56}$.

The final category of coastal fish are those that tend to inhabit rocky reefs or man-made underwater structures including artificial reefs and breakwaters ${ }^{57}$. Shipwrecks and the underwater concrete structures of the many harbours in the Bay of Naples would have increased the available habitat space for these species. Herculaneum's harbour was likely located east of the palaestra, where one of its two surrounding rivers emptied into the sea ${ }^{58}$. Thus if the harbour had a breakwater or permanent underwater structures, it is likely that these rocky reef species could be caught there. Although blotched picarel usually inhabit coastal pelagic waters, it too has been found to live on the external side of man-made breakwaters ${ }^{59}$. A single hook and line or traps and weirs would have been used to collect these fish from the reefs. It would have been impractical to use nets on the reefs as the risk of damaging the net would have been quite high. Dip nets and a single line and hook would have been effective when fishing from the harbour. The tendency of damsel fish to inhabit artificial structures may explain their large presence in the sewer assemblage ${ }^{60}$.

Using the Cardo V fish data, combined with the ecological habitats of the fish we can create a broad reconstruction of the fish market in Herculaneum. The market would have been dominated by smaller coastal non-migratory fish that had been caught that day or the previous night, particularly the sea breams. Migratory fish, such as anchovies and horse mackerel would also have been available fresh when they were in season. Larger non-migratory fish, such as garfish or rays would have occasionally been for sale fresh, although probably divided up and sold as portions. It is likely that larger fish were also salted. Finally, in addition to fresh and salted fish, the inhabitants of Herculaneum could purchase either locally made or imported fish sauce from Spain and North Africa ${ }^{61}$.

The cost of fish varied considerably and underwent significant fluctuations depending on the time of year. In general, small schooling species were the least expensive

56. Oliver, Massuti 1995, p. 184.

57. Charbonnel et al. 2002; Guidetti 2004 ; Domingues et al. 2005, p.4052 ; Froese, Pauly 2013.

58. Wallace-Hadrill 2011, p. 103; Cinque, Irollo 2008.

59. Guidetti 2004; Froese, Pauly 2013.

60. It is possible that the inhabitants of Ins. Or. II caught these fish themselves since little equipment and effort would be required. 61. De Sena, Ikämeimo 2003. 
while large migratory species such as the sea bass were the most expensive as they were most difficult to catch. Fish were least expensive in the summer, when the coast and the Sarno estuary benefited from the arrival of numerous migratory species. At this time, people could choose between the migratory varieties and those that were available year round such as the non-migratory benthopelagic coastal fish, further driving down the cost. The migratory nature of some of the larger fish, including the eels and mackerels, would have made them widely available and thus inexpensive for a short period of time. Estuary fish such as sea bass, because of the distance they had to travel to Herculaneum, were probably always slightly more expensive than the coastal species and this is reflected in the rarity of these species in the Cardo V assemblage. Thus overall, each fish species must be considered in light of its habitat requirement, migratory tendencies and the methods and equipment necessary to capture it

\section{Conclusions}

The ubiquity and variety of fish recovered from the Cardo V sewer clearly demonstrates that fishing and the sale of fish were important parts of the Herculaneum economy. In order to obtain all 43 fish taxa, fisherman had to fish from the shore, from boats along the coast and in the Sarno estuary. In addition, they had to use a range of equipment that included hooks and lines, spears, traps and a wide variety of nets such as casting nets, drag nets and seine nets. It is illogical to think that so much time, effort and investment would have been put into an activity if it was not economically viable. Clearly there was a market for these catches and the people of Herculaneum could not only afford but obviously enjoyed the variety of fish that was made available for sale. The inhabitants of Ins. Or. II were of middle to lower socioeconomic standing and yet had the desire and the financial means to purchase a wide variety of fish and fish sauce. The presence of otoliths and bones suggests that many of these fish were bought fresh and then taken home to be fried or included in soups and stews, and thus were consumed whole. The notion that fresh fish was too expensive a commodity for all but the very rich clearly does not apply to Herculaneum.

In the Edict of Maximum Prices fish are categorized as being from the sea, from rivers or sold as salted products ; somewhat helpful yet extremely broad categories ${ }^{62}$. In the absence of actual prices, the cost of fish will have to remain relative, but that does not mean that prices cannot be understood in relation to both other fish and other goods. Determining the relative costs of these many fish species requires a careful examination of the individual characteristics of each taxa and an understanding of the effort required to catch them. The geographical and ecological characteristics of a region and factors such as seasonality must always be considered. Much of this information comes from modern research into fish stocks, spawning patterns and fishing methods ${ }^{63}$. Fresh fish was an important part of the diet and the economy in Herculaneum. Understanding the importance of fresh fish in other coastal regions of the empire will require a similar combination of archaeological, scientific and ecological research at other sites.
62. $D E 5$.

63. I would like to thank Dr. Sammy De Grave for his generous help in sorting out the fish taxa and their habitat requirements. 


\section{Bibliography}

Andrews 2006 : ANDREWS (J.) - The use and development of upper floors in houses at Herculaneum, Unpublished PhD, University of Reading, Reading, 2006.

Andrews 2012 : ANDREWS (J.) - Insula Orientalis II: Latrine and drain pipes, Pers. Comm. March 5, 2012.

Bekker-Nielsen 2002 : BEKKER-NIELSEN (T.) - Nets, boats and fishing in the roman world, $C \& M, 53,2002$, p. 215-233.

Bekker-Nielsen, Bernal Casasola 2010 : BEKKER-NIELSEN(T.), BERNAL CASASOLA (D.) (eds) - Ancient Nets and Fishing Gear: Proceedings of the International Workshop on Nets and Fishing Gear in Classical Antiquity: A First Approach (Cádiz, November 15-17, 2007), Denmark, 2010.

Bernal Casasola 2010 : BERNAL CASASOLA (D.) - Fishing tackle in Hispania: Reflections, proposals and first results. In : Bekker-Nielsen, Bernal Casasola 2010, p. 83-138.

Botte 2009 : BOTTE (E.) - Salaisons et sauces de poissons en Italie du sud et en Sicile durant l'Antiquité, Naples, 2009.

Camardo 2006-2007 : CAMARDO (D.) - Ercolano : Lo scavo della fogna dell'insula orientalis II. indagine archeologica, Herculaneum Conservation Project, Unpublished report, 2006-2007.

Campana 2004 : CAMPANA (S. E.) - Photographic atlas of fish otoliths of the northwest atlantic ocean, Ottawa, 2004.

Carannante 2008-2009 : CARANNANTE (A.) - L'ultimo garum di Pompei. Analisi archeozoologiche sui resti di pesce dalla cosiddetta «officina del garum », Rivista Di Natura, Scienza e Tecnica Nel Mondo Antico, 3-4, 1, 2008-2009, p. 43-55.

Charbonnel et al. 2002 : CHARBONNEL (E.), SERRE (C.), RUITTON (S.), HARMELIN (J.), JENSEN (A.) - Effects of increased habitat complexity on fish assemblages associated with large artificial reef units (French Mediterranean coast), ICES Journal of Marine Science: Journal Du Conseil, 59 (suppl), 2002, p. 208-213.

Cinque, Irollo 2007 : CINQUE (A.), IROLLO (G.) - La paleogeografia dell'antica herculaneum e le fluttuazioni, di origine bradisismica, della sua linea di costa. In: Guzzo (P.G.) and Guidobaldi (M.P.) (eds), Nuove Ricerche Archeologiche nell'area Vesuviana (Scavi 2003-2006) - Atti Del Convegno Internazionale (Roma, 1-3 febbraio 2007), Rome, 2007, p. $425-438$.

Colloca et al. 2004 : COLLOCA (F.), CRESPI (V.), CERASI (S.), COPPOLA (S.R.) - Structure and evolution of the artisanal fishery in a southern Italian coastal area, Fisheries Research, 69, 3, 2004, p. 359-369.

Cooley, Cooley 2004 : COOLEY (A.), COOLEY (M.G.L.) - Pompeii: A sourcebook, London, 2004.

Corcoran 1963 : CORCORAN (T.H.) - Roman fishermen, $C W$, 56, 4, 1963, p. $97-102$.

Curtis 1984 : CURTIS (R.I.) - A personalized floor mosaic from Pompeii, AJA, 88, 1984, p. 557-566.
Curtis 1991 : CURTIS (R.I.) - Garum and salsamenta: Production and commerce in materia medica, Leiden, 1991.

Curtis 2001 : CURTIS (R.I.) - Ancient food technology, Leiden, 2001.

Curtis 2005 : CURTIS (R.I.) - Sources for production and trade of Greek and Roman processed fish. In : Bekker-Nielsen (T.) (ed), Ancient Fishing and Fish Processing in the Black Sea Region, Oxford, 2005, p. 31-46.

De Sena, Ikäheimo 2003 : DE SENA (E.C.), IKÄHEIMO (J.P.) - The supply of amphora-borne commodities and domestic pottery in Pompeii 150 BC-AD 79: Preliminary evidence from the house of the vestals, EJA, 6, 3, 2003, p. 301-321.

Déry 1998 : DÉRY (C.A.) - Fish as food and symbol in ancient Rome. In : Walker (H.) (ed), Fish: Food from the Waters: Proceedings of the Oxford Symposium on Food and Cookery 1997, Devon, 1998, p. 94-115.

Desse-Berset, Desse 2000 : DESSE-BERSET (N.), DESSE (J.) - Salsamenta, garum et autres préparations de poissons. Ce qu'en disent les os, MEFRA, 112, 1, 2000, p. 73-97.

Domingues et al. 2005: DOMINGUES (V.S.), BUCCIARELLI (G.), ALMADA (V.C.), BERNARDI (G.) - Historical colonization and demography of the Mediterranean damselfish, Chromis chromis, Molecular Ecology, 14, 13, 2005, p. 4051-4063.

Froese, Pauly 2013 : FROESE (R.), PAULY (D.) - Fishbase, World Wide Web electronic publication, 2013, www.fishbase.org, version (02/2013).

Gallant 1985 : GALLANT (T.W.) - A fisherman's tale: An analysis of the potential productivity of fishing in the ancient world, Gent, 1985.

Giner 2010 : GINER (C.A.) - Fishing nets in the ancient world: The historical and archaeological evidence. In : Bekker-Nielsen, Bernal Casasola 2010, p. $55-81$.

Guidetti 2004 : GUIDETTI (P.) - Fish assemblages associated with coastal defence structures in south-western Italy (Mediterranean sea), Journal of the Marine Biological Association of the UK, 84, 3, 2004, p. 669-670.

Harvey et al. 2000 : HARVEY (J.T.), LOUGHLIN (T.R.), PEREZ (M.A.), OXMAN (D.S.) - Relationship between fish size and otolith length for 63 species of fishes from the eastern North Pacific ocean, Seattle, 2000.

Herculaneum Conservation Project Scientific Committee 2009-2010: HCP, Progress Reports and Future Proposals, March 4th, 2013, http://www. herculaneum.org/hcp-home/pdf/SciComReport2010_english_210710.pdf.

Jansen 1991 : JANSEN (G.C.M.) - Water systems and sanitation in the houses of Herculaneum, MNIR, 50, 1991, p. 145-166.

Jones 1986 : JONES (A.K.) - Fish bone survival in the digestive systems of the pig, dog and man: Some experiments. In : Brinkhuizen (D.C.) and Clason (A.T.) (eds), Fish and Archaeology : Studies in Osteometry, Taphonomy, Seasonality and Fishing Methods, Oxford, 1986 (BAR series n.294), p. 53-61.

Jones 1990 : JONES (A.K.) - Experiments with fish bones and otoliths: Implications for the reconstruction of past diet and economy. 
In : Robinson (D.) (ed), Experimentation and Reconstruction in Environmental Archaeology: symposia of the Association for Environmental Archaeology no. 9 (Roskilde, Denmark,1988),Oxford, 1990, p. 143-146.

Koutrakis, Tsikliras 2003 : KOUTRAKIS (E.), TSIKLIRAS (A.) - Lengthweight relationships of fishes from three northern aegean estuarine systems (Greece), Journal of Applied Ichthyology, 19, 4, 2003, p. 258-260.

Kron 2008: KRON (G.) - Animal husbandry, hunting, fishing and fish production. In : Oleson (J. P.) (ed), Oxford handbook of engineering and technology in the classical world, Oxford, 2008, p. 175-224.

Lombarte et al. 2006: LOMBARTE (A.), CHIC (Ò.), PARISIBARADAD (V.), OLIVELLA (R.), PIERA (J.), GARCÍA-LADONA (E.) -A web-based environment for shape analysis of fish otoliths. The AFORO database, Scientia Marina, 70, 1, 2006, p. 147-152.

Maiuri 1958 : MAIURI (A.) - Ercolano : I nuovi scavi (1927-1958), Rome, 1958.

Marzano 2013 : MARZANO (A.) - Harvesting the sea: the exploitation of marine resources in the Roman Mediterranean, Oxford, 2013.

Monteix 2010 : MONTEIX (N.) - Les lieux de métier : Boutiques et ateliers d'Herculanum, Rome, BEFAR, 344, 2010.

Muñiz 2010 : MUÑIZ (A.M.) - Inferences about prehistoric fishing gear based on archaeological fish Assemblages. In: Bekker-Nielsen, Bernal Casasola 2010, p. 25-53.

Nicholson 1997 : NICHOLSON (R.) - Fish bones from the house of the Postumii, Unpublished report, 1997.

Olivar et al. 2001 : OLIVAR (M.P.), SALAT (J.), PALOMERA (I.) Comparative study of spatial distribution patterns of the early stages of anchovy and pilchard in the NW Mediterranean sea, Marine Ecology Progress Series, 217, 2001, p. 111-120.

Oliver, Massutí 1995 : OLIVER (P.), MASSUTÍ (E.) - Biology and fisheries of western Mediterranean hake (M. merluccius). In : Alheit (J.) and Pitcher (T.) (eds), Hake : Biology, fisheries and markets, Netherlands, 1995 (Chapman \& Hall Fish and Fisheries Series n.15), p. 181-202.

Pesaresi, Castaldi 2006 : PESARESI (P.), CASTALDI (M.M.) - Conservation measures for an archaeological site at risk (Herculaneum, Italy): From emergency to maintenance, Conservation and Management of Archaeological Sites, 8, 4, 2006, p. 215-236.

Pescatore et al. 2001: PESCATORE (T.), SENATORE (M.R.), CAPRETTO (G.), LERRO (G.) - Holocene coastal environments near Pompeii before the A.D. 79 eruption of mount Vesuvius, Italy, Quaternary Research, 55, 1, 2001, p. 77-85.

Pinardi et al. 2006: PINARDI (N.), ARNERI (E.), CRISE (A.), RAVAIOLI (M.), ZAVATARELLI (M.) - The physical, sedimentary and ecological structure and variability of shelf areas in the Mediterranean sea. In: Robinson (A.) and Brink (K.) (eds), The Sea. Vol. 14. Ideas and Observations on Progress in the Study of the Seas: The global coastal ocean. Interdisciplinary regional studies and syntheses, Boston, 2006, p. 1245-1332.

Ragonese $\boldsymbol{e}$ t al. 2003 : RAGONESE (S.), FIORENTINO (F.), GAROFALO (G.), GRISTINA (M.), LEVI (D.), GANCITANO (S.) et al. - Distribution, abundance and biological features of picarel (Spicaraflexuosa), Mediterranean (Trachurus mediterraneus) and Atlantic (T. trachurus) horse mackerel based on experimental bottom-trawl data (MEDITS, 1994-2002) in the strait of Sicily, MedSudMed Technical Documents, 5, 2003, p. 100-114.
Robinson 2007a : ROBINSON (M.) - The archaeological potential of the Herculaneum sewer, Unpublished preliminary report on field work done by the Herculaneum conservation project, 2007.

Robinson 2007b : ROBINSON (M.) - Preliminary report on the processing of samples from Herculaneum Cardo $V$ fogna, Unpublished preliminary report on field work done by the Herculaneum conservation project, 2007.

Rowan forthcoming : ROWAN (E.) - The identification of the otolith assemblage from the Cardo V sewer: Tools, techniques and the implications for fish consumption in Roman Herculaneum.

Sassu et al. 2001 : SASSU (N.), CANNAS (A.), FERRETTI (M.) - Gli attrezzi da pesca in uso nelle Marinerie Italiane, SFOP, 2001 (Reg. CEE N. 2080/93), p. 1-16.

Sbrana et al. 2007 : SBRANA (M.), BELCARI (P.), DE RANIERI (S.), SARTOR (P.), VIVA (C.) - Comparison of the catches of European hake (Merluccius merluccius, L. 1758) taken with experimental gillnets of different mesh sizes in the northern Tyrrhenian sea (western Mediterranean), Scientia Marina, 71, 1, 2007, p. 47-56.

Slim et al. 2007 : SLIM (L.), BONIFAY (M.), PITON (J.), STERNBERG (M.) - An Example of Fish Salteries in Africa Proconsularis: The Officinae of Neapolis (Nabeul, Tunisia). In : Lagóstena (L.), Bernal (D.) and Arévalo (A.) (eds), Cetariae 2005 : Salsas y Salazones de Pescado en Occidente durante la Antigüedad. Actas del Congresso Internacional (Cádiz, 7-9 de noviembre de 2005), Oxford, 2007 (BAR International Series 1686), p. 21-44.

Somarakis et al. 2006 : SOMARAKIS (S.), GANIAS (K.), SIAPATIS (A.), KOUTSIKOPOULOS (C.), MACHIAS (A.), PAPACONSTANTINOU (C.) - Spawning habitat and daily egg production of sardine (Sardina pilchardus) in the eastern Mediterranean, Fisheries Oceanography, 15, 4, 2006. p. 281-292.

Stanley Price 2007 : STANLEY PRICE (N.) (ed.) - Conservation and Management of Archaeological Sites, Special edition on the Herculaneum Conservation Project 8, 4, 2007.

Stergiou, Karpouzi 2001 : STERGIOU (K.I.), KARPOUZI (V.S.) - Feeding habits and trophic levels of mediterranean fish, Reviews in Fish Biology and Fisheries, 11, 3, 2001, p. 217-254.

Thomas 2010 : THOMAS (R.) - Fishing equipment from Myos Hormos and fishing techniques on the Red Sea in the Roman period. In : Bekker-Nielsen, Bernal Casasola 2010, p. 139-160.

Trakadas 2005: TRAKADAS (A.) - The archaeological evidence for fish processing in the Western Mediterranean. In: Bekker-Nielsen (T.) (ed), Ancient Fishing and Fish Processing in the Black Sea Region, Oxford, 2005, p. $47-82$.

Vogel, Märker 2010 : VOGEL (S.), MÄRKER (M.) - Reconstructing the roman topography and environmental features of the Sarno river plain (Italy) before the AD 79 eruption of Somma-Vesuvius, Geomorphology, 115, 1, 2010, p. 67-77.

Vøllestad et al. 1986 : VØLLESTAD (L.), JONSSON (B.), HVIDSTEN (N.), NÆSJE (T.), HARALDSTAD (Ø.), RUUD-HANSEN (J.) - Environmental factors regulating the seaward migration of European silver eels (Anguilla anguilla), Canadian Journal of Fisheries and Aquatic Sciences, 43, 10, 1986, p. 1909-1916.

Wallace-Hadrill 1994 : WALLACE-HADRILL (A.) - Houses and society in Pompeii and Herculaneum, Princeton, 1994. 
Wallace-Hadrill 2011 : WALLACE-HADRILL (A.) - Herculaneum: Past and future, London, 2011.

Wallace-Hadrill et al. 2008 : WALLACE-HADRILL (A.), GUIDOBALDI (M.P.), CAMARDO (D.), MOESCH (V.) - Le ricerche archeologiche nell' ambito dell'Herculaneum Conservation Project. In: Guzzo (P.G.), Guidobaldi (M.P.) (eds), Nuove ricerche archeologiche nell'area vesuviana (scavi 20032006). Proceedings of the international conference (Rome, 1-3 February 2007), Rome, 2008, p. 409-424.
Whitehead 1986 : WHITEHEAD (P.J.P.) - Fishes of the north-eastern Atlantic and the Mediterranean, California, 1986.

Wilkins 2005 : WILKINS (J.) - Fish as a source of food in Antiquity. In : Bekker-Nielsen (T.) (ed), Ancient Fishing and Fish Processing in the Black Sea Region, Oxford, 2005, p. 21-30.

Wilson 2006: WILSON (A.I.) - Fishy business: Roman exploitation of marine resources, JRA, 19, 2, 2006, p. 525-537. 



\section{Le commerce des coquillages marins}

\section{en Gaule romaine : animaux « en coquille » et chair décoquillée}

\section{Anne Bardot-Cambot}

\section{Introduction}

«Les uns ont pensé d'abord que cette couche de coquilles marines a été formée par les eaux de la mer, et n'intéresse que la géologie; les autres, qu'elle est l'ouvrage de la main de l'homme, et qu'elle intéresse l'histoire et l'archéologie » ${ }^{1}$. C'est ainsi que l'abbé Croizet, curé de Neschers dans le département du Puyde-Dôme, résume la discussion qui anima au $\mathrm{XIX}^{\mathrm{e}} \mathrm{s}$. les rencontres entre érudits. Une question était régulièrement portée au débat : comment expliquer la présence de coquilles dans des lieux parfois très éloignés des côtes ? À l'époque, la réponse fut déjà donnée par certains, notamment par le baron Chaudruc de Crazanne qui affirmait «qu'elles ne sont point fossiles comme quelques personnes l'ont cru, elles appartiennent à la variété de ces mollusques (ostrea edulis, Linn.), que l'on pêche chaque jour sur nos côtes Saintongeaises $»^{2}$. Pour l'abbé Croizet, il n'y avait pas non plus de doute : l'homme est à l'origine de leur transport, « la mer n'est pour rien dans cette affaire ${ }^{3}$. Depuis, des coquillages marins ont été mentionnés dans toute la Gaule romaine, près des côtes comme dans l'intérieur des terres (fig. 1).

À notre connaissance, l'inventaire descriptif des coquilles de la nécropole du Trion à Lyon par A. Locard en $1885^{4}$ correspond à la plus ancienne étude réalisée en France sur des conchyliorestes, c'est-à-dire des vestiges archéologiques de Mollusques marins. Il faudra ensuite attendre près d'un siècle pour que cet exemple soit suivi par divers chercheurs à l'occasion d'études le plus souvent ponctuelles. Les premiers travaux spécialisés se sont développés seulement à partir de la fin des années 1980 grâce aux recherches entamées par Fr. Brien-Poitevin dans la région méditerranéenne ${ }^{5}$. Après son décès brutal

1. Comité historique des arts et monuments, 1844-1845, p. 74.

2. Propos rapportés dans : Mémoires de la Société des Antiquaires de Normandie, 1833 , p. 390.

3. Comité historique des arts et monuments, 1844-1845, p. 74.

4. Locard 1887-1888.

5. Voir Brien-Poitevin 1996a et 1996 bour un premier bilan sur l'exploitation des coquillages marins sur les sites de la partie méditerranéenne de la province de Narbonnaise. Le même article a été édité dans deux ouvrages après le décès de Françoise Brien-Poitevin.

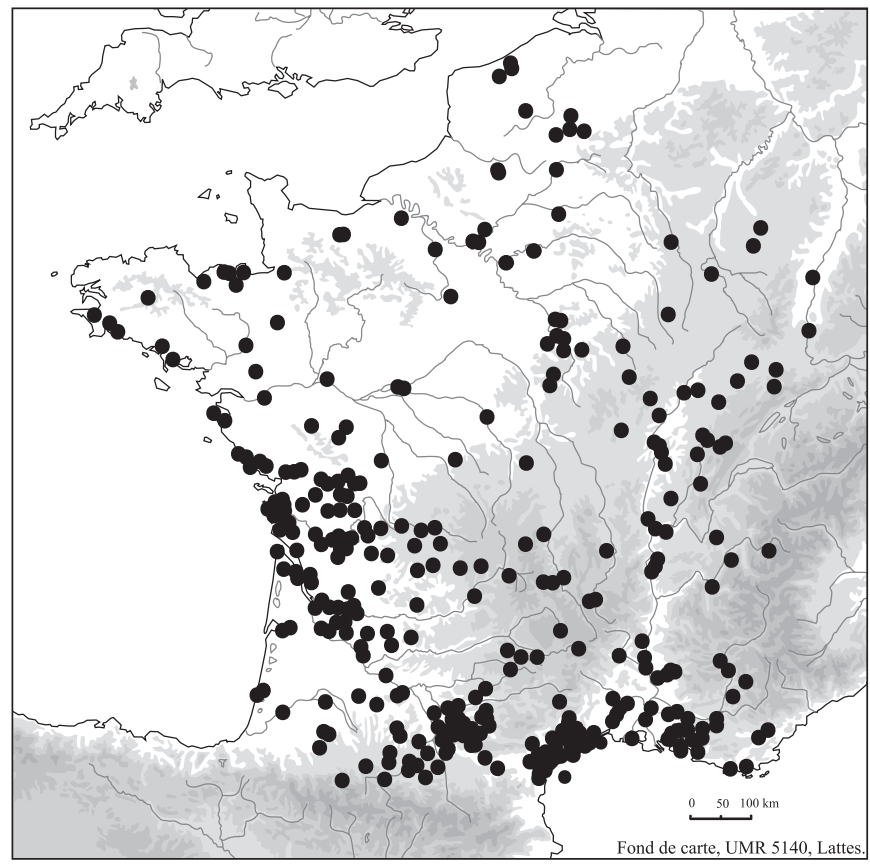

Fig. 1. Sites archéologiques d'époque romaine ayant livré des restes de coquillages marins. Carte: A. Bardot-Cambot (inventaire au 15/11/2012).

en 1995, son travail a été poursuivi, principalement par V. Forest dont les interventions systématiques sur les conchyliorestes fournissent aujourd'hui la plupart des données pour cette région. Sur la façade atlantique, plusieurs chercheurs sont également intervenus, dont Y. Gruet et C. Dupont pour les principales références strictement conchyliologiques ${ }^{6}$.

L'accumulation de ces données, alimentée de nos propres travaux ${ }^{7}$, permet désormais de traiter certains aspects de l'exploitation romaine des coquillages de manière synthétique. Notre exposé se concentrera sur le commerce, dont nous savons maintenant qu'il suit deux scénarios. Nous commencerons par évoquer le commerce des coquillages « en coquille », autrement dit

6. La bibliographie des auteurs précités a été rassemblée dans Bardot 2010.

7. Voir notre thèse de doctorat publiée en 2013 (Bardot-Cambot 2013) et les autres références citées dans cet article. 
des animaux transportés vivants. Puis, nous nous arrêterons sur une seconde solution, nouvellement envisagée par l'étude du mobilier du site atlantique de Barzan/Le Fâ (Charente-Maritime) : sur ce site, de volumineux dépôts de coquilles d'huître plate recyclées en remblais pourraient être les vestiges d'une activité de commercialisation de la chair décoquillée ${ }^{8}$.

\section{Conchyliorestes, valves, coquilles et résidus alimentaires}

L'étude des conchyliorestes, ou archéoconchyliologie, parce qu'elle est une discipline jeune et encore mal connue, commence seulement à faire l'objet d'une réflexion sur les principes théoriques de son application. La fixation de définitions, elle-même dépendante de connaissances biologiques et systématiques, est un préalable indispensable. Ainsi, nous définissons les conchyliorestes découverts au cours des fouilles comme des coquilles entières ou fragmentaires de Mollusques marins, car la coquille de ces animaux ne prend pas la même forme suivant l'une des deux classes presque exclusivement rencontrées : celle des Bivalves et celle des Gastéropodes. Chez les Bivalves, la coquille s'organise en deux organes latéralisés, les valves, articulés par une charnière. Les unités de base du conchylioreste archéologique de Bivalve sont donc la valve gauche et la valve droite. Chez les Gastéropodes, la coquille se compose d'un organe unique, le plus souvent enroulé en forme d'escargot, parfois conique comme chez les patelles, Patella sp. L'unité de base du conchylioreste archéologique devient alors la coquille elle-même. Le dénombrement des restes que nous adoptons répond à cette différence de construction. C'est pourquoi, le Nombre Minimum d'Organes (NMO), qui compte tous les organes bivalves et gastéropodes, est la somme du Nombre Minimum de Valves, gauches et droites, des Bivalves (NMVg et NMVd) et du Nombre Minimum de Coquilles des Gastéropodes (NMC).

L'identification des conchyliorestes comme des résidus alimentaires est un préalable indispensable pour aborder le commerce des coquillages destinés à la table. En effet, nous savons aujourd'hui que tous les restes ne sont pas des déchets issus de l'alimentation. À l'époque romaine, certaines coquilles sont en effet recherchées pour l'objet qu'elles constituent, pour servir à divers usages, notamment décoratifs et utilitaires ${ }^{9}$. La première

8. Forest 2003 ; Bardot-Cambot 2011.

9. Synthèse en cours en collaboration avec V. Forest. Voir notamment : Manniez 1999 ; Forest 1999 ; Manniez 2005; Bardot 2009a ; 2009b; 2010 ; 2012 ; Bardot-Cambot 2013. étape de l'étude archéoconchyliologique consiste donc à déterminer la nature des conchyliorestes. Au moins deux observations suggèrent que les restes appartiennent à des animaux recherchés vivants pour être consommés. Les valves ou les coquilles ne présentent pas de signes d'abrasion naturelle à la manière de spécimens épaves, c'est-à-dire d'animaux morts, roulés par la mer ${ }^{10}$; elles sont indemnes, suggérant qu'elles sont arrivées avec la chair qu'elles protégeaient. Elles peuvent aussi porter les traces d'actions mécaniques qui trahissent l'action de l'homme, par exemple la dissociation des valves gauche et droite d'une coquille de Bivalve, l'éclatement de la coquille chez les Gastéropodes, ou encore les empreintes d'outils employés pour récupérer le corps charnu de l'animal. Ainsi, il est certain que des huîtres ont été ouvertes alors qu'elles étaient vivantes car les stigmates du mode opératoire d'ouverture ont été identifiés sur certaines valves. Nous avons retrouvé des cassures du bord ventral, des encoches dans ce même bord qui sont parfois prolongées en face interne par des stries ou des raclages occasionnés par le passage d'une lame de couteau ${ }^{11}$ (fig. 2).

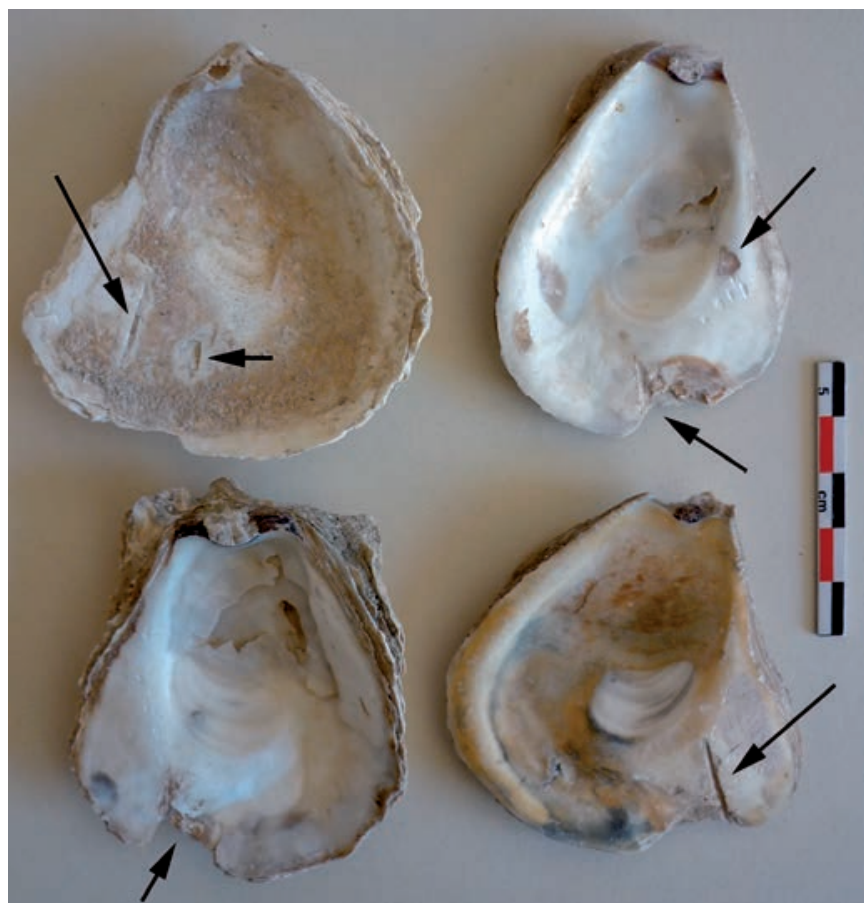

Fig. 2. Valves archéologiques d'huître plate d'Europe, Ostrea edulis, montrant des marques d'ouverture mécanique sur leur face interne. À gauche, valves gauches. À droite, valves droites. Cliché : A. Bardot-Cambot.

10. Nous devons la première définition des valves épaves à Fr. Brien-Poitevin. Voir par exemple Brien-Poitevin 1990.

11. Voir par exemple Gruet (inédit a) ; Forest 2003 ; Bardot-Cambot 2011. 


\section{Les coquillages « en coquille »}

\subsection{Les espèces commercialisées}

Le début du I ${ }^{\text {er }}$ s. ap. J.-C. apparait comme un moment fort dans l'histoire du commerce des coquillages « en coquille » en Gaule romaine. C'est en effet à partir de cette époque que leur exportation se libère du cadre strict des zones côtières auxquelles elle était auparavant restreinte, probablement à la faveur d'une nouvelle organisation administrative et routière qui facilite l'acheminement rapide et à grande échelle des marchandises $^{12}$. Des coquillages sont alors transportés jusque dans les régions les plus éloignées des côtes. En l'état actuel de notre recherche, le site de Lyon/Cybèle fournit le témoignage le plus précoce de ce nouveau commerce de longue distance, au cours des années 20-30 ap. J.-C. ${ }^{13}$ (fig. 3).
L'analyse des données archéoconchyliologiques aujourd'hui disponibles montre qu'au moins une douzaine de taxons sont transportés sur les sites de consommation, avec parmi les plus fréquents l' huître plate d'Europe, Ostrea edulis, des pétoncles, Proteopecten glaber et Chlamys varia, les moules, Mytilus edulis et Mytilus galloprovincialis, et des Gastéropodes, comme les rochers, ou murex, Bolinus brandaris et Hexaplex trunculus, et les patelles, Patella sp. ${ }^{14}$ Le commerce de ces coquillages est déterminé par des facteurs multiples et de diverses natures.

Le facteur déterminant principal réside dans la capacité des espèces elles-mêmes à supporter un long voyage. Ainsi, l'huître plate d'Europe, Ostrea edulis, qui est l'huître indigène des côtes européennes, est la plus résistante, ce qui lui permet d'être acheminée vivante sur de longues distances. Elle est donc la seule à être exportée très loin de la mer, par exemple jusqu'à Lyon/ Cybèle localisé à près de $300 \mathrm{~km}$ de la côte méditerranéenne et à quelque $500 \mathrm{~km}$ de la côte atlantique ${ }^{15}$.

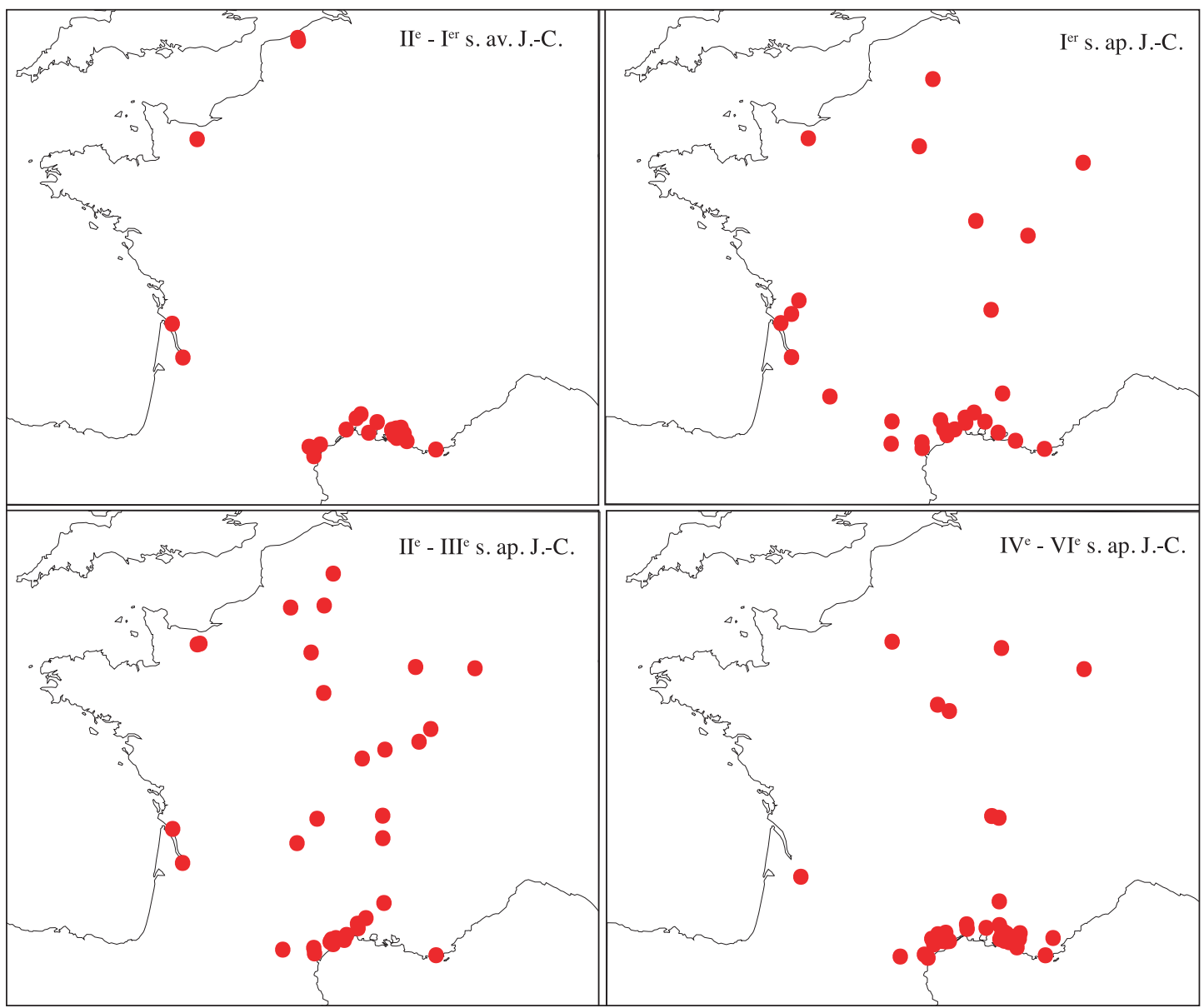

Fig. 3. Distribution géographique des découvertes de conchyliorestes marins entre les $\|^{\mathrm{e}}-\mathrm{I}^{\mathrm{er}} \mathrm{S}$. av. J.-C. et les IVe-VIe s. ap. J.-C. Carte : A. Bardot-Cambot.

12. Voir notre dernière synthèse (Bardot-Cambot 2013), notamment à partir des travaux de Françoise Brien-Poitevin et Vianney Forest en Narbonnaise méditerranéenne.

13. Bardot (inédit) ; Bardot-Cambot 2013.
14. Bardot 2010.

15. Sur le site de Lyon/Cybèle, nous avons pu déterminer qu'un lot d'huîtres venait de Méditerranée et qu'un autre était probablement originaire de l'Atlantique. (Bardot (inédit) ; Bardot-Cambot 2013). 
$\mathrm{Au}$ contraire, d'autres espèces sont fragiles et se corrompent rapidement une fois sorties de leur environnement marin, comme les moules, Mytilus sp., la palourde croisée d'Europe, Ruditapes decussatus, et le délicat peigne operculaire, Aequipecten opercularis, qui «meurt rapidement et [dont la] qualité se dégrade très vite, ce qui est [encore aujourd'hui] un obstacle majeur à la valorisation de cette espèce ${ }^{16}$. Leur distribution reste donc limitée à la proximité immédiate des côtes. Ces coquillages, encore au début du XVIII ${ }^{e}$ s., étaient d'ailleurs transportés seulement dans les environs de leur lieu de collecte. Fr. le Masson du Parc rapporte que les moules du bassin d'Arcachon (Gironde) n'étaient consommées que par les riverains du dit bassin et que les palourdes étaient apportées «en grande quantité à Bordeaux [à une cinquantaine de kilomètres du bassin d'Arcachon], outre ce qui s'en renverse dans les campagnes voisines de la baye ${ }^{17}$. Cette diffusion différente des espèces en fonction de leur résistance au transport nous fait pressentir une frontière au-delà de laquelle le commerce des coquillages se limite à celui d'une seule espèce : l'huître plate d'Europe, Ostrea edulis. Nous l'estimons à une distance de 100 et $200 \mathrm{~km}$ de la mer, en attendant de pouvoir la préciser davantage par des études micro-régionales (fig. 4).

En deçà, dans les régions que nous qualifierons de juxta-côtières, d'autres facteurs interviennent dans le choix des espèces commercialisées. Le premier est biologique. En effet, tous les Mollusques n'habitent pas dans le même domaine marin. Certains Gastéropodes sont strictement atlantiques, comme le bulot de notre actuel plateau de fruits de mer: le buccin ondé, Buccinum undatum. D'autres sont inféodés à la Méditerranée, comme «l'escargot de mer » des étals languedociens : le rocher épineux, Bolinus brandaris. L'endémisme détermine ainsi le commerce, ou non, de certaines espèces. Pour l'époque romaine, le cas le plus remarquable est celui du peigne glabre, Proteopecten glaber, qui est, après l'huître plate, l'espèce la plus abondamment diffusée, mais seulement dans la zone d'influence de son bassin d'origine, la Méditerranée (fig. 5). Ensuite, des variables écologiques se superposent à la dualité des zones géographiques de peuplement, méditerranéenne et atlantique, et influent sur le fruit de la pêche et donc sur les espèces transportées. En Languedoc et en Provence, la géologie et la topographie différentes des rivages

16. Quéro 1998, p. 106.

17. Le Masson du Parc 1727, éd. 2004, p. 25. François Le Masson Du Parc était Commissaire ordinaire de la Marine, Inspecteur général des pêches et du poisson de mer. Dans les années 1720, il a été chargé par ordre du roi Louis XV, de visiter tous les ports de pêche du littoral atlantique. expliquent probablement la divergence des approvisionnements dans ces deux régions. Les patelles, du genre Patella, se rencontrent en abondance uniquement sur des substrats rocheux, que ne craint pas non plus le rocher fascié, Hexplex trunculus : ces coquillages seraient donc moins diffusés dans la région languedocienne dont les côtes sont principalement sablo-vaseuses. À l'inverse, le rocher épineux, Bolinus brandaris, semble fuir les côtes rocheuses, comme celles de Provence, et serait donc plus facilement exporté sur les sites languedociens ${ }^{\mathbf{1 8}}$ (fig. 6). Des facteurs proprement humains jouent enfin dans le choix des coquillages commercialisés. L'apparition d'espèces ubiquistes préférentiellement sur l'une des deux façades montre en effet que le commerce n'est pas guidé uniquement par la disponibilité des espèces. Ainsi, le flion tronqué, Donax trunculus, transporté aux abords de la Méditerranée, paraît absent du commerce atlantique. Son absence ne semble pas compensée par l'exploitation de l'espèce strictement atlantique de forme proche, Donax vittatus. Les deux flions vivent pourtant dans les mêmes conditions, enfoncés dans le sable fin des zones de déferlement des vagues. Mais la pêche mise en œuvre en Méditerranée, probablement comme de nos jours à l'aide d'une drague tractée manuellement qui filtre le sable, pourrait ne pas avoir été développée en Atlantique, où la force des vagues et le jeu des marées rendent la collecte plus difficile. Un autre exemple qui nous a surpris est celui du peigne variable, Chlamys varia, et de la palourde croisée d'Europe, Ruditapes decussatus. Ces deux espèces sont diffusées sur la façade atlantique, notamment dans la région charentaise, mais pas en Méditerranée. Pourtant les palourdes sont traditionnellement prisées en Méditerranée depuis le XVIII ${ }^{\mathrm{e}}$ s., principalement la palourde jaune, ou clovisse, Venerupis aurea, qui n'est pas non plus consommée à l'époque romaine. Pour ces coquillages, il faut peut-être envisager des raisons davantage culturelles, par exemple de l'ordre du dégoût ou des interdits, à l'image d'espèces comestibles que nous ne mangeons pas actuellement.

\subsection{La qualité des coquillages}

La synthèse des observations et des résultats obtenus par l'étude des restes d'huître plate, Ostrea edulis, montre que des animaux de toutes tailles et de toutes formes ont été acheminés sur les sites, qu'ils soient côtiers ou continentaux ${ }^{19}$. Aucune norme commerciale de taille et de forme ne semble donc fixée. Un souci d'homogénéisation de la forme des huîtres pourrait toutefois apparaître

18. Bardot 2012.

19. Bardot-Cambot 2013. 
à travers certains assemblages dont les coquilles sont toutes morphologiquement proches. Parallèlement, des lots sont composés de coquillages dont la taille varie peu. Certes, ils peuvent venir de populations dont les individus ont grandi simultanément. Cependant, il est plus probable que des calibrages ont été opérés, c'est-àdire que des lots d'huîtres ont été composés en fonction de leurs tailles à partir de vrac de collecte ${ }^{20}$. Le calibrage a pu être associé à un nettoyage, car des assemblages sont parfois composés uniquement de valves d'huîtres. Autrement dit, ils ne livrent pas de débris, qu'on supposerait rapportés accidentellement lors de la collecte, comme des restes d'individus morts, des brisures ou des valves épaves d'autres espèces et des petites pierres. Tous ces éléments indésirables auront été éliminés au retour de la pêche, comme sur le site de Narbonne/Portla-Nautique (Aude) où la découverte récente d'un épais amas de conchyliorestes nous fait soupçonner le traitement de grands volumes d'huîtres plates ${ }^{21}$.

Le commerce des moules, Mytilus sp., dans les régions côtières pourrait aussi commencer par une étape de nettoyage, car celles qui nous parviennent portent rarement les vestiges des organismes qui vivent fixés à la surface de leur coquille, comme des Crustacés cirripèdes du genre Balanus, des algues et d'autres moules qui y adhèrent grâce à leur byssus ${ }^{22}$. Les données conchyliologiques que nous avons rassemblées pour les autres espèces ne permettent guère de commentaires. Néanmoins, les mesures prises sur les valves de peigne glabre, Proteopecten glaber, montrent que les jeunes individus, inférieurs à $45 \mathrm{~mm}$ de hauteur, sont presque absents des séries conchyliologiques d'époque romaine ${ }^{23}$. Nous supposons pourtant qu'ils se trouvaient mêlés aux individus adultes avec lesquels ils cohabitaient. V. Forest l'a montré pour des périodes antérieures: sur le site de Lespignan/Camp Redoun (Hérault), au Néolithique final, les assemblages étaient composés pour majorité de très petites coquilles, autour de 35/40 mm de hauteur. Les pêcheurs romains pouvaient donc disposer de peignes glabres de petite taille, mais ils ne l'ont pas fait. Selon V. Forest, ils auraient « calibré leur collecte de manière à ne pas conserver les plus petits animaux. Ce choix, éventuellement lié à un critère de qualité dans la commercialisation de l'espèce au moins à l'époque romaine, laissait aussi les animaux atteindre une taille quasi définitive ${ }^{24}$. Il nous semble encore un peu tôt pour en déduire l'existence d'une

20. Forest 2003 ; Bardot-Cambot 2013.

21. Forest 2010 ; Bardot-Cambot (étude en cours).

22. Marteil 1979, p. 115-116.

23. Bardot-Cambot 2013.

24. Forest (inédit). taille commerciale, en dessous de laquelle les peignes ne pouvaient pas être vendus. Cette hypothèse mérite toutefois d'être proposée, surtout que la taille intervient certainement comme un critère sélectif pour l'huître plate (cf. supra), qui est l'autre espèce largement commercialisée à l'époque romaine.

Ces manipulations de nettoyage et de calibrage décrivent l'activité de mareyeurs, définis aujourd'hui par le Ministère français de l'Agriculture comme «les premiers acheteurs des produits de la pêche maritime en vue de leur commercialisation pour la consommation humaine ${ }^{25}$. À ce jour, aucun indice conchyliologique ou découverte archéologique ne plaide en revanche pour le commerce d'animaux «cultivés », comme le permet aujourd'hui l'ostréiculture en incluant la maîtrise de la reproduction et de la croissance du mollusque ${ }^{26}$. Toutefois, il est certain que les Romains ont cherché à améliorer les qualités gustatives des huîtres pêchées sur les bancs naturels. Leur intervention sur les animaux pourrait s'apparenter à l'affinage moderne auquel les sources iconographiques ${ }^{27}$ et les références textuelles connues $^{28}$ font probablement référence lorsqu'elles évoquent des structures appelées ostriaria, ostrearum vivaria ou $\kappa \alpha \tau \alpha \beta \delta^{\prime} \lambda \mathrm{ol}^{29}$. Il y avait de toute évidence une finalité économique dans cette activité qui, selon Pline l'Ancien, fut développée par Sergius Orata. Il raconte en effet qu'il fut «le tout premier à créer des ostrearum vivaria dans sa propriété de Baies, au temps de 1'orateur L. Crassus, avant la guerre des Marses ; la gourmandise n'y fut pour rien, mais la cupidité : il tirait de gros revenus de ces sortes d'inventions (Ostrearum uiuaria primus omnium Sergius Orata inuenit in Baiano aetate L. Crassi oratoris ante Marsicum bellum, nec gulae causa, sed auaritiae, magna uectigalia tali ex ingenio suo percipiens) ${ }^{30}$.

\subsection{Les axes de distribution : commerce de longue distance et commerce régional}

L'huître plate, Ostrea edulis, qui est en tête du commerce de longue distance, est acheminée depuis la façade atlantique et la côte méditerranéenne, avec des zones d'influences commerciales qui se recouvrent plus ou moins largement en fonction des axes de transport

25. http://agriculture.gouv.fr/le-mareyage-articles-35-36-58

26. Bardot-Cambot 2013 ; Bardot-Cambot 2013a.

27. Kolendo 1976 ; Guérin-Beauvois 1997.

28. Pline l'Ancien, H.N., 9.168; Oribase, Des aliments, 2.58.95. ; Sidoine Apollinaire, Lettres, 8.12.

29. Bardot-Cambot 2013 ; Bardot-Cambot 2013a.

30. Pline l'Ancien, Histoire naturelle, 9.168. 


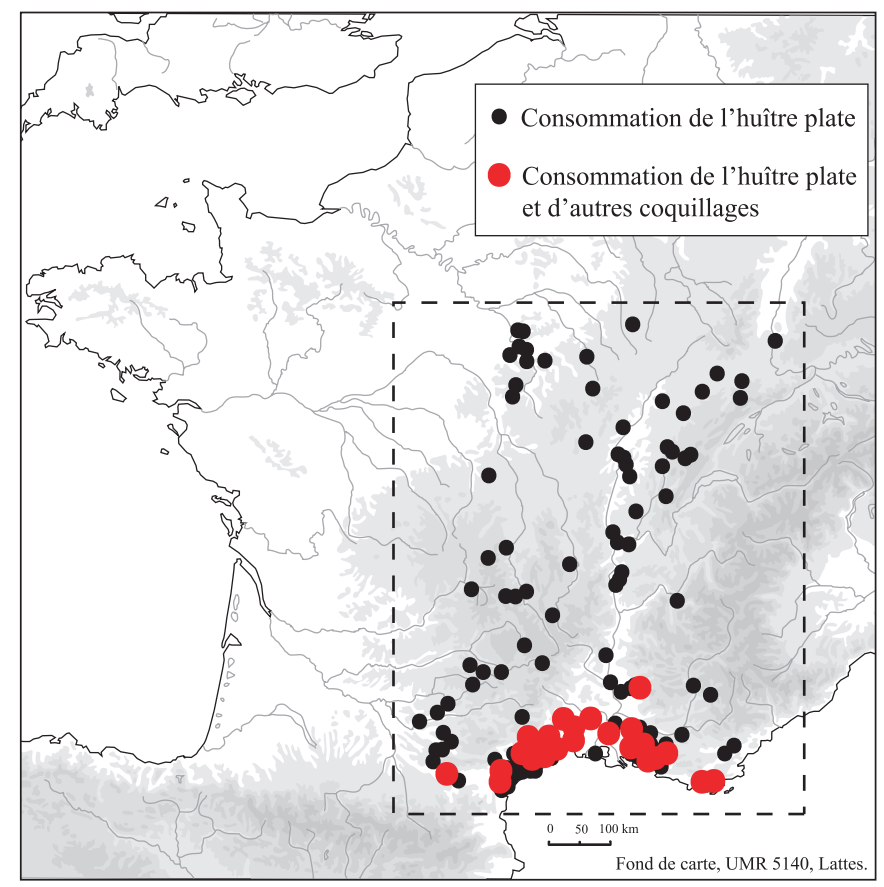

Fig. 4. Variété des coquillages commercialisés en fonction de la distance entre les sites de consommation et la mer. Carte : A. Bardot-Cambot.

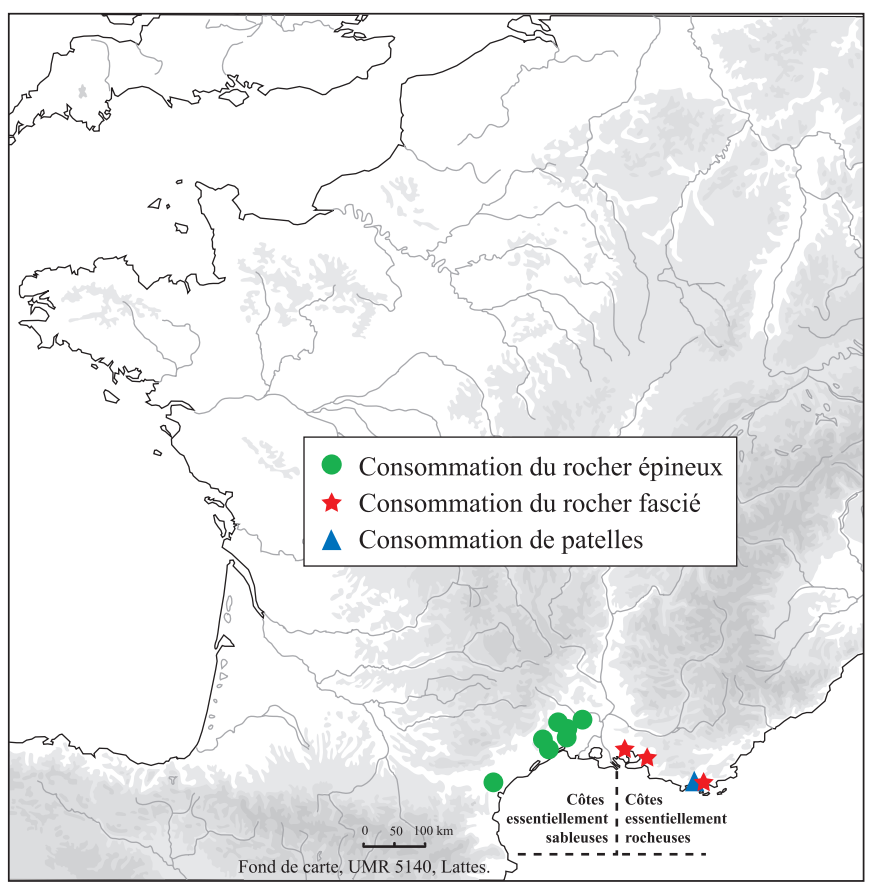

Fig. 6. Sites de consommation du rocher épineux, Bolinus brandaris, du rocher fascié, Hexaplex trunculus, et de patelles, Patella sp. Carte : A. Bardot-Cambot.

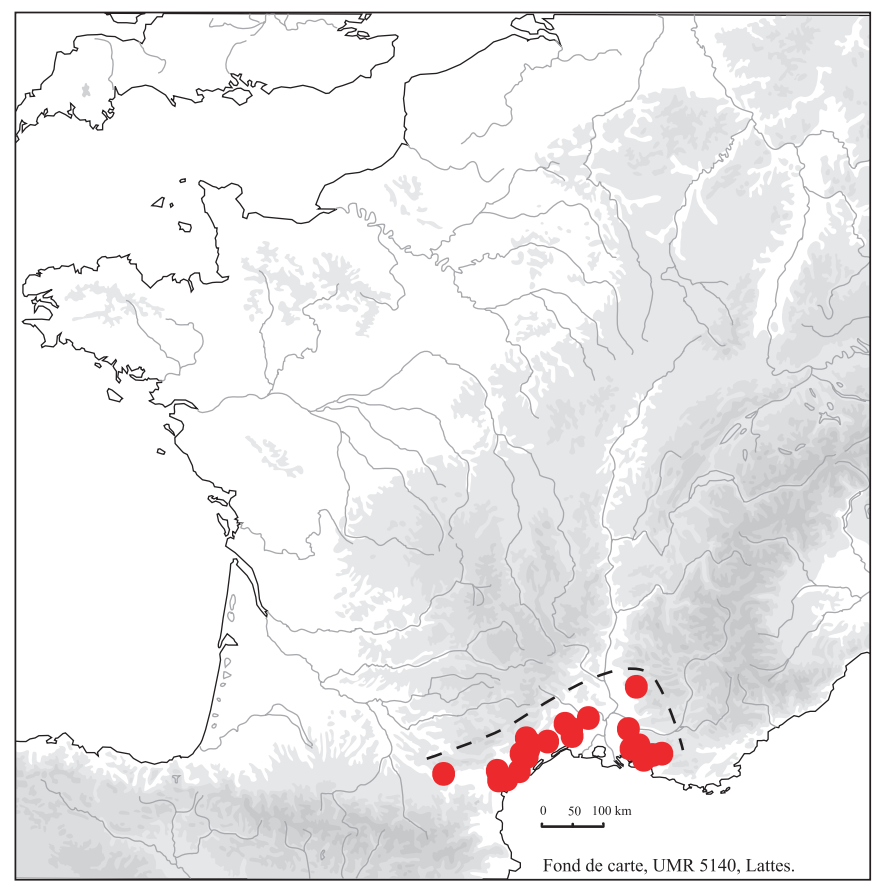

Fig. 5. Sites de consommation du peigne glabre, Proteopecten glaber. Carte : A. Bardot-Cambot.

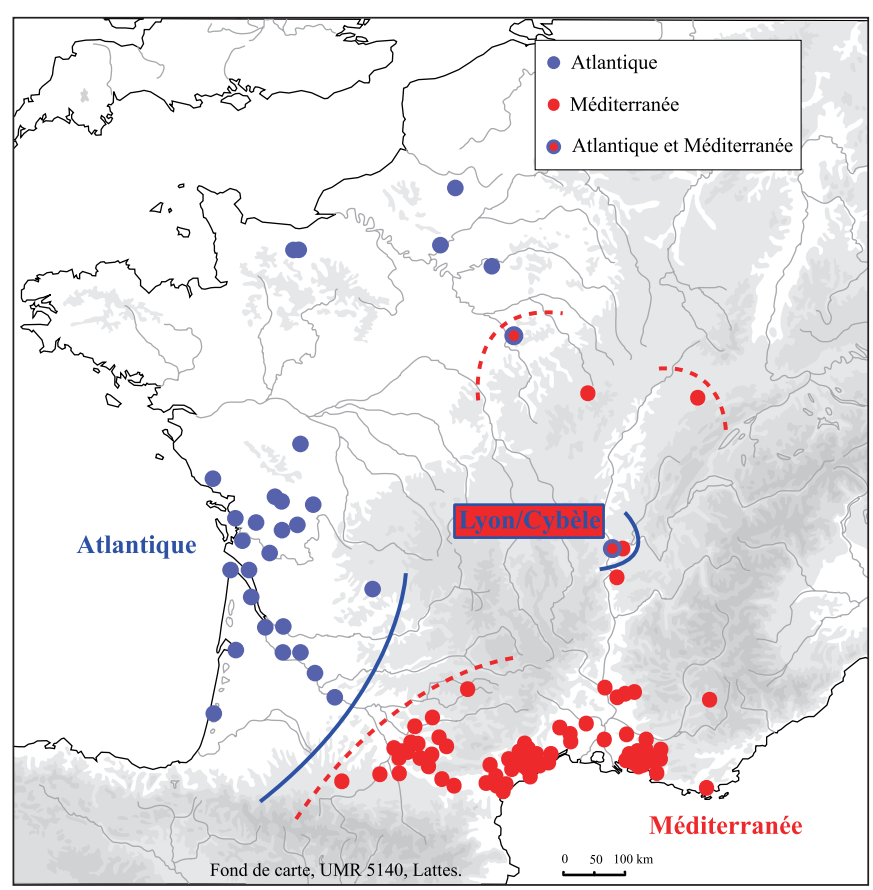

Fig. 7. Distribution géographique des assemblages d'huître plate d'Europe, Ostrea edulis, en fonction de leur origine atlantique ou méditerranéenne. Carte : A. Bardot-Cambot. 
empruntés. La limite est très nette dans le bassin aquitain, où s'affrontent clairement les aires de répartition des assemblages de type atlantique et de type méditerranéen. Au contraire, il est peut-être encore trop tôt pour aborder l'axe séquano-rhodanien où les premiers résultats montrent une interpénétration des deux grandes façades ${ }^{31}$. Rappelons qu'elles se côtoieraient sur le même site de Lyon/Cybèle ${ }^{32}$ (fig. 7). L'origine des huîtres est donnée par une somme d'indices conchyliologiques, dont le plus fiable est l'identification d'espèces accompagnatrices inféodées à un des deux grands domaines marins. Les coquilles de ces espèces ont pu servir de support de fixation aux jeunes huîtres ; elles apparaissent alors fixées au talon des valves gauches. Elles peuvent aussi correspondre à des intrus accidentels dans des lots d'huîtres insuffisamment triés. Par ailleurs, la forme des coquilles d'huîtres ressemblent parfois à une série connue sur l'une des deux façades maritimes. La taille des empreintes musculaires pourrait enfin varier en fonction du lieu où les animaux ont grandi ; elles seraient moins développées chez les spécimens méditerranéens que chez les spécimens atlantiques ${ }^{33}$.

À l'échelle régionale, les coquillages apparaissent comme un produit bien intégré dans les réseaux d'échanges, puisque des conchyliorestes se rencontrent non seulement sur des sites urbains, chefs lieux de cité et autres grandes agglomérations, mais aussi sur des sites ruraux, notamment des villae et d'autres types d'établissements souvent plus petits et dont la nature n'est pas toujours précisément fixée. En Languedoc, une partition du commerce local pourrait expliquer la singularité de certains sites. Les sites nîmois et de l'est du département de l'Hérault se distinguent des sites de la moyenne vallée de l'Hérault et de l'Aude centrale par une consommation abondante du rocher épineux, Bolinus brandaris, et du flion tronqué, Donax trunculus. Cette divergence entre les deux régions serait liée à des approvisionnements différents depuis des environnements où les deux espèces ne présenteraient pas les mêmes disponibilités. D'un côté, le Golfe d'Aigues-Mortes, qui abrite encore aujourd'hui des gisements de rocher épineux et de flion tronqué, aurait alimenté les sites nîmois et de l'est héraultais, d'un autre côté, le bassin de Thau aurait fourni les sites de l'Aude centrale et de la moyenne vallée de l'Hérault en suivant l'axe du fleuve ${ }^{34}$. Sur la façade atlantique aussi, la comparaison des assemblages

31. Bardot 2008 ; Bardot 2010.

32. cf. note 15 .

33. Bardot-Cambot 2013. Pour l'instant, nous n'avons pas trouvé d'explication satisfaisante à cette variation.

34. Bardot-Cambot à paraître ; Barberan 2012. du site de Barzan/Le Fâ ${ }^{35}$ sur la rive droite de l'estuaire de la Gironde et de plusieurs sites bordelais ${ }^{36}$ nous fait supposer des circuits commerciaux différents. Le Bassin d'Arcachon serait ainsi au départ d'un axe qui alimente Bordeaux, tandis qu'aucun lien conchyliologique n'a pour l'instant été établi avec l'estuaire de la Gironde ; ce dernier desservirait davantage les régions localisées sur sa rive droite ${ }^{37}$.

\subsection{Le transport}

Le transport des coquillages « en coquille », et celui des huîtres en particulier, a intéressé, voire intrigué, des générations d'archéologues et d'historiens. Nous savons désormais que le voyage des huîtres et leur mise en entrepôt sur les lieux de consommation se font dans des conditions de conservation sans doute moins complexes que celles qui ont été parfois imaginées. Des précautions de température et de conditionnement étaient certainement obligatoires, sans qu'il faille supposer l'utilisation de viviers pour lesquels nous n'avons trouvé ni argument sanitaire (plutôt des contre-indications) ni témoignages ethnographiques récents qui pourraient justifier de leur existence dans l'Antiquité. Cette théorie des viviers s'appuie sur une documentation ancienne, du XIX ${ }^{\mathrm{e}}$ s., sur laquelle nous sommes retournée ${ }^{38}$. Nulle part, il n'est décrit de bassin. De plus, l'interprétation de ces structures archéologiques s'appuie toujours sur la présence de coquilles qui n'ont jamais fait l'objet d'un examen attentif, au préalable de l'interprétation de viviers. Elle retient ainsi la découverte d'exemplaires entiers et fermés comme preuve que des huîtres vivantes y ont été déposées. Ce raccourci interprétatif est remis en cause par les études archéoconchyliologiques actuelles qui montrent que des coquilles retrouvées avec leurs deux valves jointes n'appartiennent pas obligatoirement à des animaux vivants au moment de leur abandon : la présence de marques d'ouverture sur la face interne des valves indique que la chair des huîtres a été extraite avant le rejet des coquilles entières ${ }^{39}$.

Nous ne connaissons rien des personnes en charge du transport des coquillages dans l'Antiquité, hormis le caractère probablement saisonnier de leur activité. Un des plus anciens témoignages de ce métier remonte à 1350. Une ordonnance rendue par le roi de France Jean II évoque des marchands forains appelés « chasse-marées ».

35. Bardot-Cambot 2011.

36. Bardot 2006 ; Bardot 2009b.

37. Bardot-Cambot 2013.

38. Id.

39. Gruet (inédit a) ; Forest 2003 ; Bardot-Cambot 2011. 
Ce nom désigne les voituriers qui achètent "la marée" aux pêcheurs, c'est-à-dire les produits de la mer, puis qui la portent dans les villes de l'intérieur des terres où ils la vendent. C'est peut-être Delamare qui nous permet finalement d'approcher d'un peu plus près les différents acteurs du commerce des coquillages «en coquille » à l'époque romaine. Il raconte qu'au début du XVIII ${ }^{e}$ s., les huîtres sont «achetées des pêcheurs par ceux qui s'attachent particulièrement à ce commerce. Ceux-ci les font venir à Paris par la rivière en bateau, ou par terre en charrettes, en fourgons, ou à la somme ; le détail s'en fait ensuite par des particuliers qui les crient dans les rues, les débitent dans les maisons où ils sont appelés, les ouvrent, et les détachent des écailles en les livrant ${ }^{40}$.

\section{La chair décoquillée}

\subsection{Données archéologiques et indices conchyliologiques}

L'huître plate, Ostrea edulis, est l'espèce qui fournit actuellement les indices les plus solides en faveur d'un commerce de chair décoquillée de Mollusque, en parallèle de celui d'animaux vivants « en coquille ». Ce mode de commercialisation nous est peu familier aujourd'hui - on ne le connaît plus en France de nos jours - mais il fut très en vogue du Moyen Âge au début du XIX ${ }^{\mathrm{e}}$ s. (fig. 8). Sur la façade atlantique, il reste encore plusieurs témoignages archéologiques du décoquillage d'huîtres, sous la forme d'amas de coquilles, produits au fil du temps par les opérateurs en charge de l'extraction de la chair.

Le site vendéen de Chauds près de Saint-Michel-enl'Herm est l'exemple le plus connu pour le Moyen Âge. Il montrait encore au début du $\mathrm{XX}^{\mathrm{e}} \mathrm{s}$. trois buttes, dont la longueur cumulée atteignait $800 \mathrm{~m}$; leur volume est estimé entre 200000 et $600000 \mathrm{~m}^{3}$, soit plusieurs milliards de coquilles. Il ne reste aujourd'hui de ces énormes amas que quelques vestiges suite à leur exploitation industrielle jusque dans les années 1970 pour l'amendement des sols et la fabrication de chaux ${ }^{41}$. D'autres amas, qui seraient également médiévaux, ont été repérés à Bourgneuf-en-Retz en Loire-Atlantique ${ }^{42}$ et à Beauvoir-sur-Mer en Vendée où les coquilles s'étendent sur plusieurs centaines de mètres de long, $30 \mathrm{~m}$ de

40. Delamare 1719, p. 124.

41. Décrites dès 1572 par H. Lancelot Voysin de La Popelinière (cité dans Godard 1995, p. 193 et Verger 2009, p. 98), les buttes de Chauds ont donné lieu à une bibliographie extrêmement abondante, dont G. Godard a fait la synthèse en 1995 (Godard 1995).

42. Gruet (inédit b) ; Tessier 1994 ; Verger 2005 ; Verger 2009. large et jusqu'à $2 \mathrm{~m}$ de haut ${ }^{43}$. Plus tard, au XVI ${ }^{\mathrm{e}} \mathrm{s}$., Durègne de Launaguet indique qu' " une véritable montagne d'écailles » s'était formée à La Teste, en bordure du Bassin d'Arcachon ${ }^{44}$. Enfin, au début du XIX ${ }^{\mathrm{e}}$ s., l'abondance des huîtres décoquillées à Granville dans la Manche était telle que leurs coquilles formaient devant le port un imposant dépôt, appelé « le talard », de 2 à $3 \mathrm{~m}$ de haut sur $300 \mathrm{~m}$ de long et presque autant de large ${ }^{45}$. Les observateurs qui se sont rendu sur ces sites précisent à chaque fois que les coquilles appartiennent pour l'immense majorité à l'huître plate. Ils sont aussi frappés par la présence de très nombreuses coquilles entières et fermées. À Saint-Michel-en-l'Herm et à Beauvoir-surMer, des études réalisées par Y. Gruet ${ }^{46}$ et C. Dupont ${ }^{47}$ ont permis de repérer des traces de couteau sur la face interne des valves indiquant que la chair était extraite en entrouvrant simplement les valves. Les coquilles, avec leurs valves encore réunies, étaient ensuite rejetées telles quelles.

Nous avons cherché pour l'époque romaine des amas qui pourraient rappeler ceux décrits précédemment, et témoigner ainsi de la commercialisation de la chair décoquillée. Notre attention s'est portée sur le site de Barzan/ Le Fâ ${ }^{48}$. Ces dix dernières années, les archéologues y ont exhumé de très nombreux restes d'huîtres attribués à Ostrea edulis, l'huître plate d'Europe ${ }^{49}$. Ces coquilles se présentaient souvent comme des exemplaires entiers et fermés. Elles ont été ramassées en l'état par les fouilleurs. Et lorsqu' au moment de la fouille les valves ont été séparées, un indice, mis en évidence par V. Forest ${ }^{50}$, nous a permis de reformer des paires et de retrouver les coquilles entières. En effet, les valves appariées et jointes au moment de leur dépôt dans l'antiquité développent au fil du temps une concrétion sur leur face interne. Elle se reconnaît facilement à sa couleur jaunâtre. Comme sur les valves médiévales de Saint-Michel-en-l'Herm et de Beauvoir-sur-Mer, nous avons repéré des séries de marques sur la face interne des valves; elles témoignent de l'ouverture des coquilles et de l'extraction de la chair entre les valves simplement entrouvertes.

Il n'existe pas à Barzan/Le Fâ d'énormes buttes de coquilles comme celles qui se sont formées sur les sites plus récents que nous avons cités. En revanche, deux couches de coquilles d'huîtres, datées de la première

43. Verger 2009 ; Dupont 2010.

44. Durègne de Launaguet 1929 cité dans Verger 2009, p. 101.

45. De la Morandière 1958, cité dans Verger 2009, p. 101-102.

46. Gruet 1986.

47. Dupont 2010.

48. Bardot-Cambot 2011 ; Bardot-Cambot 2013

49. Forest 2003 ; Bardot-Cambot 2011.

50. Forest 2003. 
moitié du II e s. ap. J.-C., nous ont interpellé à cause de leur épaisseur et de leur étendue. L'une, dégagée seulement en partie par un décapage, couvrait déjà une surface de $230 \mathrm{~m}^{2}$ pour une épaisseur variant de 20 à $40 \mathrm{~cm}^{51}$. L'autre a été repérée sur plus de $1000 \mathrm{~m}^{2}$, sans que ses limites n'aient été atteintes ${ }^{52}$. Son épaisseur est variable, de 10 à $20 \mathrm{~cm}$ et jusqu'à $30 \mathrm{~cm}$ (fig. 9). Si nous retenons une épaisseur moyenne de $30 \mathrm{~cm}$ pour la première couche et de $15 \mathrm{~cm}$ pour la seconde, le volume de coquilles abandonnées pourrait largement dépasser $200 \mathrm{~m}^{3}$ sachant que les deux couches se poursuivent au-delà des zones fouillées. D'après les prélèvements que nous avons pu faire, nous estimons que 10000 coquilles équivalent à un volume d'environ $1 \mathrm{~m}^{3}$, ce qui signifie qu'au moins deux millions de coquilles ont été rejetées à Barzan dans la première moitié du $\mathrm{II}^{\mathrm{e}}$ s. ap. J.-C. Sans atteindre les milliards de coquilles des buttes médiévales de Saint-Michel-en-l'Herm, ce chiffre nous semble suffisamment grand pour envisager que les coquilles soient issues d'une activité similaire de décoquillage ${ }^{53}$.

Une autre observation conduit à la même conclusion. La formation des deux couches barzanaises diffère de celles des amas de coquilles évoqués pour le Moyen Âge et les temps modernes. Les buttes de Saint-Michelen-l'Herm, par exemple, sont vraisemblablement des dépotoirs primaires, c'est-à-dire que leur composition n'a pas vu d'autre étape que le rejet des coquilles après la récupération de la chair. Les couches découvertes à Barzan témoignent quant à elles d'une ultime utilisation des coquilles : l'une pourrait correspondre à l'aménagement de la surface d'un espace extérieur ${ }^{54}$, l'autre sert de couche préparatoire à l'installation d'un niveau de rue $^{55}$ (fig. 9). Pour réaliser ces travaux, les constructeurs ont donc dû puiser dans un ou plusieurs tas de déchets existants. Or il est peu probable qu'une consommation régulière, même sur plusieurs mois, ait pu rendre disponible autant de coquilles. En effet, sur la base d'une consommation hebdomadaire de 80 personnes mangeant chacune 12 huîtres, il aurait fallu 40 ans pour produire une telle quantité de déchets. Au contraire, des centaines d'huîtres pouvaient être quotidiennement décoquillées et ainsi rapidement former de volumineux amas de coquilles dans lesquels les constructeurs pouvaient ensuite s'approvisionner.

\subsection{Préparation et conditionnement de la chair}

Le mode de préparation le plus simple pour la chair décoquillée était de la laisser telle quelle, en enlevant seulement les bris des coquilles qui auraient pu s'y mêler au moment de l'ouverture. Les pratiques actuelles rendent difficilement concevable cette solution. Pourtant, plusieurs auteurs l'attestent, au moins depuis le milieu du $\mathrm{XVI}^{\mathrm{e}}$ s. Elle permettait d'alléger le chargement tout en multipliant les quantités transportées. En 1555, Belon du Mans écrit que «Les Oestres qu'on apporte vers Paris, venants de l'Océan, sont grandes. Les paysans sont coutumiers de les ouvrir sur le bord de la mer, et envoient seulement la chair de dedans, afin de ne trop charger les chevaux des écailles ${ }^{\mathbf{5}}$. Des sacs de toile sont alors employés pour contenir la chair, par exemple à La Teste, au bord du Bassin d'Arcachon : selon Durègne de Launaguet, les pêcheurs d'huîtres, une fois revenus au port, « triaient les plus faciles à transporter et mettaient dans des sacs de toile la chair des mollusques lorsque les coquilles étaient trop pesantes ${ }^{57}$. Au XVII ${ }^{\mathrm{e}}$ s., la chair décoquillée est aussi acheminée dans des paniers de paille, ce qui surprend l'anglais Lister en voyage à Paris en 1698 : « On a une manière d'apporter les huîtres fraîches à Paris dont nous n'usons jamais, que je sache. C'est de les tirer de l'écaille, d'en jeter l'eau et de les mettre dans des paniers de paille: elles arrivent ainsi bonnes à être mises en étuvées et à être employées à d'autres goûts ${ }^{58}$. Cette pratique perdure au XVIII ${ }^{\mathrm{e}}$ s. ; les huîtres sont alors appelées «huîtres au panier » ${ }^{59}$ ou huîtres « huîtrées ${ }^{60}$. Si nous pouvons envisager l'exportation d'huîtres « huîtrées » à l'époque romaine, leur commerce devait se limiter aux régions côtières, car elles n'auraient pas supporté un grand voyage. D'ailleurs, les auteurs modernes précités ne décrivent pas un transport sur de très longues distances : jusqu'à Paris à quelques $200 \mathrm{~km}$ de la côte la plus proche et jusqu'à Bordeaux à $70 \mathrm{~km}$ de La Teste sur le Bassin d'Arcachon.

Pour être gardée plus longtemps, la chair nécessitait un traitement conservateur. Elle était peut-être salée au sel sec, comme il se faisait au milieu du XVII ${ }^{e}$ s. : "[les huîtres] que l'on confit pour garder, au sortir de leur écaille, seront mises par lits dans un pot de terre ou baril, et par dessus chaque lit on les poudrera de sel et d'un peu de poivre, quelques feuilles de laurier, de
51. Bouet 2003.

52. Bardot 2007 ; Tranoy 2008.

53. Bardot-Cambot 2011.

54. Bouet 2003.

55. Tranoy 2008.
56. Belon du Mans 1555, p. 417.

57. Durègne de Launaguet 1929 cité dans Verger 2009, p. 101.

58. Société des bibliophiles françois 1873, p. 143.

59. Menon 1746, éd. 1815, p. 185-186.

60. Delamare 1719, p. 124. 


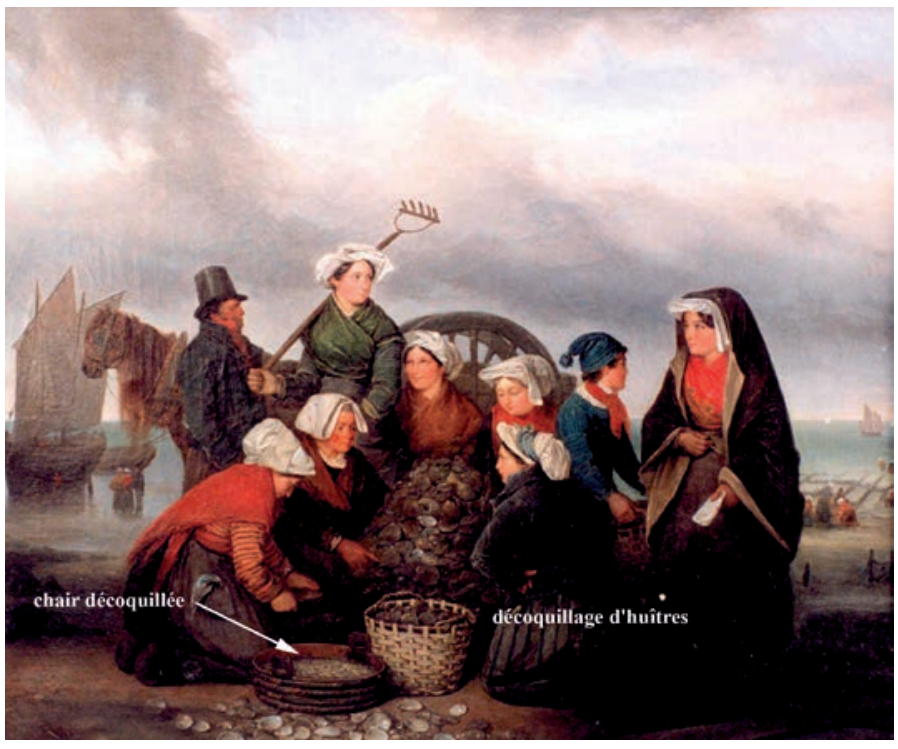

Fig. 8. Les Trieuses d'huîtres, par O. Guet, 1827. (Huile sur toile, Musée du Vieux Granville). Cliché Musée du Vieux Granville.

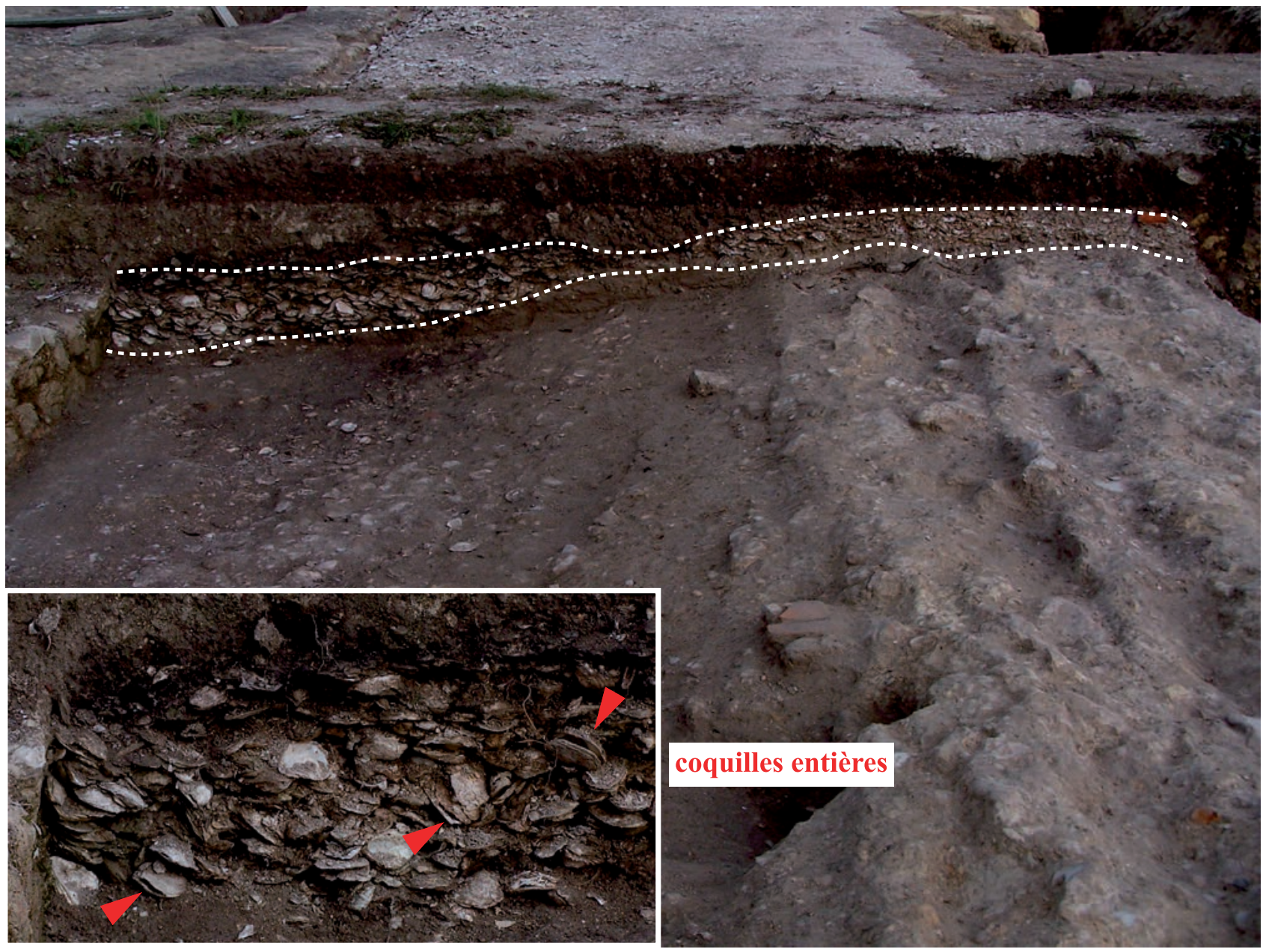

Fig. 9. Barzan/Le Fâ (Charente-Maritime), épandage de coquilles d'huître plate d'Europe, Ostrea edulis, dégagé sous le tracé d'une voie (début du IIe s. ap. J.-C.). Clichés L. Tranoy/E. Moizan. 
la cannelle en bâton, et du fenouil vert en graine ${ }^{\mathbf{6}}{ }^{1}$. Une autre préparation consistait peut-être à cuire la chair dans une saumure. Jusqu'au début du $\mathrm{XIX}^{\mathrm{e}}$ s., « les huîtres sont ainsi envoyées dans des lieux fort éloignés de la mer, empilées les unes sur les autres, sans coquilles, et dans des petits barils ${ }^{62}$. Selon un mémoire anonyme daté de 1795 , «On doit préparer une espèce de bonne eau ou court bouillon dans lequel il ne doit entrer que ce qu'il faut d'eau pour fondre le sel avant que [les huîtres] sentent la chaleur. Cela se reconnaît à la blancheur qu'elles contractent ». Puis les huîtres sont laissées à refroidir dans le mélange. Enfin, elles sont mises dans «de petits barils dans lesquels on introduit un peu de saumure et de vinaigre blanc ${ }^{63}$. Elles sont alors « des hors-d'œuvres dignes des meilleurs tables », où elles arrivent dans « des petits tonnelets ${ }^{64}$ ou dans des «vases pouvant fermer hermétiquement ${ }^{65}$. Cette solution de conservation pourrait avoir une origine plus ancienne. Elle rappelle en effet les conseils d'Apicius pour faire durer les ostreae pendant longtemps (Ostrea ut diu durent) : « lavez-les au vinaigre ou bien lavez au vinaigre un vase poissé où vous les placerez (Lauas $a b$ aceto, aut ex aceto uasculum pictum laua, et ostrea compone) » ${ }^{66}$. L'état des coquillages ainsi conservés n'est pas précisé, cependant il s'agit probablement de chair décoquillée, sinon on comprendrait mal l'utilisation du vinaigre auquel le calcaire des coquilles ne résisterait pas.

Contrairement aux coquillages «en coquille», dont nous pouvons suivre la distribution grâce aux indices que constituent leurs coquilles, les axes d'exportation de la chair, débarrassée de son enveloppe minérale, ne peuvent être définis par l'archéoconchyliologie, à moins que nous ne réussissions à identifier les contenants qui permettaient son transport. Plusieurs types de conditionnements sont décrits dans les témoignages précités. La chair expédiée fraîche, sans préparation, est mise dans des sacs de toile ou des paniers, tandis que des récipients plus petits sont utilisés pour contenir la chair salée ou cuite dans une saumure : il est fait mention de «petits barils », de «petits tonnelets », de « pots de terre » et de « vases ». Pour l'époque romaine, les sources littéraires que nous avons interrogées restent silencieuses sur l'emploi éventuel de sacs, de paniers et de petits barils. Ces

61. De Bonnefons 1655 , p. 367-368. Une recette similaire se trouve dans La Varenne 1651.

62. Collectif 1821, p. 15.

63. Cité dans De la Morandière 1958, p. 36 et repris dans Rambourg 2007, p. 214

64. Francoeur 1833, p. 60 .

65. Dumont 1877, p. 399-400.

66. Apicius, L'art culinaire, 1.9.2. solutions ne doivent pas pour autant être écartées ; elles seront toutefois difficiles à prouver par l'archéologie, car les matières périssables qui composent ces objets se conservent rarement jusqu'à nous. Apicius mentionne en revanche un récipient poissé en céramique : uasculum pictum (cf. supra). Le texte traduit que nous avons utilisé ${ }^{67}$ ne le fait pas apparaître mais le mot uasculum décrit généralement un petit vase ${ }^{68}:$ uas, uasis, signifiant "vase ou pot" et le suffixe -culum "petit" ". Ces remarques nous permettent d'attirer l'attention des céramologues sur des vases poissés, de petite contenance et pouvant être fermés.

\section{Conclusion}

Le développement des travaux spécialisés sur les conchyliorestes au cours de ces vingt dernières années apporte aujourd'hui un éclairage nouveau sur le commerce des coquillages alimentaires en Gaule romaine. Ainsi, l'étude archéoconchyliologique des restes exhumés sur les sites de consommation ne fait plus apparaître la commercialisation des animaux vivants en « coquille» sous l'angle de la seule découverte qui est le premier indice du transport des coquillages. Par la synthèse des données acquises, nous commençons en effet à mieux apprécier la diversité des aspects que recouvre ce commerce: espèces commercialisées, qualité des produits, acteurs du commerce, axes de distribution, etc. Les coquillages en « coquille » sont acheminés sur des distances plus ou moins grandes, en fonction de leur résistance au transport qui varie selon les espèces. L'huître plate, Ostrea edulis, est la plus largement diffusée, car elle est la seule à supporter de longs voyages. Les autres espèces sont l'objet d'un trafic plus régional, dont la limite vers l'intérieur des terres se situe entre 100 et $200 \mathrm{~km}$ des côtes. Leur distribution est dépendante de plusieurs facteurs. Ils sont biologiques, géologiques et topographiques lorsqu'ils touchent à la disponibilité des ressources dans l'environnement exploité ou humains quand ils abordent l'organisation des espaces commerciaux et le domaine si difficile à saisir des choix, des goûts et des interdits. Mais le commerce des coquillages « coquille » ne s'exprime pas uniquement par la distance à la mer. Chez l'huître plate spécialement, des calibrages très nets associés quelquefois à un nettoyage des lots visant à éliminer les éléments indésirables ont

67. Traduction par J. André, Les Belles Lettres, Paris, 1974.

68. Voir l'emploi de uasculum par Apulée, Métamorphoses, 9.41.3., Quintilien, Institutions oratoires, 1.2.28., 7.10.9. et Caton, De l'agriculture, 111.

69. Glare 1996. 
été mis en évidence. Ces gestes traduisent une activité de mareyage, à partir d'animaux pêchés sur les gisements naturels. Certaines huîtres ont pu subir un affinage, à défaut d'un élevage qui n'est pas prouvé à ce jour, ni par l'archéologie, ni par l'archéoconchyliologie.

L'étude des conchyliorestes, par la comparaison de découvertes antiques et d'autres témoignages archéologiques plus récents, nous fait en outre envisager le commerce d'un autre type de produit, qui est la chair décoquillée, en particulier celle de l'huître plate. Simultanément, le recours aux écrits médiévaux et modernes nous permet de saisir des pratiques a priori encore peu modifiées par les nouvelles connaissances scientifiques et leurs applications techniques, autrement dit, dont les limites de mise en œuvre sont les mêmes que celles des populations romaines. À partir de cette documentation, nous proposons donc deux solutions de transport pour la chair décoquillée dans l'Antiquité. La première impliquait un acheminement rapide, puisque la chair était laissée telle quelle. La seconde permettait un commerce plus lointain, grâce à une préparation conservatrice, soit au sel sec, soit par une cuisson en saumure. Les contenants utilisés pour conditionner la chair sont encore à découvrir, avec la piste céramique comme perspective immédiate de recherche.

\section{Bibliographie}

Barberan et $\boldsymbol{a}$ l. 2012 : BARBERAN (S.), BARDOT-CAMBOT (A.), GAFÀ (R.), LEMAIRE (B.), MALIGNAS (A.), RAUX (S.), RENAUD (A.), SILVÉRÉANO (S.) - Boire et manger sur le forum du Castellas (Murviel-lèsMontpellier, Hérault) : un dépotoir atypique daté de la première moitié du II ${ }^{\mathrm{e}}$ s. ap. J.-C., Revue archéologique de Narbonnaise, 45, 2012, p. 293-360.

Bardot (inédit) : BARDOT (A.) - Étude archéoconchyliologique. Le site de Cybèle/Lyon (Rhône), rapport dactylographié, inédit.

Bardot 2006 : BARDOT (A.) - Une question de goût : l'exploitation des coquillages marins à Bordeaux au début de la romanisation, Aquitania, 22, 2006, p. 55-73.

Bardot 2007 : BARDOT (A.) - Étude archéoconchyliologique, In : Tranoy (L.), Moizan (E.) (éd.), La Grande Avenue, Barzan (CharenteMaritime), Rapport de fouilles programmées, S.R.A. Poitou-Charentes, Poitiers, 2007, p. 123-131.

Bardot 2008 : BARDOT (A.), FOREST (V.), MACHEBOEUF (C.) - Les coquillages. In : Sanchez (C.) (dir.), La Voie de Rome. Entre Méditerranée et Atlantique, Catalogue d'exposition, Bordeaux, Archéopôle d'Aquitaine, 23 octobre 2008 - 30 mars 2009, Bordeaux, 2008, p. 73-76.

Bardot 2009a : BARDOT (A.), FOREST (V.) - L'exploitation des coquillages marins en Bas-Languedoc durant la période romaine, The territory and its resources, Studies on the rural world in the roman period, 4, 2009, p. 45-60.

Bardot 2009b : BARDOT (A.) - Étude archéoconchyliologique. In : Chuniaud (K.) (dir.), Aquitaine, Bordeaux, Auditorium. Un quartier urbain antique, Rapport final d'opération, I.N.R.A.P. Grand Sud-Ouest, S.R.A. Aquitaine, Bordeaux, 2009, p. 25-46.

Bardot 2010 : BARDOT (A.) - Les coquillages en Gaule romaine, entre Méditerranée et Rhin. Approche socio-économique et socio-culturelle, Thèse de doctorat, Université de Bordeaux 3, Bordeaux, 2010.

Bardot 2012 : BARDOT (A.) - Zones maritimes exploitées durant la période romaine : résonance conchyliologique pour les populations littorales. In : Ropiot (V.), Puig (C.), Mazière (F.), Les plaines littorales en Méditerranée nord-occidentale. Regards croisés d'histoire, d'archéologie et de géographie de la Protohistoire au Moyen Âge, Monique Mergoil, Montagnac, 2012, p. 141-158.
Bardot-Cambot 2011 : BARDOT-CAMBOT (A.) avec la collaboration de FOREST (V.) - Les coquillages marins. Consommation, commercialisation et gestion des déchets. In : Bouet (A.) (dir.), Un secteur d'habitat dans le quartier du sanctuaire du Moulin du Fâ à Barzan (Charente-Maritime), Éditions de la Fédération Aquitania, Supplément 27, Ausonius, Mémoires 26, Bordeaux, 2011, p. 895-930.

Bardot-Cambot 2013 : BARDOT-CAMBOT (A.) - Les coquillages marins en Gaule romaine. Approche socio-économique et socio-culturelle, BAR International Series 2481, Archaeopress, Oxford, 2013.

Bardot-Cambot 2013a: BARDOT-CAMBOT (A.), FOREST (V.) Ostréiculture et mytiliculture à l'époque romaine ? Des définitions modernes à l'épreuve de l'archéologie, Revue archéologique, 2013/2, p. 367-388.

Bardot-Cambot à paraître : BARDOT-CAMBOT (A.), FOREST (V.) Coquillages et coquilles du site de Villevieille. In : Houix (B.), Monteil (M.), Raynaud (Cl.) (dir.), L'agglomération antique de Villevieille (Gard) et son territoire, à paraître.

Belon du Mans 1555 : Belon du Mans (P.) - La nature \& diversité des poissons, Paris, 1555.

Bouet 2003 : BOUET (A.) (dir.) - Thermae Gallicae, Les thermes de Barzan (Charente-Maritime) et les thermes des provinces gauloises, Éditions de la Fédération Aquitania, Supplément 11, Ausonius, Mémoires 10, Bordeaux, 2003.

Brien-Poitevin 1990 : BRIEN-POITEVIN (Fr.) - Étude conchyliologique. In : Raynaud (Cl.), Le village gallo-romain et médiéval de Lunel-Viel. Les fouilles du quartier ouest, Paris, 1990, p. 309-314. (Annales Littéraires de l’Université de Besançon, 422)

Brien-Poitevin 1996a: BRIEN-POITEVIN (Fr.) - Consommation des coquillages marins en Provence à l'époque romaine. In : Gateau (F.) avec la collaboration de Trément (F.) et Verdin (F.), Carte archéologique de la Gaule, L'Etang de Berre (13/1), Paris, 1996, p. 137-142.

Brien-Poitevin 1996b : BRIEN-POITEVIN (Fr.) - Consommation des coquillages marins en Provence à l'époque romaine, Revue Archéologique de Narbonnaise, 29, 1996, p. 313-320.

Collectif 1821 : Dictionnaire des sciences naturelles, tome 22, Paris, 1821. 
Comité historique des arts et monuments 1844-1845 : Comité historique des arts et monuments, Bulletin archéologique, troisième volume, Paris, 1844-1845.

De Bonnefons 1655 : DE BONNEFONS (N.) - Les délices de la campagne, Amsterdam, 1655.

Delamare 1719 : DELAMARE (N.) - Traité de la police, tome 3, Paris, 1719.

De la Morandière 1958 : DE LA MORANDIÈRE (Ch.) - Grandeur et décadence de la pêche des huîtres dans la région granvillaise - XIXe siècle, Études normandes, $2^{\text {ème }}$ trimestre 1958, Rouen, 1958, p. 85-111.

Dumont 1877 : DUMONT (E.) - La bonne cuisine française, Paris, 1877.

Dupont 2010 : DUPONT (C.) - A large-scale exploitation of oysters during the Middle Ages at Beauvoir-sur-Mer (France). In : Carvajal Contreras (D.R.), Alvarez Fernandez (E.) (éd.), Not only food: Marine, Terrestrial and Freshwater molluscs in Archaeological sites, Proceedings of the 2nd ICAZ Archaeomalacology Working group (Santander, 2008), Munibe, Supplément 31, 2010, p. 188-198.

Durègne de Launaguet 1929 : DURÈGNE DE LAUNAGUET - Un touriste au XVI ${ }^{e}$ s., Revue philomatique de Bordeaux et du Sud-Ouest, 2, 1929, p. 73-85.

Forest (inédit) : FOREST (V.) - Étude archéoconchyliologique. Camp Redoun - Lespignan (Hérault) (périodes néolithique vérazienne et ultérieures), Rapport dactylographié, inédit.

Forest 1999 : FOREST (V.) - Étude conchyliologique des Mollusques marins de la Nécropole des Clapiès à Villeneuve-lès-Béziers (Hérault). In : Manniez (Y.), Les pratiques funéraires en Narbonnaise méditerranéenne (partie occidentale) du III e au VIII ${ }^{e}$ s., Thèse de Doctorat, Université de Provence, Aix-en-Provence, 1999, p. 129-135.

Forest 2003 : FOREST (V.) avec la collaboration de Bardot (A.) - Étude conchyliologique. In: Bouet (A.) (dir.), Thermae Gallicae, Les thermes de Barzan (Charente-Maritime) et les thermes des provinces gauloises, Éditions de la Fédération Aquitania, Supplément 11, Ausonius, Mémoires 10, Bordeaux, 2003, p. 478-502.

Forest 2010 : FOREST (V.), BARDOT (A.) - Les conchyliorestes de Port-laNautique. Narbonne, Aude. In : Sanchez (C.) (dir.), Sondages archéologiques à Port-la-Nautique (Narbonne, Aude), Rapport de sondages, volume $4 \mathrm{du}$ PCR "Les ports antiques de Narbonne", S.R.A. Languedoc-Roussillon, Montpellier, 2010, p. 87-101.

Francoeur 1833 : FRANCOEUR (L.B.) - Éléments de technologie ou description des procédés des arts et de l'économie domestique, Paris, 1833.

Glare 1996 : GLARE (P.G.W.) - Oxford latin dictionnary, Oxford, 1996.

Godard 1995 : GODARD (G.) - Les buttes de coquilles d'huîtres de SaintMichel-en-l'Herm. L'histoire d'une énigme, Recherches vendéennes, 2, 1995, p. 193-229.

Gruet (inédit a) : GRUET (Y.) - Malacofaune marine du site de la Bibliothèque multimédia à Limoges, Rapport dactylographié, inédit.

Gruet (inédit b) : GRUET (Y.), PRIGENT (D.) - Les amas coquilliers de Bourgneuf-en-Retz (sondages, étude des coquilles, plans et coupes). Un site à sel, Rapport dactylographié, inédit.

Gruet 1986 : GRUET (Y.), PRIGENT (D.) - Les buttes de Saint-Michel-enl'Herm (Vendée) : caractères de la population d'huîtres (Ostrea edulis, Linné) et de sa faune associée, Haliotis, 15, 1986, p. 3-16.
Guérin-Beauvois 1997 : GUÉRIN-BEAUVOIS (M.) - Montes suspensi testudinibus marmoreis : à propos de la représentation d'une coupole de Baïes, Mélanges de l'Ecole française de Rome, 109/2, 1997, p. 691-740.

Kolendo 1976 : KOLENDO (J.) - Parcs à huîtres et viviers sur un flacon en verre du Musée National de Varsovie, Travaux du Centre d'Archéologie Méditerranéenne de l'Académie Polonaise des Sciences, 18, Études et Travaux, IX, 1976, p. 143-158.

La Varenne 1651 : LA VARENNE - Le cuisinier françois, Paris, 1651.

Le Masson du Parc 1727, éd. 2004 : LE MASSON DU PARC (Fr.) - Pêches et pêcheurs du domaine maritime aquitain au XVIII ${ }^{e}$ s., Amirautés de Bayonne et de Bordeaux, Procès Verbaux des visites faites par ordre du Roy concernant la pesche en mer (1727), Saint-Quentin-de-Baron, éd. de 2004.

Locard 1887-1888: LOCARD (A.) - Note sur une faunule malacologique gallo-romaine trouvée en 1885 dans la nécropole du Trion. In : Allmer (A.), Dissard (P.), Trion ; Antiquités découvertes en 1885, 1886 et antérieurement au quartier de Lyon dit de Trion, Extrait des Mémoires de l'Académie des Sciences, belles-lettres et arts de Lyon, 25, vol. 2, Lyon, 1887-1888, p. 584-588.

Manniez 1999 : MANNIEZ (Y.) - Les pratiques funéraires en Narbonnaise méditerranéenne (partie occidentale) du III ${ }^{e}$ au VIII ${ }^{e}$ s., Thèse de Doctorat, Université de Provence, Aix-en-Provence, 1999.

Manniez 2005 : MANNIEZ (Y.) - Les lampes à huile dans les sépultures romaines tardives du Languedoc méditerranéen. In : Chrzanovski (L.), Lychnological Acts 1, Actes du $1^{\text {er }}$ congrès international d'études sur le luminaire antique (Nyon-Genève, 2003), Montagnac, Monographie Instrumentum, 31,2005 , p. 227-231.

Marteil 1979 : MARTEIL (L.) - La conchyliculture française. Troisième partie : L'ostréiculture et la myticulture, Revue des Travaux de l'Institut des Pêches Maritimes, 43 (1), 1979, p. 10-130.

Mémoires de la Société des Antiquaires de Normandie 1833 : Mémoires de la Société des Antiquaires de Normandie, 1833, p. 390-391.

Menon 1746 : MENON - La cuisinière bourgeoise, Paris, 1746, éd. 1815.

Quéro 1998 : QUÉRO (J.-Cl.), VAYNE (J.-J.) - Les fruits de la mer et plantes marines des pêches françaises, Delachaux et Niestlé, Paris, 1998.

Rambourg 2007: RAMBOURG (P.) - Entre le cuit et le cru : la cuisine de l'huître, en France, de la fin du Moyen Âge au XX ${ }^{\mathrm{e}}$ s. In: Ridel (E.), Barré (E.), Zysberg (A.) (éd.), Les nourriture de la mer, de la criée à l'assiette, Actes du Colloque du Musée maritime de l'île de Tatihou (Saint-Vaast La Hougue, 2003), Histoire maritime, 4, Caen, 2007, p. 211-220.

Société des bibliophiles françois 1873 : Société des bibliophiles françois - Voyage de Lister à Paris en 1698, traduit pour la première fois, publié et annoté par la Société des bibliophiles françois, Paris, 1873.

Tessier 1994 : TESSIER (M.) - Dictionnaire archéologique du Pays de Retz, Société nantaise de Préhistoire, Nantes, 1994.

Tranoy 2008 : TRANOY (L.), MOIZAN (E.), BATIGNE VALLET (C.), MATHÉ (V.), DRUEZ (M.), BARDOT (A.) - La "Grande Avenue" à Barzan (17) : les acquis des premières campagnes de fouilles (2006-2008), Aquitania, 24, 2008, p. 77-104.

Verger 2005 : VERGER (F.) - Marais et estuaires du littoral français, Belin, Paris, 2005.

Verger 2009 : VERGER (F.) - Zones humides du littoral français, Belin, Paris, 2009. 

Deuxième Partie

\section{Études archéologiques sur l'Afrique}

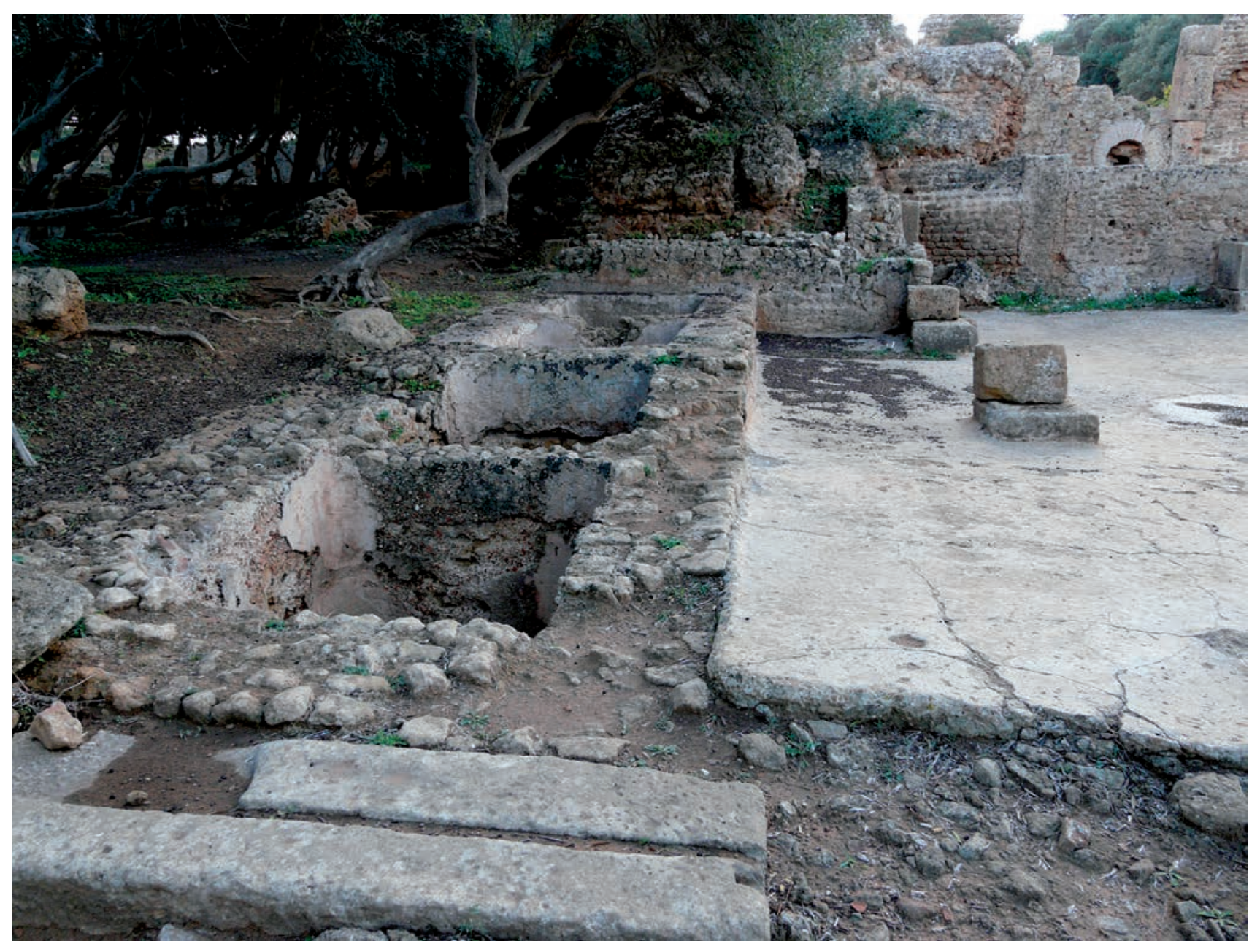





\section{La production urbaine de salaisons en Algérie à l'époque romaine : l'exemple de Tipasa (Maurétanie Césarienne)}

\section{Touatia Amraoui}

\section{Introduction ${ }^{1}$}

$\mathrm{C}$ omme on peut l'observer sur la carte publiée en 1977 par J.-M. Lassère², si des recherches archéologiques ont révélé l'existence de nombreux ateliers de transformation du poisson sur les côtes du Maroc ${ }^{3}$ - Maurétanie Tingitane - et sur les côtes de Tunisie $^{4}$ - Afrique Proconsulaire et Byzacène -, les investigations sur le territoire algérien qui comprend à la fois la Maurétanie Césarienne, la Numidie et une petite part de l'Afrique Proconsulaire, restent encore très modestes.

Toutefois, l'étude des publications anciennes - rapports de fouilles, monographies, etc. ${ }^{5}$ - permet de localiser quelques installations artisanales en rapport avec ce type de productions. Dans le cadre de mes recherches doctorales, mon intérêt s'est porté plus particulièrement sur les ateliers urbains, c'est pourquoi je m'intéresserai au seul site urbain où l'on a clairement reconnu la présence d'ateliers de salaisons : Tipasa, en Maurétanie Césarienne.

La méthode employée dans le cadre de cette analyse consiste à étudier les installations artisanales à partir de la documentation écrite, majoritairement les rapports de fouilles, et d'un travail sur le terrain. De fait, un réexamen des informations nous amène d'une part à mettre à jour et à compléter la documentation, et d'autre part à déterminer si les installations découvertes sont bien des

1. Je souhaite remercier très sincèrement les organisateurs du séminaire doctoral Fish and Ships, E. Botte et V. Leitch, ainsi que les chercheurs qui ont participé à cette rencontre dont les remarques et les encouragements m'ont été très utiles, notamment M. Sternberg, I. Vaz Pinto, M. Bonifay, A. Wilson, D. Bernal Casasola et T. Bekker-Nielsen.

2. Lassère 1982, p. 369, fig. 39 ; seuls quelques sites identifiés comme ayant compté des ateliers de salaisons sont répertoriés: Tipasa, Cherchel, Guelta et les Trois Ilots.

3. Bien qu'elle soit relativement ancienne, la synthèse de Ponsich, Tarradell 1965 reste incontournable pour les découvertes réalisées sur les côtes marocaines et ibériques.

4. Notamment Ben Lazreg et al. 1995, p. 106, fig. 2 ; Slim et al. 2004 ; Slim et al. 2007.

5. Les rapports de fouilles et croquis ont été consultés dans les centres d'archives d'Alger et d'Aix-en-Provence. ateliers de salaisons ${ }^{6}$, et si oui, quels en sont les aménagements et les particularités.

\section{Le site}

Le site de Tipasa est localisé sur la côte, à environ $25 \mathrm{~km}$ à l'est de Caesarea, capitale de Maurétanie Césarienne.

Tipasa connaît une première implantation urbaine à partir du $\mathrm{VI}^{\mathrm{e}} \mathrm{s}$. avant notre ère lors de la création d'un comptoir punique; la superficie de l'agglomération se limite à quelques hectares. Elle reçoit le titre de municipe sous Claude et est élevée au rang de colonie sous le règne d'Hadrien ${ }^{7}$. Elle est ensuite dotée d'une vaste enceinte de soixante hectares, enceinte qui ne semble entièrement occupée qu'à partir du $\mathrm{IV}^{\mathrm{e}} \mathrm{s}{ }^{8}$. La ville est prise par les Vandales en 430, mais l'occupation du site semble se poursuivre au moins jusqu'à la période byzantine ${ }^{9}$.

Tipasa n'a pas fait l'objet de fouilles programmées annuelles comme cela a été le cas pour d'autres sites algériens comme Timgad, puis Djemila ${ }^{10}$. Les fouilles, commencées à partir de la fin du XIX ${ }^{\mathrm{e}} \mathrm{s} .{ }^{11}$, ne seront réalisées que sporadiquement, surtout par des membres de l'École française de Rome en séjour en Algérie pour quelques mois ${ }^{12}$.

Ce n'est qu'à l'arrivée de J. Baradez à la direction des fouilles en 1948 et jusqu'en 1961 que des fouilles

6. J'emploierai ici le terme de salaisons au sens large, car comme cela a été longuement débattu au cours du séminaire doctoral Fish and Ships, il est encore difficile d'identifier les cuves destinées aux salaisons de celles liées plutôt à la fabrication des sauces de poissons, garum, hallec, etc.

7. Lancel 1982, p. 757-767.

8. Id., p. 767.

9. C'est ce que l'on constate à partir du mobilier publié par J. Baradez issu des fouilles stratigraphiques de la Maison des Fresques notamment (Baradez 1961b).

10. À ce sujet, cf. Oulebsir 2004.

11. Gsell 1926.

12. C'est ce que nous apprennent les rapports de fouilles annuels publiés par le Directeur des Antiquités algériennes. 


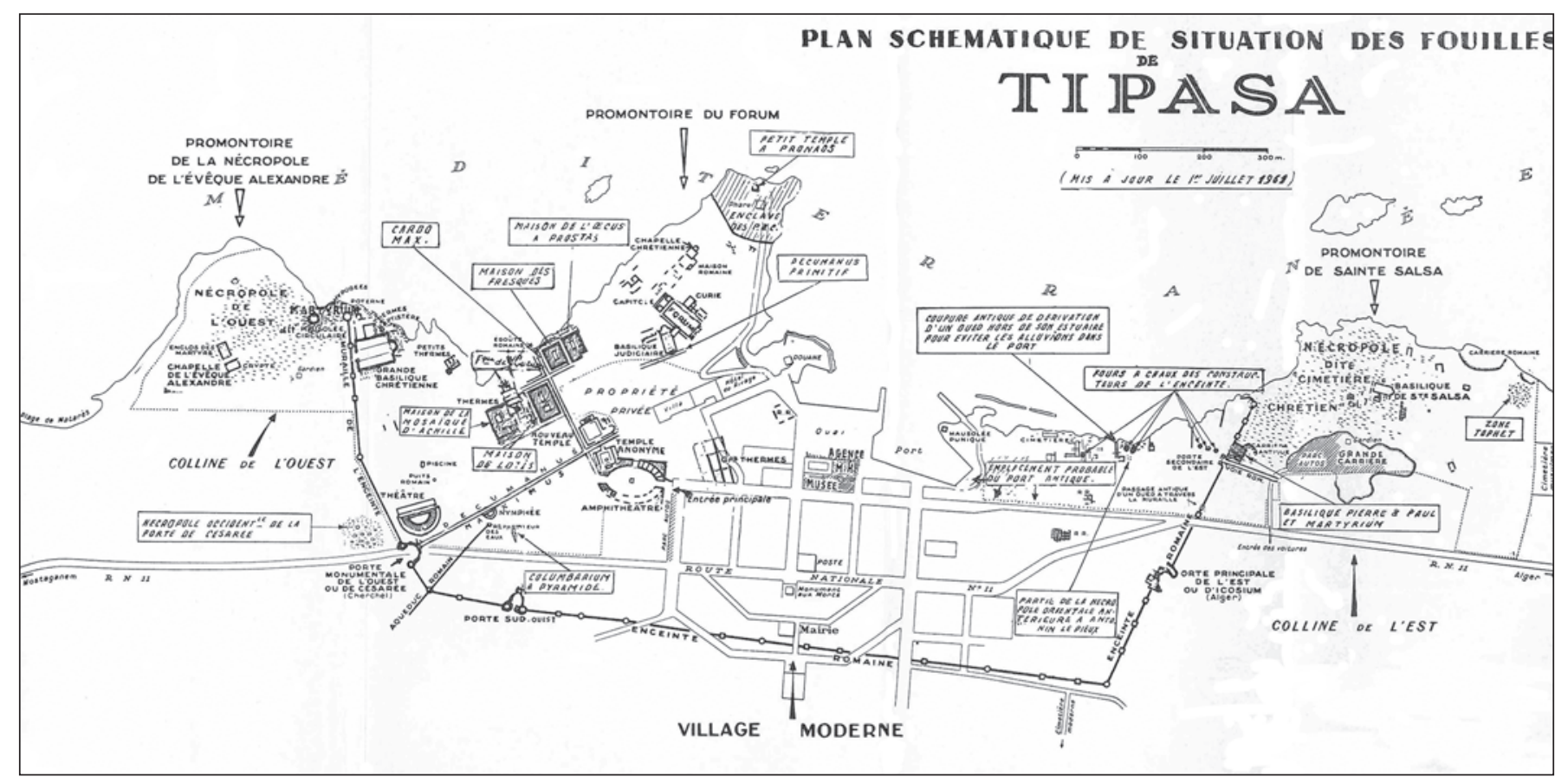

Fig. 1. Plan de localisation des vestiges de Tipasa (d'après Baradez 1961a).

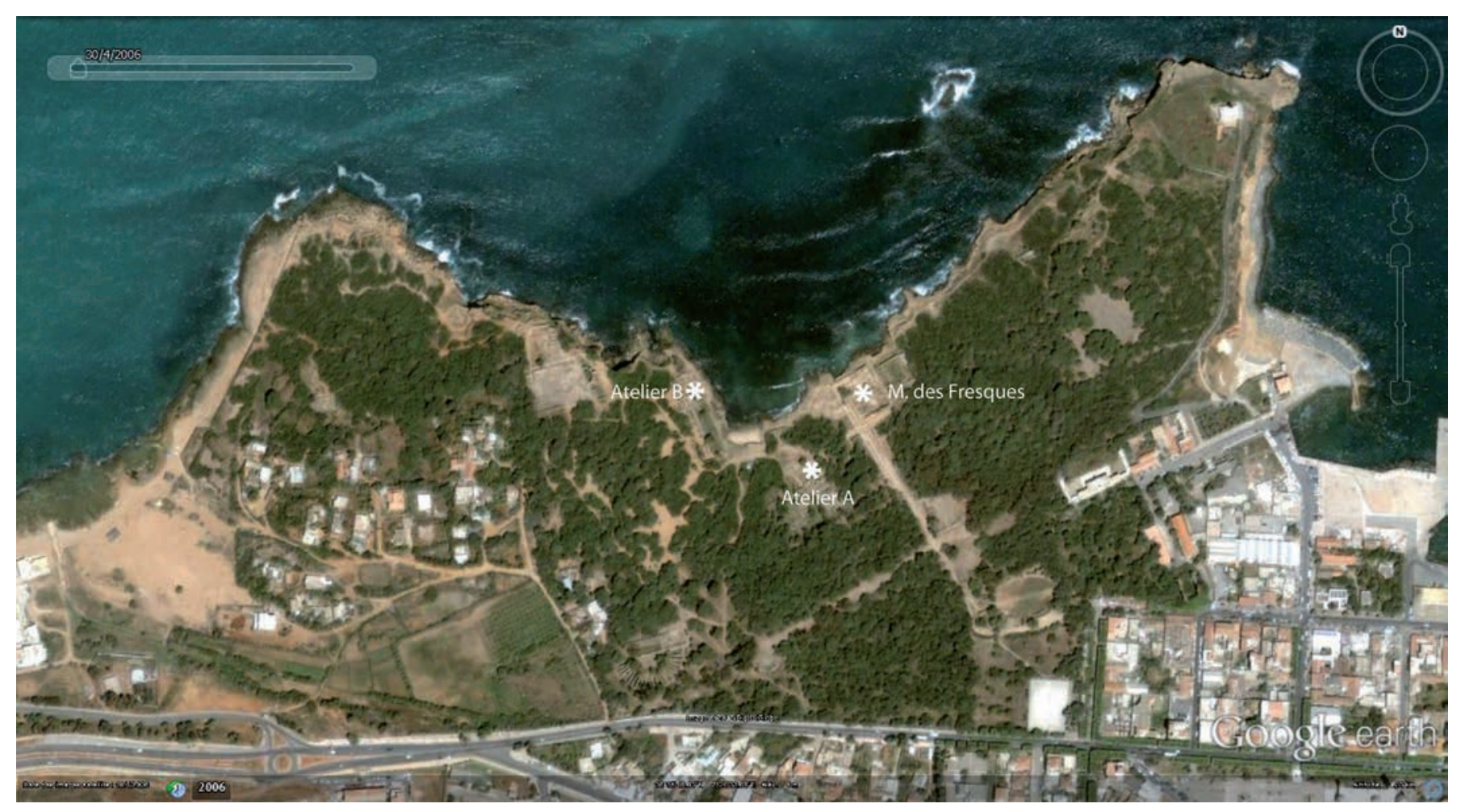

Fig. 2. Vue par satellite du site du Tipasa et localisation des installations étudiées (Google Earth, juin 2003). 
extensives débutent vraiment ${ }^{13}$. Toutefois, comme le souligne S. Lancel, on connaît mieux les nécropoles que la ville elle-même ${ }^{14}$ puisqu' après l'indépendance de l'Algérie, les recherches sont amenées à se développer surtout dans ces zones périphériques ${ }^{15}$. En effet, lorsque l'on regarde le seul «plan de localisation des vestiges » très schématique (fig. 1), on remarque à quel point le domaine urbain est encore peu connu. Par exemple, deux voies seulement ont été fouillées ponctuellement : le decumanus maximus et le cardo maximus. Pour les bâtiments fouillés, s'ils n'ont pas fait l'objet d'une publication de détail lors de leur découverte, il n'en existe à l'heure actuelle aucun plan.

En outre, le tracé reporté de l'enceinte montre que seule la partie septentrionale de la ville antique est aujourd'hui préservée, le reste de la cité antique est sous la ville moderne qui ne cesse de s'agrandir comme partout ailleurs en Algérie.

La photo par satellite (fig. 2) ne peut pas nous être d'une meilleure aide puisque le site a été conçu comme un jardin archéologique - le Parc Trémaux - à la demande des anciens propriétaires du terrain; il donne donc autant d'importance à la végétation qu'aux vestiges ${ }^{16}$. Les lacunes documentaires touchent donc une bonne partie des vestiges fouillés par J. Baradez qui n'a pas pu publier de monographie scientifique complète ${ }^{17}$; de fait, les installations de salaisons restent méconnues.

\section{Les ateliers de salaisons}

À Tipasa, les rapports de fouilles et les publications mentionnent trois «fabriques de garum » : la première que j'appelle «l'atelier A », la seconde, «l'atelier B » et enfin la troisième est localisée dans la «Maison des Fresques ».

\subsection{L'atelier A}

L'atelier A est situé dans la partie centrale du site, à environ $50 \mathrm{~m}$ du rivage actuel. Au sud, il est mitoyen des «thermes de la crique » et voisin de la «Maison de la mosaïque d'Achille » : il est donc établi en plein centre urbain (fig. 2). Au nord, il est longé par un decumanus

\footnotetext{
13. Baradez 1961a.

14. Lancel 1982, p. 778.

15. Notamment Bouchenaki 1975.

16. Baradez 1952, p. 23.

17. En effet, il décède quelques années seulement après son retour en France en 1969.
}

secondaire qui n'a pas été complètement mis au jour et dont le dallage semble avoir disparu.

D'après J. Baradez, cette «fabrique de garum» compte les pièces 1 à 6 , mais en réalité, dans l'état actuel des fouilles, seule la pièce 1 est occupée par l'atelier de salaisons qui avait été fouillée au cours du $\mathrm{XIX}^{\mathrm{e}} \mathrm{s}$. On y observe la présence de quatre bassins rectangulaires le long du mur oriental, qui ont été l'objet de plusieurs interprétations. En effet, en 1926, S. Gsell identifiait ce local comme celui d'un atelier de potier en raison de la présence de nombreux tessons, d'amas de terre glaise et de «cuves qui auraient servi de pourrissoirs pour l'argile ». Toutefois, il souligne aussi le fait qu'aucun four de potiers n'a été trouvé ${ }^{18}$. Puis, en 1950, L. Leschi propose de voir dans les aménagements de la pièce 1 , un atelier de tanneur ${ }^{19}$.

Enfin, ce n'est que dans les années 1950, lorsque J. Baradez décide d'étendre la fouille et entreprend de nettoyer le fond des bassins qu'il y découvrira des restes de poissons permettant d'identifier le local comme un atelier de salaisons. D'ailleurs, la morphologie des bassins $(1,85 \times 1,40 \times 1,10 \mathrm{~m})$ aux angles arrondis, construits en moellons, semi-enterrés et recouverts ${ }^{20}$ d'un épais enduit de tuileau rappelle la typologie de ceux découverts dans d'autres ateliers africains - notamment au Maroc : Cotta, Tahadart ${ }^{21}$, etc.

\subsubsection{Le plan}

Dans son état actuel, la pièce 1 , mesurant $164 \mathrm{~m}^{2}$, est marquée par la présence de rangées de piliers nord-sud destinés à supporter la toiture (fig. 3). Le sol présente un enduit épais. Les autres pièces découvertes après 1955 par J. Baradez ne communiquent pas avec la pièce 1 ; pour celles situées au nord, elles ne sont accessibles que depuis la rue.

Lors de sa découverte, la pièce 2 préservait un dolium. Elle est mitoyenne au sud avec une petite pièce 3 avec laquelle elle ne conserve pas de communication; on remarque la présence d'un pétrin mécanique dans cette dernière ${ }^{22}$. Au sud, en contre-haut, un bassin semi-circulaire appartenant aux thermes présente une évacuation qui est prolongée par une canalisation en pierre ; celle-ci traverse les pièces 3 et 2 pour rejoindre la rue en longeant leur mur ouest.

\footnotetext{
18. Gsell 1926, p. 113.

19. Leschi 1950, p. 20, fig. 13.

20. Ils ne présentent pas de cuvette dans le radier.

21. Ponsich,Tarradell 1965, p. 58-59.

22. Il y a une meta conique dans la cavité centrale : ce remontage est fort probablement postérieur ; ces instruments ne sont pas à leur emplacement d'origine.
} 


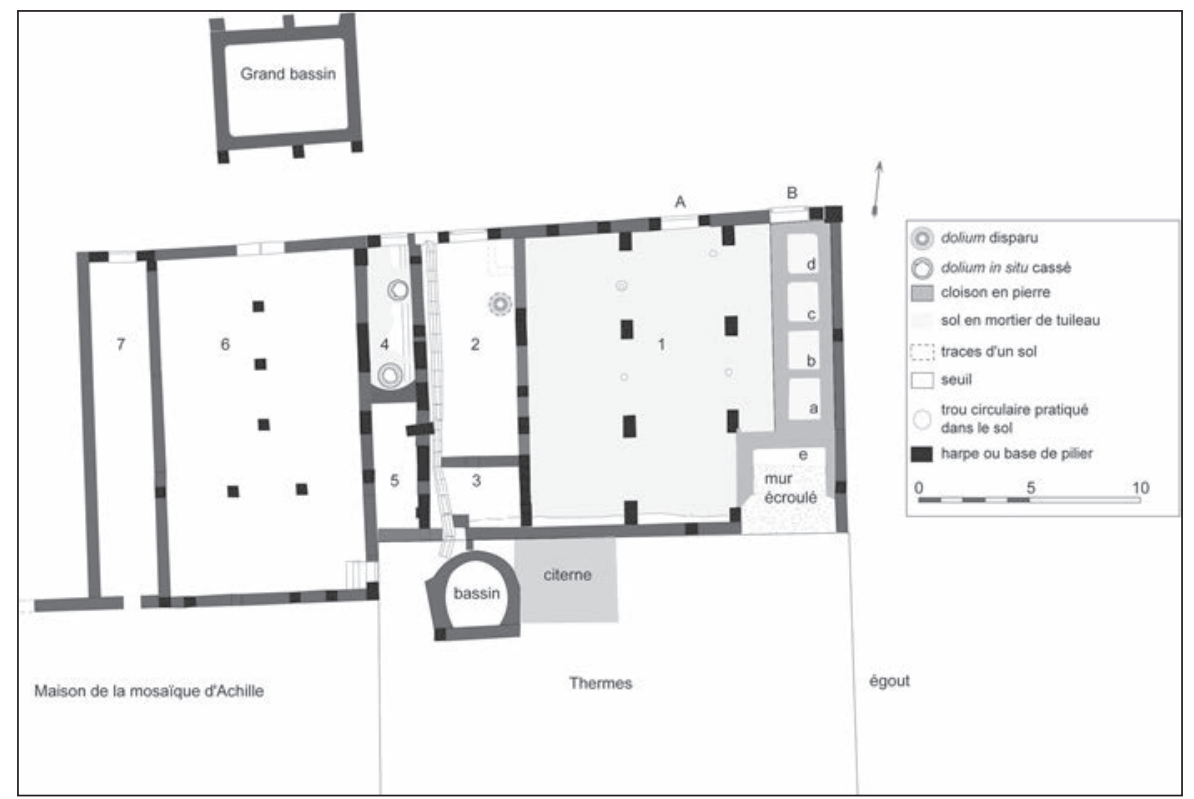

Fig. 3. Plan de l'atelier A et des pièces environnantes (plan T. Amraoui).

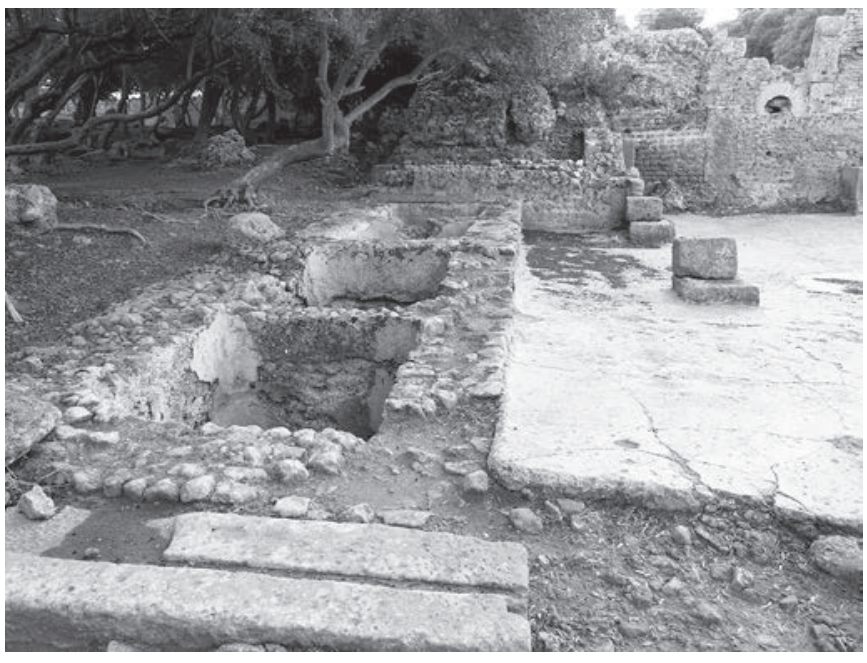

Fig. 4. Atelier $A$, pièce 1 : au premier plan, seuil $B$ et bassins de salaisons ; au second plan le bassin-citerne e et les thermes (photo T. Amraoui).

À l'ouest, la pièce 4 comportait plusieurs dolia in situ, aujourd'hui en très mauvais état malgré les restaurations; le sol en béton a été creusé pour y placer ces grands récipients. Une canalisation située sous le sol en mortier de tuileau est visible tout le long de l'espace 4 ; elle rejoint elle aussi la rue nord. Un mur curviligne de mauvaise facture sépare la pièce 4 et une pièce 5 , au sud, qui n'est pas entièrement dégagée.

À l'ouest de la pièce 4, une grande pièce 6 de $135 \mathrm{~m}^{2}$ présente des piliers supportant la toiture. Au sud-est, elle communique par quelques marches avec un espace desservant à la fois les thermes et, semble-t-il, la Maison « à la mosaïque d'Achille».
Ainsi, la pièce 1 s'avère être bien isolée des autres pièces qui fonctionnent indépendamment les unes des autres. Toutefois, l'étude du bâti que j'ai réalisée sur le terrain conduit à revoir l'évolution de l'ensemble, car l'état actuel révèle clairement qu'il y a eu différentes phases d'aménagement: trois au moins ont été reconnues ${ }^{23}$.

\subsubsection{Les différentes phases d'aménagement et l'évolution de l'atelier}

La phase 1 correspond à un état antérieur à l'implantation des bassins. En effet, l'espace de la pièce 1 préexiste comme le démontre l'existence d'un seuil à rainure longitudinale centrale et panneau mobile au pied du bassin a (fig. 4). Il est aujourd'hui visible car les murs l'environnant sont très arasés; il devait lui-même être surmonté par des blocs ou des moellons aujourd'hui disparus. Comme il est impossible qu'une porte ouvre sur le bassin a puisqu'elle aurait buté contre la paroi de celui-ci, il ne peut s'agir que d'un aménagement antérieur révélant un espace à vocation commerciale.

La phase 2 correspond à l'atelier de salaisons qui devait occuper une surface plus importante que celle découverte. L'examen de l'emplacement des piliers centraux révèle effectivement l'existence d'un module

23. Précisons tout de même que l'identification des différentes phases s'appuie sur des hypothèses établies à partir des vestiges tels qu'ils sont visibles aujourd'hui ; elles devront être vérifiées par des sondages pour confirmer et préciser l'évolution de l'espace. 


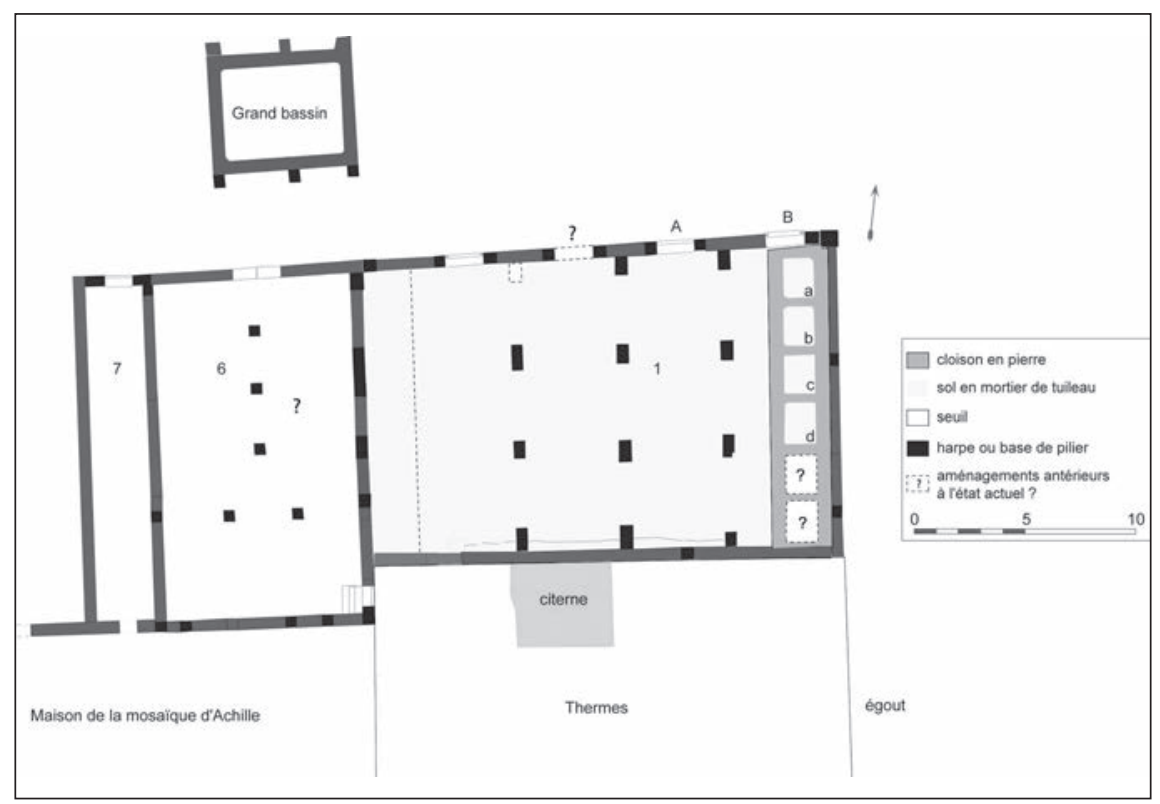

Fig. 6. Atelier A : hypothèse de restitution de six bassins pour la phase 2 (plan T. Amraoui).

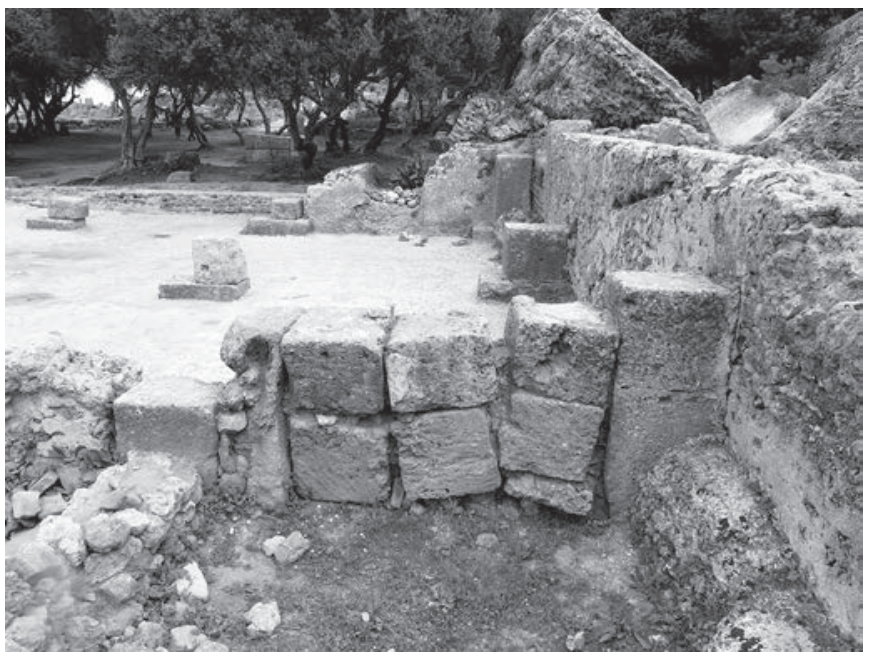

Fig. 5. Au premier plan, pièce 3 : appareils grossiers employés pour boucher l'espace entre les piliers; au second plan l'atelier A.

On remarque aussi que la « banquette » visible le long du mur sud de la pièce 1 se poursuit dans la pièce 3 (photo T. Amraoui).

régulier d'est en ouest dans l'architecture de la pièce 1. Celui-ci vient englober au moins les pièces 2 et $3:$ de fait, la pièce 1 s'étendait donc plus à l'ouest car on identifie la présence des piliers dans les murs de ces espaces qui ont été bouchés à l'aide de murs faits d'appareils grossiers (fig. 5). De plus, le mur sud de la pièce 1 présentait une sorte de banquette haute d'une vingtaine de centimètres ${ }^{24}$ dont on observe un tronçon dans la pièce 3 (fig. 5).

24. Elle est réalisée à l'aide d'un mortier de tuileau épais mêlé à quelques pierres : je pense que l'on peut identifier cet aménagement
Parallèlement, dans la pièce 1 , on peut aussi reconnaître la présence d'un autre module dans le sens nord-sud, au niveau de la série de bassins de salaisons (fig. 6). En effet, si l'on tente de reporter les mesures des bassins conservés au nord, on observe qu'il est très probable que deux bassins étaient situés au sud, là où sera implanté le bassin e au cours d'une troisième phase.

La phase 3 correspond au dernier état mis au jour par la fouille. Cet état présente quatre bassins de salaisons et la pièce 1 est plus petite car amputée d'une partie de son extension occidentale convertie en une succession de petits espaces desquels elle est complètement isolée.

Ainsi, les deux bassins de salaisons présumés auraient été bouchés; leur emplacement est occupé par le bassin e (fig. 4) dont le fond s'élève à près d'un mètre par rapport au niveau de circulation de l'atelier. Il présente des quarts-de-rond et il englobe au sud-ouest une partie d'un pilier de la pièce 1. Même si une partie du bassin est aujourd'hui encombrée par l'effondrement de l'étage des thermes, toutes ses caractéristiques conduisent à l'identifier plutôt comme une citerne que comme un bassin de salaisons. Cette réserve d'eau supplémentaire devait s'avérer nécessaire à l'approvisionnement de bains qui n'ont cessé de s'agrandir. Ainsi, contrairement à ce que pensait J. Baradez, il apparaît que ce n'est pas l'atelier qui empiète peu à peu sur les thermes, mais bien l'inverse. C'est du moins ce que l'on peut constater à partir

comme une sorte de gros solin destiné à protéger la base du mur. En effet, les espaces de travail devaient être nettoyés à grande eau, c'est pourquoi les coins fragiles ont dû être renforcés. 


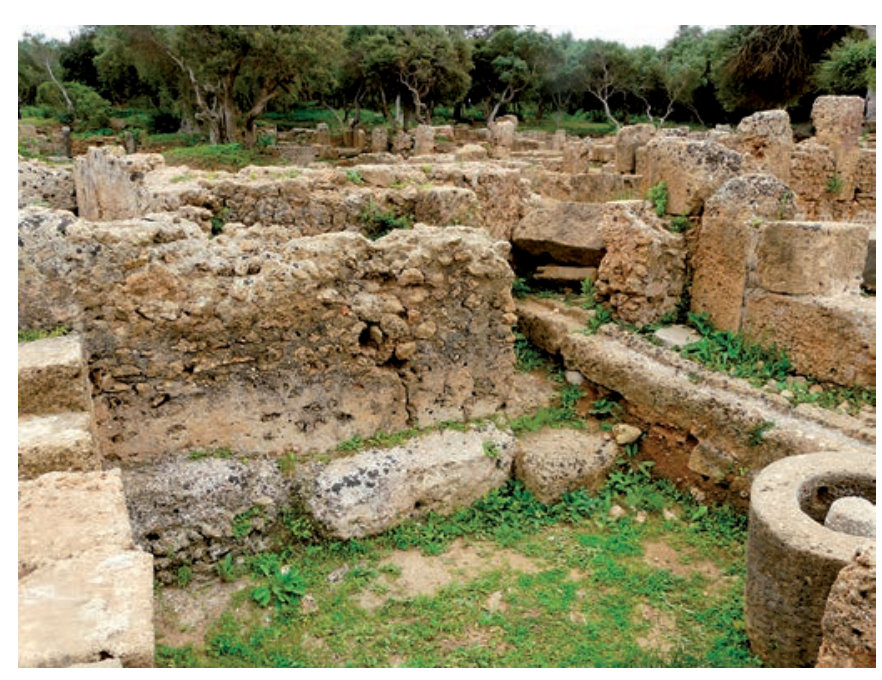

Fig. 7. Le bassin des thermes au sud de la pièce 3 et le passage de la canalisation à travers le mur détruit (photo T. Amraoui).

des plans représentant les différents stades de l'évolution architecturale des thermes réalisés par le fouilleur, même s'il est encore difficile de préciser exactement les correspondances chronologiques entre l'atelier et les thermes.

En outre, un second témoin permet aussi de constater l'agrandissement des thermes aux dépens de l'atelier: c'est la canalisation qui, venant du bassin semi-circulaire des bains, traverse les pièces 2 et 3 . En effet, le mur à travers lequel la conduite passe a été cassé et elle est construite sur un remblai (fig. 7). D'après les informations de J. Baradez, ce bassin est construit durant la «troisième époque des thermes »; le plan des bains ${ }^{25}$ est alors analogue à celui des thermes situés au nord-est du théâtre de Bulla Regia et qui sont datés du IV ${ }^{\mathrm{e}}$ s. ${ }^{26}$.

Les remarques permises par l'observation des vestiges archéologiques mise en relation avec les archives de J. Baradez conduisent à tenter quelques propositions de datation.

En ce qui concerne le mobilier conservé, les quelques éléments que $\mathrm{j}$ 'ai pu voir datent soit du $\mathrm{II}^{\mathrm{e}} \mathrm{s}$. de notre ère soit du $\mathrm{V}^{\mathrm{e}}-\mathrm{VI}^{\mathrm{e}}$ s. ; ils pourraient correspondre aux deux phases d'occupation les plus extrêmes de ce secteur.

Pour ce qui est de l'architecture et des techniques de construction, je me suis intéressée aux différents types de parement présents dans l'atelier que j'ai comparé à ceux décrits et datés par P.-M. Duval dans le cadre de son travail sur les murs des enceintes de Tipasa et de Cherchel $^{27}$. De cette comparaison, il semblerait que la

25. D'après un croquis réalisé par le fouilleur.

26. Thébert 2000, p. 134-135, pl. XXXV.

27. Duval 1946, p. 96, fig. 12 et p. 167. phase 1 présente des constructions en appareil «semigrossier » que cet auteur considérait comme antérieur au III ${ }^{\mathrm{e}}$ s., ce qui correspond avec le mobilier découvert. Cette première phase correspond à l'implantation de locaux à vocation commerciale comme le démontre le seuil B.

La phase 2 présente un appareil «grossier» qui, selon P.-M. Duval, aurait été employé entre le $\mathrm{III}^{\mathrm{e}} \mathrm{s}$. et la première moitié du $\mathrm{IV}^{\mathrm{e}} \mathrm{s}$. : ainsi, le premier état de l'atelier daterait peut-être de cette période.

Enfin, pour la phase 3, nous ne disposons que du plan des thermes qui auraient été agrandis au cours du $\mathrm{IV}^{\mathrm{e}} \mathrm{s}$. (?) aux dépens de l'atelier.

Parallèlement, à partir du mobilier mis au jour et des croquis réalisés par J. Baradez, l'abandon du secteur de l'atelier A daterait au plus tôt du VI ${ }^{\mathrm{e}}$ s., à l'instar de ce qui a été proposé par le fouilleur pour la Maison des Fresques voisine ${ }^{28}$.

\subsubsection{Bilan}

Finalement, nous pouvons réfuter l'hypothèse de Baradez selon laquelle l'atelier comptait en tout 6 pièces, étant donné que le travail de terrain a conduit à reconnaître une seule pièce principale dans l'état actuel des vestiges. De plus, il semble que l'évolution de l'atelier avait échappé à notre prédécesseur. Il apparait probable que l'atelier de salaisons s'est implanté au cours du $\mathrm{III}^{\mathrm{e}} \mathrm{s}$. de notre ère, qu'il a connu une évolution au cours $\mathrm{du} \mathrm{IV}^{\mathrm{e}} \mathrm{s}$. ; mais il est encore difficile de préciser s'il était encore en activité au $\mathrm{V}^{\mathrm{e}} \mathrm{s}$.

Subsiste un problème majeur, celui de l'approvisionnement en eau. En effet, aucun aménagement susceptible d'avoir alimenté l'atelier n'a été localisé ; le bassin situé sur la voie au nord-ouest de l'atelier n'est pas datable et il ne présente aucune trace d'aménagement en direction de la pièce 1.

D'un point de vue technique, l'ensemble de la pièce 1 est conforme aux plans connus ailleurs pour ces installations, avec ses quatre à six bassins de salaisons latéraux et sa grande aire de travail au sol bétonné. On peut citer pour comparaison de nombreux exemples où les bassins sont mitoyens d'une aire de travail où les employés préparaient le poisson sur des étals de bois comme cela a été proposé pour Nabeul par exemple ${ }^{29}$. Ailleurs, les bassins rayonnent autour d'une salle centrale munie de piliers ou bien ils sont alignés sur un ou deux côtés comme à Troia, Cotta, Tahadart, Belo Claudia ou Bolonia ${ }^{30}$ : de

28. Baradez 1961b, p. 195-199.

29. Comme on peut le voir au Musée de Nabeul sur des restitutions à l'aquarelle réalisées par J.-M. Gassend.

30. Ponsich, Tarradell 1965, p. 58-59, p. 62-63, p. 86-87, etc. 
fait, on peut se demander s'il y avait aussi d'autres bassins à l'emplacement actuel des pièces 2 et 3 . Mais, pour répondre à cette question et pour préciser la chronologie, seule la réalisation de sondages pourrait nous aider.

\subsection{L'atelier B}

L'atelier B ne figure pas dans les monographies qui portent sur Tipasa. Il est situé au pied de la colline où s'élevait la basilique chrétienne de Tipasa ; à une cinquantaine de mètres de l'atelier $\mathrm{A}$ (fig. 2) et, contrairement à ce dernier, l'atelier $\mathrm{B}$ est proche du bord de mer.

L'aspect général de l'installation est assez original puisqu'elle occupe seulement une pièce longitudinale $(10 \times 3 \mathrm{~m})$ qui comporte quatre bassins rectangulaires alignés d'est en ouest (2,20 x 1,97 m en moyenne, profondeur non mesurable) et entièrement revêtus d'un enduit de tuileau (fig. 8 et 9). Latéralement, le long des murs, le sol de circulation, complètement enduit, est très étroit, il mesure $40 \mathrm{~cm}$ en moyenne.

L'accès se fait par une large ouverture à l'est présentant un seuil de boutique avec rainure longitudinale et panneau mobile gauche, ainsi que des traces de dispositifs de fermeture. L'entrée de l'officine est précédée d'une plateforme couverte d'un épais béton de tuileau mêlé à des cailloutis; on observe aussi la présence de plusieurs blocs épars.

L'atelier B semble s'être implanté dans un espace préexistant, peut-être une boutique, car la pièce qu'il occupe est mitoyenne au nord comme au sud d'une autre pièce longitudinale aux dimensions semblables, mais celles-ci ne conservent aucun aménagement particulier. Les murs de l'atelier sont conservés jusqu'à une hauteur de $3 \mathrm{~m}$, il est possible qu'il y ait eu un étage au-dessus, auquel cas l'accès se faisait vraisemblablement en contre-haut à l'ouest à mi-hauteur de la colline.

La typologie particulière de l'officine B est originale, mais les caractéristiques de ses bassins nous conduiraient à la rattacher à un atelier de salaisons : ni les ateliers liés au travail du textile ni les tanneries ne présentaient de telles installations. D'ailleurs, la cuvette en céramique - une amphore décolletée et remployée - n'est pas sans rappeler les « cuvettes de nettoyage » mises au jour dans quelques ateliers de salaisons, dont celui de Nabeul. En outre, l'atelier B n'est pas un cas isolé puisque des ateliers de salaisons présentant des dispositions similaires ont été mis au jour à Baelo Claudia et à Sabratha ${ }^{31}$.

31. Pour Baelo Claudia, il s'agit de secteurs des ateliers C.I. IV et C.I. VII (Arévalo, Bernal 2007, p. 131, fig. 46 ; p. 180-181, fig. 125127) ; pour Sabratha (Wilson 2007, p. 173, fig. 1 et 2).

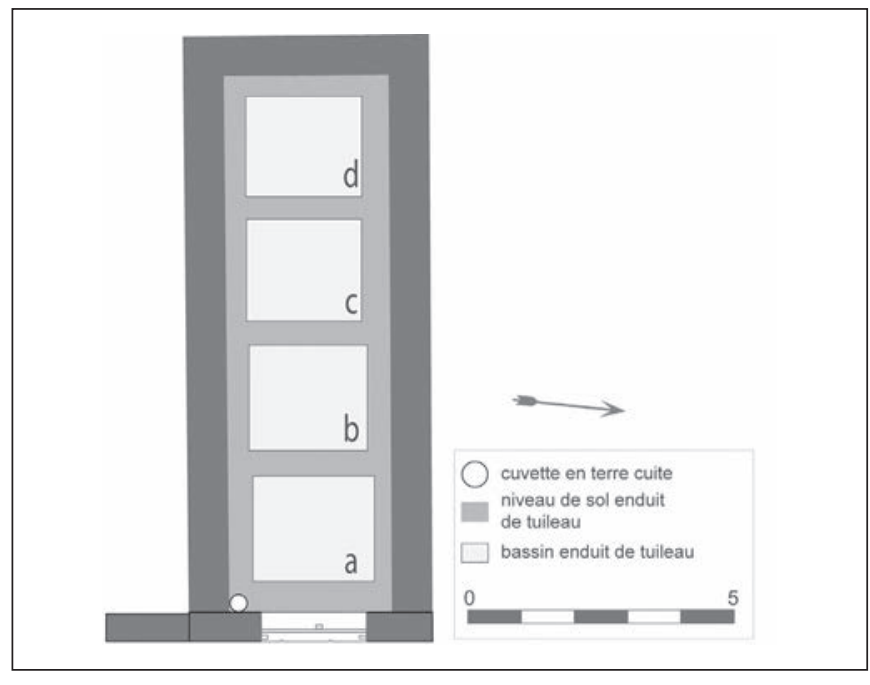

Fig. 8. Plan schématique de l'atelier B (plan T. Amraoui).

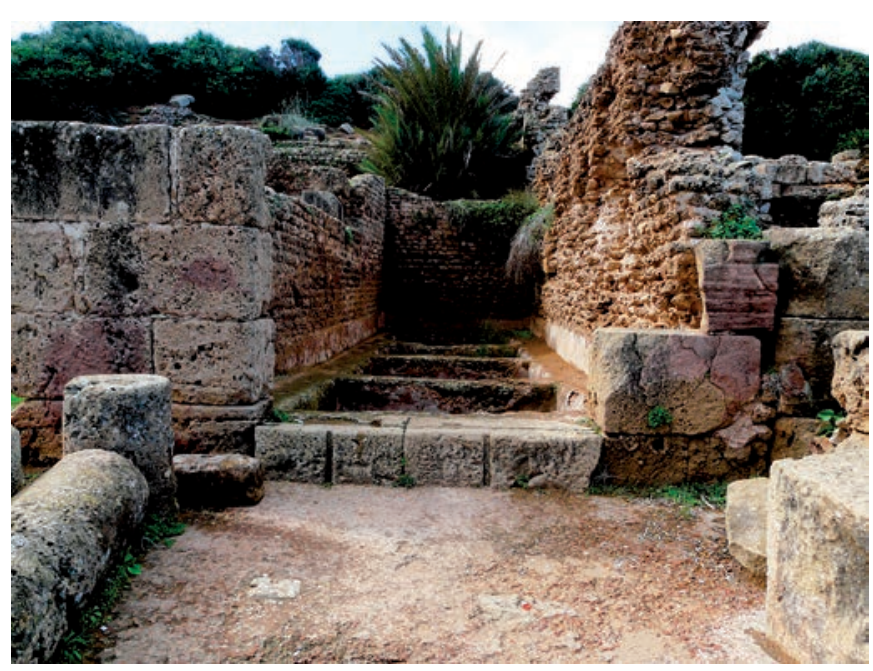

Fig. 9. Vue depuis l'est de l'atelier B (photo T. Amraoui).

Par toutes ses particularités, l'atelier B offre un bon exemple d'optimisation de l'espace car on a aménagé dans un local restreint le plus grand nombre de bassins possible; en revanche, les voies de circulation en pâtissent car l'accès aux bassins est restreint. Les employés de l'officine disposaient de peu d'espace pour circuler et travailler; ils devaient sans doute être moins nombreux que dans l'atelier $\mathrm{A}$ où ni l'accès aux bassins, ni le travail de préparation des poissons ne posaient de problèmes. Par ailleurs, l'atelier B ne compte pas d'espace de travail: on peut seulement supposer que les poissons étaient apprêtés à l'extérieur, devant l'entrée, sur la plateforme bétonnée qui fait face à la mer et qui était sans doute en partie couverte comme l'indiquent la présence de quelques bases de pilier.

Si l'atelier A disposait d'un espace de travail qui pouvait servir également à mettre les salaisons dans des 
contenants - amphores ou en dolia ${ }^{32}$ - directement sur place, il semble que l'atelier B ait été utilisé surtout pour l'étape de la macération des poissons. Il est en effet difficile d'imaginer que la mise en contenant - quel qu'il soit - des salaisons ou des sauces ait été réalisée à l'air libre ou que ces productions aient été stockées sur place. Les aménagements de l'atelier B impliquent ainsi une activité limitée du fait de la disposition des bassins et de leur nombre. Comme la préparation des poissons devait avoir lieu dehors sur la plateforme, il devait être réalisé par beau temps, ce qui pourrait indiquer une activité saisonnière ; les poissons, une fois disposés dans les bassins, étaient à l'abri durant les mois nécessaires à leur transformation en salaisons. De fait, le manque d'espace laisse aussi penser que pour l'atelier B, le lieu de production des salaisons ne pouvait être le lieu de leur commercialisation.

Pour la datation de l'atelier B, nous ne disposons d'aucune information. Remarquons que l'officine correspond à la dernière phase d'occupation de l'espace car les bassins sont en très bon état. De la même façon qu'E. Botte ${ }^{33}$ s'est posé la question de savoir si les bassins circulaires et les bassins rectangulaires différaient d'un point de vue de l'utilisation ou de la chronologie, on peut se demander si la différence entre les bassins rectangulaires à angles arrondis de l'atelier $\mathrm{A}$ et les bassins rectangulaires à angles presque droits de l'atelier $\mathrm{B}$ relève aussi d'un critère chronologique. Mais, là encore, les informations à notre disposition ne permettent pas de répondre à cette question.

\subsection{Le pseudo atelier de salaisons de la Maison des « Fresques » et les espaces à dolia}

La Maison des Fresques, fouillée par J. Baradez au cours des années 1950, est située à l'est du cardo et en bord de mer.

D'après J. Baradez, au cours d'une phase tardive d'occupation - la «phase IV » - après s'être en partie effondrée suite à un incendie, la partie nord de la maison aurait été réaménagée en atelier de salaisons. S'il date cette période d'occupation de la deuxième moitié du $\mathrm{IV}^{\mathrm{e}} \mathrm{s}$. au $\mathrm{V}^{\mathrm{e}} \mathrm{s}$., le mobilier publié en revanche est plus tardif et relève plutôt des $\mathrm{V}^{\mathrm{e}}-\mathrm{VI}^{\mathrm{e}} \mathrm{s}$. comme l'attestent notamment des lampes de type Atlante $\mathrm{X}$ ainsi que des plats Hayes 103 et 104 à décors chrétiens ${ }^{34}$.

32. L'un comme l'autre, St. Gsell et J. Baradez rapportent la découverte d'un grand nombre de tessons d'amphores et dolia dans la pièce 1 notamment.

33. Botte 2011, p. 100-101.

34. Baradez 1961b, p. 141-142, pl. VIII.
Or, sur le plan publié de la phase IV, aucun aménagement particulier en rapport avec un atelier de salaisons n'est reporté. Toutefois, la description publiée précise que «toutes les jardinières ornementales creusées dans les blocs de grand appareil sont devenues des bacs de la salerie »; ces « jardinières » étaient disposées entre les colonnes du péristyle. Sur le terrain, j'ai pu en observer deux in situ (fig. 10). Or, il s'agit de mangeoires comme l'attestent les trous encore visibles qui servaient à attacher des équidés ${ }^{35}$; elles ont donc été récupérées et utilisées comme jardinières pour orner le péristyle de la maison. Par conséquent, l'hypothèse de J. Baradez est à rejeter dans la mesure où il est impossible d'utiliser de tels petits bacs pour la macération des poissons.

Par ailleurs, J. Baradez ne précise pas la raison qui le conduit à reconnaître une activité en rapport avec la transformation du poisson, mais il intègre aussi à l'atelier une boutique abritant huit dolia qui ont presque totalement disparu depuis leur mise au jour. En effet, pour le fouilleur, il semble que les récipients faisaient eux aussi partie de la chaîne opératoire : était-ce vraiment le cas ?

Pour tenter de répondre à cette question, je me suis d'abord intéressée aux autres exemples de « boutiques à dolia » de Tipasa. Ainsi, j'ai relevé la présence d'autres attestations de ce genre de boutiques datées de l'époque tardive $\left(\mathrm{V}^{\mathrm{e}}-\mathrm{VI}^{\mathrm{e}} \mathrm{s}\right.$. $)$ correspondant à la dernière période d'occupation. Ainsi, dans le même secteur, on dénombre une boutique à dolia dans la Maison de Lotis et une autre dans la pièce 4 voisine de l'atelier A.

À Annaba, autre ville côtière, une boutique à dolia a été identifiée comme une fabrique de garum en raison de la présence de restes de poissons dans le fond des dolia ${ }^{36}$. Par conséquent cette découverte conduit à se demander s'il existait une production de sauces de poissons directement dans des récipients en céramique.

En est-il de même à Tipasa ? Est-ce la découverte de restes de poissons dans les dolia de la Maison des Fresques qui a conduit J. Baradez à l'identifier comme

35. En Afrique, et plus particulièrement en Numidie et en Afrique Proconsulaire, des «bâtiments à auges » ont été mis au jour dans plusieurs villes et bourgades : ces édifices tardifs qui ont été longuement étudiés par N. Duval puis Fr. Baratte semblent avoir eu une vocation économique peut-être en rapport avec les olives et l'huile (Duval, Golvin 1972 ; Duval, Cintas 1976 ; Baratte 2010).

Dans le cas de Tipasa, d'autres maisons présentent des auges tout comme c'est le cas aussi en Numidie dans des villes comme Timgad ou Djemila. Comme le souligne M. Blanchard-Lemée (1975, p. 138) dans sa thèse, ces contenants en pierre ont eu divers usages aussi bien dans le cadre artisanal - bassins de rinçage dans des fullonicae, etc. - que dans le cadre domestique pour le stockage des denrées alimentaires. En revanche, les récipients découverts dans la Maison des Fresques de Tipasa présentent des parois moins épaisses et ne sont pas alignés et disposés les uns contre les autres comme c'est le cas des « monuments à auges ».

36. Lassus 1958, p. 239. 


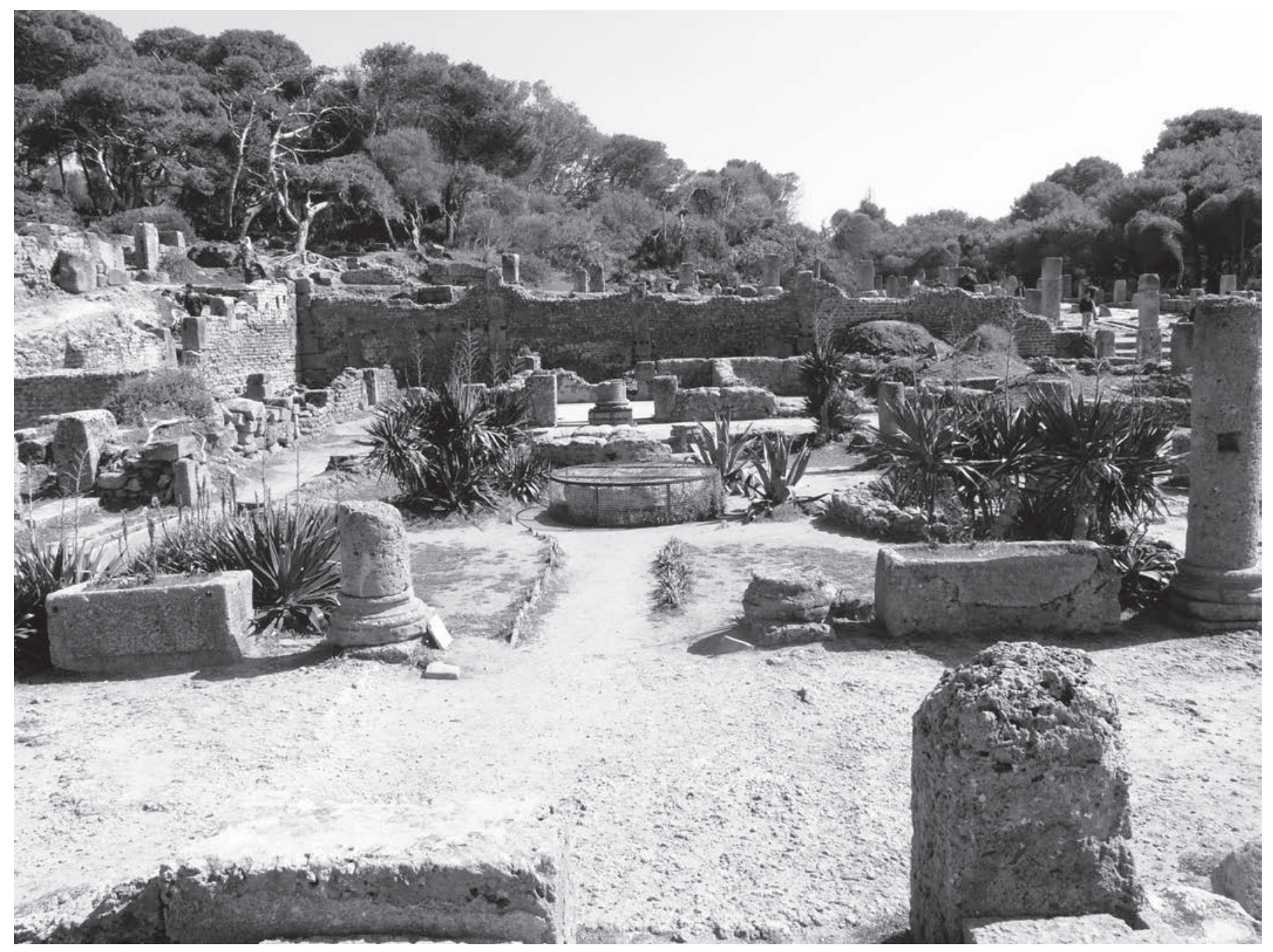

Fig. 10. Les « jardinières » du péristyle de la Maison aux Fresques (photo T. Amraoui).

un atelier de salaisons ? En est-il de même aussi pour la pièce 4 ou la Maison de Lotis ? Les rapports du fouilleur restent muets à ce sujet. Toutefois, si c'est bien le cas, l'exemple de Tipasa viendrait confirmer celui d'Annaba : on stockait des sauces de poisson ou des poissons salés dans des dolia, mais rien ne permet de préciser s'ils étaient produits à l'intérieur. En effet, cette situation n'est pas sans rappeler celle évoquée par R. Curtis et E. Botte pour l'officine à garum de Pompéi où il est probable que les dolia servaient soit à traiter des sauces par l'ajout d'autres ingrédients (vin, épices...), soit à produire directement le condiment ${ }^{37}$.

Cette comparaison est intéressante mais à l'heure actuelle il est difficile de la confirmer puisqu'il ne reste rien dans les récipients qui sont exposés à l'air libre depuis plus d'un demi-siècle. En tout cas, la présence

37. Curtis 1979 qui s'appuie sur un passage d'Astronomica de Manilius ; Botte 2009, p. 96-97. de ces contenants en céramique de taille importante dans des boutiques accessibles seulement depuis la rue, démontre clairement la commercialisation d'une denrée dans un contexte tardif. Si ce ne sont pas des salaisons, il peut tout aussi bien s'agir d'huile, de vin ou de céréales ${ }^{38}$ produits dans l'arrière-pays et vendus en ville.

\section{Conclusions}

L'étude de la production de salaisons à Tipasa met en évidence l'existence d'ateliers urbains, implantés en

38. Quelques arguments viennent supporter l'idée que ces dolia renfermaient du blé. D'une part, aux Trois Îlots on a trouvé dans les pièces à dolia un moulin à grain composé d'une meta conique et d'un catillus. De plus, rappelons qu'à Tipasa, la pièce 3 située à l'ouest de l'atelier A présente un pétrin mécanique et qu'elle est mitoyenne de la pièce 2 qui contenait des dolia. 
pleine ville dans des quartiers résidentiels, du moins c'est clairement le cas pour l'atelier A voisin de la Maison à la mosaïque d'Achille et de la Maison de Lotis. Avec quatre, voire six bassins, les ateliers restent modestes en comparaison avec les grandes officines découvertes au Maroc à Lixus ou Cotta, ou en Tunisie, à Nabeul par exemple. La fouille des vestiges situés au nord de l'atelier A, et ailleurs en bord de mer à Tipasa, permettrait peut-être de découvrir d'autres ateliers urbains de salaisons ou de sauces de poissons. En effet, un troisième atelier (C ?) a peut-être été localisé au nord-ouest de l'atelier $\mathrm{B}^{39}$.

De plus, on peut supposer que la taille modeste des ateliers urbains est due à une contrainte d'espace à disposition dans la ville tout comme l'indique clairement l'exemple de l'atelier B car il faut souligner que dans le contexte suburbain ou rural, on connaît déjà quelques exemples d'ateliers comportant une dizaine de bassins dans la province ${ }^{40}$.

Pour ce qui est de la datation de l'établissement des ateliers de salaisons à Tipasa, il semble que le plus ancien soit implanté au plus tard au début du $\mathrm{III}^{\mathrm{e}} \mathrm{s}$. de notre ère puis il connaît un déclin à une époque tardive entre le milieu du $\mathrm{IV}^{\mathrm{e}}$ et le $\mathrm{VI}^{\mathrm{e}} \mathrm{s}$. au moment où une grande partie de l'installation est sacrifiée par l'agrandissement des thermes. Il en va de même dans les zones moins urbanisées puisque l'atelier de salaisons des Trois Îlots est lui aussi abandonné à une époque tardive : les cinq bassins de salaisons sont remblayés et des pièces munies de dolia sont aménagées au-dessus ${ }^{41}$. Là encore, la présence de ces grands récipients laisse à penser qu'une nouvelle activité qui reste à déterminer se développe au détriment de la première. Le fonctionnement d'ateliers de salaisons durant l'Antiquité tardive a également été mis en évidence pour des officines découvertes au Maroc, quelques-unes à Lixus notamment ${ }^{42}$.

Enfin, à quel marché étaient destinées ces productions urbaines ? On ne pourra vraiment répondre à cette question qu'à partir de recherches sur les contenants, amphores et peut-être dolia, afin d'identifier la zone de diffusion de ces productions et les potentiels résidus organiques qu'ils renferment.

On peut émettre l'hypothèse que ces petits ateliers urbains fournissaient le marché local sans exporter leur production, car il n'y a aucune trace à l'heure actuelle d'ateliers d'amphores. On peut supposer que les productions urbaines étaient stockées et commercialisées dans des amphores remployées (comme c'est le cas à Pompéi), dans des tonneaux de bois ou encore des dolia. Si les ateliers urbains approvisionnaient un marché local, il est probable en revanche que les grandes officines rurales étaient destinées à un commerce à plus grande échelle.
39. En effet, depuis la tenue du séminaire, A. Wilson s'est rendu il y a quelques mois à Tipasa où il a identifié des restes de bassins dans la falaise ; les traces restent très modestes. Je remercie très sincèrement A. Wilson pour cette information. S'il s'agit de bassins de salaisons et non de citernes, ils semblent avoir été plus grands que ceux des ateliers A et B. Toutefois, lors de leur prospection sur le littoral algérien, R. Yorke et D. Davidson signalent dans ce secteur la présence de citernes (Yorke, Davidson 1968, p. 14-15).

40. À l'ouest, au Guelta, un atelier présentant neuf cuves a été identifié (Leglay 1955, p. 216-217).
41. Lassus 1957, p. 130.

42. Habibi 2007, p. 189. 


\section{Bibliographie}

Arévalo, Bernal 2007 : ARÉVALO (A.), BERNAL (D.) (éd.) - Las cetariae de Baelo Claudia, Avance de la investigaciones arqueológicas en el barrio meriodional (2000-2004), Cádiz-Sevilla, 2007.

Baradez 1952 : BARADEZ (J.) - Tipasa, ville antique de Maurétanie, Alger, 1952.

Baradez 1961a : BARADEZ (J.) - Quatorze années de recherches archéologiques à Tipasa, 1948-1961, méthode et bilan, Revue africaine, CV, 468-469, 1961 , p. 215-250.

Baradez 1961b : BARADEZ (J.) - Nouvelles fouilles à Tipasa. La maison des fresques et les voies la limitant, Libyca, IX, 1961, p. 49-199.

Baratte 2010 : BARATTE (F.) - Le dossier des « monuments à auges ». Etat des questions. In : Bejaoui (F.) (coord.), Actes du $66^{e}$ colloque international sur l'histoire des steppes tunisiennes (Sbeitla, session 2008), Tunis, 2010, p. 285-306.

Ben Lazreg et al. 1995 : BEN LAZREG (N.), BONIFAY (M.), DRINE (A.), TROUSSET (P.) - Production et commercialisation des salsamenta de l'Afrique ancienne. In : Morel (J.-P.) (éd.), Productions et exportations africaines, actualités archéologiques en Afrique du nord antique et médiévale, CTHS, Paris, 1995, p. 103-132.

Blanchard-Lemée 1975: BLANCHARD-LEMÉE (M.) - Maisons à mosaïques du quartier central de Djemila (Cuicul), Paris, 1975.

Botte 2009 : BOTTE (E.) - Salaisons et sauces de poissons en Italie du Sud et en Sicile durant l'Antiquité, Naples, 2009.

Bouchenaki 1975 : BOUCHENAKI (M.) - Fouilles de la nécropole occidentale de Tipasa (1968-1972), Alger, 1975.

Curtis 1979: CURTIS (R.) - The garum shop of Pompei, Cronache pompeiane, V, 1979, p. 5-23.

Duval 1946 : DUVAL (P.-M.) - Cherchel et Tipasa, recherches sur deux villes fortes de l'Afrique romaine, Paris, 1946.

Duval, Cintas 1976 : DUVAL (N.), CINTAS (J.) - IV. Encore les monuments à auges d'Afrique : Tébessa Khalia, Hr Faraoun, MEFRA, 88, 2, 1976, p. 929-959.

Duval, Golvin 1972 : DUVAL (N.), GOLVIN (J.-C.) - Haïdra à l'époque chrétienne. IV : Le monument à auges et les bâtiments similaires, CRAI, 116, 1, 1972, p. 133-172.

Gsell 1926 : GSELL (S.) - Promenades archéologiques aux environs d'Alger (Cherchel, Tipasa, Le Tombeau de la Chrétienne), Paris, 1926.
Habibi 2007 : HABIBI (M.) - Nouvelle étude chronologique du quartier industriel de Lixus. In : Lagóstena (L.), Bernal (D.) et Arévalo (A.) (éd.), Cetariae 2005, Salsas y salazones de pescado en Occidente durante la Antigüedad, Oxford, 2007, p. 183-189.

Lancel 1982 : LANCEL (S.) - Tipasa de Maurétanie I, ANRW, II, 10.2, Berlin, 1982, p. 739-786.

Lassère 1982 : LASSÈRE (J.-M.) - Ubique Populus, Peuplement et mouvements de population dans l'Afrique romaine de la chute de Carthage à la fin de la dynastie des Sévères (146 av.-235 ap.), Paris, 1982.

Lassus 1957 : LASSUS (J.) - L'archéologie algérienne en 1956, Libyca a/é, V, 1, 1957, p. 123-152.

Lassus 1958 : LASSUS (J.) - L'archéologie algérienne en 1957, Libyca a/é, VI, 2, 1958, p. 197-266.

Leglay 1955 : LEGLAY (M.) - L'archéologie algérienne en 1954, Revue africaine, XCIX, 1955, p. 212-233.

Leschi 1950 : LESCHI (L.) - Tipasa de Maurétanie, Alger, 1950.

Leveau 1984 : LEVEAU (P.) - Caesarea de Maurétanie, une ville romaine et ses campagnes, CEFR, 80, 1984.

Ponsich, Tarradell 1965 : PONSICH (M.), TARRADELL (M.) - Garum et industries de salaisons dans la Méditerranée occidentale, Paris, 1965.

Slim et al. 2004: SLIM (H.), TROUSSET (P.), PASKOFF (R.), OUESLATI (A.) - Le littoral de la Tunisie : étude géoarchéologique et historique, Paris, 2004.

Slim et al. 2007 : SLIM (L.), BONIFAY (M.), PITON (J.), STERNBERG (M.) - An example of fish saleries in Africa Proconsularis : the officinae of Neapolis (Nabeul, Tunisia). In : Lagóstena (L.), Bernal (D.) et Arévalo (A.) (éd.), Cetariae 2005, Salsas y salazones de pescado en Occidente durante la Antigüedad, Oxford, 2007, p. 21-44.

Thébert 2003 : THÉBERT (Y.) - Thermes romains d'Afrique du Nord et leur contexte méditerranéen, BEFAR, 315, Rome, 2003.

Wilson 2007: WILSON (A.) - Fish salting worshops in Sabratha. In : Lagóstena (L.), Bernal (D.) et Arévalo (A.) (éd.), Cetariae 2005, Salsas y salazones de pescado en Occidente durante la Antigüedad, Oxford, 2007, p. 173-181.

Yorke, Davidson 1968 : YORKE (R. A.), DAVIDSON (D. P.) - Roman harbours of Algeria, Report of the Maghreb Project, 1968. 



\section{Exploitation et commercialisation des ressources maritimes de la Petite Syrte : témoignages archéologiques et spécificités régionales}

\section{Ali Drine, Elyssa Jerray}

$\mathrm{L}$ es prospections et recherches récentes ont permis de mettre en évidence le rôle prépondérant de l'Afrique Proconsulaire dans la production et la commercialisation des salsamenta. Le littoral tunisien en particulier a bénéficié d'études plus approfondies, notamment dans le cadre des fouilles de l'usine à salaisons de Nabeul ou encore des prospections menées le long du littoral ${ }^{1}$. Ces travaux ont mis en lumière une véritable spécialisation de certains sites dans la production de cette denrée.

Conjointement à ces recherches, l'étude des amphores ayant transporté ces produits a permis d'appréhender les nombreuses problématiques liées à la commercialisation des salsamenta et à leurs conteneurs. Cette démarche permit en effet de faire le lien entre les sites de production et la multitude d'amphores africaines découvertes sur divers lieux de consommation mais aussi de souligner l'importance de cette denrée dans les échanges méditerranéens antiques, au même titre que l'huile ou le vin ${ }^{2}$.

C'est donc dans une démarche similaire que nous souhaitons aborder les questions de la production et de la commercialisation des produits dérivés de la pêche dans une région qui reste encore peu étudiée, celle de la Petite Syrte. Elle est pourtant mentionnée dans plusieurs sources anciennes qui font état d'une région riche et prospère et ce dès l'époque punique. Appuyant cette idée, une multitude de vestiges fut mise au jour, dont une partie est à rattacher à l'exploitation des produits de la mer.

L'objectif de notre travail est double. Il s'agit tout d'abord de mettre en évidence le potentiel économique de la Petite Syrte qui reste jusqu'à présent peu connue. Les prospections menées le long du littoral tunisien ont révélé pas moins de quarante sites présentant des restes de bassins de salaisons antiques dont dix dans la région qui nous intéresse, entre le golfe de Gabès et la frontière libyenne. Ces vestiges, attestant d'une production de salsamenta à plus ou moins grande échelle, permettent d'attribuer à ce type d'industrie un rôle important dans

1. Slim et al. 2004 ; Slim et al. 2007.

2. Ben Lazreg et al. 1995. le développement économique de cette région. Nous pouvons donc supposer qu'à l'image des nombreux sites découverts dans le Cap Bon ou le Sahel, le sud tunisien a pu également contribuer à l'approvisionnement de certains sites méditerranéens.

La question du contenant constitue le deuxième axe de recherches qui a suscité notre intérêt. Un des objectifs de nos récentes campagnes de prospections menées dans la région de Zarzis était d'établir s'il était possible d'associer un conteneur à cette production de salsamenta. La mention d'une production d'amphores sur le site d'Henchir Mdeina nous semble un point de départ idéal pour aborder cette question. Nous élargirons néanmoins aux diverses attestations de productions d'amphores connues dans la région et au matériel céramique récolté lors de nos diverses prospections ${ }^{3}$.

\section{Cadres de l'étude}

Traditionnellement la Petite Syrte désigne l'actuel golfe de Gabès et l'espace côtier compris entre les îles de Kerkennah et l'île de Jerba ${ }^{4}$. La délimitation exacte de la région variant sensiblement selon les auteurs anciens, il est possible d'associer à cet ensemble cohérent la façade plus orientale, qui va de la péninsule de Zarzis jusqu'à la frontière libyenne ${ }^{5}$.

La Petite Syrte a longtemps véhiculé l'image d'une région dangereuse et peu propice à un développement économique et commercial. Il reste en effet un trait commun à toutes les descriptions des auteurs antiques : la dangerosité des côtes. Pline décrit ces deux baies rendues «... redoutables (par) les hauts-fonds et les mouvements de la marée dans les deux Syrtes ». Lucain quant à lui parle d'une frontière incertaine entre le domaine

3. Nous remercions M. Sami Ben Tahar (chercheur à l'INP) qui a également participé à ces prospections.

4. Sur les limites de la Petite Syrte et les sources la concernant voir Trousset et al. 2004, p. 15-18; Drine 2010.

5. Pline, V, 26 et le Stadiasme par exemple donnent Sabratha comme extrémité orientale à la région de la Petite Syrte. 
maritime et le domaine terrestre, évoquant ainsi les nombreuses lagunes et sebkhas qui bordent la côte ${ }^{6}$.

Toutes ces descriptions antiques correspondent à une certaine réalité. Dans le golfe de la Petite Syrte se trouvent en effet les plus fortes marées de la Méditerranée ${ }^{7}$ et des zones de hauts-fonds qui sont davantage développées au Nord, autour des îles de Kerkennah et au Sud autour de Jerba. Au vu de ces caractéristiques géographiques particulières, Strabon décréta que « seule l'avidité mauvaise des gens du commerce » a pu les pousser à fréquenter ces côtes ${ }^{8}$.

Les études récentes nuancent quelque peu ce tableau. Les conditions de navigation sont loin d'être aussi dangereuses et s'avèrent être à l'inverse parfois meilleures que celles de la côte septentrionale : "les vents y sont moins violents, la mer rarement très grosse ${ }^{9}$. Il est communément admis que cette réputation de dangerosité fut probablement amplifiée du temps où cette région appartenait à l'empire carthaginois. Elle exprime la volonté de Carthage de préserver ses comptoirs des Grecs et des Romains ${ }^{10}$.

Cette géographie particulière du littoral, qui alterne cap, îles, presqu'̂lles et lac va toutefois constituer un facteur favorable pour le sujet qui nous intéresse: l'exploitation des produits de la mer. Nous faisons ici références aux véritables abris naturels qui ponctuent le golfe de Gabès et du lac El Bibène ${ }^{11}$ et qui menèrent les auteurs anciens à associer morphologie des côtes et pêche. Prenons pour exemple le promontoire de Ras Kaboudia où débute une zone de hauts fonds. Ce cap correspond au promontoire d'Ammon Balithon de Strabon (XVII, 3, 16) qui signale la présence d'un thynnoscopium, sorte d'observatoire «pour épier la marche des thons $\gg{ }^{\mathbf{1 2}}$.

Un autre facteur favorable à l'établissement d'industries liées aux activités de la pêche est la proximité de salines, encore exploitées aujourd'hui, et qui constituent un ingrédient indispensable à la réalisation des salsamenta ${ }^{13}$.

À ces éléments «indirects », permettant d'appuyer l'idée d'un environnement propice à la production de

6. Pline, V, 26 ; Lucain, Pharsale, IX, 303-304.

7. Mzabi 1993, p. 248-252.

8. Strabon, XVII, 836 ; Slim et al. 2004, p. 17.

9. Slim et al. 2004, p. 17.

10. Mrabet 2002, p. 452 ; Gsell 1920, IV, p. 120.

11. Mzabi 1993, p. 248-252. Aujourd'hui encore, cette région est réputée pour ses eaux poissonneuses.

12. Strabon, XVII, 3, 16.

13. Trousset 1992, p. 322 ; Drine 1999a. salsamenta, vont s'ajouter les nombreux témoignages archéologiques découverts dans la région. Pour la zone qui nous intéresse, ces vestiges nous sont connus essentiellement grâce aux campagnes de prospections menées entre 1987 et 1991 le long du littoral tunisien. Elles font état de plusieurs structures dotées de cuves de salaisons dont certaines suggèrent une production à grande échelle.

Il est possible grâce à ces recherches de dégager deux ensembles principaux ayant livré des restes de bassins (fig. 1) :

- un premier situé dans la région de Sfax, auquel on peut associer les îles de Kerkennah, avec les sites de Sidi Mansour, Henchir Chougaff, Thyna, Iunca et Borj el Hassar (Cercina) ${ }^{14}$.

- Le second se situe plus au sud, dans la région de Zarzis et autour du lac El Bibène, ensemble auquel nous pouvons associer les témoignages archéologiques de l'île de Jerba (fig. 2).

Signalons pour mémoire les sites découverts dans les environs de Gabès. Il s'agit essentiellement du site d'Oued El Akarit qui a par ailleurs livré des témoignages indiscutables de plusieurs fours à céramiques sur lesquels nous reviendrons ${ }^{15}$. Des prospections de la zone côtière allant de l'Oued el-Akarit aux abords du Djorf, ont été menées à la fin des années 1990 par Abdellatif Mrabet dans le cadre de l'élaboration de l'Atlas archéologique: seuls seize sites côtiers furent ainsi recensés parmi lesquels deux présentent des cuves assimilables à une production de salsamenta ${ }^{16}$. Il s'agit des sites d'Henchir Cheguef et Henchir Ettoual situés à deux kilomètres l'un de l'autre et aujourd'hui fortement arasés ${ }^{17}$.

Strabon décrit sur cette portion de côte une activité maritime liée au «flux et au reflux» de la mer ${ }^{18}$. Cependant la sporadicité des vestiges dans ce secteur implique une activité davantage artisanale et vivrière, en opposition avec ceux retrouvés plus au Nord et au Sud.

Si Strabon constitue une des principales sources nous permettant de saisir l'importance de la pêche dans la région, d'autres textes nous permettent d'appréhender les activités qui lui sont associées. Ceux-ci concernent notamment l'espace auquel nous allons nous intéresser plus en détail à présent, celui compris entre l'île de Jerba et la frontière libyenne.

14. Slim et al. 2004, p. 123-126, sites n ${ }^{\circ} 54-56-61$; p. 130-133, site $\mathrm{n}^{\circ} 68$.

15. Slim et al. 2004, p. 111-112, site $\mathrm{n}^{\circ} 39$.

16. Mrabet 2002, p. 454-455.

17. Ibid., p.461-462. Le site a par ailleurs révélé d’importantes jonchées de céramiques.

18. Strabon XVII, 3, 17. 


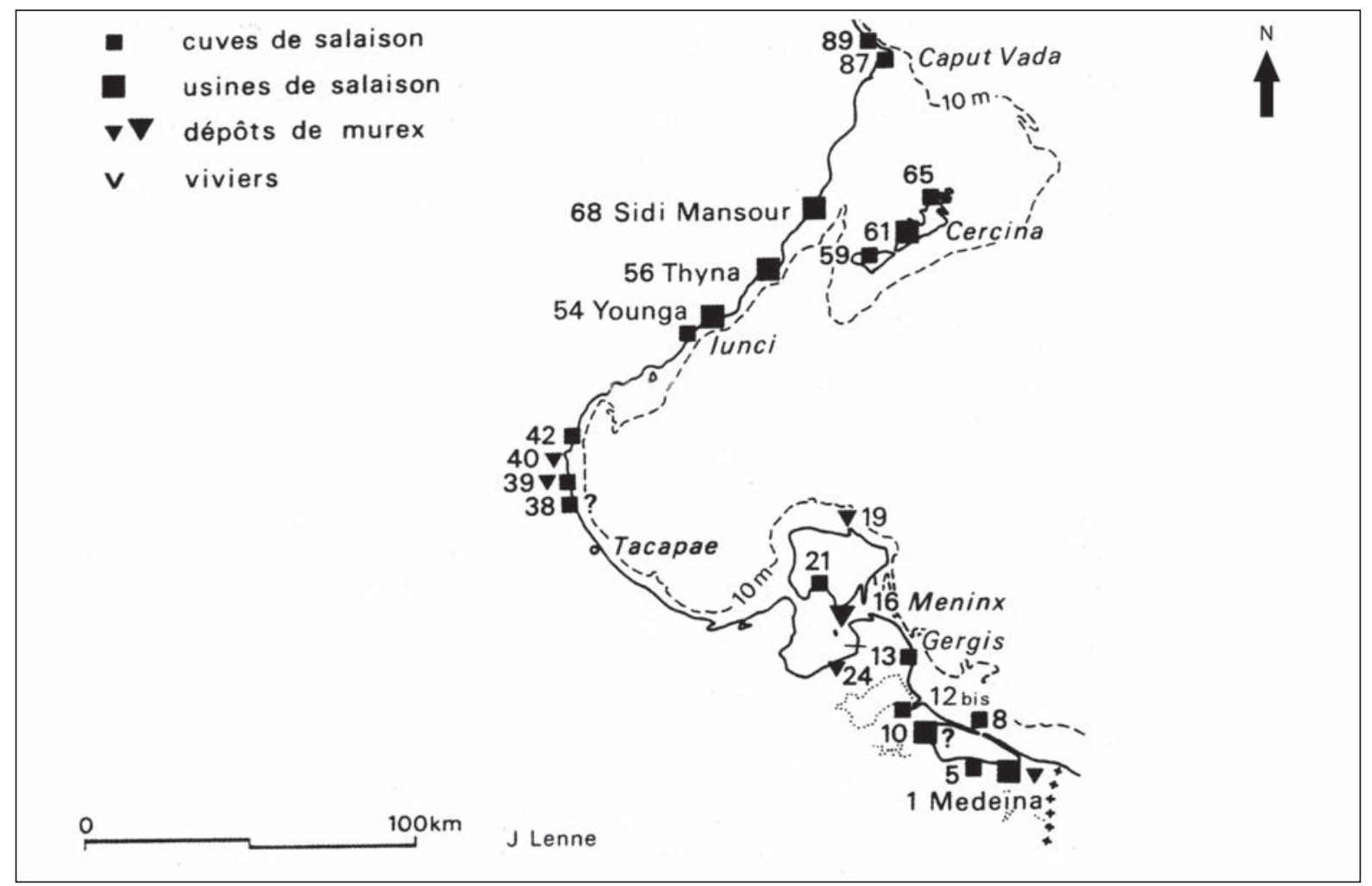

Fig. 1. Carte du littoral tunisien : localisation des principaux vestiges d'industries halieutiques découverts dans la région de la Petite Syrte (d'après un détail de Slim et al. 2004).

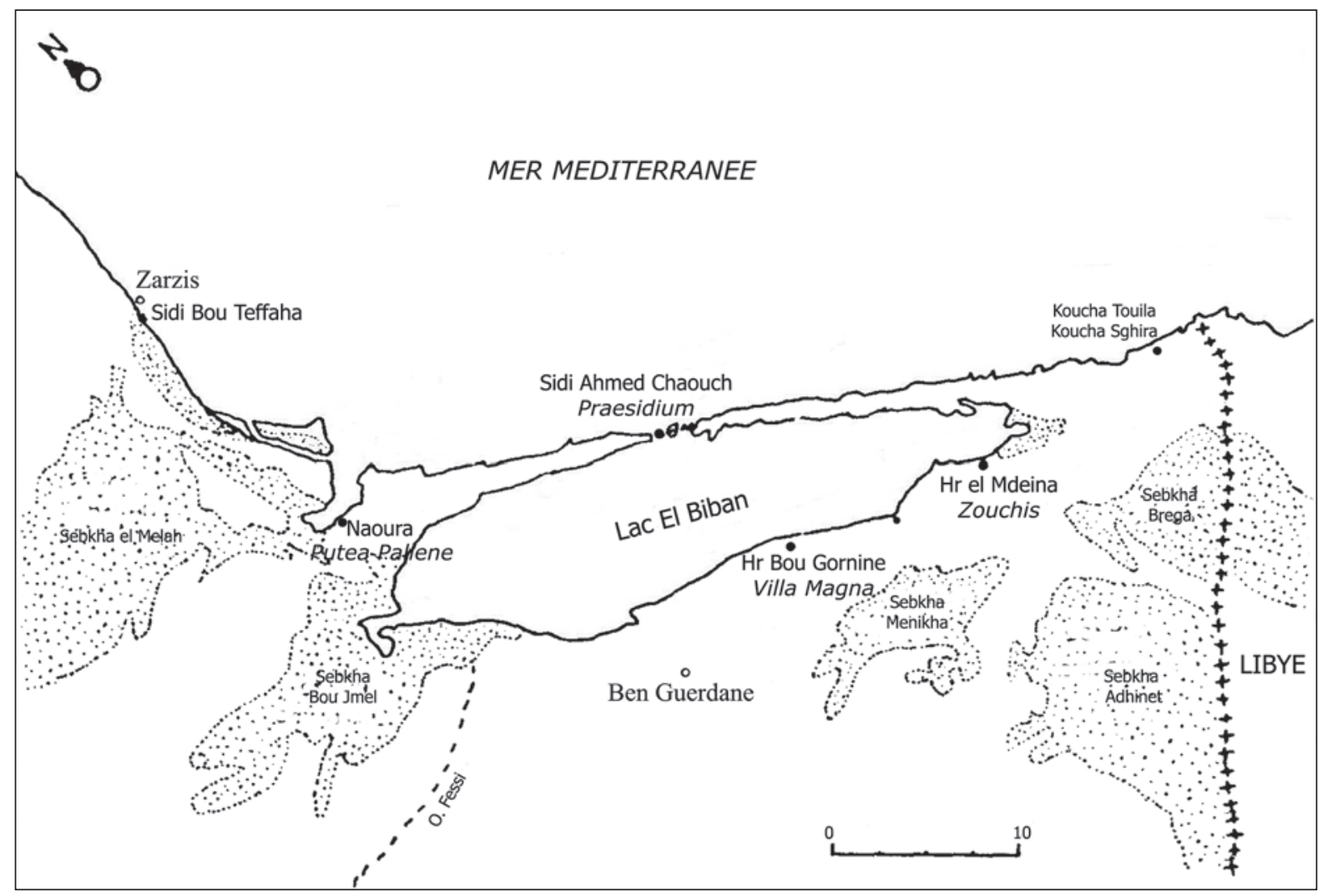

Fig. 2. Sites autour du lac El Bibène mentionnés dans le texte (d'après Drine 2002). 


\section{Quelques sites de production : pourpre et/ou salaisons?}

Dans la partie méridionale de la Petite Syrte, il est possible de dégager deux principaux centres de traitement de produits halieutiques, assez importants pour qu'il en soit fait écho dans les sources écrites. Il s'agit d'Henchir Mdeina, attribué à la Zouchis de Strabon, et de Meninx qui est connue essentiellement pour sa production de pourpre.

\subsection{Henchir Mdeina}

Avant d'être identifié au site d'Henchir Mdeina, le site était connu dans les textes grâce essentiellement à Strabon :

"Le Zuchis qui succède à la Petite Syrte est un lac de 400 stades de tour à l'embouchure fort étroite, avec une ville de même nom sur ses bords, laquelle possède des porphyrobaphées ou teintureries de pourpre et toute espèce d'établissements pour la salaison du poisson (taricheiae)». (XVII, 3, 17).

La mention de taricheiae dans le Périple de Scylax «à une journée de navigation d'Abrotonon », désigne probablement la même ville qui, selon cette source, disposait également d'un port ${ }^{19}$.

L'identification de la Zuchis de Strabon avec le site d'Henchir Mdeina est aujourd'hui généralement admise au vu de la localisation du site et de ses nombreux vestiges caractéristiques ${ }^{20}$. Situées à vingt kilomètres au N.-E. de Ben Guerdane, les ruines se trouvent sur un petit promontoire au S.-E., sur les rives du lac El Bibène. Le site fut découvert et étudié à la fin du XIX à l'époque de la colonisation française ${ }^{21}$. Dès cette époque, l'importance du lieu et sa probable vocation industrielle et commerciale avaient été reconnues. Cette lecture du site était due en partie à la première interprétation des vestiges. Le commandant Rebillet mentionne en effet la présence de « restes extrêmement imposants » dont ceux d'un « quai » et d'une série de « magasins » contigus.

Plus récemment, ce quai en question fut identifié par l'équipe de recherche du littoral comme étant en réalité les soubassements de murs d'une usine à salaisons, les élévations ayant été entamées par l'action de la mer dont

19. Périple de Scylax, 110 ; Gsell 1918, p. 123, note 11.

20. Voir Drine 1992-93.

21. Rebillet 1892, p. 126-128 ; Lecoy de la Marche 1894, p. 411-412. le niveau s'est légèrement relevé depuis l'Antiquité ${ }^{22}$. Les « magasins ${ }^{\mathbf{2 3}}$ (ou « cales sèches ${ }^{\mathbf{2 4}}$ selon les interprétations), correspondent quant à eux aux restes d'une batterie de cuves et de citernes dans un meilleur état de conservation. Le Commandant Rebillet livrait lui-même une indication précieuse corroborant cette réinterprétation, décrivant les bassins comme étant « soigneusement pourvus, sur le sol et sur les parois verticales, d'enduits en chaux hydrauliques ${ }^{25}$. Il signalait également une grande quantité de monnaies et de clous en bronze sur le site, matériel qui est encore présent dans des proportions importantes.

Aujourd'hui, le quai mentionné par le Commandant Rebillet reste aisément identifiable. Il s'agit d'un alignement de blocs en partie immergés, de bonne facture, et s'étendant sur environ 600 mètres. En revanche la série de bâtiments qui le jouxte a été sérieusement entamée par l'action de l'eau et des marées, laissant apparaître néanmoins en coupe certaines structures rectangulaires assimilables à des citernes, présentant un béton de cendre grisâtre qui semble caractéristique de la région ${ }^{26}$.

En arrière du rivage, la présence d'alignements de murs arasés couvrant tout le site confirme la présence d'une importante installation de type industriel. Aujourd'hui seules deux cuves à salaisons sont visibles mais étant recouvertes en partie, il est difficile d'en fournir les dimensions exactes (fig. 3). Elles se situent à l'extrémité Est du site, à une dizaine de mètres en arrière de l'estran. Le prolongement d'un mur qui longe le deuxième bassin et qui se poursuit sur tout le versant Est de ce petit promontoire, laisse supposer que ces cuves s'inscrivaient à l'intérieur d'un ensemble clos qui comprenait vraisemblablement d'autres structures similaires. Il est à noter que l'essentiel des fragments d'amphores récoltés sur le site fut découvert à cet endroit.

Des alignements de murs arasés semblables sont également visibles à l'entrée du site, à l'ouest, soit à plus de 600 mètres des cuves décrites ci-avant. Il s'agit d'une série de cinq structures rectangulaires accolées, d'environ trois mètres de large chacune.

Dans le même secteur, des fouilles clandestines ont révélé la présence de certaines structures de forme arrondie (fig. 4-5). Est-il possible de les associer à une activité associée à l'extraction de la pourpre ? A proximité en effet, la présence d'une multitude de restes de

22. Trousset 1992 , p. 324-325.

23. Rebillet 1892, p. 126.

24. Lecoy de la Marche 1894, p. 411.

25. Rebillet 1892, p. 126.

26. Slim et al. 2004, p. 24-25. 
coquillages broyés et de nombreux foyers témoigne probablement de cette industrie.

En l'absence de fouilles ou de sondages, beaucoup de questions restent encore en suspens et la signification d'une partie de ces structures nous échappe. De nouvelles études permettraient d'apporter des informations cruciales quant à la typologie des structures de production inhérentes à l'extraction de la pourpre et des « toute espèce d'établissements » ${ }^{27}$ dédiés aux salsamenta. La vocation uniquement industrielle du site fait de Zouchis un endroit privilégié pour aborder ces questions.

\subsection{Jerba et le cas de Meninx}

Il nous a semblé intéressant d'établir un parallèle entre le site d'Henchir Mdeina et la ville de Meninx qui est également mentionnée dans les sources pour son industrie de la pourpre. L'île de Jerba a bénéficié dans les années 2000 d'un projet associant l'Institut National du Patrimoine de Tunis et l'Académie Américaine de Rome. La documentation issue de ces travaux constitue aujourd'hui une grande partie de nos connaissances sur le sud tunisien ${ }^{28}$. Les prospections ont ainsi révélé l'existence de divers sites de productions, dont les plus évidents sont les fours à céramiques. Concernant les sites de production liés aux produits de la mer, les vestiges archéologiques sont plus difficiles à interpréter.

L'activité halieutique de l'île semble majoritairement dévolue à l'exploitation de la pourpre. Plusieurs sites en effet font état de concentrations de rebuts de murex concassés, caractéristiques de cette industrie ${ }^{29}$. Grâce à la mention de Pline, la ville de Meninx est dans l'historiographie étroitement liée à l'exploitation de ce coquillage. Il note en effet: "La pourpre la plus estimée en Asie est celle de Tyr, en Afrique celle de Meninx et de la côte gétule de l'océan, en Europe celle de Laconie ${ }^{30}$. La mention d'un procurator bafii Girbitani, provinciae Tripolitanae dans la Notitia Dignitatum, atteste également de l'importance et de la continuité de cette industrie à Jerba mais également dans la région ${ }^{31}$.

27. Strabon, XVII, $3,17$.

28. Jerba 2009.

29. Les sites ayant livré des témoignages de production de pourpre à Jerba : Ghizène ; Guellala (Haribus).

30. Pline, H.N., 127.

31. Notitia Dignitatum, occ. XI, 69, (Ed. O. Seek, Berlin 1876). Concernant la pourpre de Meninx et ses diverses mentions dans les sources voir Drine 2007 ; Drine 2008 ; Jerba 2009, p. 167-174.
Les fouilles ont ainsi révélé la présence d'un véritable quartier voué à cette industrie, à proximité duquel on trouve d'importants amoncellements de débris de coquillages pouvant atteindre jusqu'à 8 ha. La présence de plusieurs bassins, de citernes et de foyers atteste d'un processus d'exploitation quasi industriel. (fig. 6). Est-il envisageable qu'une partie de ces cuves ou bassins soit également vouée à la fabrication des salsamenta?

Certains éléments suggèrent une intensification de la production de salsamenta au cours du $\mathrm{V}^{\mathrm{e}} \mathrm{s}$., dans le secteur des horrea notamment, qui semble perdre sa fonction première de stockage pour privilégier cette industrie. Les fouilles d'une cuve d'époque tardive, les restes de poissons découverts sur les parois de plusieurs amphores ainsi qu'une accumulation d'écailles de poissons à proximité confirment cette hypothèse ${ }^{32}$ (fig. 7). Il demeure néanmoins délicat de comprendre la destination exacte de chacune des structures découvertes et de fournir une estimation quant à la capacité de production du site.

Le rapprochement entre les sites de Meninx et Mdeina nous amène par conséquent à nous interroger sur la typologie des structures dévolues à l'exploitation de la pourpre et des salsamenta. Alors qu'à Meninx tout plaide en faveur d'un site dont l'extraction de la pourpre a constitué la principale activité, à Mdeina en revanche, le témoignage de Strabon nous permet d'envisager une certaine forme de diversification de ces activités. Il est probable que l'exploitation du poisson ou du coquillage pouvait alterner au gré des saisons ${ }^{33}$. Plusieurs sites méditerranéens attestent par ailleurs d'une production conjointe de ces deux denrées.

D'autres sites ont révélé la présence de structures dont la typologie évoque celle des bassins à salaisons. Signalons celui de Sidi Bou Teffaha, à proximité de Zarzis ${ }^{34}$ ou de Naoura ${ }^{35}$ (Putea Pallene), situé sur les bords de la lagune de la Bahar Alouane et où des bassins furent découverts plus récemment (fig. 8-9). Nous émettons cependant quelques doutes quant à l'identification du bassin de la figure $n^{\circ} 8:$ de dimensions réduites, il présente des caractéristiques communes avec les bassins de salaisons comme l'enduit de béton de tuileau qui recouvre les parois. Cependant la petite canalisation, au sommet, ne nous semble pas caractéristique de ce type

32. Jerba 2009, p. 227-229.

33. Ben Lazreg 1995, p. 114-115 ; Drine 2008.

34. Trousset 2004, site ${ }^{\circ} 13$, p. 98 . Découvert à la fin du $\mathrm{XIX}^{\mathrm{e}}$ s., l'alignement de bassins avait été identifié à tort comme étant des « entrepôts d'huile »: Du Breuil de Pontbriand 1906, p. 251-252.

35. Slim 2004, p. 98 , Site $n^{\circ} 12$ bis. 


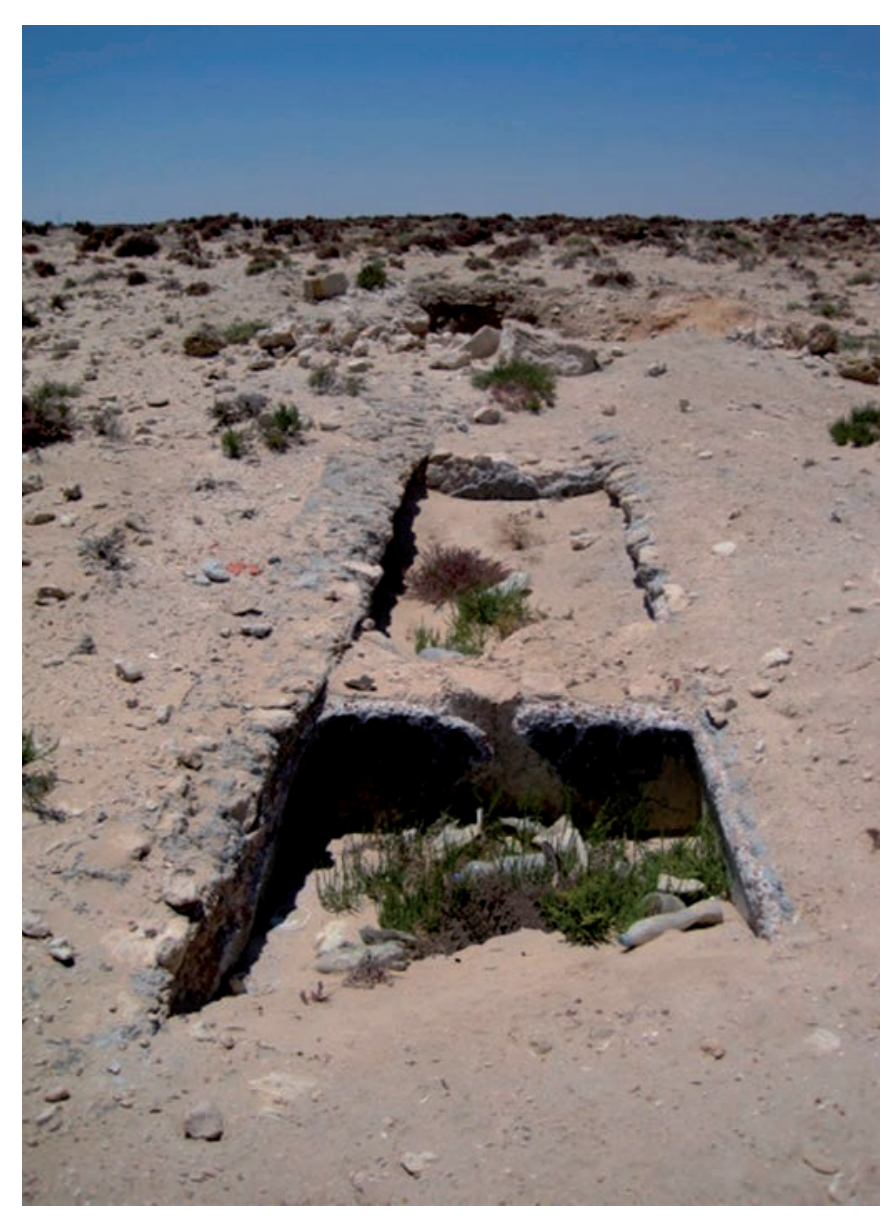

Fig. 3. Henchir Mdeina : bassins de salaisons.
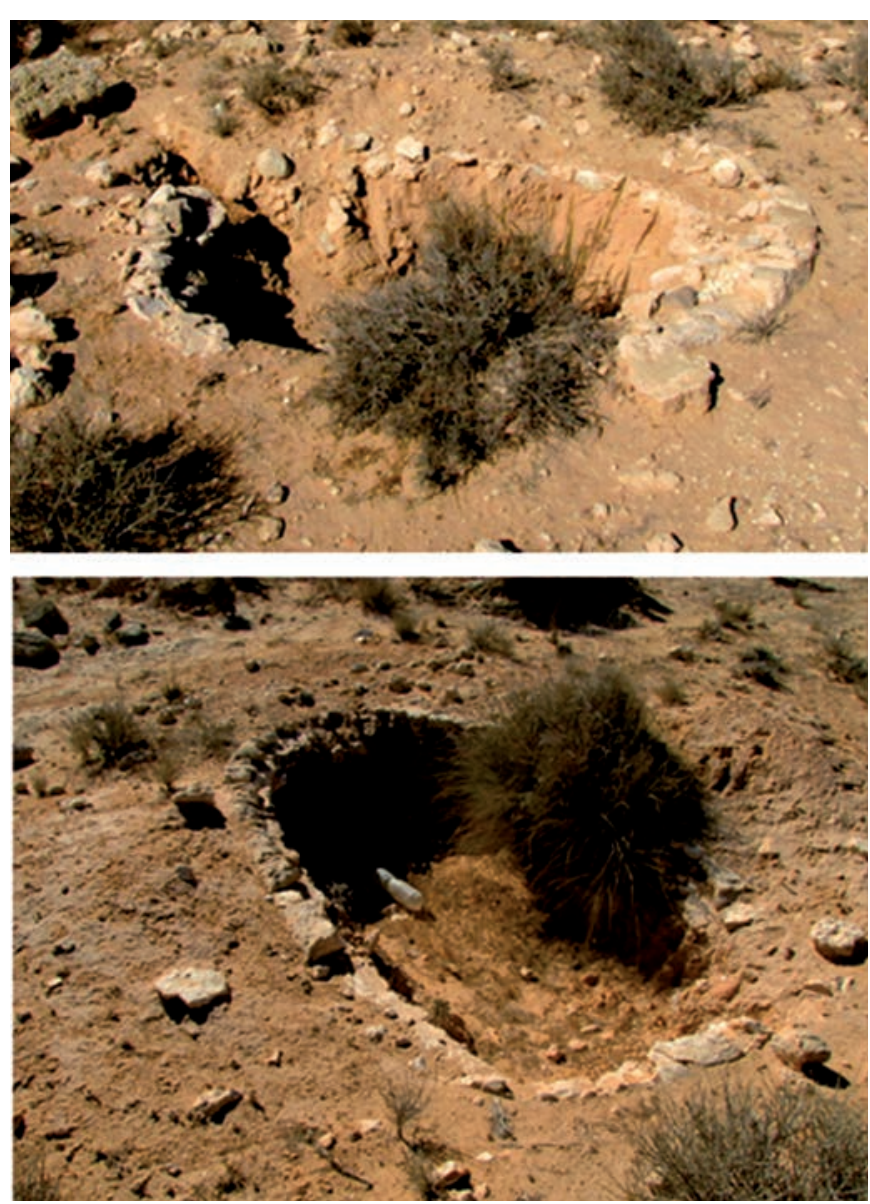

Fig. 4-5. Exemples de structures découvertes à Henchir Mdeina.

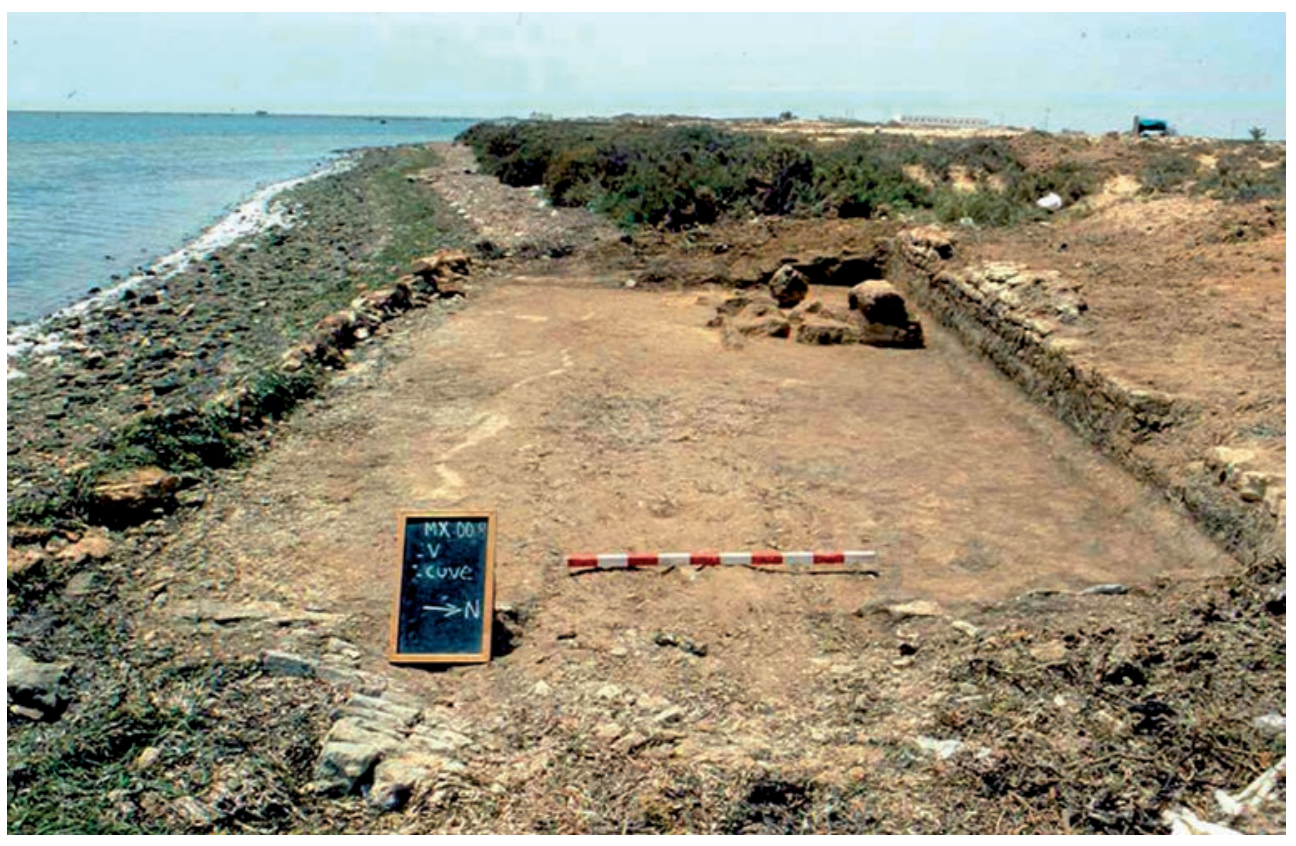

Fig. 6. Cuve fouillée à Meninx. 


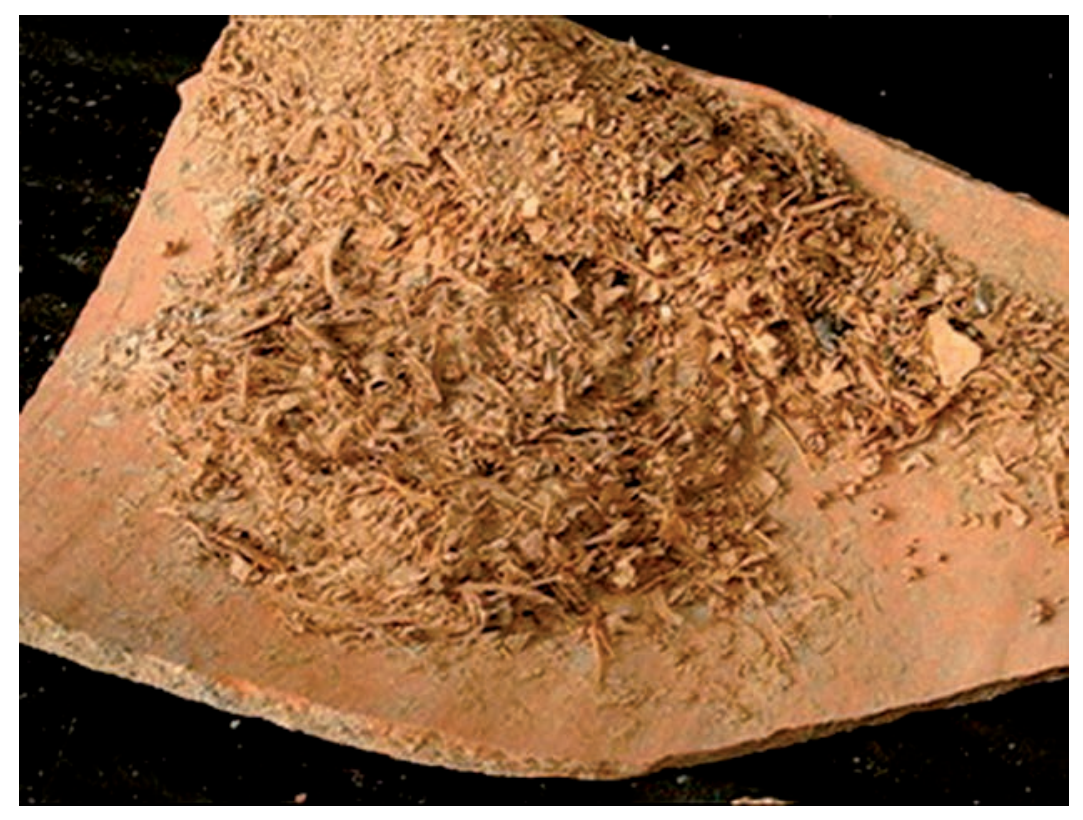

Fig. 7. Restes de poissons

découverts sur les parois d'une

amphore de Meninx.
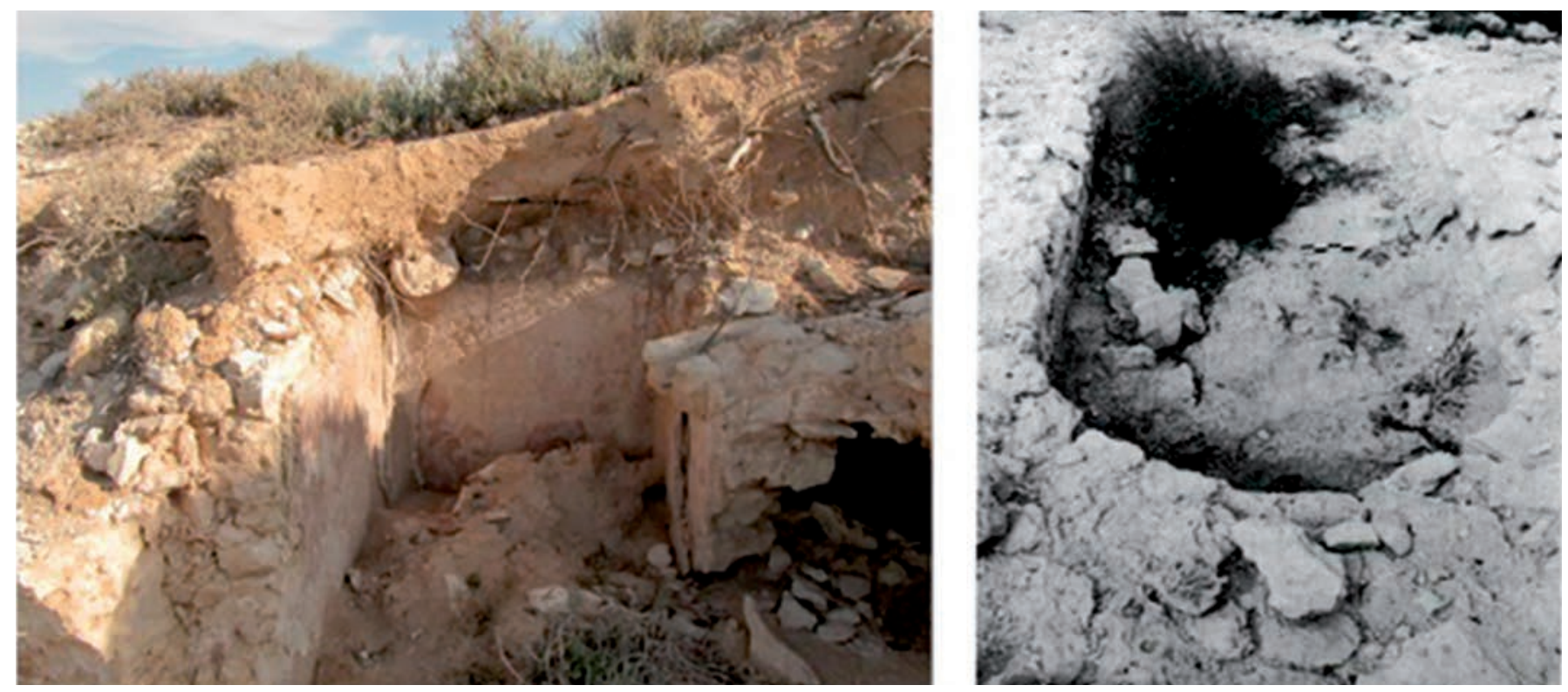

d'exploitation. Ainsi, en l'absence de recherches plus approfondies, seul le bassin découvert dans les années 2000, avec ses angles arrondis caractéristiques, peut être attribué à une production de salsamenta ${ }^{36}$.

Le choix de nous arrêter sur les sites d'Henchir Mdeina, de Meninx et de Naoura fut motivé par diverses raisons. Les deux premiers tout d'abord figurent parmi les plus connus, que ce soit grâce aux sources anciennes ou aux recherches récentes menées à Jerba. Si dans le cas de Meninx, ces activités s'insèrent dans un cadre urbain bien délimité, qui va semble-t-il de pair avec

36. Drine 2002, p. 2003 ; Drine, 1992-93, pl. IV, fig. 5. le développement de la ville, la présence de bassins à Henchir Mdeina et à Naoura implique différentes structures de production. Dans le premier cas, l'occupation du site semble exclusivement tournée vers la mer et l'exploitation de la pêche. Seule une nécropole fut découverte à proximité mais nous ne disposons d'aucune information relative à une ville ou un domaine auquel cette exploitation pourrait être rattachée. Les mentions de bassins à Naoura ou encore à Bou Gornine ${ }^{37}$, impliquent quant à elles une production moindre et qui semblent en relation avec une villa, du moins avec un établissement agricole et maritime.

37. Slim 2004 , p. $94, n^{\circ} 5$ et p. $98, n^{\circ} 12$ bis. 
Lorsque nous avons choisi de nous intéresser à la production de salsamenta dans la région de la Petite Syrte, un de nos objectifs était d'enrichir ce dossier de nouvelles données céramologiques et d'aborder plus spécifiquement la question du conteneur. Comme nous l'avons rappelé au début de notre article, cet aspect fut plus largement abordé dans le nord de la Tunisie et notamment dans les environs proches de deux usines à salaisons : Nabeul et Salakta ${ }^{38}$.

Les diverses études concernant la Petite Syrte ont mis en évidence les nombreux facteurs propices au développement d'une industrie halieutique ainsi que divers témoignages archéologiques attestant de celleci. Les sources ainsi que les dimensions des sites de Meninx et d'Henchir Mdeina révèlent quant à elles la probable implication de cette région dans un commerce au long cours ${ }^{39}$. S'il est plus difficile d'appréhender la commercialisation de la teinture de la pourpre, celle des salsamenta en revanche implique un transport en amphore qui nous laisse davantage d'indices archéologiques ${ }^{40}$. Est-il par conséquent possible d'associer cette production de salsamenta «syrtique » à un conteneur ?

Parmi le large éventail des productions d'amphores romaines «tunisiennes », il semble qu'il soit possible aujourd'hui de distinguer une partie de celles affectées au transport des salsamenta. Bien que non définitives, ces hypothèses de travail sont le résultat d'une conjonction d'éléments : découvertes d'ateliers à proximité d'installations liées au traitement du poisson, constatations typologiques ou encore découvertes d'exemplaires poissés dans des épaves notamment ${ }^{41}$.

Concernant les conteneurs produits en Libye et plus précisément le territoire correspondant à la Tripolitaine occidentale, la question reste posée ${ }^{42}$. De nouvelles découvertes semblent cependant démontrer que l'amphore tripolitaine II constitue le type courant le plus probable pour avoir contenu cette denrée. Dans la région de Lepcis Magna en effet, fut mis au jour un atelier d'amphores tripolitaines II localisé à proximité d'une usine de salaisons ${ }^{43}$. Cet emplacement pourrait constituer un indice quant au contenu de cette amphore qui est encore débattu. D'autres fours découverts dans les

38. Slim et al. 2007 ; Ben Lazreg et al. 1995.

39. Jerba 2009, p. 209-210.

40. Signalons tout de même la mention de la pourpre dans le Tarif de Zaraï attestant de la commercialisation de ce produit : Trousset 2002, p. 365-366. Selon l'auteur, aux côtés des éponges et du garum, la pourpre mentionnée ne peut provenir que du Golfe de Gabès.

41. Bonifay 2004, p. 471-472.

42. Wilson 2002, p. 248 ; Bonifay 2004, p. 92.

43. Capelli, Leitch 2011. environs de Tripoli attestent également de la production de ce type d'amphores ${ }^{44}$.

\section{3. État des connaissances dans la région de la Petite Syrte}

Au Nord de la Petite Syrte, nous disposons de deux ateliers bien attestés, tous deux localisés à proximité d'usines à salaisons (fig. 10). Il s'agit des ateliers de Thyna et d'Oued el Akarit ${ }^{45}$. La localisation de ces fours à amphores ne suffit pas cependant à établir le contenu de celles-ci. Parmi les types produits apparaissent en effet des amphores africaines I, bien identifiées pour avoir contenu de l'huile. Concernant les amphores africaines II et Keay 25 produites également sur ces deux ateliers (seulement la variante IID à Oued el Akarit), plusieurs indices tels que la poix présente sur certaines de ces amphores découvertes lors de fouilles sousmarines notamment, plaident en faveur d'un contenu non oléicole ${ }^{46}$. Les recherches actuelles ne permettent pas cependant de trancher en faveur du vin ou des salsamenta.

Plus au sud, l'essentiel de nos connaissances au sujet des fours de la région est issu des recherches menées sur l'île de Jerba (fig. 11). Leur période d'activité s'échelonne de l'époque punique à aujourd'hui sans interruption. Parmi ces sites, dix-sept ont produit de la céramique antique ${ }^{47}$. Leur localisation, en majorité en milieu rural, et les types produits n'évoquent pas cependant des formes connues pour avoir transporté des salsamenta. Il s'agit en effet en majorité d'amphores d'imitation du type Dressel 2/4, bien identifiées comme ayant contenu du vin. Aux côtés de cette production majoritaire, Sergio Fontana mentionne cependant une production d'amphores tripolitaines I, d'africaines II et de Keay $25^{48}$. S'il est généralement admis que les amphores tripolitaines I aient transporté de l'huile, les deux autres types mentionnés par Sergio Fontana peuvent impliquer un contenu relatif à une production de salsamenta.

44. Bakir 1967, p. 242-243; Faraj Shakshuki, Shebani 1998.

45. Bonifay et al. 2002-2003, p. 162.

46. Sur les questions du contenu et de l'incompatibilité de l'huile et de la poix voir : Bonifay 2004, p. 463-473.

47. Pour cette étude, nous avons préféré laisser de côté les attestations de productions d'amphores puniques de Jerba. À ce sujet et concernant leur contenu voir Jerba 2009, p. 271-278 ; Fentress 2001. 48. La production du type africaine II se concentre selon l'auteur sur les sites de Meninx, Gmir et Gallala. Concernant le type Keay 25, des attestations sont signalées à Meninx et Gmir: Jerba 2009, p. 287-289. 


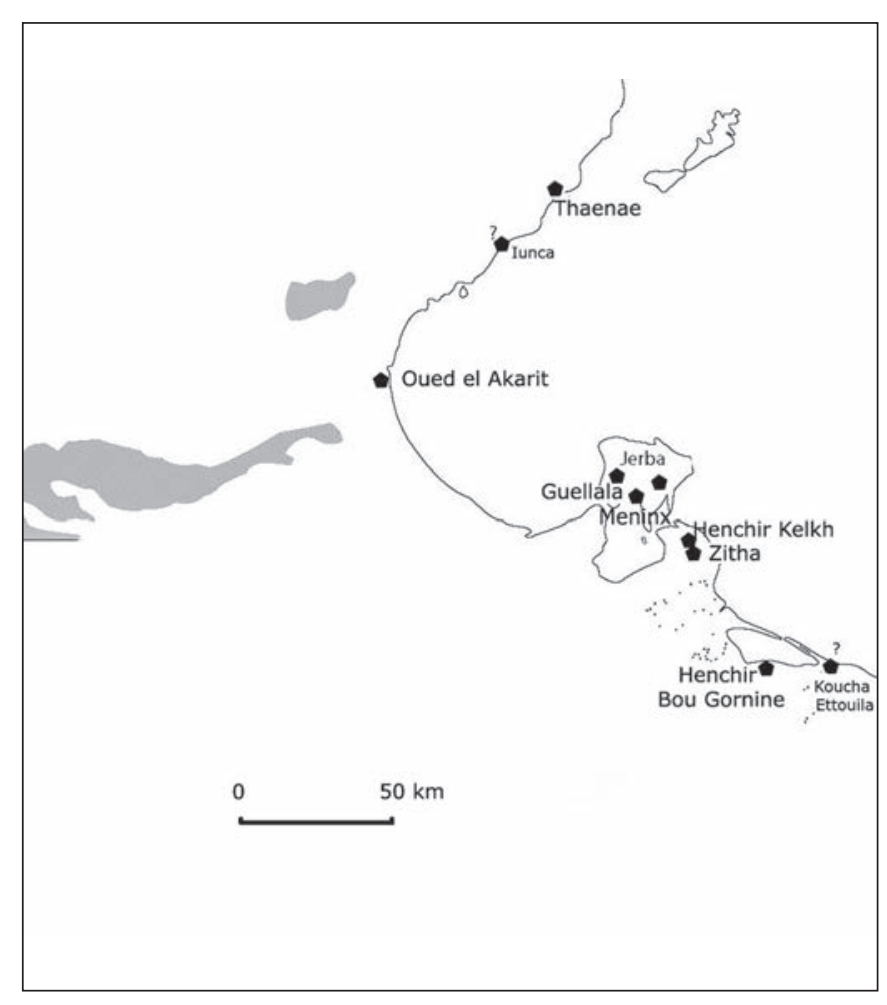

Fig. 10. Localisation des fours à amphores dans la région de la Petite Syrte.

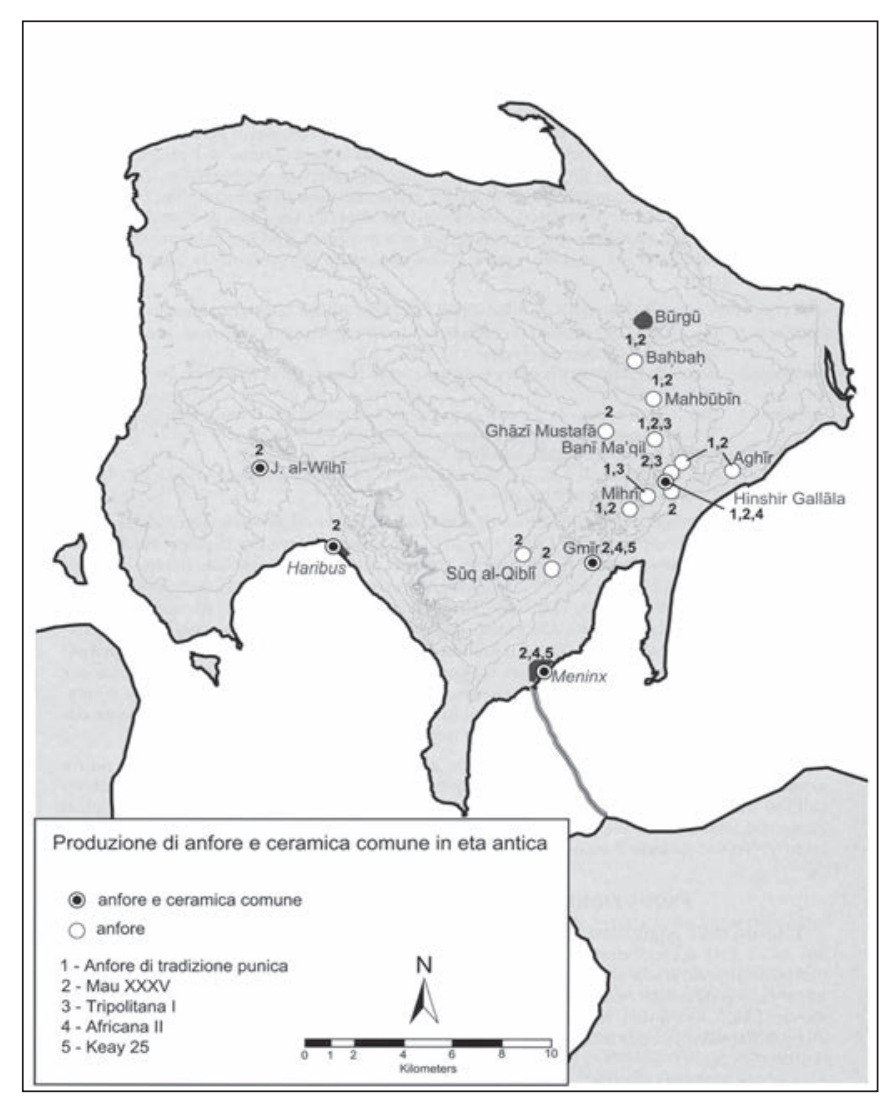

Fig. 11. Fours à amphores découverts à Jerba (d'après Jerba 2009).
Sur le continent, l'atelier de Zitha, à une dizaine de kilomètres à l'ouest de la ville de Zarzis, constitue un des principaux ateliers connus dans la région ${ }^{49}$. L'étude de la céramique récoltée en surface démontre que celuici produisit essentiellement des amphores dites de Tripolitaine (type I et III) ainsi que des amphores d'imitation du type Dressel 2/4, autrement dit des amphores à huile et à vin. Notons déjà l' absence significative du type Tripolitaine II. Bien qu'en moins grandes proportions, l'atelier a également produit des amphores africaines IIA. Comme pour les ateliers précédents, il est à noter que Zitha se situe à proximité de bassins de salaisons.

Les fours inédits découverts à Henchir Bou Gornine, sur les bords du lac El Bibène, semblent quant à eux avoir produit uniquement des amphores à huile tripolitaines I et III. Notons une nouvelle fois l'absence du type II.

Un des premiers constats, suite à ce bref inventaire de nos connaissances, est la transition qui s'opère au niveau d'Oued el Akarit entre les amphores dites « africaines » et «tripolitaines ». L'appellation de ces dernières, produites dès le $\mathrm{I}^{\text {er }} \mathrm{s}$. av. J.-C., du nom d'une province qui ne sera effective qu'au début du $\mathrm{IV}^{\mathrm{e}} \mathrm{s}$., bien qu'anachronique semble ainsi néanmoins correspondre à une certaine réalité.

Pourtant, à l'époque impériale du moins, ce constat ne semble s'appliquer en Tripolitaine tunisienne qu'aux amphores à huile. En effet, alors que nous disposons aujourd'hui de plusieurs ateliers attestant d'une production d'amphores tripolitaines I et III, nous n'avons jusqu'à présent aucune attestation de productions d'amphores tripolitaines II. En revanche, à Jerba comme à Zitha, existent de possibles productions d'amphores africaines classiques, de types africaine II (Jerba et Zitha) et Keay 25 (Jerba uniquement). Plus connue dans le nord du pays, la présence dans cette région d'ateliers ayant produit ces amphores surprend ${ }^{50}$. S'il est possible que la production de Keay 25 à Jerba ait pris la relève des amphores d'imitation du type Dressel 2/4 dont la production cesse entre la fin du $\mathrm{I}^{\text {er }}$ et du $\mathrm{II}^{\mathrm{e}}$ après J.-C. ${ }^{51}$,

49. Bonifay et al. 2010, p. 156-158. Les productions de l'atelier font l'objet d'une thèse en cours : E. Jerray, La production d'amphores tripolitaines dans la région de Zitha, sous la direction de A. Mrabet (Université de Sousse) et de X. Lafon (Université de Provence).

50. Tous les ateliers ayant produit ce type se situent au Cap Bon ou au Sahel. Signalons tout de même les amphores découvertes à $\mathrm{Bu}$ Njem pour lesquelles René Rebuffat suggère une production locale : Rebuffat et al., 1969.

51. L'arrêt de la production de ce type n'est pas encore définitivement établi. Sergio Fontana mentionne la présence d'amphores de ce type dans des niveaux de la moitié du $\mathrm{III}^{\mathrm{e}}$ s. ap. J.-C. Il reste possible néanmoins qu'il s'agisse de matériel résiduel : Jerba 2009, p. 282. 


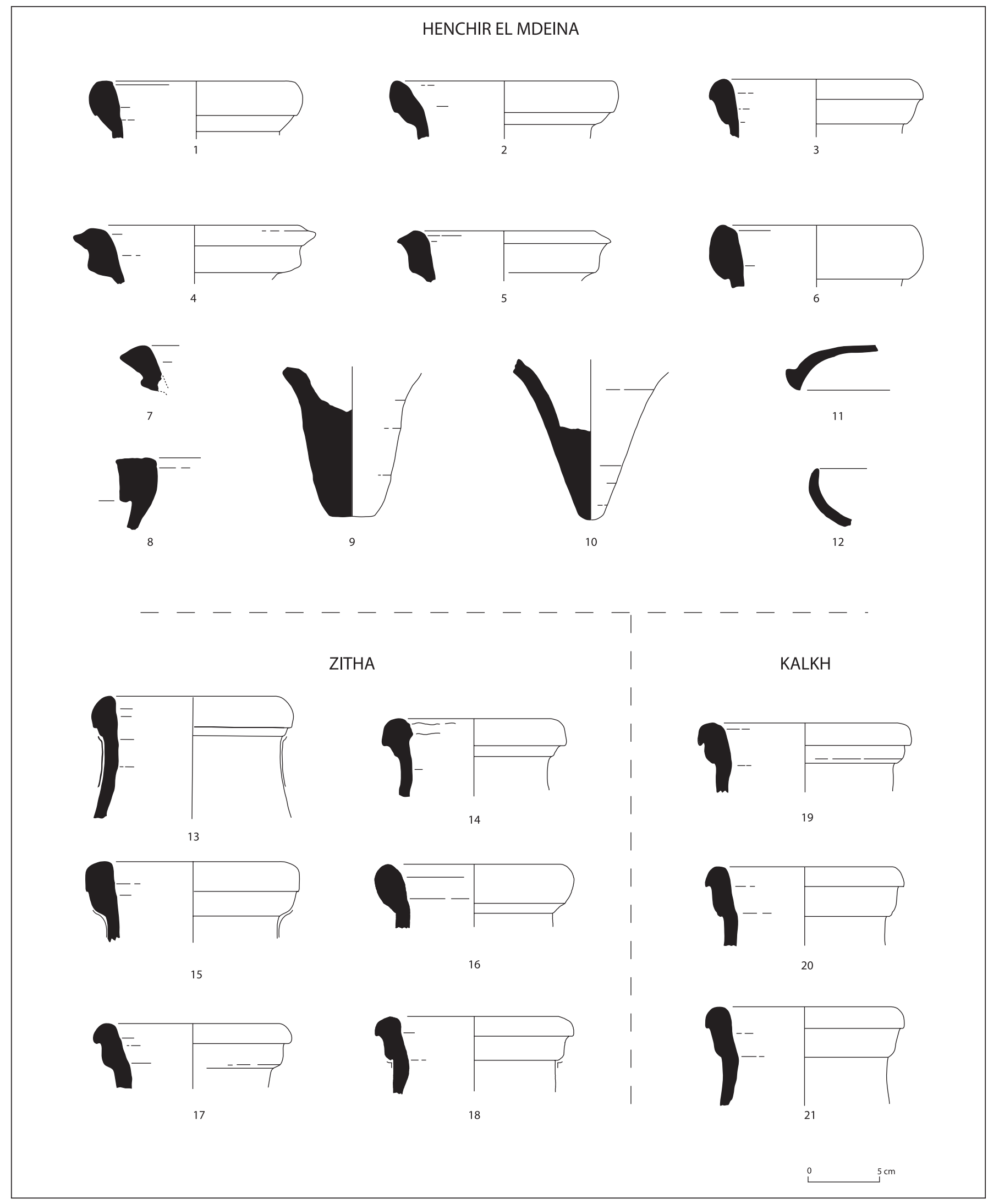

Fig. 12. Henchir Mdeina : Amphores: africaines IIA (1-3), Tripolitaine II (4-5, 7), Africaine IIC (ou Keay 57 ?) (6), Hammamet 2 ?(8), fond d'amphore africaine (9), fond d'amphore tripolitaine (10) ; Céramique culinaire : Hayes 181 (11), Hayes 182 (12) ; Zitha - Henchir Kalkh : Africaines IIA régionales (13-21) (échelle 1:4). 
la question concernant les amphores africaines II reste posée.

Les prospections menées sur l'usine de salaisons d'Henchir Mdeina ne nous ont pas davantage permis d'associer un conteneur à cette production de salsamenta. Parmi les types présents, les amphores africaines IIA et les tripolitaines II sont parmi les plus fréquentes mais elles apparaissent dans des proportions équivalentes (fig. 12, $\left.\mathrm{n}^{\circ} 1-5,10\right)$. Les fours signalés sur les sites de Koucha Touila et Koucha Sghira ${ }^{52}$, à une dizaine de kilomètres de Henchir Mdeina, pourraient constituer un élément important à cette étape de la recherche, à l'image des fours à amphores tripolitaines II découverts dans la région de Lepcis Magna. Malheureusement, nos prospections ne nous ont pas permis de nous rendre dans cette zone jugée peu sûre. La prochaine étape de notre travail consiste donc à déterminer si nous sommes bien en présence d'un atelier d'amphores, ensuite s'il est possible d'associer celui-ci à la production de salsamenta.

Hormis sur le site d'Henchir Mdeina, l'amphore Tripolitaine II demeure absente de la majorité des sites prospectés. Nous avons néanmoins noté un type récurrent qui s'est dégagé au fil de nos campagnes et qui présente selon nous des caractéristiques communes avec le type Africaine IIA. Ce type, généralement assimilé à l'amphore tripolitaine III, présente à l'instar de celle-ci un bord à doppio gradino mais reste peu évasé. Il est caractérisé par un gradin supérieur tombant, couvrant parfois légèrement le gradin inférieur bien arrondi (fig. 12, $\mathrm{n}^{\circ} 9$, 17-21). Notons en particulier le surcuit récolté sur le site de production de Henchir Kalkh qui présente de fortes similitudes avec certains bords de Salakta ou de Thyna (fig. 12, n8, 19). Seulement, en l'absence d'exemplaires complets, nous permettant d'apprécier la morphologie générale de l'amphore et la forme des anses notamment, il serait prématuré d'en tirer une quelconque conclusion.

Alors que les ateliers d'amphores constituent les principales attestations d'une production d'huile et de

52. Zaghdoud 2005, p. 178-179. Notons le toponyme arabe « koucha » qui signifie four. vin régionale ${ }^{53}$, les productions de salsamenta offrent ainsi une situation totalement inverse. Face aux nombreux bassins découverts, il demeure difficile d'associer un conteneur à cette production. La présence d'une production d'amphores africaines IIA conjuguée à l'absence d'amphores tripolitaines II sur plusieurs sites de la région, permet néanmoins d'envisager une production d'amphores à salsamenta dont la typologie se rapproche davantage de celle des ateliers de Byzacène.

Peu de certitudes donc mais beaucoup d'hypothèses permettant d'entrevoir les nombreuses perspectives de recherches à venir. Il est aujourd'hui primordial de poursuivre les prospections et de préciser la typologie de ces différents ateliers d'amphores. Sans la découverte de nouveaux fours et une étude typo-chronologique détaillée de ces ateliers d'une part, et des sites de production de salsamenta de l'autre, il demeure en effet délicat d'associer ces deux types d'industries.

La vision d'ensemble que nous avons essayé de présenter ici nous a permis de mettre en évidence l'intérêt d'intégrer les données concernant la production de salsamenta dans une dynamique régionale en l'associant à d'autres témoignages d'activités économiques. La production de murex, qui implique un commerce au long court, et la spécialisation de certains sites dans l'industrie halieutique, invitent à penser que l'exploitation des produits de la mer jouait un rôle moteur dans le développement et le maintien économique de la région. La présence de ces divers témoignages archéologiques sur la route du littoral sous-tend également l'idée selon laquelle ces diverses activités furent imbriquées et participaient au même essor économique ${ }^{54}$.

L'étude des amphores a permis de pointer un autre aspect lié à la localisation même de cette région, à cheval entre ce que seront au $\mathrm{IV}^{\mathrm{e}} \mathrm{s}$. les provinces de Byzacène et de Tripolitaine. Cette particularité fait de la Petite Syrte un contexte original pour appréhender les questions relatives aux structures de production ou aux amphores, faisant le lien entre la Tunisie et la Libye occidentale.

53. Sur les vestiges de pressoirs et les meules découverts dans la région de Zarzis voir Drine 1999 et 2001 ; à Henchir Bou Gornine : Rebillet 1892, p. 128.

54. Signalons les sites de Bou Gornine, Naoura ou encore Hr Sidi Ahmed Chaouch identifiés respectivement aux stations Villa Magna, Villa privata, Putea Pallene et Praesidium des itinéraires. 


\section{Bibliographie}

Bakir 1966-1967 : BAKIR (T.) - Archaeological News, Libya Antiqua, 3-4, 1966-1967, p. 242-243.

Ben Lazreg et al. 1995 : BEN LAZREG (N.), BONIFAY (M.), DRINE (A.), TROUSSET (P.) - Production et commercialisation des salsamenta de l'Afrique ancienne. In : L'Afrique du Nord antique et médiévale. Production et exportations africaines. Actes du VI e colloque d'Histoire et d'Archéologie de l'Afrique (Pau, 25-29 octobre 1993), Paris, CTHS, 1995, p. 103-142.

Bonifay et al. 2002-2003 : BONIFAY (M.), CAPELLI (C.), MARTIN (T.), PICON (M.), VALLAURI (L.) - Le littoral de la Tunisie : étude géoarchéologique et historique (1987-1997) : la céramique, Antiquités Africaines, 38-39, 2002-2003, p. 125-202.

Bonifay 2004 : BONIFAY (M.) - Études sur la céramique romaine tardive d'Afrique, Oxford, Archaeopress, 2004.

Bonifay et al. 2010: BONIFAY (M.), CAPELLI (C.), DRINE (A.), FANTAR (M.), GHALIA (T.) - Approche archéologique et archéométrique de la production d'amphores puniques et romaines sur le littoral tunisien, Actes du 1er séminaire (Nabeul, 28-29 novembre 2008), Unité de Recherche « Histoire et Patrimoine du littoral tunisien », INP, Tunis, 2010, p. 147-160.

Capelli, Leitch 2011 : CAPELLI (C.), LEITCH (V.) - A Roman amphora production site near Lepcis Magna: petrographic analyses of the fabrics, Libyan Studies, 42, 2011, p. 69-72.

Drine 1992-1993 : DRINE (A.) - Le site d'El Mdeina au sud d'El Biban, la «Zouchis » de Strabon ?, Reppal, 7-8, 1992-1993, p. 103-115.

Drine 1999 : DRINE (A.) - Restes de pressoirs à huile et à vin à Gigthi et à Zarzis, Africa, 17, 1999, p. 47-68.

Drine 1999a : DRINE (A.) - La gestion du sel dans l'Antiquité, les exemples de Carthage et de Rome, dans Actes du colloque international sur la gestion des biens de l'Etat à travers l'histoire, (Tunis, 10-11 mars 1999), Ministère des domaines de l'Etat et des affaires foncières et le Centre de recherches et d'études administratives, Tunis, 1999, p. 77-78.

Drine 2001 : DRINE (A.) - Meules à grain et pétrins autour du lac El Bibèn et à Gigthi. In : Brun (J.-P.) et Jockey (P.) (eds.), Techniques et sociétés en Méditerranée. Hommages à Marie-Claire Amouretti, Maisonneuve et Larose, Paris, 2001, p. 251-260.

Drine 2002 : DRINE (A.) - Autour du Lac El Bibèn, les sites d'El Mdeina et de Bou Garnin, Africa Romana, XIV, vol. III, 2002, p. 2001-2014.

Drine 2008: DRINE (A.) - Témoignages archéologiques sur les activités halieutiques de Meninx. In : Napoli (J.) (éd), Ressources et activités maritimes des peuples de l'Antiquité : actes du Colloque international de Boulogne-surMer (12-14 mai 2005), Dunkerque, 2008, p. 127-137.

Drine 2010 : DRINE (A.) - La Petite Syrte dans l'Antiquité : Sources littéraires et archéologiques, Actes du $1^{\text {er }}$ séminaire (Nabeul, 28-29 novembre 2008), Unité de Recherche « Histoire et Patrimoine du littoral tunisien », INP, Tunis, 2010, p. 103-118.
Faraj Shakshuki, Shebani 1998: FARAJ SHAKSHUKI (M.), SHEBANI (R.) - Archaeological News 1997, Libya antiqua, n.s. 4, 1998, p. 279-282.

Gsell 1918 : GSELL (S.) - Histoire ancienne de l'Afrique du Nord, Tome 2, Paris, 1918.

Jerba 2009 : FENTRESS (E.), DRINE (A.), HOLOD (R.) - An island through time : Jerba studies. Vol. 1, The Punic and Roman periods, JRA supplement 71, Portsmouth, Rhode Island, 2009.

Lecoy de la Marche 1894 : Cdt LECOY DE LA MARCHE - Recherche d'une voie romaine du Golfe de Gabès vers Ghadamès, BCTH, 1894, p. 389-413.

Mrabet 2002 : MRABET (A.) - La Petite Syrte dans l'Antiquité : approche géohistorique et archéologique de la côte de Gabès, Africa Romana, XIV, 2002, p. 450-467.

Mzabi 1993 : MZABI (H.) - La Tunisie du sud-est : géographie d'une région fragile, marginale et dépendante, 1993, Tunis.

Rebillet 1892 : REBILLET (C.) - Le Bahira Des Biban Et Mdeina, BCTH, 1892, p. 126-128.

Rebuffat et al. 1969 : REBUFFAT (R.), GASSEND (J.-M.), GUÉRY (R.), HALLIER (G.) - Bu Njem 1968, Libya Antiqua, 6-7, 1969-1970, p. 9-105.

Slim et al. 2007 : SLIM (L.), BONIFAY (M.), PITON (J.), STERNBERG (M.) - An example of fish salteries in Africa Proconsularis, the officinae of Neapolis, Nabeul, Tunisia. In : Lagóstena (L.), Bernal (D.), Arévalo (A.) (eds.), Cetariae 2005. Salsas y salazones de pescado en occidente durante la Antigüedad (Cadiz, 7-9 novembre de 2005), Oxford, BAR International, 2007, p. 21-44.

Trousset et al. 2004 : TROUSSET (P.), PASKOFF (R.), OUESLATI (A.), SLIM (H.), LENNE (J.), BONIFAY (M.) - Le littoral de la Tunisie : étude géoarchéologique et historique, Paris, CNRS Editions, 2004.

Trousset 1992 : TROUSSET (P.) - La vie littorale dans la Petite Syrte. Dans Histoire et archéologie de l'Afrique du Nord: Spectacles, vie portuaire, religions : actes $d u V^{e}$ Colloque international réuni dans le cadre du $115^{e}$ Congrès national des sociétés savantes (Avignon, 9-13 avril), Éditions du CTHS, 1992, p. 317-332.

Wilson 2002 : WILSON (A.) - Marine resource exploitation in the cities of coastal Tripolitania, Africa Romana, XIV, Rome, 2002, p. 429-436.

Wilson 2007: WILSON (A.) - Fish-salting workshops in Sabratha. In : Lagóstena (L.), Bernal (D.), Arévalo (A.) (eds.), Cetariae 2005. Salsas y salazones de pescado en occidente durante la Antigüedad (Cadiz, 7-9 novembre de 2005), Oxford, BAR International, 2007, p. 173-181.

Zaghdoud 2005 : ZAGHDOUD (A.) - Côtes, ports et activités littorales en Tripolitaine tunisienne dans l'Antiquité, Master de recherches, Université de Sousse, Sousse, 2005. 


\section{Fish and Ships in the desert? The evidence for Trans-Saharan trade in fish products}

\section{Victoria Leitch}

$\mathrm{F}$ lish and ships in the desert? These are perhaps two of the least likely things you would normally associate with the hot, dry, vast sandy stretches of Libya's Sahara. Camels, however, are known as 'ships of the desert', and are able to travel extensive distances across inhospitable desert, delivering people and goods, and often moving in large groups. These caravans stopped at oases for refreshment; which often became important entrepôts. Recent work by David Mattingly's archaeological team in Fazzan ${ }^{1}$ has highlighted the relatively surprising quantity of Roman goods being imported to the Saharan zone, by both camels and donkeys, including oil and wine in transport amphorae, so why not fish? This question has not previously been investigated, so my aim in writing this paper was to examine the available evidence to ask to what extent we can talk of fish and ships in the desert. First I present an overview of the sites and desert trade, secondly I investigate the direct evidence for fish trade, thirdly I look at indirect evidence through containers, fourthly I examine demand for these products in the desert and then finally I look at where the fish products in the desert may originally have been produced. The concluding analyses interrogate the validity of the original question.

Although few sites away from the Libyan coast have been investigated, the excavations and surveys that have been carried out, published to varying degrees of detail, allow questions about fish trade to be raised. The sites include the Roman forts of Gheriat-al-Gharbia

Fig. 2. Map of sites in Libya mentioned in this study (imagery ( $\mathrm{ESRI}$; map by Dr Martin Sterry).

1. Mattingly et al. 2007a, 2008, 2009, 2010a, 2011.

and $\mathrm{Bu} \mathrm{Njem}$, the pre-desert Libyan valleys survey and settlement at Ghirza, and further south in Fazzan, the Garamantian stronghold in the Wadi-al-Ajal and its capital, Garama, as well as Aghram Nadharif, and the Wadi Tanezzuft Valley, near Ghat to the west.

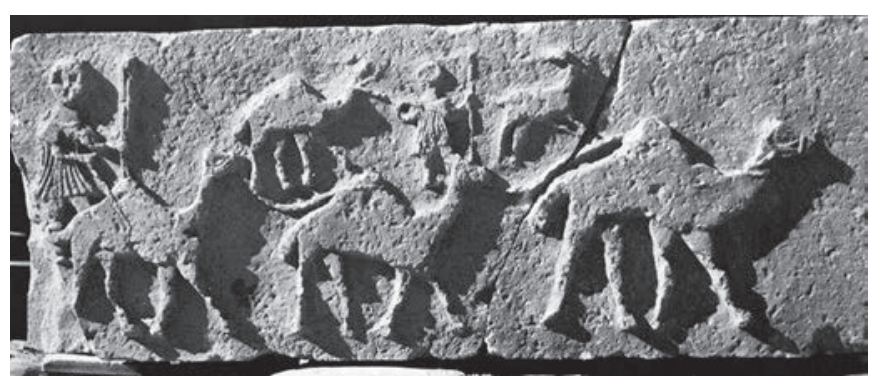

Fig. 1. Camel train from Ghirza tomb (Brogen, Smith 1984, plate 110b).

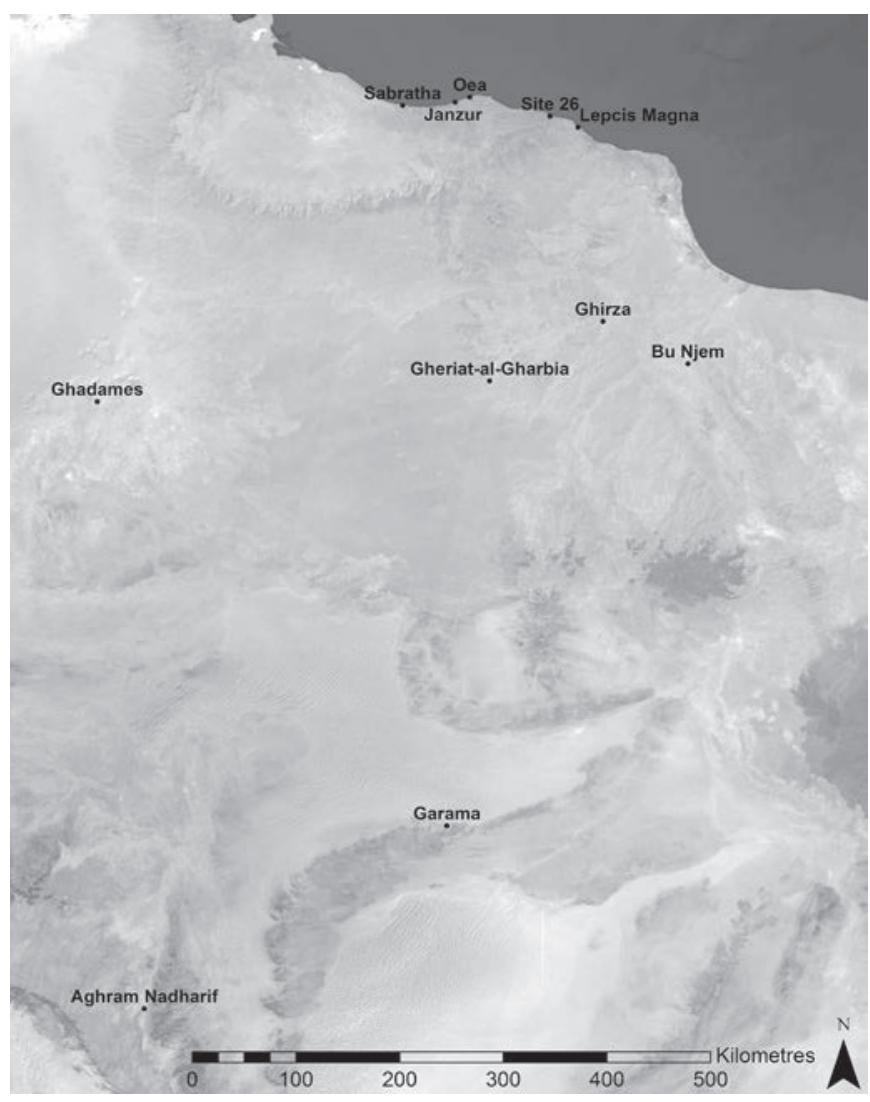




\section{Desert trade: an overview}

\section{Bu Njem}

The fort at $\mathrm{Bu} \mathrm{Njem}$, situated along the river elKebir, $100 \mathrm{~km}$ from the coast and $300 \mathrm{~km}$ from Lepcis Magna was excavated between 1967 and 1980 by a French team. ${ }^{2}$ Inscriptions date the building of the fort to 201, which was garrisoned by a detachment from the Legio III Augusta from Lambaesis. The camp was abandoned between 259 and $263 .^{3}$ The pottery drawings in the publication are not identified or dated but include what looks like African Red Slip ware (ARS) A, D, C, Roman cooking wares from Tunisia, African lamps and mainly Tripolitanian amphorae, but also a number of late Africana amphorae from Tunisia, suggesting that occupation went on from after the abandonment of the fort and into the 5th century. ${ }^{4}$ The development of the settlement around the fort, recently surveyed but not yet published by Michael Mackensen's team, certainly suggests a non-military population involved in trade and that the fort became an important node in longerdistance trade systems. ${ }^{5}$ A number of ostraca found at $\mathrm{Bu} \mathrm{Njem}$ and studied by Marichal refer to the arrival of Garamantes at $\mathrm{Bu}$ Njem with donkeys and barley. ${ }^{6}$ There are also references to ships and Lepcis Magna, confirming that trade went both north and south. ${ }^{7}$

\section{Gheriat el Gharbia}

The fort of Gheriat el Gharbia is currently being investigated by Michael Mackensen. ${ }^{8}$ It is known through inscriptions that it was built under Septimus Severus in AD201 and was probably garrisoned until at least AD238 and perhaps up to AD275, also by a detachment from the Legio III Augusta. ${ }^{9}$ The pottery includes ARS A, D and C, Tripolitanian sigillata and lamps, and amphorae mainly from Tripolitania but also from Tunisia and a small number of eastern imports, giving us clues about the direction of trade and suggesting that the area remained occupied after the garrison left until at least the 5 th century. ${ }^{10}$

2. See Rebuffat et al. 1966-67, 1969-70, 1974-75, 1976-77.

3. Bu Njem 1969-70, p. 20.

4. Bu Njem 1969-70, p. 53-85.

5. Wilson 2012.

6. Marichal 1992, p. 111 and Ostracon 72.

7. Marichal 1992, p. 104 and Ostraca 89, 97, 98, 104.

8. Mackensen 2010, 2011.

9. Mackensen 2010.

10. Id., p. 398-413; 2011, p. 317-25.

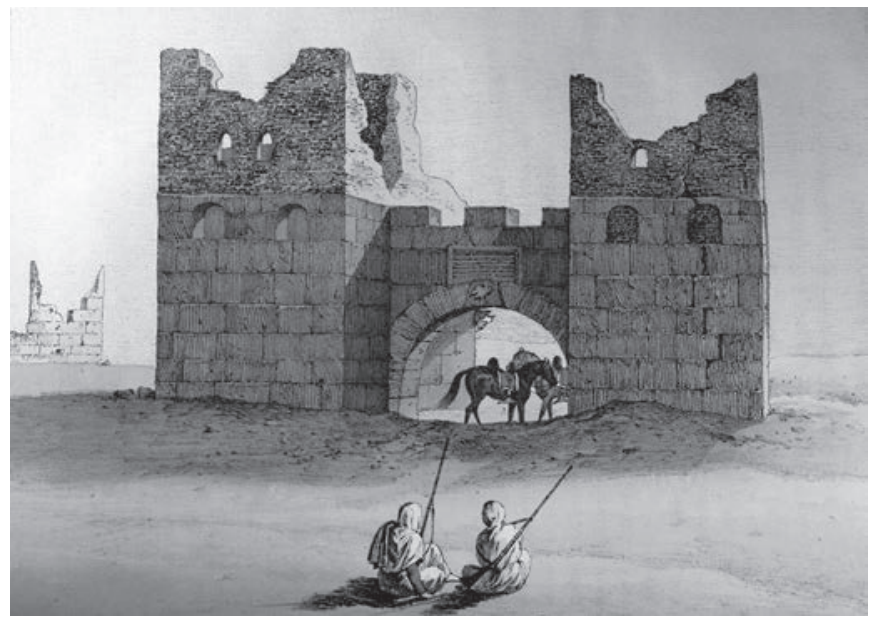

Fig. 3. North gate at Bu Njem (George Francis Lyon 1821).

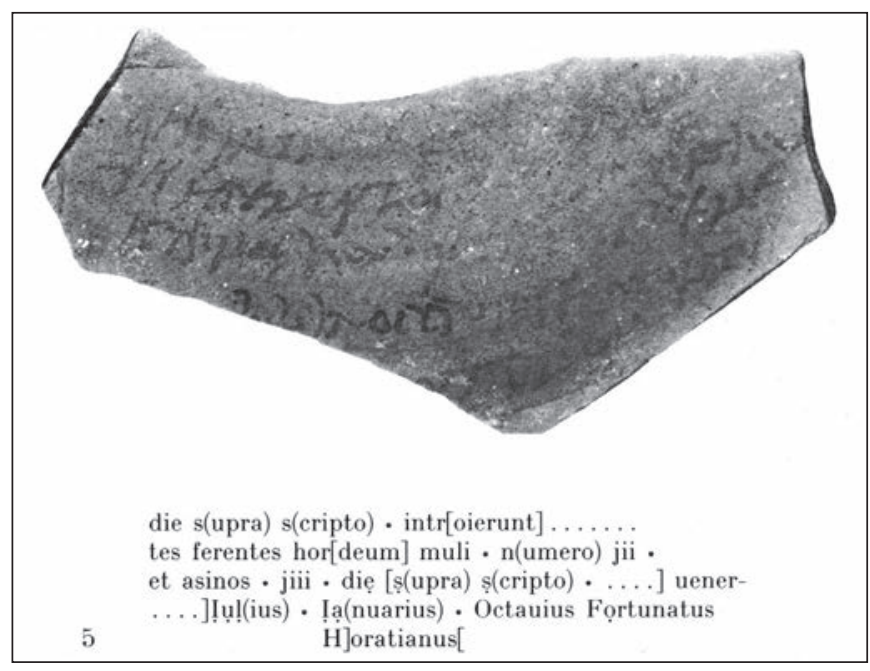

Fig. 4. Extract from ostracon 74 at Bu Njem.

These two forts, situated near oases, represented the limits of Roman domination. On the one hand the soldiers were provisioned by the army for basic supplies but on the other the soldiers bought goods from merchants, creating new trade routes and demands that fed local production and longer distance trade. We see similar patterns in Egypt, where the consumption of salted fish was widespread and fairly cheap: in AD143 the dipla 12 litre amphora was sold for one drachma (P. Oxy. III 520). Also salted fish "temachia" were imported by the soldiers stationed in the forts of Eastern desert of Egypt, attested by ostraca at Mons Claudianus, Maximianon, ${ }^{11}$ and Didymoi. ${ }^{12}$ These Libyan fort sites thus could have acted as frontier markets, as well as centres for taxation and controlling trade going south. ${ }^{13}$

11. Cuvigny 2003, O.Claud, 233 and O.Max 876.

12. Cuvigny 2012, p. 32.

13. eg Trousset 2003 on taxes at Zaraï. 


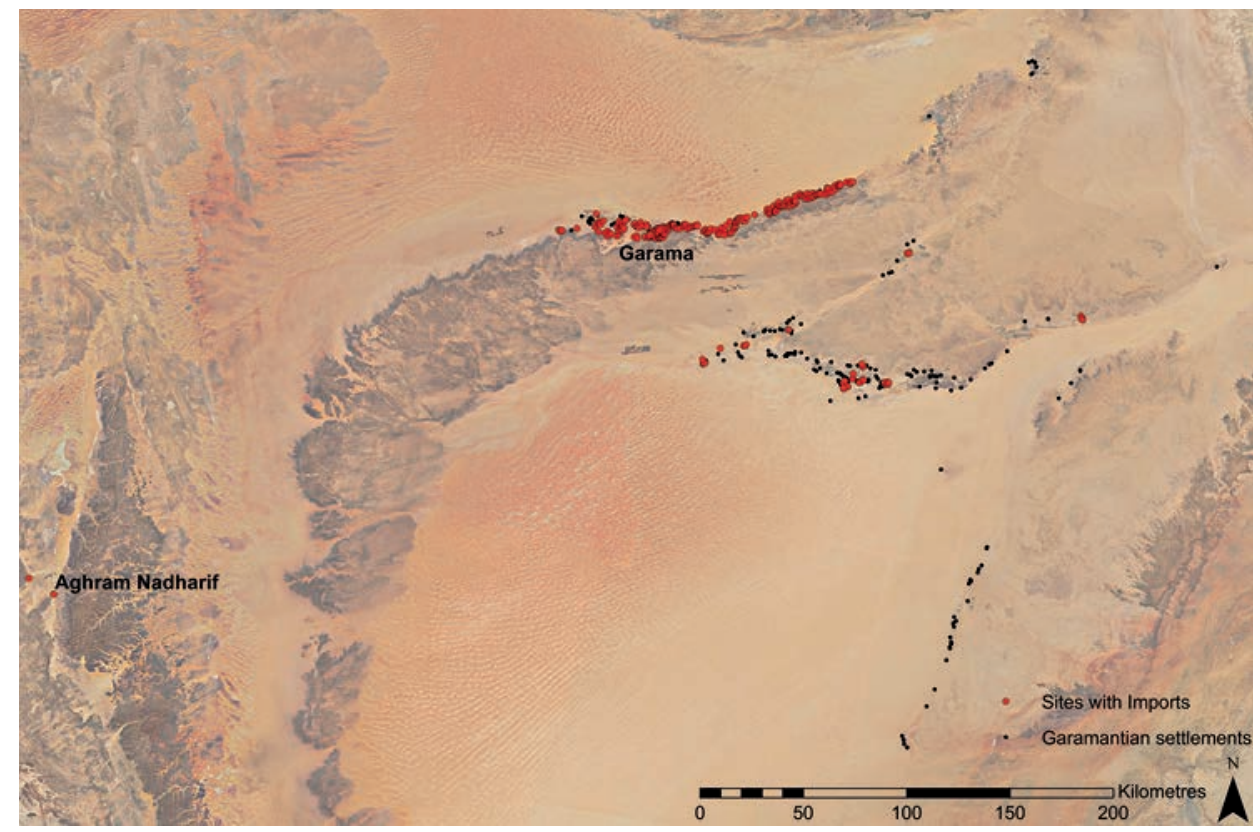

Fig. 5. Map of the Wadi-al-Ajal (imagery @ ESRI; map by Dr Martin Sterry).

\section{Ghirza}

The settlement of Ghirza is in the pre-desert, a land characterised by alternating uplands and wadi basins. Ghirza is $250 \mathrm{~km}$ south east of Lepcis Magna and $130 \mathrm{~km}$ from the coast to the northeast. It is the largest settlement in the pre-desert and is characterised by farmhouse buildings dated from the mid 2 nd to 5 th century and mausolea, though it is thought to have existed before the Roman period. ${ }^{14}$ The arrival of the Romans at the forts meant that Ghirza and the pre-desert fell under Roman control, which greatly stimulated agriculture and trade, well into the late Roman period. The pottery includes some Italian Sigillata and then much later 4th to 6th century ARS and lots of Tripolitanian Red Slip ware (TRS). The lamps are African and Tripolitanian and date from the 2 nd to 6th century. ${ }^{15}$ The amphorae were not recorded, but there are reliefs showing probable Tripolitanian amphorae. ${ }^{16}$ The indication is that settlement was more intense from the 4 th century.

\section{Libyan Valleys}

Surveys carried out by the British ULV survey counted over 2500 sites, mainly farms connected with agriculture and the production of oil and wine. ${ }^{17}$ The

14. Brogan, Smith 1984, p. 34-35 and fig. 1 map.

15. $I d .$, p. 234-41 for pottery report.

16. Id., plate $82 \mathrm{a}$.

17. Farming the Desert 1996a, p. 111-158, and in particular plate $126 \mathrm{~b}$ which depicts wine production. evidence demonstrates intensive farming and water management systems and the grand funerary mausolea are a testament to the wealth of this population, much of which may have come from agriculture and trade. As we see at Ghirza, the development of this area was probably initiated by the military presence and associated trade, which continued after the abandonment of the forts. The grain, oil and wine surpluses would have been sold to the forts and perhaps north to Lepcis Magna and Mediterranean markets. However, their main trade may have been local, for the increasing population in the Libyan Valleys. Andrew Wilson also argues that the Libyan Valley farms traded south with Fazzan. ${ }^{18}$ No amphorae workshops have been found in the area, but amphorae have, suggesting that they were brought in from elsewhere for bottling or more likely amphorae used for goods coming in from the north were reused. Other containers such as skins may also have been used (see below on Alternative Containers).

\section{Wadi-al-Ajal}

The Garamantes were a native Libyan civilisation with their stronghold in the Wadi-al-Ajal in Fazzan, centred around the capital at Garama. They seem to have been involved in trade from the 6th century $\mathrm{BC}$ to at least the 5 th or 6 th century AD (see fig. 5 for distribution of sites and imported material in the Roman period). ${ }^{19}$ Their management of water resources meant they could

18. Wilson 2012, p. 430-31.

19. Mattingly et al. 2010b, p. 523-30. 
cultivate crops and their position as an oasis between the Roman forts and sub-Saharan African put them in a powerful strategic position, trading north and south. The Romans tried to control the area, and Cornelius Balbus from Cadiz, proconsul of Africa, led a campaign there in 20 or $19 \mathrm{BC}$, for which he received a triumph in Rome. ${ }^{20}$ Although it is clear that he did not fully conquer Fazzan, his campaign may have initiated closer ties with the region, as part of Augustus's wish to expand and control the borders of the empire - with an eye on the potential for trade with sub-sahara regions. The knock-on effect of closer links between the Garamantes and the Romans was of course the importation of more Roman goods, which began in earnest in the late 1st century AD. Goods imported from the north included Italian and Gaulish finewares in the early Roman period, taken over by ARS in the 2nd century and an abundance of mainly Tripolitanian amphorae. ${ }^{21} \mathrm{In}$ addition, there is a large quantity of glass, ${ }^{22}$ a pattern we also see in Oman in the 1 st century ${ }^{23}$ and the Axoumite kingdom in the 3rd to 6th centuries ${ }^{24}$, where it was used for funerary purposes. Dates, new crops, alum, salt, natron, metal objects, beads, semi-precious stones and gold may have come from Fazzan itself or the sub-Sahara, and gave the Garamanians goods to trade with the Romans, alongside the main trade in slaves and perhaps exotic animals. ${ }^{25}$

This brief overview demonstrates that there was a great deal of trade circulating between the coast, the Roman forts, the pre-desert settlements and Fazzan. These sites highlight the eastern routes, going from the coast via the Hamada el Hamra to the Roman forts and into the Wadi al-Ajal, the centre of the Garamantian territory. There is also a possible route going from Fazzan to Ghat and Ghadames, and then north to Sabratha or Jerba, however this route was somewhat longer and for the moment we do not have sufficient evidence from Ghadames to advance the question of trade at Ghadames and its connection with the other sites. In essence, the abundance of ARS, oil and wine amphorae, some of which came from coastal sites, would certainly suggest that salted fish and fish sauce could have been part of regular trade to the desert. The customs tariff from Zarai in Numidia dated to AD202, although some way from

20. Pliny NH V, 36; Mattingly 2001; Bernal, Arévalo 2011, p. 249; Desanges 1978, p. 189-195.

21. Dore et al. 2007; Mattingly et al. 2010b; Leone 2013.

22. Hoffman 2007; Cole, Hoffman 2007a, b; Hoffman 2010; Hoffman 2013.

23. Whitehouse $1998 ; 2000$.

24. Morrison 1989; Harlow 2000.

25. Mattingly et al. 2007b, 2010b (in particular summary p. 526530), 2013. the Libyan desert, provides evidence for the types of goods that were crossing the African frontier for onward travel south, and the list includes garum. ${ }^{26}$

\section{Direct evidence from fish remains}

First of all, it is important to stress the major problems with collecting fish bones on excavations. Fish bones are extremely hard to spot for an average archaeologist, and the only way to find them is through wet sieving. ${ }^{27}$ Inge Bodker Enghoff, during work on a medieval excavation in Denmark, demonstrated that unless careful sieving is systematically practised, the presence of fish will be grossly underrepresented ${ }^{28}$ Of course for fish sauce, the bones would have been sieved out, so no evidence would remain and the only way of detecting this would be through residue analysis of the amphorae. More hopeful are shellfish remains, which survive well.

\section{Bu Njem}

At $\mathrm{Bu} \mathrm{Njem}$ no fish bones were found, probably for the reasons suggested, and it needs also to be considered that in the late 1960s and 70s when the excavations were carried out, detailed scientific analysis was not yet practised. However, the shellfish, dolium galea, common in the Mediterranean, was found in the building with niches; and in the principia, the shellfish murex brandaris, also common in the Mediterranean and used for making purple dye. ${ }^{29}$ It is, however, highly unlikely that purple dye was made at $\mathrm{Bu} \mathrm{Njem}$, and far more likely that it was made on the coast, as demonstrated by Andrew Wilson's investigations at Roman Sabratha and Lepcis Magna, where he noted the presence of crushed murex shells. ${ }^{30}$ Instead, murex were probably eaten at Bu Njem: a habit mentioned by ancient authors such as Ennius and Hicesius. ${ }^{31}$ Both these shellfish contexts date to the main period of military occupation in the early 3rd century.

\section{Ghirza}

At Ghirza oyster shells were found in a large building, but the specialist who looked at them thought they were probably dead when collected and so were not

\footnotetext{
26. Trousset 2003, p. 263.

27. Ruth Pelling, pers com.

28. Bekker-Nielsen, Bernal 2007 p. 199.

29. Bu Njem 1969-70; 1976-77, p. 37-77.

30. Wilson 2002, p. 433-34.

31. Botte 2009, p. 60.
} 

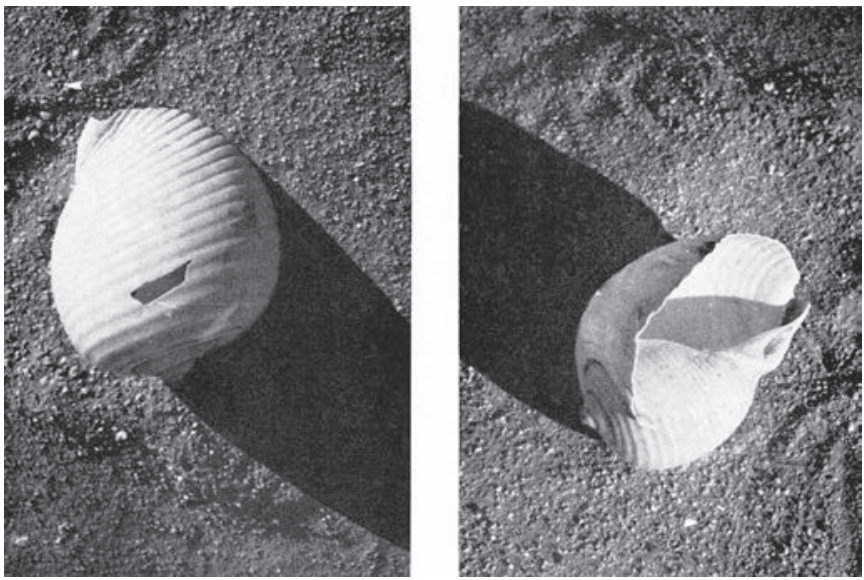

Fig. 6. Shellfish dolium galea found at Bu Njem (Rebuffat et al. 1970, plate XLI).

used for food, and it is instead suggested that they were used as a temper for the handmade pottery. ${ }^{32}$ However, it seems highly unlikely that merchants purchased and transported dead oysters, but instead it is more probable that they sold live oysters, a luxury item, to the wealthy owners of the building they were found in. We know, for example, that oysters were traded long distances, particularly in Gaul (see Bardot-Cambot, this volume). There are also a number of fish representations on the funereal monuments - some of these may have been symbolic, associated with the celestrial ocean, and fish were also a good luck symbol ${ }^{33}$. However, such an abundance of fish symbols also suggests an association with fish consumption at Ghirza.

\section{Libyan Valleys}

M. Van der Veen's examination of the botanical remains from the Libyan Valleys survey brought to light the vertebra of a sea fish Sparus pagrus pagrus, couch's sea bream, in a midden at site Kh01001. ${ }^{34}$ This fish is common off the shores of Libya today, mainly found in mud and gravely ground in beds of vegetation in water up to $200 \mathrm{~m}$ deep. These fish can grow up to $75 \mathrm{~cm}$ and weigh $10 \mathrm{~kg}$, but the bone found suggests a $25 \mathrm{~cm}$ length and a weight of $300 \mathrm{~g}$. Similar remains have been found at Berenice, the Roman coastal city in modern day Bengahzi in north eastern Libya. ${ }^{35}$ Looking at the context of this find, site Kh01001 contained 1st to 5th

32. Brogan, Smith 1984, p. 94-95, 284, 290.

33. eg Brogan and Smith 1984, plates 109b, 119a, 121.

34. Farming the Desert 1996a, p. 253; Farming the Desert 1996b, p. 139.

35. Wheeler 1979 , p. 25-6.
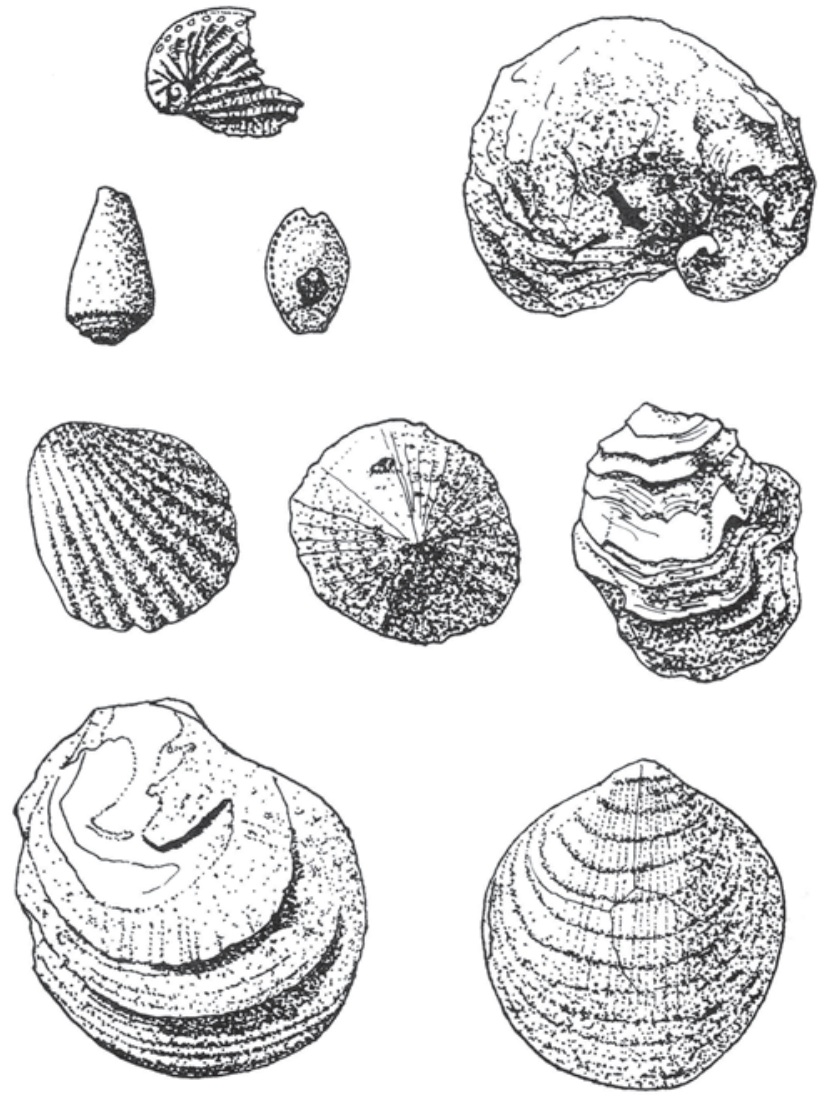

Fig. 7. Oysters found at Ghirza (Brogan and Smith 1984, fig. 94).

century Roman pottery, including ARS Hayes 6, 68, 87, 90, 104 and Tripolitanian II amphorae. This site was in close proximity to a large fortified farm with a Roman press, cistern and an extensive surrounding settlement. Another smaller farm nearby had Tripolitanian amphorae, including form II, and several late Roman amphorae such as Lepmiminus II (probably for garum ${ }^{36}$ ) and Keay 62 (Kh41, 2: 357, 359). So certainly fish was consumed in the pre-desert in the Roman period, although to what extent we do not know.

\section{Garama, Wadi-al-Ajal}

Excavations at the Garamantian capital of Garama revealed a fish vertebra found in botanical samples. ${ }^{37}$ Ruth Pelling and Hannah Russ recently re-examined the bone. ${ }^{38}$ Apparently the bone is a caudal vertebra from the Mugilidae fish family (mullets) suggesting a fish of

36. Bonifay 2004a, p. 82 .

37. Pelling in Mattingly et al. 2001, p. 146.

38. Ruth Pelling, English Heritage, Hannah Russ, University of Sheffield. 
approximately $30 \mathrm{~cm}$ in length. It compares favourably with the thinlip grey mullet (Liza ramada). However, there are other mullets in the Liza genus that it could potentially be - such as Liza aurata (golden grey mullet) or Liza saliens (leaping mullet), which being the same genus have similar vertebral morphology. All these mullets have a similar distribution - Mediterranean coasts and coasts on the NE Atlantic. We know that they were salted in antiquity. ${ }^{39}$ All three species inhabit coastal waters and enter estuarine areas at times. The context in Garama is surprisingly early, being 2nd to 1st century $\mathrm{BC}$, suggesting very early Roman trade, or referring back to the Punic trading phase in Fazzan - testified by many well-made punic coarseware bowls from the 3rd to 2 nd century BC and early amphorae, including GrecoItalic types. ${ }^{40}$ So, sparse as this evidence is, it is another hint at fish trade, from an early date, which could be interpreted as a sign that the Garamantes appreciated fish products even before the Roman period and therefore may well have sought such products when links with the Romans opened up.

\section{The Wadi Tanezzuft Valley, near Ghat}

As a final note, it is interesting that in the Wadi Tanezzuft Valley, ${ }^{41}$ near Ghat, to the very far west of the Garamantian territory, there were no fish remains, despite thorough archaeo-botanical collection. There are also very few Roman imports so this region seems to have remained outside the influence of Roman eating and drinking habits, of which fish was an important element.

\section{Indirect evidence from amphorae}

Investigations into the transportation of fish products suggest that amphorae were the most commonly used containers for salted fish and garum. The use of amphorae for shellfish is debated, as many amphorae with shellfish inside them have been found on shipwrecks and it is argued that the shellfish infiltrated the amphorae after the ship sunk. However, Emmanuel Botte points out that the ancient sources testify to the consumption and trade of shellfish and that an African Mau 11 found at Pompeii with an inscription MOL might be interpreted as MOLLIA, referring to shellfish - but this could have

39. Botte 2009, p. 25.

40. Dore et al. 2007, p. 336-341, 364-367.

41. Alhaique 2002.

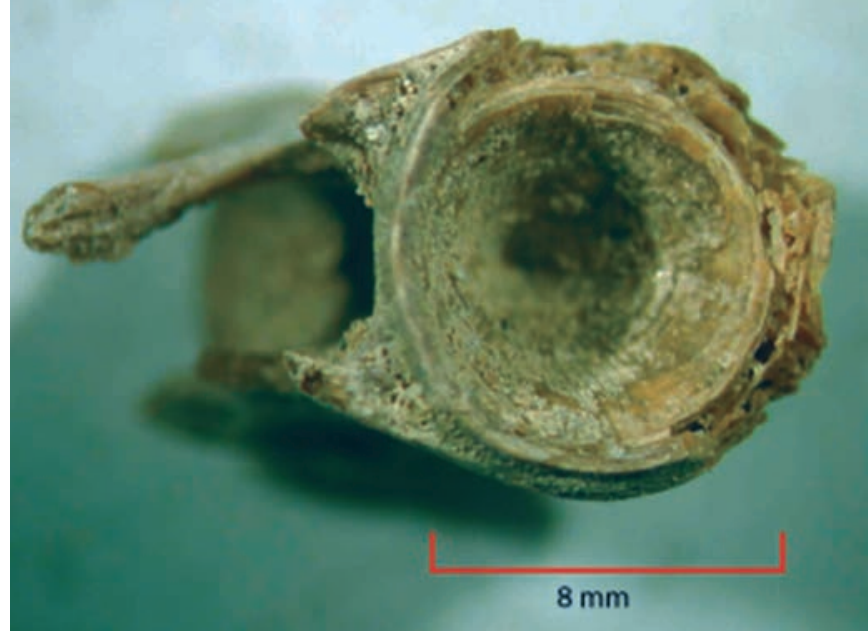

Fig. 8. Caudal vertebra from the Mugilidae fish family (Ruth Pelling)

been marked to signify a change of use. ${ }^{42}$ Also, shellfish do not grow in all environments, and so the environment of the shipwreck may indicate if the shellfish were brought in from elsewhere.

\section{Tripolitania II and Africana IIA, C and D amphorae}

Even if we know that salted fish were transported in amphorae, how do we know which types? The debate about the contents of certain types of amphora is ongoing and difficult to resolve, ${ }^{43}$ particularly with re-use to consider and the new evidence that probably all amphorae were pitched. ${ }^{44}$ For fish, pitch lining was appropriate, and certain African amphorae types show pitch more than others. For example the large Africana IIA (end 2nd to mid 3rd century) IIC (mid 3rd to 4th) and IID (mid 3 rd to early 4th) are usually pitched and have generally been associated with wine or fish products, ${ }^{45}$ such as an amphora containing shellfish found on the shipwrecks of Giglio Porto and Pampelonne. ${ }^{46}$ At Fazzan, we have the much smaller Africana I, which was generally used for oil, but this form may have been selected and reused there due to its size, which was easier for desert transport, particularly if donkeys were used, and its contents may therefore have varied. For Tripolitanian amphorae, it is widely demonstrated that Tripolitania I and III have no apparent traces of pitch and so were for oil, as testified

\footnotetext{
42. Botte 2009, p. 38.

43. Bonifay 2004b, Garnier 2004; Garnier et al. 2011.

44. Garnier et al. 2011, especially p. 411-12 demonstrates that even Dressel 20 amphorae were pitched but the olive oil dissolved the pitch which then moves to the core is no longer visible.

45. Bonifay 2004a, p. 107-118.

46. Botte 2009 , p. 38.
} 
at Monte Testaccio, ${ }^{47}$ but that Tripolitania II, dated to the early 1 st to 5 th century, were often pitched and used either for wine or fish products, and are an evolution of the punic Van der Werff 3 amphora. ${ }^{48}$ However, typologies are modern inventions, so care must be taken in assuming that particular forms always corresponded to particular contents. In addition, there are potential problems with the identification of Tripolitania II amphorae as fish storage vessels. Firstly, the Van der Werff 3 from which it evolved is thought to have carried wine; ${ }^{49}$ second, other than the workshops at Sabratha, we do not yet have proof for sizeable fish production workshops along the Libyan coast, and tanks recorded in survey may have been for wine storage; third, the Tripolitania II amphora in the Ghirza relief is in a banquetting context, so probably pointing to wine; and finally, tuna, the main fish used for salting, typically inhabit the western and central Mediterranean waters and some research suggests limited migration to the Libyan coast, ${ }^{50}$ which could meant that fish salting was probably a minor industry in Libya, where other fish, such as mullet, were used, but on a much smaller scale. So perhaps the most we can say is that Tripolitania II were principally for wine, but we cannot exclude the possibility that they also carried fish products.

\section{Amphorae production}

Another way of tying particular amphora types to fish products is by looking at the close proximity of amphora production sites to fish installations, and noting the types produced. One recent example of this is the Lepcis Magna hinterland survey which covered $27 \mathrm{~km}$ west of Wadi Giabrun. ${ }^{51}$ Tanks and an amphora production site were found in very close to one another - samples from the amphorae production site have since been examined by Claudio Capelli who concluded that they were definitely from the kiln site, and the forms are predominantly Tripolitania II. ${ }^{52}$ But the tanks may have been for wine storage. In addition, a survey undertaken by Chris Preece at Janzour, $18 \mathrm{~km}$ west of Tripoli found rock-cut channels and a rectangular basin, which could be for fish salting, though this is unlikely if there was a

47. eg Revillla Calvo, 2007.

48. Bonifay 2004a, p. 89-90 for summary of evidence.

49. Bonifay 2004a, p. 89.

50. Fromentin, Lopuszanski 2013. This requires more indepth investigation to clarify.

51. Directed by Luisa Musso and the University of Roma Tre, see Schorle, Leitch 2012 for preliminary findings.

52. Capelli, Leitch 2011. channel link to the vat, in which case it would have been for fish breeding, which would more likely have been just to serve a villa. There were at least five kilns nearby but only four pottery sherds were published including a Tripolitania I amphora, so this does not yet provide us with any convincing evidence for a fish factory and associated amphora production. ${ }^{53}$

To sum up, there are problems with the typological association of certain amphora types with fish products from the Libyan coast, but the Tripolitania II seems the most likely, and in addition, the Sahara seems to have Africana IIA amphorae which are thought to have contained fish.

\section{Amphorae from Bu Njem}

At $\mathrm{Bu}$ Njem 125 amphorae were recorded. Of these, 82 are Tripolitanian, including 19 Tripolitania II forms and 4 Tripolitania II/III (the designation II/III is because forms II and III have similar rims but different handles, and when the handles are missing it can be difficult to definitively catagorise them). ${ }^{54}$ There are also 22 Africana forms, of which 20 are Africana IIA, which are a candidate for fish products. ${ }^{55}$ Certainly the Tripolitania II and Africana IIA amphorae would have contained wine for the thirsty soldiers and those in the settlement, but we can hypothesise that some of them may have contained fish products.

\section{Amphorae from Gheriat al Gharbia}

At Gheriat al Gharbia survey and excavation revealed that more than $50 \%$ of the amphorae were Tripolitanian. The table published by Mackensen does not distinguish between Tripolitania II and III but the illustrations demonstrate that there were several Tripolitania II variants suggesting that their presence was not insignificant. There is also an illustration of an Africana IIA. ${ }^{56}$

\section{Amphorae from Ghirza}

Although the amphorae from Ghirza were not studied or published, there are reliefs showing probable

53. Preece 2011.

54. Bu Njem 1969-70, p. 99-105: Tripolitanian II: nos A9-12, 34, 42, 49, 51-6, 58, 60, 64, 65, 73, 80; Tripolitanian II/III: A19, 22, 38, 41.

55. Bu Njem 1969-70, p. 103 fig. 21: Africana IIA nos 99-119.

56. Mackensen 2010, p. 412-413. 


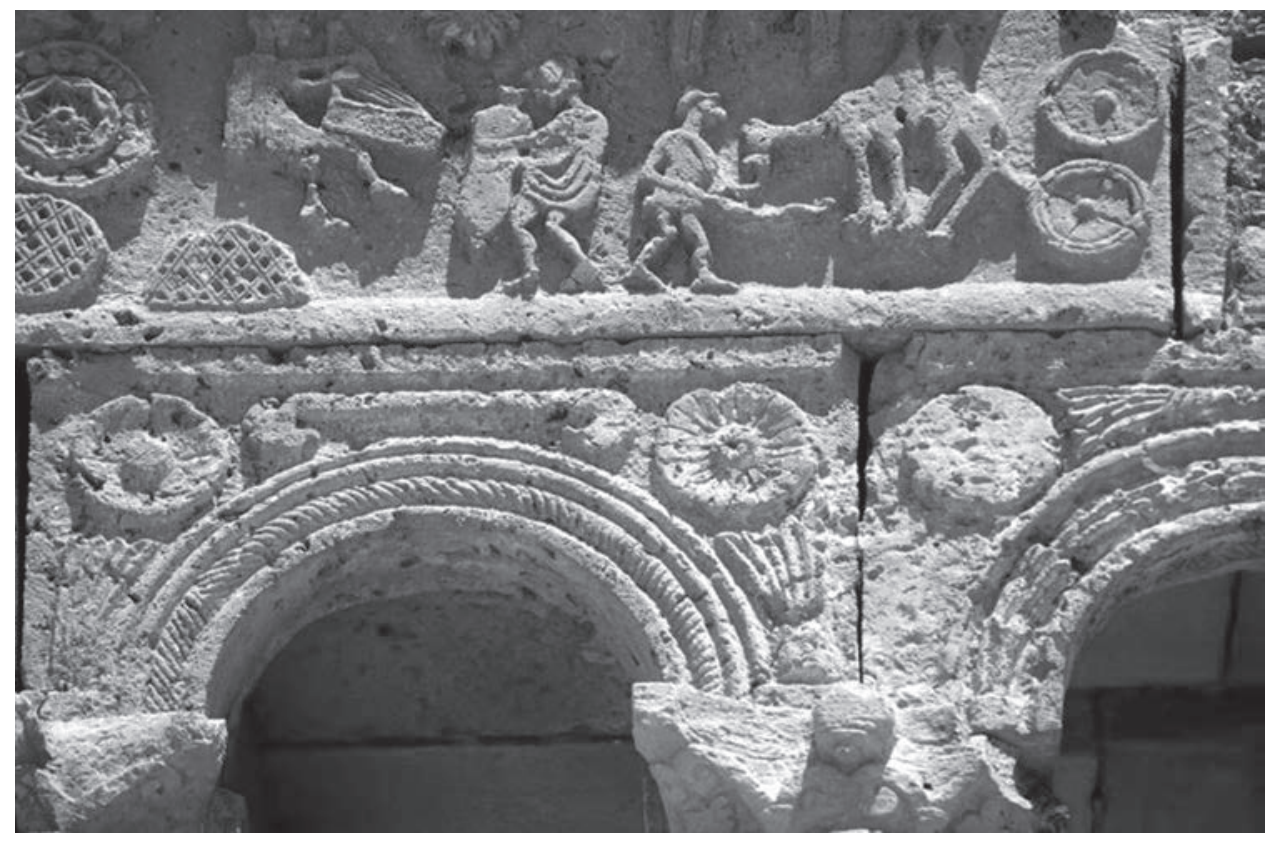

Fig. 9. Ghirza relief with amphora (Brogan, Smith 1984, plate 82a).

Tripolitanian II amphorae. One is a banqueting context: there is a seated man playing the citar, and next to this a camel loaded with four amphorae, and between them a man carrying a large amphora, the shape of which resembles a Tripolitania II. The other stone show camels and amphora (not photographed). ${ }^{57}$ Certainly the banqueting relief suggests wine amphorae, and throws into question the use of Tripolitania II for fish, but we cannot yet discount the possibility that this amphora type was also used for fish.

\section{Amphorae from the Libyan Valleys}

The Libyan Valleys report published only a very small amount of amphorae, with the majority of the body sherds being categorised as unidentified coarsewares - David Mattingly, who was on the original survey team, confirmed that there were in fact very few amphorae remains on the ground, and even fewer diagnostic sherds. The published amphorae include mainly Tripolitania I and III, but there are a few examples of Tripolitania II, nos 4, 6, 7, which appear on several sites. ${ }^{58}$ Some of these Tripolitania II amphorae were found in a press building where they were reused for

57. With thanks to Andrew Lawrence, University of Bern, for the photo and suggestion, see also p. 205 n.21.

58. Farming the Desert 1996b, p. 355-361. storing wine or oil. ${ }^{59}$ Others may originally have carried fish from the coast, though there is no proof for this yet.

\section{Amphorae from the Wadi-al-Ajal}

Amphorae from survey and excavation, carried out in the 1960s and as part of David Mattingly's Fazzan Project in the early 2000s have been published in The Archaeology of Fazzan 2. The amphora report written by the late John Dore groups Tripolitania II and III amphorae together, due to their fragmented nature, his mid Roman Fazzan type 21. Some of these can certainly be classed as Tripolitania II. ${ }^{60}$ Additional material includes amphorae from the museum storeroom, which were photographed and recorded by John Dore, and the pottery from David Mattingly's most recent Desert Migrations Project. ${ }^{61}$ A preliminary analysis, however, indicates that there is a whole range of Tripolitania amphorae that do not fit into any previously known categories (such as the Tripolitanian I, II, III series) and for which the contents remain a complete mystery. Amongst these are a small early Roman form (Dore's Fazzan type 13) with a wide mouth, which could conceivably have

59. This site was published as an oil press, but see Brun 2004, p. 186 for an argument that it was probably for wine, like many other presses in the region.

60. Dore 2007, fig. 41.13 .

61. Leitch, current research as part of David Mattingly's TransSahara Project, University of Leicester. 
been made for transporting salted fish. However, until work resumes in Fazzan and residue analysis carried out, this question remains unanswered. In addition, it is worth considering whether or not the amphroid flagons, which seem to have Tripolitanian fabrics, and which would certainly have carried something for their journey across the desert, may have contained wine or indeed fish sauce.

\section{Amphorae from Aghram Nadharif}

The fortified citadel of Aghram Nadharif, investigated by an Italian mission, represents an interesting contrast to Garama. Although still within the Garamantian kingdom and linked to caravan routes, it was on the southern fringes and there are in fact very few Roman imports, and the report does not mention fish remains. It should be noted, however, that a number of Tripolitanian amphorae are mentioned, including form II, ${ }^{62}$ hinting at perhaps the limited infiltration of fish products.

\section{Alternative containers}

Two possible alternatives to amphorae known in the Roman world for transporting goods, liquid and solid, are skins and barrels. The first point to consider is whether or not these materials are suitable for fish products. Elise Marlière and Josep Torres Costa looked at the use of these alternative materials in Africa. ${ }^{63}$ Skins were used principally for water, milk, oil and wine. Obviously they would not be suitable for more bulky salted fish, but we know that they were sometimes pitched or coated in butter to make them impermeable, so why not use them for garum? In the area of Oued el Gattar in the high step lands of central Tunisia olive oil was produced alongside ARS pottery but not amphorae, making it certain that skins were used, corroborated by a Hayes 55C plate of second half of the 4th century depicting camels carrying skins, which were of course much lighter. ${ }^{64}$ The use of barrels is attested in Africa, such as on a mosaic from Carthage, from the second half of the 1 st century, ${ }^{65}$ and of course wood was far more abundant in Tunisia during the Roman period. Emmanuel Botte points out that the shape of barrels made more economical use of space for packing salted fish, and in 2nd-century Italy we know

62. Felici 2006, p. 245.

63. Marlière, Torres-Costa 2007.

64. Id., p. 91, fig. 4.

65. Id., p. 95, fig. 7a. that barrels were used for fish. ${ }^{66}$ Also, a barrel found at Fos-sur-Mer near Marseille dated to the end of the 1st century contained sardines. ${ }^{67}$ So, although we have no direct evidence from Libya for the use of skins or barrels for carrying fish products, this is a possibility that we should bear in mind.

\section{Demand for Roman goods in the Desert}

The evidence for fish trade in the desert is certainly not in abundance, but alongside the arguments concerning amphora types used for fish, the possibility seems more real. An additional factor to consider is the impact of the appearance of Roman goods that may have stimulated demand for these new products such as olive oil, wine and possibly fish, as well objects such as finewares or glass. For the garrisons at the frontier forts, it is certain that they would have imported goods such as oil, wine and fish, and since we know they traded with the Garamantes it is highly probably that fish made it south along with oil and wine. However, garum, particular to the Roman cuisine, may not have suited Saharan cooking habits or even been particularly popular. We know from the mixture of local and Roman goods found in Garamantian graves ${ }^{68}$ that they were not identifying fully with the Roman way of life, and for instance continued to use particular handmade casseroles that were unlike the African forms so ubiquitous at Mediterranean Roman sites. Another possibility is that Roman merchants were living in Fazzan and ordered these goods (a similar question arises for the Roman amphora found at Arikamedu, in the Bay of Bengal ${ }^{69}$ ) but we have no evidence to support a Roman population and the quantity of Roman amphorae suggests that they were used by the wider population.

\section{Where did the fish come from?}

Evidence along the Libyan coast for fish production is slowly increasing thanks to new survey work. Perhaps the best known examples are from Sabratha. Andrew Wilson's summary and his own personal observations show that there were numerous groups of vats over a metre wide and deep, lined with waterproof mortar

66. Botte 2009, p. 166-168.

67. Id., p. 167.

68. E.g. Mattingly et al. 2010b, p. 222-298, burial catalogue for Saniat bin Huwaydi and Desert Migrations work by the Trans-Sahara Project.

69. Tchernia 2011, p. 138-39. 

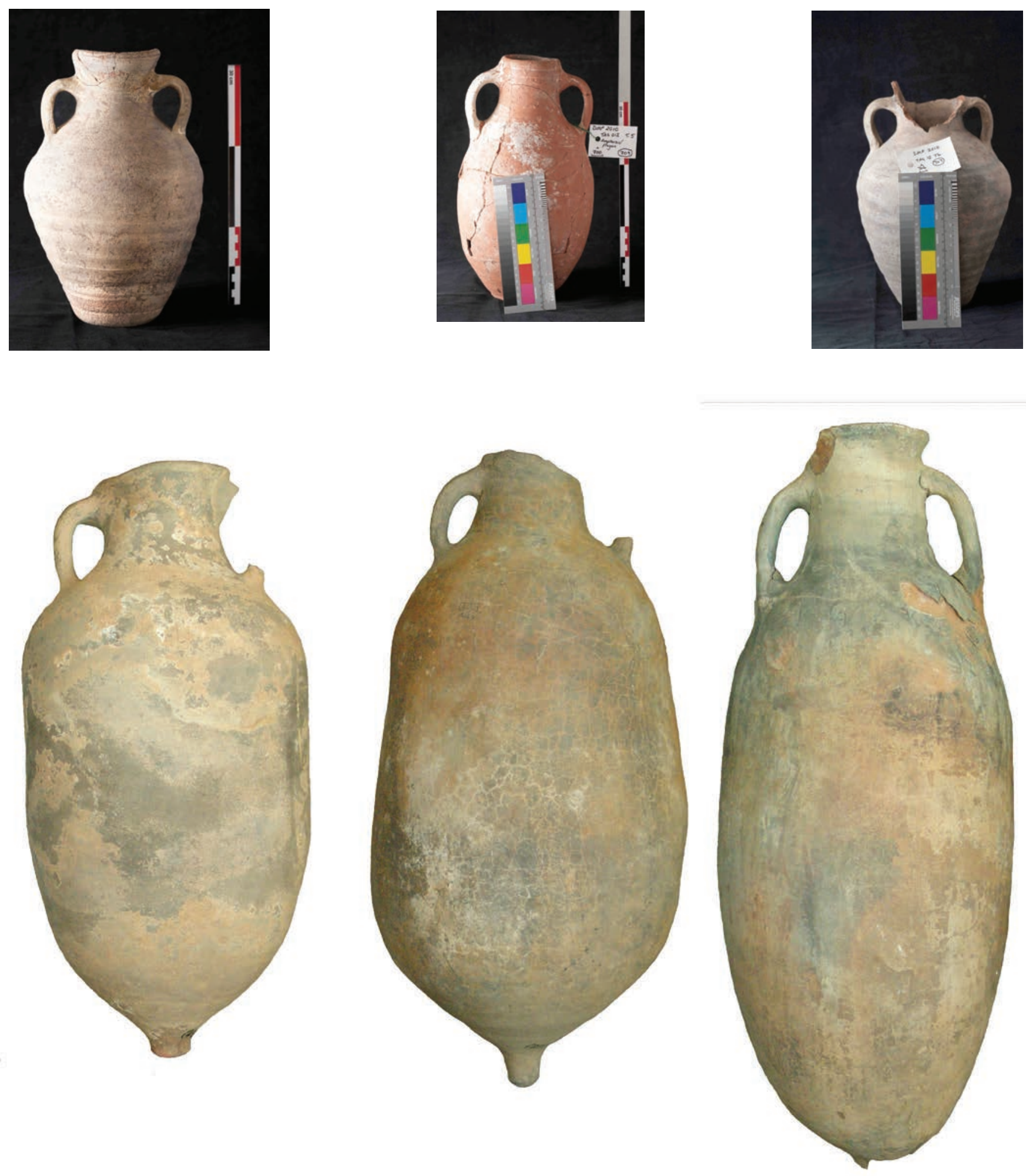

Fig. 10. Wide-mouthed Fazzan type 13 amphora and amphroid flagons from Tripolitania found in Fazzan (Photos by John Dore, Toby Savage). 
and similar to fish salting vats in Salakta. ${ }^{70}$ Associated smaller vats may have been used for making garum, liquamen or hallec. There are at least 18 workshops, and probably more, dating from the 1 st to 2 nd century, signalling highly organised urban fish production. Andrew Wilson attempted to calculate the volume of production which even when deliberately minimised indicates a surplus, and he suggests that those living on the coast probably ate fresh rather than salted fish, so assumed the salted products were mainly for export. However, salted fish was another type of dish, so the locals probably did buy this in addition to fresh fish, particularly as fresh fish are seasonal, so salted fish would have been eaten in between seasons. This factory at Sabratha is also much smaller than other known factories that exported their products, such as Lixus, Cotta, Troia or Salakta. An additional problem with associating Sabratha with large-scale export of fish products is that no amphora production site has yet been discovered. That said, Nina Keay's pottery report indicates an increase in the number of local/regional amphora forms in the early imperial period, with Tripolitanian types representing $47 \%$ of the amphora total from the first half of the 1st century to the 3rd century. ${ }^{71}$ David Peacock studied the fabrics and concluded that the Tripolitanian types formed a textually homogenous group, perhaps pointing to a common origin in the Sabratha area. ${ }^{72}$

In addition to Sabratha, there are the two recent surveys already mentioned at Lepcis Magna and Janzur near Tripoli. The Lepcis Magna survey revealed a landscape of villas, many associated with olive or wine presses, and also a rock-cut square pool which may have been used for keeping live fish. One villa had associated tanks and nearby many Tripolitanian amphora sherds. ${ }^{73}$ However, it must be recognised that villa production was often just for local markets, and the tanks could have been for wine, likewise the amphorae.

At Janzur the rock-cut channels suggest fish-traps or pens, though these were probable for live fish for local consumption. West of Janzur, Preece also found a large rectangular basin adjacent to the sea, which could have been for fish, and to the east at the regatta complex a series of pools bordered by a barrier of rock with sluices cut into it, as seen also at Apollonia for keeping fish. ${ }^{74}$ But this is not a clear indication for fish salting factories and export trade. Mohamed Hesein's survey work in Cyrenaica also opens up the possibility of fish production sites, though it is unlikely that these products were exported in the direction of Fazzan. ${ }^{75}$

So the evidence to support the theory for large-scale fish production along the Libyan coast is as yet lacking. It would seem more sensible to suggest that fish products were relatively rare, and luxurious, in Libya, and certainly in the desert.

\section{Conclusions and future directions of research}

The research undertaken for this paper would suggest that the title 'Fish and Ships in the Desert' has some validity, though the volume of fish trade is a question that remains unanswered. Direct evidence from fish and shellfish remains in the Libyan Valleys, at $\mathrm{Bu}$ Njem and in the Wadi-al-Ajal prove that fish were transported there. Indirect evidence from amphora types which probably carried fish products found at Gheriatel-Gharbia, Bu Njem, the Libyan Valleys and in the Wadi-al-Ajal suggest the presence of salted fish trade and garum, and perishable containers such as skins and barrels may also have been used. In addition, the fact that many other Roman goods were traded in the desert, such as oil, wine, pottery and glass suggest a demand for Roman goods and cultural objects, and that fish may have been another such item. To better answer this question, more surveys and excavations on the Libyan coast need to be carried out to establish first, whether we are looking at fish production or in fact storage tanks for wine or other products and second, the true scale of fish production. Finally, residue analyses of amphorae that may have carried fish need to be undertaken, especially on the Tripolitania II amphora that may well have been exclusively for wine.

\footnotetext{
70. Wilson 2007.

71. Keay 1989 , p. $67-70$

72. Peacock, Seager Smith 1989, p. 70; Keay 1989, p. 80.

73. Schorle, Leitch 2012.
}

74. Preece 2011

75. See Mohamed Hesein's contribution in this volume. 


\section{Bibliography}

Alhaique 2002 : ALHAIQUE (F.) - Archaeozoology of the funerary structures. In : Di Lernia (S.), Manzi (G.) (eds), Sands, Stones and Bones. The Archaeology of Death in the Wadi Tanezzuft Valley (5000-2000 BP), Firenze, 2002, p. 181-196.

Ancient nets and fishing gear 2007 : BEKKER-NIELSEN (T.), BERNAL CASSASOLA (D.) (eds) - Ancient nets and fishing gear: proceedings of the international workshop on 'Nets and fishing gear in Classical Antiquity: a first approach' (Cadiz, November 15-17 2007), Cadiz, 2007.

Bonifay 2004a : BONIFAY (M.) - Études sur la céramique romaine tardive d'Afrique, Oxford, 2004.

Bonifay 2004b : BONIFAY (M.) - Que transportaient donc les amphores africaines ? In : Papi (E.) (ed.), Supplying Rome and the empire: the proceedings of an international seminar held at Siena-Certosa di Pontignano (May 2-4, 2004), 2004 (JRA suppl. 69), p. 8-24.

Botte 2009 : BOTTE (E.) - Salaisons et sauces de poissons en Italie du sud et en Sicile durant l'Antiquité, Naples, 2009.

Brogan, Smith 1984 : BROGAN (O.), SMITH (D. J.) - Ghirza. A Libyan Settlement in the Roman Period, London, Tripoli, 1984 (Society for Libyan Studies/Department of Antiquities).

Capelli, Leitch 2011 : CAPELLI (C.), LEITCH (V.) - A Roman amphora production site at Lepcis Magna: scientific analyses, Libyan Studies, 42, 2011, p. 89-92.

Cole, Hoffman 2007a : COLE (F.), HOFFMAN (B.) - Beads. In : Mattingly et al. 2007b, p. 469-477.

Cole, Hoffman 2007b : COLE (F.), HOFFMAN (B.) - Glass objects from the FP. In : Mattingly et al. 2007b, p. 491-492.

Cuvigny 2003 : CUVIGNY (H.) (éd.) - La Route de Myos Hormos. L'armée romaine dans le désert oriental d'Égypte. Praesidia du désert de Bérénice, 2 vol., Le Caire, IFAO, 2003 (FIFAO 48/1 et 2).

Cuvigny 2012 : CUVIGNY (H.) (éd.) - Didymoi. Une garnison romaine dans le désert Oriental d'Égypte. II. Les textes (Praesidia du désert de Bérénice IV), Le Caire, 2012 (FIFAO 67).

Desanges 1978: DESANGES (J.) - Recherches sur l'activité des Méditerranéens aux confins de l'Afrique, Rome (CEFR, 38), 1978.

Dore et al. 2007 : DORE (J. N.), LEONE (A.), HAWTHORNE (J.) - The pottery type series. In : Mattingly et al. 2007b, p. 305-431.

Farming the Desert 1996a: BARKER (G.), GILBERTSON (D.), JONES (B.), MATTINGLY (D.) (eds) - Farming the Desert: The UNESCO Libyan Valleys Archaeological Survey, Vol. 1: Synthesis, Paris/London, 1996 (UNESCO/Society for Libyan Studies).

Farming the Desert 1996b: BARKER (G.), GILBERTSON (D.), JONES (B.), MATTINGLY (D.) (eds) - Farming the Desert: The UNESCO Libyan Valleys Archaeological Survey, Vol. 2: Gazetteer and Pottery, Paris/London, 1996 (UNESCO/Society for Libyan Studies).
Felici 2006 : FELICI (F.) - The Roman Pottery. In : Liverani (M.) (ed.), Aghram Nadarif. A Garamantian citadel in the Wadi Tannezzuft, Firenze, 2006, p. 241-248.

Fromentin, Lopuszanski 2013 : FROMENTIN (J.-M.), LOPUSZANSKI(D.) - Migration, residency and homing of Bluefin tuna in the western Mediterranean sea, ICES Journal of Marine Science, October 2013.

Garnier 2004 : GARNIER (N.) - Analyses du contenu des amphores africaines. In : Papi (E.) (ed.), Supplying Rome and the empire: the proceedings of an international seminar held at Siena-Certosa di Pontignano (May 2-4, 2004), 2004 (JRA suppl. 69), p. 25-32.

Garnier et al. 2011: GARNIER (N.), SILVINO (T.), BERNAL CASASOLA (D.) - L'identification du contenu des amphores: huile, conserves de poisons et poissage, SFECAG, Actes du Congres d'Arles, 2011, p. 397-416.

Harlow 2000 : HARLOW (M.) - Glass and beads. In : Phillipson (D. W.), Archaeology at Aksum, Ethiopia, 1993-7, 1-2, London, 2000, (Memoirs of, the British Institute in Eastern Africa 17), p. 458-60.

Hoffman 2007 : HOFFMAN (B.) - Vessel glass and faience, In : Mattingly et al. 2007b, p. 480-490.

Hoffman 2013 : HOFFMAN (B.) - Discussion of the glass from Old Jarma, In : Mattingly et al. 2013, p. 409-420.

Hoffman et al. 2010 : HOFFMAN (B.), MATTINGLY (D. J.), TAGART (C.), COLE (F.), WILD (J. P.) - Non-ceramic finds from CMD's excavations and the work of M. S. Ayoub'. In : Mattingly et al. 2010b, p. 411-488.

Keay, Dore 1989 : KEAY (N.), DORE (J. N.) (eds) - Excavations at Sabratha 1948-51, vol II: the Finds, part 1 The amphorae, coarse pottery and building materials, London, 1989.

Leone 2013 : LEONE (A.) - Pottery from the FP excavations at Jarma. In : Mattingly et al. 2013, p. 325-408.

Mackensen 2010 : MACKENSEN (M.) - Das severische Vexillationskastell Myd(---)/Gheriat el-Garbia am limes Tripolitanus (Libyen). Bericht über die Kampagne 2009, MDAIR, 116, 2010, p. 363-458.

Mackensen 2011 : MACKENSEN (M.) - Das severische Vexillationskastell Myd(---) und die spätantike Besiedlung in Gheriat el-Garbia (Libyen), Bericht über die Kampagne im Frühjahr, 2010, MDAIR, 117, 2011, p. 247-375.

Marichal 1992 : MARICHAL (R.) - Ostraka de Bu Njem, Tripoli, 1992.

Marlière, Torres Costa 2007 : MARLIÈRE (E.), TORRES COSTA (J.) Transport et stockage des denrées dans l'Afrique romaine : le rôle de l'outre et du tonneau ? In : Mrabet (A.), Remesal Rodriguez (J.) (eds), In Africa et in Hispania: études sur l'huile africaine, Barcelona, 2007, p. 85-106.

Mattingly 2001: MATTINGLY (D. J.) - Nouveaux aperçus sur les Garamantes : un état saharien ?, Antiquités Africaines, 37, 2001, p. 45-61.

Mattingly et al. 2007a : MATTINGLY (D. J.), LAHR (M.), ARMITAGE (S.), BARTON (H.), DORE (J. N.), DRAKE (N.), FOLEY (R.), MERLO (S.), 
SALEM (M.), STOCK (J.), WHITE (K.) - Desert Migrations: people, environment and culture in the Libyan Sahara, Libyan Studies, 38, 2007, p. 115-56.

Mattingly et al. 2007b: MATTINGLY (D. J.), DANIELS (C. M.), DORE (J. N.), EDWARDS (D.), HAWTHORNE (J.) - The Archaeology of Fazzān. Volume 2, Site Gazetteer, Pottery and other Survey Finds, London, 2007 (Society for Libyan Studies, Department of Antiquities).

Mattingly et al. 2008 : MATTINGLY (D. J.), LAHR (M.) (with contributions by others) - DMP II: 2008 fieldwork on burials and identity in the Wādī al-Ajāl, Libyan Studies, 39, 2008, p. 223-62.

Mattingly et al. 2009 : MATTINGLY (D. J.), LAHR (M.), WILSON (A. I.) DMP V: investigations in 2009 of cemeteries and related sites on the west side of the Taqallit promontory, Libyan Studies, 40, 2009, p. 95-131.

Mattingly et al. 2010a: MATTINGLY (D. J.), ABDULI (H.), ABURGHEBA (H.), AHMED (M.), ALI AHMED ESMAIA (M.), BAKER (S.), COLE (F.), FENWICK (C.), GONZALEZ RODRIGUEZ (M.), HOBSON (M.), KHALAF (N.), LAHR (M.), LEITCH (V.), MOUSSA (F.), NIKITA (E.), PARKER (D.), RADINI (A.), RAY (N.), SAVAGE (T.), SCHÖRLE (K.), STERRY (M.) - DMP IX: Summary report on the fourth season of excavations of the Burials and Identity team, Libyan Studies, 41, 2010, p. 89-104.

Mattingly et al. 2010b: MATTINGLY (D. J.), DANIELS (C. M.), DORE (J. N.), EDWARDS (D.), HAWTHORNE (J.) - The Archaeology of Fazzān. Volume 3, Excavations carried out by C. M. Daniels, London, 2010 (Society for Libyan Studies, Department of Antiquities).

Mattingly et al. 2011 : MATTINGLY (D. J.), ABDULI (H.), AHMED (M.), COLE (F.), FENWICK (C.), FOTHERGILL (B. T.), GONZALEZ RODRIGUEZ (M.), HOBSON (M.), KHALAF (N.), LAHR (M.), MOUSSA (F.), NIKITA (E.), NIKOLAUS (J.), RADINI (A.), RAY (N.), SAVAGE (T.), STERRY (M.), WILSON (A. I.) - DMP XII: excavations and survey of the so-called Garamantian Royal Cemetery (GSC030-031), Libyan Studies, 42, 2011, p. 89-102.

Mattingly et al. 2013: MATTINGLY (D. J.), DANIELS (C. M.), DORE (J. N.), EDWARDS (D.), LEONE (A.), THOMAS (D. C.) (eds) - The Archaeology of Fazzān. Volume 4, Survey and Excavations at Old Jarma (Ancient Garama) carried out by C. M. Daniels (1962-69) and the Fazzān Project (1997-2001), London, 2013 (Society for Libyan Studies/Department of Antiquities).

Morrison 1989 : MORRISON (H. M.) - The glass. In : Munro-Hay (S.), Excavations at Aksum: An Account of Research at the Ancient Ethiopian Capital Directed in 1972-74 by the Late Dr Neville Chittick, London, 1989, (Memoirs of the British Institute in Eastern Africa 10), p. $189-209$.

Peacock, Seager Smith 1989 : PEACOCK (D.), SEAGER SMITH (R.) - Punic amphora stamps. In : Keay (N.), Dore (J. N.) (eds) Excavations at Sabratha 1948-51, vol II: the Finds, part 1 The amphorae, coarse pottery and building materials, London, 1989, p. 71-79.

Pelling 2001 : PELLING (R.) In : D. Mattingly (ed) - The Fazzan Project 2001: Preliminary report on the 5th season of work, Libyan Studies, 32, p. $133-53$.
Preece 2012 : PREECE (C.) - Janzur: anchorage, trade, industry and development on the Tripolitanian littoral, Libyan Studies, 43, 2012, p. 47-58.

Rebuffat et al. 1966-67 : REBUFFAT (R.), GASSEND (R.), GUERY (R.), HALLIER (G.) - Bu Njem 1967, Libya Antiqua, III-IV, 1966-67, p. 49-137.

Rebuffat et al. 1969-70 : REBUFFAT (R.), GASSEND (R.), GUERY (R.), HALLIER (G.) - Bu Njem 1968, Libya Antiqua, VI-VII, 1969-70, p. 9-105.

Rebuffat et al. 1969-70 : REBUFFAT (R.), GASSEND (R.), GUERY (R.), HALLIER (G.) - Bu Njem 1970, Libya Antiqua, VI-VII, 1969-70, p. 107-165.

Rebuffat 1974-75 : REBUFFAT (R.) - Bu Njem 1971, Libya Antiqua, XI-XII, 1974-75, p. 189-241.

Rebuffat 1976-77 : REBUFFAT (R.) - Bu Njem 1972, Libya Antiqua, XIIIXIV, 1976-77, p. 37-77.

Revilla Calvo 2007 : REVILLA CALVO (V.) - Les amphores africaines du II et $\mathrm{III}^{\mathrm{e}}$ siècles du Monte Testaccio (Rome). In : Mrabet (A.), Remesal Rodriguez (J.) (eds), In Africa et in Hispania: Etudes sur l'huile africaine, Barcelona, 2007, p. 269-297.

Schörle, Leitch 2012 : SCHÖRLE (K.), LEITCH (V.) - Report of the preliminary season of the Lepcis Magna coastal survey, Libyan Studies, 43, 2012, p. 149-154.

El Theatrum Balbi de Gades 2009 : BERNAL (D.), ARÉVALO (A.) (eds) - El Theatrum Balbi de Gades: Actas del Seminario "El Teatro Romano de Gades. Una Mirada al future” (Cadiz, 18-19 novembre de 2009), Cadiz, 2011.

Trousset 2003 : TROUSSET (P.) - Le tarif de Zaraï : essai sur les circuits commerciaux dans la zone présaharienne, Antiquités africaines, 38-39, 2003, p. 369-373.

Whitehouse 1998 : WHITEHOUSE (D.) - Excavations at ed Dur (Umm alQaiwain, United Arab Emirates): The Glass Vessels, Leuven, 1998.

Whitehouse 2000 : WHITEHOUSE (D.) - Ancient glass from ed-Dur (Umm al-Qaiwain, U.A.E.), Glass excavated by the Danish expedition, Arabian Archaeology and Epigraphy, 11, 2000, p. 87-128.

Wilson 2002 : WILSON (A. I.) - Marine resource exploitation in the cities of coastal Triplitania, L'africa Romana, XIV, 2002, p. 429-36.

Wilson 2007 : WILSON (A. I.) - Fish-salting workshops in Sabratha. In : Lagóstena (L.), Bernal (D.), Arévalo (A.) (eds), Cetariae 2005. Salsas y Salazones de Pescado en Occidente durante la Antigüedad. Actas del Congreso Internacional (Cádiz, 7-9 de noviembre de 2005), Oxford, 2007 (British Archaeological Reports, International Series 1686), p. 173-81.

Wilson 2012 : WILSON (A. I.) - Saharan trade: short-, medium- and long-distance trade networks in the Roman period, Azania: Archaeological Research in Africa, 47.4, 2012, p. 409-449.

Wheeler 1979: WHEELER (A.) - Fish bones and marine molluscs. In : Barker (G.), Economic life at Berenice: the animal and fish bones, marine molluscs and plant remains, p.1-49. In : Lloyd (J.) (ed), Excavations at Sidi Khrebish, Benghazi (Berenice) vol. II, Tripoli, 1979 (Libya Antiqua Suppl. 5. 2), p. 25-6. 



\section{Ancient marine resource exploitation in the coastal strip of Cyrenaica: Some evidence of fish-related industry in Cyrenaica?}

\section{Mohamed A Hesein}

\section{Introduction}

$\mathrm{T}$ he economic and productive activities of Roman Cyrenaica have received little attention in scholarship. Most of the information about manufactures and production is very restricted. Olive and wine presses, well known from other parts of North Africa, have not yet been fully documented or studied in this region ${ }^{1}$. The most important work has been carried out at the ancient sites of Euesperides and Berenice, both of which lie beneath the modern city of Benghazi $^{2}$, revealing considerable information regarding the economic and trade activities of this part of Cyrenaica. However, almost nothing has hitherto been known about the level of coastal exploitation in the region and its economic role in Cyrenaica. Although some archaeological missions are working at a few coastal sites in this region, many questions regarding the economic and manufacturing roles of these sites have not been answered. Information about fish-related manufacturing and production is still very obscure. Until now only rare studies have examined the scale of exploitation of the marine resources in the region ${ }^{3}$ or the extent to which the Cyrenaican coastal inhabitants used the sea as a source of income. A survey carried out by the author in 2010 and 2012 has revealed new evidence of abundant archaeological remains scattered along the shore of $\mathrm{Cyrenaica}^{4}$, indicating intensive exploitation of

I would like to express my greatest gratitude to Dr. Victoria Leitch for her continuous support and encouragement. I am grateful to Dr. Nick M. Ray and Dr. Matthew Hobson for their feedback and advice on the early draft of this paper. I am most grateful to Ahmed Emrage and David Davidson for sharing with me their research before publication. A special thanks to Professor David Mattingly, my PhD supervisor, for his useful and fruitful suggestions and guidance. Finally, I wish to thank my friend Ahmed El-Hayan for motivating and helping me during my field survey. Any errors or mistakes in the article are mine.

1. Wilson 2004; Buzaian 2009. Oil and wine presses in Cyrenaica are currently being surveyed and studied by Ahmed Buzaian.

2. Wilson et al. 1999; Lloyd 1977/1979.

3. Wilson, Megías 2008.

4. The data demonstrates in this article is a preliminary examination of some archaeological remains which seem to be more

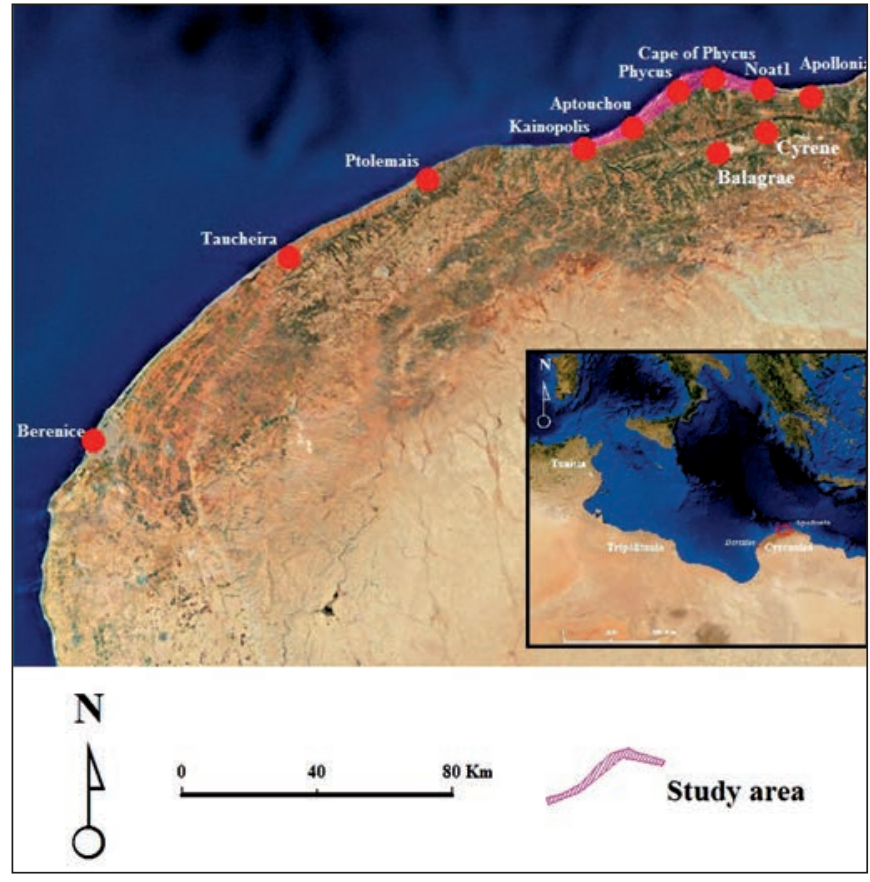

Fig. 1. The distribution of sites within the study area (c) Mohamed A Hesein).

marine resources. The purpose of this paper is to analyse the evidence to assess the likelihood of fish-related production activities in the area.

\section{Area studied}

The field survey documented six sites that were probably associated with the exploitation of marine resources. The sites are distributed within an area measuring $50 \mathrm{~km}$ west-east (Fig. 1) lying along the coastal strip of Al-Jabel Al-Akhdar (Green Mountain). Starting from the ancient site of Kainopolis (El-Agla), located about $35 \mathrm{~km}$ east of the ancient site of Ptolemais (Tolmeitha), to the area of Noat1, about $15 \mathrm{~km}$ to the west of Apollonia (Susa).

likely related to fish production. For more discussion and analytical studies of these remains, see my forthcoming PhD thesis (Hesein forthcoming). 


\section{The archaeological remains}

\subsection{Cape of Phycus (Al-Mamloh)}

Al-Mamloh is an archaeological site that lies about $7 \mathrm{~km}$ east of Phycus. Here, a number of archaeological remains are preserved in an area covering more than $1 \mathrm{~km}^{2}$, including remains of a fortification, a villa and an industrial complex. This latter structure lies $35 \mathrm{~m}$ from the sea and covers an area of $2000 \mathrm{~m}^{2}$ (Fig. 2).

Large-scale excavation is needed to understand the function of the site, however, from the ground we can assume that the site comprised a rectangular structure surrounded by external walls. There is a well located $9 \mathrm{~m}$ in front of this structure which is still in use today.

The building consists of a set of tanks of different shapes and sizes, mainly rectangular, built of stone and lined with opus signinum (Fig. 2a). By tracing the foundations the following features can be identified:

Eight tanks (numbered from 1 to 8), which seem to vary in size and shape. Most are rectangular apart from tank 6 which has curved corners. The dimensions of the tanks are $2.80 \times 2.40 \mathrm{~m}, 1.50 \times 2.50 \mathrm{~m}, 1.60 \times 2.40 \mathrm{~m}$, $1.60 \times 1.50 \mathrm{~m}, 1.60 \times 1.40 \mathrm{~m}, 1.50 \times 2.50 \mathrm{~m}, 1.20 \mathrm{x}$ $1.30 \mathrm{~m}, 1.20 \times 1.13 \mathrm{~m}$ and $1.00 \times 0.70 \mathrm{~m}$. Depths are uncertain.

Three basins can be only partly traced $(9,10$ and 11). Although their shape and size cannot be accurately determined, it is probable that they were the same shape as the basins next to them. For instance, basin 9 is more likely to be similar in shape to basins 1 and 2 .

\subsection{Phycus (Zawiet El-Hamama)}

Phycus lies $25 \mathrm{~km}$ to the north-west of Cyrene and about $30 \mathrm{~km}$ west of Apollonia. The archaeological remains that appear to be related to fish production are located in two different areas (sites 1 and 2) within the ancient site of Phycus (Figs. 3, 3a and 3b).

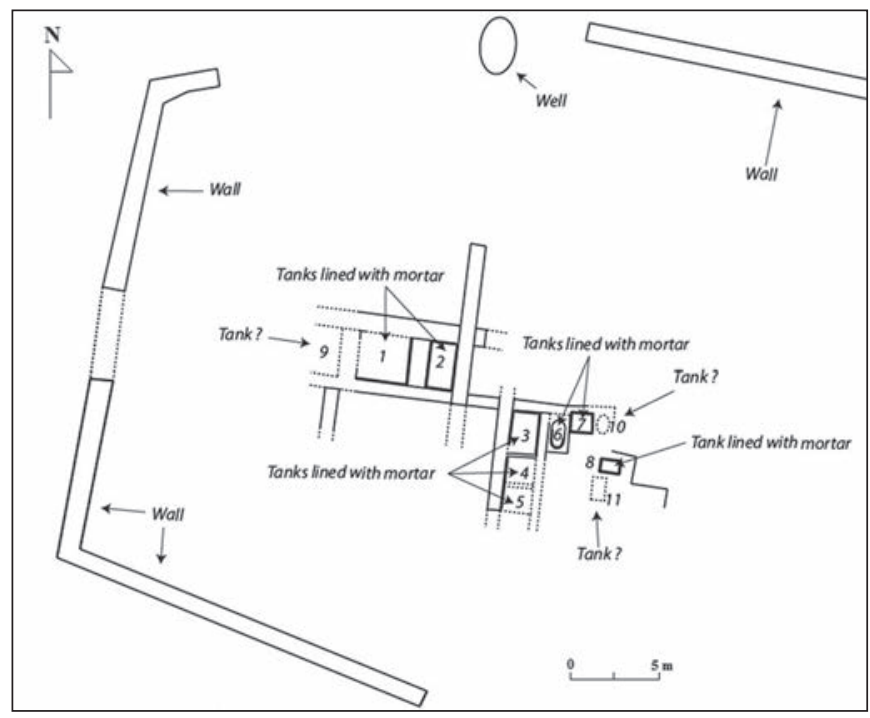

Fig. 2. The possible fish-processing site at cape of Phycus (Al-Mamloh) (C) Mohamed A Hesein).

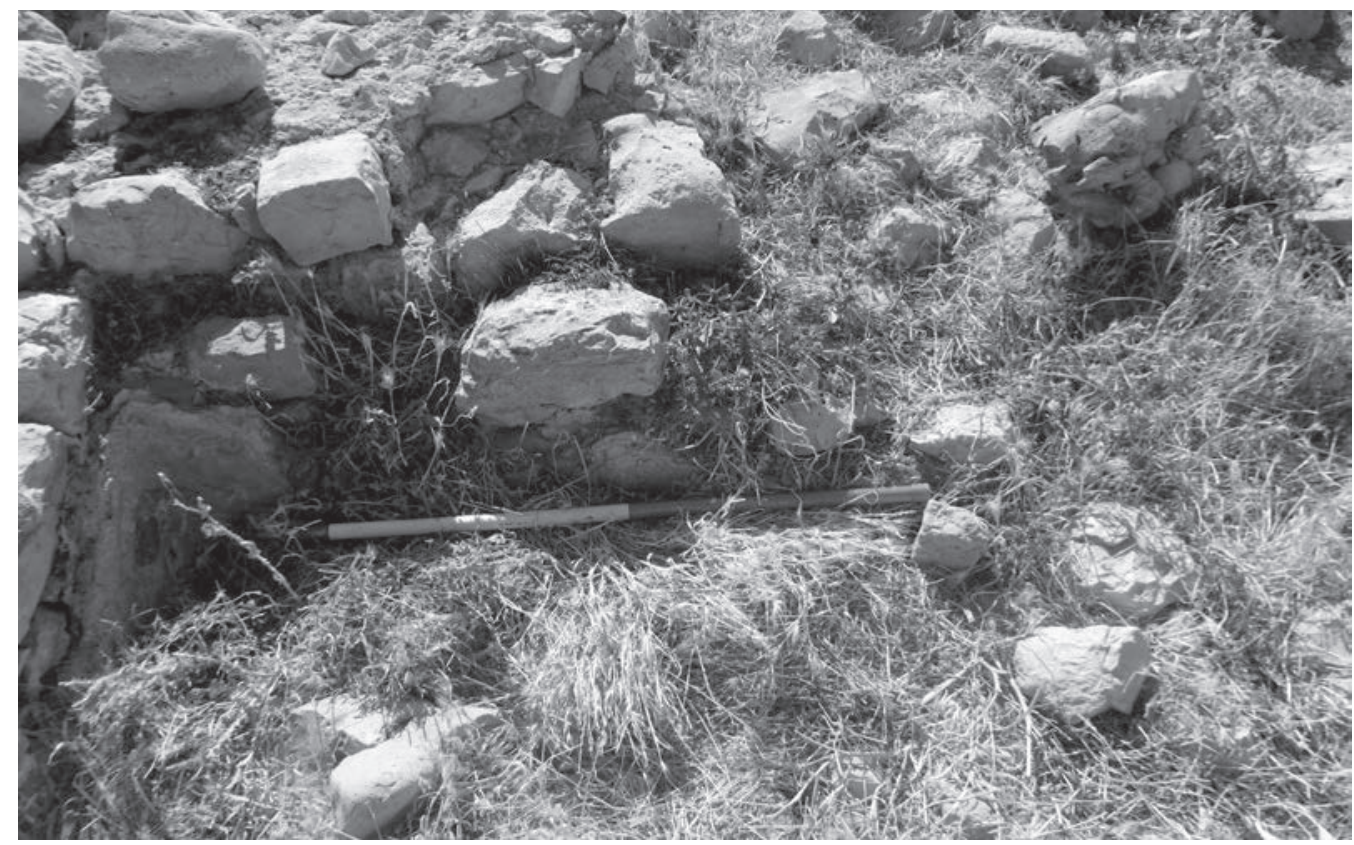

Fig. 2a. Detail of waterproofing in Vat 3, facing west (ㄷ Mohamed A Hesein). 


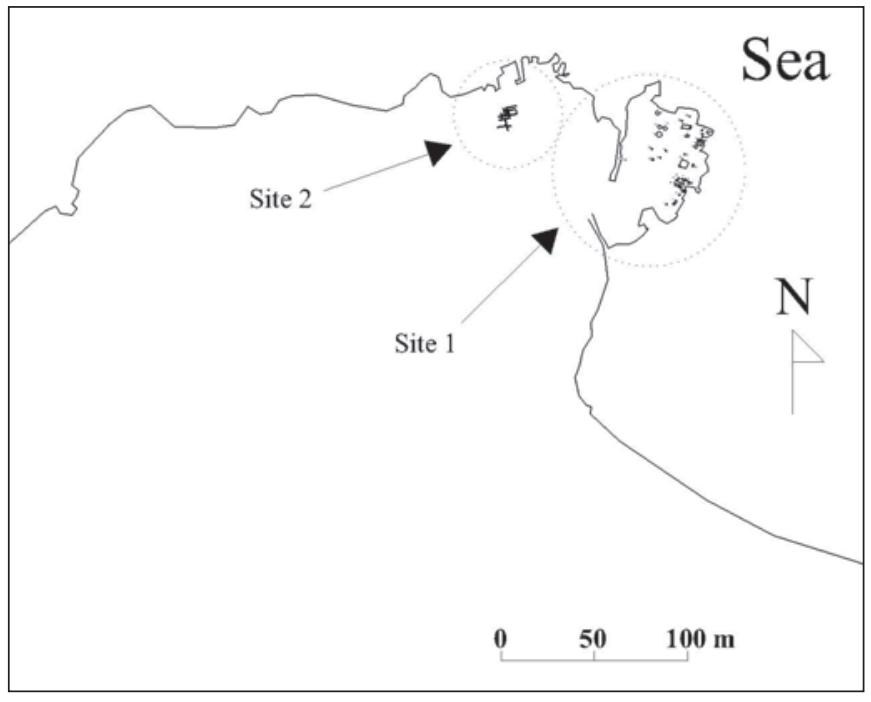

Fig. 3. Possible fish-related productions at the ancient site of Phycus (Zawiet El-Hamama) (C Mohamed A Hesein).

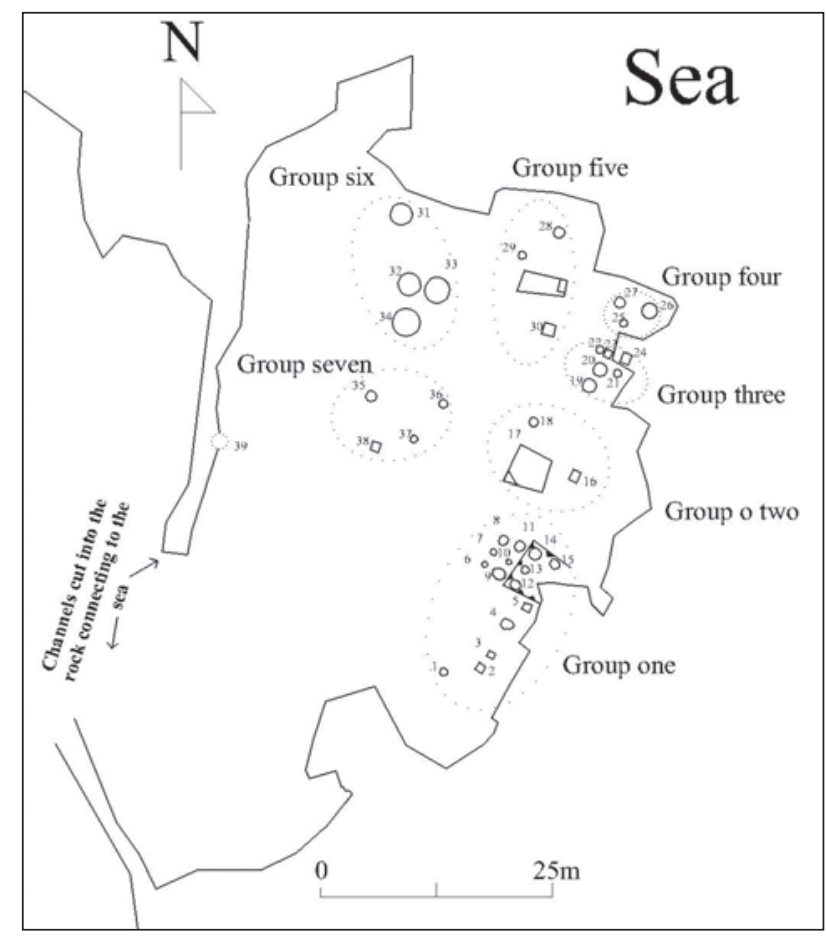

Fig. 3a. Distribution of tanks in site 1 at Phycus (Zawiet El-Hamama) (C Mohamed A Hesein).

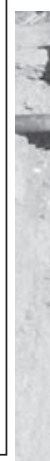

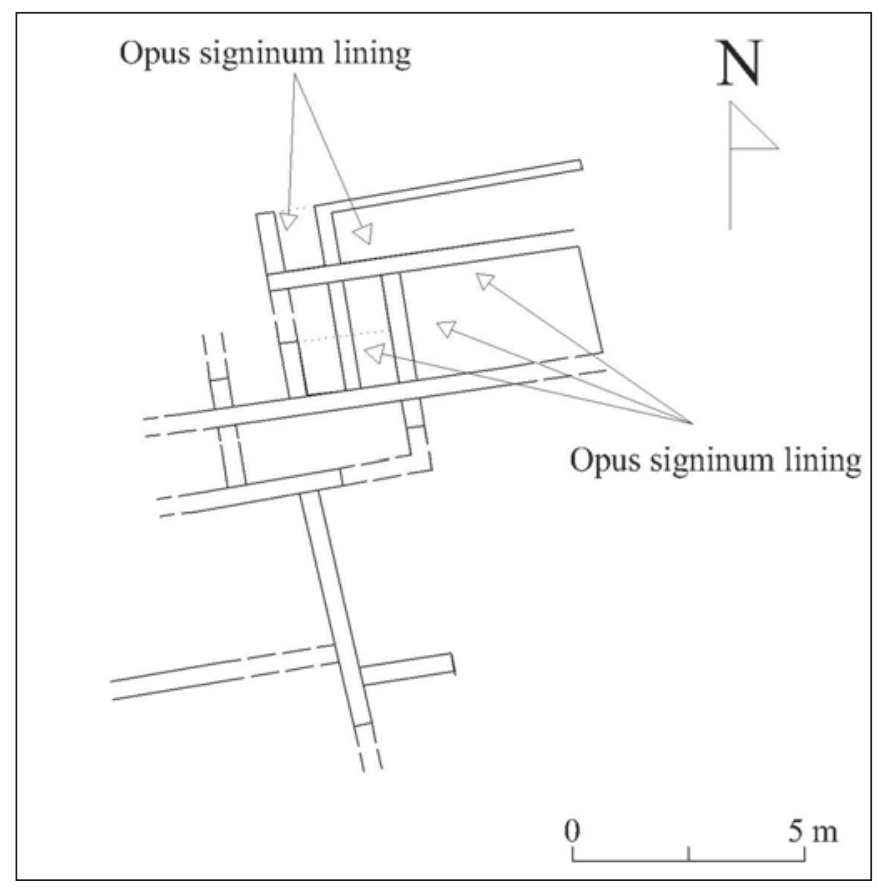

Fig. 3b. Initial plan for the site 2 (tanks?) at Phycus (Zawiet El-Hamama) (c Mohamed A Hesein).

Fig. 3c. Vat 2 within group 1, facing west (Photo: Mohamed A Hesein).

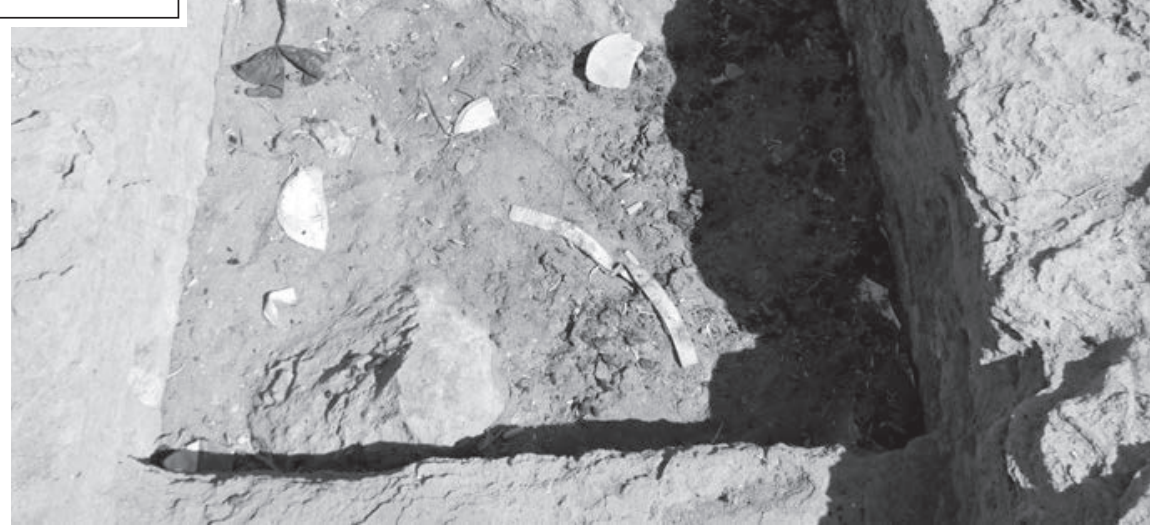




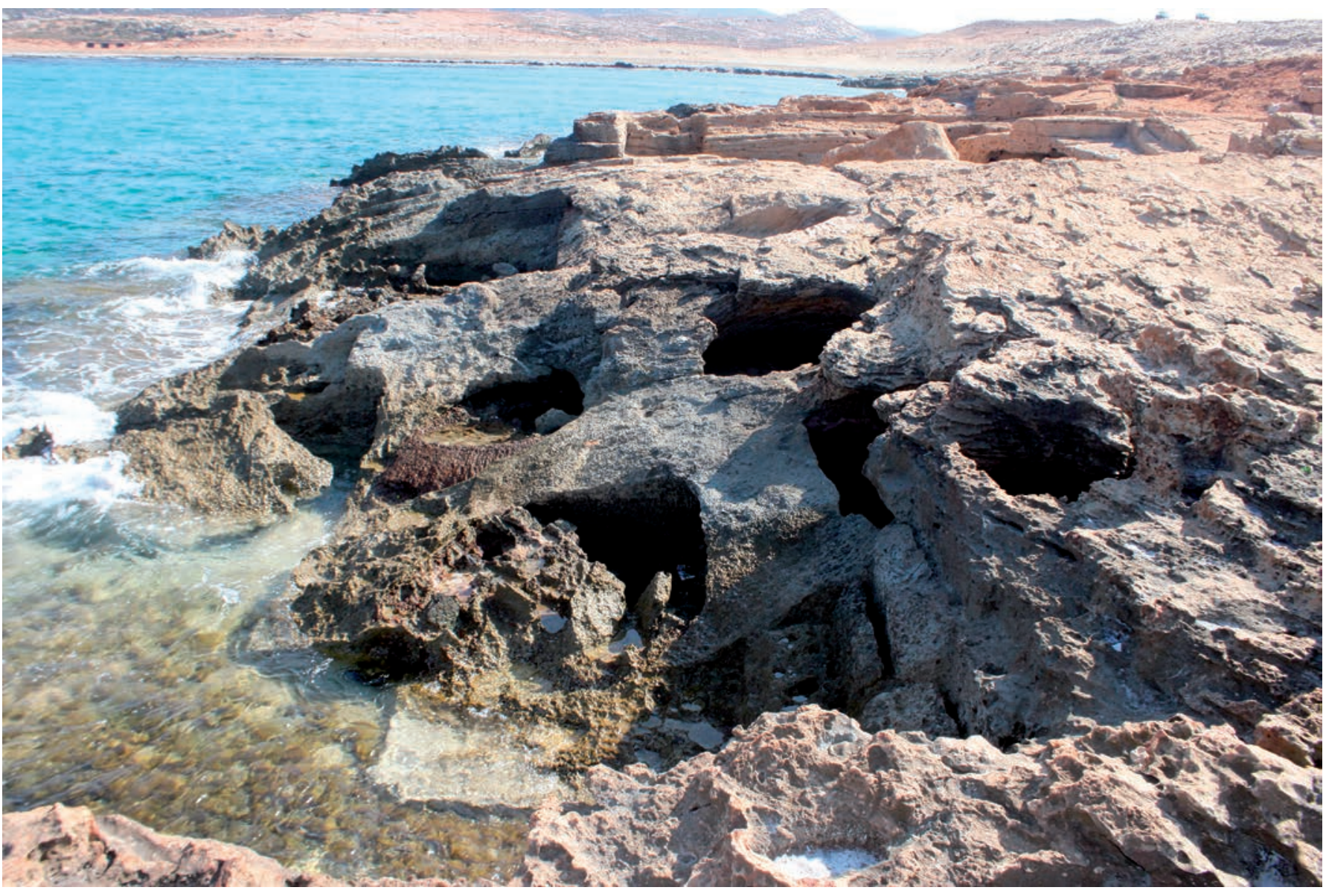

Fig. 3d. Side of group 3, looking south (৫ Mohamed A Hesein).

\subsubsection{Site 1}

The site lies on the eastern headland of the promontory. This zone contains more than 30 tanks or vats (Fig. 3a) distributed as seven groups in an area of $2000 \mathrm{~m}^{2}$.

\section{Group one}

1 - A row of five vats cut into the rock vertically (Numbered from 1 to 5). Vat 2 (Fig. 3c) measures $1 \mathrm{~m}^{2}$, while vats 3 and 5 are rectangular measuring $0.70 \times$ $0.60 \mathrm{~m}$ and $0.90 \times 0.95 \mathrm{~m}$ respectively. Vats 1 and 4 are bottle-shaped ${ }^{5}$, their opening diameters are $1 \mathrm{~m}$ and $1.4 \mathrm{~m}$. The depth was not identified for this group because of the accumulation of soil that covered them. All vats are lined with waterproof plaster (opus signinum).

5. It is remarkable that the most of the vats recorded at site 1 at Phycus and sites 1 and 2 at Al-Hanya seem to be bottle-shaped, widening out below a narrow neck. In any case, the diameter that has been provided is the measurement of the opening mouth.
2 - A row of ten vats (numbered from 6 to 15) cut into the rock. All the vats are lined up three by three. The vats vary in size and shape, six having a round mouth (vats 6 , $7,8,10,11,13,14$ and 15 ) measuring $0.80,1,0.75,1.15$, $0.75,1.25,1$ and $1.5 \mathrm{~m}$ in diameter respectively and two are oval (vats 9 and 12) measuring 1.4 and $1.25 \mathrm{~m}$. All the vats are lined with opus signinum. The first line of three vats $(12,13,14$ and 15) was built half a metre lower than the ground level of the others in the group.

\section{Group two}

This is a set of three vats $(16,17$ and 18$)$. Vats 16 and 17 are rectangular, measuring $1.20 \times 0.95 \mathrm{~m}$ and $4.36 \times 3.87 \mathrm{~m}$ respectively. Vat 18 is bottle-shaped with an opening diameter of $1.20 \mathrm{~m}$. As with Group One, the three vats are lined with opus signinum.

\section{Group three}

This set of 6 vats (19, 20, 21, 22, 23 and 24) (Fig. 3d). is located 3.70 m north of Group Two. Vats 19, 20, 21 and 22 are bottle-shaped, with outlet diameters of 1.50 , 
1.40 and $1.20 \mathrm{~m}$ respectively. Vats 22 and 23 were interconnected measuring $(2.0 \times 3.0 \mathrm{~m})$ and were faced with opus signinum. The eastern side of vats 21 and 22 facing the sea is completely destroyed by erosion, which allows us to estimate its depth as more than $1.5 \mathrm{~m}$.

\section{Group Four}

To the north of Group Three is a set of three bottleshaped vats (25 (Fig. 3e), 26 and 27). Vat 25 has been eroded by the sea, leaving its southern side visible in section. It has a circular opening measuring $0.85 \mathrm{~m}$ in diameter. It is about $2 \mathrm{~m}$ in depth with its cylindrical shaft lined with opus signinum. Vats 26 and 27 are located to the north of the previous one and are bottleshaped, measuring 1.70 and $1.20 \mathrm{~m}$ respectively. Their depths have not been identified as they are full of soil. Both are lined with opus signinum.

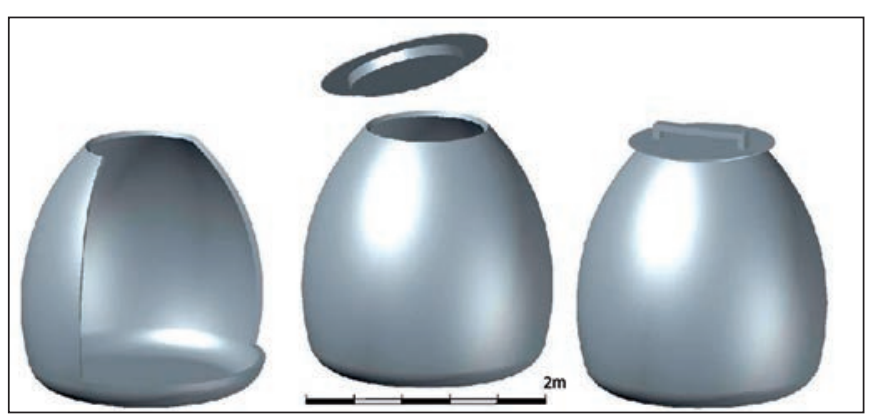

Fig. 3e. An imagined vat which is similar to the shape of vat 25 in Phycus, the total capacity of this vat is about $5.25 \mathrm{~m}^{3}$.

The lid shown in this image is just imaginary, and its shape does not rely upon archaeological evidence (๑ Mohamed A Hesein).

\section{Group five}

This group is a set of three vats $(28,29$ and 30) of varying shape and size. Vats 28 and 29 are bottle-shaped with outlet diameters of $1.23 \mathrm{~m}$ and $0.89 \mathrm{~m}$ respectively. Vat 30 is rectangular measuring $1.30 \times 1.24 \mathrm{~m}$. There is a rectangular cut in rock located between vat 28,29 and 30 of unclear purpose. The depth of all these cannot be determined because they are full of soil, as for nearly all the vats at this site.

\section{Group Six}

This group is located to the northwest of Group Four and contains four vats $(31,32,33$ and 34$)$. These are the largest bottle-shaped vats (Fig. 3f) at the site with opening diameters of $2.25 \mathrm{~m}, 2.48 \mathrm{~m}, 2.8 \mathrm{~m}$ and $3.1 \mathrm{~m}$ respectively, again with undetermined depths. All four vats are lined with opus signinum.

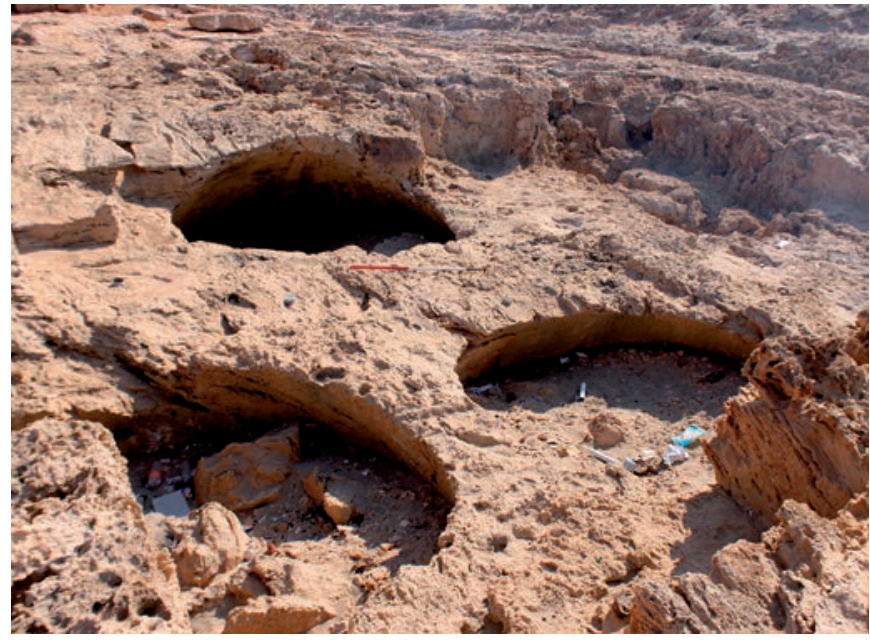

Fig. 3f. Vats 32, 33 and 34 within group 6, facing south-west (C) Mohamed A Hesein).

\section{Group seven}

A set of four vats $(35,36,37$ and 38) of varying size and shape, located between 4 and $7 \mathrm{~m}$ apart. Vats 35 , 36 and 37 are bottle-shaped with opening diameters of $1.2,1$ and $0.76 \mathrm{~m}$ respectively and are lined with opus signinum. The remaining vat (38) has a rectangular opening leading to a large rectangular tank measuring about $3.0 \times 2.0 \mathrm{~m}$ with a depth of at least $2 \mathrm{~m}$. The tank is lined with opus signinum. This tank most probably served as a water cistern.

There are two channels cut into the rock running from the sea into the site. One runs north to south and is about $2 \mathrm{~m}$ wide and about $1 \mathrm{~m}$ deep. The other runs from the southeast to the northwest and is about $2 \mathrm{~m}$ wide and $0.20 \mathrm{~m}$ deep.

\subsubsection{Site 2}

This site is located to the west of site 1 . It is difficult at the moment to identify the whole plan of this site as it is covered by sand. Some of the visible remains indicate a complex building lying beneath the sand. The general impression is that it possessed a set of tanks or basins (?) of different sizes and shapes (mostly rectangular) built of stone and lined with opus signinum (Fig. 3b).

\subsection{Aptouchou (Al-Haniya)}

A number of vats were found along the shore of the ancient site of Haniya, $13 \mathrm{~km}$ west of Phycus. The vats can be divided into two groups according to their location (Fig. 4). 


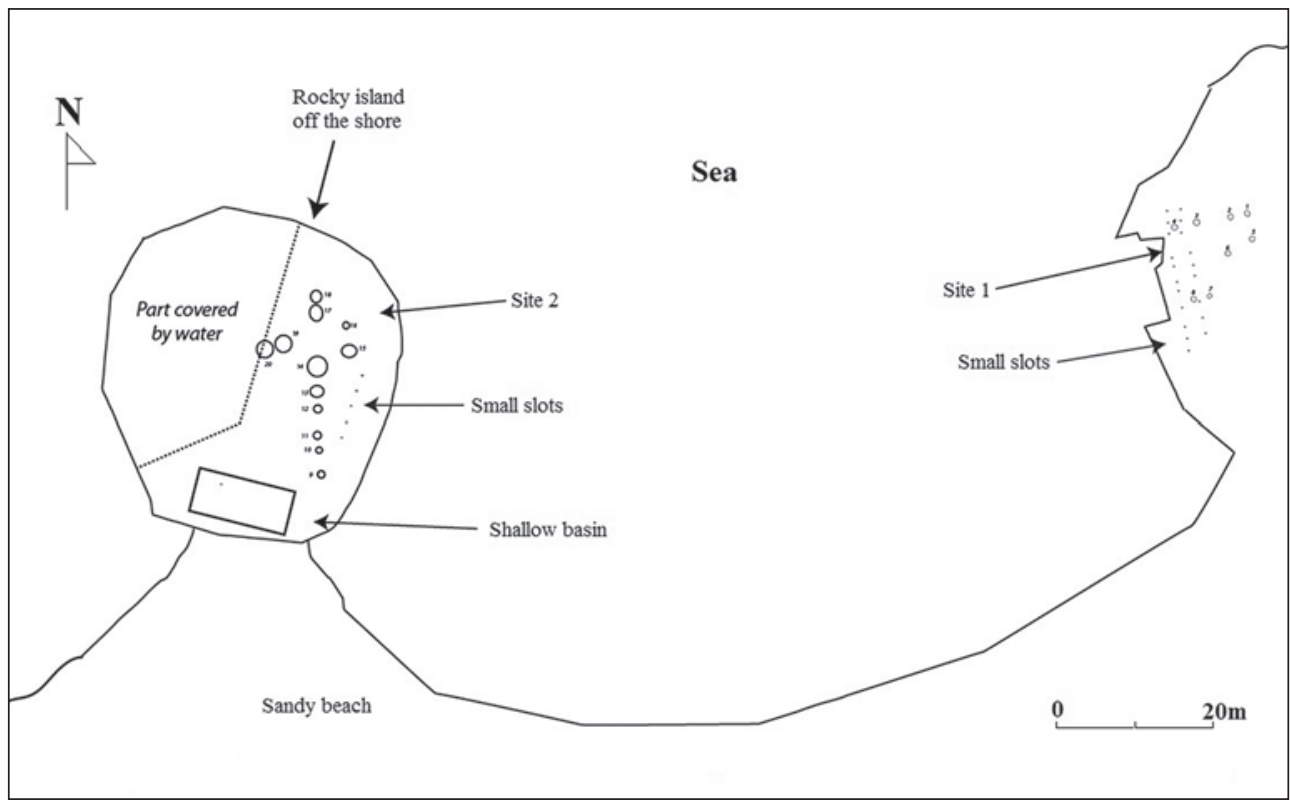

Fig. 4. Distribution of vats within site 1 and 2 at ancient Aptouchou (Al-Haniya) (๔ Mohamed A Hesein).

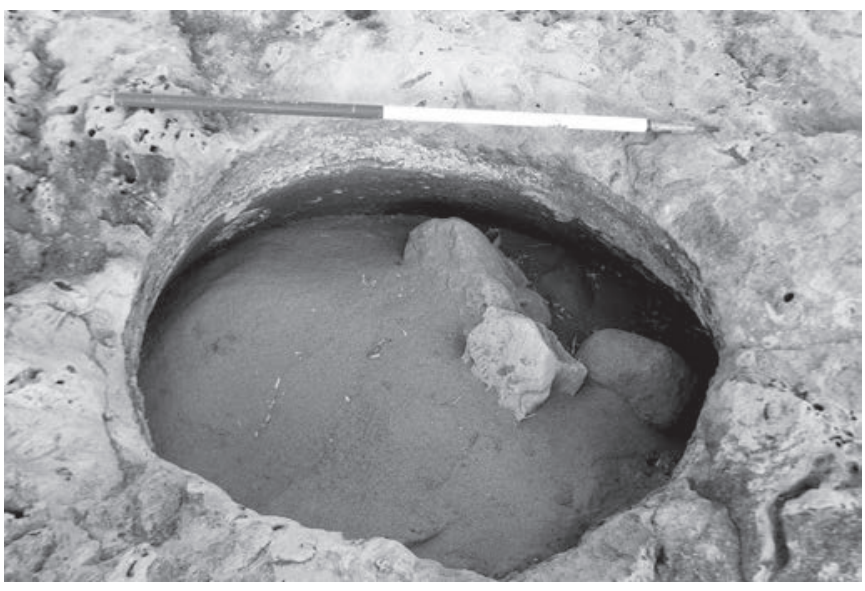

Fig. 4a. Vat 3 within site 1 at Aptouchou (Al-Hanya), facing south-east (৫) Mohamed A Hesein).

\subsubsection{Site 1}

A set of vats (numbered from 1 to 8 ) lies on the rocky area overlooking the sea. All the vats are cut into the rock and are circular with neck diameters of $0.90,0.80$, $0.90,0.80,0.80,0.70,0.70$, and $0.80 \mathrm{~m}$ respectively with unidentified depths (Fig. 4a).

\subsubsection{Site 2}

This group occupies a small rocky island adjoining the shore, located $200 \mathrm{~m}$ to the west of site 1 . The depth of the water around the island varies. For instance, on the shore side the water does not exceed $0.50 \mathrm{~m}$ in depth, whereas on the other sides, the water is $1.50 \mathrm{~m}$ to $2.50 \mathrm{~m}$ in depth. The island and site 1 serve to form a bay.

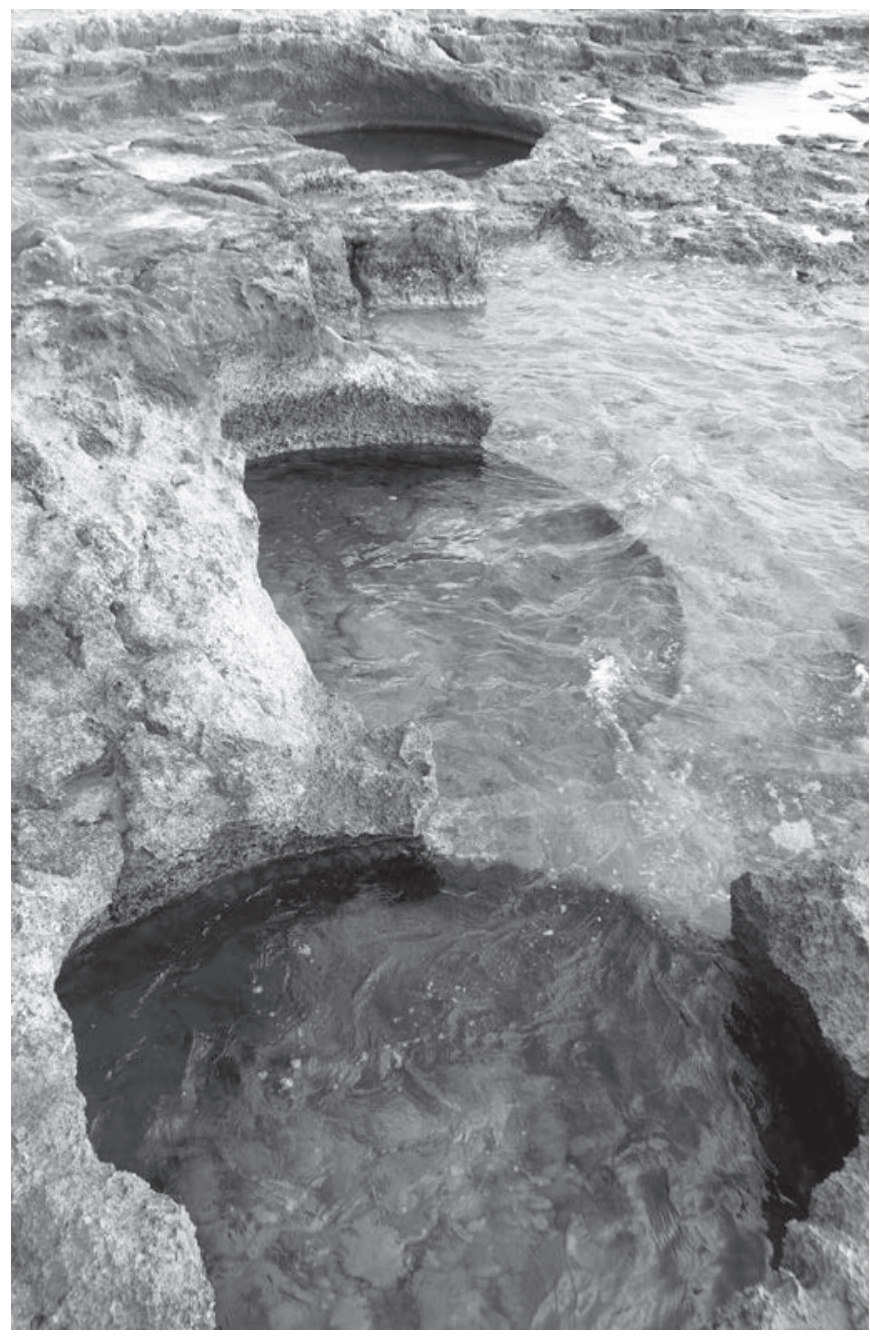

Fig. 4b. Vats 4, 5 and 6 within site 2 at Aptouchou (Al-Hanya), facing south (@ Mohamed A Hesein). 
Site 2 consists of 12 circular vats in a line (Fig. $\mathbf{4 b}$ ), cut into the rock. These vats vary in size with their diameters being: $1.10,0.85,1.10,1.150,1.60,2.80,1.70$, $0.90,2.20,1.70,2.30$ and $2.40 \mathrm{~m}$. In both areas there are small slots cut into the rock $0.2 \mathrm{~m}$ in diameter. This might suggest that the vats were covered, and that the slots supported wooden columns holding some sort of roof. All of the vats in both areas are lined with opus signinum.

\subsection{Kainopolis (Al-Agla)}

Al-Agla lies $30 \mathrm{~km}$ north-west of Phycus and $35 \mathrm{~km}$ east of the ancient site of Ptolemais. As with other sites that have been found along this coast, there are a number of archaeological remains scattered around the site which might belong to fish-related production (Fig. 5).

A set of twelve vats lies in shallow water (numbered from 1 to 12), installed in four rows (Fig. 5a). Each row consists of three vats of $2 \mathrm{~m}$ diameter. Because they are covered by water and sand their depths cannot be identified and it is difficult to assess whether they are lined with opus signinum.

The second set of vats (numbers 13 and 14) is located $10 \mathrm{~m}$ to the south of the first set and consists of two circular vats built of small stones mixed with opus signinum and small ceramic fragments (Fig. 5b). The upper parts of the vats are eroded away. The bases have $2 \mathrm{~m}$ diameters. The remaining height of both vats does not exceed $0.20 \mathrm{~m}$. They seem to be similar in size to vats recorded at the ancient sites of Berenice and Taucheira ${ }^{6}$.

The third set of vats comprises two vats (numbered 15 and 16) built of stones and lined with a thick layer of opus signinum to the south-west of vats 13 and 14. It is difficult at the moment to reconstruct the whole structure without excavation (Fig. 5c). However, on the ground it seems that they are rectangular, similar to one of the examples to the west.

A vat (number 17) built of stone and lined with a thick layer of opus signinum is located to the south-west of vat 16. Unlike the previous examples, this one takes a large circular shape with a diameter of $4 \mathrm{~m}$.

It is worth mentioning that these vats or basins exist with other archaeological features within the building complex. Large-scale investigation and excavation is needed to get a more detailed picture of these sites.

6. Lloyd 1977; Buzaian 2000.

\section{Discussion}

In evaluating the significance of the ancient fishprocessing industry in Cyrenaica, two points should be considered. First, we must note the references made by ancient writers to the high demand for marine products in the Roman period, especially the growing demand for fish sauces such as garum and liquamen. ${ }^{7}$ Secondly, we need to assess if there was a growth in this industry over time at coastal sites with the construction of new sites or the development of pre-existing ones. Certainly the exploitation of marine products seems to have increased during the Roman period in this area.

\subsection{Evidence from ancient texts}

The ancient texts mention more than 25 sites along the coast of Cyrenaica $^{8}$, of which my survey only covers a small number. Some pre-existing ports flourished and developed into independent cities. For example, Apollonia, the port of Cyrene, was established as a small harbour to serve the city, but grew considerably and became an independent city. The same scenario happened at Barce and its port (Ptolemais). These examples show that access to the sea went beyond the need for an easy means of transportation and indicate a growing interest in the active exploitation of marine resources. Additionally, Cyrenaica is not an isolated example, but displays a similar path of development noted at many sites around the Mediterranean.

Synesius (letter 148) describes villagers who live far south of Cyrenaica. He stated there were no urban agglomerations, roads or commercial areas in that region. Two important statements can be extracted. First, there was production and marketing of salt in the coastal region of Cyrenaica. As he said in the letter "the people here do not take to the sea, even for the purpose of getting their salt". Secondly, Cyrenaican people, at least who live near to the sea, were aware of the importance of the sea as a source of food, as he said "the people here refuse to believe that the sea too is able to nourish mankind ".

\subsection{The evidence from the archaeology - fish or other productions?}

The intensive installations along the shore of Cyrenaica offer possible confirmation for the large-scale

7. Trakadas 2004a; Curtis 1983; 1991

8. Scylacis Caryandensis 108; Strabo Geography 20; Ptolemy Geography IV; Stadiasums Magni Maris; Synesius 170, 171. 


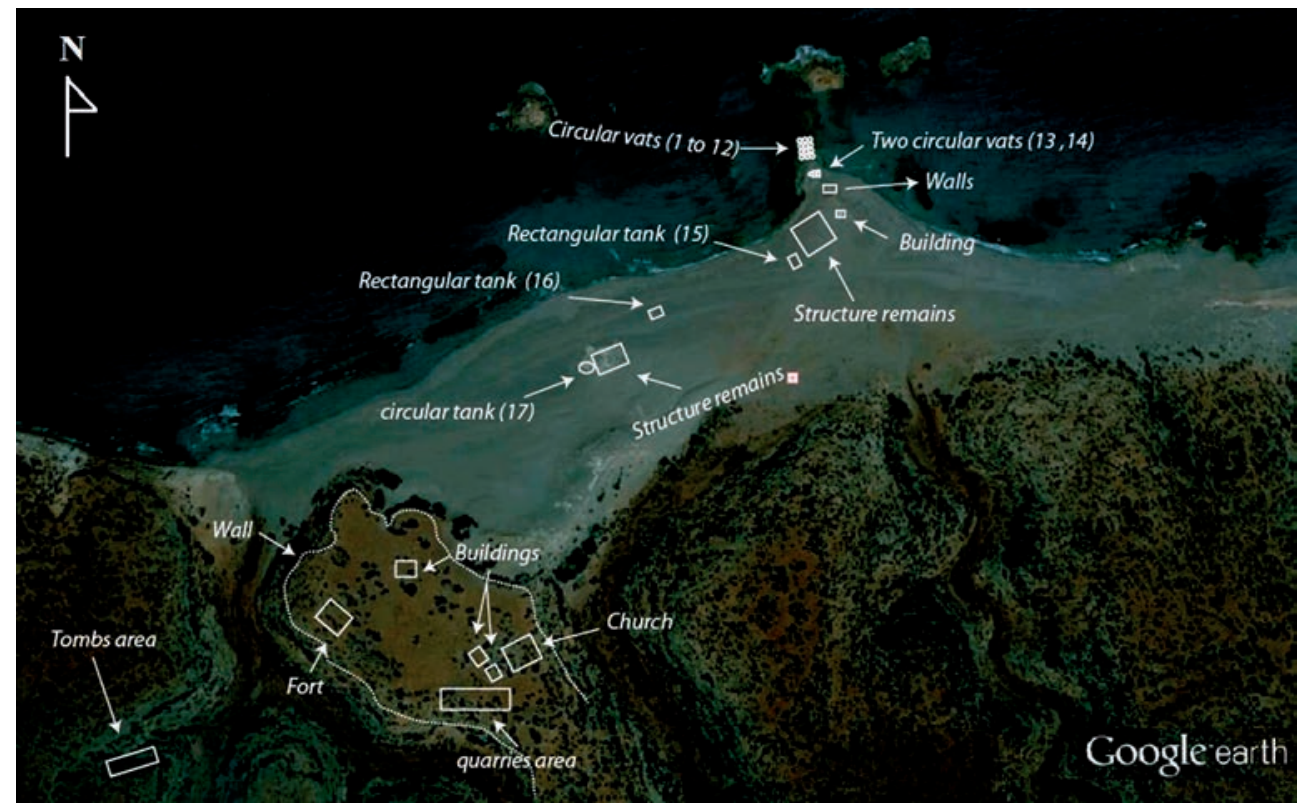

Fig. 5. Google Earth imagery illustrating the distribution of remains at Kainopolis (Al-Agla).

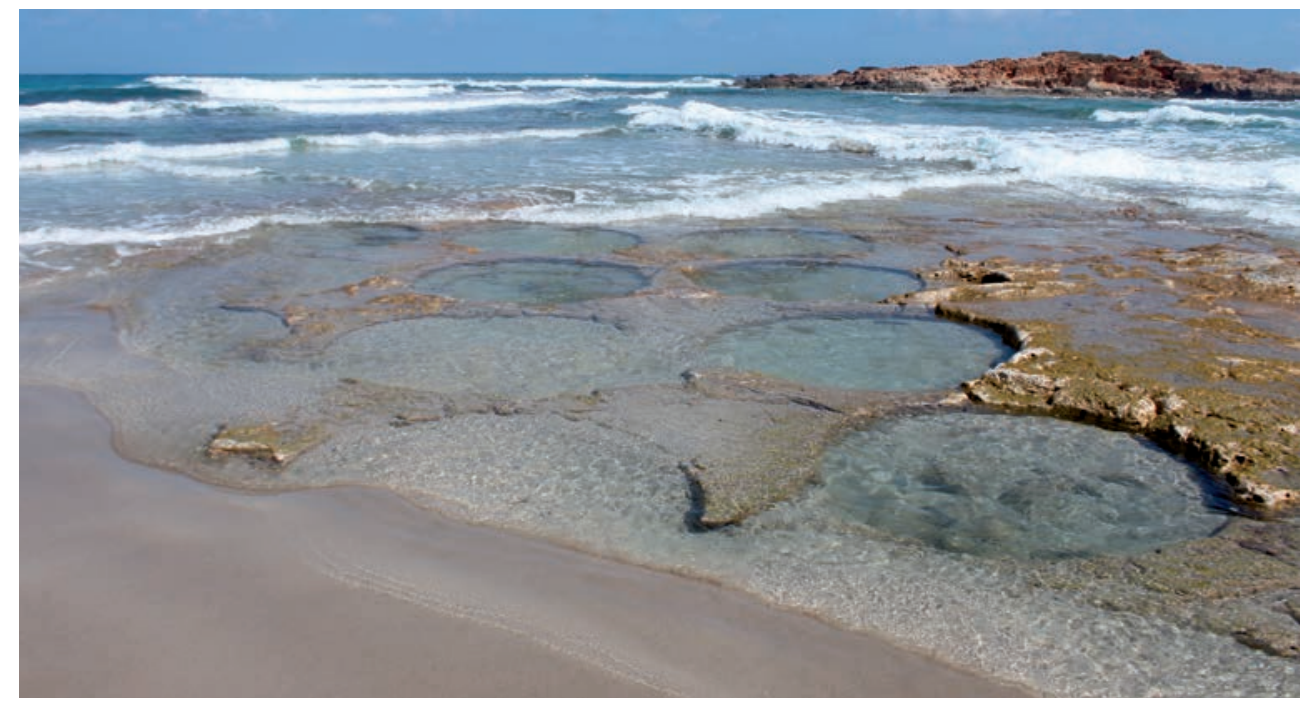

Fig. $5 \mathrm{a}$. Vats by the shore in Al-Agla, facing north (๔ Mohamed A Hesein).

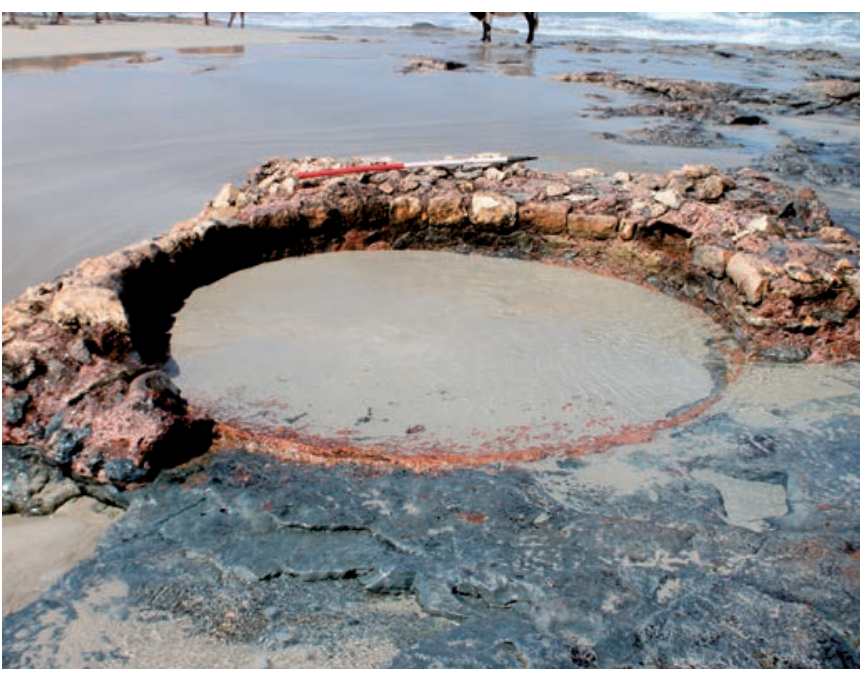

Fig. 5b. Vat 13, facing west (@ Mohamed A Hesein).

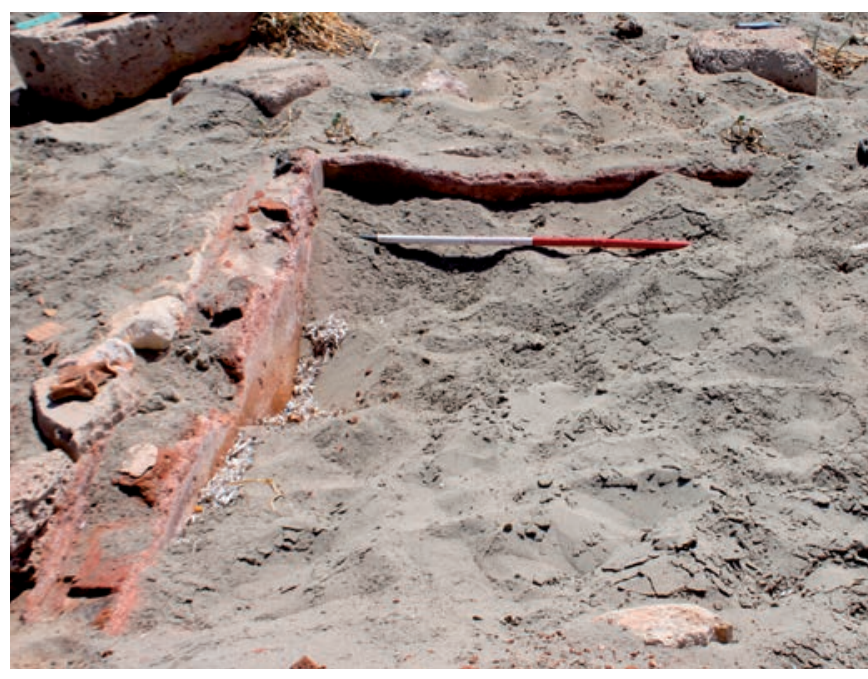

Fig. 5c. Vat 15, facing east (@ Mohamed A Hesein). 
exploitation of marine resources. The presence of a large variety of vats on, or a few metres from the sea requires us to consider the exact purpose of their construction. However, if we admit theoretically that the main purpose of these vats was to keep and preserve fresh water, then why would a site such as Phycus reserve an area for more than 35 vats cut into the rock? There are four wells (two of which are still in use today) a few hundred metres west of the promontory where the vats were cut. Why did they need these huge quantities of water? I think it is inaccurate to adopt the interpretation of fresh water storage.

Hypothetically, it is more practical to build one large cistern for keeping water instead of building 6,9 or 12 aligned vats containing a low volume of water. Additionally, the deliberate arrangements of the vats indicate that the purpose was for an elaborate process and different types of products.

In addition, the water cistern that found in Cyrenaica had a different geometric arrangement. In a personal communication, Ahmed Emrage confirms that in his recent field survey in Cyrenaica, three types of water cistern have been identified. The first type has a narrow opening (Fig. 6a) leading to a huge water collecting square chamber; the depth of this type is up to $6 \mathrm{~m}$. The second is a vaulted rectangular cistern containing one or two chambers (Fig. 6b), more than two in some cases, divided by an arched wall. This type of water cistern has been found in different areas in Cyrenaica such as Ptolemais. ${ }^{9}$ The third is a huge rectangular shape, with a roof sometimes supported by a column.

Presumably, some of the larger vats I have identified were for the collection and preservation of water. Such quantities suggest that there was an industrial process being carried out nearby which required a huge amount of water.

Another production process that can be rejected is purple dye manufacture. The possibility of such production is not compatible with rock-cut vats. As Andrew Wilson states "the production of purple dye required heating the shellfish, which could not be done in sunken vats". ${ }^{10} \mathrm{He}$ confirms that the new evidence that comes from purple dye production sites at Meninx (Jerba) and Euesperides (Benghazi) suggests that this production did not need vats ${ }^{11}$. Furthermore, the absence of remains of murex shells or burning remains at the sites described above supports this view. Indeed, these vats do not seem to have been intended for textile dyeing, leather tanning

9. Kenrick 2013.

10. Wilson 2006, p. 527.

11. Wilson 2006; Wilson, Tébar Megías 2008.

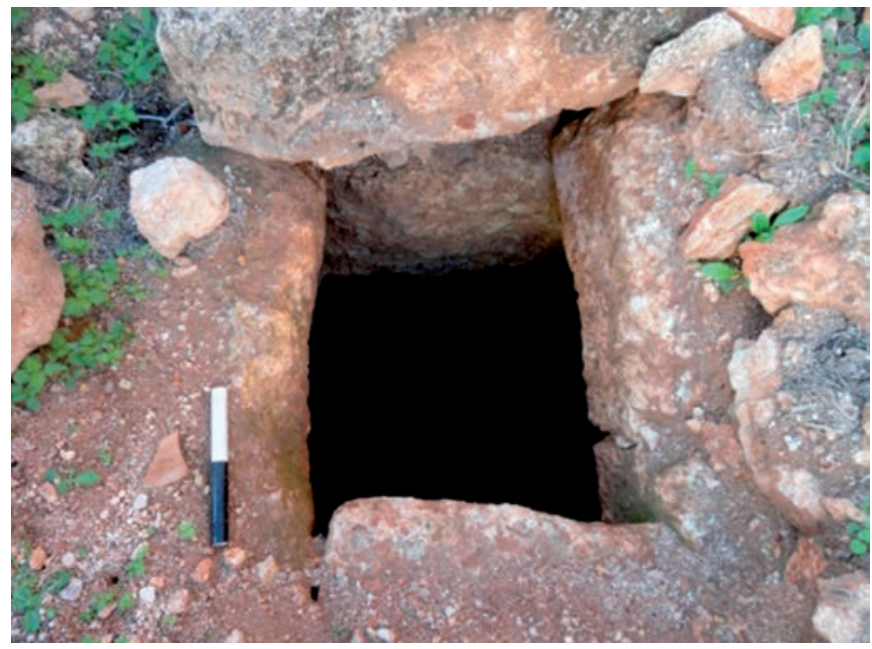

Fig. 6a. Water cistern, type 1, facing north (from Emrage forthcoming).

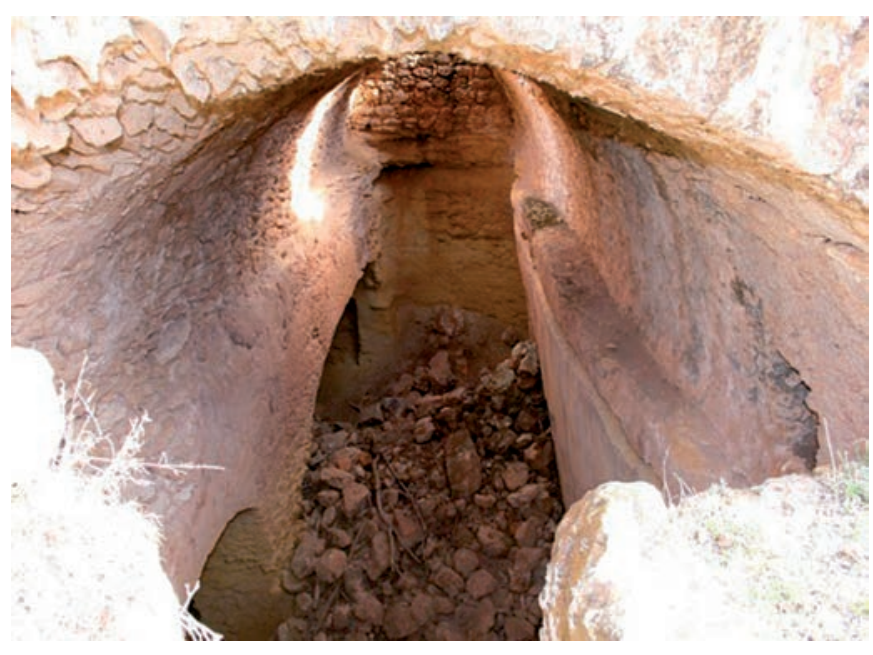

Fig. 6b. Example of vaulted cistern that found in Cyrenaica, facing north (from Emrage forthcoming).

or rinsing. Such tanks would require the vat to be built above ground level with their bases at floor level ${ }^{12}$.

Nevertheless, the absence of permanent elements such as oil presses around these installations excludes the possibility that these vats were for keeping olive oil products. Additionally, presses were mainly built in the hinterland of the main cities and not on the coast. This has also been confirmed by the recent archaeological field survey by Ahmed Buzaian ${ }^{13}$.

There remain two possible productions which might have carried out in these vats: wine fermentation and fish-related production. Wilson ${ }^{14}$ refers to a number of bottled-shaped vats which have a similar structure to

12. Wilson 2003; Tébar Megías, Wilson 2008.

13. Buzaian 2012.

14. Wilson 2001. 
those presented above. These vats have been recorded inside the circuit wall of some coastal cities, namely Ptolemais, Taucheira, Berenice ${ }^{15}$ and another set of five vats was located in the rocky area by the shore of Apollonia ${ }^{\mathbf{1 6}}$. Wilson argues that such vats are more likely to be associated with wine production using a treading floor.

However, Wilson does not seem to demonstrate any concrete evidence for the existence of treading floors associated with those vats, except the one at Taucheira which he seems to be in some doubt about. He states that "since no olive pressing structures have been found nearby (such as orthostats, press beds or olive mills), I am inclined to believe that they were more likely to have been used for the fermentation of wine. This suggestion receives some support from the presence a little to the north, though not in strict demonstrable association with the vats, of a feature which I would identify as a wine treading floor" 17 .

Although I have some doubt about the presence of fish-related production within cities, as this would produce a strong and unpleasant smell during the process ${ }^{\mathbf{1 8}}$, garum workshops have been found inside the ancient city of Pompeii ${ }^{19}$. Indeed, there is no sign of an associated treading floor near the vats mentioned by Wilson at Apollonia ${ }^{20}$. Adding to that the occurrence of submerged vivaria $^{21} 100 \mathrm{~m}$ to the north-east of these vats, it seems very likely that these vats could have been associated with fish-related production.

Looking at another example from Apollonia, work carried out by a French mission revealed a house containing six vats (with depths of $3.00 \mathrm{~m}$ ) sunk into the ground, similar to those found at Taucheira ${ }^{22}$. Samples from the vats have been taken for chemical analysis; the first results did not show any evidence of fish processing in these vats. Subsequently, in personal communication, the French chemist who did the analysis confirmed to me that, after comparing the results from the Apollonia vats with those from other fish production sites around the Mediterranean, fish sauce might be present in the samples. If the new chemical evidence confirms that

15. In terms of location, it should differentiate between vats located inside the circuit walls of cities (e.g. those mentioned by Wilson), and those along the shore (e.g. those identified by the author in the surveyed area, and those by the shore of Ptolemais mentioned by Yorke and Davidson).

16. Flemming 1972; Lloyd 1977; Buzaian 2000; Wilson 2001.

17. Wilson 2001, p. 32.

18. Curtis 1991.

19. Bernal et al. 2009.

20. Based on personal observation of these vats.

21. Flemming 1972.

22. Buzaian 2000; Wilson 2001. fish products were in these vats, it strongly suggests that such vats inside the city walls could be involved, to some degree, in fish production.

However, square or rectangular area with drainage which might have connected to these vats does not seem to exist in my survey area. This excludes the hypothesis of an association with wine-treading vats such as the one found at the ancient site of Balagrae ${ }^{23}$.

Also, it is a mistake to assume that wine was pressed inland and then brought in animal skins to the shore for storage in these vats while awaiting shipping. It is impractical on several grounds, not least the multiple transhipments of wine or olive oil, between pressing and shipping. Add to that, cutting one big vat in the ground instead of six is more beneficial for storing a single type of substance (as explained above for water). Additionally, it makes more sense to fill wine or olive oil directly from transport skins into amphorae and then to store them in a warehouse while waiting for shipping, marketing or local consumption.

The existence of these vats a few metres from the sea, and especially on the promontories and small islets seems to suggest the possibility that they could be used for fish-related products. Similar examples have been noted by the shore in Ptolemais. Many vats cut into the rock in the promontory have been recorded by Yorke and Davidson and have been initially interpreted as a fish factory ${ }^{24}$. Supporting this view, are the large quantities of fish-related production sites that have been found along the shores of Mediterranean. Some of these industries were cut into the rocky areas.

Identical forms were found in different places along the coast of Tunisia. At the ancient site of Gummi (Mahdia), for example, 153 vats cut into the rock were found. They come in four main shapes: 64 circular (almost oval), 39 rectangular, 5 cylindrical and 1 square ${ }^{25}$. This set of vats lie on a peninsula which overlooks the passage for seasonal fish migration. Such geometrical structures and shapes were found at other sites, such as Thaenae, Sullecthum, Sidi Daoud and El-Mamoura in Tunisia and have been interpreted as cetariae for the fish industry ${ }^{26}$. In Algeria, according to Yorke and Davidson, a number of circular fish vats cut into the rock were found in Tipasa and other rectangular fish tanks cut into the rock were found at the ancient site of Cherchel ${ }^{27}$. In southern Spain and Morocco, as a third example, fish production

23. Balagrae is an ancient city locating inland about $15 \mathrm{~km}$ to the west of Cyrene (see Fig. 1). Buzaian, Bentaher 2002/2006.

24. Yorke, Davidson forthcoming.

25. Ameur 2005.

26. Id.

27. Yorke, Davidson 1969. 
tanks of different sizes and shapes were found cut into the rock (Fig. 7) ${ }^{28}$.

Some of these features seem to have the same character as those found on the coast of Cyrenaica. Several fish vats (cetariae) were found along the coast between Santa Pola and Punta de L'Arenal cut into the rock in the promontory areas ${ }^{29}$. Circular vats, for example, sunk into the ground were also found at the ancient site of Baelo. Furthermore, in Ceuta, there are large circular lined holes cut into the ground located within a fish installation.

It is worth mentioning that these types of features found in different fish production sites such as Calpe and Punta de L'Arenal have been interpreted as vats for producing fish sauces ${ }^{30}$.

Elsewhere in the Mediterranean, on Crete, which faces the coast of Cyrenaica, rows of vats varying in size and cut into the rock were found at Chersonesos and Siteia. The vats served as vivaria for storing live fish during the migratory seasons, to be sold later in the markets rather than as breeding basins ${ }^{31}$. Similarly, several rock-cut tanks connected to the sea by channels were found in Tunisia, and were used for breeding or holding fish for salting ${ }^{32}$. These types of tank connected to the sea by channels were identified also in Apollonia ${ }^{33}$ and other sites in Cyrenaica ${ }^{34}$.

Producing fish sauces and other fish products does not require a specific shape or size of container ${ }^{35}$. Manilius and Columella state that salted fish were placed in succession in large cetariae or ceramic containers ${ }^{36}$. Supporting this idea, the dolia that have been found in the garum workshop at Pompeii suggest (Fig. 8) that they were used as containers for making garum $^{37}$. The circular shape is highly suggestive of an installation for making garum sauce, as such structures facilitate stirring, which is part of the process ${ }^{38}$.

The second set of examples of what seem to be fish tanks comprise rectangular tanks set next to each other. These tanks were found in different locations in the surveyed area such as Phycus, Cape of Phycus and

28. Trakadas 2004b.

29. Id.

30. Id.

31. Davaras 1974.

32. Slim et al. 2004.

33. Flemming 1972.

34. For further discussion of vivaria, see my forthcoming thesis.

35. Slim et al. 2007; Curtis 1983.

36. Manilius 5.656-81; Columella 12.55.4.

37. Bernal et al. 2009; Wilson 2006.

38. Trakadas 2004b.



Fig. 7. Cetariae cut into the rock at Praia de Angeiras (Trakadas 2004b, p. 59).

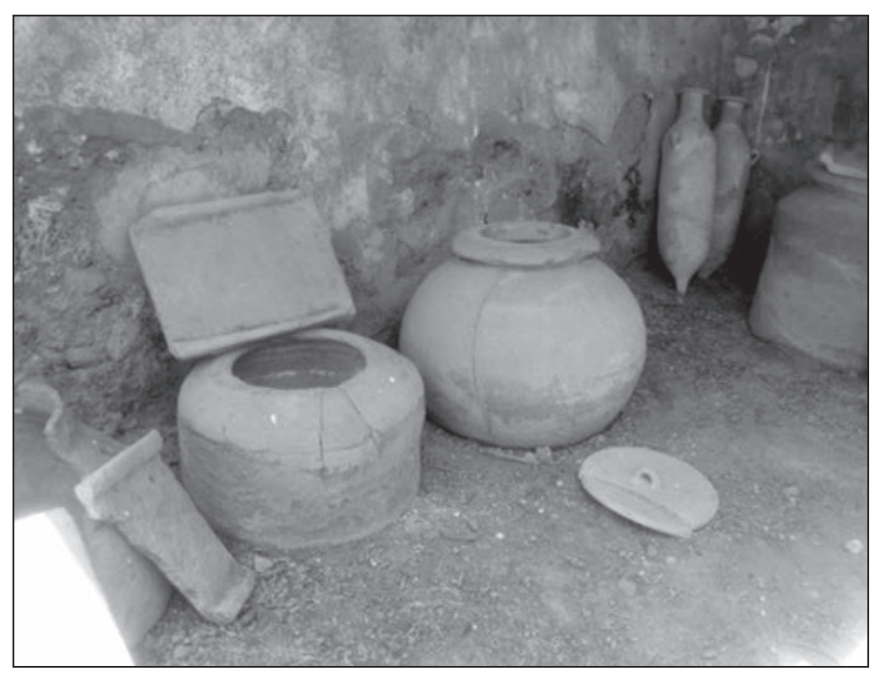

Fig. 8. Dolia that have been found in the garum workshop at Pompeii (๔) Mohamed A Hesein). 
Kainopolis. It is difficult to trace the whole structures as most of them are covered by sand or disturbed by human activities. Large-scale excavation is needed to obtain a comprehensive picture of the remains, their depth and their exact function. Generally, the structures are probably sets of tanks of different shapes and sizes mainly rectangular. They were built of brick and the interior walls were faced with opus signinum.

However, my preliminary interpretation, related to the size, shape and location a few metres from the sea, is that they were fish salting tanks. These tanks seem to have the same structural format to examples found in Sabratha and interpreted as salted fish tanks by Andrew Wilson ${ }^{39}$ and those found along the coast of Tunisia ${ }^{40}$. The square and rectangular tank shapes are probably the most common types for salted fish cetariae that have been found around the Mediterranean basin.

\section{Conclusion}

The rectangular and square vats scattered along the shore of Cyrenaica such as those at Phycus and Cape of Phycus might be attributed, with some confidence, to the production of salted fish. However, the neighbouring bottle-shaped vats should be interpreted with caution at the present time. Wine fermentation is one possibility, but garum production should not be discounted.

Large-scale excavation and chemical analyses are required to prove this idea conclusively and to provide evidence for what was carried out at these manufacturing sites. However, my interpretation is based on the comparison of vats of similar shapes and sizes along the coast of North Africa, and the location of these vats close to the sea. It seems likely that the function of these sites could be fish-related processing, with garum production being carried out in the bottle-shaped vats, and salted fish processing in the rectangular or square tanks.

\section{Bibliography}

Ameur 2005 : AMEUR (Y.) (2005) - Recherches sur les installations halieutiques à Gummi à l'époque antique. In : Hassen M. (ed.), Byzacium antique et Sahel médiéval: Urbanisme et Occupation du Sol. Colloque sur l'urbanisme au Sahel organisé à Monastir (20-21Juillet 2001), Université de Tunis I, 2005, p. 37-80.

Ben Lazreg et al. 1995 : BEN LAZREG (N.), BONIFAY (M.), DRINE (A.), TROUSSET (P.) - Production et commercialisation des salsamenta de l'Afrique ancienne. In : Trousset (P.) (ed.), Productions et exportations africaines: actualités archéologiques en Afrique du Nord antique et médiévale. VI ${ }^{e}$ colloque international sur l'histoire et l'archéologie de l'Afrique du Nord (Pau, octobre 1993 - $118^{e}$ congrès), Paris, 1995, p. 103-142.

Bernal et al. 2009 : BERNAL (D.), COTTICA (A.), ZACCARIA (A.) - El garum de Pompeya y Herculano (2008-2012). Sintesis de la primera campana del proyecto hispano-italiano, Informes y Trabajos 3, 2009.

Bouzian 2012 : BOUZIAN (A.) - Oil presses in Cyrenaica [lecture], annual meeting of Society of Libyan Studies, 4 December 2012, London.

Buzaian 2000 : BUZAIAN (A.) - Excavations at Tocra (1985-1992), Libyan Studies 31, 2000, p. 59-102.

Buzaian, Bentaher 2002 : BUZAIAN (A.), BENTAHER (F.) - Preliminary report on two seasons of excavations at Balagrae (al-Beida), Libyan Studies, 33,2002 , p. $125-132$

Buzaian, Bentaher 2006 : BUZAIAN (A.), BENTAHER, (F.) - Excavations at Balagrae (al-Beida) 2001-2003. In: Fabbricotti (E.), Menozzi (O.), Cirenaica: studi, scavi e scoperte. Atti del X Convegno di Archeologia cirenaica (Chieti 24-26 novembre 2003), BAR International Series, Oxford, 2006, p. 153-162.

Curtis 1983 : CURTIS (R.) - In defense of garum, Classical Journal, 78 (3), 1983, p. 232-240.

Curtis 1991: CURTIS (R.) - Garum and Salsamenta: Production and Commerce, Studies in Ancient Medicine, Leiden, 1991.

Davaras 1974 : DAVARAS (C.) - Rock-Cut Fish Tanks in Eastern Crete, ABSA, 69, 1974, p. 87-93.

Emrage forthcoming : EMRAGE (A.) - Roman forts and fortified farms in Cyrenaica, $\mathrm{PhD}$ thesis, Leicester, University of Leicester.

39. Wilson 1999.

40. Slim et al. 2004; Ben-Lazreg et al. 1995. 
Flemming 1972 : FLEMMING (N.) - Cities in the Sea, London, 1972.

Hesein forthcoming: HESEIN (M.) - Bridging the Eastern and Western Mediterranean: The Roman Harbour Sites on the Coast of Cyrenaica, Libya, $\mathrm{PhD}$ thesis, Leicester, University of Leicester.

Jones, Little 1971 : JONES (B.), LITTLE (H.) - Coastal Settlement in Cyrenaica, Journal of Roman Studies, 61, 1971, p. 64-79.

Lloyd 1977 : LLOYD (J.) (ed.) - Excavations at Sidi Khrebish, Benghazi (Berenice), I, Tripoli, Supplements to Libya Antiqua, 1977.

Lloyd 1979 : LLOYD (J.) (ed.) - Excavations at Sidi Khrebish, Benghazi (Berenice), II, Tripoli, Supplements to Libya Antiqua, 1979.

Polish Archaeological Mission in Ptolemais, Libya 2011 : Preliminary Reports [Online] Available from < http://ptolemais.pl/pdf/Ptolemais_ Preliminary_Report_2007-2009.pdf > [30 September 2012].

Slim et al. 2004: SLIM (H.), TROUSSET (P.), PASKOFF (R.), OUESLATI (A.) - Le littoral de la Tunisie. Étude géoarchéologique et historique, Études d'Antiquités africaines, Paris, 2004.

Slim et al. 2007 : SLIM (L.), BONIFAY (M.), PITON (J.), STERNBERG (M.) - An example of fish salteries in Africa Proconsularis: the officinae of Neapolis (Nabeul, Tunisia). In : Lagóstena (L.), Bernal (D.), Arévalo (A.) (eds), Cetariae 2005. Salsas y Salazones de Pescado en Occidente durante la Antigüedad. Actas del Congreso Internacional (Cádiz, 7-9 de noviembre de 2005), BAR International series, 1686, 2007, p. 21-44.

Tébar Megias, Wilson 2008 : TÉBAR MEGIAS (E.), WILSON (A.) Classical and Hellenistic textile production at Euesperides (Benghazi, Libya): preliminary results. In : Alfaro Giner (C.), Karali (L.) (eds.), Vestidos, textiles y tintes (Purpureae Vestes II): Estudios sobre la Produccion de Bienes de Consumo en la Antigüedad, Universidad de Valencia, Servicio de Publicaciones, Valencia, 2008, p. 49-59.

Trakadas 2004a: TRAKADAS (A.) - The archaeological evidence for fish processing in the Western Mediterranean. In : Bekker-Nielsen (T.) (ed), Ancient Fishing and Fish-Processing in the Black Sea Region, Aarhus, 2004, p. 47-82.

Trakadas 2004b : TRAKADAS (A.) - Ancient marine resource exploitation in the Western Mediterranean: the contribution of the fish-salting industry of
Mauretania Tingitana (Morocco), Institute of Classical Archaeology, Aarhus University, Denmark [Online] Available from <http://hmapcoml.org/projects/ m\&b/Documents/Trakadas_HMAP-Med.pdf > [15 December 2012].

Wilson 1999 : WILSON (A.) - Commerce and industry in Roman Sabratha, Libyan Studies, 30, 1999, p. 29-52.

Wilson 2001 : WILSON (A.) - Urban economies of late antique Cyrenaica. In : Kingsley (S.), Decker (M.) (ed), Economy and exchange in the East Mediterranean during late Antiquity, Oxbow Books, Oxford, 2001, p. 28-43.

Wilson 2003 : WILSON (A.) - The archaeology of the Roman fullonica, Journal of Roman Archaeology, 16, 2003, p. 442-466.

Wilson 2004: WILSON (A.) - Cyrenaica and the late antique economy, Ancient West and East, 3.1, 2004, p. 143-154.

Wilson 2006a : WILSON (A.) - Fishy business: Roman exploitation of marine resources, Journal of Roman Archaeology, 19.2, 2006, p. 525-537.

Wilson 2006b : WILSON (A.) - New light on a Greek city: archaeology and history at Euesperides. In : Fabbricotti (E.), Menozzi (O.) (eds.), Cirenaica : studi, scavi e scoperte. Atti del X Convegno di Archeologia cirenaica (Chieti 24-26 novembre 2003), BAR International Series, Oxford, 2006, p. 141-152.

Wilson, Tébar Megías 2008 : WILSON (A.), TÉBAR MEGÍAS (E.) - Purple dye production at Hellenistic Euesperides (Benghazi, Libya). In : Napoli (J.) (ed.), Ressources et activités maritimes des Peuples de l'Antiquité, Actes du Colloque international de Boulogne-sur-Mer (12-14 mai 2005), Boulognesur-Mer, 2008, p. 231-238.

Wilson et al. 1999: WILSON (A.), BENNETT (P.), BUZAIAN (A.), EBBINGHAUS (S.), HAMILTON (K.), KATTENBERG (A.), ZIMI (E.) Urbanism and Economy at Euesperides (Benghazi): preliminary report on the1999 season, Libyan Studies, 30, 1999, p. 147-168.

Yorke, Davidson 1969 : YORKE (R.), DAVIDSON (D.) - Roman Harbours of Algeria, Underwater Association Report, 1969.

Yorke, Davidson 1973 : YORKE (R.), DAVIDSON (D.) - Tolmeita \& Tocra. Roman Harbours of Cyrenaica, Underwater Association Minisymposium, 1973.

Yorke, Davidson forthcoming: YORKE (R.), DAVIDSON (D.) - The Hellenistic Harbour of Ptolemais. 

Troisième Partie

\section{Études archéologiques méditerranéennes}
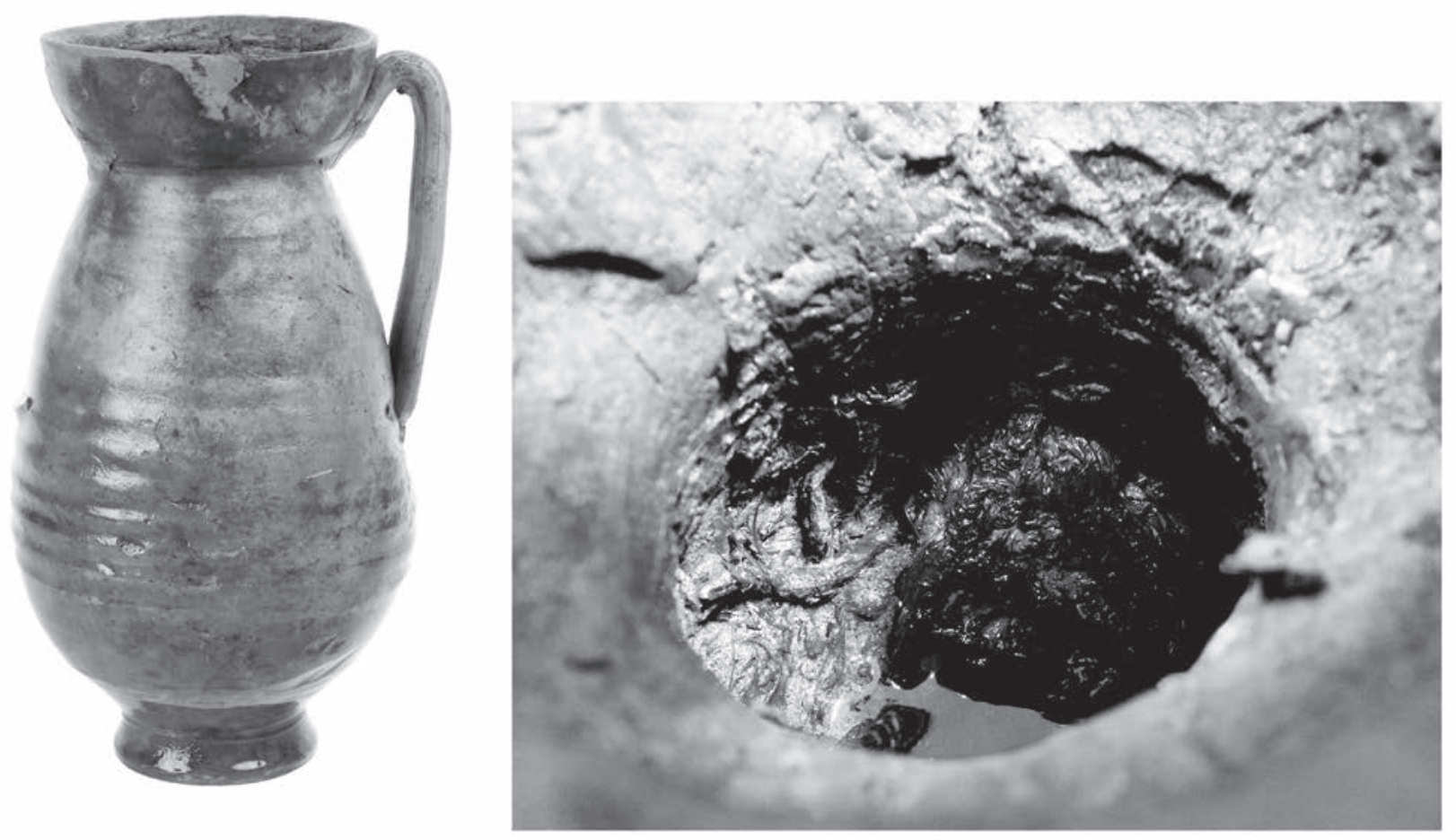



\title{
An overview of the fish-salting production centre at Tróia (Portugal)
}

\author{
Inês Vaz Pinto, Ana Patrícia Magalhães, Patrícia Brum
}

\section{Introduction}

The site of Tróia is located in the southwestern coast of Portugal on a sandy peninsula that separates the estuary of the Sado River from the Atlantic Ocean (fig. 1 and 2). In Roman times this sand spit was probably still a line of islands and the Roman settlement was possibly in the island of Achale referred in this area by Rufus Avienus in Ora Maritima (v. 182-184) ${ }^{1}$.

It was certainly part of the territory of the civitas of Salacia (modern Alcácer do Sal) and the closest urban centre, c. $4 \mathrm{~km}$ away across the waters of Sado River, was the city of Caetobriga (modern Setúbal).

The heavy erosion the site suffers from the tides coming into the Sado estuary strongly contributed for its early discovery. Tróia appears in the literature since the 16 th c. as a Roman settlement with fish-salting vats ${ }^{2}$ and is frequently visited and referred by authors in the following centuries ${ }^{3}$.

The first acknowledged excavations took place in the 18th c. by future Queen D. Maria I ${ }^{4}$ and in the 1850's an important series of excavation campaigns were carried on by Sociedade Archeologica Lusitana, from Setúbal. The main results of these works were the discovery of habitation buildings and a bath complex. In the 20th c., from 1948 up to the 70's, excavations were carried on by the directors of the today National Museum of Archaeology, exposing, in particular, several fish-salting factories, the bath complex, cemeteries and a Christian basilica.

A number of articles on specific aspects and materials resulting from these works were published, but only in 1994 was there a consistent presentation and interpretation of the industrial complex by R. Étienne, Y. Makaroun and F. Mayet ${ }^{5}$.

In 2006 began a new project, promoted by troiaresort, for the conservation and presentation of the Roman ruins

1. Referred by Alarcão 2004, p. 323.

2. Barreiros 1561; Resende 1593.

3. Castelo-Branco 1963.

4. Costa 1933, p. 19.

5. Étienne, Makaroun, Mayet 1994.

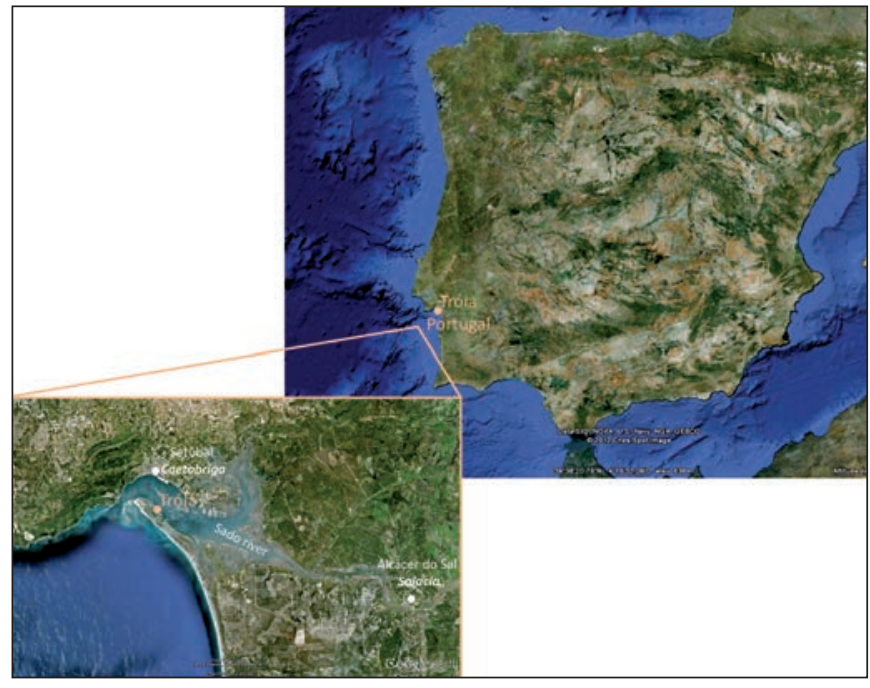

Fig. 1. Location of Tróia (www.googleearth.com)

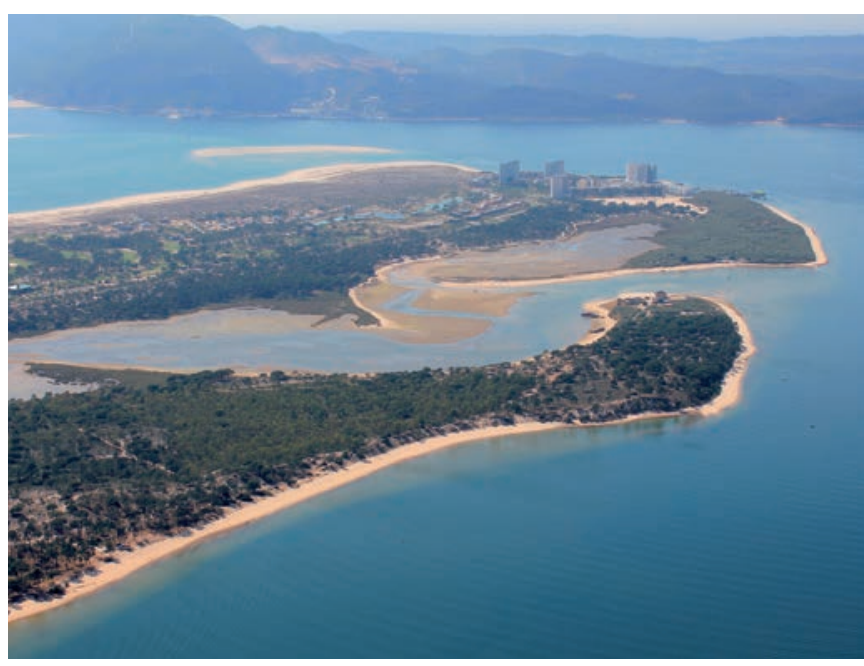

Fig. 2. Aerial photo of the northwest end of the peninsula of Tróia (৫) Troiaresort.

to the public. The necessary archaeological works, carried on by the authors, provided new information and an overall perception of the site that justifies this updated overview of the site of Tróia. It will focus in particular on the importance of the fish-salting facilities, the occupation rhythms and the nature of the settlement. 


\section{A large fish-salting production centre}

The environment of Tróia is highly favorable to fishsalting production. The shores of the Sado River have a long tradition of high quality salt exported in large quantities and its estuary and the surrounding ocean waters are extremely rich in fish up to this day providing an important fishing activity.

In 1987 J. Edmondson referred the site of Tróia as a vast fish-processing complex but only presented a rather late workshop resulting from the segmentation of a larger one $^{6}$. In 1994 R. Étienne, Y. Makaroun and F. Mayet documented the evolution of two large "factories", presented also a small one and referred several others in the shore of the estuary demonstrating Tróia as the largest fish-salting production centre in the West ${ }^{7}$.

A recent survey of the fish-salting facilities at Tróia ${ }^{8}$, either uncovered by excavations or exposed by the tides, revealed twenty five "fish-salting workshops" or production units, that is, compartments with vats along the walls around a patio. Sometimes workshops were connected by a corridor (e.g. workshops 1 and 2 (fig. 3)) or in the same building (e. g. workshops 12 and 13 (fig. 4)) and it is assumed that they belonged to the same "factory". But for most workshops it is impossible to know if they were autonomous or belonged to more complex facilities, or if distinct workshops had the same management. In the 3rd c. or later the large workshops were divided in smaller units not always easy to define and count.

The fish-salting workshops, located inland or more often next to the waterline, spread along the Sado estuary shoreline (fig. 5). They vary considerably in size but only three types have been recognized.

The most common type is a four-side vat workshop with a rectangular plan with lines of vats along the walls and around a proportionate patio. Some would be quite large, like workshops 1, 4, 12, 13 and 23 (fig. 6), and others smaller, like workshops 2 and 21 (fig. 7).

The second type is a U-shaped workshop with vats along three walls around a patio with the entrance in its longer side, like workshops 3, 5, 6 and possibly others rather incomplete like 10 (fig. 8).

The third type, with no complete example preserved, has two parallel lines of vats separated by a narrow patio or corridor and is probably also U-shaped, with a short line of vats in one top. There is no complete example but

6. Edmonson 1987, p. 122-125 presents a workshop later published as usine 1A by Étienne, Makaroun, Mayet 1994, p. 84 and fig. 51.

7. Étienne, Makaroun, Mayet 1994, p. 69-99, 118.

8. Pinto, Magalhães, Brum 2011. workshops 15, 17, 19 and 20 fit in this type and workshop 9 may be an example of its top (fig. 9).

Nine very incomplete workshops were not classifiable because they may fit in more than one type (fig. 10).

Since workshop 2 dates from the Tiberian period, and is the earliest building known at Tróia, we know the rectangular four-side vat workshop was built at Tróia since the beginning of the production centre. Workshop 1 was connected and therefore contemporaneous to workshop 2, and workshops 12 and 13 were abandoned in the 2nd c., meaning the larger and smaller version of the four-sided vat workshop were both common in the $1 \mathrm{st}-2$ nd c. All but 12 and 13 were divided in smaller workshops certainly in the 3rd c. for workshops 1 and 2, and probably at the same time for the others.

Even if no other workshop is dated, the three-side vat U-shaped workshop is also certainly from the 1st - 2nd c. since workshop 6 was divided in smaller units with a vat divided in a second moment, and was abandoned in the early or mid 4th c. Since we believe the workshops built at a low level, today in the waterline (workshops 3, 5-10, $12-13,15,17-25)$ and most of them with large vats, are from the 1st - 2nd c., workshops 3 and 5 must be also from the first phase. In what concerns the third type, it includes another four workshops on the waterline, some of them were subdivided in a second moment (19 and 20 ) or with a vat subdivided (15) and therefore they must also belong to the first phase.

Only three workshops with very small vats located over sand dunes at higher levels (11, 14 and 16 (fig. 10), too incomplete to be classified in any type, are certainly late and may date to the 4th - 5th c.

Therefore the three types recognized are certainly from the 1 st -2 nd c. Yet the four-side vat type may be slightly earlier at Tróia since workshops 1, 2 and 4 seem to occupy larger areas, but this is a mere hypothesis.

Since all workshops except for the small 11, 14 and 16 are considered from the 1 st - 2 nd c., it means the fishsalting production centre of Tróia reached its highest production capacity in that period. Measuring the preserved vats (length, width and depth) from the original workshops and calculating their volumes results in a minimum production capacity of $1,429 \mathrm{~m}^{3}$ but only 80 of the 165 visible vats were measurable (fig. 11). With this production capacity Tróia surpasses the largest recognized western fish-salting production centre at Lixus, with a capacity of $1,013 \mathrm{~m}^{39}$. Since no larger centre was yet discovered in the Mediterranean, in the Black Sea or elsewhere, Tróia was certainly one of the largest

9. Ponsich, Tarradell 1965, p. 9-37. 
fish-salting production centres of the Roman Empire in the 1 st - 2nd c. AD.

This high production capacity at Tróia is due not only to the number of workshops but also to the large size of many of the vats. Twenty four measurable vats from six workshops $(1,4,5,6,12$ and 22) had a depth of 1.90 to $2.30 \mathrm{~m}$ and an inside volume between $20 \mathrm{~m}^{3}$ and $35 \mathrm{~m}^{3}$ while eight vats from five workshops had a volume over $35 \mathrm{~m}^{3}$ with similar depth. Two of these were exceptionally large: workshop 23 vat $1(7.03 \times 4.25 \times$ $2.25 \mathrm{~m})^{10}$ had a capacity of $67.22 \mathrm{~m}^{3}$ and workshop 6 vat $1(3.70 \times 7.45 \times 2.07 \mathrm{~m})$ had a capacity of $57.06 \mathrm{~m}^{3}$. Other workshops, on the other hand, had smaller ones, like workshop 2, whose largest vat was $1.38 \mathrm{~m}$ deep with a capacity of just $12.19 \mathrm{~m}^{3}$.

After the rupture of the late 2 nd - early 3rd c., discussed in the following pages, some workshops were abandoned, many were subdivided and some had vats divided in smaller ones meaning a downsizing of Tróia's production capacity.

Not knowing the moment of abandonment of many of the workshops on the shoreline, we prefer not risking a calculation of the general production capacity of Tróia after the 2 nd c. for now. But the factory with workshops 1 and 2, the best studied even if not fully excavated, is an example of the effects of the economic retraction that affected Tróia after the 1st - 2nd c. production peak (fig. 12), even if the table presented only considers fully preserved vats and therefore excludes the non-excavated vats of workshop 1 and thirteen visible but not measurable vats of workshop 2.

According to these numbers, workshops 1 and 2 together suffered a reduction in their volume of $1 / 8$ of their initial capacity, but workshop 2a managed, in the third phase, to triplicate its capacity, suggesting economic growth in the 4 th $\mathrm{c}$.

Other areas were more affected. The abandonment of workshops 12 and 13, some of the peripheral workshops, after the 2nd c., may indicate a shrinking of the occupation area. And the inactivation of workshop 6 in the first half of the 4th c. suggests a more drastic production reduction that was not at all compensated by the very small new workshops 11, 14 and 16 .

\section{The rhythms of occupation}

The consistent study and interpretation by R. Étienne, Y. Makaroun and F. Mayet of the fish-salting factories uncovered at Tróia revealed three phases of occupation,

10. Étienne, Makaroun, Mayet 1994, p. 99. the first one in the $1 \mathrm{st}-2 \mathrm{nd} \mathrm{c}$., the second corresponding to the 3rd c. - early 4th and the third to the 4th and 5th c. ${ }^{11}$

The research developed by the authors from 2007 to the present confirmed these conclusions bringing more evidence, more detail and sometimes more precision to the dating.

\subsection{The first phase (1st - 2nd c.)}

New data concerning the beginning and the end of the first phase of occupation of the large factory of workshops 1 and 2 resulted from works in workshop 2 and in the storeroom area next to it.

An excavation in this area, next to the northeast wall of workshop 2 (fig. 13), exposed stratigraphic units with Italic type terra sigillata Consp. 22 and 25.1, one fragment of the South Gaulish terra sigillata cup form Drag. 27, Italic and Baetican Dressel 2-4 and regional Dressel 14 var. A amphorae that point to a date in the Tiberian period. They date the construction of workshop 2 and since these are the earliest levels ever detected in Tróia, they also date the founding of the production centre at Tróia for now ${ }^{12}$.

That also means Tróia is the earliest fish-salting centre so far known in the low valley of the Sado river but contemporaneous to amphora kilns in Largo da Misericórdia (Setúbal) ${ }^{13}$ and Abul (Alcácer do Sal) ${ }^{14}$, located on the other shore of the river where clay was abundant. These kilns would provide Tróia, always dependent on amphorae made on the other shore.

The large number of workshops believed to have been built and active during this phase suggests great economic activity. The only change detected in the course of this period is the digging and building of the well located in the patio of workshop $1^{15}$. A trench opened for conservation purposes along the wall of the staircase of that well revealed a stratigraphy with three successive floors (fig. 14). The earliest one (unit [738]) covered the layers related to the construction of the well with a number of ceramics from the $1 \mathrm{st}-2 \mathrm{nd}$ c. with several fragments of Gaulish terra sigillata with marks, but also 2nd c. amphorae, the regional Dressel 14 var. C and Dressel 20 from Hadrian's period, meaning the well was most probably built in the first half of the 2 nd c. It accounts for the progressive investment in this large workshop along this phase.

11. Étienne, Makaroun, Mayet 1994.

12. Pinto, Magalhães, Brum 2011, p. 135-138.

13. Silva 1996.

14. Mayet, Silva 2002.

15. Pinto, Magalhães, Brum 2010. 


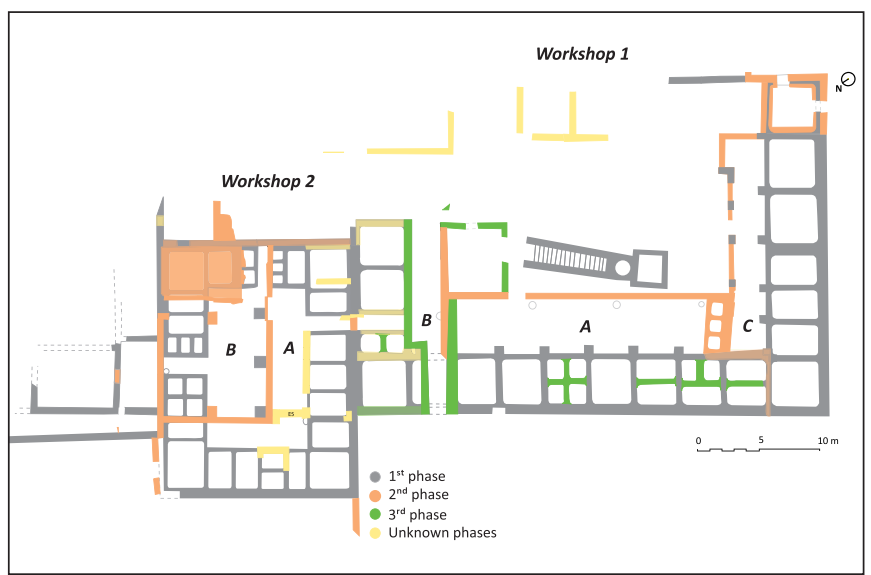

Fig. 3. Fish-salting factory with workshops 1 and 2 in its three phases (A. P. Magalhães based on Étienne, Makaroun and Mayet, 1994, fig. 51 and J. L. Madeira (2008, unpublished).

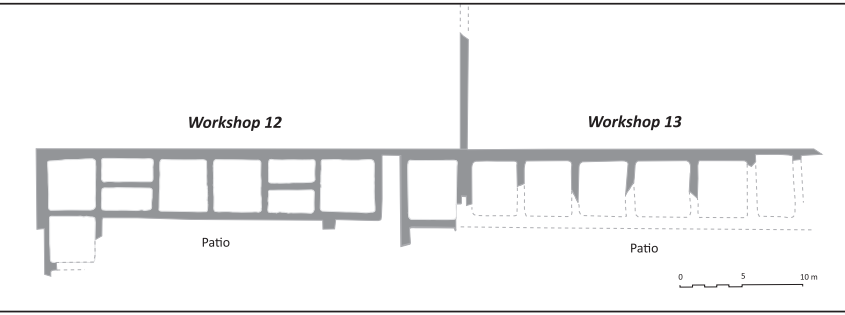

Fig. 4. Fish-salting factory with workshops 12 and 13 (1st - 2nd c.) (A. P. Magalhães based on J. L. Madeira (Pinto, Magalhães, Cabedal in press)).

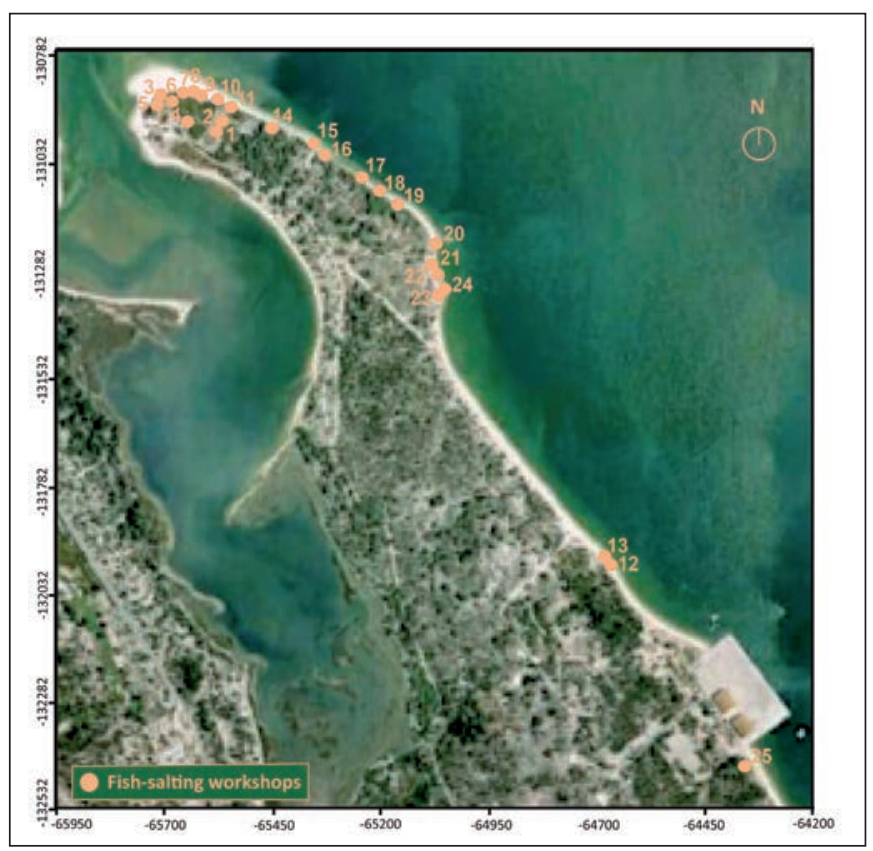

Fig. 5. Location of fish-salting workshops at the site of Tróia (A. P. Magalhães (www.googleearth.com))

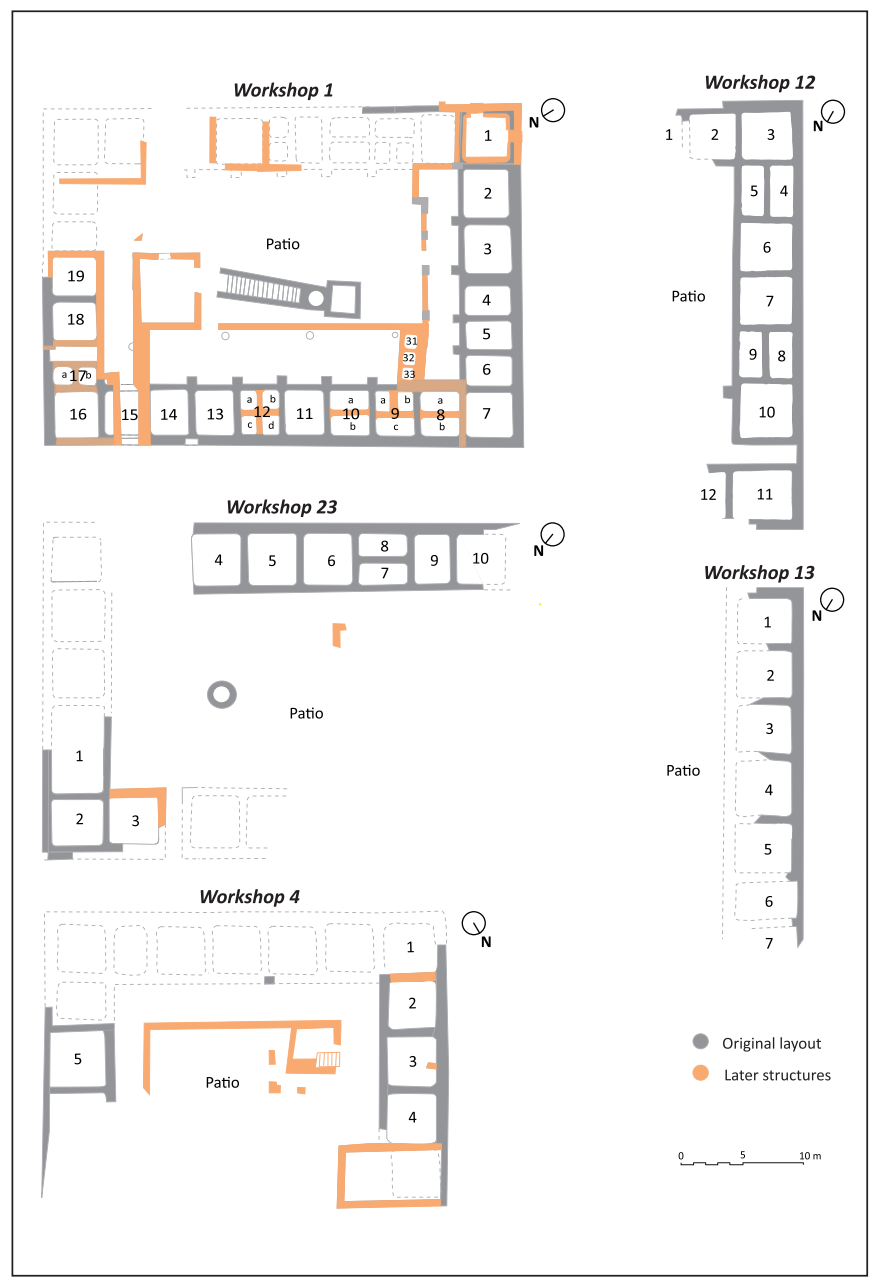

Fig. 6. Large four-side vat workshops with proportionate patios (A. P. Magalhães based on topographical survey by IPPAR (2006, unpublished)).

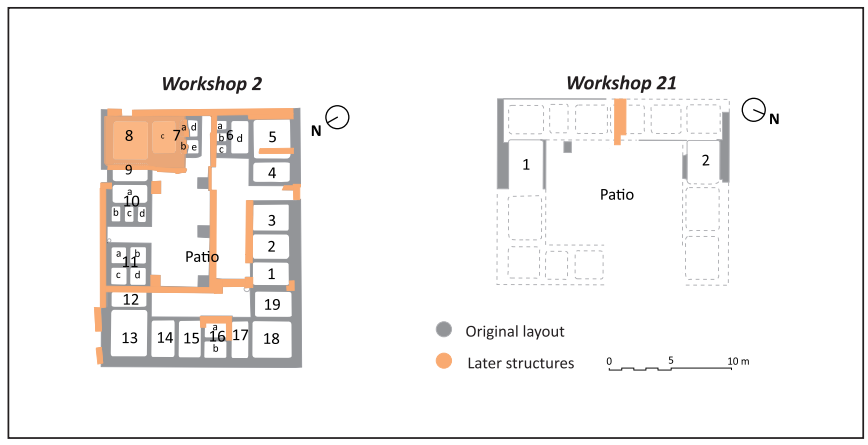

Fig. 7. Four side vat workshops with proportionate patios (A. P. Magalhães based on topographical survey by IPPAR (2006, unpublished), Étienne, Makaroun and Mayet, 1994, fig. 51 and J. L. Madeira (2008, unpublished)). 


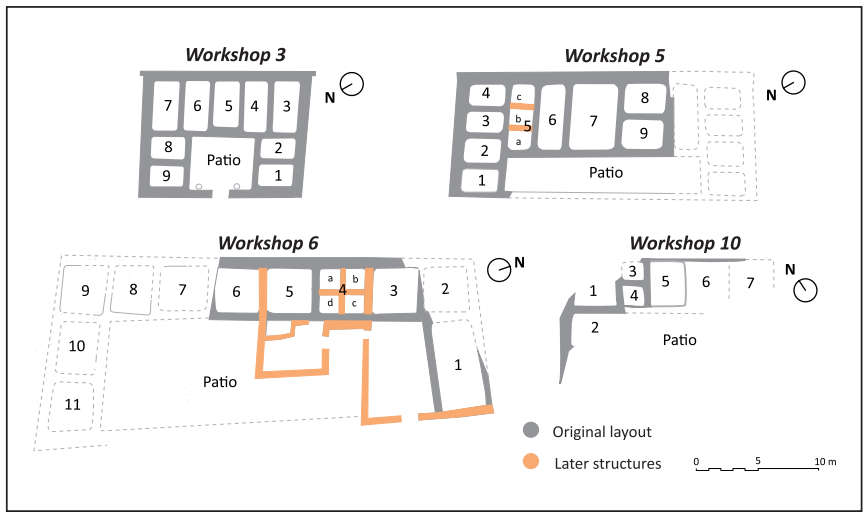

Fig. 8. Three-side vat U-shaped workshops with the entrance on the large side of the patio (A. P. Magalhães based on topographical survey by IPPAR (2006, unpublished)).

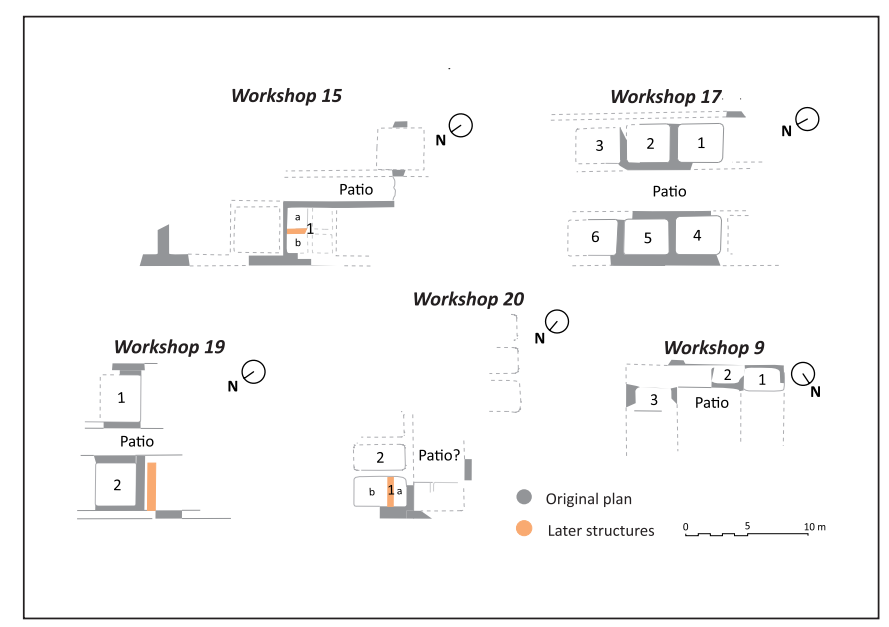

Fig. 9. Workshops formed by two lines of vats separated by a narrow patio or corridor, probably U-shaped (A. P. Magalhães based on topographical survey by IPPAR (2006, unpublished)).

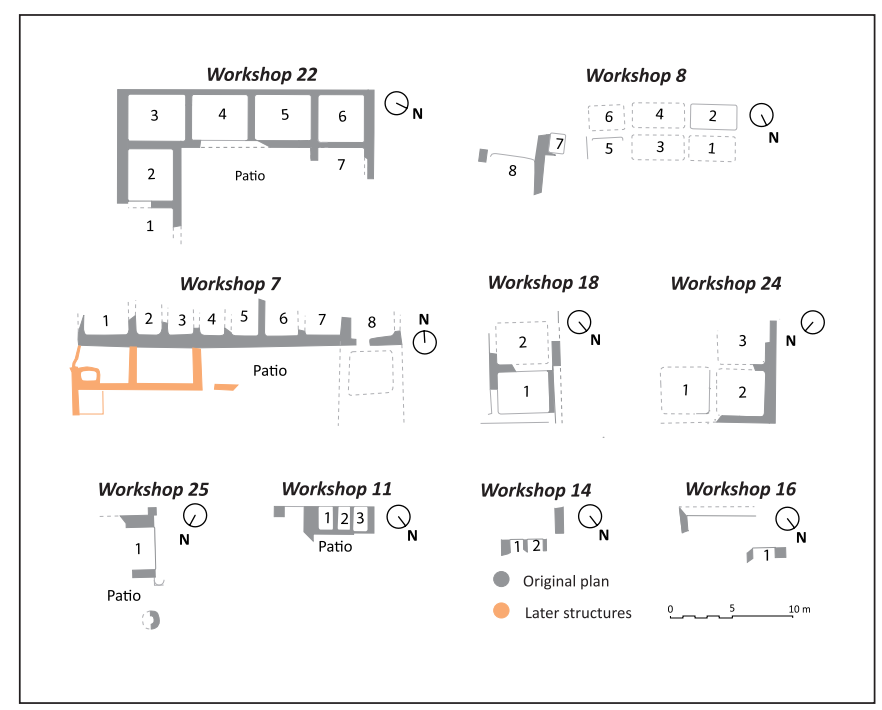

Fig. 10. Unclassifiable workshops

(A. P. Magalhães based on topographical survey by IPPAR (2006, unpublished)).
Based on the filling of workshop 1 vats 1 and 15, R. Étienne, Y. Makaroun and F. Mayet inferred, at the end of the first phase, a period of abandonment in the late 2 nd c. before destruction ${ }^{16}$. This abandonment also happened in workshop 2 where vats 6,8 and 9 were excavated in 2007 to reveal that they only served in the first phase of occupation, having been abandoned in the second half of the 2 nd c. ${ }^{17}$. They were clean from fish remains and their deposits contained Hispanic terra sigillata (Drag. 27, Drag. 37, And. 1), African Red Slip type A (Hayes 9B), amphorae Dressel 14 and Late Dressel 14 (Dressel 14 Tardia) among other things. Moreover, vat 9 revealed wall lining fragments fallen over the broken pottery in the bottom of the vat confirming a period of abandonment before reuse.

In contrast to workshop 1, those vats did not hold any signs of destruction from collapsing walls or roof, the refuse deposits and wall lining in vats 8 and 9 having been covered by a sand filling destined to support pavements on top belonging to the second phase.

The southeast workshops 12 and 13 (fig. 4), certainly belonging to one sole "factory", were studied in $2007^{18}$. It was clear these workshops and the surrounding area were only occupied in the 1 st -2 nd c. and abandoned at some imprecise moment of the 2 nd c.

Vat 3 of workshop 12 was excavated to reveal no signs of fish remains or refuse, just a layer of fallen roof tiles and clay with rare fragments of ceramics, two of them of Dressel 14 amphora. Apparently the area was abandoned not long after the vat was emptied from its last production since the roof material fell on an empty pavement and the collapse seems to have been due to its decay and not to any sudden event.

The absence of refuse on the floor of the vat and of any ceramics after the 2 nd c. in the courtyard behind the workshop suggests the area was abandoned when the factory became inactive.

Was the abandonment due to the same causes as in workshops 1 and 2 or was it due to others reasons, like an early advance of the waters, since nowadays more than three quarters of these workshops have been taken away by the tides?

The fact is that in the excavated $1 \mathrm{st}-2 \mathrm{nd} \mathrm{c}$. vats in three workshops there were no remains of the last production, the vats having been carefully cleaned. Did it mean, as F. Mayet and C. Tavares da Silva have pointed out, that the vats were ready for the next production? ${ }^{19}$ Was there a non previewed interruption of the usual

16. Étienne, Makaroun, Mayet 1994, p. 82.

17. Pinto, Magalhães, Brum 2010a.

18. Pinto, Magalhães, Cabedal in press.

19. Mayet, Silva 2010, p. 122. 


\begin{tabular}{|c|c|c|c|c|c|c|}
\hline Workshop & Lenght ( $m$ ) & $\begin{array}{l}\text { Width } \\
\text { (m) }\end{array}$ & Area $\left(\mathrm{m}^{2}\right)$ & $\begin{array}{l}\text { Visible } \\
\text { vats }\end{array}$ & $\begin{array}{c}\text { Measurable } \\
\text { vats }\end{array}$ & Volume $\left(\mathrm{m}^{3}\right)$ \\
\hline 1 & 39,50 & 28 & 1106 & $>19$ & 19 & $>464,94$ \\
\hline 2 & 21,00 & 16,5 & 346,5 & 31 & 18 & $>65,66$ \\
\hline 3 & 13,40 & 10,1 & 108 & 9 & 9 & 103,07 \\
\hline 4 & 32,80 & $>21,2$ & $>695,36$ & $>5$ & 3 & $>99,97$ \\
\hline 5 & $>18,50$ & 10,2 & $>188,7$ & $>9$ & 9 & $>183,31$ \\
\hline 6 & $\begin{array}{r}\text { c. } 34,70- \\
39,00\end{array}$ & 14 & c. 462 & 11 & 6 & $>177,92$ \\
\hline 7 & 26,20 & $>2,90$ & $>75,98$ & $>8$ & 0 & $>0$ \\
\hline 8 & 21,50 & $>2,03$ & $>43,65$ & $>8$ & 2 & $>19,13$ \\
\hline 9 & 12,75 & $>4$ & $>51$ & $>3$ & 1 & $>7,74$ \\
\hline 10 & 16,70 & $>10$ & $>167$ & $>7$ & 0 & $>0$ \\
\hline 12 & 34,15 & $>11,80$ & $>402,97$ & $>12$ & 1 & $>34,81$ \\
\hline 13 & $>23,00$ & $>3$ & $>69$ & $>7$ & 0 & $>0$ \\
\hline 15 & $>22,50$ & 10,9 & $>245,25$ & $>1$ & 0 & $>0$ \\
\hline 17 & $>11,00$ & 12 & $>132$ & $>6$ & 1 & $>13,94$ \\
\hline 18 & $>3,20$ & $>2,58$ & $>8,26$ & $>2$ & 1 & $>13,93$ \\
\hline 19 & $>7,00$ & 11,8 & $>82,6$ & $>2$ & 2 & $>18,45$ \\
\hline 20 & 6,00 & 9,5 & $>57$ & $>2$ & 1 & $>15,44$ \\
\hline 21 & 19,40 & $>7$ & $>135,8$ & $>2$ & 2 & $>31,21$ \\
\hline 22 & 20,80 & $>11$ & $>228,8$ & $>7$ & 3 & $>96,18$ \\
\hline 23 & $>39,00$ & 27 & $>730,8$ & $>10$ & 1 & $>67,22$ \\
\hline 24 & $>5,00$ & $>8,50$ & $>42,5$ & $>3$ & 0 & $>0$ \\
\hline 25 & $>10,00$ & $>3$ & $>30$ & $>1$ & 1 & $>16,41$ \\
\hline Total & 39,50 & & & $>165$ & 80 & $>1429,31$ \\
\hline
\end{tabular}

Fig. 11. Area, number of vats and production capacity of the workshops considered from the 1 st - 2nd c.

\begin{tabular}{|c|c|c|r|r|r|}
\hline \multicolumn{2}{|c|}{ Workshop 1 } \\
\hline \multicolumn{2}{|c|}{ First phase - 1st- 2ndc. } & \multicolumn{2}{|c|}{ Second phase - 3rd c. } & \multicolumn{2}{c|}{ Third phase - 4th c. } \\
\hline \multirow{3}{*}{ workshop 1 } & \multirow{3}{*}{$464,94 \mathrm{~m}^{3}$} & workshop 1a & $168,13 \mathrm{~m}^{3}$ & workshop 1a & $154,06 \mathrm{~m}^{3}$ \\
\cline { 3 - 6 } & & workshop 1b & $82,59 \mathrm{~m}^{3}$ & \\
\cline { 3 - 6 } & & workshop 1c & $157,56 \mathrm{~m}^{3}$ & workshop 1c & $157,56 \mathrm{~m}^{3}$ \\
\hline Total & $464,94 \mathrm{~m}^{3}$ & & $408,28 \mathrm{~m}^{3}$ & \multicolumn{3}{|c}{$311,62 \mathrm{~m}^{3}$} \\
\hline
\end{tabular}

\begin{tabular}{|c|c|c|r|r|r|}
\hline \multicolumn{5}{|c|}{ Workshop 2 } \\
\hline \multicolumn{2}{|c|}{ First phase - 1st- 2ndc. } & \multicolumn{2}{c|}{ Second phase - 3rd c. } & \multicolumn{2}{c|}{ Third phase - 4th c. } \\
\hline \multirow{2}{*}{ workshop 2 } & \multirow{2}{*}{$65,66 \mathrm{~m}^{3}$} & workshop 2a & $39,25 \mathrm{~m}^{3}$ & workshop 2a+1b & $120,25 \mathrm{~m}^{3}$ \\
\cline { 3 - 6 } & & workshop 2b & $15,99 \mathrm{~m}^{3}$ & workshop 2b & $15,99 \mathrm{~m}^{3}$ \\
\hline Total & $65,66 \mathrm{~m}^{3}$ & & $55,24 \mathrm{~m}^{3}$ & & $136,24 \mathrm{~m}^{3}$ \\
\hline
\end{tabular}

\begin{tabular}{|c|c|c|}
\hline \multicolumn{3}{|c|}{ Workshops 1 and 2 } \\
\hline First phase - 1st- 2ndc. & Second phase - 3rdc. & Third phase - 4th c. \\
\hline $530,60 \mathrm{~m}^{3}$ & $463,52 \mathrm{~m}^{3}$ & $447,86 \mathrm{~m}^{3}$ \\
\hline
\end{tabular}

Fig. 12. Production capacity of workshops 1 and 2 in their three phases. 
seasonal labor? Planned or not, what caused this interruption? There is no satisfying answer.

It is clear that it was not a local event, since the rupture after the late $2 \mathrm{nd} \mathrm{c}$. is well known as the $3 \mathrm{rd} \mathrm{c}$. crisis and was a reality in the Southwest of Hispania and in the Northwest of Morocco as F. Mayet and C. Tavares da Silva have documented ${ }^{20}$. These authors claim that only a major natural catastrophe may explain such a general destruction and abandonment at the same moment. An earthquake followed by a tsunami would have destroyed everything in the shoreline, like salt marshes, fish-salting factories, fishing boats and amphora kilns, causing a long lasting negative effect on the economy of these regions ${ }^{21}$.

At Baelo Claudia, in the near province of Baetica, the works of the University of Cadiz revealed clear evidence of abandonment in the late $2 \mathrm{nd}$ c. in several areas including a building in the industrial quarter where it was very obvious the collapse of the walls only happened over a thick filling of refuse ${ }^{22}$. Moreover, multiple evidence point to a possible "general abandonment" or of good part of the insulae of the barrio meridional that includes the industrial quarter. This abandonment was not due to any violent episode or fire, and fishing and fish-salting activities kept going since the abandonment levels were rich in residues of these activities ${ }^{23}$. The real cause is not known.

Neither at Tróia did the archaeological record give the answer so far. There is no evidence, at the end of the first phase, of a major sudden destruction of the buildings just as at Baelo Claudia. But while at Baelo the industry kept going for a while, at Tróia the abandonment is testified by the inactive vats. And the effective interruption of the production was recently confirmed by a tomb built in the patio of workshop 1, next to the well, and violated and refilled in the second quarter of the 3 rd c. ${ }^{24}$

\subsection{The second phase (3rd - early 4th c.)}

The socio-economic changes in the 3rd c. are more than evident at Tróia at different levels. The large fishsalting workshops appear divided in smaller ones; there is a radical change in the amphorae with a diversification of their shapes; and even the funerary practices change with the introduction of inhumation in the late $2 \mathrm{nd} \mathrm{c}$.

\footnotetext{
20. Id., p. 123-125.

21. Id., p. 128-129.

22. Bernal et al. 2007, p. 383-389.

23. Id., p. 452.

24. Pinto, Magalhães, Brum 2010, p. 140-141 and figs. 6, 8-9.
}

The recent works have brought some evidence on the dating of the beginning of the second phase in workshops 1 and 2.

Workshop 2 was divided in two smaller workshops and one of them, workshop 2B, was covered by a new pavement with a layer of pottery fragments. Among many fragments on the surface, only regional Dressel 14 and Baetican Almagro 50 amphorae were detected. The presence of this last amphora and the absence of Almagro 51c var. B, omnipresent by mid $3^{\text {rd }} \mathrm{c}$., points to a date between the late $2 \mathrm{nd} \mathrm{c}$. and the second quarter of the 3rd c. In a second moment, vat 8 was filled with sand and covered by a pavement that had one fragment of African Red Slip type C Hayes 50 indicating a date not earlier than the second quarter of the 3rd c. These construction moments are not dated with precision, but since the vat had refuse in the bottom, we presume that only a short period ran between the construction of the new pavement of the patio and the remodeling of that vat into a compartment.

In workshop 1 the only datable evidence is the clay floor that covered the above mentioned tomb in the patio next to the well. We proposed to date this floor to the second quarter of the 3rd c. due to the abundant 2 nd c. and some 3rd c. ceramics it contained, the latest being African Red Slip type C and amphorae Almagro 51c, var. $\mathrm{B}^{25}$. Since this floor was built after a period of abandonment, confirmed by the tomb, we believe it is the new floor resulting from the remodeling of the workshop when it was divided in several smaller units, leaving the well in a central yard.

Therefore both workshops 1 and 2 may have restarted the production in the first half of the 3rd c. but workshop $2 \mathrm{~B}$ at an earlier moment than the others.

According to R. Étienne, Y. Makaroun and F. Mayet, the new workshop $1 \mathrm{~B}$ resulting from the division of workshop 1 was attached to workshop 2 still undivided $^{26}$. The evidence and interpretation just presented point to the division of this workshop probably in the first quarter of the 3rd c. and we believe workshop 2A was not connected to workshop $1 \mathrm{~B}$ during this phase since there are signs of the entranceway between the two having been blocked and later on reopened (in the third phase). Workshop 1B would then be autonomous with its patio with access to the well as the other production units of workshop 1.

The above mentioned workshops subdivided possibly in the 3rd c. (workshops 6 and 21) suggest the activity restarted in different areas of the settlement reusing the old workshops but on a slightly reduced scale.

25. Id, p. 139-140.

26. Étienne, Makaroun, Mayet 1994, p. 84-85 and fig. 56. 


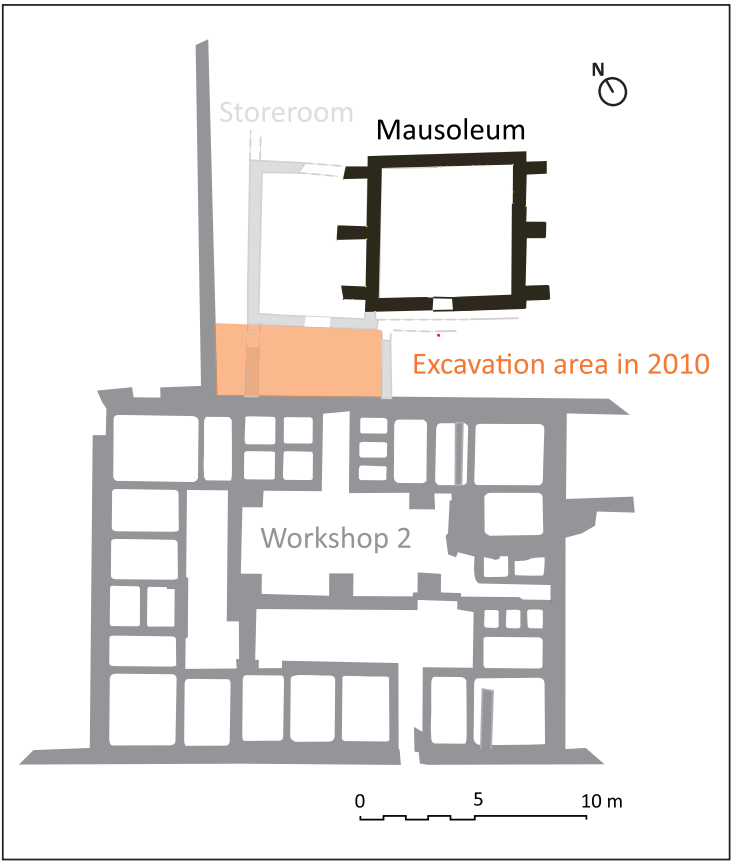

Fig. 13. Location of excavation area next to workshop 2 (A. P. Magalhães based on Étienne, Makaroun and Mayet, 1994, fig. 51 and J. L. Madeira (2008, unpublished)).

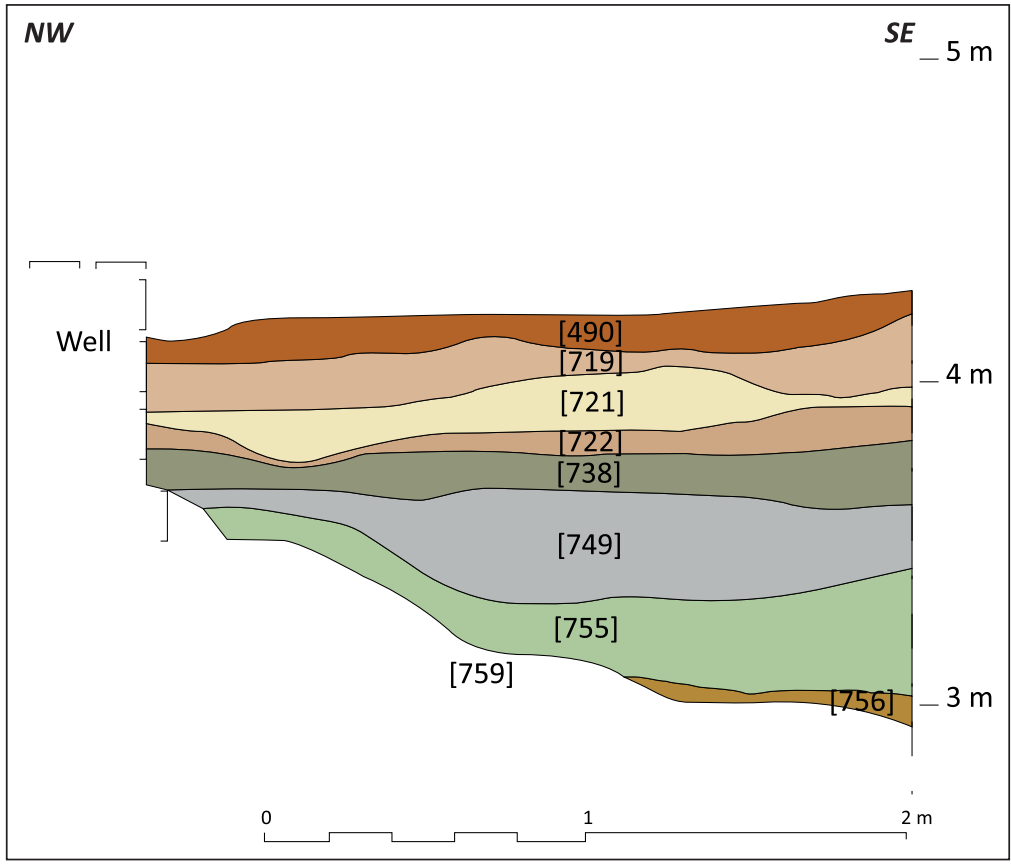

Fig. 14. Northeast section in the sounding next to the well of workshop 1 (A. P. Magalhães)

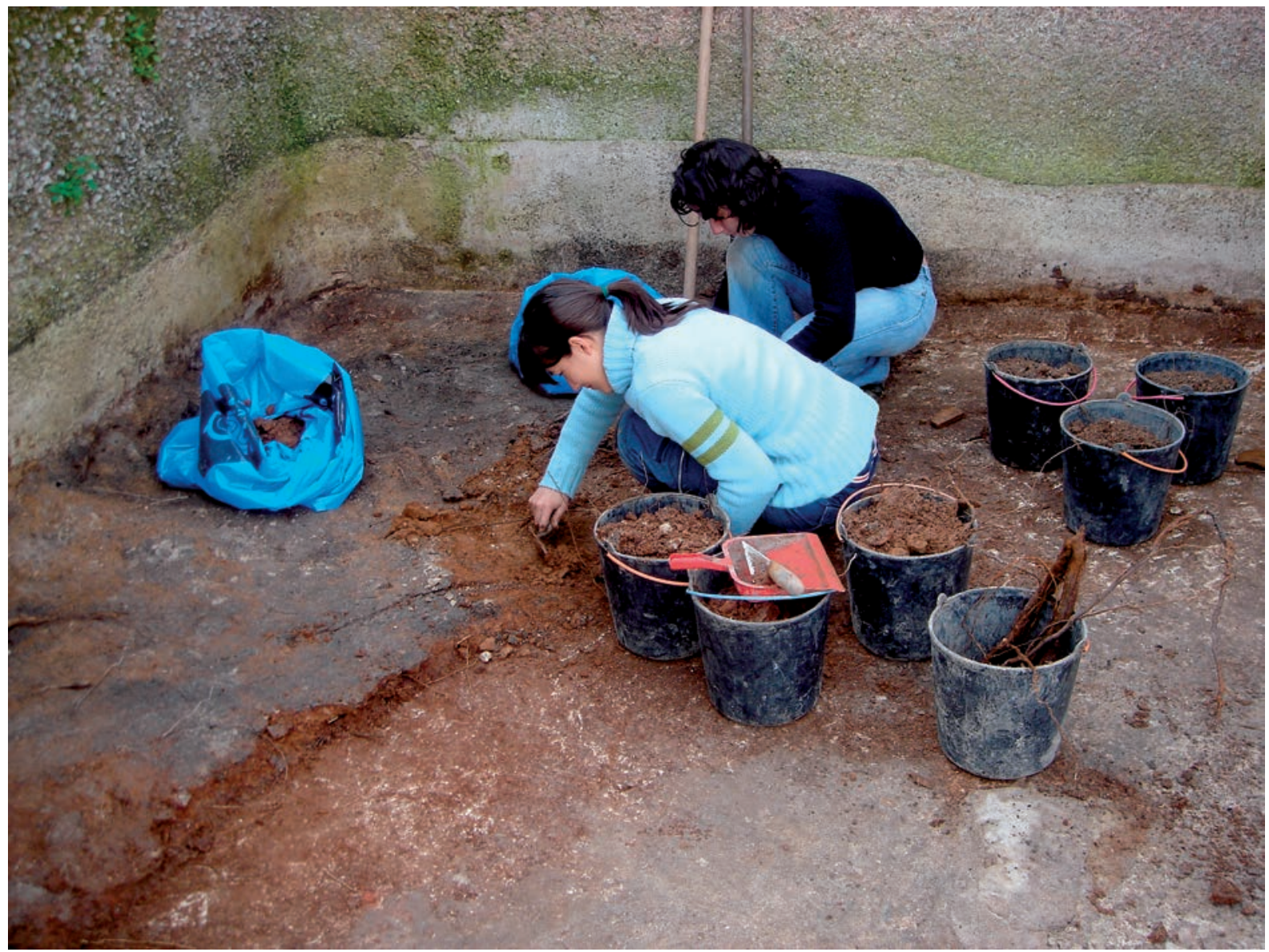

Fig. 15. Aspect of the excavation of the fish products remains layer in workshop 6 vat 3 ((I. V. Pinto). 


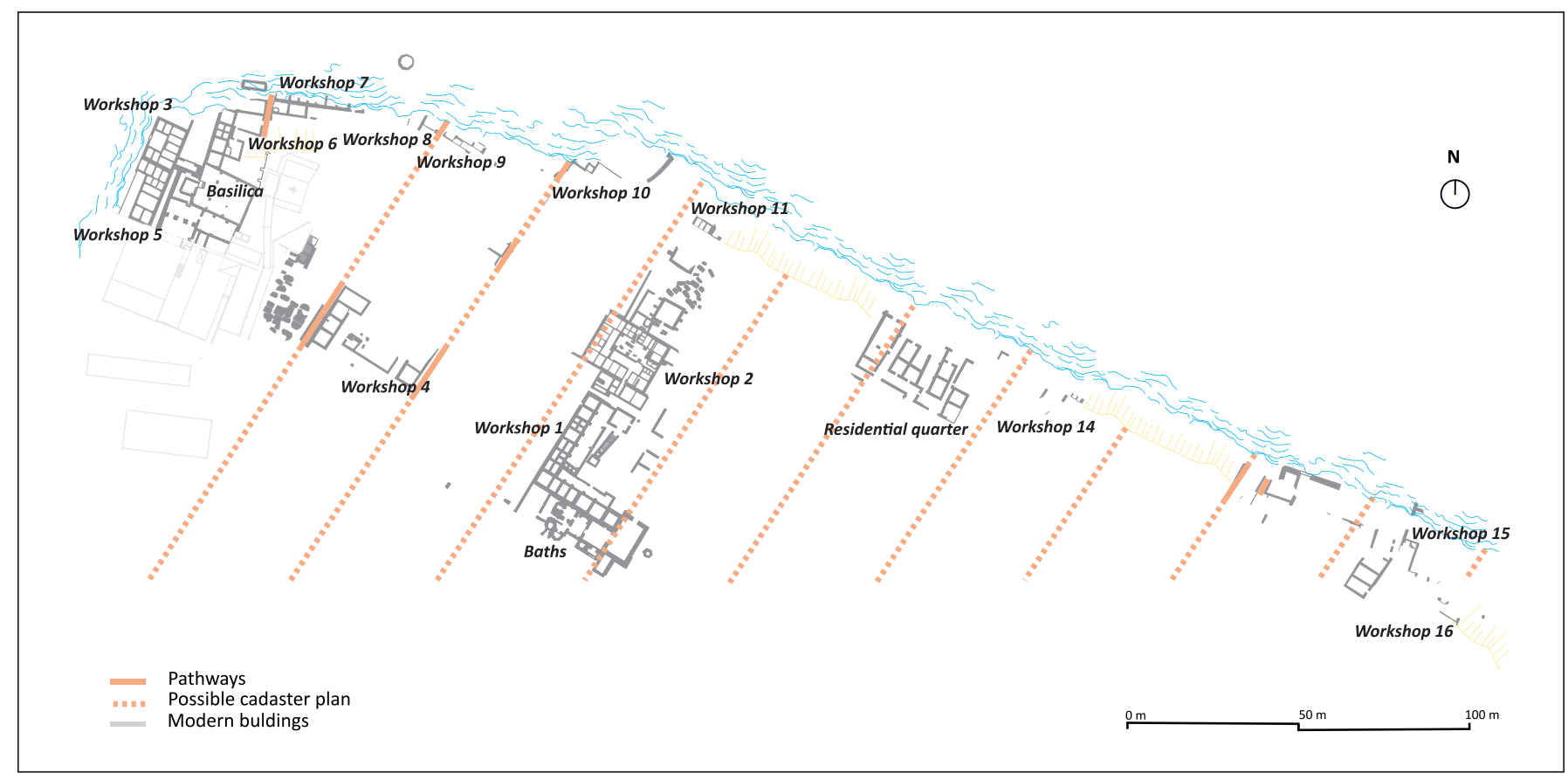

Fig. 16. Possible cadastre plan of Tróia (A. P. Magalhães based on topographical survey by IPPAR (2006, unpublished)).

This phase lasted until there were cases of abandonment and remodeling in the first half of the 4th c., but the break between the second and the third phase is not well defined and different areas had different developments and possibly timings.

The one example of abandonment is workshop 6 vat 3 whose bottom was excavated before it was recovered by a beach refilling ${ }^{27}$. The vat was partially destroyed and regularly flooded by the tides, but surprisingly the lowest units of its filling were preserved in the southwest part, including a layer of fish products remains (fig. 15). This last unit [1307] just had rims of African Red Slip type $\mathrm{C}$ Hayes 50 var. A and amphora African II C pointing to a dating in the late 3rd c. - first half of the 4th, but possibly not later than the early 4 th c.

Even if this workshop was divided in smaller ones, the abandonment could probably extend to the whole productive unit, since its southwest part was reused as a cemetery and later built over by a Christian basilica. It is the only documented case, so far, of a vat or workshop abandoned in the first half of the 4th c.

\subsection{The third phase (4th-5th c.)}

The third phase was inferred by R. Étienne, Y. Makaroun and F. Mayet from the walls built over vat

27. Silveira et al. in press.
15 later than the first wall subdividing workshop 1 . The northeast line of vats was then definitely separated from the rest of the workshop by a wall over its southwest limit and connected to workshop $2 \mathrm{~A}^{28}$.

Workshop 2A had the entranceway to workshop 1 reopened and considerably augmented its production capacity by acquiring at least four new vats (workshop 1 vats 16-19), three of them very large.

Workshop 2 did not give any dating element to this enlargement neither did workshop 1 for the second walls over vat 15 . R. Étienne, Y. Makaroun and F. Mayet suggested the first half of the 4th c. but could not confirm it.

The recent works next to the well of this workshop revealed a second floor [721], this one paved with mortar and not well preserved (fig. 14). It contained African Red Slip type C (Hayes 58A and 50A/B) and a few fragments of type D (Hayes 58), regional amphorae Almagro 51c, var. B and Keay 78/Sado 1, Baetican amphorae Almagro 50 and 51c and some African amphorae, probably Tripolitania III and African II or III, datable from the end of the 3rd c. to the mid 4th c. ${ }^{29}$ This is the evidence of works having been done in workshop 1 in the first half of the 4th c. even if it is not possible to physically connect them with the new dividing walls in the northeast area.

Other areas of Tróia showed changes in the first half of the 4th c. Part of workshop 6, as mentioned above, was turned into a funerary precinct and so was the probable

28. Étienne, Makaroun, Mayet 1994, p. 88.

29. Pinto, Magalhães, Brum 2010, p. 139. 
house southwest of this workshop whose last wall paintings were dated to the end of the $3 \mathrm{rd} \mathrm{c}$., early 4 th. ${ }^{30} \mathrm{~A}$ sounding in workshop 6 vat 8 revealed that before the pavement of the basilica was built, this vat had been reused as a collective sepulchre with several tombs and sealed with a cover of opus signinum. Under the cover there was a Keay 78/Sado 1, var. B amphora rim not earlier than the mid 4th c. Therefore the cemetery may have been installed in the 4th c., after the production ceased in this workshop.

But if the downsizing of the fish-salting facilities is evident in the 3rd and 4th $\mathrm{c}$. with productive units giving place to other uses, the production continued in other workshops and workshop 2A triplicates its production facilities in the late $3 \mathrm{rd}$ or first half of the 4th c.

This last phase of fish-salting production ends in the first half of the 5th c. The best evidence is the filling of the abandoned vats and the layers that covered the whole area of workshops 1 and 2 documented both by old and recent excavations.

One of the authors (APM) recently studied the terra sigillata and African Red Slip from workshop 1 from old excavations (1956-1961) and a 2008/2009 excavation of an area southeast of the well ${ }^{31}$. The pottery came essentially from garbage dumps accumulated in the vats and in the large patio of workshop 1. Their study revealed significant imports of African Red Slip type D (Hayes $59,61,67,80,91$ being the most abundant) with a peak in the late 4 th - early 5 th c. pointing to an abandonment of the production in the second quarter of the 5 th $\mathrm{c}$. The study of the amphorae comforts this chronology with the predominance of Almagro 51c var. C over other types and some rare examples of 5th c. imported amphorae like Keay XXXV B and Late Roman $1 \mathrm{a}^{32}$.

Vats 1 and 5 and vat 7c in workshop $2^{33}$ had pointed to a mid 5th c. dating based mainly on the presence of Hayes 80A in African Red Slip type D. Since their set of forms is similar to that recently studied, those levels should also be assigned to the second quarter of the 5 th c., including form Hayes 80A.

\subsection{Later phases}

Vat 19 and vats 1 and 5 in workshop 2, certainly as others excavated in the past, were left with the fish remains from the last production and were then filled with refuse and later with wall debris. It is clear people

30. Maciel 1996, p. 235-238.

31. Silva 2010.

32. Pinto, Magalhães, Brum 2012.

33. Id., p. 529. stopped producing not bothering to clean the vats, but did not abandon the area for a certain time. In workshop 2 a number of late small walls, some forming small compartments and the removal of vat 7c $3 \mathrm{rd} \mathrm{c}$. floor ${ }^{34}$ suggest this workshop was still in use for other purposes. In a second moment tombs were built in the area, at different levels, some on the floor of the patio of workshop 2 , one inside workshop 1 vat 16 and many were excavated in the debris layers.

In the northwest area of workshop 2, untouched, it was possible to register the destruction layers of the workshop. In the southwest area units of roof and wall collapse were interposed by sand layers that suggest decay over a rather long period of time with collapsing episodes followed by accumulations of windblown sand.

There is a severe decline since the midst of the 5 th c. $^{35}$ but the latest imported fine ware, though quite rare, lasts through the 6th c. ${ }^{36}$ meaning other unexcavated areas may have had a longer occupation. The site was abandoned to be covered by sand dunes. A popular quatrain tells Tróia was razzed to the ground by a "sand rain".

\section{An industrial quarter, a vicus or a city ?}

The Roman remains at Tróia spread along $1.5 \mathrm{~km}$ in the shoreline but the deep sand dunes and the pine forest difficult the definition of the proper limits of the site. Yet the two southeastern factories (workshops 12-13 and 25, fig. 5) seem rather isolated and were certainly peripheral. Those southeast of workshop 15 to workshop 24 are implanted in a nearly continuous line of constructions but it is not clear if the area to southwest was also urbanized. It is the area from workshop 15 to northwest that would be densely constructed even if a large part hasn't been excavated. This area represents approximately 4 hectares but it originally extended further to the northeast, this part having been taken away by the tides. There is no doubt that it was a large settlement.

Since Roman Tróia has not yet been identified with any of the settlements referred by classic texts, only with Avienus's island of Achale, the question is if it ever became a real city or if it was an industrial vicus or simply an industrial quarter.

Referring only the most recent interpretations, J. Alarcão presented Tróia as a secondary urban agglomerate or a vicus, possibly the Caepiana of Ptolemy ${ }^{37}$. J. Soares and C. Tavares da Silva, on the other hand,

34. Id., p. 534-537.

35. Silva 2010, p. 112.

36. Étienne, Makaroun, Mayet 1994, p. 43-49.

37. Alarcão 2011, p. 326-327. 
referred Tróia as the main industrial quarter of the city of Caetobriga, its location on an island reinforcing its dependence on the urban agglomerate on the other shore $^{38}$.

It is obvious that Roman Tróia had some town planning since buildings generally have the same alignment northeast-southwest with small variations, and a proposal of the cadastre plan of Tróia was presented by Jorge de Alarcão in $2011^{39}$. An essay to draw, in the top plan of Tróia, the visible pathways bordering and separating several workshops and other buildings brought unexpected results. Prolonging those bordering workshop 4 to northeast revealed they were perfectly aligned with the narrow paths that separate workshops 8 from 9 and workshop 10 from a building to northwest, forming a long rectangular lot. Since workshop 4 is c. $33 \mathrm{~m}$ wide, this lot would be c. $35 \mathrm{~m}$ wide, this measure coinciding with one actus, the basic unit of Roman agrimensura (120 Roman feet equal to $35.52 \mathrm{~m}$ ). Since the factory with workshops 1 and 2 seemed to fit into a similar long narrow lot, a grid of one actus wide lots was applied to the supposed "urban" area of Tróia (fig. 16). In fact, that factory fits roughly in one of those lots. Only the southeastern part of the baths, considered from the 3th c., is on the next lot, and a second phase wall prolonging workshop 2's southwestern wall invades the lot to northwest. The buildings of the residential quarter exceed the northwest limit of another supposed lot but they do not belong to the first construction phase as J. Alarcão has pointed ${ }^{40}$. At the northwest end of the urban area, including workshops 3, 5, 6, 7 and 8, the orientation of buildings and streets is irregular and more chaotic. It was probably originally a peripheral area where the buildings and the street grid adjusted to the shoreline. The southeastern workshops 20 to 24 do not seem to be implanted on a regular grid either. This cadastre plan coincides roughly with that proposed by Jorge de Alarcão even if we are not able to propose perpendicular axes.

It is quite evident there was a delimitation of the land consisting on a cadastre plan of rectangular equidistant lots one actus wide even if it is not obvious how far southeast that went.

This cadastre plan is not that of a city (colonia or municipium) since there is no cardus or decumanus nor real streets, only narrow sand paths between buildings, sometimes as narrow as $1.20 \mathrm{~m}$ and not wider than $1.80 \mathrm{~m}$. The paths dividing the lots seem also too narrow for a vicus. It is also certain these lots were not for cultivation for the white sand soil of Tróia was not suitable for agriculture.

Looking at the buildings exposed at Tróia, the omnipresent fish-salting factories stand out by their number and some by their size, and they are scattered through the whole excavated area. Apparently the reason to occupy the sandy land of Tróia was to install a large fish-salting production centre since the size of the lots seems adjusted to that purpose and factories seem to have occupied the largest part of the lots. Its location at the mouth of the river next to the ocean, on a flat area of easy access, was convenient for fishermen to deliver their catch and for trade boats to fetch their cargoes. Salt-marshes and pottery workshops would deliver by boat, from shore to shore, the salt and the amphorae.

Either Salacia, the civitas capital, or Caetobriga, across the river, could have taken the initiative to prepare the land of Tróia for the installation of fish-salting factories. Did Caetobriga install an industrial quarter $4 \mathrm{~km}$ away to protect itself from the nasty smell of the fish sauces preparation? Since Caetobriga has the same strategic position as Tróia, and its own fish-salting factories, it seems possible that Salacia, upriver, would install an industrial centre at the mouth of the river. The homage referred in an incomplete inscription to L. Cornelius Bocchus, provincial flaminius, military tribune of the III Legio Augusta ${ }^{41}$ and member of an important family from that city, may recall the intervention of Salacia in its beginnings.

Even if it started as an industrial quarter, the development of the fish-salting business brought economic prosperity and trade connections that gave Tróia a reasonable autonomy. It remained dependent on building materials and foodstuffs and the tights with Caetobriga, the nearest city, were certainly very strong. But the wealthy residences with wall paintings and mosaics, the Mithraic and Christian temples, the cemeteries with funerary epigraphy, the abundant imports in terra sigillata and amphorae as the quality of metal and bone objects are signs of the dwelling of rich as well as common people, slaves, freedman and foreigners. They point to a very lively and dynamic urban agglomerate whose name will hopefully be revealed in the future.

38. Soares, Silva 2012, p. 63-65.

39. Alarcão 2011, p. 337.

40. Id., p. 337.

41. CIL II 5180; Encarnação 1984, p. 276. V. also Diogo, Trindade 1999 and Morais 2007. 


\section{Conclusion}

The twenty five fish-salting workshops identified at Tróia make this production centre one of the largest in the Roman world from the 1 st to the 5 th c. AD. The evidence points to the planned occupation of the sandy soil of Tróia with the purpose of installing an industrial complex with fish-salting factories. Recent works have confirmed the rhythms of occupation proposed by the first studies and confirm a period of great prosperity in the $1 \mathrm{st}-2 \mathrm{nd} \mathrm{c}$. followed by an unexplained temporary abandonment in the second half of the 2nd c. The fishsalting activities restarted apparently in the beginning of the 3rd c. reusing the old factories but the production capacity was reduced by the division of workshops and vats and the abandonment of some production units. The beginning of the 4th c. must have been another moment of change with the abandonment of one large workshop, or part of it, and the reorganization of others. Active at least up to the middle of the 5th c., Tróia was definitely a very productive pole of the large fish-salting centre of the low Sado valley.

\section{Bibliography}

Alarcão 2004 : ALARCÃO (J.) - Notas de arqueologia, epigrafia e toponímia - I, Revista de Arqueologia, 7-1, 2004, p. 317-342.

Alarcão 2011 : ALARCÃO (J.) - Os Cornelli Bocchi, Tróia e Salacia. In : Cardoso (J. L.) and Almagro-Gorbea (M.) (eds), Colóquio Internacional dedicado a Lucius Cornelius Bochus (Tróia, 2010), Lisboa-Madrid, (Academia Portuguesa da História. Real Academia de la Historia), 2011, p. 323-348.

Barreiros 1561 : BARREIROS (G.) - Chorographia de alguns lugares que stam em hum caminho que fez Gaspar Barreiros ó anno de MDXXXXVJ começa[n]do na cidade de Badajoz em Castella te á de Milam em Italia; $\mathrm{co}[\mathrm{m}]$ algu[m]as outras obras cujo catalogo vai scripto com os nomes dos dictos lugares na folha seguinte, Coimbra, 1561.

Bernal $\boldsymbol{e}$ t al. 2007 : BERNAL (D.), ARÉVALO (A.), LORENZO (L.), CÁNOVAS (A.) - IX. Abandonos en algunas insulae del barrio industrial a finales del siglo II d.C. In : Arévalo (A.) and Bernal (D.) (eds), Las cetariae de Baelo Claudia. Avance de las investigaciones arqueológicas en el barrio meridional (2000-2004), Cádiz, 2007, p. 383-453.

Castelo-Branco 1963 : CASTELO-BRANCO (F.) - Aspectos e problemas arqueológicos de Tróia de Setúbal, separata da revista Ocidente, vol. LXV, 1963.

Costa 1933 : COSTA (A. I. M.) - Estudos sobre algumas estações da época luso-romana nos arredores de Setúbal, O Arqueólogo Português, vol. XXIX, 1933, p. 2-31.

Diogo, Trindade 1999 : DIOGO (A. M. D.), TRINDADE (L.) - Homenagem a L. Cornelius Bocchus encontrada nas Termas dos Cássios (Lisboa), Ficheiro Epigráfico, 60, 1999.

Edmonson 1987: EDMONDSON (J. C.) - Two industries in Roman Lusitania, Mining and Garum Production, Oxford, BAR International Series 362, 1987.

Encarnação 1984 : ENCARNAÇÃO (J. D') - Inscrições romanas do Conventus Pacensis : subsídios para o estudo da romanização, Coimbra, Instituto de Arqueologia da Faculdade de Letras, 1984.
Étienne, Makaroun, Mayet 1994 : ÉTIENNE (R.), MAKAROUN (Y.), MAYET (F.) - Un grand complexe industriel à Tróia (Portugal), Paris, 1994.

Maciel 1996: MACIEL (J.) - Antiguidade tardia e paleocristianismo em Portugal, Lisboa, 1996.

Mayet, Silva 2002 : MAYET (F.), SILVA (C. T.) - L'atelier d'amphores d'Abul (Portugal), Paris, 2002.

Mayet, Silva 2010 : MAYET (F.), SILVA (C. T.) - Production d'amphores et production de salaisons de poisson : rythmes chronologiques sur l'estuaire du Sado, Conimbriga, vol. XLIX, 2010, p. 119-132.

Morais 2007 : MORAIS (R.) - Contributo para o estudo da economia na Lusitânia romana, Saguntum (P. L. A. V.), 39, 2007, p. 133-140.

Pinto, Magalhães, Brum 2010 : PINTO (I. V.), MAGALHÃES (A. P.), BRUM (P.) - Sondagem junto ao poço da oficina de salga 1 de Tróia, Conimbriga, vol. XLIX, 2010, p. 133-159.

Pinto, Magalhães, Brum 2010a : PINTO (I. V.), MAGALHÃES (A. P.), BRUM (P.) - Ceramic assemblages from a fish-salting factory in Tróia (Portugal), Rei cretariae romanum fautores, Acta 41, 2010, p. 375-384.

Pinto, Magalhães, Brum 2011 : PINTO (I. V.), MAGALHÃES (A. P.), BRUM (P.) - O complexo industrial de Tróia desde os tempos dos Cornelii Bocchi. In: Cardoso (J. L.) and Almagro-Gorbea (M.) (eds), Colóquio Internacional dedicado a Lucius Cornelius Bochus (Tróia, 2010), LisboaMadrid, Academia Portuguesa da História. Real Academia de la Historia, 2011, p. 133-167.

Pinto, Magalhães, Brum 2012 : PINTO (I. V.), MAGALHÃES (A. P.), BRUM (P.) - Un dépotoir du Ve siècle dans l'officine de salaisons 1 de Tróia, Portugal, Rei cretariae romanum fautores, Acta 42, 2012, p. 397-406.

Pinto, Magalhães, Cabedal in press : PINTO (I. V.), MAGALHÃES (A. P.), CABEDAL (V.) - O núcleo fabril do Recanto do Verde (Tróia), Setúbal Arqueológica, 14 


\section{AN OVERVIEW OF THE FISH-SALTING PRODUCTION CENTRE AT TRÓIA}

Ponsich, Tarradell 1965 : PONSICH (M.), TARRADELL (M. ) - Garum et industries antiques de salaison dans la Méditerranée Occidentale, Paris, 1965.

Resende 1593 : RESENDE (A.) - De Antiquitatibus Lusitaniae, 1593.

Silva 1996: SILVA (C. T.) - Produção de ânforas na área urbana de Setúbal : a oficina romana do Largo da Misericórdia. In : Filipe (G.) and Raposo (J. M. C.) (coords), Ocupação romana dos estuários do Tejo e do Sado (Actas das primeiras jornadas sobre romanização dos estuários do Tejo e do Sado, Seixal,1991), Lisboa, 1996, p. 43-54.

Silva 2010 : SILVA (A. P. M.) - A terra sigillata da oficina de salga 1 de Tróia : contextos de escavações antigas (1956-1961) e recentes (2008-2009), master thesis, Lisboa, Faculdade de Letras da Universidade de Lisboa, 2010, unpublished.

Silveira et $\boldsymbol{a l}$. in press : SILVEIRA (T.), ANDRADE (F.), PINTO (I. V.), MAGALHÃES (A. P.), CABEDAL (V.) - Enchimento de praia para protecção das ruínas romanas de Tróia: projecto e acompanhamento arqueológico, Setúbal Arqueológica, 14.

Soares, Silva 2012 : SOARES (J.), SILVA (C. T.) - Caetobriga, uma cidade fabril na foz do Sado. In: Portugal Romano.com Revista de Arqueologia Romana, Ano 1, $\mathrm{n}^{\circ}$ 2, June 2012. 



\section{Fish processing and salted-fish trade in the Punic West : New archaeological data and historical evolution}

\section{Antonio M. Sáez Romero}

\section{Studying ancient fishing in the far West}

$\mathrm{D}$ ealing with fishing in the Strait Region in Antiquity (fig. 1) inevitably means to discussing fish-processing and at the same time about producing salt and the use of salt-works, and identifying a convincing relationship between these activities. However, in the opinion of the author it is necessary to add at least two activities to the elements of the regional economy developed from the arrival of the Canaanite settlers. The first activity is shipbuilding, on which virtually no direct information is currently available, except for a few vague allusions in ancient literary sources. Secondly, the pottery production is in a diametrically opposed situation, as it currently stands as one of the best archaeologically characterized economic activities in a representative part of the Punic Strait Region. More recently the regional mints of western coastal cities should be added to this list, actively participating in the economic exchange mechanisms (acceleration towards a market economy) and integrating in the iconography of many of their coinage series representations of fishes (like tuna) (fig. 2), which constituted one of the economic foundations of the region.

Thus, it is clear that an approach to the analysis of fishing and fish-processing in this western area in the pre-Roman period forces us to focus our attention on other factors that were traditionally linked to the basic extraction processes, and that helped to complete the commercialization of these fish by-products. In this paper we will attempt to discuss succinctly all these hypotheses and new data, trying to provide a concise and updated review of the current state of research of these topics, closely linked to the cultural roots and craft traditions found in the geo-historical region of the Straits of Gibraltar.

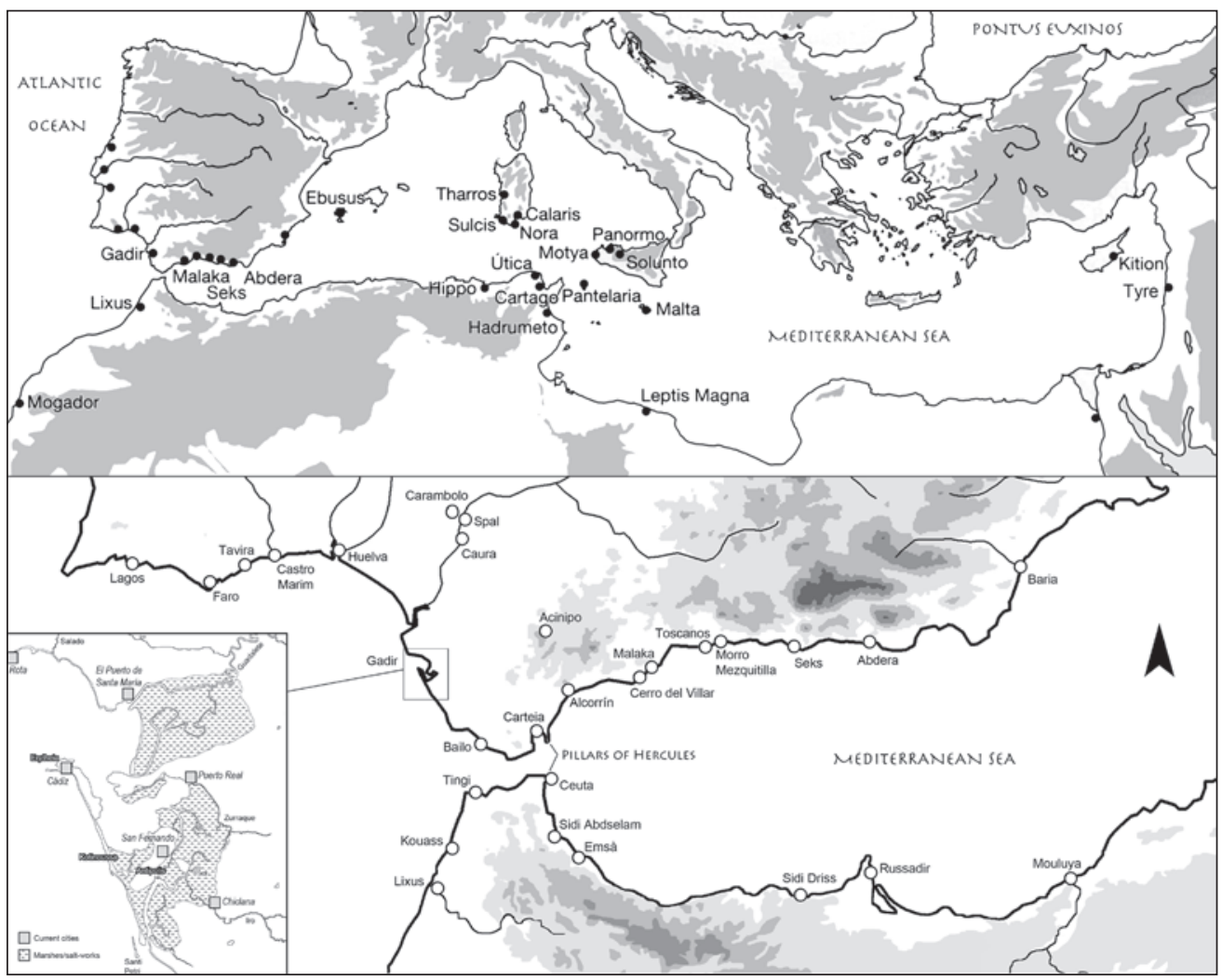

Fig. 1. Maps indicating the main sites mentioned in the text. At bottom left, current settlement patterns in the Bay of Cadiz. (৫ A. Saez). 

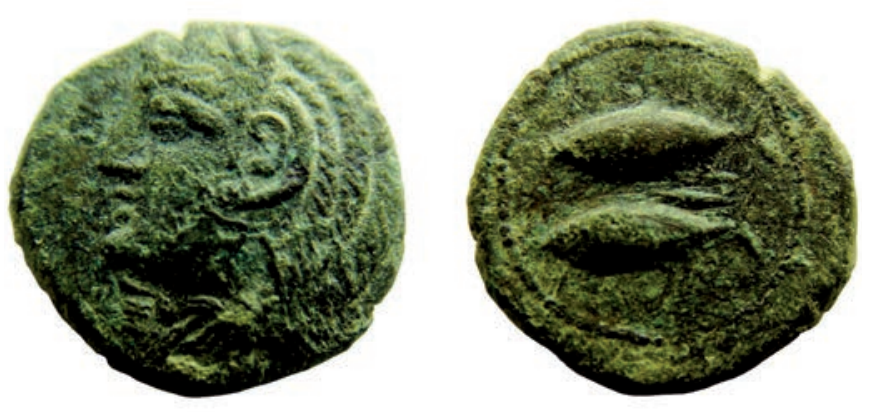

Fig. 2. Bronze of the mint of Gadir, with Melkart/Hercules and tuna (coins from Torre Alta pottery workshop) (@ A. Saez).

\subsection{Ancient fishing, salt-fish and literary sources}

The long voyages, fishing away from home and extended stays abroad should have been well known experiences to many western Phoenicians, ever familiar with and closely linked to the sea. Unfortunately, only a little direct evidence about this aspect of the lives of people of the Strait in pre-Roman times has been recovered; a lifestyle that could be a general feature of broad sectors of the population of colonial (and latter urban) settlements. Despite this, the small set of indirect evidence left by ancient writers has been (and still is) a basis for the analysis of fishing and especially fish-processing in the Punic Far West ${ }^{1}$.

These texts refer to the commercialisation of Gadiritan salted-fish mainly belonging to different literary genres and medical treatises (Hippocrates). Much of the latter were transmitted by a more indirect route, for example the quotation of passages from the much later work of authors like Atheaneus of Naucratis (2nd/3rd c. AD). Thus, although most of the sources of Classical and Hellenistic periods explicitly refer to Gadir, there are traces of a more diversified involvement among urban sites along the Strait area. In all cases the entries are too generic to define which products or qualities were referenced, but it seems that it would had been tárichos (salted-fish in portions or complete, depending on size), preferably tuna and after later texts sturgeon or meagre (traditionally associated to less salty by-products).

The consequence of the process of evolution of western Phoenician cities and its integration into the Roman Republic did not affect at all the role of fishprocessing industry in the socio-economic regional framework, which contemporary scholars have highlighted precisely because of this characteristic. Beyond

1. Lopez Castro 1997. the chronological and cultural limits self-imposed on this paper, we find evidence of this extremely stimulating process in Strabo's descriptions of the seashores of ancient Turdetania, which is the northern atlantic sector of the Strait region.

\section{An incredible fishing wealth: an overview}

One key aspect in offsetting out the context of the Punic regional fishing and fish-processing is the natural biological wealth of the coasts and seawaters of the area, especially on the atlantic side, explicitly quoted and praised by ancient authors. Recent historiography has also highlighted these advantages, suggesting the possible role of the fishing wealth of the region (and especially seasonal catches, continuous and predictable) as one of the reasons that could have led to the Phoenicians taking a remarkable interest in establishing colonies in the Far West and the Central Mediterranean ${ }^{2}$. Also, historiography has underlined the location of many of these Phoenician colonies being in areas located close to essential resources (like marshes used for salt-works facilities) and good for fishing (and particularly for the installation of tuna-traps, almadrabas).

For the final settlement of Levantine settlers in this western bound of the ancient world, the exceptional richness of this western coast and its fishing grounds all along the Straits of Gibraltar region would have thus become an attraction that complemented the traditional ones (metals, exotic products and raw materials, etc.). Thereby, the conjunction of this privileged environment and the Canaanite advanced technology (much more advanced than the indigenous) would have ensured not only subsistence but also the beginning of the development of patterns of a surplus-type exploitation of these marine resources.

\subsection{Archaeo-ichthyology: current state of research}

On the basis of this ichthyologic wealth of the 'Strait region' and the first archaeo-zoological data, recent investigations have offered fresh views of this natural situation to explain how it could influence the generation of different micro-economies (exploitation strategies) in the region, and at the same time how it constrained the progress in each area of the fish-processing industry. This proposal focuses on the possible existence of two

2. Morales, Roselló 1988. 


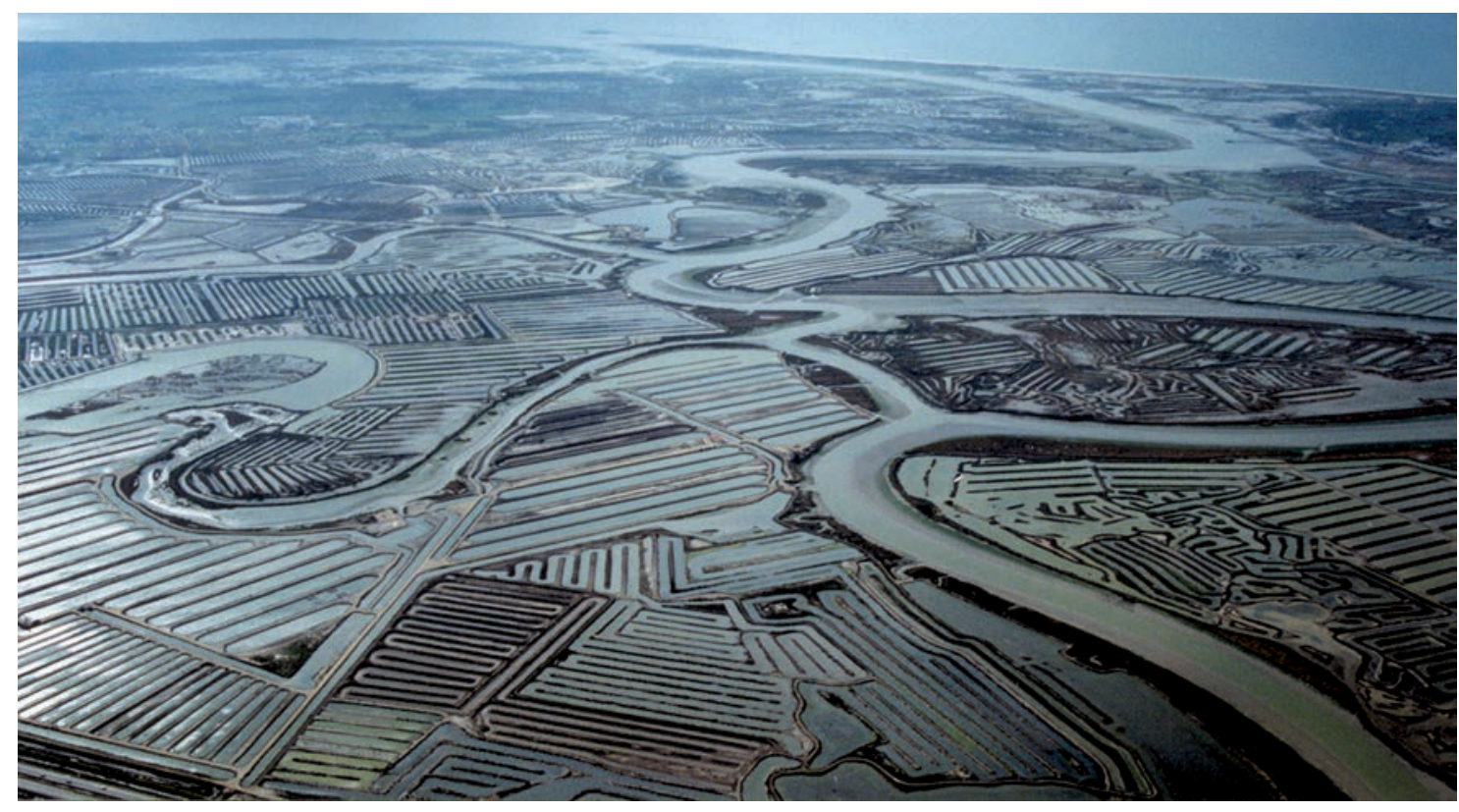

Fig. 3. Actual salt-works in Cádiz Bay, with the island of Sancti Petri and the Atlantic coast in the background (๔ Gerencia Municipal de Urbanismo de San Fernando).

differentiated biological, fishing and productive frames (Atlantic circle vs. Mediterranean Circle) that could have largely determined the composition of the saltedfish by-products on both sides of the Pillars.

In fact, it has been pointed out ${ }^{3}$ that this feature is one of the most significant characteristics of current research, emphasizing existing marked differences between the two coasts from one side of the Strait to the other with respect to dominant ichthyofauna (not only recognized in consumption centres but also in the production ones). In the case of the Mediterranean coast this differences would result in a preponderance of possible use of little size fishes such as engraulis encrasicolus (white anchovy), sardines, bogues or blotched picarels for the production of salted-fish and sauces from at least Roman imperial period ${ }^{4}$. This interesting discussion is currently at the mercy of a progressive increase in the quantity and contextualization of faunal information ${ }^{5}$, especially that recorded in the industrial deposits and inside of non-reused containers.

\subsection{Geoarchaeology and "archaeology of salt"}

Thus, clay, pottery kilns, fish and basins were ready to converge towards a common purpose from early

3. García, Ferrer 2006.

4. Ibid., p. 24.

5. Morales, Roselló 2006. moments of Canaanite presence in the West in many corners of the Strait Region. But as noted before, it is necessary to draw attention on another of the essential elements in this successful combination: salt production and the presence of salt-works in these colonial centres or western Phoenician cities. The later references of Strabo's geography describe a region rich in rock salt and brackish outcrops in the inland and riddled with large tidal estuaries, marshes, shallow waters and salty creeks that certainly offered excellent possibilities for systematic exploitation ${ }^{6}$. In the particular case of Gadir, the same author also explicitly states that its merchants used salt for direct exchange with the Atlantic populations in exchange for metals ${ }^{7}$.

The Gadiritan settlement so far has led the debate on the location of ancient salt-works in the large local marshy areas (fig. 3). Recent research projects concerning the diachronic analysis of the geomorphological evolution of the coastline of Cadiz Bay during the Holocene have recorded pottery sherds and ancient structures (both Punic and Roman), but this evidence still does not allow an unequivocal interpretation of the salt-works facilities ${ }^{8}$. Strabo's references show that the intense exploitation of these intertidal marshlands would have been mainly linked to the local fish-salting activity, even generating enough surpluses to trade with this marine salt. Many other western cities of Phoenician

6. Strabo, 3.2.6.

7. Strabo, 3.5.11.

8. Alonso et al. 2003; Arteaga, Schulz 2008. 
origin, often located next to river mouths (and thus endowed with marshy estuaries) may have followed this Gadiritan model, using in many cases their own salt production for local fish-processing factories.

\section{Fishing and salted-fish during the Orientalizing and Archaic periods}

Prior to the establishment of the colony of Gadir in the beginning of 1st millennium $\mathrm{BC}$, the growing evidence dating from the Late Bronze Age indicates that fishing and shell-fishing were already part of the daily life of the indigenous population of Cadiz Bay and of large areas of the Straits coast ${ }^{9}$. However, it is clear that even from an advanced pre-colonial stage the Phoenician technological contribution may have revolutionized fishing strategies and patterns of many coastal areas of the region. Barely modified environment and fishing grounds would had suffered (especially from stable settlement of the Levantine peoples) a much more intense and effective exploitation, as a result of the importation of advanced fishing techniques and probably fish-preservation processes.

The debate of the origins of these products in the context of the Punic western economy has moved in recent decades to a main question: whether their emergence was caused by rising of urban phenomenon (from 6th c. BC) or whether it was instead the crystallization of a trend already established. In the last two decades it seems that in the historiography a "non-industrialized" role has been assigned (basically linked to subsistence) to archaic fishing. This is quite different from the role attributed to these marine activities from 6th c. BC as an emerging regional economic flagship replacing the metal trade ${ }^{10}$. Several archaeological reports generated over the past decade and a review of other evidence that has remained in the background, as well as adding to the discussion the archaic pottery production, begin to outline a different scenario in which the salted-fish was regularly traded from the first contacts between Tartesians and Canaanites ${ }^{11}$.

The exceptional set of evidence rescued from the excavations in the area of Méndez Núñez/Plaza de las Monjas (Huelva), probably the oldest Phoenician trading deposits so far recovered in the Atlantic side of this western bound, has revealed some significant traces of

9. López, Ruiz 2010.

10. García 2001.

11. Sáez 2010, 2011a. fishing and fish consumption ${ }^{12}$. The evidence was read as a sign of pre-colonial commercial contacts or the settlement of a first small stable Levantine contingent, and generally the finds were dated towards the central section of $9^{\text {th }} \mathrm{c}$. BC century or in the early-8th c. BC. The development of active fishing and fish consumption seems to be well attested, subject to monographic publication of archaeofaunal analysis. So far, many fish remains include species such as sea bass, snapper, bream, rays, sardines, cuttlefish, crustaceans and even a skull fragment have been identified and attributed to an unspecified cetacean.

Furthermore, the site has provided the current earliest evidence in the western Phoenician colonial area of a container filled with preserved fish presumably for commercial purposes (an unclassified sherd indicated fish scales affixed to the inner surface of the container). In any case, the movement of fish by-products as early as the last decades of 9th c. BC (and thus the import of technology, well known to the Tyrians in the Eastern Mediterranean before the colonial diaspora), is an example that should warn us about the validity of the traditional hypothesis that identified archaic fishing exclusively as a subsistence activity.

\subsection{Fish consumption and salt-fish trade in the Western Archaic colonies}

The strongest contextualized evidence of the archaic colonial stage has been found at the site of Cerro del Villar (Malaga), regarding fishing, fish-processing, purple dye production and amphora manufacture ${ }^{13}$. The interaction of these major Phoenician coastal settlements with the indigenous inland shows forcefully almost all the elements included in the extraction-processing-commercialization-consumption cycle together.

On the management of fish products and fish packaging the results of the campaign of 1995 must be highlighted, because they revealed a large residential sector and a wall located close to the river, both dated to the first half of the 7th c. BC (Sector 8). The most interesting find in this area was a section of a colonnaded street, full of small rooms interpreted as retail shops following an oriental pattern (süqu or souk), which seems to have constituted a market place or shopping street. Inside one of these small shops two archaic amphoras T-10121 were found, one of which contained fish

12. González et al. 2004.

13. Aubet et al. 1999; Delgado 2011. 
remains still inside ${ }^{14}$. These would have been displayed there for sale.

However, the most outstanding finds related to archaic western fish-processing would had been those linked to a building investigated in Sector 2/6 of the site. This structure was immediately related to the fishing and processing of catches (as well to purple dye production), interpreted as a rectangular building used all along the 7 th c. $\mathrm{BC}^{15}$. The ichthyofauna recovered in these archaic layers was clearly dominated quantitatively by clupeids (sardina pilchardus) and a lower volume of a broad range of seabream (sparidae), with a minor presence of other species like mackerel, mullet, bass, etc. ${ }^{16}$

These data from the Phoenician settlements like Toscanos and Cerro del Villar (and probably in the future, Malaka, Morro de Mezquitilla and many more), become even more informative if we connect them with archaeological record recovered from the Depresión de Ronda (the Malaga hinterland), an area with important overland routes though river valleys that enabled crossing the coastal foothills. Such evidence, with specimens apparently of considerable size (of sturgeon, galeorhinus galeus and pagrus pagrus), suggests the possibility that inland transportation could have supplied "preservation systems, salting" to enable fish products to be used long after processing in coastal settlements ${ }^{17}$.

However, one finding dominates this reduced sample of consumption of marine fish species, that is the arrival of these fish by-products to the Tartesian inland as early as the 7th century BC, probably carried by the western Phoenicians. As pointed out by the excavators, the find consisted of a Phoenician archaic amphora (T-10121) that appeared quite well preserved at the corner of one of the excavated rectangular huts. Its content was made up of a sawdust-like mass, consisting of a large amount of scales and fish vertebrae.

\subsection{Fishing and amphora production in Cadiz bay during the Archaic period}

The growing evidence of the colonial Phoenician fishing and its possible relationship with an early fishprocessing industry also finds some archaeological support in Cadiz Bay. Based on both recent excavations

\footnotetext{
14. Aubet 1997.

15. Aubet 1993.

16. Rodríguez 1999.

17. Aguayo 2001, p. 74-77.
}

and proposed approaches or interpretative hypotheses, the first scientific attempt to this subject came from archeo-ichthyology, with a thorough interdisciplinary analysis of the archaic levels recorded in a stratigraphical survey practiced in the fortified continental village of Castillo de Doña Blanca (CDB). The consumption of imported tuna (maybe processed) in this archaic stage at $\mathrm{CDB}$ was probably one of the most important results provided by this analysis ${ }^{18}$.

In addition, many other indications of a close relationship with archaic fishing in the insular environs of Gadir had emerged in recent years, especially on the margins of the navigable channel between the islands of Kotinoussa and Erytheia (especially on its northern shore, the historical city centre of current Cádiz). Recently, new evidence has been added to this discussion from rescue excavations undertaken on the site of Canovas de Castillo (Cádiz). The interpretation given by the excavators of the clay-floors and archaic levels of occupation recorded over the sandy dunes, considering as well the organic components observed, is that it could have been intermittently occupied. The absence of buildings or stable structures led its excavators to discard any relationship with a colonial (urban) foundation, but to propose a close relationship of this settlement with fishing, perhaps acting as a watchtower (thynnoskopeia) for seasonal tuna fishing ${ }^{19}$. Other sites next to Canovas, like Teatro Andalucía or Cine Comico, also suggest that halieutic activities were developed by Gadir settlers from the early days of the Canaanite colony.

In spite of the faunal particularities and local fishing techniques, the available archeo-ichthyological regional evidence seems to be sufficient to confidently believe that there were significant economic structures in the archaic western colonies that depended upon fishing (and that there was a certain impact of fish by-products in the dietary habits of tartessian elites even from precolonial times). Whether these products consisted of whole or chopped salted-fish and / or salty fish sauces close to gàron cannot be determined at the moment. These data sketch a colonial western world where some specialized fishing (and perhaps with a certain volume of surplus) had already occupied an important place in the subsistence economy and played a role, that is to be determined accurately, in commercial networks.

18. Roselló, Morales 1994

19. Córdoba, Ruiz 2005. 


\section{The "crisis of metal trade" and the Late-Archaic changes}

The end of the Archaic period is set, in historical terms, as a tremendously rich and complex stage, a time of transition for the western Phoenician world that worked as a hinge between the colonial phase and the emergence of a new context of interactions (with a definite prominence of cities and citizenships). This genesis of multiple urban settlements inherently resulted in deep changes that shaped a new face for the Phoenician settlement in the West: self-government, new socio-cultural and political identities, innovative economic and trade mechanisms, etc. However, this new order seems to have been created more from a reformation of continuing archaic processes, than from a break from the preceding stage of Canaanite colonies. So continuities and changes within a continuing stream can be noted, at least in terms of fishing, pottery production and other industrial tasks.

One of the most active discussions has been focused on the so-called 'crisis of metal trade' (which developed from the first half to the mid / late-6th c. BC). This was especially significant in the Huelva area because of the abandonment of several settlements closely linked to the extraction-transformation and circulation of silver. These sudden changes probably created a possible gap in the regional economy, once opulent and thriving. In the Atlantic coast of south-west Iberia, it had been assumed that the regional response turned (at least on the coast) towards an exponential increase of halieutic activities, especially through the proliferation of settlements linked to the production and distribution of fish by-products and salt, following the example shown by the literary sources referring to Gadir. To summarise, the fact is that Gadir likely was the main beneficiary by this drift towards the rising urbanisation at the end of archaic period.

\section{A case study for Classical and Hellenistic periods: Gadir/Gades}

As noted in the section of this paper dedicated to classical texts, there is no archaeological or historical room for doubt about the involvement of other areas of the Straits in the maritime and fish-processing activities and the profits of this growing business. This occurred in a classical Mediterranean world characterized by large commercial exchange networks and a revolution in eating habits. However, in contrast to what has been observed so far for the archaic period, the verifiable archaeological record in the Gadiritan hinterland is prolific, while for other western cities this information is only just becoming known; official information is either partially released or unpublished, so unfortunately there are no alternative models for comparison with the Gadiritan case by now.

Faced with this panorama, and with the full conviction that other models were developed in the mediterranean shore of southern Iberia or coastal Mauritania, currently the Gadiritan pattern results such as the main case study for the region, being supported by more archaeological, literary and zoo-archaeological data (fig. 4). As a general framework, the first steps of the increase in urbanisation must have entailed the establishment of a stable and legally organized territorial hinterland, with poorly defined limits at the moment, but at least extending all along the insular territory from the Erytheia (in the north) to the main sanctuary on the southern boundary. In this area of different landscapes, as well as extensive intertidal marshes suitable for the development of saltworks there was potential for several fishing strategies and techniques, and for pottery production ${ }^{20}$.

The interaction with the mainland shore is not fully clarified. Nor is the relationship with the great-fortified centres (Castillo de Doña Blanca, Chiclana) or the coastal ridges closest to the insular territory (like the marshes located between the salty creek of Zurraque and Melkart sanctuary itself, or the west coast of current El Puerto de Santa María). Each side has provided archaeological evidence relating to pottery production or/and fish-salting activities and significant data about fisheries and fish consumption during the classical/hellenistic period. Although so far this information has been analyzed altogether as part of pre-Roman settlement patterns of Cadiz Bay, we must keep in mind the lack of security about if these fortified villages and industrial facilities were shaping an unique economic or political entity (Gadir).

\subsection{Salt-fish factories in the main island}

\subsubsection{Some suggestive traces from Camposoto area}

The fish-processing facilities and fishing locations were distributed both on the Atlantic coasts of the island and on the mainland coast of current El Puerto de Santa María, the closest to Erytheia island and the northern end of Kotinoussa (but, as noted, we can only clearly

20. Sáez 2008 


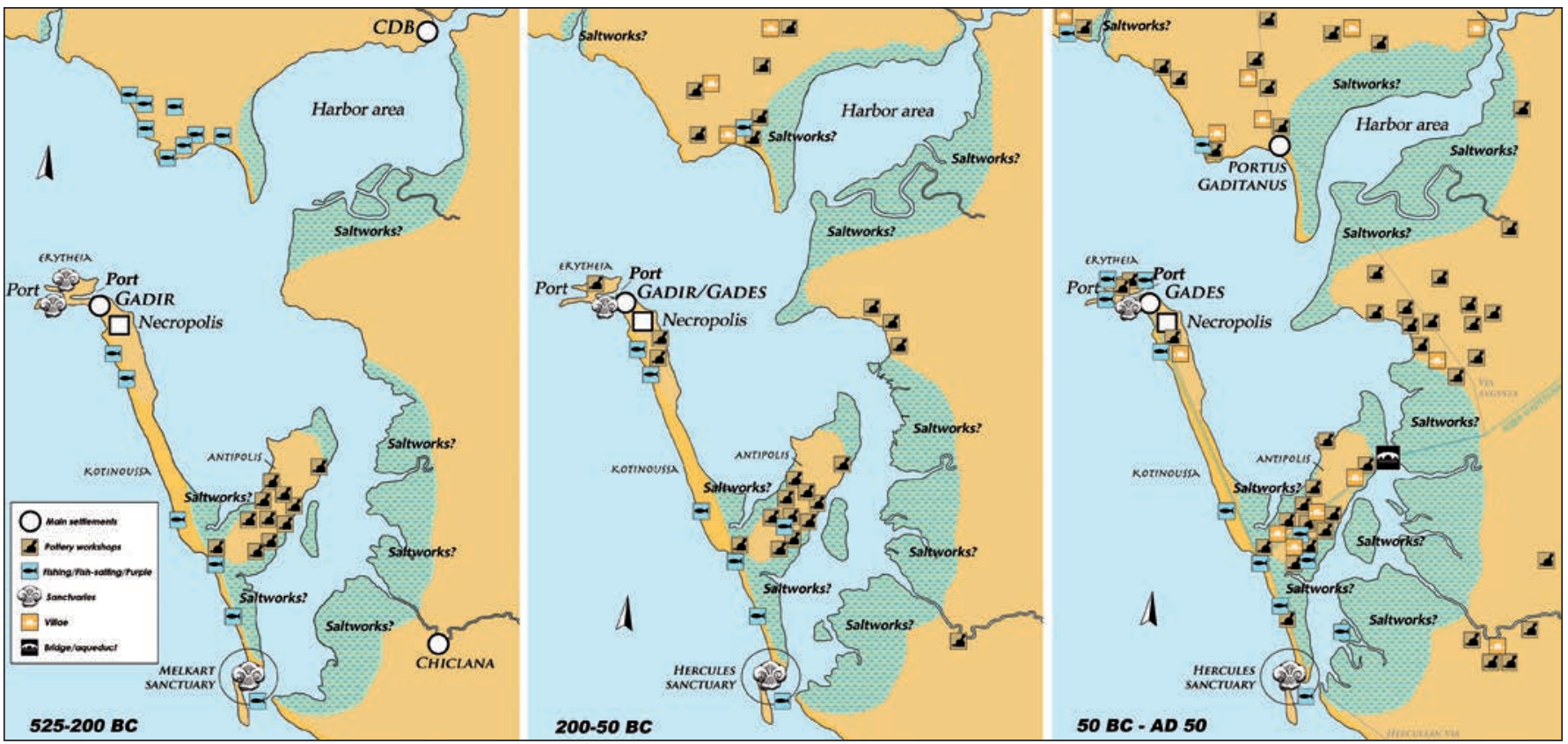

Fig. 4. Schematic synthesis of the evolution of settlement patterns in the Bay of Cadiz from the late-archaic stage until the early Roman imperial phase (๑) A. Saez).

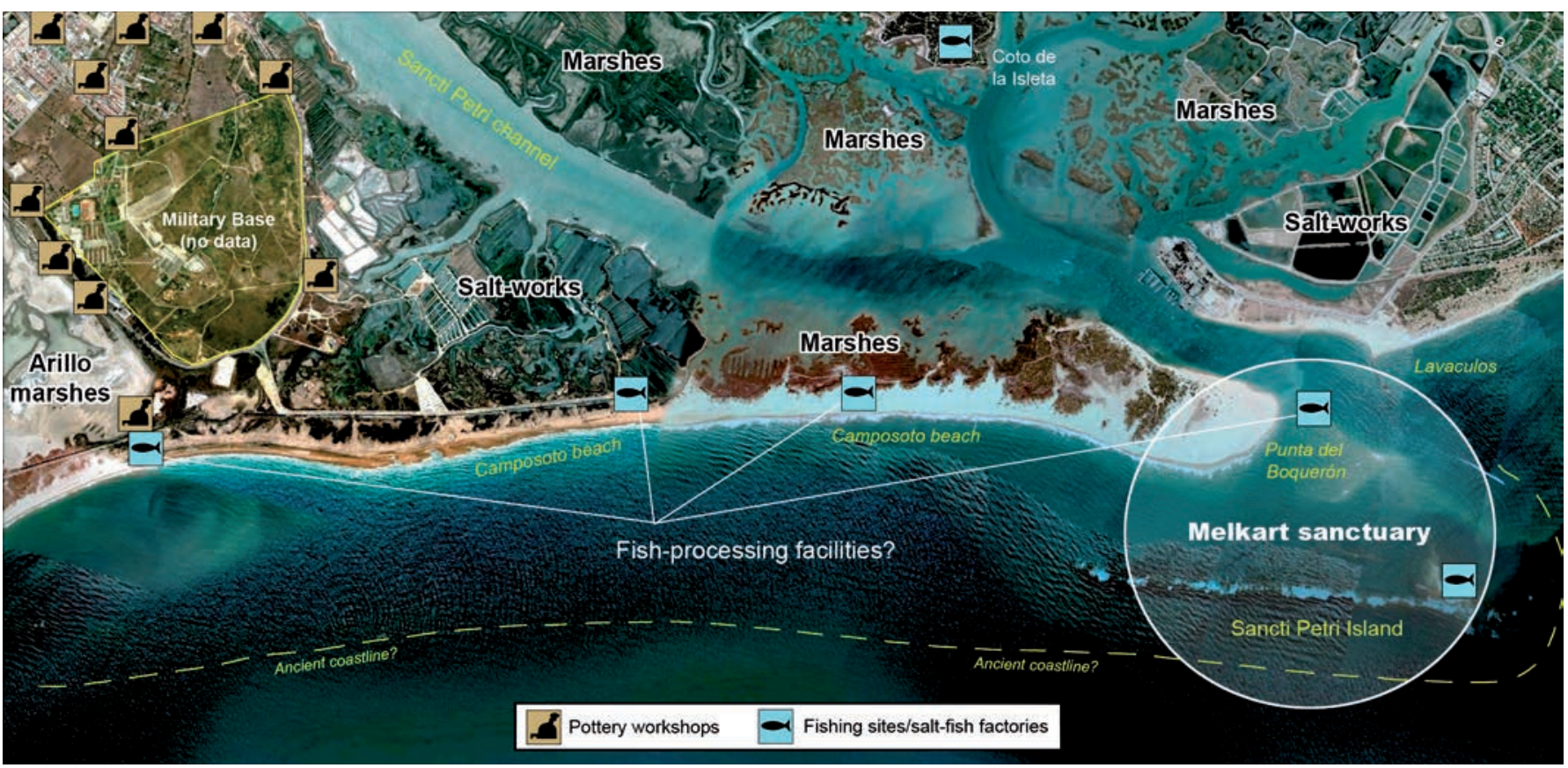

Fig. 5. Summary of the main archaeological landmarks in Camposoto beach area indicating major sites and geo-archaeological hypotheses (৫ A. Saez from Google Earth).

assure a Gadiritan origin only for the group of facilities located on the insular territory). The detailed analysis developed through the last decade has shown that this type of insular fish-salting facilities is represented by at least two illuminating examples (Plaza de Asdrubal and San Bartolomé, both unpublished), but probably the number of fishing areas on the Atlantic insular coast and in the Gadiritan harbour surroundings had to be much higher.

In fact, a growing quantity of archaeological evidence suggests that the long stretch of shoreline nowadays known as Camposoto beach (fig. 5), adjacent to the sanctuary of Melkart location, could have hosted some of 


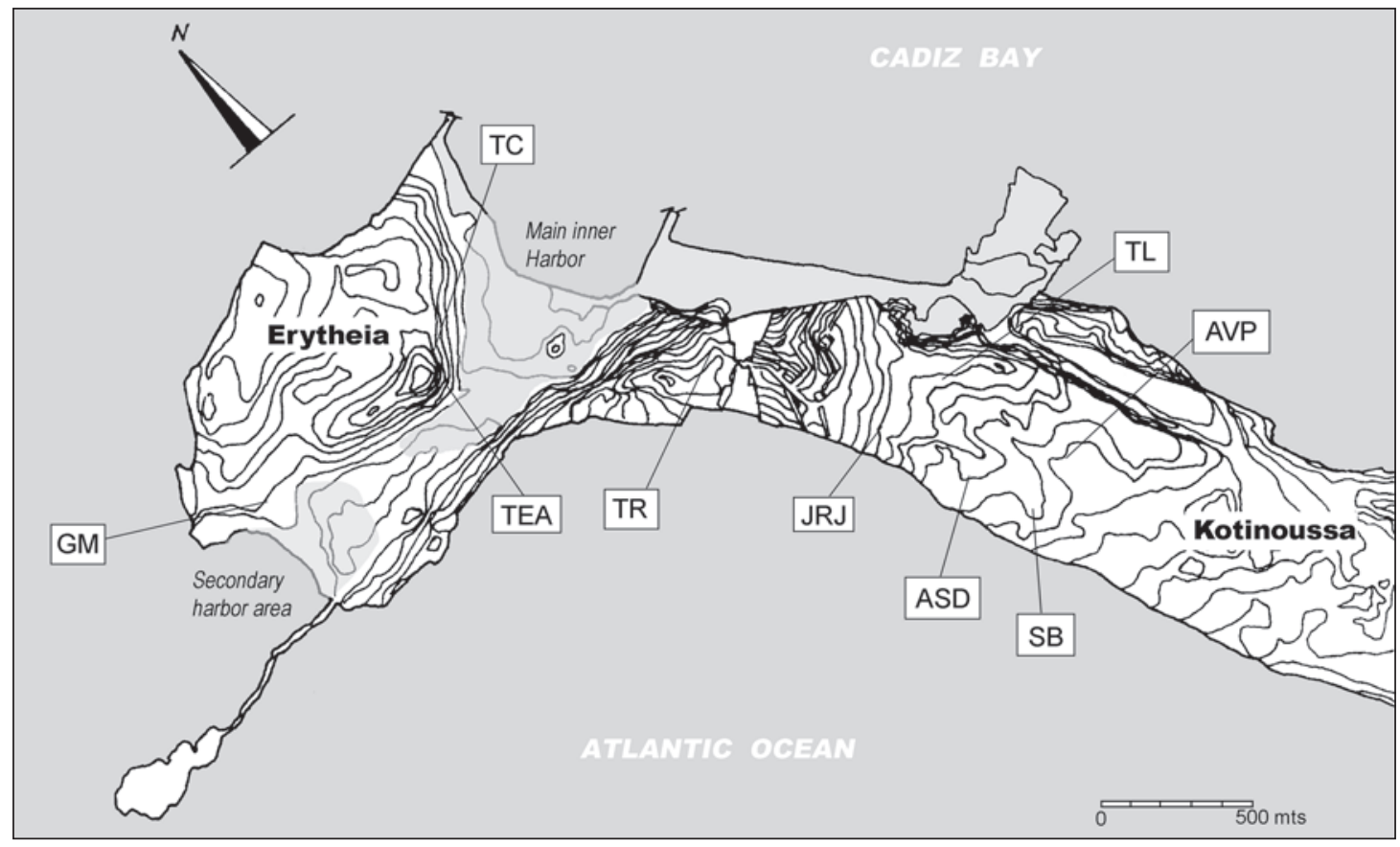

Fig. 6. Main sites located in ancient Erytheia Island linked to fishing, fish-processing and/or pottery production in punic and roman periods: Gregorio Marañon (GM), Teatro Andalucía (TEA), Teatro Cómico (TC), Troilo (TR), Juan Ramon Jimenez

(JRJ), Plaza de Asdrubal (ASD), San Bartolome (SB), Tolosa Latour (TL), Avenida de Portugal (AVP). (৫ A. Saez).

such facilities (Sáez/Díaz 2012). Recent excavations on the small island of Sancti Petri itself, at the south end of the sandbar, yielded pottery and other finds dating from the 5 th $/ 1$ st c. BC, possibly related to these industrial activities (this rocky island has indeed a long tradition for the installation of tuna-traps, an activity which continued until a few decades ago). In sum, although it is still a poorly researched area, it seems plausible that at several points along this insular paleoshore (initially located about $200 \mathrm{~m}$ west of todays coastline) at least some fish-processing factories and fisheries from the Punic period would have been settled.

\subsubsection{Salt-fish factory of Plaza de Asdrúbal}

In the north of the insular territory (fig. 6) rescue excavations have recovered valuable information about at least two examples of fish-processing facilities equipped with basins and other specific structures. The northernmost, Plaza de Asdrubal Square (Cadiz), has been excavated during several campaigns between the eighties and mid-nineties, with outstanding results in the excavations of 1997-1998 ${ }^{21}$. These latest digs have enabled an industrial building to be analyzed (surrounded

21. Muñoz, Frutos 2009; Muñoz 2012. by the Gadiritan Punic and late-punic necropolis). It was provided with at least two pairs of oval basins for salting and other paved rooms adjoining (fig. 7). Also documented were waste pits, fish bones and fishing gear. The earliest evidence of activity points to a first phase dated to the 5 th $\mathrm{c}$. $\mathrm{BC}$, continuing through various stages until the Roman early-imperial period.

\subsubsection{Salt-fish factory of San Bartolomé}

The second of these factories in the northern insular hinterland was partially excavated during 2007-2008 in San Bartolomé/Chinchorros area of modern Cadiz. Its general plan and dimensions were closely similar to the preceding complex, with several rooms paved with opus signinum and at least two pairs of oval basins intended for salting, in addition to abundant pits filled with waste materials (including large quantities of amphorae, with very few faunal remains). This fish-processing factory was in operation from the beginning of the 5 th $\mathrm{c}$. BC until the last decades of $2 \mathrm{nd} \mathrm{c.} \mathrm{BC}$.

\subsection{Salt-fish factories of continental coast}

Since the eighties, in the northern mainland coast of the bay a significant number of settlements were also 

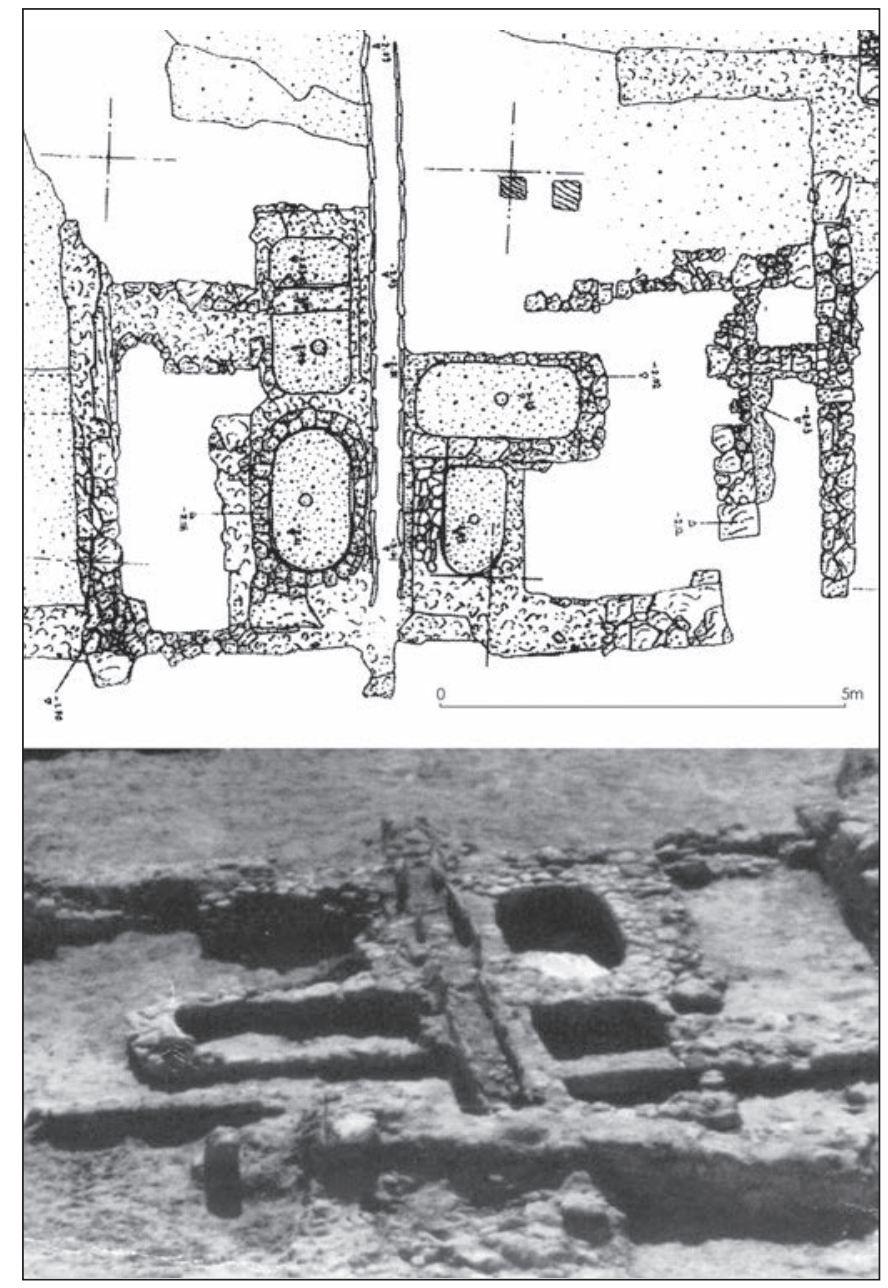

Fig. 7. Plan and aerial view of the oval basins located in the Plaza de Asdrúbal salt-fish factory in the excavations of 1997-1998 (after Muñoz, Frutos 2009)..

identified. These have been associated with the production of Punic salted-fish (notably after the excavation of Las Redes site in 1980/1983 ${ }^{22}$ ). Surface surveys conducted by the local museum of El Puerto de Santa María traced more than twenty-five sites, but only a really small group have been extensively surveyed or excavated. It is therefore difficult to determine whether all points were truly fish-processing facilities or other types of industrial or rural secondary settlements ${ }^{23}$.

\subsubsection{Fresh data from Puerto-19 site}

Excavations conducted between 1996-1997 on the site of Puerto-19 headed by J. M. Gutierrez ${ }^{24}$, have

22. cfr. Muñoz et al. 1988.

23. Ruiz et al. 2006.

24. Gutierrez 2000. allowed these theoretical models about these continental salt-fish factories to be investigated thoroughly. In this sense, it is necessary to highlight that the results of the campaigns in P-19 suggest that this a settlement pattern should be discarded, and that cases as represented by Puerto-14 (isolated pits/wasters and working pavements) actually probably were working spaces and dumps linked to industrial building complexes (as exemplified by the 1997 Sector 1 at Puerto-19). The 1996 campaign focused on the excavation of the main building of the factory (fig. 8), excavating several oval basins, pavements, walls of several rooms and courtyards and lots of Punic pottery and remains of fishing gear.

The settlement was founded sometime in the second half or last third of the 6th c. BC in an elevated sandy area near the ancient coastline. This foundation phase is well characterized by the presence of pits full of ceramic sherds and ashes located under the main rooms of the complex (beneath the basins), perhaps as a result of ritual practices. Above these pits a square building equipped with several specialized spaces was built, one of them reserved for a pair of oval basins, with a large outdoor courtyard in which perhaps amphora containers were stored ready to be filled. Around this building, small pits or accumulations of materials were located (mainly pottery), perhaps related to manufacturing and daily consumption processes of artisans and of the fishprocessing factory.

Archaeological levels associated with this first phase provided abundant pottery remains, especially local amphorae Ramon T-11213, a type traditionally associated with the overseas trade of salted-fish by-products. Also, other interesting elements were recovered, like bronze/lead fishing gear (hooks, net weights) and ceramic tableware (local red-glaze or coarse, attic black-gloss wares, etc.). These were linked to the daily consumption processes developed by artisans/workers. Much of this material was documented in Sector 1 (excavated in 1997), a secondary outdoor working area close to the main building of the factory.

This first building was abandoned towards the last quarter of the 5 th century BC. On its remains was built a new smaller building with a different orientation, also characterized by a rectangular plan and equipped with a couple of basins. Wasters and pits grew in significant quantity around the perimeter of the factory, affecting previous structures. Phases II and III, linked to the activity of this second building, would had extended from the beginning of the 4th c. BC to the final stretch of 3rd c. $\mathrm{BC}$, when the settlement was finally abandoned. 


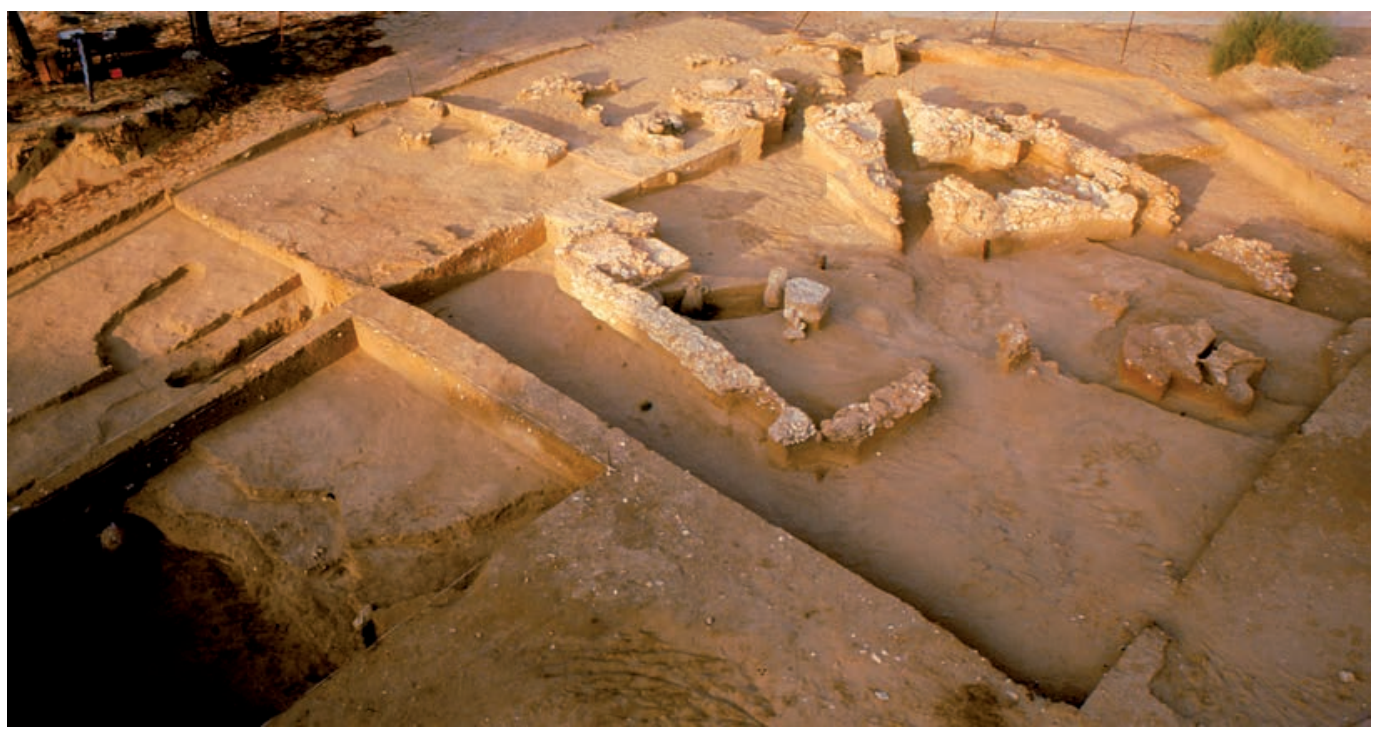

Fig. 8. Aerial view of the results of 1996 campaign in Puerto-19 (๑ J. M. Gutiérrez).

Finds associated with these later stages were mainly recovered from large landfills in the vicinity of the building equipped with basins (like the outstanding deposit UE-136). We must highlight the large number of 'fishy' amphorae and tableware and other ceramics used by the workers of the factory, plus lead net weights, bronze hooks and other fishing gear. The presence of abundant remains of grape seeds (vitis vinifera, identified by Prof. G. Pérez Jordà from University of Valencia) and possible bronze billhooks, raise the possibility that in addition to salted-fish Puerto-19 could also had been devoted to agricultural (wine) production ${ }^{25}$.

\subsection{The Punic urban plan of Gadir and the pottery workshops}

The continuous steady excavating over the last couple of decades has enabled after much consideration the existence of an intense and organized occupation of the plains and low hills of the ancient Antipolis Island to be proposed. Thus, this southern side of this insular territory turned into a suburb of the city focused mainly on marine resources and specially pottery production between ca. 525/206 $\mathrm{BC}^{26}$. These pottery workshops possibly were established following a reasonably regularized pattern composed of stable 'plots' that would have been generated in this insular area not before the late 6th c. BC (as the currently available archaeological data suggests). The large area of the hinterland devoted to pottery (amphora) production, with dozens of

25. López, Ruiz 2007.

26. Sáez 2008. contemporary centres of production (producing enough for ceramic self-sufficiency for daily issues and obviously for maritime trade), could help to illustrate the deep local economic (and demographic?) changes and growth.

In these insular pottery kiln sites, undoubtedly prevailed amphora production output at all times (fig. 9). But as far as we know, almost each workshop was 'mixed', where the manufacture of other ceramic classes or categories was a daily task (including red-glazed and grey tablewares, coarse and cooking wares, net weights or terracottas). Altogether, these Gadiritan kilns produced large quantities of transport containers that would had been essentially aimed at supplying local fish-salting facilities and external commerce ${ }^{27}$.

The importance of salted-fish production and trade remained indelibly imprinted in many of the amphorae that carried to the Atlantic and Mediterranean bounds. Seals, whose iconography often includes (among other topics) scenes representing tuna, dolphins, other fishes, artisans during the packaging process, etc., illustrate very well the importance of fishing and trade activities in Gadiritan everyday life (fig. 10). These stamps on local amphorae emerged in Gadir from the 4th c. BC, but available data suggest that it would be from the second half of the $3 \mathrm{rd} \mathrm{c}$. BC and especially during the 2 nd c. $\mathrm{BC}$ when the use of these marine and industrial iconographies increased.

27. Ramon et al. 2007. 


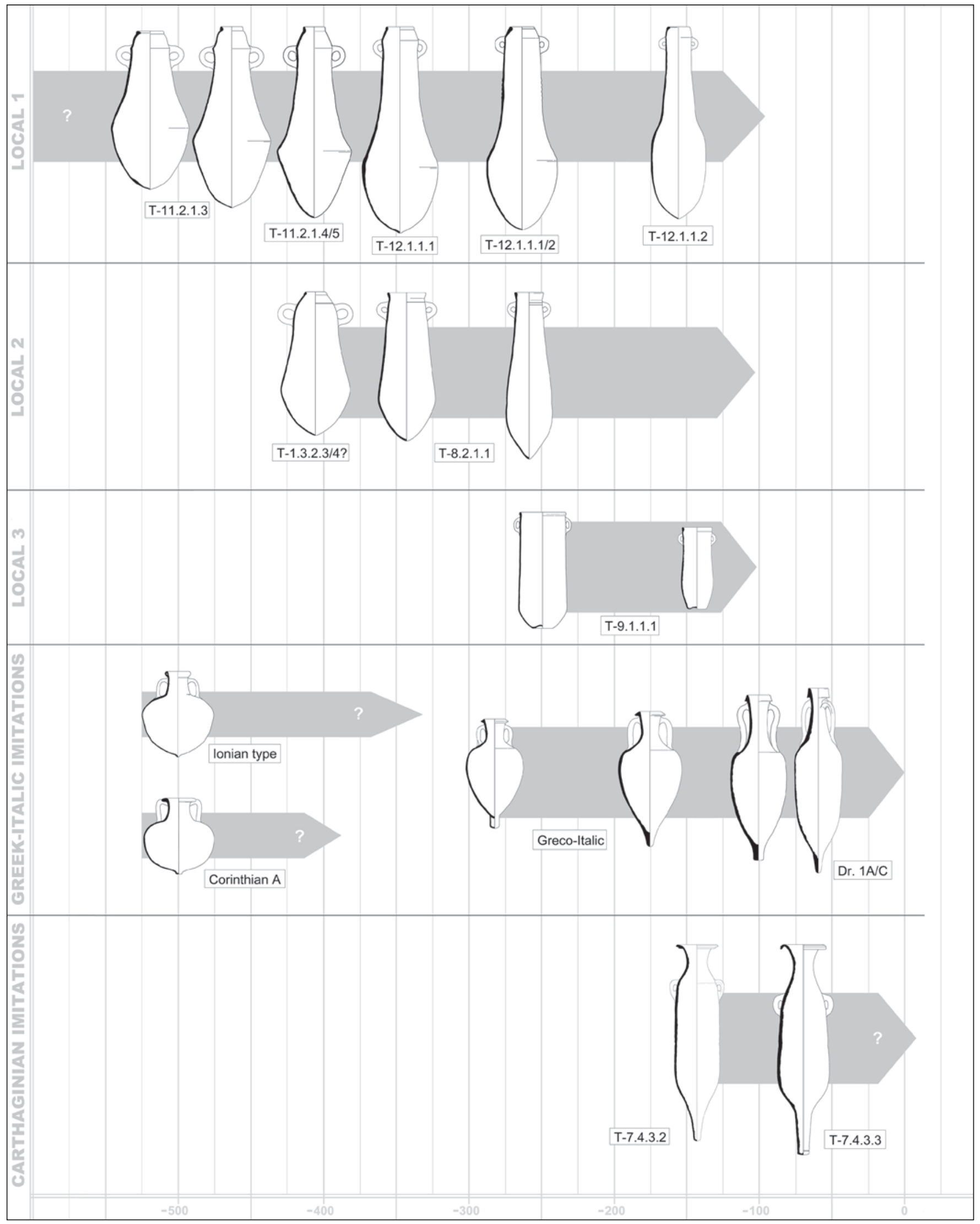

Fig. 9. Evolution of main types of amphorae produced in the pottery workshops of Gadir/Gades between late-archaic stage and the Augustan period (৫) A. SAEZ after Ramon 1995). 


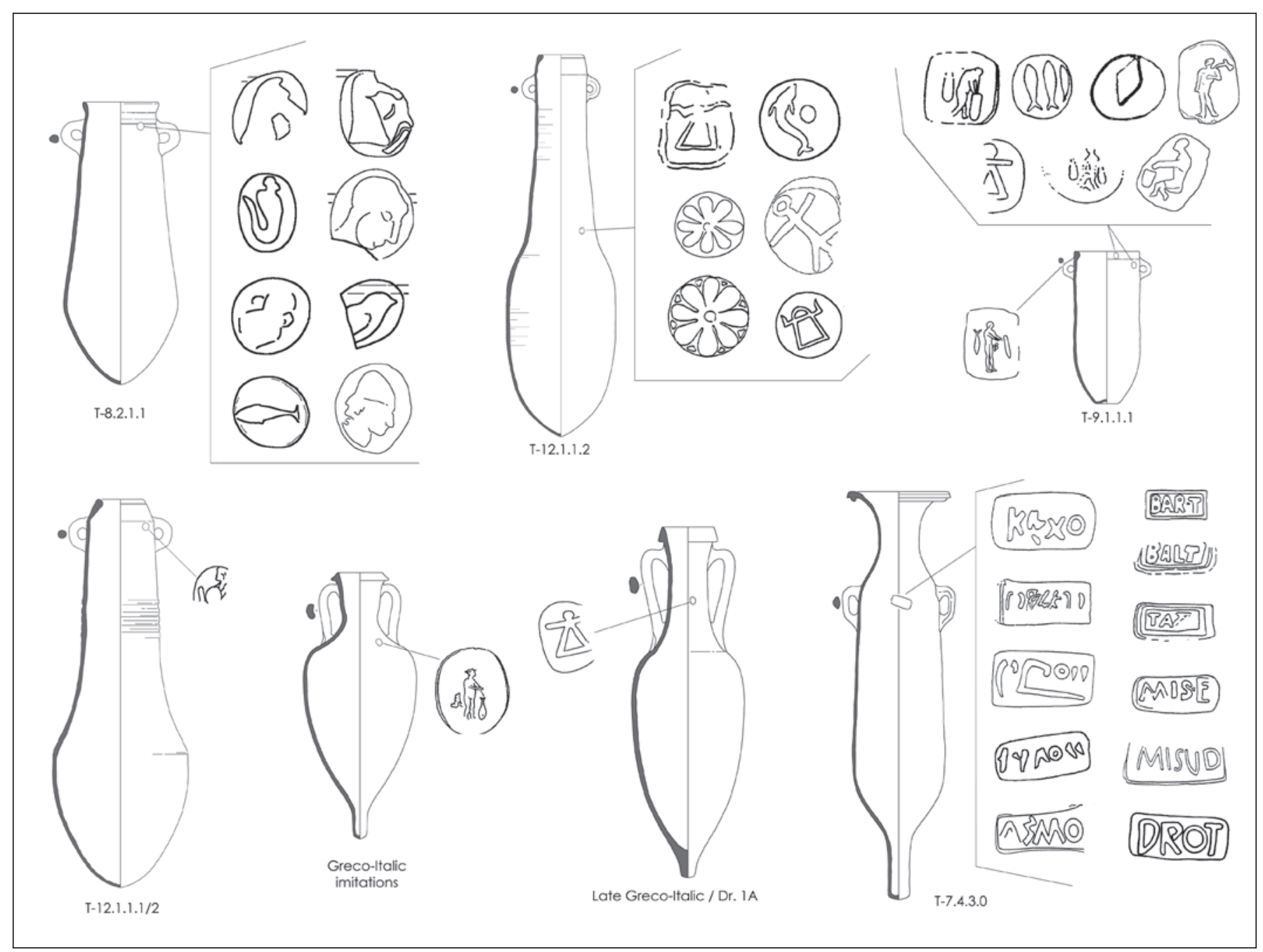

Fig. 10. Local amphora types and iconographies and epigraphic contents of their stamps (4th-2nd c. BC) (@ A. Saez).

\section{Gadir/Gades. Evolution and romanization of urban plan and economy}

The discussion about the long phase of integration and adaptation of these traditional Punic industrial networks into the Roman world, developed among the 2nd/1st centuries $\mathrm{BC}$, has become a topic relevant to this specialized historiography in the last decades, with approaches that have revolved primarily around the study of the pottery workshops and their settlement/exploitation patterns. More recently, the emergence of intensive rural exploitation (roman villa model) in the Iberian Peninsula and especially in the hinterland of Gadir/Gades has been added to this debate ${ }^{28}$. Overall, the available information does not seem to point to a linear and homogeneous

28. López 1995; García 1998; Lagóstena 2001. transitional process for the entire region, there being significant distinguishing nuances between both sides and shores of the Strait region.

In the case of Cadiz Bay, recent archaeological research has revealed a remarkable phenomenon of persistence in the same place for centuries for both pottery workshops and fish-processing facilities (with successive phases and remodelling). But all pre-Roman industrial cells did not share this general trend. Thus, the continental complexes generally continued to function just until ca. 206 BC (like continental fortified villages, $\mathrm{CBD}$ and Chiclana), whilst in the insular hinterland pottery production and fish-processing facilities continued firing and salting, at least until the end of the 2nd c. BC, and in several cases, extended their lifecycle until the latter decades of 1 st $\mathrm{c}$. BC or even the first half of 1 st $\mathrm{c}$. AD. 
Local pottery workshops and fish-salting centres, both from a socio-economic point of view and physically (structures, spatial patterns, technologies, etc.), experienced successive 'romanizing' impulses, particularly obvious in the archaeological record since the mid-2nd c. BC. From these first stages rapid changes can be identified, like the rise and crystallization of new concepts about territorial planning, changes in social structure and legislation, introduction or growth of slavery for industrial purposes (at least to a perceptible level), technological innovations, productivity over quality, diversification of products and external markets, etc.

\section{1. "Hybrid" industrial facilities during Late- Hellenistic period in Gades}

From the late-2nd c. BC progressively a new model of local industrial facility seems was generated, the seed of the later production centres of the early-imperial Roman period. New fish-processing establishments, larger and frequently integrating small/medium figlinae and other activities gradually replaced the preceding Punic territorial scheme. These new local complexes either occupied areas traditionally only used by potters, or more usually expanding and reshaping Punic fish-salting factories already in operation.

In Luis Milena (in the central area of the Antipolis), the Punic pottery workshop became (maybe during the 2nd c. BC) a bigger settlement with large building/s (equipped with oval basins and several rooms paved with opus signinum) and the activity of potters probably continued (fig. 11). Recent excavations in 2007 have also identified pits filled with large quantities of murex shells, evidence of its systematic exploitation in order to obtain the valuable purple dye dating from the first quarter of 2nd c. BC ${ }^{29}$. Similar examples of this evolution of former Punic fish-processing facilities (or pottery workshops) have also been verified on the opposite boundary of the Gaditan insular territory (Plaza de Asdrúbal could be the most outstanding case, abandoned as well during the early-imperial period).

\subsection{The last step on the way: changes during Augustan period}

As noted before, the end of the historical process, both on the coast of Tingitana and in Baetica, would

29. Bernal et al. 2011. had led to a general renovation of this marine industry in late-Republican decades with the introduction of new technological advances and commercial-productive parameters. Small traditional factories would had been unable to compete in this new scenario, in which possibly oligarchic Punic elites themselves would had chosen to join the drift towards increasing volume of production and trade even if it meant assuming social/economic imported formulas from italic sphere. It is still too soon to determine accurately how this affected each urban centre individually, but certainly it seems that the coastal section located between Gades and Carteia should have been one of the main experimental contexts regarding this evolution of western 'salted-fish economy' ${ }^{30}$.

New huge factories (cetariae) appeared in Gades, during the last decades of $1 \mathrm{st} \mathrm{c}$. BC. They were equipped with numerous quadrangular basins, placed close to the main portuary channel, along the Atlantic coast and maybe other propitious locations around the seashore of Cadiz Bay ${ }^{31}$. Some examples have been excavated at Teatro Andalucia (fig. 12), La Caleta and Cine Cómico, in former Erytheia Island, then perhaps part of an industrial suburb that also included pottery workshops and other infrastructure (as officinae tinctoriae for purple dye exploitation). These supplementary activities would have been located in the immediate surroundings of the harbour and the cetariae ${ }^{32}$. Moreover, probably all marshlands of the bay would have been used for the installation of salt-works. The emergence of large private rural villae also helped the multiplication of figlinae (specially amphora production), which spread through both the insular and the continental coastal countrysides ${ }^{33}$.

To summarise, until coming under the great transformations of the Augustan period (within just over a hundred years), the traditional industrial landscape designed by the productive and territorial Punic system would have been reduced to a new fully romanized context, characterized by large suburban factories and villae frequently equipped with figlinae. The foundations of this system would had been established in the last decades of the republican period, but the activity of some of these new cetariae and figlinae continued to the beginnings of Late Antiquity.

30. Arévalo, Bernal 2007.

31. Expósito 2007.

32. Bernal et al. 2008.

33. Bernal and Sáez 2008. 


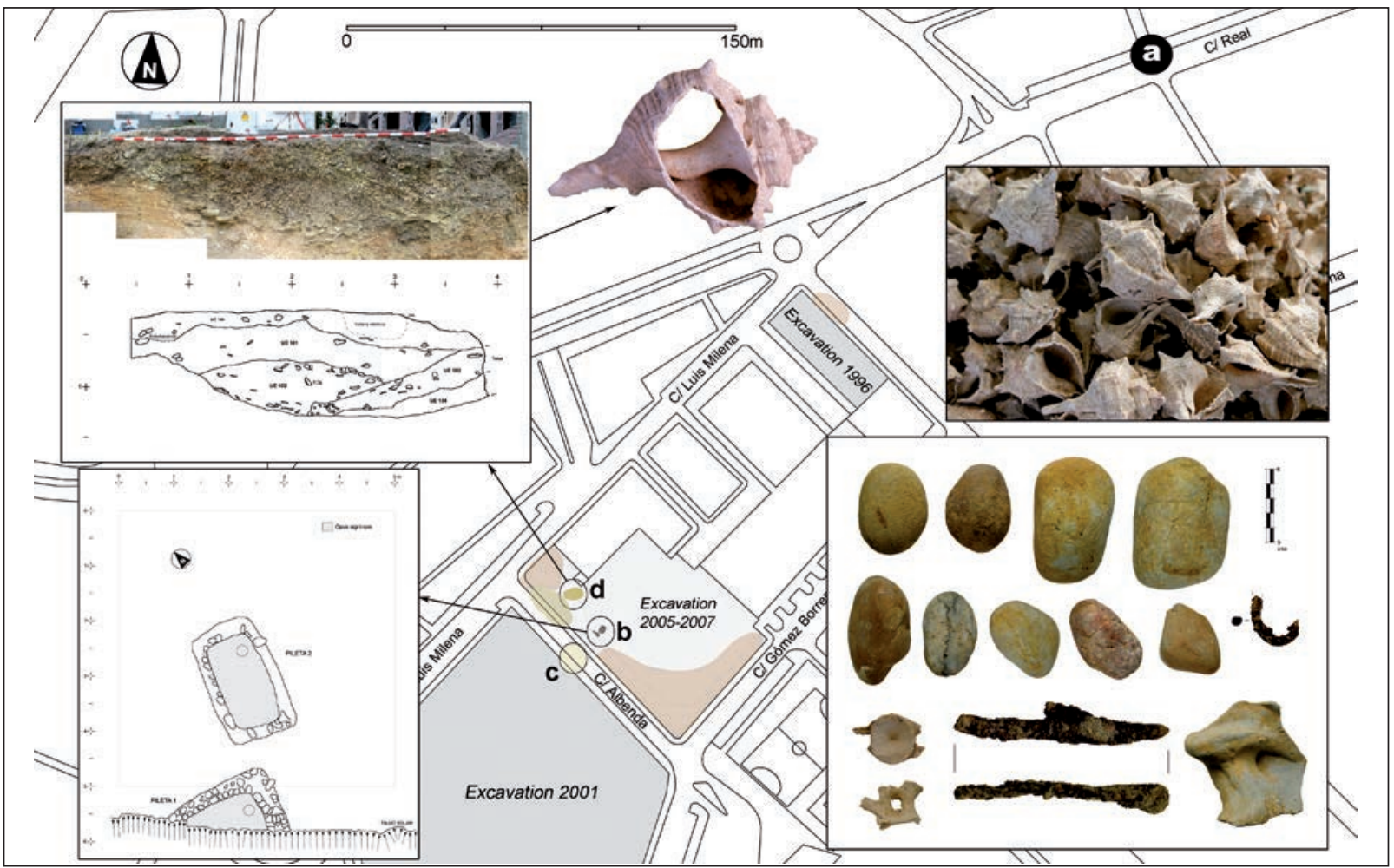

Fig. 11. Location of the sites of Calle Real (a) and Luis Milena in the central part of ancient Antipolis. Are also indicated the location of the pseudo-oval basins (b) of Luis Milena, remains of buildings and pavements of opus signinum (c) and a dump linked to pottery production and purple dye fulfilled with murex shells. Bottom right, possible crushing stones, iron hook, iron spear, fish bones and pottery refuse (after Bernal et al. 2011).

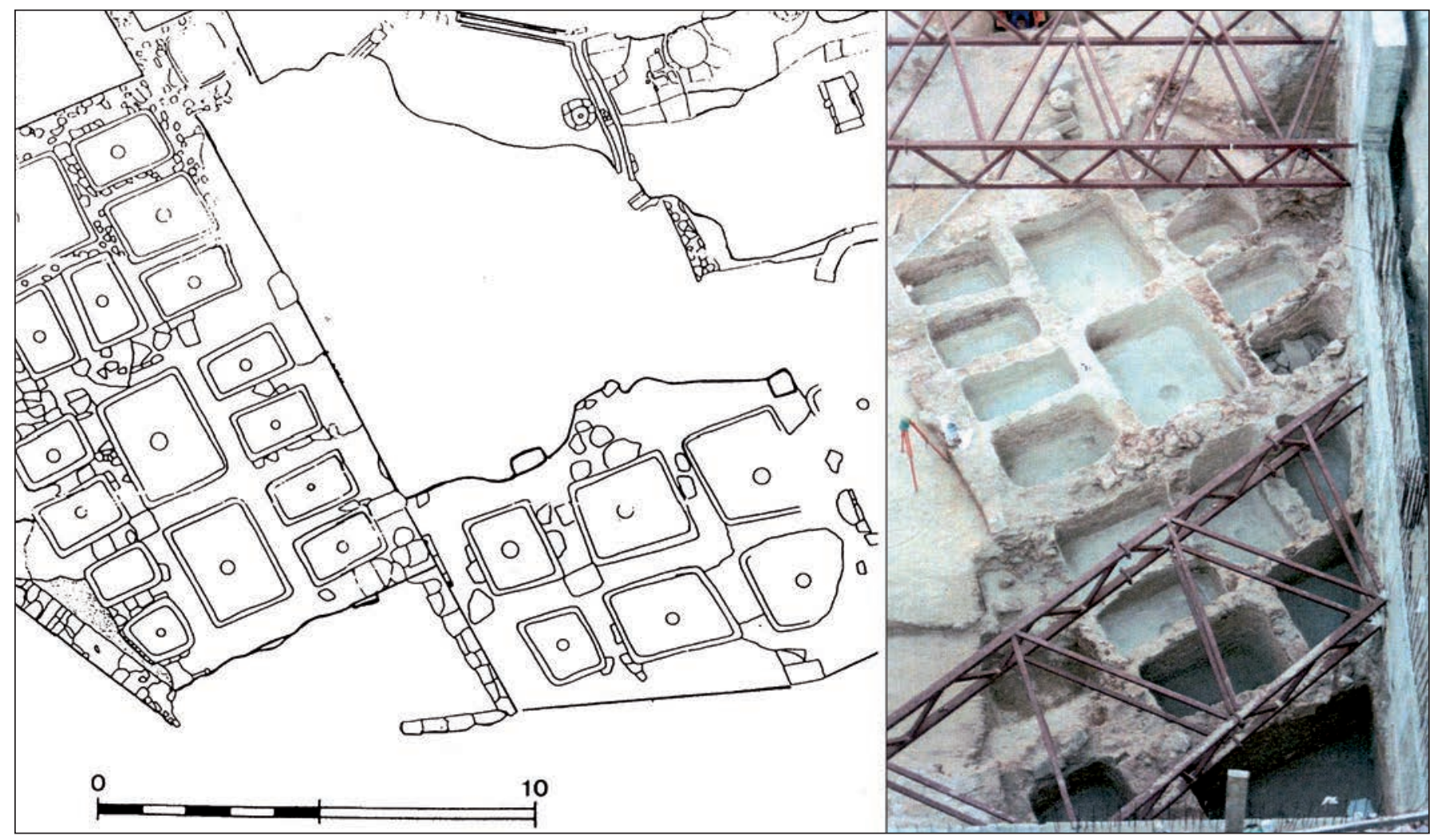

Fig. 12. Plan and photograph of roman fish-processing factory of Teatro Andalucía (after Muñoz, Frutos 2009) . 


\section{Bibliography}

Aguayo 2001 : AGUAYO DE HOYOS (P.) - Estructuras indígenas, comercio y comerciantes en la época de la colonización fenicia en Málaga (VIII-VI a.C). In : Wulff (F.), Cruz (G.) and Martínez (C.) (eds), Comercio y comerciantes en la Historia Antigua de Málaga (Siglo VIII a. C. año 711 d. C.), Actas II Congreso de Historia Antigua de Málaga, Málaga, 2001, p. 69-97.

Alonso et al. 2003 : ALONSO (C.), GRACIA (F. J.), MENANTEAU (L.) - Las salinas de la Bahía de Cádiz durante la Antigüedad: visión geoarqueológica de un problema histórico, Spal, 12, Universidad de Sevilla, 2003, p. 317-332.

Arévalo, Bernal 2007 : ARÉVALO (A.), BERNAL (D.) (eds) - Las cetariae de Baelo Claudia. Avance de las investigaciones en el barrio meridional (2000-2004). Junta de Andalucía, 2007, Seville.

Arteaga, Schulz 2008: ARTEAGA (O.), SCHULZ (H. D.) (eds) - Geoarqueología y proceso histórico en la Bahía de Cádiz. Revista AtlánticaMediterránea de Prehistoria y Arqueología Social, 10, Cádiz, 2008.

Aubet 1993 : AUBET (M. E.) - Cerro del Villar, Guadalhorce (Málaga). El asentamiento fenicio y su interacción con el hinterland. In: Investigaciones Arqueológicas en Andalucía. Proyectos (1985-1992), Seville, 1993, p. 471-480.

Aubet 1997 : AUBET (M. E.) - Un lugar de mercado en el Cerro del Villar. In : Aubet (M. E.) (ed), Los fenicios en Málaga. Universidad de Málaga, 1997, p. 197-221.

Aubet et al. 1999: AUBET (M. E.), CARMONA (P.), CURIÀ (E.), DELGADO (A.), FERNÁNDEZ (A.), PÁRRAGA (M.) - Cerro del Villar I. El asentamiento fenicio en la desembocadura del Guadalhorce y su interacción con el hinterland, Seville, 1999.

Bernal $\boldsymbol{e}$ t al. 2008 : BERNAL (D.), DÍAZ (J. J.), LAVADO (M. L.) - Un taller alfarero en el barrio industrial urbano de Gades. A propósito del horno cerámico de la c/ Solano (Cádiz), Spal, 17, Universidad de Sevilla, 2008, p. 317-322.

Bernal, Sáez 2008 : BERNAL (D.), SÁEZ (A.) - Fish-Salting Plants and Amphorae Production in the Bay of Cadiz (Baetica, Hispania). Patterns of Settlement from the Punic Era to Late Antiquity. In : Vanhaverbeke (H.) et al. (eds.), Thinking about Space. The potencial of surface survey and Contextual Archaeology in the definition of space in Roman Times, Lovaina, 2008.

Bernal et al. 2011 : BERNAL (D.), SÁEZ (A.), BUSTAMANTE (M.) - Entre la pesca y la púrpura en el Gadir tardopúnico. Actuación arqueológica en el conchero de la C/ Luis Milena de San Fernando. In: Alfaro (C.) et al. (eds), Purpureae Vestes III. Textiles and Dyes in Ancient Mediterranean World: Textiles y tintes en la ciudad antigua (Naples, 13-15 november 2008). Universidad de Valencia-Centre Jean Bérard, Valencia, 2011, p. 157-180.

Córdoba, Ruiz 2005 : CÓRDOBA (I.), RUIZ (D.) - El asentamiento fenicio arcaico de la calle Cánovas del Castillo (Cádiz). Un análisis preliminar. In: Congreso Internacional El Periodo Orientalizante, III Simposio de Arqueología de Mérida (Mérida, 2003), Anejos de AEspA, XXXIII (2), CSIC IAM-Mérida, 2005, p. 1269-1322.

Curtis 1979 : CURTIS (R.) - The production and commerce of fish sauce in the western roman empire. A social and economic study. Ann Arbor-London, 1979.
Delgado 2011 : DELGADO (A.) - La producción de cerámica fenicia en el Extremo Occidente: hornos de alfar, talleres e industrias domésticas en los enclaves coloniales de la Andalucía Mediterránea (siglos VIII-VI a.C.). In : Costa (B.), Fernández (J. H.) (eds), Yōserim : la producción alfarera feniciopúnica en occidente. XXV Jornadas de Arqueología Fenicio-Púnica (Ibiza, 22-26 de noviembre de 2010), Trabajos del MAEF 66, Ibiza, 2011, p. 9-48.

Expósito 2007 : EXPÓSITO (J. A.) - ¿Dónde se encuentran las cetariae de Gades? Revisión arqueológica y estado de la cuestión sobre el emplazamiento de las factorías de salazón romanas de la ciudad de Cádiz. In : Lagóstena (L.), Bernal (D.) and Arévalo (A.) (eds), Cetariae 2005. Salsas y salazones de pescado en Occidente durante la Antigüedad (Cádiz, 7-9 de noviembre de 2005), BAR International Series 1686, Oxford, 2007, p. 367-385.

García 1998 : GARCÍA (E.) - La producción de ánforas en la Bahía de Cádiz en época romana (ss. II a.C.-IV d.C.), Ed. Gráficas Sol, Écija, 1998.

García 2001 : GARCÍA (E.) - Pesca, sal y salazones en las ciudades feniciopúnicas del sur de Iberia. In : XV Jornadas de Arqueología Fenicio-Púnica (Ibiza, 2000), Ibiza, 2001, p. 9-66.

García 2008 : GARCÍA (E.) - Entre el consumo de lujo y el gusto popular: las salazones de la Iberia púnica y su romanización (ss. V-I aC). Una perspectiva histórica y cultural. In : Napoli (J.) (ed), Ressources et activités maritimes des peuples de l'Antiquité, Cahiers du Littoral, 2, nº 6, Boulogne, 2008, p. 87-108.

García, Ferrer 2006 : GARCÍA (E.), FERRER (E.) - Producción y comercio de salazones y salsas saladas de pescado del litoral andaluz en Época Fenicio-Púnica. Temas y problemas. In : Simposio Internacional Producão e comércio de preparados piscícolas durante a Proto-história e a Época Romana no Ocidente da Península Ibérica. Homenagem a Françoise Mayet, Setubal Arqueológica, 13, Setubal, 2006, p. 19-38.

González et al. 2004 : GONZÁLEZ (F.), SERRANO (L.), LLOMPART (J.) - El emporio fenicio precolonial de Huelva (ca. 900-770 a.C.), Madrid, 2004.

Gutiérrez 2000 : GUTIÉRREZ (J. M.) - Aportaciones a la producción de salazones de Gadir : la factoría púnico-gaditana Puerto 19, Revista de Historia de El Puerto, 24, El Puerto de Santa María, 2000, p. 11-46.

Lagóstena 2001 : LAGÓSTENA (L.) - La producción de salsas y conservas de pescado en la Hispania Romana (II a.C.-VI d.C.), Colección Instrumenta, 11, Publicaciones de la UB, Barcelona, 2001.

López 1995 : LÓPEZ (J. L.) - Hispania Poena. Los fenicios en la Hispania romana. Ed. Crítica, Barcelona, 1995.

López 1997 : LÓPEZ (J. L.) - Los fenicios occidentales y Grecia. In : II Reunión de Historiadores del Mundo Griego Antiguo. Homenaje al Profesor Fernando Gascó (Seville, december 1995), Seville, 1997, p. 95-105.

López, Ruiz 2007 : LÓPEZ (J. L.), RUIZ (J. A.) - Arqueología de la Vid y el vino en El Puerto de Santa María, Revista de Historia de El Puerto 38, El Puerto de Santa María, 2007, p. 11-36.

López, Ruiz 2010 : LÓPEZ (J. L.), RUIZ (J. A.) - Arqueología y etnografía de los recursos marinos en el Puerto de Santa María (Cádiz), Revista de Historia de El Puerto, 44, $1^{\circ}$ semestre, 2010, p. 9-57. 
Morales, Roselló 1988 : MORALES (A.), ROSELLÓ (E.) - La riqueza del Estrecho de Gibraltar como inductor potencial del proceso colonizador de la Península Ibérica. In : I Congreso Internacional El Estrecho de Gibraltar (Ceuta, 1987), vol. I, Madrid, 1988, p. 447-457.

Morales, Roselló 2006 : MORALES (A.), ROSELLÓ (E.) - La pesca en la Antigüedad andaluza : una perspectiva biológica. In : Historia de la pesca en el ámbito del Estrecho. I Conferencia Internacional (1-5 de june 2004, El Puerto de Santa María), vol. I, Seville, 2006, p. 41-79.

Muñoz 2012 : MUÑOZ (A.) - Artes y aparejos de pesca fenicio-púnicos en el Mediterráneo occidental : el ejemplo del Círculo del Estrecho. In : Costa (B.) and Fernández (J.) (eds), Sal, pesca y salazones fenicios en Occidente. XXVI Jornadas de Arqueología Fenicio-Púnica (Ibiza, 2011), Valencia, p. 33-83.

Muñoz, Frutos 2009 : MUÑOZ (A.), FRUTOS (G.) - La pesca y las conservas en la Bahía de Cádiz en época fenicio-púnica. In: Bernal (D.) (ed) Arqueología de la pesca en el Estrecho de Gibraltar. De la Prehistoria al fin del Mundo Antiguo, Monografías del Proyecto Sagena I, 2009, Madrid, p. 81-131.

Muñoz et al. 1988 : MUÑOZ (A.), FRUTOS (G.), BERRIATUA (N.) Contribución a los orígenes y difusión comercial de la industria pesquera y conservera gaditana a través de las recientes aportaciones de las factorías de salazones de la Bahía de Cádiz. In : I Congreso Internacional El Estrecho de Gibraltar (Ceuta 1987), vol. I, Madrid, 1988, p. 487-508.

Ramon 1995 : RAMON (J.) - Las ánforas fenicio-púnicas del Mediterráneo Central y Occidental, Universitat de Barcelona, Colección Instrumenta, 2, Barcelona, 1995.

Ramon et al. 2007 : RAMON (J.), SÁEZ (A.), MUÑOZ (A.) - El taller alfarero tardoarcaico de Camposoto, Monografías de Arqueología 26, Junta de Andalucía, Seville, 2007.
Rodríguez 1999 : RODRÍGUEZ (C. G.) - La pesca y la explotación marina y fluvial. Las ictiofaunas del Cerro del Villar. In : Aubet (M. E.) et al., Cerro del Villar-1. El asentamiento fenicio de la desembocadura del río Guadalhorce y su interacción con el hinterland, Seville, 1999, p. 320-324.

Roselló, Morales 1994 : ROSELLÓ (E.), MORALES (A.) (eds) - Castillo de Doña Blanca. Archaeo-environmental investigations in the Bay of Cádiz, Spain (750-500 BC), BAR International Series, 593, Oxford, 1994.

Ruiz et al. 2006 : RUIZ (D.), RUIZ (J. A.), LÓPEZ (J. J.) - La pesca en época prerromana en la bahía de Cádiz (Apéndice sobre las factorías de salazones en El Puerto de Santa María). In : I Conferencia Internacional Historia de la Pesca en el ámbito del Estrecho (1-5 june 2004, El Puerto de Santa María), I, Seville, 2006, p. 269-338.

Sáez 2008 : SÁEZ (A.) - La producción cerámica en Gadir en época tardopúnica (siglos -III/-I). BAR International Series, 1812 (2 vols.), Oxford, 2008.

Sáez 2010 : SÁEZ (A.) - La producción alfarera y la economía salazonera de Gadir: balance y novedades, Mainake XXXII (II), Universidad de Málaga, 2010, p. 885-932.

Sáez 2011a : SÁEZ (A.) - Balance y novedades sobre la pesca y la industria conservera en las ciudades fenicias del área del Estrecho. In : Bernal (D.) (ed) Pescar con Arte. Fenicios y romanos en el origen de los aparejos andaluces. Catálogo de la exposición (Baelo Claudia, december 2011-julio 2012). Monografías del Proyecto Sagena, 3, Universidad de Cádiz, 2011, p. 255-297.

Sáez, Díaz 2012 : SÁEZ (A.), DÍAZ (J. J.) - Entre tierra y mar, entre lo púnico y lo romano. Adaptaciones económicas y territoriales en un medio cambiante: algunas notas sobre paleogeografía y sistemas de explotación del hinterland insular de Gadir/Gades. In : Mora (B.) and Cruz (G.), La etapa neopúnica en Hispania y el Mediterraneo centro occidental : identidades compartidas, Universidad de Sevilla, 2012, p. 259-300. 


\section{Nouvelles données sur les pots dits « à garum » du Latium, d'après les découvertes subaquatiques du Rhône (Arles)}

\section{David Djaoui, Gaël Piquès, Emmanuel Botte}

\begin{abstract}
$\mathrm{A}$ ux céramiques à sauces et salaisons de poissons d'époque romaine a été attribuée une catégorie de pots produits dans la région du Latium, dont quelques exemplaires ont été trouvés en Gaule méridionale. Leur dénomination générique comme « pots à garum » résulte, au départ, de deux découvertes isolées ayant livré des macro-restes de poisson, l'une à Pompéi ${ }^{1}$ et l'autre à Port-La-Nautique ${ }^{2}$, ainsi que d'une inscription peinte trouvée dans le Rhône mentionnant de la sardine ${ }^{3}$. La présence de ces pots dans les contextes portuaires d'Arles, de Narbonne, d'Antibes ${ }^{4}$ et de Fréjus ${ }^{5}$ ainsi que les quelques attestations unitaires réalisées sur des bateaux (cf. infra) permettaient de leur assigner une fonction liée à la vaisselle de bord ${ }^{6}$. À ces différentes hypothèses fondées sur de trop rares exemplaires, les récentes découvertes subaquatiques du Rhône apportent le témoignage d'une soixantaine d'individus.

L'essentiel de ces découvertes a été réalisé au cours d'une mission de fouille et relevage du chaland galloromain Arles-Rhône 3. Cette épave était recouverte par plus de $900 \mathrm{~m}^{3}$ de dépotoir portuaire. Cette accumulation d'amphores et de céramiques s'intègre dans un plus vaste ensemble (Gisement A) situé de part et d'autre du pont de la voie rapide (fig. 1). Les différentes prospections de surface ne permettent pas toujours de préciser la chronologie du contexte de découverte. On notera toutefois que les pots du Latium découverts au-dessus de l'épave Arles-Rhône 3 se situent entre le naufrage de l'épave, daté autour de 50-60 ap. J.-C. et un terminus ante quem situé aux environs de 130-140 ap. J.-C. Les quantités importantes de sigillées sud-gauloises et de céramiques à paroi fine de Bétique indiquent un pic d'activité à la période flavienne.
\end{abstract}

Aujourd'hui, ces données quantitatives importantes, associées aux tamisages systématiques des pots entiers

1. Gasperetti 1996, p. 32.

2. Sanchez 2003, p. 117-118 fig. $53 \mathrm{n}^{\circ} 8$.

3. Long et al. 2009, p. 588.

4. Pellegrino 2007 , p. $53 \mathrm{n}^{\circ} 54$.

5. Rivet 2010, p. 103, fig. 433.

6. Sanchez 2011. et à la découverte de nouvelles inscriptions peintes, permettent de proposer un premier véritable bilan. Après avoir présenté et actualisé les connaissances concernant les pots du Latium, nous développerons de nouvelles problématiques que suscitent les découvertes issues des fouilles subaquatiques du Rhône.

\section{Les pots du Latium : état des connaissances}

\subsection{Typologie}

D'un point de vue typologique, ces pots connus à Ostie sous la dénomination Ostia II, 401 se composent de deux variantes principales (fig. 2). Un pot piriforme, à bord haut et profil concave (fig. $\mathbf{2}, \mathbf{n}^{\circ} \mathbf{9}$ et $\mathbf{p l .} \mathbf{1}$ ), et un pot plus ovoïde, avec une lèvre interne le plus souvent triangulaire (fig. $\mathbf{2}, \mathbf{n}^{\circ} \mathbf{4 1}$ et $\mathbf{p l .} \mathbf{2 - 5}$ ). I. Pohl ${ }^{7}$ voit une évolution de la forme où les exemplaires piriformes seraient plus précoces. C'est en effet ce qu'on peut observer sur l'épave Dramont D datant de 50 ap. J.-C. ${ }^{8}$ et dans le vaste dépotoir portuaire de Port-la-Nautique, daté entre la fin du ${ }^{\text {er }}$ s. av. J.-C. et le troisième quart du I ${ }^{\text {er }}$ s. ap. J.-C. ${ }^{9}$ Un dernier pot piriforme trouvé sur l'épave Sherki Bank $\mathrm{D}$, datée entre 80 et 50 av. J.-C., pourrait correspondre à la forme la plus ancienne ${ }^{10}$. Cette évolution morphologique semble se confirmer sur les exemplaires issus de la fouille de l'épave Arles-Rhône 3. Les quatre pots piriformes, trouvés lors de l'opération de 2011, se situent en effet dans l'environnement immédiat de l'épave, c'est-àdire entre 50 et 60 ap. J.-C. Et aucun exemplaire n'a été inventorié au sein des couches superficielles du dépotoir.

\footnotetext{
7. Pavolini 2000.

8. Joncheray 1974, pl. 5, a.

9. Sanchez 2003, p. 117-118 fig. $53 \mathrm{n}^{\circ} 8$.

10. Épave échouée dans la zone de «Sherki Bank». C'est une zone de haute mer peu profonde, située entre la Sicile et la Tunisie. De nombreux récifs, comprenant les Esquirques, deux grands récifs rocheux d'origine volcanique entourés par un banc de sable et les récifs de Keith, ont entraîné dans cette zone le naufrage de nombreux navires. McCann, Oleson 2004, p. 74 fig. 4.38
} 


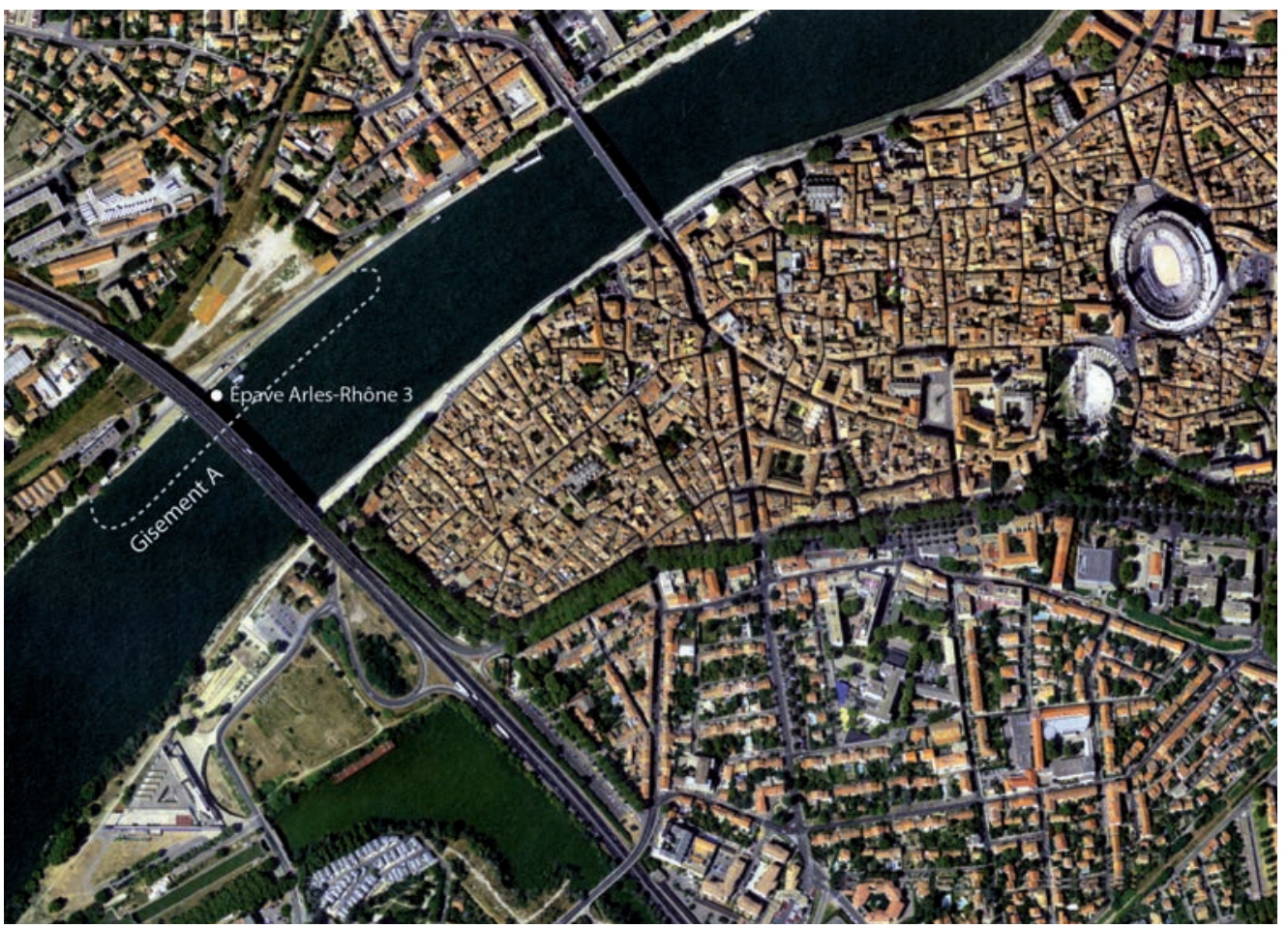

Fig. 1. Vue aérienne de la ville d'Arles avec la délimitation du Gisement A (@) Parc naturel régional de Camargue et Dynamiques Écologiques et sociales en milieux deltaïque).

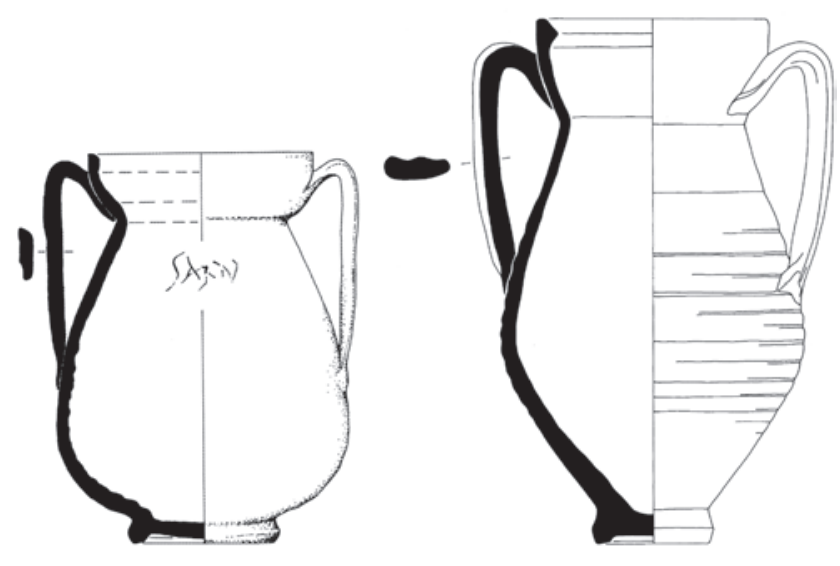

Fig. 2. Les deux variantes principales des pots du Latium (Échelle 1/3, piriforme $n^{\circ} 9$ et ovoïde $n^{\circ} 41$ ) (Dessin A.Véléva, D.A.O. D. Djaoui)

\subsection{Production}

Plusieurs découvertes attestent que ce type de céramique est produit au moins depuis l'époque augustéenne ${ }^{11}$. Si des exemplaires tardifs d'époque antonine sont attestés, la grande majorité des découvertes oriente vers une production à la période flavienne.

Ces pots ont été trouvés parmi les rejets de cuisson, datés du troisième quart du $\mathrm{I}^{\text {er }} \mathrm{s}$. ap. J.-C., au voisinage

11. Olcese 2003, p. 193 ; Bertoldi 2012, p. 82-83. de Sutri (à $40 \mathrm{~km}$ au nord de Rome), dans l'officine de La Celsa (banlieue nord de Rome), datée du ${ }^{\text {er }}$ et $\mathrm{II}^{\mathrm{e}} \mathrm{s}$. ap. J.-C. ${ }^{12}$ et à Rome, sur le Janicule, où ce type de vase a été découvert dans un dépotoir d'atelier de potiers ${ }^{13}$. Les pots piriformes à lèvre simple semblent apparaître dans les premières décennies du ${ }^{\mathrm{er}} \mathrm{s}$. ap. J.-C. et les pots ovoïdes à lèvre interne triangulaire à partir de l'époque flavienne ${ }^{14}$.

La pâte de ces conteneurs, de couleur beige à orangée, est compacte et contient de petites et fines inclusions blanches ainsi que, parfois, des paillettes de mica et des nodules rouges. Une différence s'observe également sur la texture de la pâte entre les pots piriformes et les autres. Une surface lisse, douce au toucher avec des inclusions très fines caractérise les quelques exemplaires piriformes du Rhône alors que les pots ovoïdes présentent des surfaces plus rugueuses avec de nombreuses aspérités superficielles de calcite (point de chaux).

\subsection{Diffusion}

Avant les découvertes subaquatiques du Rhône, seuls quelques exemplaires isolés étaient attestés dans le bassin méditerranéen, mais la majorité provenait de Rome,

12. Voir la carte dans Olcese 2003, fig. 1 p. 11.

13. Olcese 2003, p. $94-95$; Olcese 2012, p. 193-196, fig. 54 ; p. 238-240, fig. 43 .

14. Bertoldi 2012, p. 82-83. 
Ostie et de la zone du Latium. Aux vases répertoriés par Gloria Olcese ${ }^{15}$, on peut ajouter celui mis au jour sur le Forum Transitorium de Rome, dans des niveaux de comblement datés du $\mathrm{II}^{\mathrm{e}} \mathrm{s}$. de notre ère ${ }^{16}$.

\subsection{Origine du contenu halieutique des pots du Latium}

Deux vases découverts à Pompéi et à Narbonne ont incité G. Olcese, et d'autres à sa suite, à qualifier ce récipient de « contenitore di salse di pesce » car ils contenaient des restes de poissons. Pour Pompéi, des arêtes ont été découvertes dans un exemplaire de la domus de C. Iulius Polibius ${ }^{17}$. Pour Narbonne, c'est dans le vaste dépotoir portuaire de Port-la-Nautique, daté entre la fin du I ${ }^{\text {er }}$ s. av. J.-C. et le troisième quart du ${ }^{\text {er }}$ s. ap. J.-C. que
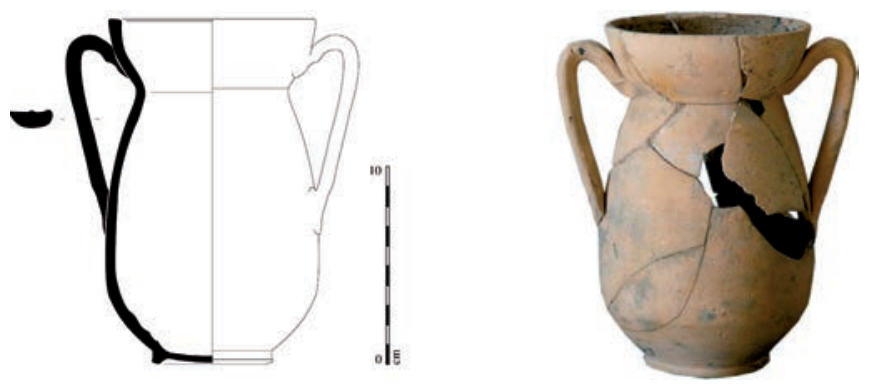

Fig. 3. Pot du Latium de Port-La-Nautique ( C. Sanchez, CNRS).

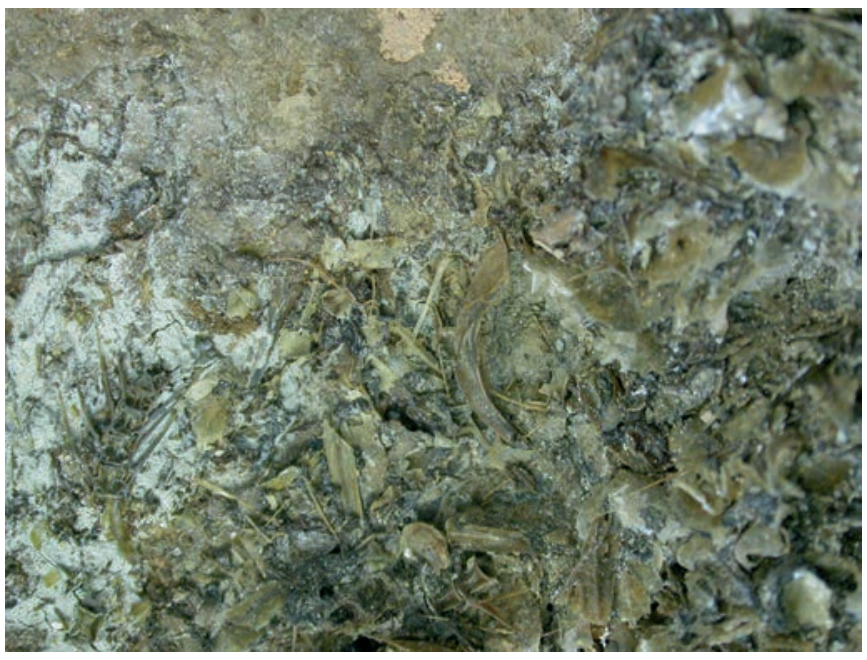

Fig. 4. Ossements d'alevins de sardine observés dans le pot du Latium de Port-La-Nautique (C G. Piques, CNRS).

15. Olcese 2003, p. 94-95. De manière générale, le conteneur apparaît pour la première fois dans les publications à la fin des années 1960.

16. Marucci 2006, p. 76 fig. $6 \mathrm{n}^{\circ} 20=$ type C. C. 12 de l'auteur.

17. Gasperetti 1996, p. 32. des alevins de sardines ont été identifiés par G. Piquès dans un de ces pots (fig. 3-4) ${ }^{\mathbf{1 8}}$.

En parallèle, les fouilles du Rhône avaient également révélé sur l'un des pots, lors des campagnes précédentes, l'inscription «sardi » (RHO.05.Z99.349), interprétée comme sardina ${ }^{19}$.

\section{L'apport des fouilles subaquatiques menées lors de l'opération de fouille et relevage de l'épave Arles-Rhône 3}

\subsection{Confirmation de la nature halieutique des pots du Latium}

Lors de l'opération de 2011, le contenu des pots a été systématiquement conservé et placé au réfrigérateur en vue d'un tamisage ultérieur. Si l'analyse d'éventuels ichtyorestes présents dans ces prélèvements reste à faire, une simple observation des parois internes de ces pots a déjà permis d'attester la présence de poisson dans plusieurs d'entre eux. Ces restes pris dans la poix n'étaient pas toujours visibles à l'œil nu. Leur reconnaissance a nécessité le plus souvent l'emploi d'une loupe binoculaire après prélèvement et tamisage de la poix à une maille minimale de $0,25 \mathrm{~mm}$. Ainsi sur un échantillon de 18 pots, entiers ou archéologiquement complets, au moins 16 s'avèrent contenir des restes de poissons. Il s'agit en général d'ossements de maquereaux et de représentants de la famille des Clupéidés. À ces examens, il faut ajouter, sous réserve d'identification précise, l'observation d'écailles dans 12 autres de ces pots. Enfin, une visite rapide à Marseille du matériel issu du dépotoir portuaire du chantier de Jules Vernes a permis d'identifier 6 pots du Latium dont 4 présentaient des écailles de poisson et, pour l'un d'entre eux, des vertèbres en connexion ${ }^{20}$. Ces différentes observations viennent ainsi confirmer les premières hypothèses émises sur leur contenu, celle de produits à base de poisson. Pour en savoir plus sur la nature de ces produits, sauces ou salaisons, le tamisage du remplissage des pots d'Arles Rhône 3 devrait apporter des données complémentaires. En attendant, nous présentons ici les résultats d'une première analyse des restes d'ichtyofaune recueillis dans l'une de ces céramiques.

18. Sanchez 2003, p. $117-118$ fig. $53 \mathrm{n}^{\circ} 8$

19. Long et al. 2009, p. 588.

20. Fouilles inédites dirigées par Antoinette Hesnard, que nous remercions. 


\subsection{Analyse du pot du Latium $n^{\circ} 22$}

\subsubsection{Matériel et méthode}

Le contenu de ce pot, constitué d'un amas d'ossements de poisson pris dans une gangue boueuse (fig. 5) a été dans un premier temps tamisé à l'eau, au musée départemental Arles antique, à l'aide d'un tamis de 0,25 mm. Les restes d'ichtyofaune ainsi recueillis (fig. 6) ont été calibrés au travers d'une colonne de tamis de $2 \mathrm{~mm}, 1 \mathrm{~mm}, 0,5 \mathrm{~mm}$ et $0,25 \mathrm{~mm}$, afin de faciliter le tri par pièce anatomique. L'essentiel du matériel se répartit entre 2 et $0,5 \mathrm{~mm}$; la maille de $0,25 \mathrm{~mm}$ ne contenant que des fragments de lépidotriches et de la poudre d'ossements. Dans l'ensemble, les os présentent un état de conservation remarquable. Seuls quelques-uns sont fragmentés, notamment des parasphénoïdes, des operculaires, des interoperculaires et des sous-operculaires. Il faut noter également le faible nombre d'écailles. En excluant les épines et les rayons de nageoires (axonostes et lépidotriches) ainsi que les écailles et les rayons branchiostèges, on dénombre à peu près 8000 restes de poissons dans ce pot. Ne pouvant effectuer, faute de temps, la diagnose de chacun d'entre eux, l'analyse a porté sur une sélection de pièces réparties sur l'ensemble du squelette. Triées à chacune des mailles de tamis, elles nous ont permis de déterminer par taxons, le nombre minimum d'individus, la taille ainsi que les parties anatomiques représentées. On ajoutera enfin que parmi ces os ont été retrouvés de nombreux restes d'insectes, notamment des pupes de larves de mouches qui devront être examinés par un entomologiste.

\subsubsection{Les poissons identifiés et leur représentation anatomique}

Les ossements contenus dans ce pot du Latium sont attribués à cinq taxons : Scomber scombrus (maquerau commun), Alosa fallax (alose), Sprattussprattus (sprat), Engraulis encrasicholus (anchois), et Soleidae (famille de la sole).

\section{Les restes de maquereaux}

Pour le maquereau, le premier constat à souligner est une surreprésentation des os de la partie avant du crâne par rapport à ceux du reste du corps. Le décompte des os pairs et impairs situés en avant d'un axe perpendiculaire au centre du neurocrâne livre un nombre minimum de quatorze individus alors que pour la moitié arrière du crâne et le rachis, le NMI obtenu ne dépasse pas six individus (fig. 7). Cette disproportion apparaît également dans le décompte des vertèbres. En sachant qu'un maquereau entier se compose de trente vertèbres, on devrait obtenir pour quatorze individus environ 420 vertèbres dans cet échantillon. Or le contenu du pot n'a livré que 174 vertèbres, qui correspondent à peu près aux rachis complets de six spécimens. Le second constat porte sur la présence de traces de découpe sur des os situés sur cet axe perpendiculaire au centre du neurocrâne. Sont concernés plusieurs os frontaux, des carrés et des keratohyales qui sont tranchés et dont la partie postérieure résultant de la découpe n'a pas été retrouvée (fig. 8). Ce mode de découpe original a été identifié sur les crânes de maquereaux des amphores de l'épave Sud Perduto ${ }^{21}$ (fig. 9). Mais pour les spécimens de cette épave, à l'inverse de ceux de notre échantillon, seuls les ossements de la partie arrière du crâne et du rachis étaient représentés.

On peut ainsi estimer que le contenu de ce vase renferme six maquereaux entiers, auxquels s'ajoute la partie antérieure du crâne de huit autres spécimens dont il nous manque le reste du corps. La taille de ces poissons a été évaluée en comparant la mesure de leurs os avec celle de spécimens actuels, ce qui nous a permis par la même occasion d'affiner l'estimation du NMI. Nous avons sélectionné pour cela le dentaire et le hyomandibulaire, situés de part et d'autres de l'axe de découpe. Les mesures de l'ensemble des dentaires droits correspondent pour certaines à celles de maquereaux de taille inférieure à $200 \mathrm{~mm}$ et ne dépassant pas $275 \mathrm{~mm}$ pour les autres (fig. 10). Les tailles des spécimens entiers, d'après les mesures des hyomandibulaires, resteraient inférieures à $213 \mathrm{~mm}$ (fig. 11).

\section{Les restes de Clupeidés}

Cette famille, à laquelle appartient la sardine, a deux représentants dans cet échantillon : l'alose feinte (Alosa fallax) et le sprat (Sprattus sp.). Pour l'alose, la diagnose de l'espèce a pu être réalisée d'après la morphologie du dentaire, suffisamment caractéristique pour la différencier d'Alosa alosa. Quant au sprat, dont plusieurs os se distinguent bien de ceux de l'alose, une confusion est possible avec la sardine pour certaines pièces comme le dentaire. Ce n'est en revanche pas le cas pour l'operculaire et les vertèbres qui peuvent tous être attribués au genre Sprattus dont le seul représentant sur les côtes de la Méditerranée occidentale est Sprattus sprattus.

D'après le nombre des différents os de la tête, il y aurait environ trente aloses et neuf sprats dans le pot (fig. 12). Toutes les vertèbres de ces deux espèces n'ont pas encore été extraites du refus de tamis de $0,5 \mathrm{~mm}$, mais on en dénombre d'ores et déjà un peu plus de 1700. En sachant que le rachis d'une alose et d'un sprat

21. Desse-Berset, Desse 2000. 
en possède une cinquantaine, on devrait avoir pour 39 spécimens environ 1950 vertèbres. C'est à peu près l'estimation du nombre qui devrait être atteint une fois le tri terminé, ce qui nous laisse penser que ces poissons étaient entiers.

L'alose est un poisson marin qui se reproduit en eau douce. Une fois écloses, les jeunes aloses redescendent les cours d'eau pour séjourner dans les estuaires ou les lagunes avant de partir pour la mer. Les spécimens de notre échantillon correspondent à ces jeunes aloses en partance pour la mer. Ce sont des spécimens de petite taille, en début de deuxième année de vie d'après les lignes d'arrêt de croissance observées sur leurs vertèbres. Quant aux sprats représentés, il s'agit également de petits poissons, de taille inférieure à celle des jeunes aloses. Le sprat est une espèce côtière pouvant supporter de fortes baisses de salinité et fréquenter ainsi les lagunes et les estuaires.

\section{Les restes d'anchois et de sole}

Parmi ces ingrédients figurent également trois anchois et une petite sole. Les ossements de ces poissons semblent correspondre à des spécimens entiers. Il s'agit dans les deux cas d'espèces côtières pouvant fréquenter les estuaires ou les lagunes ouvertes sur la mer. La sole est toutefois un poisson benthique, vivant sur le fond, à la différence de l'alose, du maquereau, de l'anchois et du sprat, qui sont des espèces grégaires pélagiques.

\subsubsection{Interprétation des données}

Ce pot du Latium renfermait une préparation élaborée à partir d'une trentaine de jeunes aloses, de six petits maquereaux, de quelques anchois et sprats ainsi que d'une petite sole. À cela s'ajoutent huit parties antérieures de têtes tranchées de maquereau dont il manque le reste du corps (fig. 13).

Cette constatation renvoie aux conserves de maquereaux de l'épave Sud-Perduto 2 dont il manquait, à l'inverse de notre échantillon, la partie antérieure du crâne. Pour N. Desse-Berset et J. Desse, cette découpe permettrait de vider les maquereaux de leur sang, afin d'éviter la corruption rapide des chairs et en améliorer la conservation. En outre, le sang pouvait fort bien être prélevé pour fabriquer, parallèlement, un garum $^{22}$. Il semblerait que cela soit le cas pour l'élaboration du produit qui nous concerne. On peut supposer en effet que la tête des maquereaux était tranchée au dessus du pot, de manière à faire écouler le sang dans le récipient pour le mêler directement aux autres ingrédients dont le

22. Desse-Berset, Desse 2000. sel. Les maquereaux ainsi saignés devaient être utilisés pour une conserve (salsamenta) dans un autre pot ou une amphore. Il faut noter que parmi les os de cet échantillon qui présentent des traces de découpe, figure également une partie postérieure de neurocrâne. Il s'agit là d'un maquereau complet, qui ne devait peut-être pas convenir pour une salsamenta, mais dont la tête a néanmoins été tranchée pour en faire écouler le sang.

L'hypothèse d'une préparation élaborée directement dans le pot est privilégiée pour deux raisons. La cohérence des NMI obtenus à partir de chacun des os des parties anatomiques représentées, ainsi que la présence de déchets de têtes tranchées insignifiantes qui ne sont là qu'en raison d'une découpe liée à la récupération du sang. Concernant la quantité de restes recueillis, il est difficile de dire si elle représente l'ensemble du produit initial. Le déficit de quelques vertèbres et d'os de la tête, qui auraient dû figurer dans cet échantillon, pourrait s'expliquer par une perte post-dépositionnelle d'une partie du contenu au fond du Rhône.

Enfin à quelle préparation à base de poisson mentionnée dans les textes antiques ce produit pourrait-il se rattacher? Il doit s'agir d'un produit pâteux, qui devait pouvoir se manger avec du pain. Les os, de petite taille et, qui plus est, ramollis par le sel, pouvaient très bien être ingérés. Ces ingrédients et ce mode de préparation pourraient correspondre à la définition que Pline l'Ancien fait de l'allec, c'est-à-dire celle d'un rebut de la fabrication du garum qui aurait ensuite été produit pour lui-même à partir d'une multitude d'espèces et notamment de petits poissons : «L'allec, rebut du garum, n'est qu'une lie grossière et mal filtrée. Cependant on s'est mis à en préparer aussi spécialement avec un poisson tout petit et sans valeur: nous l'appelons ариа, les Grecs aphyé, parce que ce petit poisson est engendré par la pluie. Les gens de Fréjus le font avec un poisson qu'ils appellent loup. L'allec est devenu ensuite un objet de luxe, les espèces s'en sont multipliées à l'infini; par exemple, il existe un garum ayant la couleur du vin miellé, si liquide et si agréable qu'on peut le boire. Il en est une autre espèce, réservée aux pratiques superstitieuses de la continence et aux cérémonies religieuses des Juifs, que l'on prépare avec des poissons non dépourvus d'écailles. Ainsi l'allec a étendu son domaine aux huîtres, aux oursins, aux orties de mer, aux foies de surmulet, et l'on s'est mis à faire putréfier le sel de mille façons pour les plaisirs de bouche. » (Pline l'Ancien, NH, XXXI, 94-95, traduction G. Serbat à la CUF).

En complément de ces analyses, de nouvelles inscriptions peintes ont été enregistrées sur plusieurs exemplaires. 


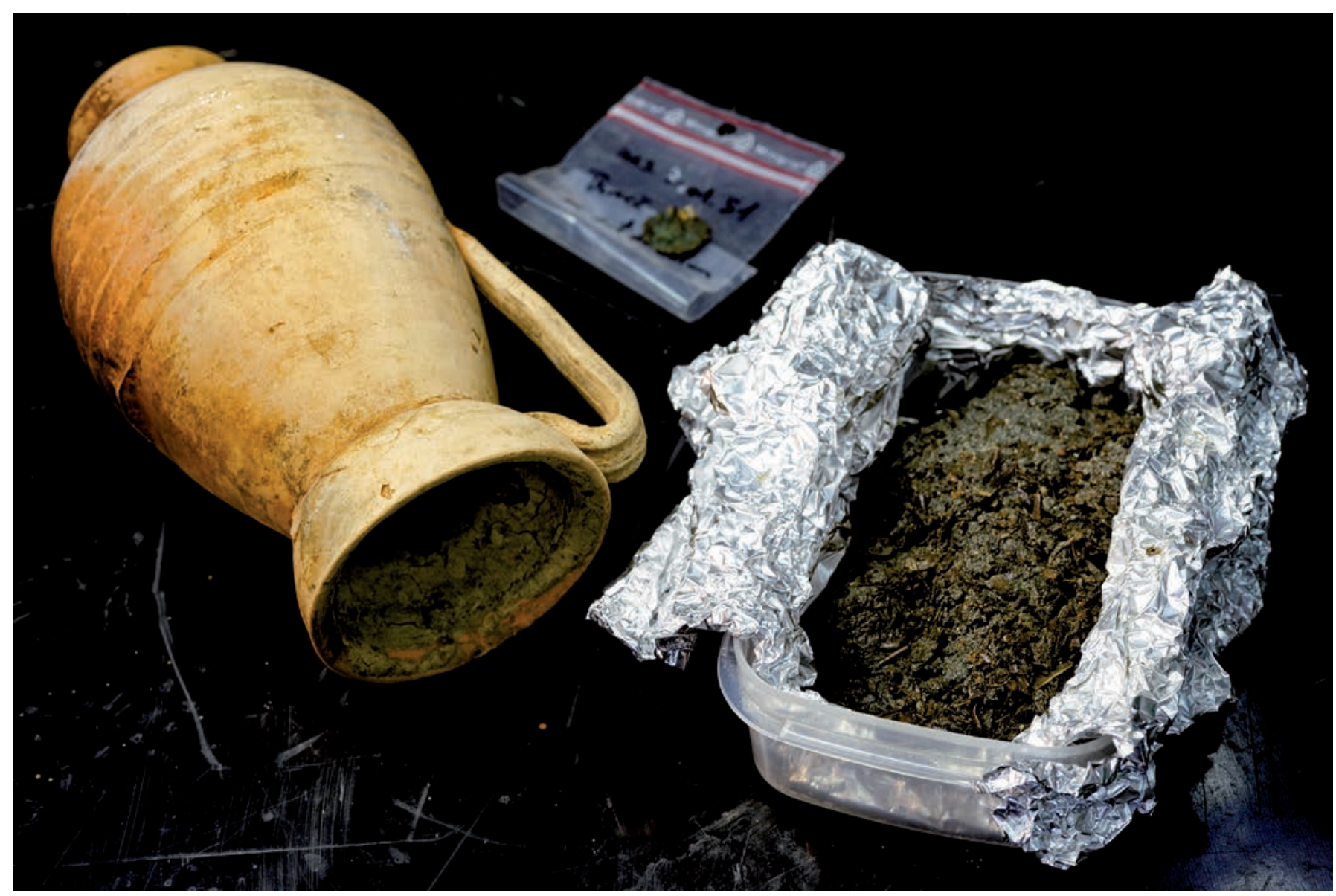

Fig. 5. Le pot du Latium n²2 et son contenu non tamisé (๑ Remi Benali/CG13).

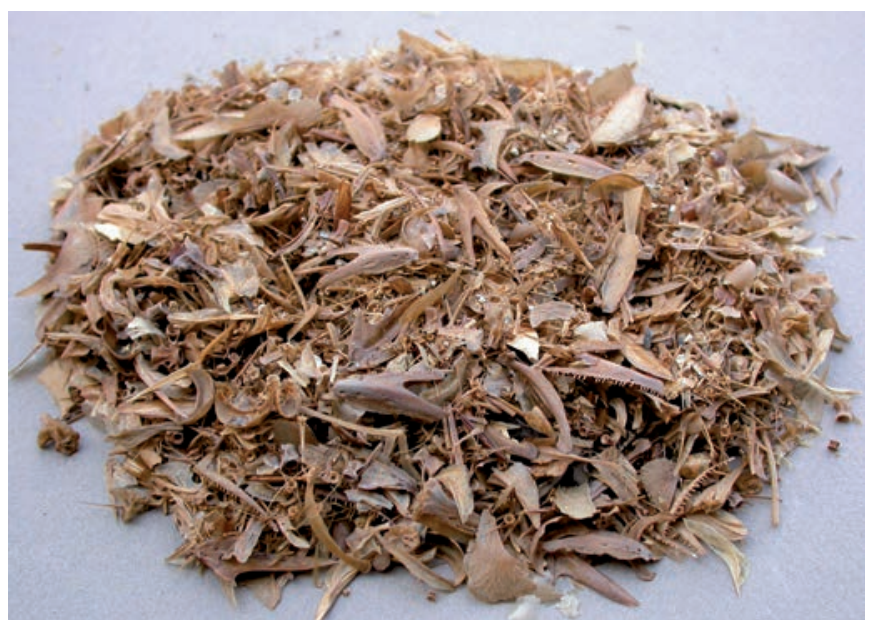

Fig. 6. Restes d'ichtyofaune recueillis dans le pot du Latium $n^{\circ} 22$ (C Remi Benali/CG13).

Fig. 7. Pot du Latium $n^{\circ} 22$ Evaluation pour Scomber scombrus (le maquereau) du nombre minimum d'individu (NMI) d'après le décompte et les dimensions de plusieurs os pairs et impairs.

\begin{tabular}{|c|c|c|c|c|c|c|}
\hline & & \multirow[t]{2}{*}{ os impairs } & \multicolumn{2}{|c|}{ os pairs } & \multirow[b]{2}{*}{ NR } & \multirow[b]{2}{*}{ NMI } \\
\hline & & & droit & gauche & & \\
\hline \multirow{9}{*}{ 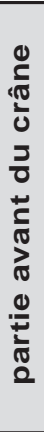 } & vomer & 12 & & & 12 & 12 \\
\hline & dentaire & & 14 & 12 & 26 & 14 \\
\hline & articulaire & & 13 & 12 & 25 & 13 \\
\hline & maxillaire & & 13 & 14 & 27 & 14 \\
\hline & prémaxillaire & & 13 & 14 & 27 & 14 \\
\hline & carré & & 11 & 7 & 18 & 11 \\
\hline & frontal & & 12 & 13 & 25 & 14 \\
\hline & urohyale & 10 & & & 10 & 10 \\
\hline & keratohyale & & 11 & 9 & 20 & 11 \\
\hline \multirow{6}{*}{ 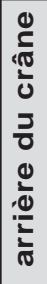 } & épihyale & & 6 & 6 & 12 & 6 \\
\hline & préoperculaire & & 4 & 4 & 8 & 5 \\
\hline & operculaire & & 3 & 1 & 4 & 4 \\
\hline & métaptérygoide & & 3 & 2 & 5 & 4 \\
\hline & hyomandibulaire & & 3 & 2 & 5 & 5 \\
\hline & basioccipital & 5 & & & 5 & 5 \\
\hline \multirow{4}{*}{$\begin{array}{l}\frac{n}{c} \\
\frac{0}{0} \\
\frac{\pi}{0}\end{array}$} & vertèbre $n^{0} 1$ & 6 & & & 6 & 6 \\
\hline & vert. thoraciques & 53 & & & 53 & 6 \\
\hline & vert. pré/caudales & 111 & & & 111 & 6 \\
\hline & dernière vertèbre & 5 & & & 5 & 5 \\
\hline
\end{tabular}




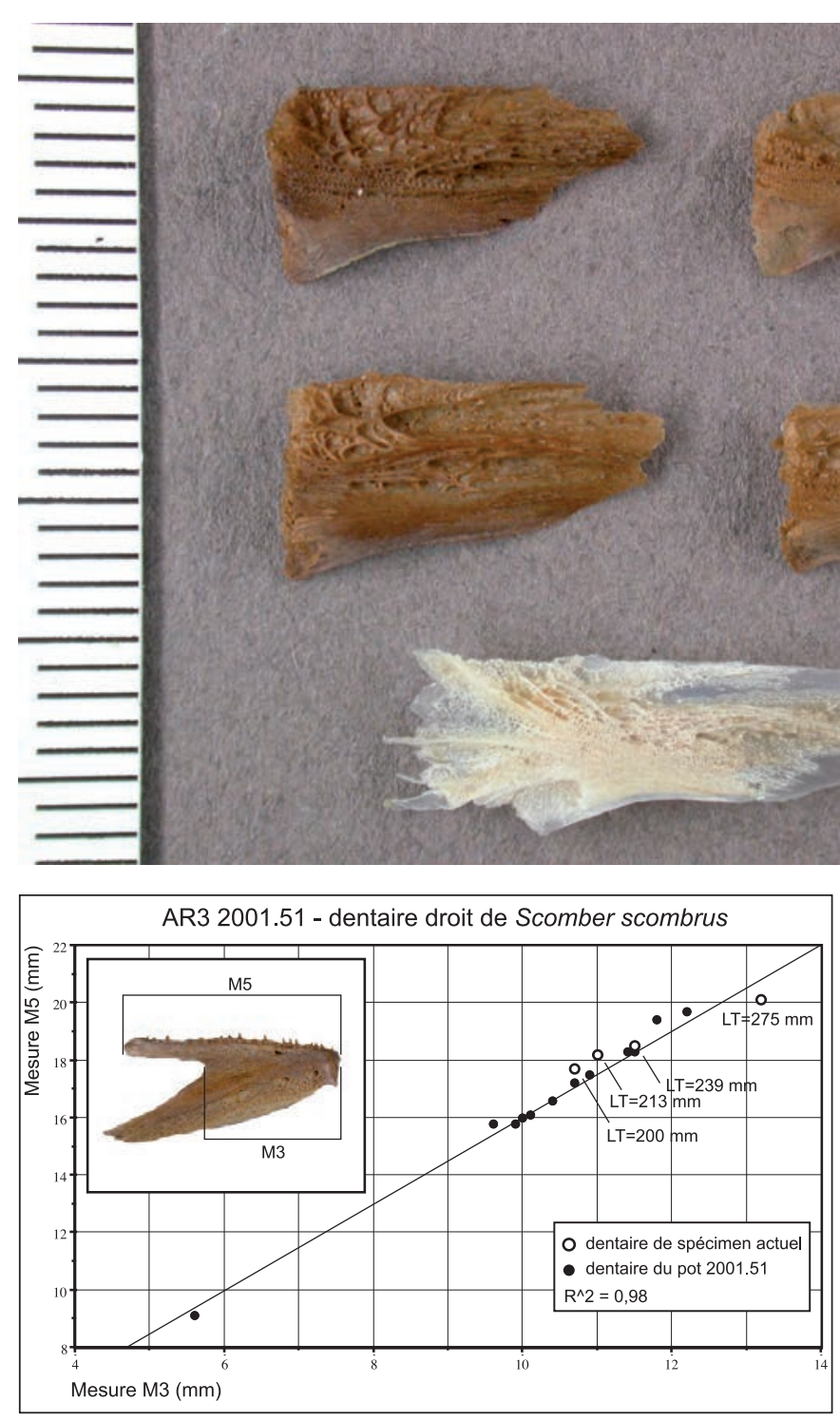

Fig. 10. Evaluation de la longueur totale (LT) des maquereaux du pot $\mathrm{n}^{\circ} 22$, d'après les mesures des dentaires comparée à celle de spécimens actuels de taille connue.

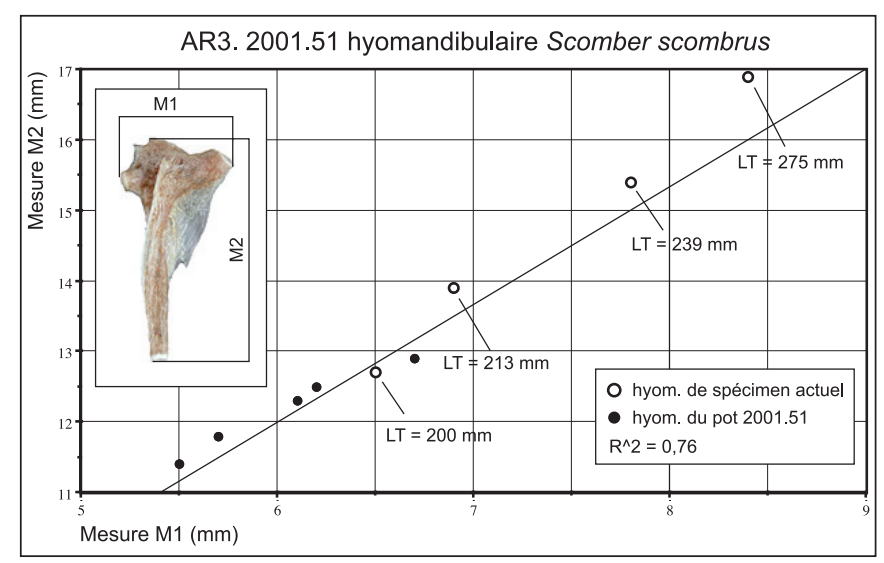

Fig. 11. Evaluation de la longueur totale (LT) des maquereaux du pot $\mathrm{n}^{\circ} 22$, d'après les mesures des hyomandibulaires comparée à celles de spécimens actuels de taille connue.
Fig. 8. Échantillon d'os frontal tranchés de maquereau, issus du pot du Latium $n^{\circ} 22$, comparés à un os frontal entier d'un maquereau actuel (@ G. Piquès).
Fig. 9. Axe de découpe des crânes de maquereaux du pot du Latium n²2 et de ceux de l'épave de SudPerduto 2 (Desse-Berset, Desse 2000).

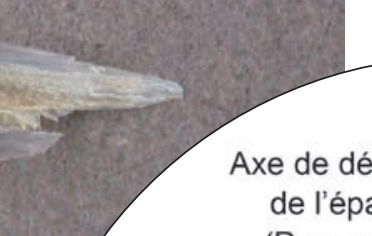
(Desse-Berset, Desse 2000)

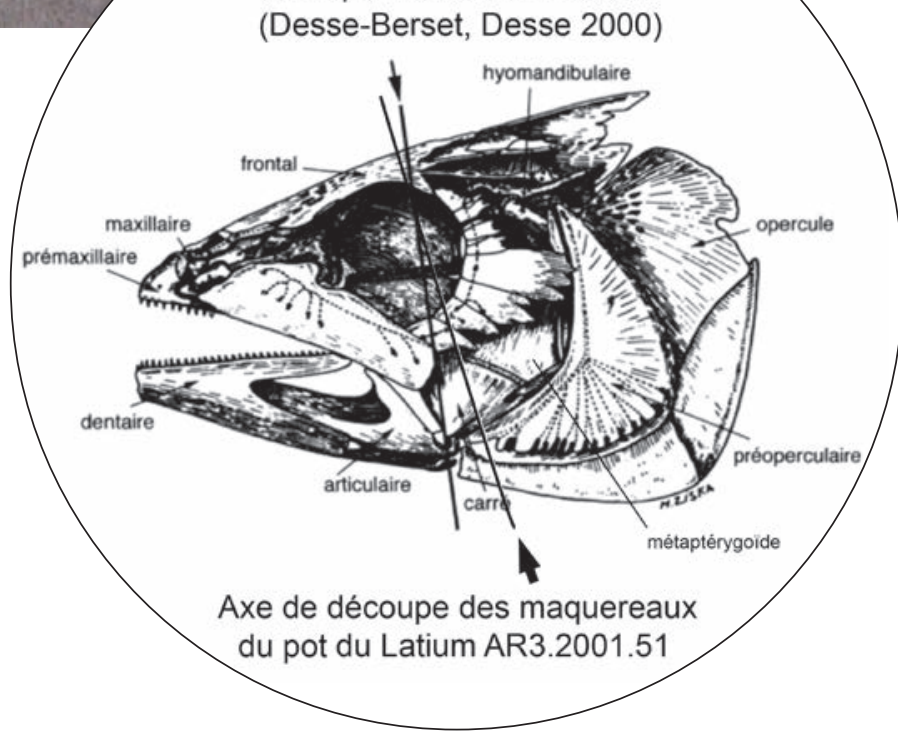

\begin{tabular}{|l|c|c|c|c|}
\cline { 2 - 5 } \multicolumn{1}{c|}{} & \multicolumn{2}{c|}{ Clupeidae } & \multicolumn{2}{c|}{} \\
\cline { 2 - 5 } \multicolumn{1}{c|}{} & Alosa fallax & Spratus sp. & $\begin{array}{c}\text { Engraulis } \\
\text { encrasicholus }\end{array}$ & Soleidae \\
\cline { 2 - 5 } \multicolumn{1}{c|}{} & alose & sprat & anchois & sole \\
\hline dentaire & 53 & 16 & 4 & 1 \\
\hline maxillaire & 51 & 16 & 5 & 1 \\
\hline carré & 50 & 14 & 4 & 2 \\
\hline urohyal & \multicolumn{2}{|c|}{23} & 1 & 1 \\
\hline keratohyale & \multicolumn{2}{|c|}{63} & 4 & 2 \\
\hline épihyale & \multicolumn{2}{|c|}{33} & 3 & 2 \\
\hline operculaire & 42 & 5 & 2 & 2 \\
\hline hyomandibulaire & 59 & 18 & 5 & 2 \\
\hline vertèbres & \multicolumn{2}{|c|}{$>1732$} & 75 & 29 \\
\hline dernière vertèbre & 27 & 6 & & 1 \\
\hline NMI & 30 & 9 & 3 & 1 \\
\hline
\end{tabular}

Fig. 12. Evaluation, pour le pot $n^{\circ} 22$, du nombre minimum d'individu (NMI) par taxons identifiés (autres que Scomber scombrus) d'après le décompte de plusieurs os pairs et impairs. 


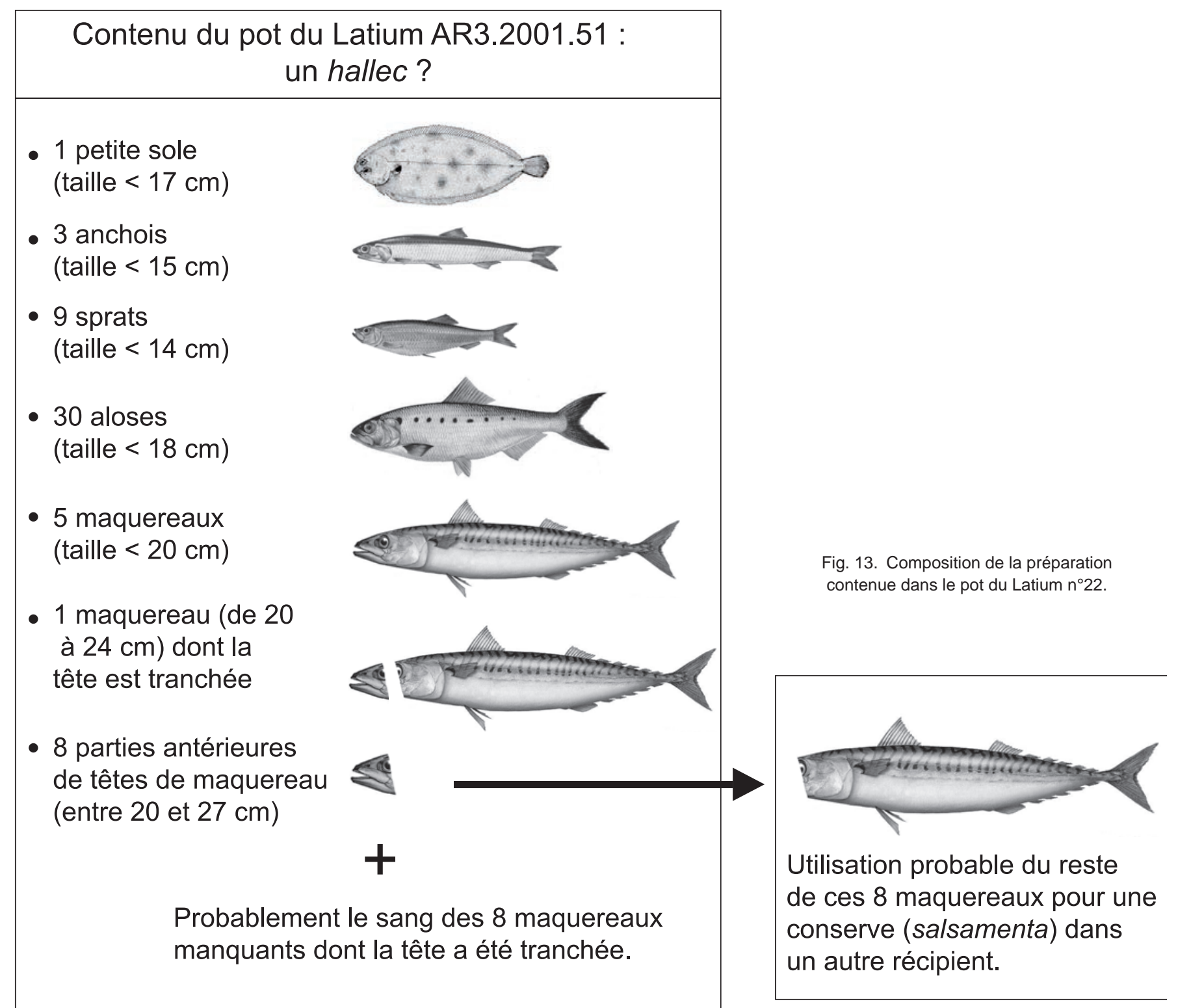

\subsection{Nouvelles données épigraphiques}

Le col d'un pot du Latium découvert dans le Rhône livre en position centrale des inscriptions peintes de couleur noire dont la lecture peu évidente suggère une hypothèse intéressante (pl. $\left.\mathbf{4}, \mathbf{n}^{\circ} \mathbf{3 4}\right)$. Compte tenu de la nature halieutique présente dans $40 \%$ des pots prélevés dans le Rhône, nous développons l'inscription en araneus, c'est-à-dire une vive. Dans son traité sur les remèdes que fournissent les animaux aquatiques, Pline mentionne contre le venin de la vive l'application d'un cataplasme confectionné avec la chair du poisson ${ }^{23}$. Juste après le $\mathrm{N}$ de $\operatorname{aran}($ eus), et disposées en diagonale, figurent les lettres RIL. Si la lecture n'est pas assurée, elle trouve néanmoins des comparaisons sur deux fragments de col d'amphore Dressel 14 trouvées sur l'épave Pecio Gandolfo (Alméría) ${ }^{24}$. Sur la quatrième ligne du premier col on peut lire les lettres RIL, et sur le deuxième col, la mention RIL apparaît sur la cinquième ligne. On remarquera que dans les deux cas cette inscription se trouve sur une amphore contenant du poisson. L'interprétation de ces lettres reste inexpliquée par les auteurs. On signalera également dans le Rhône, sous le fond d'un pot de forme indéterminée, la mention SEX.I.S et dessous, une nouvelle fois, la mention énigmatique RIL.

24. Liou, Rodriguez Almeida 2000, p. 22. 
Sur un autre pot, placé également en position centrale et de couleur noire, on peut lire grâce à la photographie infrarouge un titulus C() DOM[--]NIGRA (pl. 2, $\left.\mathbf{n}^{\circ} 11\right)$. U. Ehmig a remarqué que la taille, relativement importante, de la première et de la deuxième lettre, respectivement le $\mathrm{C}$ et le $\mathrm{T}$, devait annoncer le début de deux termes différents. Avec Nigra en position finale, on pourrait par conséquent avoir des tria nomina. Le prénom pourrait débuter par un $\mathrm{C}$ ou encore un $\mathrm{T}^{25}$. Il ne fait pas de doute qu'en l'absence totale de lisibilité des premières lettres, la seule mention nigra aurait été interprétée comme [Oliva] Nigra. Cette erreur d'interprétation aurait été d'autant plus facilitée que sur un autre pot, la lecture de l'inscription $O L I V(-)$ ne souffre d'aucune ambiguïté (pl. 3, n²5). Marquées à l'encre rouge, de grandes lettres sont peintes sur le haut de la panse et en position médiane. Sur un autre pot du Latium, et suivant une disposition identique, c'est-à-dire réalisée également avec de l'encre rouge et en milieu de panse, on lit CEPA, c'est-à-dire oignon (pl. 4, $\left.\mathbf{n}^{\circ} \mathbf{2 6}\right)$. Ces deux nouvelles inscriptions sont pour le moins étonnantes, car il semblait bien que les quelques attestations épigraphiques, et les macro-restes analysés dans les différents pots, renvoyaient systématiquement à un contenu à base de poisson. Des recherches récentes, menées à Pompéi, ont permis d'enrichir le répertoire épigraphique de le mention cet(us). On signalera enfin, et toujours à Pompéi, des ollae qui portent des inscriptions Hallex / optima $^{26}$.

Ces nouvelles données épigraphiques rendent compte des difficultés de lecture et d'interprétation de ce type de source. Elles livrent également et de façon inattendue, la présence d'olive et d'oignon alors que la nature halieutique semble pourtant bien acquise. Compte tenu de ces tituli picti, trois hypothèses sont envisageables. Celle d'un pot associant dans des sauces ou des salaisons de poisson des condiments de nature différente, celle d'un pot au contenu polyvalent pouvant contenir aussi bien du poisson, des olives ou des oignons, ou encore celle d'une réutilisation du conteneur.

\subsubsection{Recette à base de poisson}

Les mentions Oliva et Cepa pourraient faire référence à une recette mélangeant le poisson avec différents condiments tels que les olives ou les oignons. On retiendra ainsi la phrase de Martial $(3,77,5)$ « Capparin et putri cepas allece natantis » faisant allusion à une mixture à

25. Nous avons privilégié le $\mathrm{C}$ car le style calligraphique sur le $\mathrm{N}$ et le I de nigra semble terminer la tête de ces deux lettres par une épaisseur verticale que l'on pourrait prendre pour la barre d'un T. 26. CIL IV, 9409 et 9410. base de câpres, d'oignons et d'allec. Dans ce sens, le pot du Latium portant la mention Cepa a conservé dans la poix des restes de poisson. On note enfin, pour le $\mathrm{V}^{\mathrm{e}} \mathrm{s}$. av. J.-C., une inscription sur plaque en plomb, découverte à Lattes, qui mentionne une commande non honorée dans laquelle est précisée, entre autres, du garum aux olives ${ }^{27}$.

\subsubsection{Pot à usage polyvalent : les conserves d'olives et d'oignons}

Les conserves d'olive ( Oliuarum conditura ») dans un pot sont mentionnées dans les textes antiques avec des recettes concernant aussi bien les olives blanches ${ }^{28}$, les olives foncées ${ }^{29}$, les olives noires ${ }^{30}$ que les modes de conservation ${ }^{31}$ et/ou de préparation ${ }^{32}$. Les tituli picti des amphores ont confirmé la conservation d'olives dans du defrutum à Soissons ${ }^{33}$, à Vindonissa ${ }^{34}$ ou dans du dulcia à Augst et à Nyon ${ }^{35}$. Au milieu du $\mathrm{III}^{\mathrm{e}}$ s. ap. J.-C., on trouve également des inscriptions peintes mentionnant ce fruit, sur des pots en pâte calcaire, dont trois ont été trouvés à Mayence (oliva [pi]cena, olivae, olivae s[extarius] $s$ [semis]) et un autre à Bliesbruck (oliva picena) ${ }^{36}$. De la même façon, les oignons («cepae conditura») peuvent être placés dans un vase de terre sur une couche de thym et d'origan ${ }^{37}$. Dans l'état actuel de nos connaissances, aucune autre attestation épigraphique mentionnant des oignons n'a été enregistrée sur une céramique.

\subsubsection{Réutilisation des pots de conserves de poisson}

L'hypothèse d'une réutilisation peut également être évoquée. Les grandes lettres rouges, placées en position médiane sur la panse pourraient alerter le consommateur sur un contenu différent de celui auquel la forme du pot le destinait. Les inscriptions secondaires Hallex trouvées à Cologne sur une amphore vinaire Haltern $70^{38}$ et Mulsum sur une amphore à dérivés de poissons Beltran II issue des fouilles subaquatiques du Rhône ${ }^{39}$ étaient inscrites en rouge.

\footnotetext{
27. Bats 2010, p. 750.

28. Caton, Agr. 117 ; Columelle, XII, 49.4.

29. Columelle, XII, 49.6-7 «De oliuis fusci».

30. Columelle, XII, 50 « Nigrarum oliuarum conditura».

31. Columelle, XII, 49.6-7 « ex dulci».

32. Columelle, XII, 50.6 «Oliuam Ciliciensem sic condito ».

33. Lequément, Massy 1980.

34. Bohn 1926.

35. Dangréaux, Desbat 1988.

36. Ehmig 2006, Albrecht 1998, p. 321-328.

37. Columelle, XII, 10.

38. Ehmig 2009 p. 31 tab. 2.

39. Je tiens à remercier Luc Long, conservateur en chef du DRASSM, de m'avoir autorisé à publier ces informations inédites.
} 

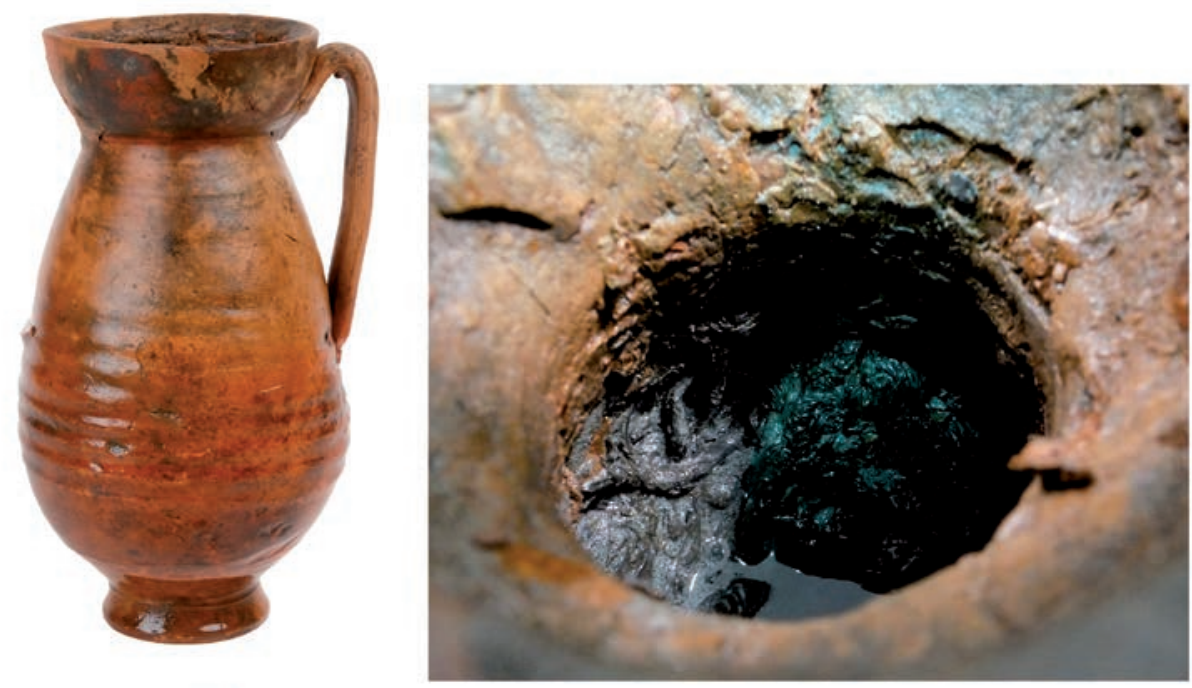

Fig. 14. Arles-Rhône 3, pot du Latium $n^{\circ} 22$ contenant des restes de cordage (cliché : Arc-Nucléart).

Module 3

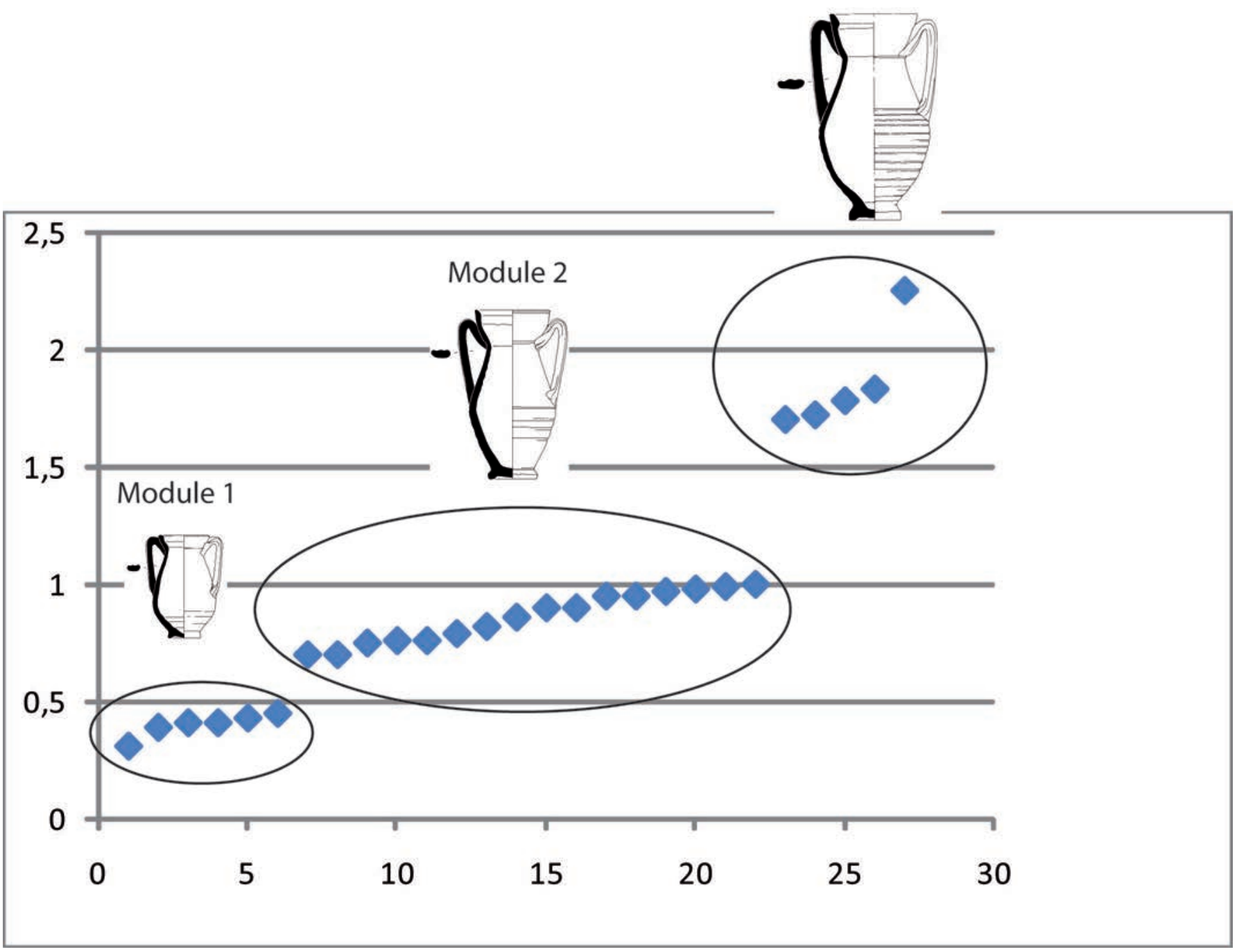

Fig. 15. Capacités volumétriques des pots du Latium ovoïdes. 


\subsection{Système de fermeture et notion de modules}

Le nombre important de pots complets et entiers permet également de s'interroger sur la notion de module. Néanmoins, à partir de quelle limite doit-on fixer le contenu du produit pour en calculer le volume ? Cette précision est importante car le système de fermeture a des répercussions sur le calcul du volume et par conséquent sur la détermination des modules.

\subsubsection{Système de fermeture des pots du Latium}

Ces conserves devaient recevoir un système de fermeture efficace pour isoler les salaisons de l'oxygène et éviter ainsi que le contenu ne pourrisse, même si la quantité de sel employée dans la préparation devait déjà assurer une protection. Il semble par conséquent peu probable de situer le niveau du produit à ras bord du pot. Une partie rigide devait s'intercaler entre la liaison col/ panse et une adjonction de poix devait assurer l'étanchéité du système. Dans ce sens, on remarquera que les exemplaires du Rhône présentent systématiquement des traces de poix interne sur les bords, sans aucune présence d'écailles. Malheureusement aucun bouchon n'a été conservé en place. Seule une corde ou un reste de vannerie retrouvé à l'intérieur du pot $\mathrm{n}^{\circ} 22$ offre une hypothèse intéressante dans la mesure où l'intégralité du contenu halieutique du pot a été conservée (fig. 14). Selon F. Médard ${ }^{40}$, en charge de l'étude des textiles du dépotoir, l'étroitesse de l'ouverture peut plaider pour une disposition intentionnelle du contenu. Ces fragments de cordage n'ont pas pu être prélevés car, sous l'effet de leur propre masse, les éléments imprégnés d'eau et de boue se déchiraient.

Dans le cadre de cette hypothèse, la corde pouvait être imprégnée de poix pour assurer aussi bien la rigidité d'obturation que l'étanchéité de la conserve. La résine pouvait ainsi recouvrir l'ensemble à ras bord du pot. Les découvertes subaquatiques du Rhône ont déjà offert, dans le même secteur de l'épave Arles-Rhône 3, un exemple probant de réutilisation de ces matières modestes réalisées avec les «moyens du bord ${ }^{41}$ : en 2006, un panier constitué de corde, enduite de poix, permettait ainsi de constater que les propriétés de la résine assuraient aussi bien la rigidité des parois verticales du panier que son imperméabilité.

40. Société Anatex.

41. La corde, indispensable aux manœuvres et à l'amarrage du bateau et la résine, assurant l'entretien régulier de l'étanchéité des planches constitutives de la coque, constitue en effet une matière première disponible sur les bateaux.

\subsubsection{Notion de modules}

À partir de cette limite, fixée par conséquent entre la panse et le col, nous avons calculé pour les pots ovoïdes, c'est-à-dire les plus nombreux, les volumes des pots (pl. 6). Les premières mesures réalisées sur 25 pots à partir du logiciel de calcul de volume du site internet de la SFECAG ${ }^{42}$ ont été reportées sur un graphique pour y situer d'éventuelles grappes (fig. 15). Trois modules se différencient alors :

- Module 1 compris entre 0,30 et 0,45 litre

- Module 2 compris entre 0,65 et 1 litre

- Module 3 compris entre 1,70 et 2,25 litres

On remarquera que du module 1 au module 3 la différence entre le pot le plus petit et le plus grand s'accentue. L'écart est de 1 setier pour le module 1, 2 setiers pour le module 2, 4 setiers pour le module 3 . On observe que pour un pot de même hauteur, une légère inflexion de la panse peut augmenter considérablement le volume du contenu. Il semble, par conséquent, peu opportun de multiplier les formats et plus avantageux de suivre l'analyse graphique des grappes. Dans ce cas précis, la mesure de la tare et celle du poids du contenu auraient été plus profitables au consommateur. Néanmoins, aucune inscription peinte ou graffiti n'a permis de trouver les lettres TP de Testa Pondo ${ }^{43}$. De même on ne relève aucun chiffre pouvant spécifier une unité de volume ou de mesure.

\subsection{Potentiel quantitatif des pots du Latium dans le Rhône et conséquence fonctionnelle}

Jusqu'à présent, les différentes campagnes de carte archéologique dans le Rhône et les campagnes de fouille programmée sur l'épave Arles-Rhône 3 avaient permis d'inventorier régulièrement ce type de pots. Dans le cadre de cette étude thématique, l'une des données particulièrement intéressantes de l'opération de relevage d'Arles-Rhône 3 concerne le potentiel quantitatif de ces pots dans le Rhône. Au sein d'une zone limitée à l'emprise sédimentaire du chaland antique, la découverte d'une cinquantaine de pots minimum laisse clairement supposer la présence de plusieurs centaines de pots le

42. http://sfecag.free.fr/contenance.html.

43. La formule $T P$ a été gravée sur des céramiques dites de réserves à Trèves en Germanie Supérieure et à Javols-Anderitum (Lozère) (Marot et al. 2007, p. 325-413) et en tituli picti sur un col d'amphore africaine Schöne-Mau XL trouvé dans le Rhône sur les fouilles du relevage de l'épave Arles-Rhône 3. 
long du Gisement A du Rhône. Peut-on alors reconsidérer la nature fonctionnelle de ces pots ? Doit-on continuer de privilégier l'hypothèse de conserves à destination des marins ou plutôt celle de produits commercialisés sur le port d'Arles ou ailleurs?

\subsubsection{Dotation de bord des marins ou marchandises d'exportation?}

Considérés jusqu'à présent comme de la vaisselle de bord, les quantités observées dans le Rhône permettent aujourd'hui de s'interroger sur une fonction commerciale, non plus seulement en direction des marins, mais vers le territoire du midi de la Gaule. Autrement-dit, peut-on suivre, ou appréhender, une diffusion de ces pots, au-delà des espaces portuaires et des bateaux ?

Un premier constat s'impose. Au regard des contextes de découvertes, l'hypothèse de la vaisselle de bord semble être privilégiée. En dehors de la zone tyrrhénienne de l'Italie ${ }^{44}$, ces pots semblent, en effet, se retrouver exclusivement dans les contextes portuaires (cinq à Fos, trois à Port-La-Nautique, un sur le littoral d'Antibes, un à Agde, six à Marseille, soixante à Arles) ainsi que sur les épaves mais en un seul exemplaire (épave Dramont $\mathrm{D}^{45}$, épave de $\mathrm{Nemi}^{46}$, épave d'Alberti de Lipari ${ }^{47}$ et épaves du chantier de Pise ${ }^{48}$ ).

Les contextes de consommation de la vallée du Rhône (Valence, Saint-Romain-en-Gal, Lyon) ne semblent pas témoigner de leur présence ${ }^{49}$. Les trois pots du Latium découverts à Port-La-Nautique demeurent isolés et ne possèdent aucun parallèle dans les contextes de consommation ${ }^{50}$. Pour Arles, il est toutefois difficile de faire la différence entre les rejets de consommation et ceux du port. Le chantier de fouille-relevage de 2011 a en effet permis de constater qu'une partie des rejets domestiques étaient également précipités dans les eaux du Rhône.

L'absence des pots du Latium dans les contextes de consommation lyonnais et narbonnais indique à priori que ces pots ne remontent pas le Rhône et ne sont pas diffusés sur la côte occidentale de la Narbonnaise. Leur commerce à longue distance pourrait être en revanche orienté essentiellement vers la côte orientale de la

\footnotetext{
44. Olcese 2003, p. 94-95.

45. Joncheray 1974.

46. Ucelli 1940, p. 122.

47. Nous tenons à remercier Jean-Pierre Brun pour ces informations.

48. Camili et al. 2005, p. 95 fig. 7.

49. Informations T. Silvino et A. Desbat que nous remercions.

50. Informations Corinne Sanchez que nous remercions.
}

Narbonnaise. Arles, bien évidemment, avec une soixantaine d'exemplaires circonscrits dans une zone réduite du Rhône, apporte quelque crédit à cette hypothèse. Le port de Marseille, enfin, totalise pour l'instant seulement six pots du Latium, mais ce comptage ne concerne qu'une infime partie des fouilles du chantier Jules Verne ${ }^{51}$. Il est fort probable qu'un examen attentif dans les dépôts municipaux de la ville de Marseille permette d'accroître considérablement ce chiffre.

L'un des indices d'une diffusion commerciale, à prendre avec beaucoup de prudence, pourrait concerner la « reproduction » des pots du Latium dans le registre des céramiques fines. Des formes comparables sont connues, en glaçure plombifère, en Italie à Rome ${ }^{52}$, Luzzi, San Vito (Cosenza) ${ }^{53}$, à Sanremo (Ligurie) ${ }^{54}$; en Sardaigne à Tharros ${ }^{55}$; en Espagne à Mataró ${ }^{56}$; en Syrie (Doura-Europos) ${ }^{57}$; en France à Aix en Provence ${ }^{58}$ et dans un contexte plus tardif à Lyon (Haut-de-SaintJust) ${ }^{59}$. On signalera que deux exemplaires, dont un complet, ont été retrouvés dans le Rhône ${ }^{60}$. Des formes identiques existent également en sigillée africaine A (Atlante I, tav. XXII, n 7).

Une autre remarque concerne l'absence de graffiti, caractéristique de l'appropriation des pots par les marins. Sur aucune des céramiques trouvées à Arles, Narbonne, Marseille, Fos ou encore Antibes, le moindre graffito n'est signalé. Même constat sur les quelques pots du

51. Nous tenons à remercier Manuel Moliner, responsable du service archéologique de Marseille, pour ces informations, certes très approximatives, mais qui recouvrent la réalité de l'ampleur du dépotoir portuaire marseillais.

52. Découverte réalisée dans un dépotoir tardif de la Domus Tiberiana (Meylan Krause 2002, p. 99, pl. 10-11 n $167-173$, pl. 34 $\left.\mathrm{n}^{\circ} 501\right)$.

53. À San Vito (Cosenza) dans la tombe ${ }^{\circ} 14$, de la fin du $\mathrm{I}^{\mathrm{er}} \mathrm{s}$. ap. J.-C. (Guzzo 1974).

54. Datation : fin du I ${ }^{\text {er }}$ s. ap. J.-C. (Guzzo 1974 et Lopez-Mullor 1981).

55. Hayes 1972.

56. Villa romaine de Torre Llauder. Datation : fin du I ${ }^{\mathrm{er}}$ s. (LopezMullor 1981, p. 214-215).

57. Guzzo 1974.

58. ZAC Sextius-Mirabeau Ilot F., datation : fin $\mathrm{I}^{\mathrm{er}}-$ milieu $\mathrm{II}^{\mathrm{e}} \mathrm{s}$. (informations inédites communiquées par Núria Nin, responsable du service archéologique de la ville d'Aix-en-Provence).

59. Datation : fin $\mathrm{II}^{\mathrm{e}}$-début $\mathrm{III}^{\mathrm{e}}$ (Desbat 1986).

60. Djaoui 2011, p. 75. Nous tenons à remercier Pauline Gohier, doctorante de l'Université d'Aix-Marseille, pour m'avoir renseigné sur ces différentes attestations en glaçurée plombifère. Pour P. Gohier, qui doit soutenir une thèse sur La céramique à glaçure plombifère du Haut-Empire en France méditerranéenne, les datations de Mataró et Luzzi (et peut-être de Tharros) doivent être prises avec prudence car elles sont basées sur celles de Sanremo. 
Latium découverts à bord des épaves. Ce constat, pour le moins étonnant, va à l'encontre du témoignage fourni par les sigillées italiques et hispaniques assimilées dans le Rhône, avec quelques certitudes, à de la vaisselle de bord, et qui portent le plus souvent les marques de leur appropriation fonctionnelle (dessin d'ancre, de proue de bateau, de feuille de fougère, tria nomina...). De la même façon, et plus proche de la fonction des pots du Latium, les pots dénommés «pot de barque » ou encore «trapus » sont assez régulièrement gravés sur leur carène ${ }^{61}$. Sur 18 de ces pots trouvés dans le Rhône, on dispose d'au moins cinq graffiti.

On notera enfin que les trois modules prédéfinis se déclinent dans des volumes relativement peu importants. Les modules 1 , compris entre 0,30 et 0,45 litre semblent désigner plutôt des quantités unitaires dont il serait assez surprenant d'en faire le commerce. Pour les modules 2 et 3, il est impossible de se prononcer. La qualité et/ou la rareté du produit pourrait être un argument commercial pour en écouler des petites quantités. Or, pour l'exemple de l'allec, on constate que ce produit est plutôt décrié dans les textes antiques. Caton, en l'absence d'olives, en donne à ses esclaves ${ }^{62}$, Martial l'associe à des aliments sans valeur ${ }^{63}$ et Plaute s'en sert pour proférer des insultes ${ }^{64}$. Au temps de Pline l'Ancien, il semblerait pourtant que ce produit gagne en notoriété, à l'image de la mention Hallex optimum inscrit sur plusieurs conteneurs de Pompéi ${ }^{65}$. Mais, jusqu'à présent, aucune épave ne semble témoigner d'une cargaison, même secondaire, constituée de pots, qu'il s'agisse des pots du Latium ou d'autres conteneurs assimilés.

\section{Conclusion}

La découverte d'une soixantaine de pots du Latium dans le Rhône a été l'occasion d'amorcer une étude préliminaire sur l'identification de leur contenu. Une première observation de la paroi interne des exemplaires complets et/ou entiers a permis de constater que sur 18 exemplaires 16 d'entre eux contenaient des restes de

61. Ces pots, systématiquement poissés, sont retrouvés aussi bien sur des épaves que dans les contextes portuaires, dans une zone géographique située entre Arles et Fréjus, et ce durant une période limitée à la deuxième moitié du ${ }^{\mathrm{er}}$ siècle ap. J.-C. Selon Lucien Rivet qui a réalisé une première étude sur ce matériel, ces pots de faible consommation étaient en priorité destinés « aux gens de mer » (Rivet 2006, p. 637).

62. Caton, Agr. 58.

63. Martial, III, 77, 5.

64. Plaute, Poen. 1310, « hallec uiri ».

65. CIL IV, 5717-5719, 9407 et 9410. poisson. À ces données s'ajoutent 12 autres pots dont la poix a conservé la présence d'écailles.

Ces résultats corroborent ainsi les attestations halieutiques de Pompéi et Narbonne et permettent d'assigner à ces pots un contenu spécifique à base de poisson. Les analyses ichtyologiques réalisées sur les pots de PortLa-Nautique et d'Arles ont également permis de préciser que le produit était constitué, dans les deux cas, de petits poissons. Ce constat semble se vérifier par les tituli picti indiquant pour le Rhône des sardines et de la vive, et pour Pompéi, de l'hallex, dont Pline indique justement qu'il était constitué de «pisciculo minimoque » ${ }^{\mathbf{6}}$.

Compte tenu de ces résultats, les mentions d'olive et d'oignon, portées sur deux des pots du Rhône, évoquent des recettes constituées à base de poisson. Cette hypothèse s'accorde avec la présence de restes de poisson dans le pot portant la mention Cepa.

Ces résultats montrent également que ce conteneur définissait bien un contenu spécifique. Leur vocation commerciale reprendrait ainsi la valeur sémantique des amphores avec toutefois une vente qui n'était pas forcément destinée à l'exportation mais plutôt à destination des marins. La découverte de ces conserves en Gaule méridionale dans les contextes portuaires et sur les épaves correspond vraisemblablement à la dotation de bord des bateaux. La quantité importante de pots trouvée dans le Rhône, et dans une moindre mesure dans le port de Marseille, suggère que cette communauté professionnelle devait constituer des clients privilégiés pour écouler ces denrées.

Fort de ces données quantitatives, ichtyologiques et épigraphiques, il est tentant de dégager un premier schéma commercial. L'origine de certains poissons, que ce soit l'alose ou les sprats, situe le domaine de pêche dans une zone d'estuaire que l'on placerait volontiers à l'embouchure du Tibre. Dans ses filets, les plus jeunes poissons, que ce soient les alevins de sardines, les anchois, les sprats, les aloses, les soles, les plus petits maquereaux ou encore les vives étaient peu exploitables en salaisons dans des amphores ${ }^{67}$. De plus, la concurrence avec les produits de Bétique, dont témoigne le peu d'exportations des Dressel 21/22 en dehors de

\footnotetext{
66. XXXI, 44, 97.

67. Ulrike Ehmig mentionne les inscriptions peintes ALLEX/ HALLEX sur des amphores de Bétique (Ehmig 1996 p. 31 tab. 2). On note également la présence de tituli picti secondaires mentionnant ALLEX sur une amphore Haltern 70 trouvée à Cologne (Ehmig 2009 p. 31 tab. 2). Néanmoins ces exemples restent très rares.
} 
l'Italie $^{68}$, était une donnée non négligeable pour s'engager dans la production et la commercialisation d'un contenu halieutique en amphore. Ces petits poissons, qualifiés par Pline de « peu de valeur ${ }^{69}$ pouvaient ainsi constituer la matière première d'un produit plus élaboré, voire de luxe ${ }^{70}$ dont le conditionnement exigeait un conteneur spécifique. Pour les producteurs, ce produit halieutique pouvait alimenter un marché potentiel énorme, constitué de milliers de marins. Au final, la confection du produit réclamait des pots, des petits poissons, quelques condiments et du sel. À partir de là, une chaîne opératoire pouvait s'enclencher en sélectionnant, pour certains pots, des petits poissons, avec du sang issu d'une découpe précise de la tête de plus gros poissons, et pour d'autres pots, des salaisons, dont il est très probable que les mêmes poissons étêtés et vidés de leur sang du premier pot étaient, par la suite, « recyclés » dans un deuxième $\operatorname{pot}^{71}$. Un tel commerce nécessitait une logistique importante. Il fallait se procurer les pots, acheter le poisson, conserver le sel et les aromates, trier les poissons, que ce soit par taille ou par espèce, et organiser la préparation du produit. Pour finir, les pots ainsi préparés devaient être stockés au moins deux semaines pour assurer la décomposition du produit.

À partir de là des négociants pouvaient assurer la vente sur place, que ce soit à Rome, où le poisson frais pouvait facilement être acheminé, ou encore à Ostie. Dans ce schéma théorique et compte tenu de la vocation halieutique des pots du Latium, l'éloignement géographique de l'atelier de Sutri, placé à $40 \mathrm{~km}$ au nord de Rome, exigeait alors un transport vide des pots jusqu'à Rome $^{72}$.

On soulignera enfin que si l'hypothèse d'une dotation de bord est clairement privilégiée, la quantité importante de pots du Latium permet d'ancrer dans le port d'Arles, et pour la période flavienne, des centaines de bateaux en provenance d'Italie, majoritairement d'Ostie ${ }^{73}$. Mais

68. Botte 2009.

69. XXXI, 44.96 : « ex inutili ».

70. XXXI, 44. $100:$ : Transiit deinde in luxuriam».

71. Les analyses ichtyologiques des autres pots du Rhône pourront peut-être nous renseigner sur de telles pratiques.

72. La production et la circulation de la céramique dans la moyenne vallée de Tibre à l'époque impériale a permis de montrer que les céramiques produites en Étrurie du Sud était exportées dans la ville de Rome (Bousquet et al. 2004). De plus, on ne peut pas ignorer la possibilité que des ateliers étaient implantés à proximité des zones de confection du produit.

73. En dehors des communes et des culinaires régionales, les pâtes claires et siliceuses des ateliers du Latium (Sutri et La Celsa) constituent la catégorie la mieux représentée des importations rhodaniennes (Long et al. 2009). quel type de produit était exporté à partir de l'Italie ? Les quelques amphores Dressel 2/4 italiennes trouvées dans le Rhône ne permettent pas d'y déceler un véritable commerce. Pour une chronologie précoce, située entre le changement d'ère et Tibère, on peut bien évidemment envisager le passage des bateaux citernes chargés de commercialiser le vin italien dans des dolia $^{74}$. De la même façon et pour une chronologie plus tardive, bien que difficile à établir, l'importation en tonneaux de produits d'Italie peut également être envisagée ${ }^{75}$. Cependant, l'usage de ces derniers n'est que supposé et non attesté en Italie centrale et, selon les spécialistes, les navires à dolia n'ont navigué que pendant une courte période, située entre le changement d'ère et la première moitié du I ${ }^{\text {er }}$ s. ap. J.-C. ${ }^{76}$ Mais ne peut-on pas également $\mathrm{y}$ voir les vestiges d'un commerce de redistribution à partir des ports de Rome ? Dans cette hypothèse, l'étude des amphores orientales, dont un premier inventaire a été réalisé avec l'aide de Séverine Lemaître, a permis de comptabiliser plus d'une centaine d'individus de 17 types différents dont $41 \%$ viennent de Crète. À ce niveau de l'étude, cette hypothèse pourrait expliquer le contraste entre des céramiques communes orientales, quasi anecdotiques dans le Rhône, et la présence relativement importante d'amphores crétoises présentes aussi bien à Arles, Lyon qu'aux frontières septentrionales de l'Empire ${ }^{77}$. On remarquera que d'autres produits importés comme les marbres pourraient expliquer également la présence de ces bateaux ${ }^{78}$. Le marbre blanc de Carrare ainsi que celui coloré, issu des mêmes carrières (Le Turquin), ou encore ceux d'Asie Mineure, de Grèce ou d'Égypte, présents en fragments dans le dépotoir portuaire, et dans les différents sites antiques d'Arles, pourraient également attester d'un commerce en partance des ports de Rome ${ }^{79}$.

74. Marlier 2008. Tel est l'avis de M.-B. Carre et Fr. Cibecchini, exprimé lors d'une table-ronde sur les dolia, organisée à Lattes les 26 et 27 septembre 2013.

75. Djaoui, Tran à paraître.

76. Tel est l'avis de Fr. Cibecchini, exprimé lors d'une table-ronde sur les dolia, organisée à Lattes les 26 et 27 septembre 2013.

77. Lemaître 2000, Lemaître 2005.

78. À l'extrémité du lobe de l'embouchure du Rhône, trois épaves chargées de six à sept blocs de marbre de quatre tonnes chacun confirment la diffusion rhodanienne des marbres méditerranéens (Long, Picard 2009, p. 250).

79. Informations tirées du rapport d'opération de 2011 sur le chantier de fouille-relevage de l'épave Arles-Rhône 3. L'étude sur les marbres colorés du Rhône a été réalisée par Delphine Remeau (doctorante en Archéologie à l'Université Paul Valéry-Montpellier III). 


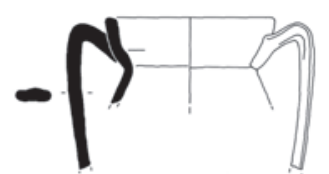

1
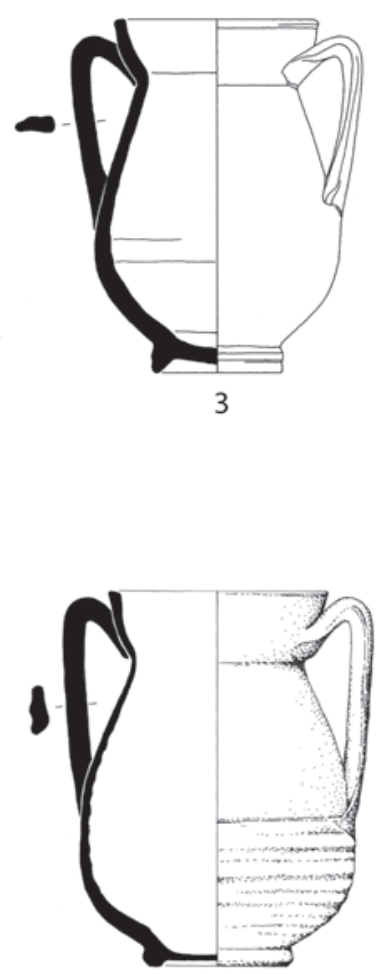

6

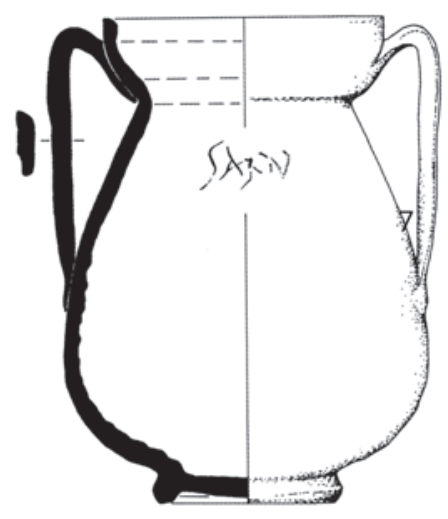

9
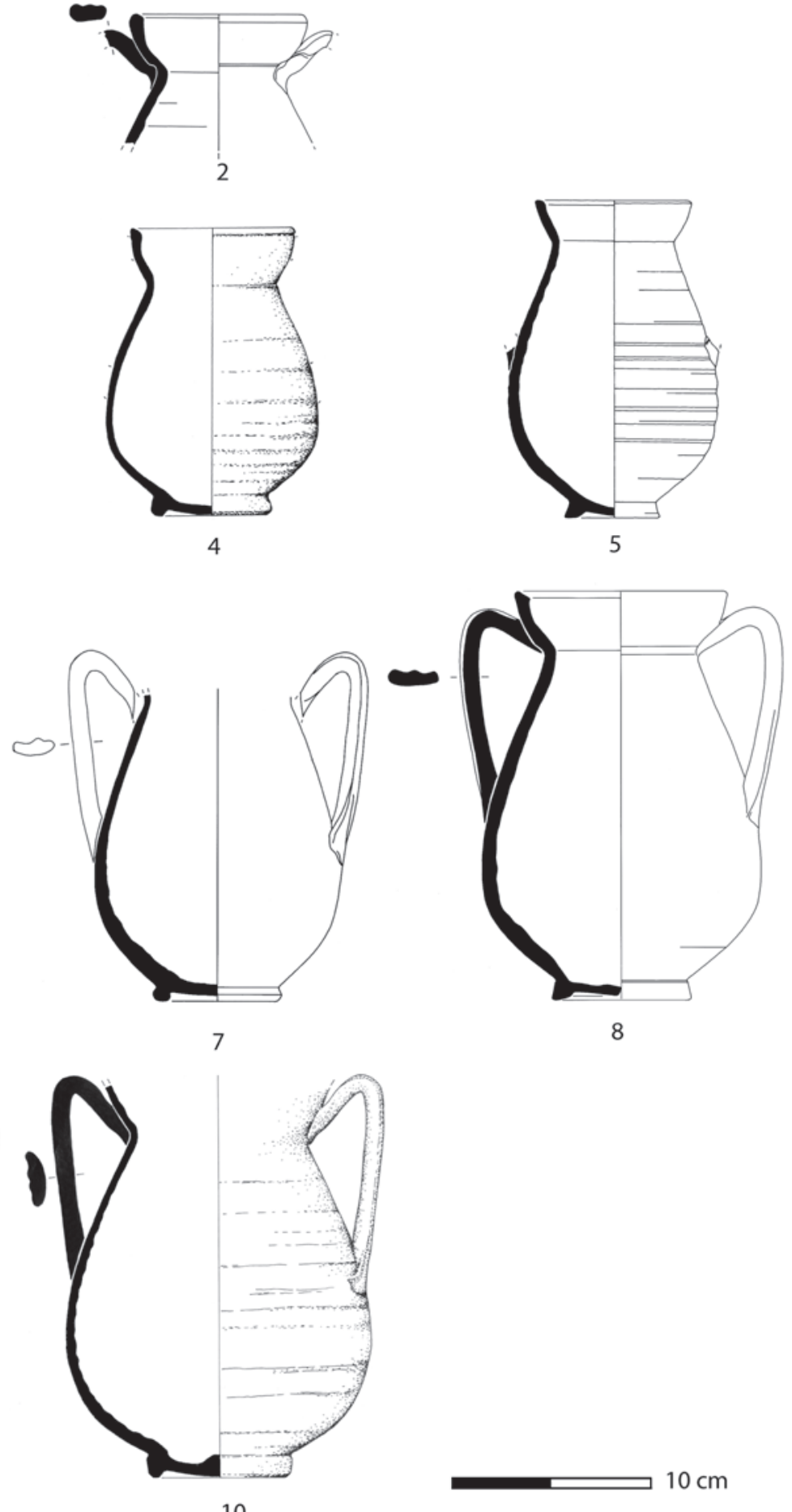

10

Planche 1. Pots du Latium piriformes, fouilles du Rhône (dessins A. Véléva, DAO D. Djaoui). 


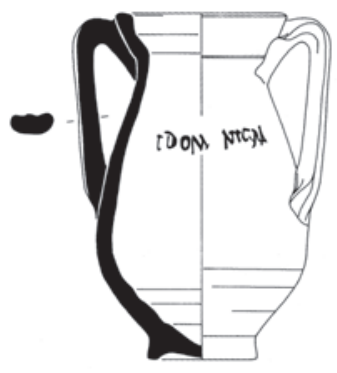

11

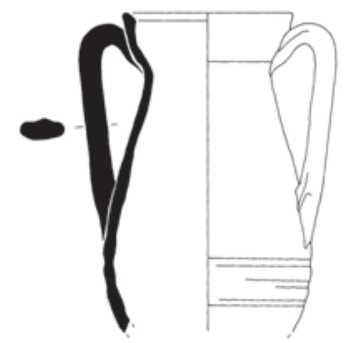

12
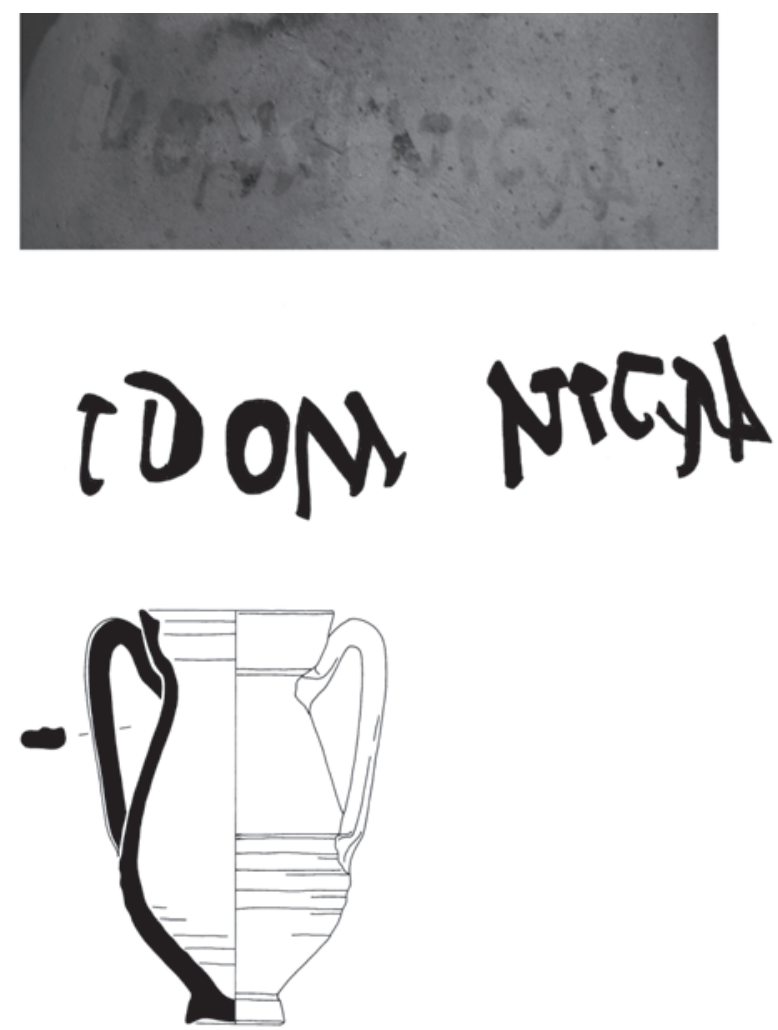

13

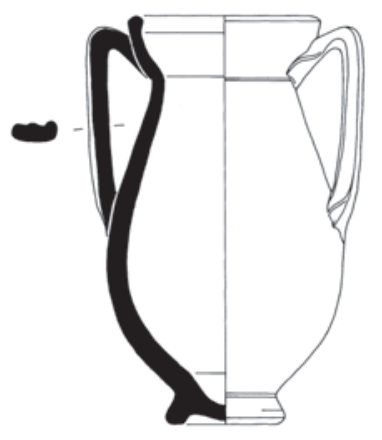

14

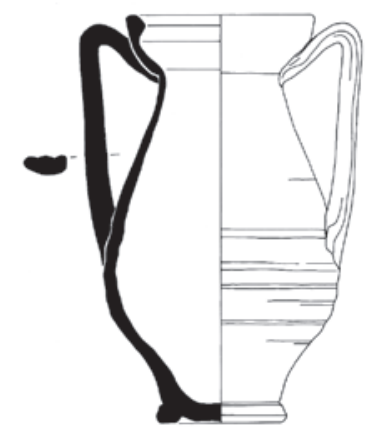

15

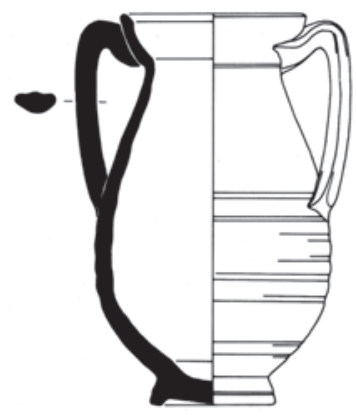

16

$10 \mathrm{~cm}$

Planche 2. Pots du Latium de module 1, fouilles du Rhône (dessins A. Véléva, DAO D. Djaoui). 

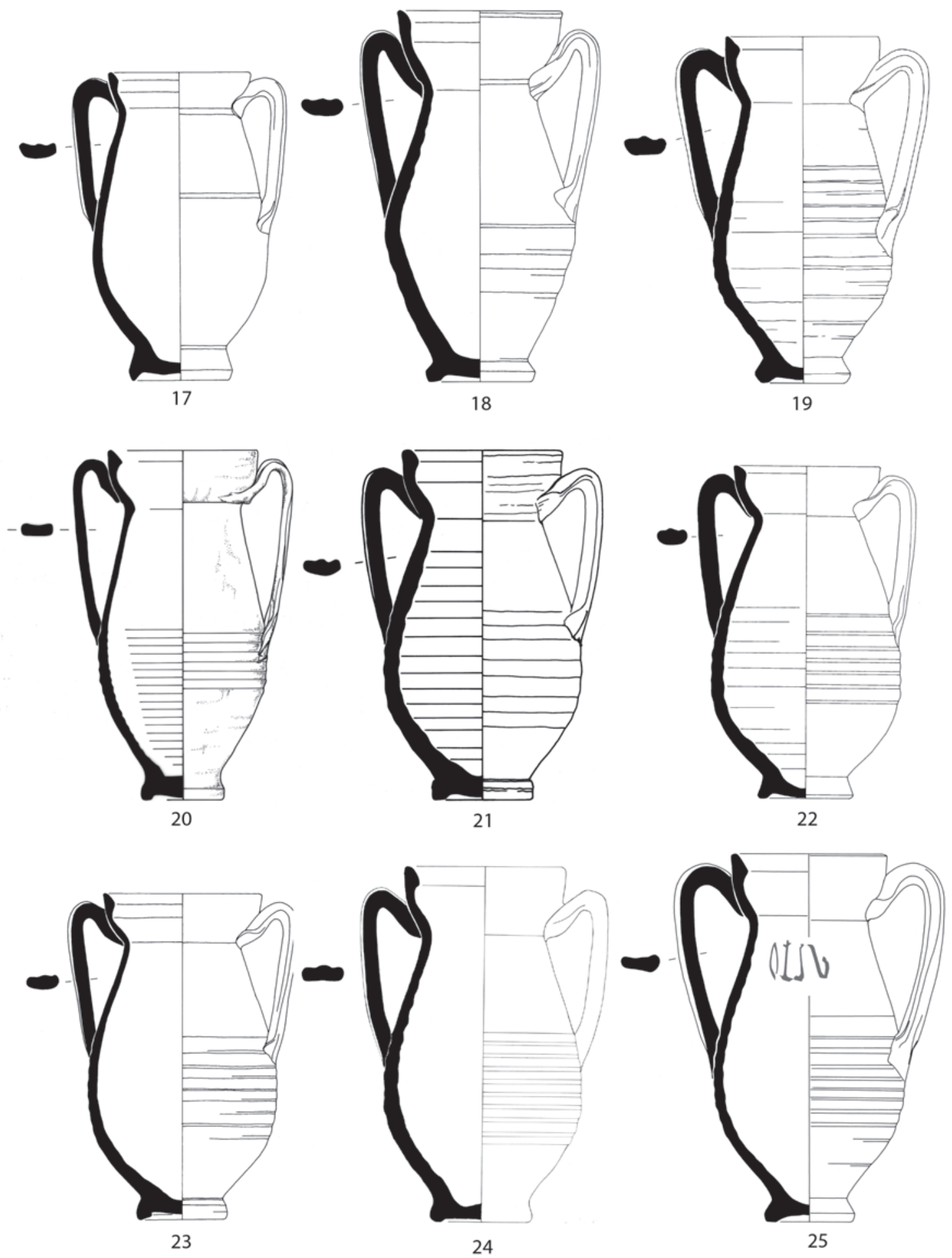

$10 \mathrm{~cm}$

Planche 3. Pots du Latium de module 2, fouilles du Rhône (dessins A. Véléva, DAO D. Djaoui). 

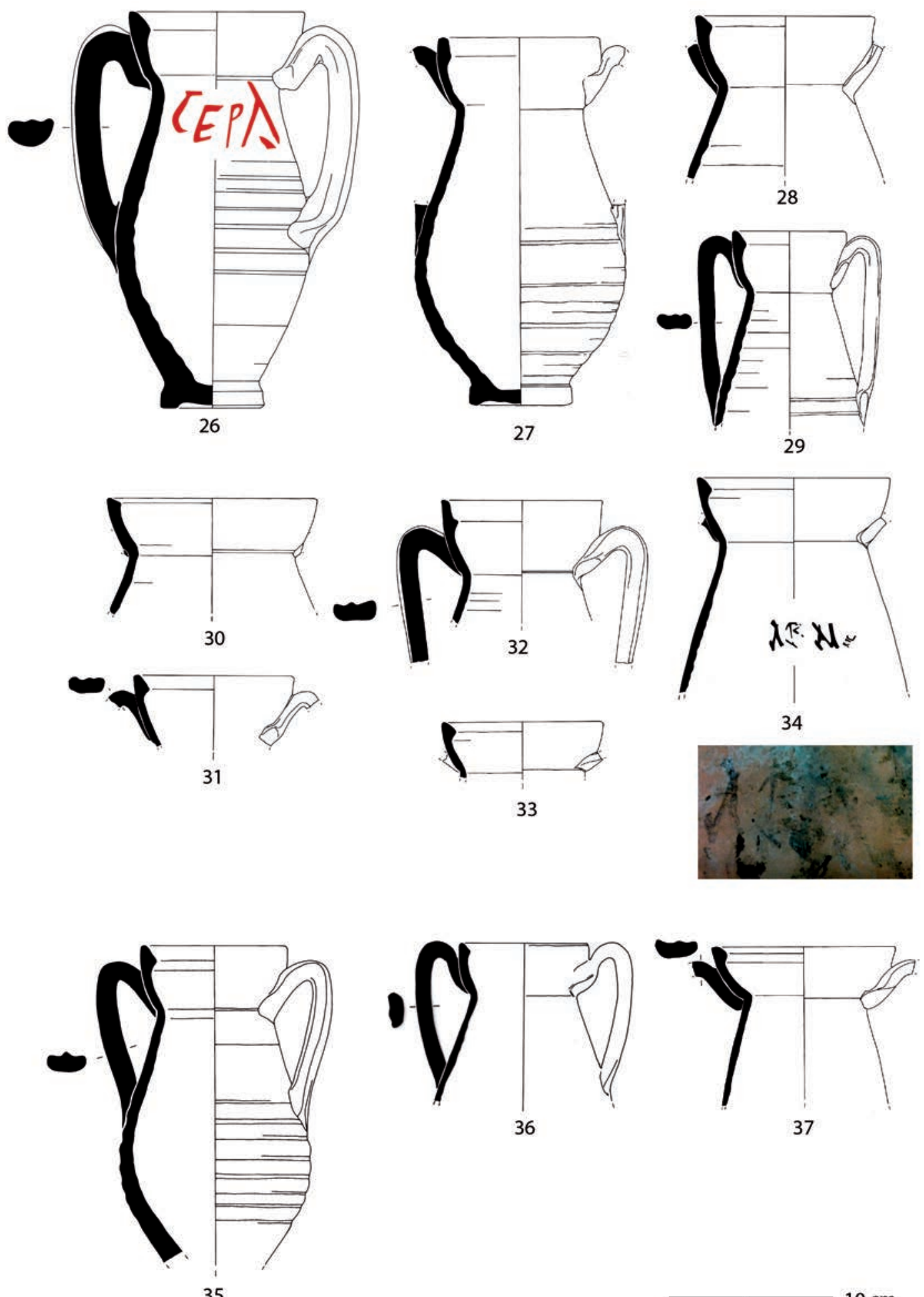

$10 \mathrm{~cm}$

Planche 4. Pots du Latium de module 2, fouilles du Rhône (dessins A. Véléva, DAO D. Djaoui). 


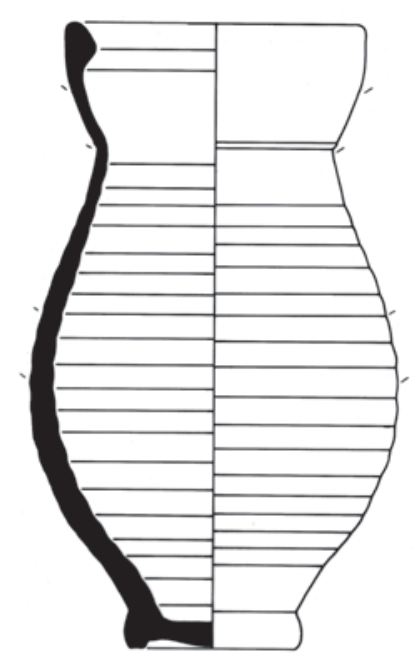

38

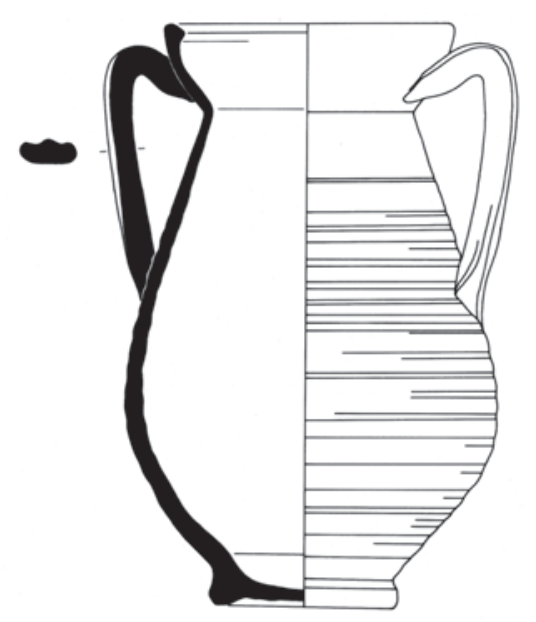

40

$10 \mathrm{~cm}$

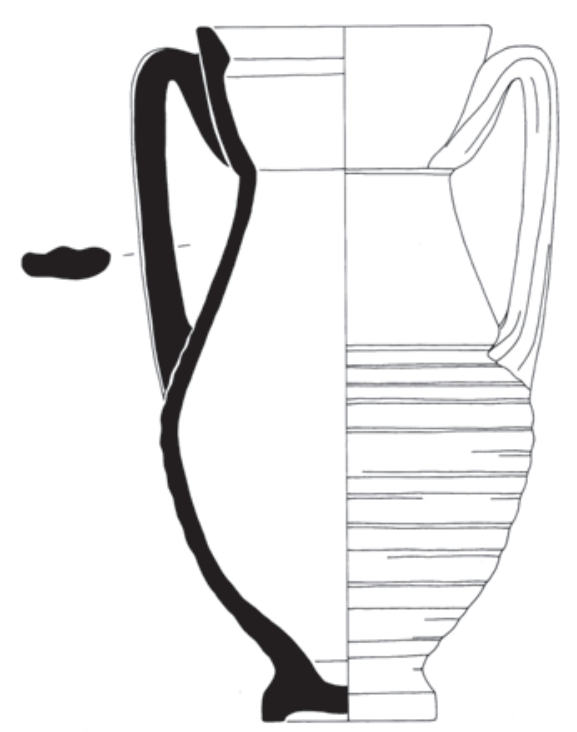

39
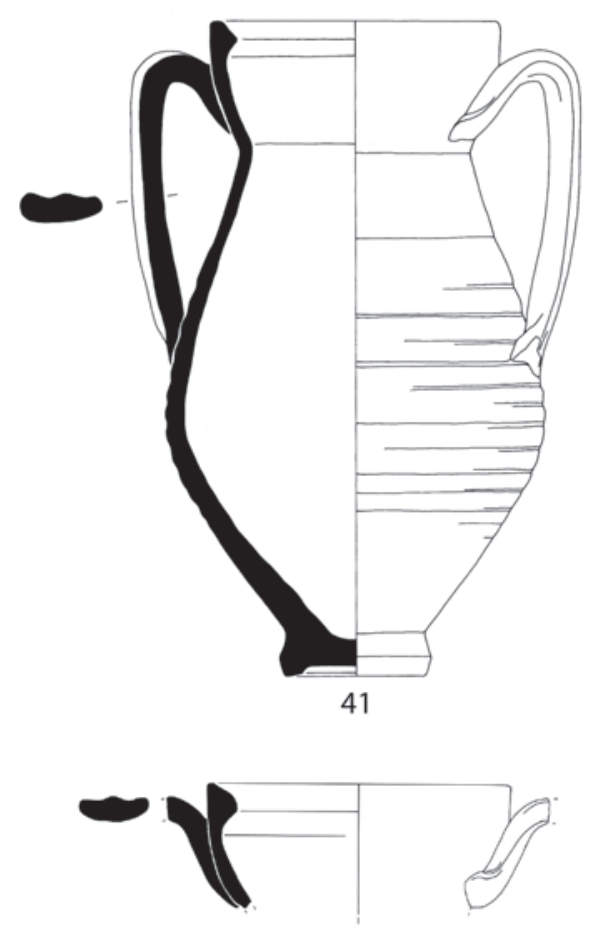

42

Planche 5. Pots du Latium de module 3, fouilles du Rhône (dessins A. Véléva, DAO D. Djaoui). 

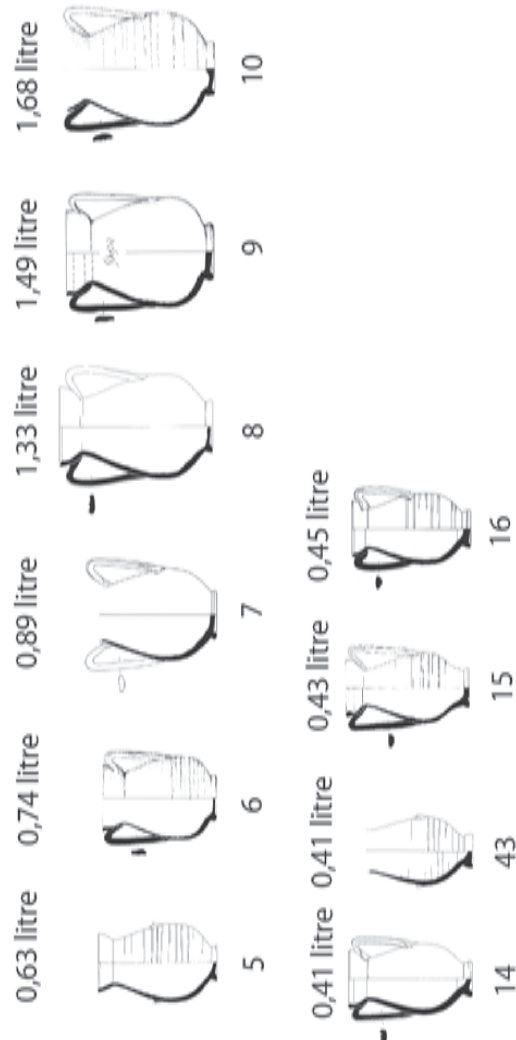

旁

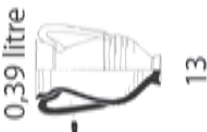

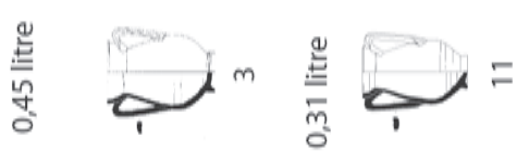

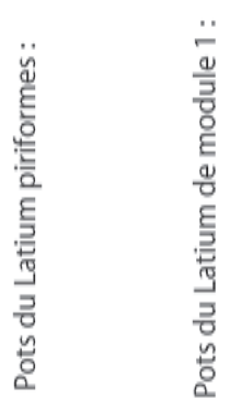

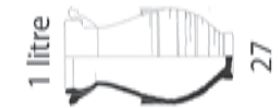
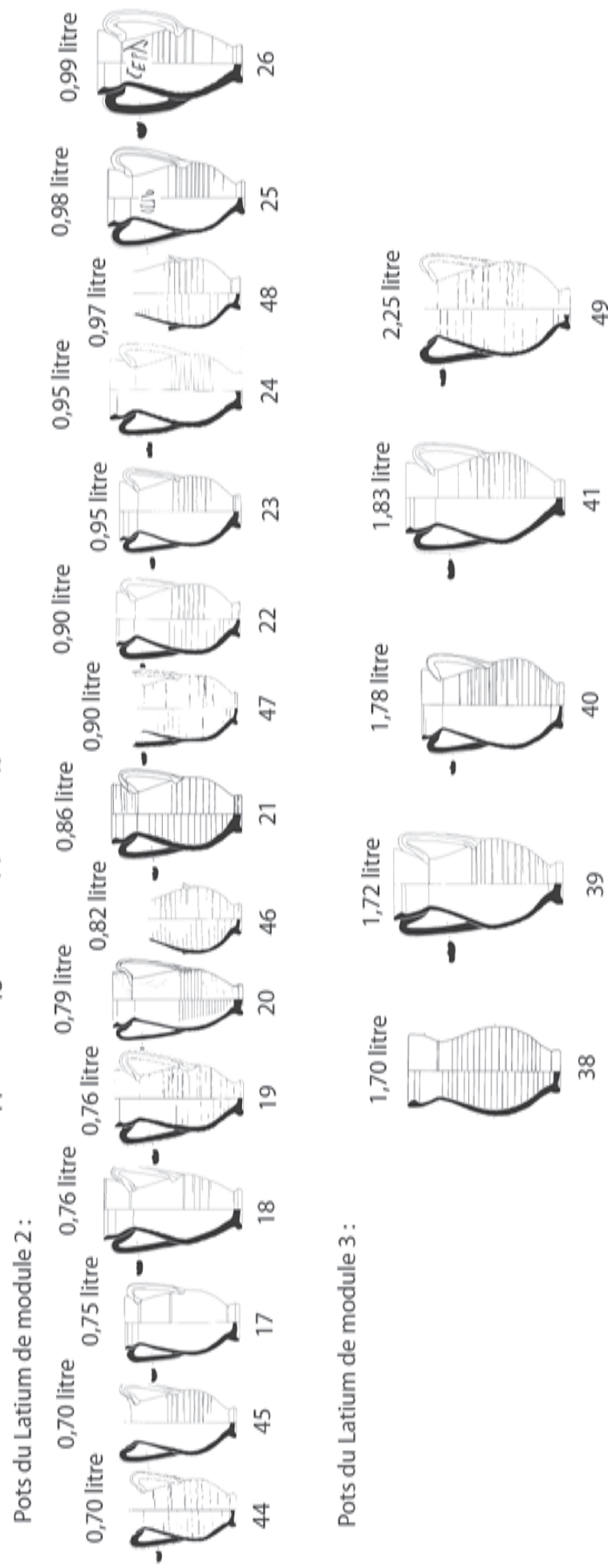


\section{Bibliographie}

Albrecht 1998 : ALBRECHT (P.-A.) - Note sur un lot de pots à provision du III ${ }^{\mathrm{e}}$ siècle apr. J.-C. contenant des olives du Picenum découvert à Bliesbruck (Moselle). In : Rivet (L.) (ed.), SFECAG, Actes du Congrès d'Istres (1998), Marseille, 1998, p. 321-328.

Atlante I : CARANDINI (A.) (dir.) - Atlante delle forme ceramiche, I, Ceramica fine romana nel bacino mediterraneo (medio e tardo impero), Enciclopedia dell'arte antica classica e orientale, Rome, Enciclopedia Italiana, 1981

Bagini 1992 : BAGINI (M.) - La ceramica invetriata campano laziale in Liguria, RStudLig, 58, 1992, p. 131-146.

Bats 2010 : BATS (M.) 2010 - Une lettre sur plomb à Lattes, Lattara, 21, p. $749-756$.

Berti et al. 1970 : BERTI (F.), CARANDINI (A.), FABBRICOTTI (E.) Ostia II, Le terme del Nuotatore, Scavo dell'ambiente I, Rome, Studi Muscellanei, 16, 1970.

Bertoldi 2012 : BERTOLDI (T.) - Ceramiche comuni dal suburbio di Roma, Univeristà di Roma, Studi di Archeologia, 1, 2012.

Bertrand 1992 : BERTRAND (E.) - Les amphores d'un vide sanitaire du $\mathrm{I}^{\text {er }}$ siècle à Lyon (Saint-Just). In : Rivet (L.) (ed.), SFECAG, Actes du Congrès de Tournai (1992), Marseille, 1992, p. 265-277.

Bohn 1926: BOHN (O.) - Pinselschriften auf Amphoren aus Augst und Windisch, Anzeiger für Schweizerische Altertumskunde, XXVII, p. 197-212.

Botte 2009 : BOTTE (E.) - Salaisons et sauces de poissons en Italie du sud et en Sicile durant l'Antiquité, Naples, CJB, coll. CJB, 31, Archéologie de l'artisanat antique, 1, 2009.

Bousquet et al. 2004 : BOUSQUET (A.), FELICI (F.), ZAMPINI (S.) Produzione e circolazione del materiale ceramico nella media valle del Tevere in epoca imperiale e tardoantica. In : Coarelli (F.), Patterson (H.) (eds), Mercator Placidissimus, The Tiber Valley in Antiquity, New research in the upper and middle river valley (Rome, 27-28 february 2004), Rome, Edizioni Quasar/ British School at Rome-Università di Perugia, 2004, p. 621-654.

Braemer et al. 2012: BRAEMER (F.), PASQUALINI (M.), PELLEGRINO (E.) - La céramique commune de Marseille à Gènes. Productions locales et importées (II ${ }^{\mathrm{e}}$ av. J.-C.-III ${ }^{\mathrm{e}}$ ap.). Apports à la connaissance des catégories fonctionnelles, faciès de consommation, modes d'approvisionnement, organisation des productions. In : Batigne Vallet (C.) (ed.), Les céramiques communes dans leur contexte régional, faciès de consommation et mode d'approvisionnement, Actes de la table ronde organisée à Lyon (2009), Lyon, CNRS, Travaux de la Maison de l'Orient et de la Méditerranée, 60, p. 71-85.

Bruni 2000 : BRUNI (S.) - Le navi antiche di Pisa, Firenze, Edizioni Polistampa, 2000.

Camilli et al. 2005 : CAMILLI (A.), REMOTTI (E.), BARRECA () - Cibi, derrate alimentari e commerci dal contesto delle navi antiche di Pisa. In : Cibi e Sapori nel Mondo Antico, Sillaben musée de Florence, 2005, p. 92-97.
Carandini, Panella 1973 : CARANDINI (A.), PANELLA (C.) - Ostia III, Le terme del Nuotatore di Ostia, Rome, StuMisc, 21, 1973.

Colls et al. 1977: COLLS (D.), ETIENNE (R.), LEQUEMENT (R.), LIOU (B.), MAYET (F.) - L'épave de Port Vendres II et le commerce de la Bétique à l'époque de Claude, Paris, CNRS, Archaeonautica, 1, 1977.

Dangreaux, Desbat 1987 : DANGREAUX (B.), DESBAT (A.) - Les amphores du dépotoir flavien du Bas-de-Loyasse à Lyon, Gallia, 45, 1987, p. 115-153.

Desbat 1986 : DESBAT (A.) - Céramiques à glaçure plombifère des fouilles de Lyon (Hauts-de-Saint-Just, rue des Farges, La solitude), Figlina, 7, 1986, p. $105-124$.

Desbat 2004: DESBAT (A.) - Le commerce des vins à Ludgunum. In : Brun (J.-P.), Poux (M.), Tchernia (A.) (eds), Le Vin, Nectar des Dieux, Génie des hommes, Lausanne, Pôle Archéologie du Département du Rhône, 2004, p. 254-263.

Desse-Berset, Desse 2000 : DESSE-BERSET (N.), DESSE (J.) - Salsamenta, garum et autres préparations de poissons. Ce qu'en disent les os, MEFRA, 112, 1, 2000, p. 73-97.

Di Giovanni 1996 : DI GIOVANNI (V.) - Produzione e consumo di ceramica da cucina nella Campania romana (II a.C.-II d.C.). In : Bats (M.) (ed.), Les céramiques communes de Campanie et de Narbonnaise ( $I^{\mathrm{er}} s$. av. J.-C. $-I^{\mathrm{e}}$ s. ap. J.-C.), La vaisselle de cuisine et de table, Actes des Journées d'étude (Naples 1994), Naples, CJB, coll. CJB, 14, 1996, p. 65-104.

Djaoui 2009 : DJAOUI (D.) - Les céramiques fines et diverses. In : Long (L.), Picard (P.) (eds), César. Le Rhône pour mémoire, Arles, Actes Sud/MDAA, 2009, p. 300-303.

Djaoui 2011 : DJAOUI (D.) - Interprétation des masses amphoriques recouvrant l'épave Arles-Rhône 3. In : Djaoui et al. 2011, p. 56-117.

Djaoui et al. 2011 : DJAOUI (D.), GRECK (S.), MARLIER (S.) (eds) Arles-Rhône 3, Le naufrage d'un chaland antique dans le Rhône, enquête pluridisciplinaire, Actes Sud, Arles, 2011.

Djaoui, Tran à paraître : DJAOUI (D.), TRAN (N.) - Une cruche du port d'Arles et l'usage d'échantillons dans le commerce de vin romain, MEFRA, 126-2, à paraître.

Ehmig 1996 : EHMIG (U.) - Garum für den Statthalter. Eine Saucenamphore mit Besitzeraufschrift aus Mainz, Mainzer Archäologische Zeitschrift, 3, 1996, p. 25-56.

Ehmig 2006 : EHMIG (U.) - Die Oliven ins Töpfchen - Pinselaufschriften auf Töpfchen in Mainz und dem Mainzer Umland und Begriff penuarium auf römischen Amphoren, Xantener Berichte, 14, 2006, p. 73-80.

Ehmig 2009 : EHMIG (U.) - Tituli Picti auf Amphoren in Köln II, Kölner Jahrbuch, 42, 2009, p. 393-445.

Étienne, Mayet 2002 : ÉTIENNE (R.), MAYET (F.) - Salaisons et sauces de poissons hispaniques, Paris, De Boccard, 2002. 
Gasperetti 1996 : GASPARETTI (G.) - Produzione e consumo della ceramica da mensa e dispensa nella Campania romana. In : Bats (M.) (ed.), Les céramiques communes de Campanie et de Narbonnaise ( ${ }^{\mathrm{er}} \mathrm{s}$. av. J.-C. $-\mathrm{II}^{\mathrm{e}} \mathrm{s}$. ap. J.-C.), La vaisselle de cuisine et de table, Actes des Journées d'étude (Naples, 1994), Naples, CJB, coll. CJB, 14, 1996, p. 19-63.

Guzzo 1974 : GUZZO (P. G.) - Luzzi. Località S. Vito (Cosenza). Necropoli di età romana, NSc, XXVIII, 1974, p. 449-470.

Hayes 1972 : HAYES (J. W.) - Late Roman Pottery, Londres, 1972.

Joncheray 1974 : JONCHERAY (J.-P.) - Étude de l'épave Dramont D, dite « des pelvis », Cahiers d'Archéologie subaquatique, 3, 1974, p. 21-48.

Lemaitre 1995 : LEMAITRE (S.) - Les importations d'amphores orientales à Lyon de l'époque augustéenne au début du III' ${ }^{\mathrm{e}}$ siècle ap. J.-C., Étude préliminaire. In : Rivet (L.) (ed.), SFECAG, Actes du Congrès de Rouen (1995), Marseille, 1995, p. 195-205.

Lemaitre 1998 : LEMAITRE (S.) - Note sur les importations de vins de Méditerranée orientale à Lyon sous le Haut Empire, In : El Vi a l'Antiguitat. Economia, producció i comerç al Mediterrani occidental, Actas del II colloqui d'arqueologia romana Badalona, 1998, p. 163-167.

Lequément, Massy 1980 : LEQUEMENT (R.), MASSY (J.-C.) - Importation à Soissons d'olives au defrutum en provenance de Bétique, Cahiers Archéologique de Picardie, 7, 1980, p. 263-266.

Liou, Rodriguez Almeida 2000 : LIOU (B.), RODRÍGUEZ ALMEIDA (E.) - Les inscriptions peintes des amphores du Pecio Gandolfo (Almería), MEFRA, 112-1, 2000, p. 7-25.

Long et al. 2006 : LONG (L.), PITON (J.), DJAOUI (D.) - Le dépotoir d'Arles sous le Haut-Empire, Fouilles subaquatiques du Rhône, Gisement A (I ${ }^{\mathrm{er}}-\mathrm{II} \mathrm{e}^{\mathrm{e}}$ siècle ap. J.-C.). In : Rivet (L.) (ed.), SFECAG, Actes du congrès de Pézenas 2006, Marseille, 2006, p. 579-588.

Long et al. 2009 : LONG (L.), PITON (J.), DJAOUI (D.) - Les céramiques communes des gisements du Rhône à Arles, le faciès portuaire d'époque impériale. In : Pasqualini (M.) (ed.), Les céramiques communes d'Italie et de Narbonnaise, Structures de production, typologies et contextes inédits (II $S$. av. J.-C. - III s. ap. J.-C.) , Actes de la table ronde de Naples (2-3 novembre 2006), Naples, CJB, coll. CJB, 30, p. 569-614.

Lopez Mullo 1981 : LOPEZ MULLOR (A.) - Notas para una classificacion de los tipos mas frecuentes de la ceramica vidriada romana en Cataluna, Ampurias, 43, 1981, p. 201-215.

Marangou-Lerat 1995 : MARANGOU-LERAT (A.) - Le vin et les amphores de Crète, de l'époque classique à l'époque impériale, Paris, De Boccard, Études crétoises, 30, 1995.

Marlier 2009 : MARLIER (S.) - Architecture et espace de navigation des navires à dolia, Archaeonautica, 15, 2009, p. 153-173.

Marot $\boldsymbol{e}$ t al. 2007: MAROT (E.), FABRE (L.), FERDIERE (A.), MARTIN (M.), POUPON (F.), PILLAULT (S.) - Une resserre incendiée au début du $\mathrm{II}^{\mathrm{e}}$ ap. J.-C. à Javols-Anderitum (Lozère), RAN, 40, 2007, p. $325-413$.

Martin 2009: MARTIN (M.) - Les céramiques sigillées. In : Long (L.), Picard (P.) (eds), César, le Rhône pour mémoire, Actes Sud/MDAA, Arles, 2009, p. 304-318.

Martin-Kilcher 1994 : MARTIN-KILCHER (S.) - Die Römischen Amphoren aus Augst und Kaiseraugst, 3 : Archäologische und naturwissenchaftliche
Tonbestimmungen, Augst, Römermuseum, Forschungen in Augst, band 7, 1994.

Marty 2002: MARTY (F.) - Aperçu sur les céramiques à pâte claire du golfe de Fos. In : Rivet (L.), Sciallano (M.) (eds), Vivre produire et échanger: reflets méditerranéens. Mélanges offerts à Bernard Liou, Montagnac, Mergoil, Archéologie et Histoire Romaine, 8, 2002, p. 201-220.

McCann, Oleson 2004 : McCANN (A.M.), OLESON (J.P.) - Deep-water shipwrecks off skerki bank: the 1997 survey, Journal of Roman archaeology, Suppl. 58, 2004.

Meylan Krause 2002 : MEYLAN KRAUSE (M.-F.) - Domus Tiberiana, analyses stratigraphiques et céramologiques. Fouilles 1984-1987, BAR, International Series 1058, 2002

Olcese 1993: OLCESE (G.) - Le ceramiche comuni di Albintimilium. Indagine archeologica e archeometrica sui materiali dell'area del Cardine, Firenze, Ed. Giglio, 1993.

Olcese 2003: OLCESE (G.) - Ceramiche comuni a Roma $e$ in area romana: produzione, circolazione e tecnologia (tarda età repubblicanaprima età imperiale), Mantova, Società Archeologica Padana, Documenti di Archeologia, 28, 2003.

Panella 2001 : PANELLA (C.) - Le anfore di età imperiale nel Mediterraneo occidentale, Céramiques hellénistiques et romaines, III. Paris, Presses Universitaires Franc-Comtoises, 2001, p. 177-275.

Papi 1985 : PAPI (E.) - Ceramica comune. In : Ricci (A.) (ed.), Settefinestre. Una villa schiavistica nell'Etruria romana III, La villa e $i$ suoi reperti, Modène, ed. Panini, 1985, p. 93-107.

Pavolini 2000 : PAVOLINI (C.) - La ceramica comune. Le forme in argilla depurata dell'antiquarium, Roma, Instituto poligrafico e zecca dello stato, Scavi di Ostia, 13, 2000.

Pellegrino 2007 : PELLEGRINO (E.) - Du garum sur toutes les tables. In : Garum et Pissalat, De la pêche à la table. Mémoires d'une tradition, catalogue d'exposition du musée d'Archéologie d'Antibes, Antibes, Editions Snoeck/Direction de la ville d'Antibes, 2007, p. 49-58.

Piton, Djaoui 2009 : PITON (J.), DJAOUI (D.) - Les céramiques communes et culinaires. In : Long (L.), Picard (P.) (eds.), César, le Rhône pour mémoire, Arles, Actes Sud/MDAA, 2009, p. 300-303.

Ponsich, Tarradell 1965 : PONSICH (M.), TARRADELL (M.) - Garum et industries antiques de salaisons dans la Méditerranée occidentale, Paris, Bibliothèque de l'École des Hautes Études Hispaniques, XXXVI, 1965.

Rivet 2006 : RIVET (L.) - Le pot trapu à deux anses du littoral de la Narbonnaise. In : Rivet (L.) (ed.), SFECAG, Actes du Congrès de Pézenas (2006), Marseille, 2006, p. 627-639.

Rivet 2010 : RIVET (L.) - Recherches archéologiques au cœur de Forum Iulii, Les fouilles dans le groupe épiscopal de Fréjus et à ses abords (19791989), Paris, Errance/CCJ, BIAMA, 6, 2010.

Sanchez 2000 : SANCHEZ (C.) - Port-la-Nautique, principal débarcadère de Narbonne. In : Narbonne, 25 ans d'archéologie, Catalogue d'exposition, Narbonne, 2000, p. 71-72.

Sanchez 2003 :SANCHEZ (C.) - Au carrefour des influences méditerranéennes et continentales, Le rôle de Narbonne dans le commerce antique. In : Dellong (E.) (ed.), Carte archéologique de la Gaule, 11/1. Narbonne et le Narbonnais, 2003, p. 117-123. 
Sanchez 2009 :SANCHEZ (C.) - Production et consommation des céramiques communes de la colonie romaine de Narbonne (II ${ }^{\mathrm{e}}$ av./ $\mathrm{V}^{\mathrm{e}}$ ap. J.-C.). In: Pasqualini (M.) (ed.), Les céramiques communes d'Italie et de Narbonnaise, Structures de production, typologies et contextes inédits (II ${ }^{e}$ s. av. J.-C. - III s. ap. J.-C.), Actes de la table ronde de Naples (2-3 novembre 2006), Naples, CJB, coll. CJB, 30, 2009, p. 471-492.

Sanchez 2011 : SANCHEZ (C.) 2011 - Vaisselle de bord et petits conteneurs, l'exemple des céramiques communes de la collection Bouscaras à Port-laNautique (Narbonne). In: Sanchez (C.), Jézégou (M.-P.) (coord.), Zones portuaires et espaces littoraux de Narbonne et sa région dans l'Antiquité, $\mathrm{M}$. A. M., 2011, p. 143-173.

Santamaria 1984 : SANTAMARIA (C.) - L'épave «H » de La Chrétienne à Saint Raphaël (Var), Archaeonautica, 4, 1984, p. 9-52.
Tchernia 2011 : TCHERNIA (A.) - Les Romains et le commerce, Centre Jean Bérard /Centre Camille Jullian, Naples, Études du CJB, 8 ; BiAMA Hors collection, 2011.

Tortorella 1981 : TORTORELLA (S.) - Ceramica da cucina. In : Carandini (A.) (dir.), Atlante delle forme ceramiche I, Ceramica fine romana nel bacino mediterraneo (Medio e Tardo Impero), Rome, (Enciclopedia dell'arte antica, Classica e orientale), 1981, p. 208-227.

Ucelli 1940 : UCELLI (G.) - Le Navi di Nemi, Rome, Istituto Policagrafico dello stato, 1940 (1996). 



\section{La Sardinia tra Penisola Iberica e Africa immersa in un mare di « sale » I d.C.-VII d.C.}

\section{Cristina Nervi}

I 1 titolo di questo contributo si ispira ad una metafora riguardante il ruolo svolto dalla Sardegna all'interno delle rotte commerciali nel Mediterraneo occidentale. L'isola ha sempre rivestito, per la sua posizione e la sua collocazione geografica, una funzione mediatrice all'interno degli scambi, dei movimenti di genti e di prodotti nell'area mediterranea occidentale, non solo in epoca romana, ma anche in periodi precedenti.

L'arco cronologico che si andrà a ripercorrere parte dalla dominazione imperiale romana dell'isola per giungere all' epoca tardo-antica ${ }^{1}$. I siti oggetto di questo studio sono posti lungo le coste meridionale, occidentale e settentrionale dell'isola sarda e focalizzano l'attenzione su approdi, o porti, che, per la loro posizione, costituivano una sosta obbligata per le imbarcazioni lungo le rotte che solcavano il Mediterraneo. Tra i percorsi marittimi è da annoverare la rotta verso la Penisola Iberica, che probabilmente incontrava nelle Isole Baleari un punto di mediazione, sosta e scambio ${ }^{2}$, e si dipartiva verso la costa occidentale della Sardegna, proseguendo quindi per cabotaggio verso nord e verso sud, per poi raggiungere in entrambi i casi la Penisola Italica. Le Baleari presumibilmente erano il punto di appoggio anche per gli scambi verso la zona della Gallia e dell'Alto Tirreno ${ }^{3}$. Da ricordare quindi le rotte da e verso il nord Africa,

1. Lo studio si baserà essenzialmente sulle importazioni di anfore da salagione verso la Sardegna; le aree di produzione di tali tipi anforici sono la Penisola Iberica (Spagna e Portogallo), per cui si hanno riferimenti certi tra anfora e prodotto e il nord Africa, area per la quale non si ha la certezza che i tipi presi in esame siano riconducibili unicamente al trasporto di salsamenta. Il ruolo svolto dall'Africa all'interno dei commerci che coinvolgono la Sardegna è così rilevante, da non poter esser trascurato, pur essendo consci della non certa connessione tra prodotto e contenitore nel caso proprio delle anfore da pesce di produzione africana.

Nel presente testo -inoltre- non sono contemplati tipi anforici orientali, non riconducibili -così come le anfore africane- con certezza al trasporto di salsamenta (come l'AM 72 da Beirut, o l'AM 54 e la G 198 dalla Cilicia), poiché lo stato attuale delle pubblicazioni su materiali sardi non ne consente l'individuazione, ovvero non ne risultano pubblicati. Ringrazio il Professor Paul Reynolds per avermi fornito tempestivi, precisi ed approfonditi dati sull'argomento.

2. Reynolds 2010, p. 117.

3. Reynolds 2010, p. 96.

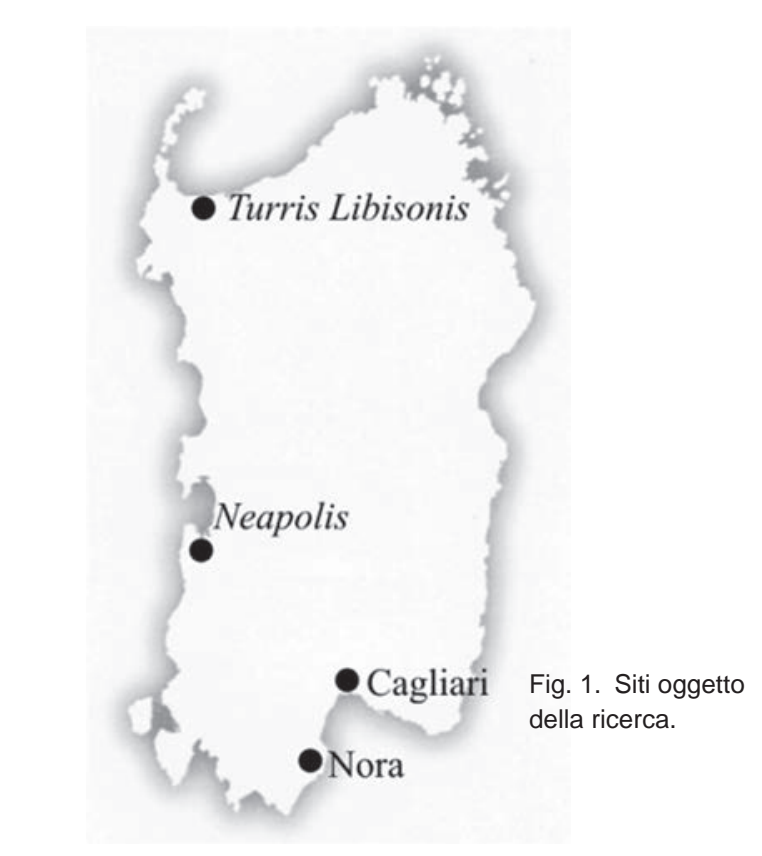

terra che da sempre costituì per l'isola sarda un punto di riferimento, soprattutto a partire dal III sec. d.C., ma già in epoca fenicio-punica e probabilmente in periodo pre-coloniale ${ }^{4}$.

Le città su cui è caduta la scelta sono pertanto : Turris Libisonis (fig. 1), l'attuale Porto Torres, posta lungo la costa settentrionale ; Neapolis, collocata all'interno del Golfo di Tharros ${ }^{5}$, ed a sud Cagliari e Nora, entrambe affacciate sull' ampia insenatura del Golfo di Cagliari.

La scelta è stata, inoltre, determinata dalla necessità di consultare repertori ceramici molto ampi - nel caso di Turris Libisonis ${ }^{6}$, che però presentano una data di pubblicazione non recente, che risale alla metà degli anni 80 del precedente secolo, oppure repertori ceramici editi recentemente, nel corso degli anni 2000, per Neapolis ${ }^{7}$, Nora $^{8}$ e Cagliari ${ }^{9}$.

4. Bondì 2006, p. 175-183.

5. L'attuale Golfo di Oristano.

6. Villedieu 1984.

7. Garau 2006.

8. Piccardi 2003 e Franceschi 2009.

9. Cisci 2006. 
Il primo punto critico dello studio è la differenza nella quantità di materiale edito, se per Turris Libisonis si è nell'ordine di migliaia di frammenti, per Neapolis, Nora e Cagliari si è nell'ordine di decine. Tale fattore dovrà essere necessariamente tenuto presente all'atto della presentazione dei dati statistici - attraverso grafici -, poiché crea di conseguenza una differenziazione nelle conclusioni che se ne trarranno.

La selezione dei materiali ha riguardato quelli provenienti da centri urbani, per tentare di determinare la destinazione dei prodotti da salagione e non tenendo in considerazione i relitti, che spesso, per lo meno per quelli rinvenuti nei mari sardi, non sono riconducibili ad un unico carico e non determinano la destinazione dei prodotti, tranne per quelli in prossimità di bracci di mare prospicienti grandi centri urbani, ma piuttosto la rotta che seguivano le navi nel corso del trasporto ${ }^{10}$.

Si tratterà di anfore - pertanto - rinvenute in centri urbani costieri, che permettono di ricostruire le rotte percorse ed il termine ultimo di destinazione.

Turris Libisonis ${ }^{11}$ è l'attuale Porto Torres - ancora oggi il maggiore porto della costa settentrionale sarda - è collocata a nord nel Golfo dell' Asinara. Delle sue origini precedenti all'epoca romana poco resta. La città è la sola colonia della Sardegna -ad eccezione di Uselis ${ }^{12}$ - ; la sua deduzione risale presumibilmente all'epoca cesariana o augustea, forse ad una data attorno al 46 - 42 a.C.

La sua condizione di colonia la porta ad essere popolata di genti provenienti dalla Penisola Italica ed appartenenti soprattutto alla tribù Collina, di estrazione sociale non elevata. Si tratta probabilmente di una colonia di popolamento e non militare, il suo porto costituiva il principale punto di approdo nella rotta attraverso le Bocche di Bonifacio. Le strutture portuali erano situate all'incirca nell' attuale zona portuale della darsena. Sono testimoniati resti dei magazzini per il deposito del grano destinato alla Penisola Italica, che vennero distrutti per l'edificazione di una poderosa struttura muraria difensiva, databile al V d.C., probabilmente necessaria difesa al sopraggiungere dei Vandali. Tra i resti si conservano il ponte romano, che era collocato lungo il principale asse viario diretto a sud, verso Cagliari, le terme, il foro, le necropoli. La città viene ricordata in un mosaico, attualmente conservato nel Piazzale delle Corporazioni ad Ostia.

Neapolis è collocata all'estremità inferiore del Golfo di Tharros $^{13}$. Fu nuova fondazione cartaginese ; il greco

10. Mastino et al. 2005, p. 207-245.

11. Mastino, Vismara 1994.

12. Si tratta dell'attuale centro di Usellus (OR) nella Sardegna centro-occidentale (Mastino 2005, p. 291-294).

13. Golfo di Oristano.
Neapolis probabilmente riprende il toponimo punico Qrsthdsht: mercato nuovo. L'area di fondazione del centro è determinata dalla sua posizione all'interno dell'attuale Golfo di Oristano. Il sito è stato incluso nel presente studio in virtù della recente pubblicazione dei materiali, raccolti con survey nella zona immediatamente a ridosso dell'area dell' antica città, nella zona periurbana, attualmente sottoposta a vincolo, da cui sono emersi alcuni resti notevoli. La sua collocazione a metà circa della costa occidentale della Sardegna fa della città un ideale approdo per le merci che giungevano da occidente. Il centro fu punico e quindi romano, ma di esso non è certa la condizione giuridica. Tra i materiali rinvenuti, è presente una grande quantità di importazioni, provenienti dalla Penisola Italica, anche di datazione precoce, quando il sito era ancora punico. A differenza di altri siti sardi - tra cui Nora, di cui si parlerà in seguito - gli abitanti di Neapolis appaiono inseriti nel mercato italico del Mediterraneo e non sembrano legati unicamente e massicciamente a prodotti punici di importazione africana o di produzione locale ${ }^{14}$.

Cagliari ${ }^{15}$ si affaccia sulla costa meridionale della Sardegna. E' ancora attualmente uno dei principali porti dell' isola. La sua distanza dall'Africa di circa $300 \mathrm{~km}$ - più vicina all'Africa che alla Penisola Italica - ne fa un approdo ideale per le importazioni di prodotti africani. I contatti con l'Africa sono precoci : i Fenici si innestano su popolazioni di origine locale, lasciando il posto ai Punici e quindi ai Romani. Attraverso la precoce intuizione ed alleanza con Cesare, la città assurge nel corso del I a.C. a condizione di municipium, con a capo i quattuorviri. Come Turris Libisonis i suoi mercatores erano così affermati da venir effigiati nel Piazzale delle corporazioni ad Ostia.

Nora ${ }^{16}$, dista circa $40 \mathrm{~km}$ da Cagliari, si affaccia sul golfo omonimo. Fu città fenicia di nuova fondazione ; allo stato attuale delle ricerche non sembra che l'area fosse frequentata in epoche precedenti, quali quella nuragica. Sorge sopra un promontorio con la possibilità di tre approdi, il suo porto principale è collocato nell'insenatura ad occidente. La città romana diviene precocemente municipium, probabilmente in maniera analoga alla vicina Cagliari, tramite una immediata alleanza con Cesare. Sono preservati numerosi resti, tra

14. Neapolis attesta, così come Olbia (Pisanu 2008, p. 30-31), contatti commerciali precoci con la costa tirrenica italica, documentati dall'importazione di anfore a partire dal IV sec. a.C., quando negli altri porti sardi è documentata una preponderante presenza di materiale importato punico, proprio perché l'isola si trovava ancora sotto il dominio cartaginese.

15. Colavitti, Tronchetti 2003, p. 9-23.

16. Tronchetti 2000, Tronchetti 2003 ; Giannattasio 2003 ; Bonetto et al. 2009. 
cui l'unico teatro conservato in elevato della Sardegna. La città mostra un forte aspetto di continuità con il suo passato punico; i dati archeologici mostrano numerosi elementi : tipi ceramici, tecniche di edificazione, che trovano ascendenti nel periodo cartaginese.

I grafici che ora andrò a discutere comprendono la quantità di importazioni di anfore contenenti prodotti da salagione, suddivise per tipi e, per quanto possibile, per aree di produzione.

Per quanto riguarda Turris Libisonis ${ }^{17}$ (fig. 2), tra le anfore importate dalla Penisola Iberica, le produzioni ispaniche attestano: Dressel 14, Dressel 7-11, Beltrán IIB probabilmente prodotte in Betica. Osservando il grafico quantitativo delle anfore provenienti dagli scavi di Turris Libisonis i picchi indicati con il colore grigio chiaro si riferiscono a quei tipi che, in assenza di specificazione da parte dell'autore, potrebbero essere riconducibili a produzioni lusitane/sud-ispaniche ${ }^{18}$, quindi Almagro 50, Almagro 51C, Almagro 51AB. I dati raccolti non consentono - in totale assenza di analisi mineralogiche e petrografiche - di stabilire un' area di produzione certa. E' documentata anche la presenza del tipo Beltrán $72^{19}$, la cui area di produzione attualmente oscilla tra la costa betica ${ }^{20}$ e la Lusitania ${ }^{21}$.

Ho scelto di introdurre anche un grafico inerente le anfore di produzione africana, anche se non si hanno certezze del fatto che esse contenessero unicamente prodotti da salagione ${ }^{22}$. Nel grafico, pertanto, sono presenti quei tipi che - presumibilmente - avrebbero potuto trasportare salsamenta. La scelta è stata dettata dal fatto che a partire dal III d.C. la Sardegna, come del resto tutto il Mediterraneo occidentale, viene investita da un elevata percentuale di importazione di prodotti dal nord Africa. Eliminare in toto dal presente studio le produzioni africane, poiché non riconducibili con precisione al proprio contenuto, avrebbe indotto ad una distorsione

17. Villedieu 1984, p. 18, 21, 24, 26, 29, 30, 32, 36, 41, 44, 49, 50, 52, 56, 60, 62, 65, 67, 70, 73, 77, 79, 81, 83, 89, 101, 103 e 104.

18. Le aree produttive delle anfore Almagro 50 e 51 possono essere collocate in Lusitania, in Baetica ed in piccola quantità nella Tingitana. La definizione di Simon Keay (Keay 1984, p. 151) produzioni "sud-ispaniche" meglio comprende ed include la vasta gamma di possibili zone di produzione, in assenza di analisi archeometriche che determinino con certezza la regione di provenienza.

19. Villedieu 1986, p. 145-162.

20. Si veda a riguardo il catalogo on-line : Amphorae ex Hispania (Bernal Casasola 2012, Ficha Beltrán 72, Amphorae Ex Hispania. Paisajes de producción y consumo (amphorae.icac.net), 7 de Agosto de 2012).

21. Per la provenienza dall'area lusitana si veda il catalogo on-line dell'Università di Southampton : http://archaeologydataservice.ac.uk/ archives/view/amphora_ahrb_2005/details.cfm?id=42\&CFID $=4481$ 9\&CFTOKEN=93BCA277-170D-486C-A848952713AD8D9D.

22. Bonifay 2004, p. 474-475.

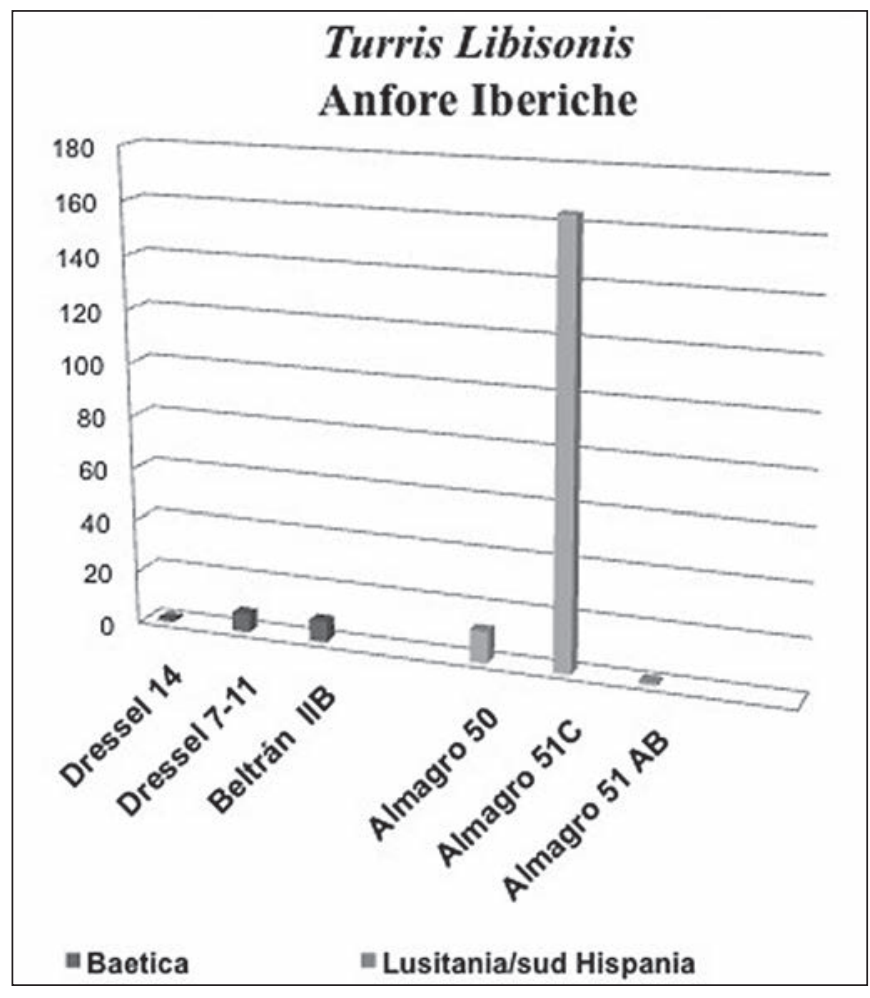

Fig. 2. Turris Libisonis. Anfore iberiche.

della determinazione delle importazioni di prodotti derivati del pesce verso la Sardegna dopo il III d.C. e quindi non sarebbe stato possibile tracciare con approssimata veridicità le rotte di importazione di salsamenta attraverso il bacino occidentale del Mediterraneo.

Si è scelto quindi di includere tra i dati statistici anche quelli derivanti dalle anfore di produzione nord-africana, che presumibilmente potevano contenere prodotti da salagione, pur essendo consapevoli che non si possiede, allo stato attuale, la certezza del contenuto riferibile a salsamenta.

Evitare di considerare le anfore da conserva del pesce di produzione africana, non possedendo certa attribuzione per le forme, significherebbe falsare, se non alterare, il panorama delle importazione dei prodotti da salagione, più in generale fornire un'errata interpretazione dei traffici e delle rotte mediterranee verso la Sardegna, soprattutto per quanto riguarda l'epoca più tarda romana.

A Turris Libisonis ${ }^{\mathbf{2 3}}$ (fig. 3) sono attestate : Africana II in quantità elevata, senza distinzione per i tipi ${ }^{24}$,

23. Villedieu 1984, p. 21, 24, 26, 28, 29, 32, 35, 36, 38, 41, 43, 44, $46,48,49,50,52,56,59,60,62,65,70,73,77,79,81,83,88,89$, 97, 99, 101, 103 e 104.

24. Oltre ai frammenti notevoli - orli, anse e fondi - inseriti nel grafico, sono stati rinvenuti 12.261 frammenti di pareti attribuiti genericamente all'Africana II, esclusi dal grafico, per non falsare la lettura degli altri picchi, che sarebbero risultati illeggibili. 


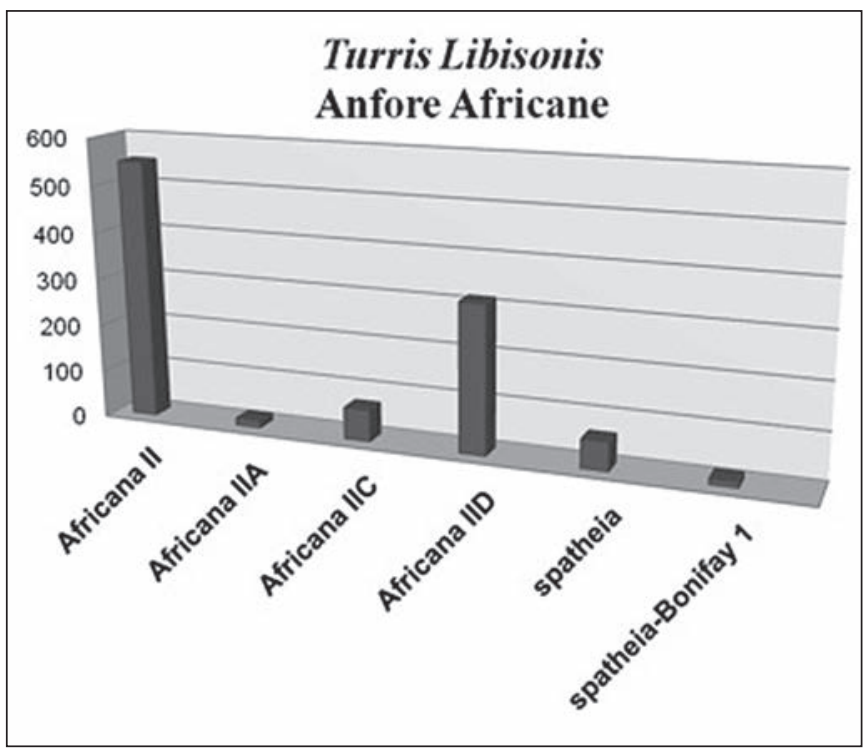

Fig. 3. Turris Libisonis. Anfore africane.

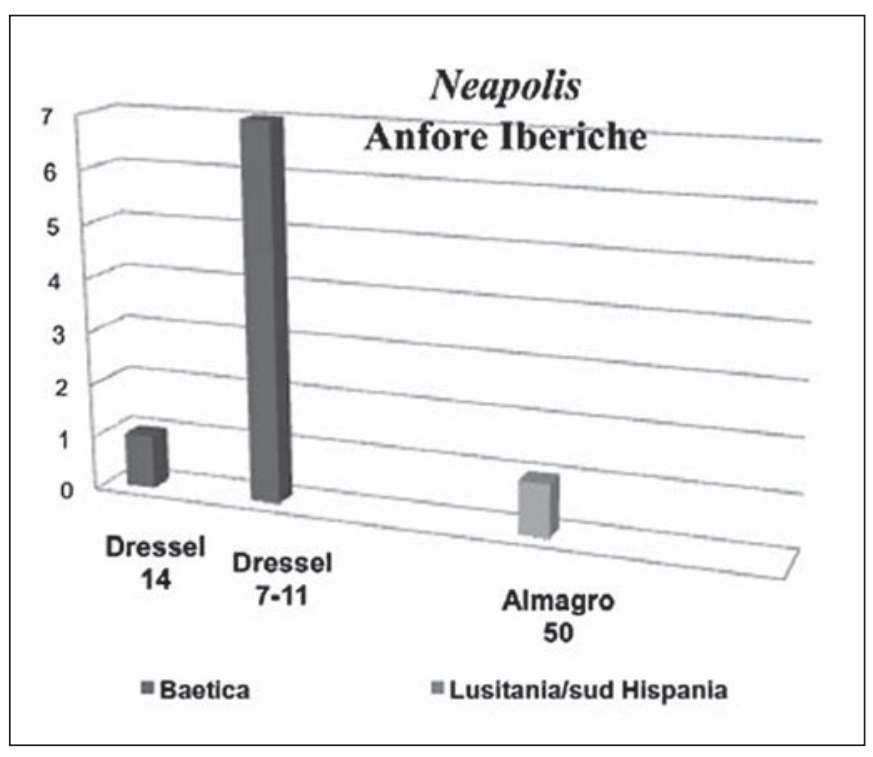

Fig. 4. Neapolis. Anfore iberiche.

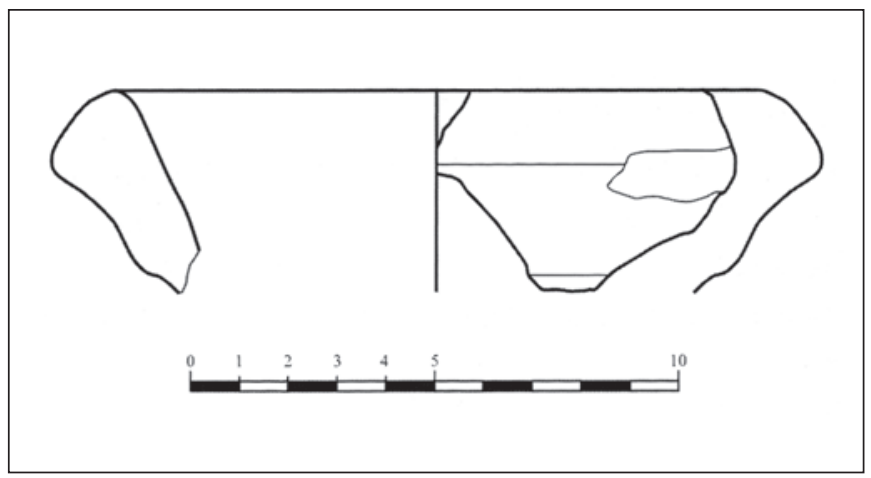

Fig. 5. Neapolis. Orlo di Dressel 7-11 (da Garau 2006, fig. 102.3, p. 176)

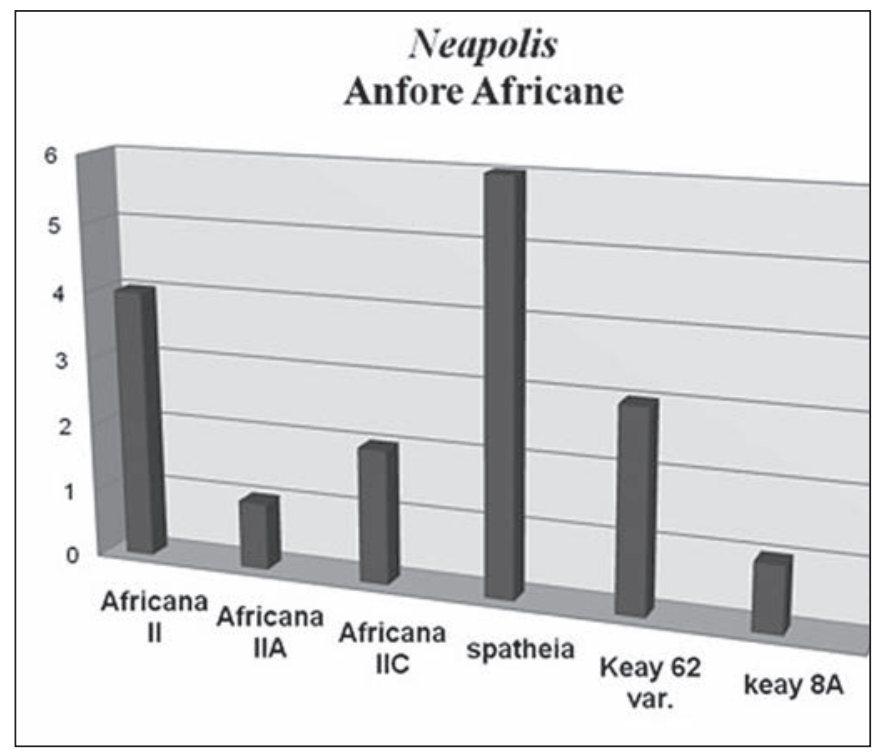

Fig. 6. Neapolis. Anfore africane.

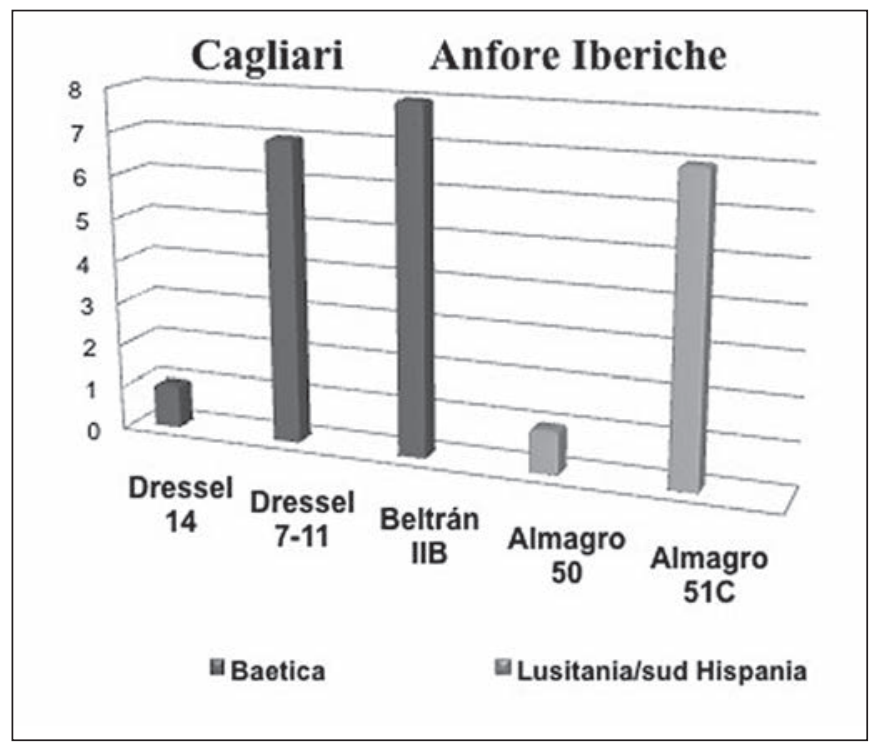

Fig. 7. Cagliari. Anfore iberiche.

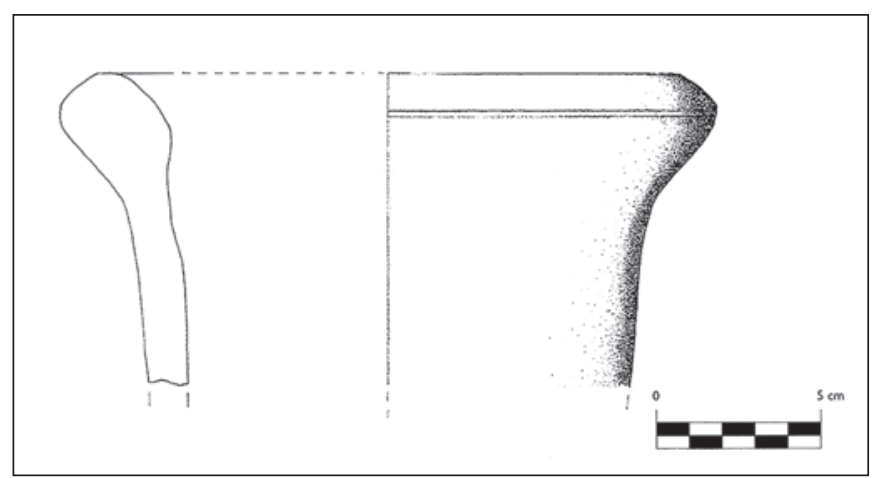

Fig. 8. Cagliari. Orlo di Dressel 14 (da Cisci 2006, C. 23, p. 121). 
quindi Africana IIA, Africana IIC e quantità piuttosto massiccia di Africana IID; gli spatheia non presentano una differenziazione nella tipologia, per cui il tipo 1 di Bonifay - probabilmente veicolo di prodotti da salagione - è stato identificato solo raramente, grazie al supporto dei disegni pubblicati ; nella maggior parte dei casi per i frammenti di spatheia non sono stati forniti disegno o descrizioni tali da permettere l'attribuzione al tipo Bonifay 1 ; si è scelto di includere ugualmente nel grafico il dato, in maniera tale che non vada perso, per eventuali possibili accertamenti futuri ${ }^{25}$.

Neapolis ${ }^{26}$ (fig. 4) presenta frammenti di anfore iberiche : Dressel 14, Dressel 7-11 di probabile produzione betica (fig. 5) ; l'Almagro 50 risulta essere l'unica attestazione da area lusitana/sud-ispanica.

Si deve quindi ribadire, come punto critico della ricerca, e come già affermato precedentemente, che mentre per Turris Libisonis i dati sono stati desunti da frammenti nell'ordine delle migliaia, per Neapolis, Cagliari e Nora i grafici comprendono solo decine di frammenti.

Fra le importazioni nordafricane di Neapolis (fig. 6) si segnala una forte percentuale attribuita genericamente alla Africana II, senza alcuna distinzione riconducibile ai sottotipi. Sono presenti anche Africana IIA e IIC ; quindi, come per Turris Libisonis, è documentata una forte quantità di spatheia, per i quali non è stata possibile l'attribuzione certa al tipo 1 di Bonifay, contenente probabilmente prodotti da salagione, ed infine sono attestate le Keay 8A e le Keay 62, che consentono di ipotizzare l'importazione di salsamenta sino al VII d.C. ${ }^{27}$

A Carales (fig. 7) i tipi anforici attestati sono: Dressel 14 (fig. 8), Dressel 7-11 (fig. 9) e Beltrán IIB (fig. 10), probabilmente di produzione betica; fra le anfore che potrebbero provenire da area lusitana/sudispanica le Almagro 50 (fig. 11.1) ed un'importante percentuale di Almagro $51 \mathrm{C}^{28}$ (fig. 11.2).

Le importazioni nord-africane di Cagliari ${ }^{29}$ (fig. 12) mostrano la presenza soprattutto di Africana IIA e IIC (fig. 13), come nei casi precedenti : spatheia - senza alcuna possibilità di differenziazione tra i tipi - ed infine, ancora come a Neapolis, le Keay 62 (fig. 14), che

25. A Turris Libisonis è attestata anche la presenza di Dressel 21-22 provenienti dall'Italia meridionale e dalla Sicilia (Botte 2009, p. 120).

26. Garau 2006, p. 96, 115, 176, 199, 207, 214, 227.

27. Garau 2006, p. 47, 48, 104, 131, 132, 161, 175, 189, 200, 211, 214.

28. Cisci 2006, p. 120-121, 132-133.

29. Cisci 2006, p. 125, 127, 130.

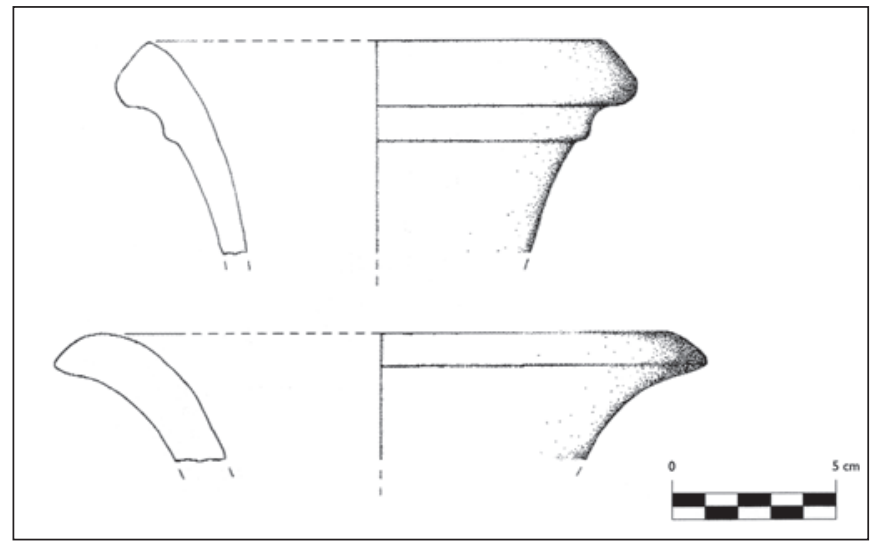

Fig. 9. Cagliari. Orli di Dressel 7-11 (da Cisci 2006, C. 22, p. 120).

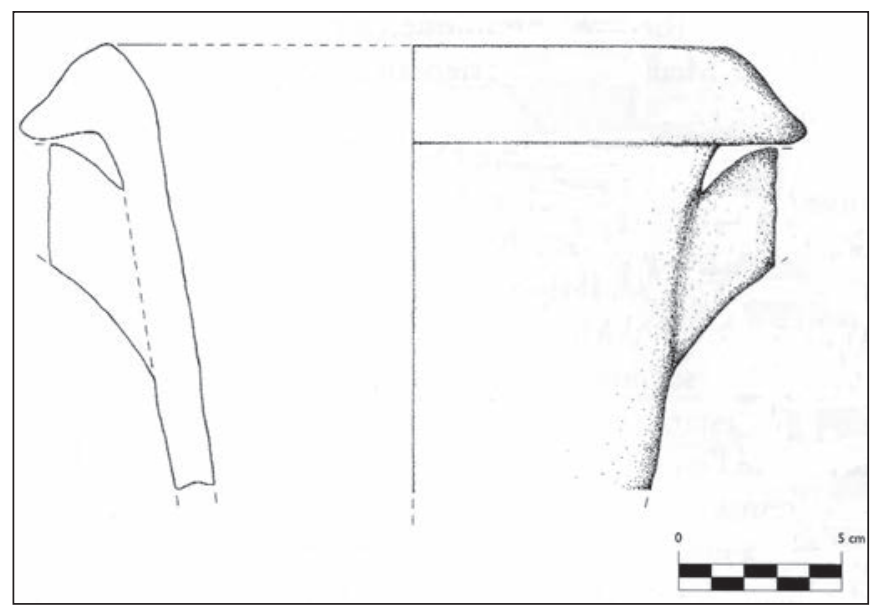

Fig. 10. Cagliari. Orlo di Beltrán IIB (da Cisci 2006, C. 24, p. 121).

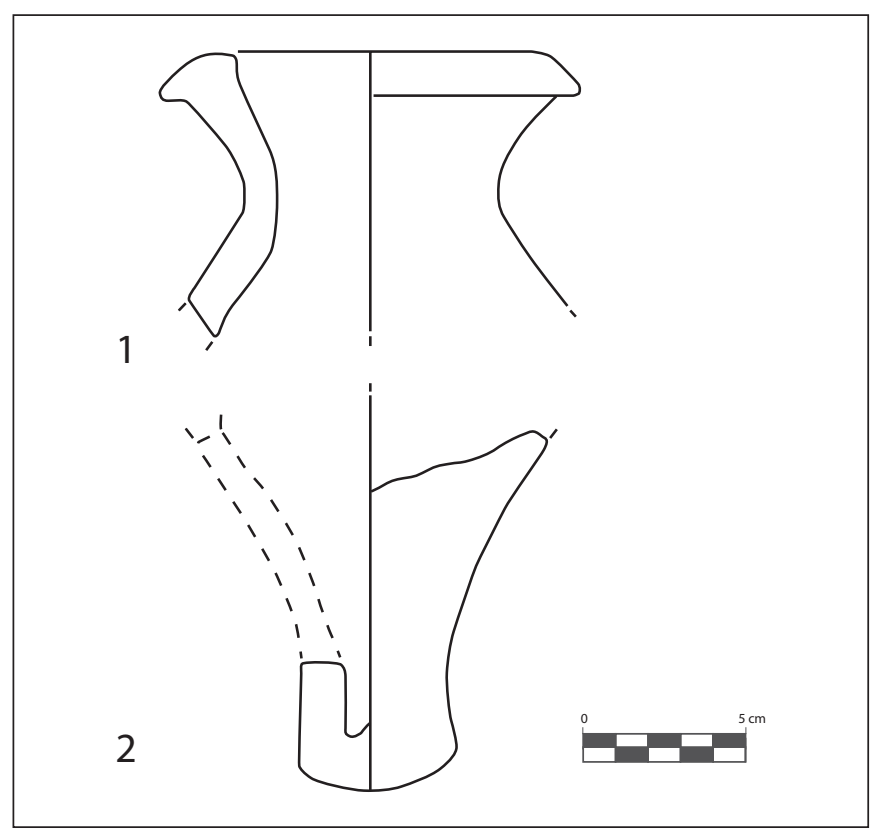

Fig. 11. Cagliari. 1. Orlo di Amagro 50 (da Cisci 2006, C. 30.62, p. 133) ; 2. Puntale di Almagro 51C (da Cisci 2006, C. 30.63, p. 133). 


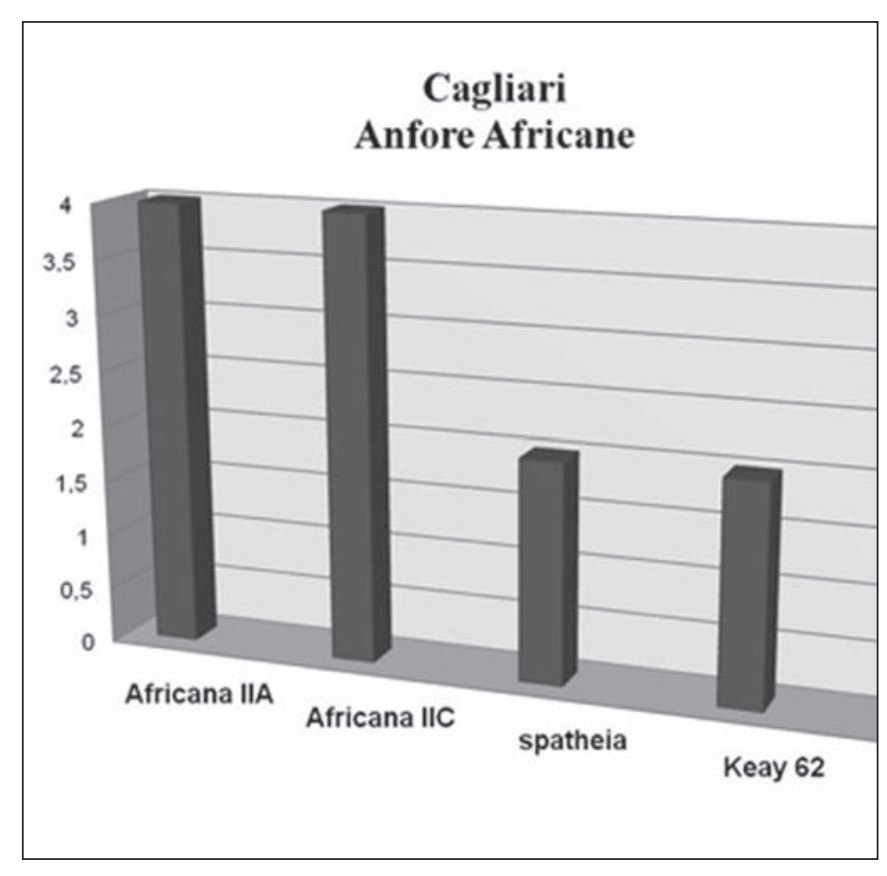

Fig. 12. Cagliari. Anfore africane.

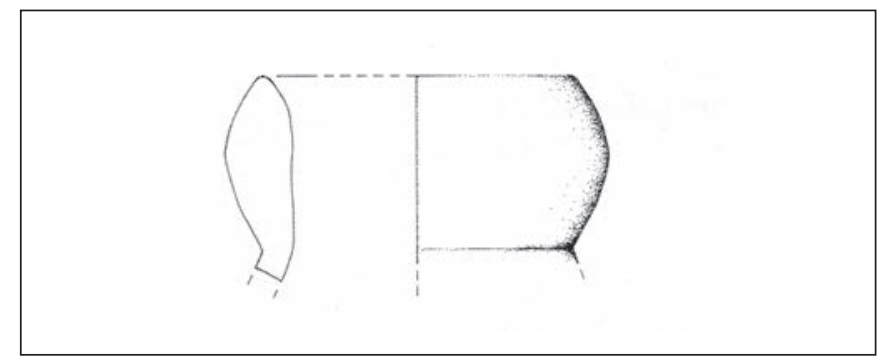

Fig. 13. Cagliari. Orlo di Africana IIC (da Cisci 2006, C. 28.42, p. 128).

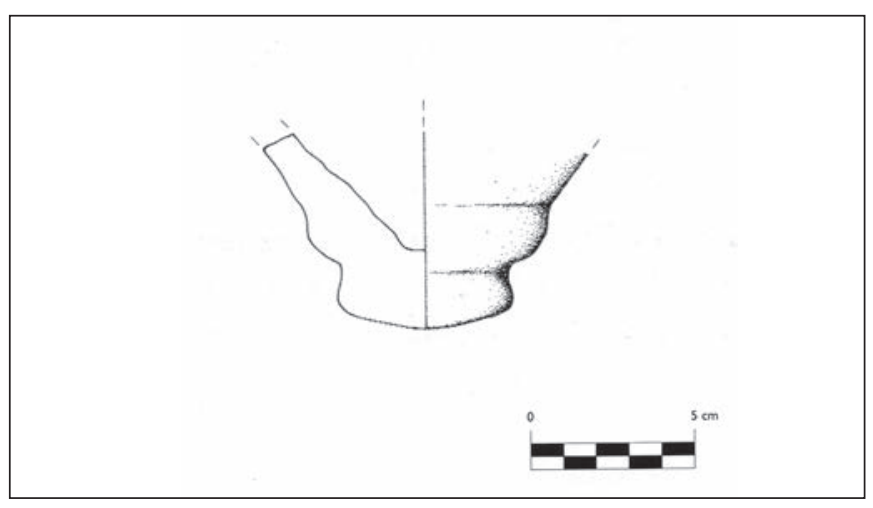

Fig. 14. Cagliari. Puntale di Keay 62 var./Bonifay tipo 47 (da Cisci 2006, C. 28.56, p. 128).

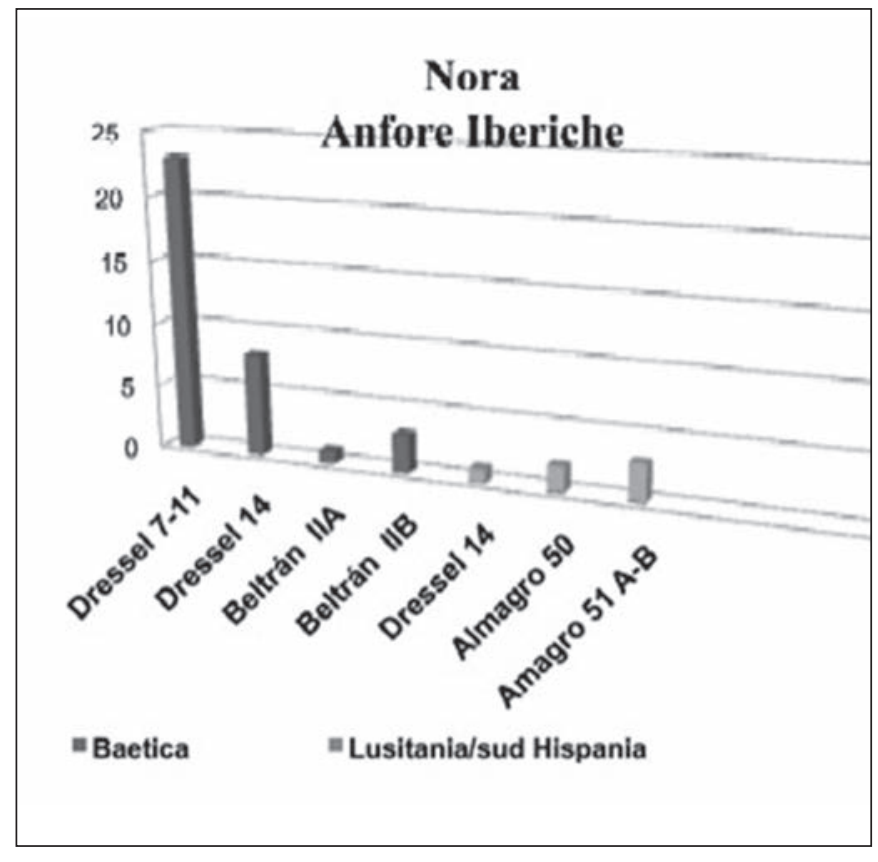

Fig. 15. Nora. Anfore iberiche.

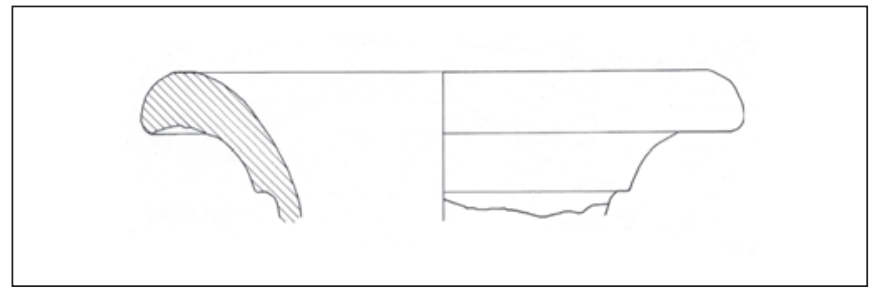

Fig. 16. Nora. Orlo di Dressel 7-11. Scala 1:3 (da Piccardi 2003, tav. 64. 3).

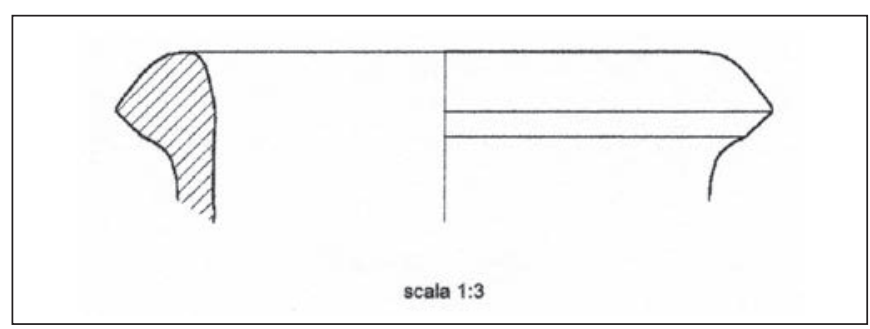

Fig. 17. Nora. Orlo di Dressel 14 betico (da Francheschi 2009, fig. 23, p. 738).

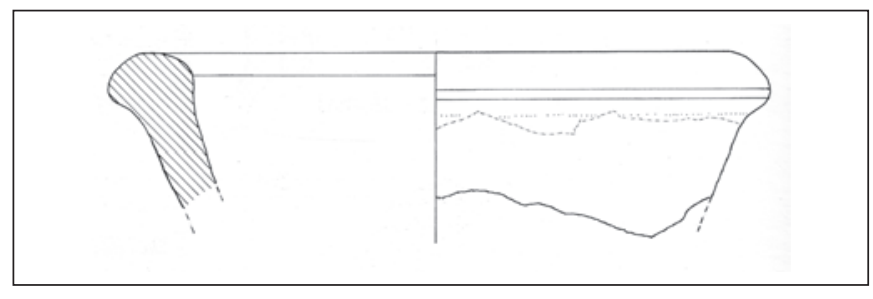

Fig. 18. Nora. Orlo di Dressel 14 lusitano. Scala 1:3 (da Piccardi 2003, Tav. 54.5). 
inducono a considerare importazioni documentabili sino al VII d.C. ${ }^{30}$

Infine Nora (fig. 15) tra le anfore di produzione iberica presenta: Dressel 7-11 (fig. 16) in maggiore quantità, affermando un precoce e forte legame con l' $\mathrm{Hi}$ spania, Dressel 14 (fig. 17), Beltrán IIA ${ }^{31}$ e Beltrán IIB di produzione betica ; l'unica attestazione certa, perché dovuta ad analisi degli impasti, di Dressel 14 lusitane (fig. 18) e quindi le Almagro 50 e 51 AB (fig. 19), probabilmente lusitane/sud-ispaniche ${ }^{32}$. E' documentata anche la presenza del tipo Beltrán $72^{33}$, di produzione iberica ${ }^{34}$.

Tra le produzioni di area nord-africana (fig. 20) si evidenzia immediatamente la presenza di Tripolitana II (fig. 21) ; questo legame con l'area tripolitana è da evidenziarsi, poiché non è attestata in alcuno dei siti trattati in precedenza (Turris Libisonis, Neapolis o Cagliari). Si documentano inoltre l'Africana II, senza alcuna distinzione per i sottotipi, Africana IIA, spatheia del tipo 1 di Bonifay ed ancora la Keay 62, che ci inducono ad attribuire anche al VII d.C. le importazioni di salsamenta $^{35}$. La cronologia bassa è confermata anche dalla attestazione di Keay $8 \mathrm{~A}^{36}$, tale dato non è stato incluso nel grafico, poiché non è stato possibile quantificare il numero dei frammenti rinvenuti, ma risulta, comunque, interessante per affermare il proseguire di importazione di prodotti da salagione, provenienti dall' area nord- africana verso la città di Nora, sino al VII d.C.

Ho inserito quindi all'interno di un unico grafico i dati derivanti dalle differenti aree di importazione, suddividendoli per secoli.

A Turris Libisonis ${ }^{37}$ (fig. 22) i primi prodotti importati provengono dall'area betica, a partire dal II d.C. si innestano in maniera evidente quelli dall' area africana, che perdurano elevati e stabili sino al IV d.C. ; dal III d.C. si affacciano i primi contatti con l'area lusitana/ sud Hispania, che proseguono sino al V d.C., così come quelli africani, che subiscono, però, una forte flessione proprio in $\mathrm{V}$ d.C.

Da evidenziare immediatamente l'assenza di importazione di prodotti da salagione in VI-VII d.C.

30. E' documentata anche la presenza di Dressel 21-22. Per la loro area di produzione vedi nota 25 in questo contributo.

31. Pavoni, Pettenò 2003, p. 119.

32. Piccardi 2003, p. 216-217; Franceschi 2009, p. 737-739; Cirrone 2010, p. 313.

33. Bassoli 2010a, p. 107 ; Bassoli 2010b, p. 114.

34. Riguardo l'area di produzione del tipo Beltrán 72 vedi le note 20 e 21 in questo contributo.

35. Piccardi 2003, p. 218-220; Franceschi 2009, p. 739-741.

36. Del tipo Keay $8 \mathrm{~A}$ non viene fornito alcun dato statistico, che consenta di individuare il numero di frammenti rinvenuti.

37. Villedieu 1984, p. 166-173, 178-195.

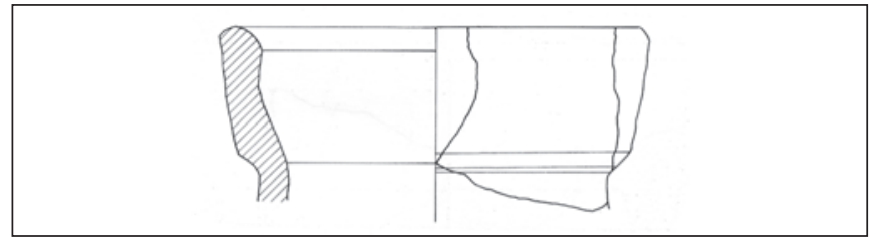

Fig. 19. Nora. Orlo di Almagro 51 AB. Scala 1:3 (da Piccardi 2003, Tav. 54.7)

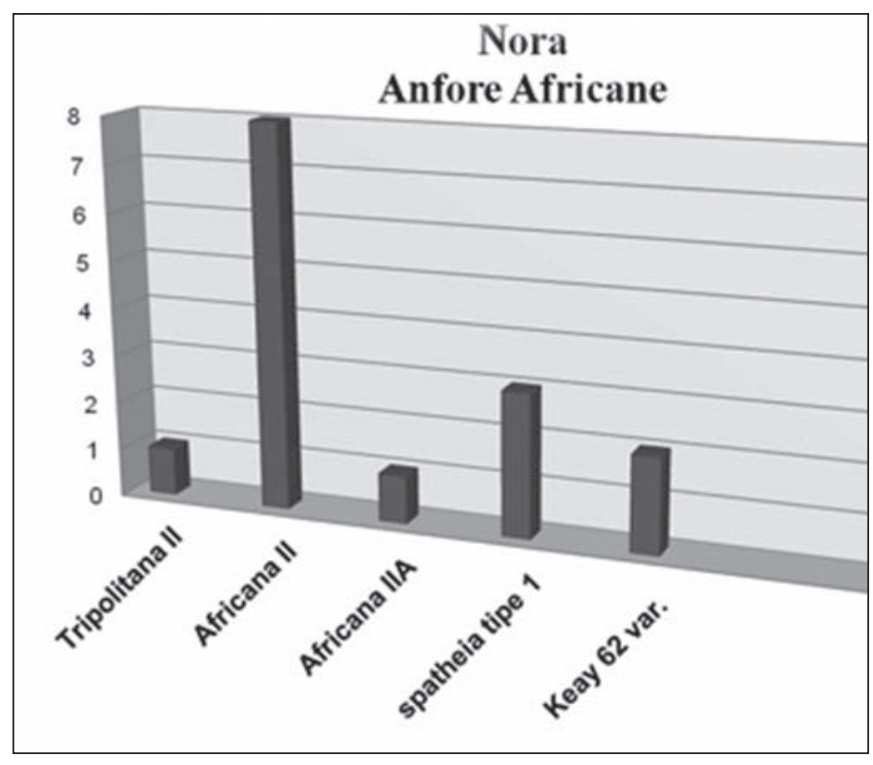

Fig. 20. Nora. Anfore africane.

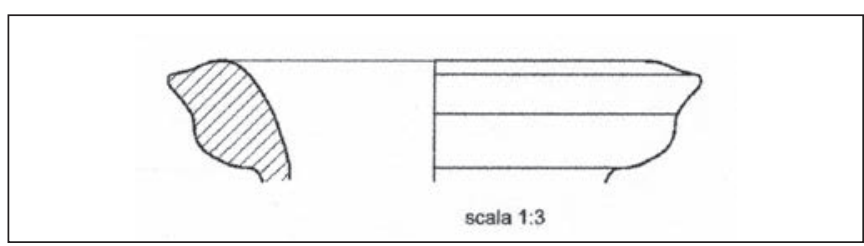

Fig. 21. Nora. Orlo di Tripolitana II (da Franceschi 2009, fig. 32, p. 740).

Il dato potrebbe essere legato al fatto che dal $\mathrm{V} \mathrm{d.C.} \mathrm{la}$ città subì un forte decremento a causa dell'attacco vandalico, tanto che suoi magazzini - fatti edificare in epoca severiana, il cui scopo era quello di stoccare soprattutto il grano prodotto nella zona a sud della città, che poi veniva smerciato a Roma - vennero distrutti e su di essi venne edificata una cinta muraria, databile proprio al $\mathrm{V}$ d.C., che è stata interpretata come struttura difensiva contro le incursioni vandaliche. Nelle fondazioni delle mura sono stati impiegati numerosissimi frammenti di anfore probabilmente contenute negli horrea demoliti ${ }^{38}$.

38. Si può inoltre ipotizzare che la mancanza di attestazioni post V d.C. sia legata alla specifica situazione dell'area indagata, da cui sono derivati i dati oggetto di studio, e non sia da estendersi all'intero panorama delle importazioni verso Turris Libisonis. 


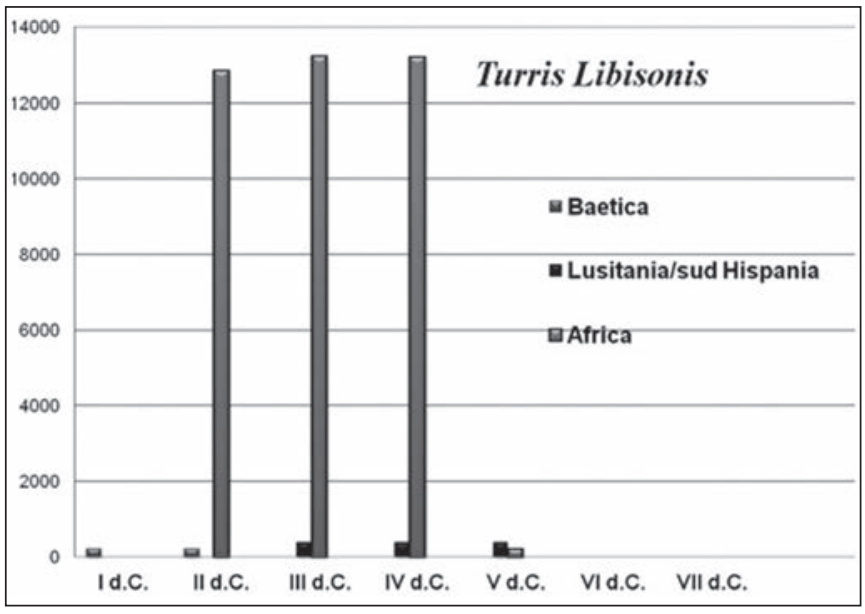

Fig. 22. Turris Libisonis. Importazioni anforiche.

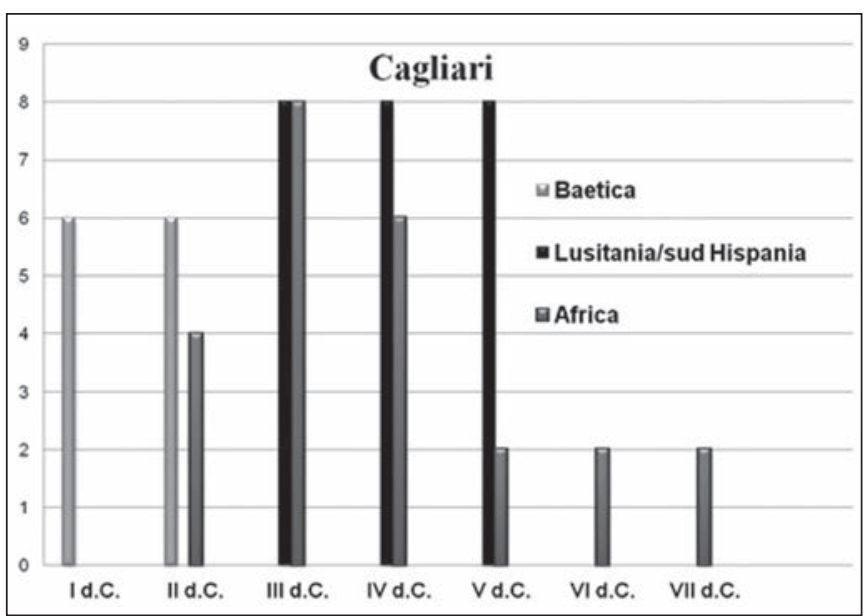

Fig. 24. Cagliari. Importazioni anforiche.

Neapolis (fig. 23) ha contatti precoci e corposi per l'importazione di prodotti da salagione con l'area betica per il I ed il II d.C., dal II d.C. ad essi si affiancano subito in maniera elevata i prodotti africani, che perdurano sino al V d.C., con un picco nel IV d.C. ; le anfore lusitane/ sud-ispaniche sono presenti dal III al V d.C. in maniera minoritaria ; il mercato, a partire dal III d.C., appare completamente monopolizzato da anfore africane, la cui importazione decresce in VI d.C., ma si incrementa in VII d.C.

Cagliari $^{39}$ (fig. 24) presenta importanti e precoci contatti con l'area betica a partire dal I d.C., ad essi si affiancano in maniera minoritaria in II d.C. quelli africani, che raggiungono il proprio apice in III d.C.; le attestazioni lusitane/sud-ispaniche sono numerose e nel III d.C. eguagliano quelle africane. Le anfore lusitane/ sud-ispaniche permangono invariate ed elevate in III, IV

39. Cisci 2006, p. 120-136.

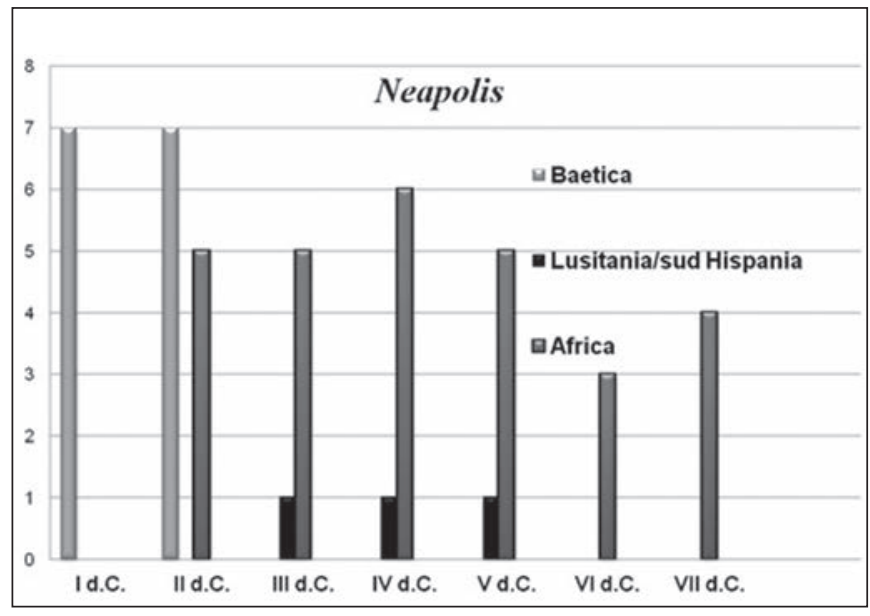

Fig. 23. Neapolis. Importazioni anforiche.

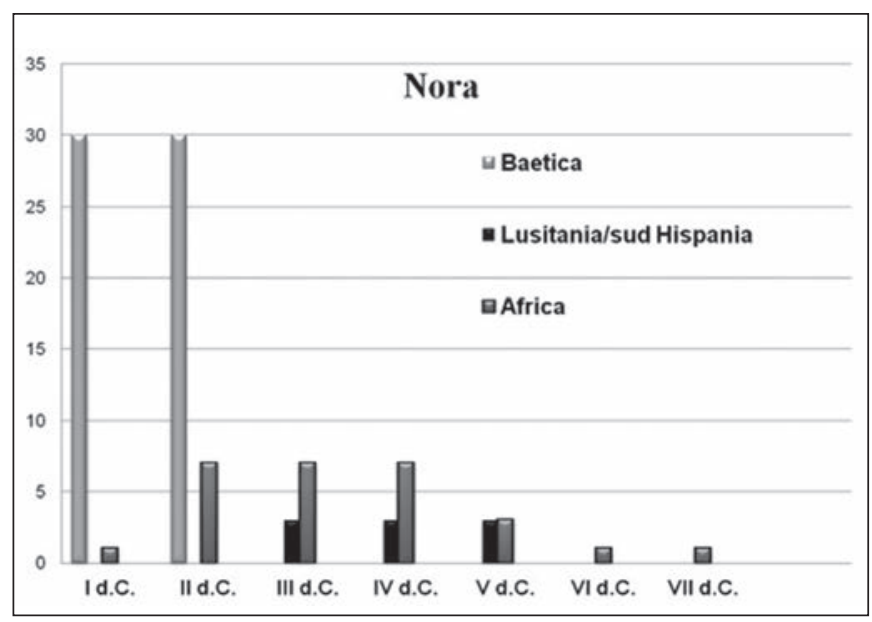

Fig. 25. Nora. Importazioni anforiche.

e V d.C., mentre quelle africane calano sensibilmente in IV ed in maniera più elevata in V, VI, VII d.C., mantenendo - però - costante la mole di prodotto importato.

Nora $^{40}$ (fig. 25) presenta i maggiori contatti con la Betica : essi sono attestati in I e II d.C. Da evidenziare il precoce, anche se molto debole, legame con l'area africana a partire dal I d.C. ; le importazioni dal nord Africa si mantengono costanti in II, III e IV d.C. ; ad esse si affiancano in III, IV e V d.C. in quantità costante quelle dalla Lusitania/sud Hispania ; i legami continuativi con l'Africa proseguono sino al VII d.C., anche se evidenziano una graduale diminuzione tra IV, V, e VI d.C. ed una uguale portata tra VI e VII d.C.

Ho tentato di determinare - solamente nei casi in cui era possibile farlo e pertanto collegando il tipo anforico alla probabile origine - la zona di produzione delle anfore nell' area nord africana col fine di ricostruire quali

40. Piccardi 2003, p. 236 ; Franceschi 2009, p. 733-745. 


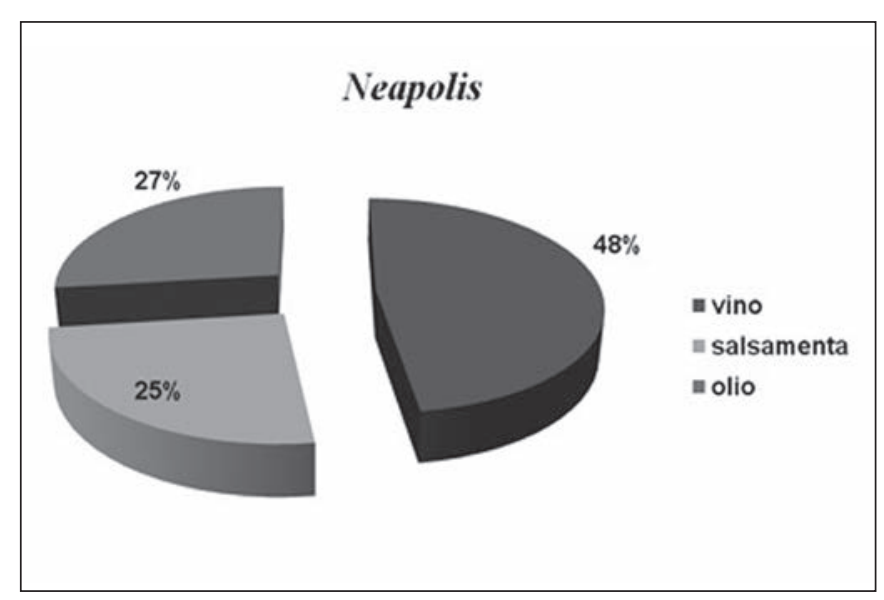

Fig. 26. Turris Libisonis. Maggiori prodotti importati.

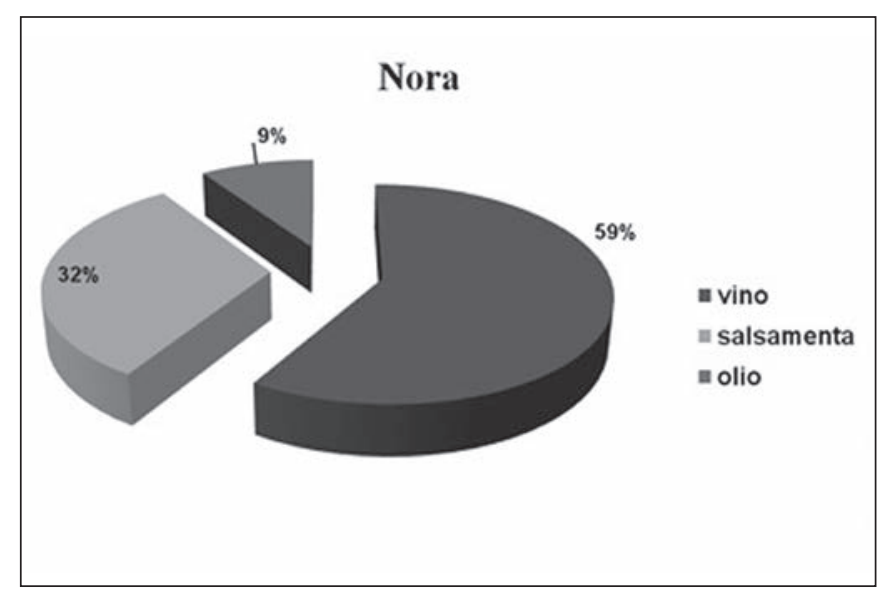

Fig. 28. Cagliari. Maggiori prodotti importati.

potrebbero essere state le rotte di esportazione verso la Sardegna.

Per quanto riguarda i contatti di Turri Libisonis sono attestate importazioni dalla Zeugitana, dalla Bizacena, dalla Proconsolare, dall' area di Nabeul e del Sahel.

Neapolis documenta anch'essa contatti con Zeugitana, Bizacena, Proconsolare e Nabeul.

A Carales sono presenti importazioni da Zeugitana, Bizacena, Proconsolare e dalla zona di Nabeul.

Nora a partire dal I d.C. denota precoci legami con la Tripolitania, cui si affiancano Zeugitana, Bizacena, Proconsolare e areale di Nabeul.

Si deve, ancora una volta, rammentare che i dati sino ad ora elencati riguardano unicamente anfore contenenti, probabilmente, prodotti da salagione ed in ulteriore riduzione, solo quelle per cui è stato possibile determinare l'area di produzione nel nord Africa.

Inserendo i salsamenta nel panorama più ampio delle importazioni, annoverando i principali prodotti - vino ed

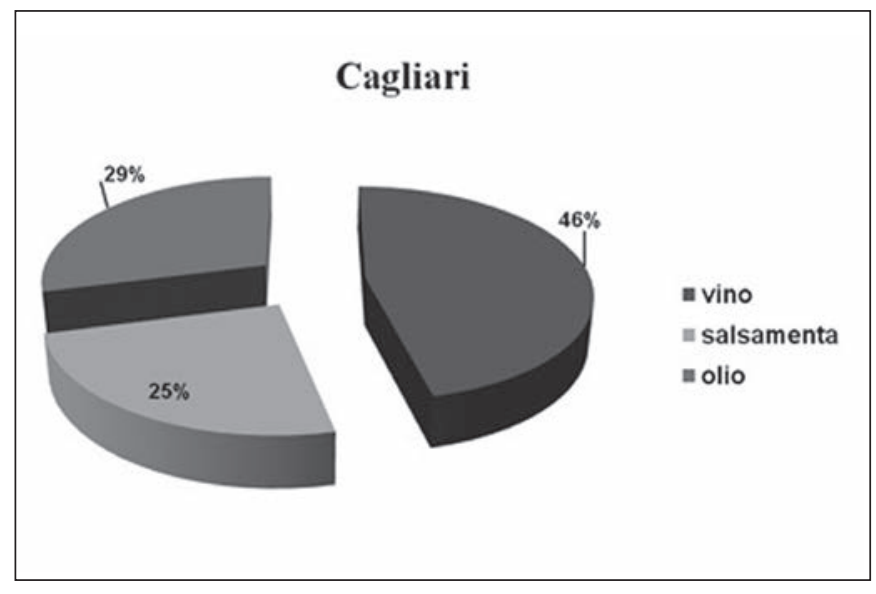

Fig. 27. Neapolis. Maggiori prodotti importati.

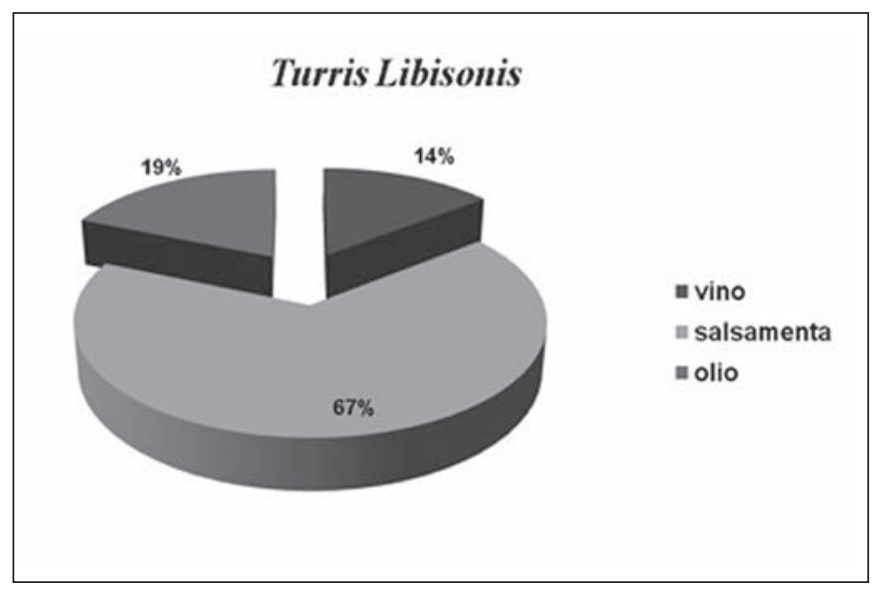

Fig. 29. Nora. Maggiori prodotti importati.

olio - si evidenzia come a Neapolis (fig. 26) ${ }^{41}$, Cagliari (fig. 27) ${ }^{42}$ e Nora (fig. 28) ${ }^{43}$ la percentuale di prodotti da salagione si aggiri attorno al 25\%-32\% delle importazioni, mentre a Turris Libisonis ${ }^{44}$ (fig. 29) la percentuale giunge sino al $67 \%$, una motivazione di tale divario potrebbe essere legata allo studio di materiali di Porto Torres posteriori al III d.C., non comprendenti pertanto una vasta percentuale di prodotti dei secoli precedenti.

Nel panorama delle importazioni di prodotti da salagione verso la Sardegna si sono potute determinare differenti rotte.

41. Nel dettaglio delle importazioni il vino rappresenta il $48 \%$ e l'olio il $27 \%$ del totale.

42. Le importazioni cagliaritane attestano il $46 \%$ di vino ed il $29 \%$ di olio.

43. A Nora il vino è di gran lunga il prodotto più importato (59\%), mentre l'olio è attestato solo per il $9 \%$.

44. A Neapolis il vino importato rappresenta il $14 \%$ del totale dei prodotti e l'olio il $19 \%$. 
Quella che dalla Lusitania, attuale Portogallo, attraverso lo stretto di Gibilterra ${ }^{45}$ giungeva sino alle Baleari, alla costa occidentale della Sardegna, presumibilmente nella parte centrale, presso Neapolis e si dipartiva verso nord per cabotaggio sino a giungere a Turris Libisonis e proseguire quindi verso il Lazio ; una sua variante era costituita dal costeggiare le rive orientali della Corsica e giungeva, attraverso l'isola d'Elba, alla costa toscana, presso le attuali Livorno e Pisa.

La rotta dalla Penisola Iberica, attraverso le Isole Baleari, una volta dipartitasi si dirigeva anche verso la costa meridionale sarda, transitando nel braccio di mare tra l'antica Sulki, odierna Sant'Antioco, e la Sardegna, giungendo - probabilmente per cabotaggio, come dimostrerebbero i relitti naufragati nelle cale meridionali della Sardegna - quali Cala Piombo ${ }^{46}$, a Bithia, Nora e Carales.

Proprio da Carales si dipartivano due possibili vie di navigazione verso il Lazio ed Ostia, oppure verso la Campania e Pozzuoli ${ }^{47}$.

L'Africa diviene, soprattutto a partire dal III d.C., monopolizzatrice dei mercati del Mediterraneo occidentale ed in particolare della Sardegna, attraverso quel braccio di mare definito dalla fonti proprio Mare Africano. Per questa ragione ho scelto di inserire dati statistici relativi ad importazioni di salsamenta dall'Africa, perché il panorama delle possibili rotte dei prodotti da salagione, sarebbe risultato alterato, se privo della percentuale cospicua di anfore africane.

Si deve tenere presente che la distanza dalla costa settentrionale dell' Africa alla Sardegna è di soli $300 \mathrm{~km}$ - la navigazione in antichità avveniva in circa un giorno e mezzo, o due giorni ${ }^{48}$ - e che Cagliari è più vicina a tali sponde che non a quelle dell'Italia attuale.

Fatta tale doverosa premessa, vi erano probabilmente più rotte di importazione dall'Africa : la prima proprio proveniente dal porto di Cartagine, che sempre costituì la testa di ponte privilegiata nei commerci verso la Sardegna ed altre che si dipartivano dalla costa orientale dell'attuale Tunisia, considerando quei prodotti ceramici

45. Proprio dall'officina di El Rinconcillo nella Baia di Algeciras, di fronte a Gibilterra, proviene un'anfora del tipo Dressel $1 \mathrm{C}$ con bollo SCG rinvenuta a Tharros nel Golfo di Oristano. Tale reperto costituisce un'attestazione certa di contatto e scambio tra Sardegna e Betica (Sotgiu 1987, 21, nº7, tav. I). Ringrazio il Professor Darìo Bernal Casasola per avermi fornito le precise indicazioni a riguardo (Bernal Casasola, Jiménez-Camino Álvarez , 2004, p. 603).

46. Mastino et al. 2005, p. 212-213.

47. Da ricordare l'importante ruolo rivestito dal porto di Puteoli nel corso dell'età tardo-repubblicana (Mastino et al. 2005, p. 51), come attesterebbe anche la fonte: Philostr. Vita di Apollonio di Tyana VII, 12.

48. Secondo quanto calcolato sul sito dell'Università di Stanford : http://orbis.stanford.edu/. che giungevano dalla Bizacena e dalla Zeugitana ${ }^{49}$. Le fonti annoverano, inoltre, quella da Tabraca ${ }^{50}$ e per quanto concerne i dati desunti dalle importazioni di Tripolitana II verso la città di Nora, probabilmente un contatto avvenne anche con tale area produttiva.

Le rotte africane sarebbero più facilmente tracciabili se all'interno del materiale ceramico importato potessero essere incluse anche le ceramiche fini (Sigillata Africana) e la ceramica Africana da Cucina. Nel ricostruire i collegamenti Africa-Sardegna via mare si è tenuto presente anche la mole dei dati desunti dallo studio di tali classi ceramiche, che hanno permesso di individuare differenti rotte dalle coste del nord-Africa, presumibilmente con la prevalenza di quella proveniente dall' area di Cartagine.

Il rinvenimento nel golfo di Gonnesa di un relitto che trasportava prodotti da salagione ispanici, sia anfore africani, che Sigillata Africana ${ }^{51}$, impone la necessità di contatto lungo la rotta delle due diverse aree di produzione. Il contatto poteva avvenire direttamente in Betica, oppure lungo le coste settentrionali dell'Africa o infine in terra sarda. Si potrebbe ipotizzare, pertanto, un collegamento marittimo che costeggia Marocco, Algeria e Tunisia, per mostrare concretamente i contatti tra area ispanica e nord africana.

In questo caso le rotte romane, indicate soltanto per i salsamenta, vanno completate con quelle di altri prodotti (verso la Gallia o il litorale del Sud della Francia, verso la costa Tarraconese e verso la Sicilia ed infine verso il bacino orientale del Mediterraneo). Le vie marittime romane ricalcano quanto stabilito dalle rotte interne puniche nel bacino del Mediterraneo occidentale ${ }^{52}$. Si può inoltre evidenziare in epoca cartaginese la presenza della rotta lungo le coste settentrionali dell'Africa, che partiva dal litorale atlantico per giungere a Cartagine. Le rotte solcate dai Romani erano necessariamente già state sperimentate da Fenici e Punici.

Nell'ambizione di questo intervento esisterebbe anche la volontà di stabilire possibili indizi di diffusione in zone interne della Sardegna di prodotti da salagione. I dati emergono da survey (fig. 30) effettuate non troppo capillarmente sull'isola. Si annoverano unicamente i tipi anforici attestati, poiché non è stato possibile dedurre dai repertori i dati quantitativi. In generale si può osservare che la maggior parte dei prodotti sono stati rinvenuti in territori riferibili a città costiere, porti di notevole entità. Turris Libisonis, nell' area del bacino del Rio Mannu - il fiume alla cui foce sorse l'approdo che diverrà l'attuale Porto Torres, in una zona fortemente romanizzata per via

\footnotetext{
49. Bonifay 2004, p. 486.

50. Itin. Ant. p. 82.

51. Salvi, Sanna 2000, p. 61-69.

52. Bondì et al. 2009, fig. 2, p. 437.
} 


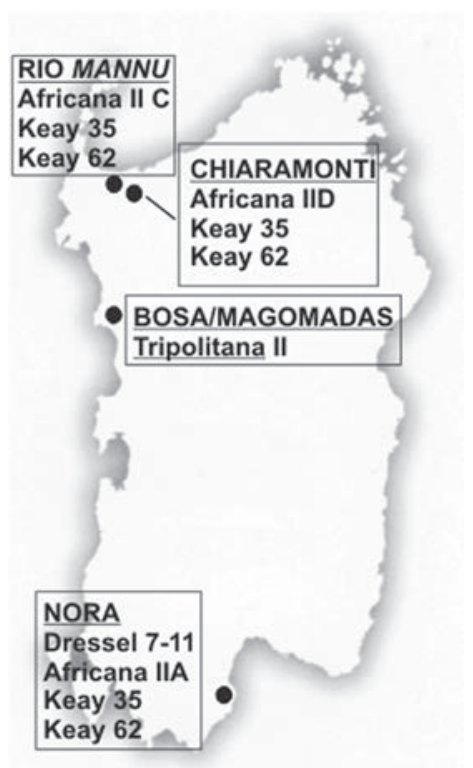

Fig. 30. Surveys. Rinvenimenti di anfore da salsamenta.

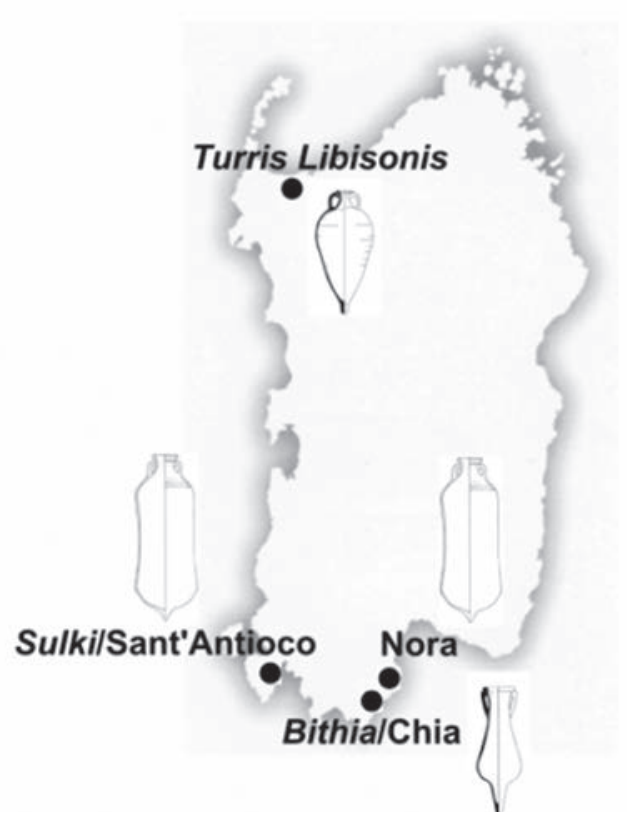

Fig. 31. Riutilizzo in necropoli di anfore da salsamenta. delle grandi risorse agricole e minerarie - ha restituito frammenti di anfore di importazione africana (Africana IIC, Keay 35 ed Keay $62^{53}$ ). Si deve ricordare che tutta l'area alle spalle di Turris Libisonis fu in epoca romana un fiorente bacino di prodotti di esportazione, tanto che l'attuale toponimo Romangia, è riconducibile al termine "romano" : infatti territorio del comune di Chiaramonti sono stati rinvenuti frammenti di Africana IID, Keay 35 e Keay $62^{54}$.

Scendendo lungo la Sardegna occidentale si incontra, presso il territorio degli attuali comuni di Bosa e Magomadas, il ritrovamento di Tripolitana II $^{55}$ : qui sulla costa erano presenti approdi, tra cui quelli delle città di Bosa e di Cornus. Il contatto con la Tripolitania si attesta in questa zona della Sardegna e, come è stato già evidenziato, anche nella città di Nora lungo le coste meridionali dell'isola.

Proprio il territorio di Nora è stato oggetto di una ricognizione di tipo estensivo e diacronico, tra le attestazioni si evidenziano importazioni di anfore del tipo Africana IIA, Keay 35 e Keay 62 ed in questo caso sono stati documentati anche contatti anche con la Betica (Dressel 7-11) ${ }^{\mathbf{5 6}}$.

Sembrerebbe che l'entroterra norense sin dalla prima epoca imperiale, avendo come riferimento uno dei maggiori porti della Sardegna meridionale, abbia importato,

53. Milanese et al. 2010, p. 225.

54. Id., p. 226.

55. Biagini 1998, p. 667-693.

56. Nervi 2001. presumibilmente per via fluviale, prodotti da salagione destinati anche ai propri insediamenti rurali.

La continuità sino all'epoca tardo antica pone una questione nodale, quale fosse il rapporto del territorio con Nora in tale periodo. Evidentemente era avvenuto un cambiamento, se non lo si vuole definire decadimento, forse in favore della vicina Cagliari, che divenne precocemente anche sede episcopale. Le importazioni verso il territorio di Nora dimostrano la sua continuità di vita ed il suo essere ancora inserito negli scambi mediterranei anche in epoca tardo romana.

Un ulteriore dato di analisi è quello ascrivibile a possibili usi secondari (fig. 31) delle anfore contenenti prodotti da salagione. A Turris Libisonis ${ }^{57}$ è attestato, nella necropoli occidentale, l'utilizzo di un' anfora lusitana (Almagro 51C) come sepoltura ad enchytrismòs.

Nella necropoli di Bithia - insediamento fenicio di VIII a.C., poi fiorente centro punico e successivamente romano, così importante da esser caput viae - è documentato il rimpiego di un anfora betica del tipo Beltrán IIB ${ }^{58}$.

Nella necropoli presumibilmente di epoca tardo antica posta sotto l'attuale chiesa di Sant'Antioco, antica Sulki, è stata il riutilizzata in ambito funerario l'Africana IIA, così come nella necropoli della città di Nora ${ }^{59}$.

Esistono documentazioni archeologiche derivanti da survey che indicano, nel territorio immediatamente retrostante Turris Libisonis, la presenza di probabili

57. Boninu, Pandolfi 2008, p. 1794.

58. Tronchetti 1987, p. 17-18.

59. La Fragola 2000, p. 216. 
strutture per la produzione di salsamenta, tali dati possono essere riportati anche per Tharros, Neapolis e Sulki.

Nel quartiere nord-occidentale di Nora, in un' area che in epoca fenicia era occupata da attività artigianali, gli archeologi hanno individuato tre vasche, che sono state ricondotte alla produzione di prodotti da salagione ${ }^{60}$.

Nel porto di Olbia sono documentate tracce di probabile lavorazione di grandi pesci pelasgici ${ }^{61}$.

Si sono inoltre tentati di indagare possibili indizi, che potrebbero ricondurre all'attestazione di lavorazione sarda di prodotti da salagione (fig. 32).

Tra essi la fonte letteraria Strabone ${ }^{62}$, che in I d.C. ci documenta del passaggio di tonni e della loro pesca in Sardegna.

Indizi più labili, che di per sé potrebbero anche risalire ad epoche successive a quella romana, sono : i toponimi che ricordano il sale : Perda e Sali ${ }^{63}$, ad est di Nora; le saline di Turris Libisonis, quelle di Sant'Antioco, di San Teodoro ${ }^{64}$ e di Cagliari ${ }^{65}$, situate attualmente nell' area orientale della città, che venivano già sfruttate in II a.C. e che in epoca alto medievale furono amministrate da ordini monastici. Si riscontrano anche toponimi che riconducono alle saline, come Capo delle Saline, nella costa occidentale sarda, ed altri che si ricollegano ad aree in cui avveniva la pesca del tonno, come Isola $S a$ Tonnara o le tonnare del Golfo dell'Asinara e quelle poste sull'Isola di San Pietro, di fronte all'antica Sulki, visitate nell'Ottocento dal piemontese Alberto Ferrero Della Marmora ${ }^{66}$; sempre nell'area sud-ovest sarda quelle di Sant'Antioco (Cala Sapone) e di Portoscuso, così come sulle sponde meridionali presso Porto Pino ; mentre lungo la costa occidentale sono documentate le tonnare di Pittinuri e del seno del Flumentorgiu. Nel Golfo di Gonnesa è attestata la pesca del tonni in epoca di dominazione spagnola ${ }^{67}$, così come nel Golfo di

60. Giannattasio 2007, p. 10-11 ; Giannattasio 2010, p. 1489-1499. $\mathrm{Si}$ deve ricordare che in periodo romano, l'area di scavo con rinvenimenti di vasche era situata lungo la via che conduceva al porto occidentale della città e quindi in zona prospiciente il mare. E' ipotizzabile che le strutture rinvenute non siano connesse ad una produzione di carattere industriale, ma per uno smercio a livello locale. 61. Nell'area dell'antico porto di Olbia, nella zona del relitto indicato come R15, sono emersi frammenti di pelvis, un mazzuolo e resti di macellazione di pesce, costituiti unicamente da teste e code e non da altre parti del corpo dell'animale. Un rinvenimento singolare è costituito da gruppi di lische caudali di grandi pesci ; in particolare alcune di esse conservano tracce della legatura vegetale che le teneva unite assieme (Riccardi 2003, p. 71).

62. Strab. 3.2.7.

63. In Sardo significa : pietra di sale.

64. Sito della costa nord-orientale sarda (Sanciu 2010, p. 12).

65. Per le saline in Sardegna: Ghiotto, Campanella 2009, p. 333-

340 ; Ghiotto 2009, p. 83-95 ; Garbati 2011, p. 112.

66. Della Marmora 2008, p. 283-289 e fig. 12, p. 285.

67. Salvi, Sanna 2000, p. 22.

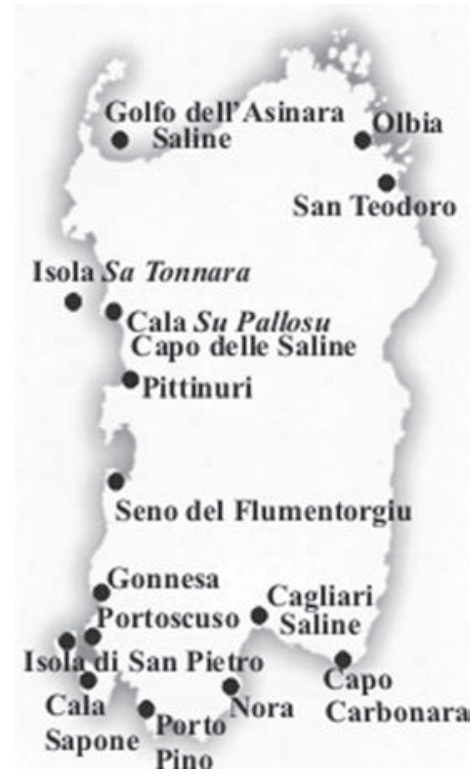

Fig. 32. Saline, tonnare e toponimi legati al sale o alla pesca.

Nora ${ }^{68}$ ed ancora nella punta sud orientale sarda a Capo Carbonara.

Tutti indizi che ci portano a pensare una continuità nella lavorazione, cui mancano completamente prove certe, come la documentazione di anfore romane da salsamenta di produzione sarda.

La continuità sino all'epoca moderna della lavorazione del tonno e dei prodotti derivati del pesce è ancora presente in Sardegna, come dimostrano le produzioni di filetti di tonno, di buzzonaglia, la parte più vicina alla lisca del tonno, o di ventresca, parte pregiata nella cavità addominale e da ultima, ma non per importanza, di bottarga.

Un legame tra mare e sale, passato e presente che sembra non esser ancora destinato a cessare ${ }^{69}$.

68. Lo sfruttamento delle risorse del mare a Nora è attestato già in età punica (Finocchi 2002, p. 161), sino all'impianto di una tonnara attiva ancora in epoca moderna. Gli Archivi di Stato di Cagliari del 1571 riportano la concessione in perpetuo del braccio di mare da Capo Pula a Carbonajre (Capo Carbonara) a favore di Jacopo Alagon conte di Sorris con la facoltà di impiantare tonnare e poterle alienare a favore di chiunque.

69. Vorrei ringraziare tutti coloro che mi hanno supportato e "spronato" in questo mio lavoro : Sónia Bombico - senza i cui incitamenti nulla sarebbe stato scritto -, Gianluca Minetto, Eliana Piccardi, Paola Puppo, Umberto Pisano, e Silvia Festuccia che in Kharayeb (Libano) ha pazientemente riletto le bozze ; tutti coloro - Michel Bonifay, Stefania Pesavento Mattioli, Annalisa Marzano, Ines Vaz Pinto - che con le loro osservazioni, o critiche, hanno contribuito a migliorare il mio intervento ed, in particolare, chi mi ha offerto la possibilità di presentare i risultati della mia ricerca alla Summer School "Fish\&Ships. Production et commerce des denrées halieutiques dans la Méditerranée antique", tenutasi a L'École française de Rome ed alla British School at Rome nel giugno 2012. 


\section{Bibliografia}

Bassoli 2010a : BASSOLI (C.) - Campagne di scavo 2006-2008. Gli ambienti $\mathrm{Ce}, \mathrm{Cj}$ e Cl, Quaderni norensi, 3, 2010, p. 87- 108.

Bassoli 2010b : BASSOLI (C.) - Considerazioni sulle classi ceramiche degli interri tardo antichi degli ambienti Ce e Cj, Quaderni norensi, 3, 2010, p. 109-134.

Bernal Casasola, Jiménez-Camino Álvarez 2004: BERNAL CASASOLA (D.), JIMÉNEZ-CAMINO ÁLVAREZ (R.) - El taller de El Rinconcillo en la Bahìa de Algeciras. El factor itálico y la economía de exportacion (ss. I. a.C. - I d.C.). In : Bernal Casasola (D.), Jiménez-Camino Álvarez (R. ) (ed.), Figlinae Baeticae. Talleres alfareros y producciones cerámicas en la Bética romana (ss. II a.C. - VII d.C.), Oxford, 2004, p. 589-606.

Biagini 1998 : BIAGINI (M.) - Archeologia del territorio nell' Ager Bosanus : ricognizioni di superficie nel comune di Magomadas (Nuoro), L'Africa romana, XII, 1998, p. 667-693.

Bondì 2006 : BONDÌ (S.F.) - Mobilità delle genti nel Mediterraneo fenicio e punico : qualche riflessione, L'Africa romana, XVI, 2006, p. 175-183.

Bondì et al. 2009: BONDÌ (S.F.), BOTTO (M.), GARBATI (G.), OGGIANO (I.) - Fenici e Cartaginesi. Una civiltà mediterranea, Roma, 2009.

Bonetto et al. 2009 : BONETTO (J.), FALEZZA (G.), NOVELLO (M.) e GHIOTTO (A.R.) (eds) - Nora. Il foro romano. Storia di un'area urbana dall'età fenicia alla tarda antichità. 1997-2006, Padova, 2009.

Bonifay 2004 : BONIFAY (M.) - Études sur la céramique romaine tardive d'Afrique, Oxford, 2004.

Boninu, Pandolfi 2008 : BONINU (A.), PANDOLFI (A.) - Colonia Iulia Turris Libisonis. Dagli scavi archeologici alla composizione urbanistica, L'Africa Romana, XVII, 2008, p. 1777-1818.

Botte 2009 : BOTTE (E.) - Salaisons et sauces de poisons en Italie du Sud et en Sicile durant l'Antiquité, Napoli, 2009.

Cirrone 2010 : CIRRONE (E.) - Uno spaccato della cultura materiale a Nora (Ca) nel II d.C. : i materiali di riempimento di un vano nell' area $\mathrm{AB}, \mathrm{A} \Omega Г \mathrm{H}$, Atti della Scuola di Specializzazione in Archeologia - Università di Pisa -, IV-V, 2010, p. 305-323.

Cisci 2006 : CISCI (S.) - Contenitori per la conservazione ed il trasporto. In : Martorelli (R.), Mureddu (D.) (eds), Archeologia urbana a Cagliari. Scavi in Vico III Lanusei (1996-1997), Cagliari, 2006, p. 112-136.

Colavitti, Tronchetti 2003 : COLAVITTI (A.M.), TRONCHETTI (C.) Guida archeologica di Cagliari, Sassari, 2003.

Della Marmora 2008: DELLA MARMORA (A.) - Itinerario dell'Isola Sardegna, Nuoro, 2008.

Finocchi 2002 : FINOCCHI (S.) - Considerazioni sugli aspetti produttivi di Nora e del suo territorio in epoca fenicia e punica, Rivista di Studi fenici, XXX, 2002, p. 147-186.

Franceschi 2009: FRANCESCHI (E.) - Le anfore romane. In : Bonetto (J.), Falezza (G.), Ghiotto (A.R.), Novello (M.) (eds), Nora. Il foro romano.
Storia di un'area urbana dall'età fenicia alla tarda antichità. 1997-2006, II.2, Padova, 2009, p. 733-745.

Garau 2006: GARAU (E.) - Da Qrsthdsht a Neapolis. Trasformazioni dei paesaggi urbano e periurbano dalla fase fenicia a quella bizantina, Ortacesus, 2006.

Garbati 2011: GARBATI (G.) - Il sale, le saline e la salagione. In : Manfredi (L.I.), Soltani (A.) (eds), I Fenici in Algeria. Le vie del commercio tra il Mediterraneo e l'Africa Nera, Bologna, 2011, p. 110-114.

Ghiotto 2009 : GHIOTTO (A.R.) - La produzione e lo sfruttamento di sale marino nella Sardegna romana, Sardinia, Corsica et Balaeres, VI, 2009, p. 83-95.

Ghiotto, Campanella 2009 : GHIOTTO (A.R.), CAMPANELLA (L.) - Lo sfruttamento del sale marino nella Sardegna antica. In : Melis (M.G.) (ed), Uomo e territorio. Dinamiche di frequentazione e di sfruttamento delle risorse naturali nell'antichità, Sassari, 2009, p. 333-340.

Giannattasio 2003 : GIANNATTASIO (B.M.) (ed) - Nora. Area C. Scavi 1996-1999, Genova, 2003.

Giannattasio 2007: GIANNATTASIO (B.M.) - La campagna 2004. Il pozzo : la struttura, tecnica costruttiva, funzione, Quaderni norensi, 2, 2007, p. 3-13.

Giannattasio 2010 : GIANNATTASIO (B.M.) - Officine per la produzione del garum : urbanistica e tipologia. Il caso di Nora, L'Africa Romana, XVIII, 2010, p. 1489-1499.

Keay 1984 : KEAY(S.) - Late Roman Amphorae in the Western Mediterranean. A typology and economic study: the Catalan evidence, Oxford, 1984.

La Fragola 2000 : LA FRAGOLA (A.) - Ceramica comune ed altri materiali dalle tombe romane di Nora (CA), Quaderni della Soprintendenza archeologica per le province di Cagliari ed Oristano, 17, 2000, p. $209-236$

Mastino 2005 : MASTINO (A.) - Storia della Sardegna, Recco, 2005.

Mastino et al. 2005 : MASTINO (A.), SPANU (P.G.), ZUCCA (R.) - Mare Sardum. Merci, mercati e scambi marittimi della Sardegna antica, Roma, 2005 .

Mastino, Vismara 1994 : MASTINO (A.), VISMARA(C.) - Turris Libisonis, Sassari 1994.

Milanese et al. 2010 : MILANESE (M.), BIAGINI (M.), CHERCHI (M.), MARRAS (G.), PADUA (G.), VECCIU (A.) - Ceramiche tardo antiche da ricognizioni di superficie nella Sardegna nord-occidentale. In : Menchelli (S.), Santoro (S.), Pasquinucci (M.), Guiducci (G.) (eds), LRCW3 Late Roman Coarse Wares, Cooking Wares and Amphorae in the Mediterranean. Archaeology and archaeometry. Comparison between western and eastern Mediterranean, Oxford, 2010, p. 225-233.

Nervi 2001: NERVI (C.) - Il territorio nord-occidentale di Nora in epoca romana: studio dei materiali della ricerca di superficie, Tesi di Specializzazione in Archeologia classica, 2001, inedita. 


\section{CRISTINA NERVI}

Pavoni, Pettenò 2003 : PAVONI (M.G.), PETTENÒ (E.) - Ritrovamenti di anfore nelle acque di Nora. In: Tronchetti (C.) (ed), Ricerche su Nora -II (anni 1990-1998), Cagliari, 2003, p. 117-123.

Piccardi 2003 : PICCARDI (E.) - Anfore. In : GIANNATTASIO (B.M.) (ed), Nora. Area C. Scavi 1996-1999, Genova, 2003, p. 209-236.

Pisanu 2008 : PISANU (G.) - Olbia Punica e il mondo tirrenico, Bollettino di Archeologia on-line, 2008, p. 26-35. http://151.12.58.75/archeologia/bao_ document/articoli/4_Pisanu_paper.pdf.

Reynolds 2010 : REYNOLDS (P.) - Hispania and the Roman Mediterranean $A D$ 100-700, Londra, 2010.

Riccardi 2003 : RICCARDI (E.) - Relitti, e non solo, dal porto di Olbia. In : Amucano (M.C.), D’Oriano (R.), Pietra (G.), Riccardi (E.), Sanciu (A.), Tilocca (G.), Viaggi per mare. Viaggi per l'aldilà. Vecchi e nuovi rinvenimenti olbiesi, Olbia, 2003, p. 51-86.

Salvi, Sanna 2000 : SALVI (D.) - I. Sanna, L'acqua e il tempo. Prospezioni di archeologia subacquea nelle acque di Gonnesa, Cagliari, 2000.

Sanciu 2010 : SANCIU (A.) - San Teodoro. Museo della Civiltà del Mare. La raccolta archeologica, Sassari 2010.
Sotgiu 1987: SOTGIU (G.) - Parva epigraphica Sardiniae, I. Tharros. Instrumentum domesticum (in particolare dagli scavi di G. Pesce, aa. 19561964), Quaderni della Soprintendenza per i Beni Archeologici per le province di Cagliari e Oristano, 4, II, 1987, p. 21-31.

Tronchetti 1987 : TRONCHETTI (C.) - Bithia I : la tomba 49 della necropoli romana, Quaderni della Soprintendenza per i Beni Archeologici per le province di Cagliari e Oristano, 4, II, 1987, p. 15-20.

Tronchetti 2000 : TRONCHETTI (C.) (ed) - Ricerche su Nora -I (anni 19901998), Cagliari, 2000.

Tronchetti 2003: TRONCHETTI (C.) (ed) - Ricerche su Nora -II (anni 1990-1998), Cagliari, 2003

Villedieu 1984 : VILLEDIEU (F.) - Turris Libisonis : fouille d'un site romain tardif à Porto Torres. Sardaigne, Oxford, 1984.

Villedieu 1986: VILLEDIEU (F.) - Turris Libisonis - Porto Torres (Sardegna), il contesto delle mura. In : Giardina (A.) (ed), Società romana e impero tardo antico, III. Le merci, gli insediamenti, 1986, p. 145-162. 


\section{Salting the East: evidence for salted fish and fish products from the Aegean sea in Roman times}

\section{Tatiana Theodoropoulou}

\section{Introduction}

$\mathrm{F}$ lish was a staple in the Roman diet. According to Curtis trade in preserved fish, particularly salted, was "a brisk business for many inhabitants of the Mediterranean provinces" ${ }^{1}$. Modern research is revealing a growing body of evidence for large-scale fish-salting activities in the western parts of the Roman Empire. On the other hand, very little is known about relevant practices in the eastern provinces of the Mediterranean. Curtis states that "salting installations in the Greek East have yet to be discovered" 2 . Admittedly, this issue has not been extensively studied in Greece so far.

Fresh fish has always been a part of Greek markets as an alternative protein source, and the marketing of fish in Classical societies has been extensively discussed ${ }^{3}$. This tradition certainly continued down to Roman times, as suggested in the sources. At the same time, processed fish are known to have been preferred and consumed by the Greeks from the Classical period onwards. Although sporadic archaeological finds and ancient sources confirm the production and transportation of such products from across the Mediterranean (Byzantium, Crimea, Spain, Sicily) to the Aegean as early as the Classical period $^{4}$, the record is far from complete.

Questions about the fish-salting industry and trade in fish products can be approached though various lines of evidence, as suggested by Højte: fishing equipment, watchtowers, processing facilities, fish remains, transportation equipment, descriptive sources and pictorial representations ${ }^{5}$. This paper brings together several types of available evidence of salted fish-industry, trade and consumption of salted fish products in the Greek and Graeco-Roman worlds, with the emphasis on zooarchaeological remains. A recent archaeoichthyological analysis of two fish assemblages from the

1. Curtis 1984, p. 58.

2. Curtis 2005, p. 38.

3. Davidson 1997, p. 15-16; Mylona 2008, p. 75, 81.

4. Curtis 2001, p. 318.

5. Højte 2005, p. 133.
Hellenistic-Roman town of Dion in Northern Greece serves as the backbone of this paper, to address questions of procurement, production and trade of salted fish in the Aegean. Literary and other lines of evidence are used, in order to highlight aspects of this important component of the Roman economy and diet in ancient and Roman Greece.

\section{Zooarchaeological evidence of processed fish in the Aegean}

Although archaeoichthyological studies from Aegean sites are increasing, the discovery of zooarchaeological remains associated with processed fish from all periods of antiquity is surprisingly low.

The earliest faunal material hitherto found in Greece comes from 5th c. BC Corinth. Among the transport jars found in the Punic Amphora Building there is a large quantity of Mañá-Pascual A4 amphorae, suggestive of a considerable level of trade and consumption of their contents in Corinth. These amphorae come from Punic centres, known in antiquity for their trade in salted and pickled fish, suggesting that they contained fish, whose remains were found scattered in the building ${ }^{6}$. Two different types of amphorae seem to indicate two different contents. The archaeometric analysis by Maniatis et al. concluded that "wherever the amphoras were made, the nature of the two technologies is indicative that one ware was probably good enough for carrying fish in oil or brine, its quality being very consistent, while the second ware was very porous, suitable for dry contents" 7 . The fish remains consisted of packs of scales, while vertebrae and cranial bones were scarce ${ }^{8}$. Fish bones were primarily attributed to the gilthead sea bream, as well as tunny. According to the specialists who examined the remains, the products found in the amphorae consisted

6. Zimmermann Munn 2003, p. 201. There is no precise information on the exact provenance of these bones, whether from inside the amphorae or from the filling of the building.

7. Maniatis et al. 1984, p. 221.

8. Zimmermann Munn 2003, p. 201, n. 47, cf. fig. 12.5 . 
of fillets cut into 4-6 cm lengths so as to fit through the narrow mouth of the Punic amphorae. On the basis of these finds, excavators came to the conclusion that fish salting and trading centers of Southern Spain were known to the Greeks as early as the 5th century BC and that a thriving trade took place between this area and Corinth at that time 9 .

Despite the importance of this assemblage to the history of food in ancient Greece, it has long been thought to be a rather isolated find, complementing primary literary evidence of the consumption of salted fish in this part of the Mediterranean. The latter issue is even less well documented archaeologically for the following periods, thus leading to a rather biased record. The recent study of two Roman fishbone contexts from Roman Dion brought forward the issue of salted fish products in Roman Greece. The following paragraphs summarise the results of the zooarchaeological study and related questions ${ }^{10}$.

Dion is a Hellenistic-Roman town situated at the foot of mount Olympus, Northern Greece, today at approximatively $6 \mathrm{~km}$ from the shore of the Thermaic gulf (fig. 1) ${ }^{11}$. The first assemblage was retrieved from inside an amphora excavated in 1994 in the so-called House of the Hydraulis ${ }^{12}$. The house lies to the east of the main Agora of Dion, opposite the villa of Dionysos, next to the Praetorium with two tavernas ${ }^{13}$. The complex comprised a number of rooms, organised around a colonnaded courtyard, and was built on two levels. A covered gallery ran across the west side of the building, facing onto the main street. The house yielded a great number of storage jars, metal objects, as well as a musical instrument, the hydraulis. The amphora associated with the fishbones was found intact, however its type remains to be identified (ongoing study). It contained a large number of fish vertebrae, neurocranial fragments, cranial skeletal elements, as well as a many fin spines, ribs and rays (fig. 2, table 1). The state of preservation of most of the bones was good, albeit a higher fragmentation of more fragile cranial bones.

The assemblage consisted exclusively of remains

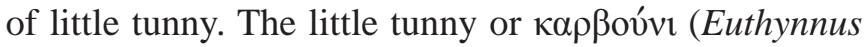
alletteratus Rafinesque, 1810) inhabits temperate and tropical areas of the Atlantic Ocean, the Mediterranean

9. Zimmermann Munn 2003, p. 203, 207-209 suggests Gades as a possible origin. Cf. idem. n. 134, Athenaeus Deipnosophistae 3.118d ("Let a Byzantine fish-slice come to our revels, and let a Cádiz bellyslice enter beside").

10. Theodoropoulou 2011.

11. For a general introduction to the site: Pantermalis 1997; 2000a.

12. Vasileiadou 2011, p. 49.

13. Pantermalis 1992; Praetorium cum tabernis duuabus et apparatura, Pantermalis 2000b, p. 377, 383, fig. 1 ; 2002, p. 424, fig. 2.

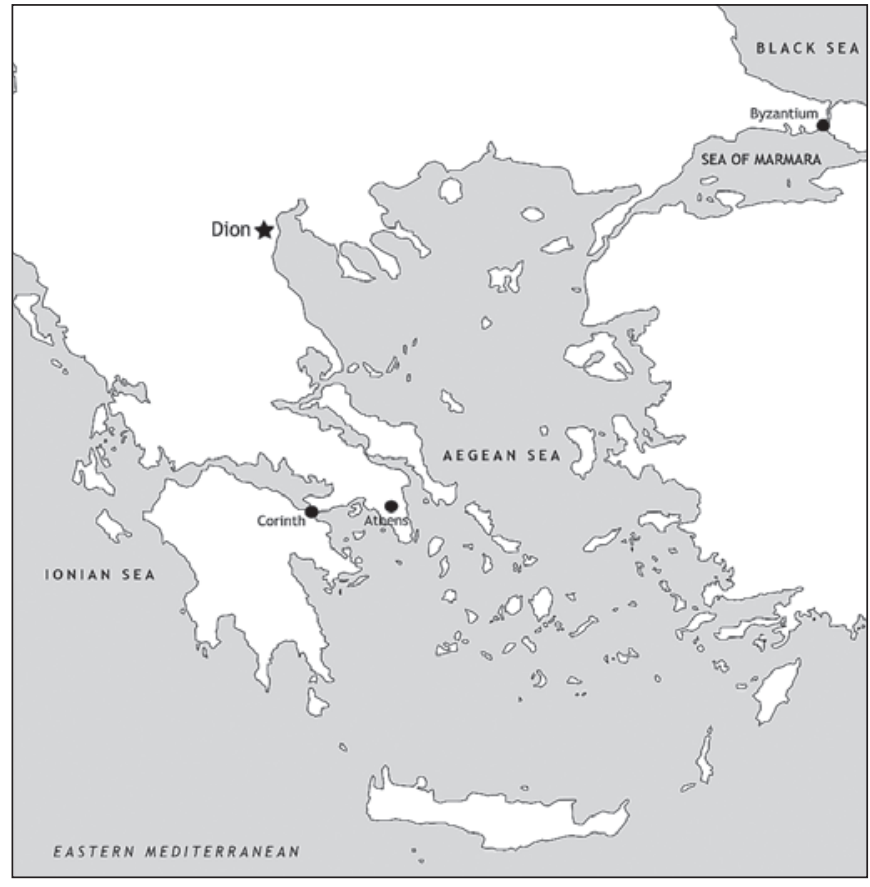

Fig. 1. Map of the Aegean and location of Dion ( T. Theodoropoulou).

and the Black Sea ${ }^{14}$. Atlantic little tuna is an epipelagic and neritic fish, more coastal than other tuna species, typically occurring in inshore waters. This species lives in schools together with other scombrids, but has a tendency to scatter during certain periods of the year. It is considered less migratory than other tuna species. The maximum size in the Mediterranean is about $100 \mathrm{~cm}$ fork length and about $12 \mathrm{~kg}$ weight, however size in modern commercial catches ranges roughly from 30 to $80 \mathrm{~cm}$ fork length ${ }^{15}$.

Several skeletal part observations on the faunal assemblage from the House of the Hydraulis pointed to the presence of at least 6 complete or sub-complete individuals. Size reconstruction showed that the remains belonged to fish that measured between 40 and $80 \mathrm{~cm}$ (fork length) (fig. 3) ${ }^{16}$. The reconstructed lengths of little tunnies converted to a total weight for 6 whole fish $(2500-8300 \mathrm{~g})^{17}$ allowed an estimate for the amphora contents of an average of $35 \mathrm{~kg}$ of fish each. Although

14. Collette, Nauen 1983, p. 35.

15. Id.

16. The allometric method in archaeo-ichthyology is based on the fact that inferior organisms, such as fish, tend to grow in size and weight steadily. Similarly, almost all elements of their skeletons show remarkable correlations between their various measures and the size (length and body mass) of fish themselves. It is thus possible to reconstruct the size and weight of fish found in archaeological sites, Desse, Desse-Berset 1996.

17. According to the length/weight ratio provided by Kahraman, Orey 2001, p. 724-725. 


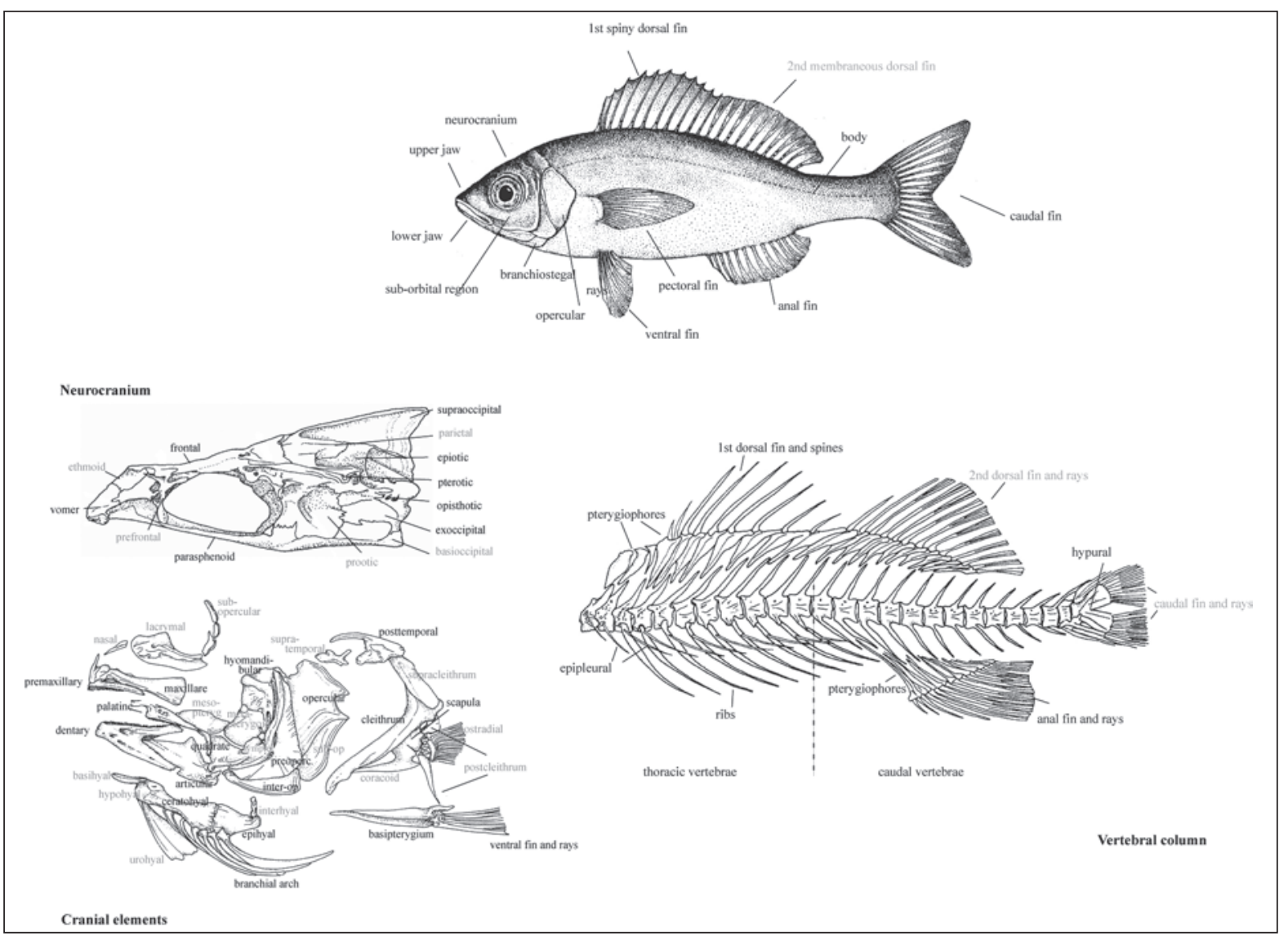

Fig. 2. External morphology and skeleton of a fish. In black letters the identified skeletal elements from the House of the Hydraulis, in grey the missing ones (৫) T. Theodoropoulou).

\begin{tabular}{|l|l|c|}
\hline \multicolumn{2}{|l|}{ Skeletal part } & Total NISP \\
\hline Cranium & Neurocranium & 16 \\
& Suspensorium & 108 \\
& Opercularia & 13 \\
\hline Branchial skeleton & & 6 \\
\hline Body & Fins/ribs/rays & 88 \\
& Vertebral column & 198 \\
\hline Total NISP & $\mathbf{4 3 9}$ \\
\hline
\end{tabular}

Table 1. Skeletal representation of fishbones from the House of the Hydraulis.

Fig. 3. Length-weight relationship of Eythunnys alletteratus basedon modern specimens and reconstructed lengths of Dion specimens (after Kahraman, Orey 2001, modified).

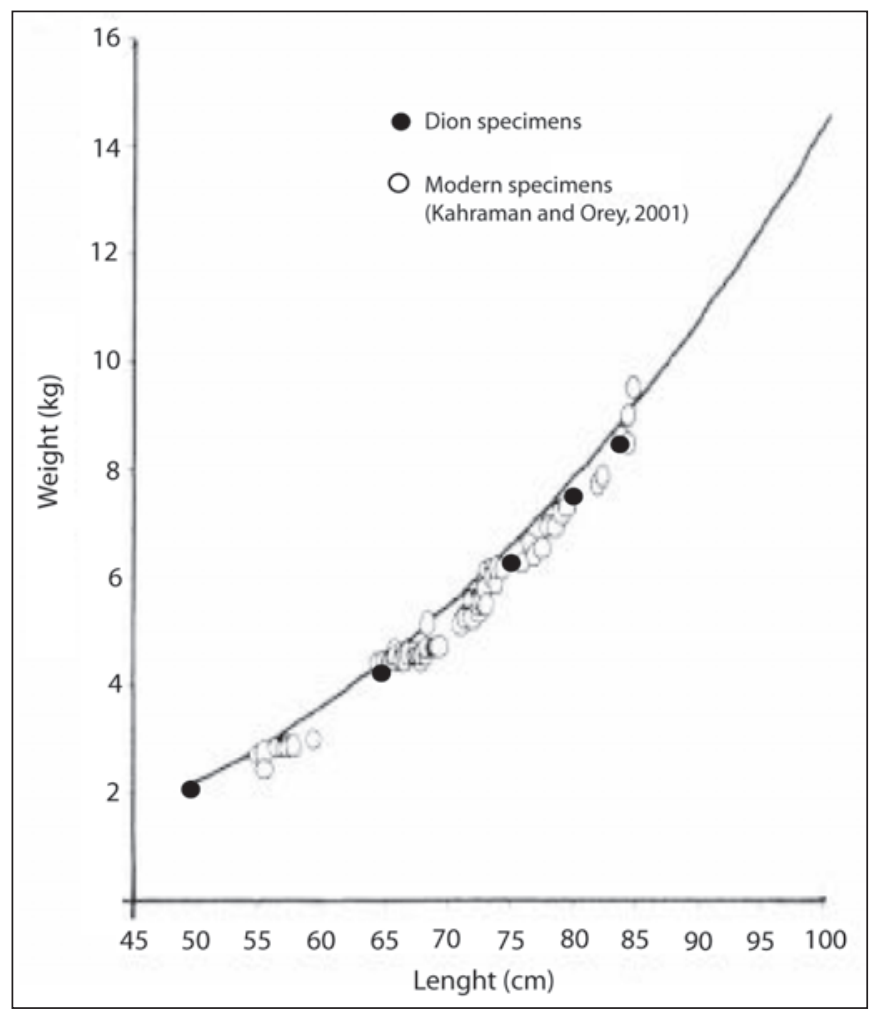




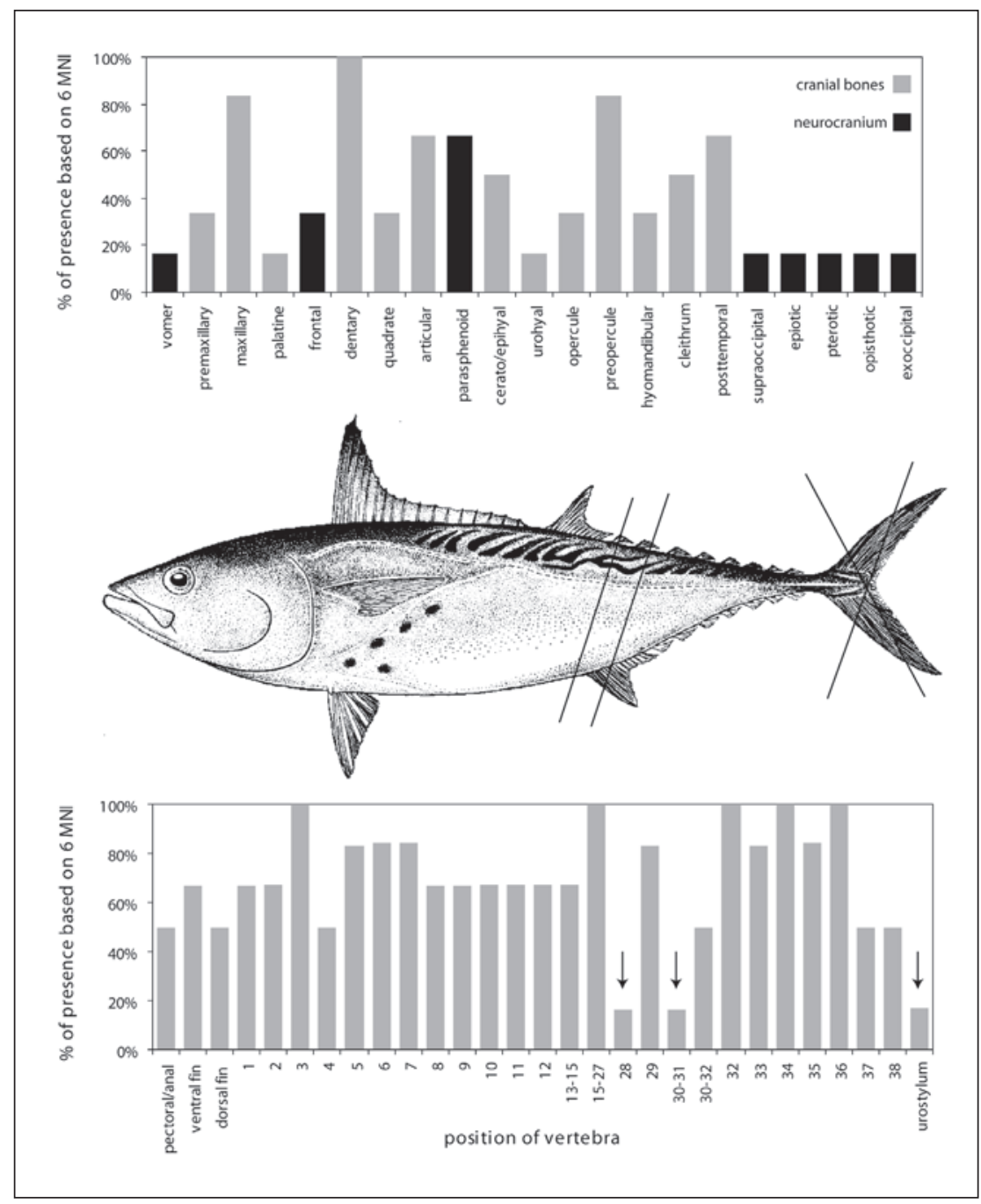

Fig. 4. Head and body part representation of little tunnies from the House of the Hydraulis based on the recconstruction of 6 individuals (৫ T. Theodoropoulou).

the exact dimensions of the amphora associated with the fish remains are not known ${ }^{\mathbf{1 8}}$, experimental approaches to similar assemblages can shed light on the capacity of this type of vessel ${ }^{19}$. Information on amphora mouth diameters may also be useful when it comes to the question of placing whole fish of a certain size (i.e. girth) into an amphora. Estimated girth of reconstructed little tunny lengths from the House of the Hydraulis ranges between 28.5 and $48.5 \mathrm{~cm}$ for fresh fish ${ }^{20}$. On the other hand, it is not clear whether these fish have been deposited whole or in chunks inside the amphora. The presence of whole fish heads inside the vessel is indicated by the recovery of nearly the entire range of bones from the suspensorium (articulating dentaries and articulars) and parts of

\section{Ongoing study.}

19. Desse et al. 2002. Desse-Berset, Desse 2000, in their experiment with a Dressel 7 amphora, they managed to fit 25 large mackerels of an average size of $40 \mathrm{~cm}$ and $650 \mathrm{~g}$, equal a total weight of $16 \mathrm{~kg}$, in the vessel.

20. Based on the equation provided by Santos et al. 2006, table 2. the skull. Moreover, the whole range of vertebrae is represented, with a relatively high representation of both abdominal and caudal vertebrae (fig. 4). The observed under-representation of caudal vertebrae nos. 28 to 30 might be due either to post-depositional factors or to the processing of fish prior to placing into the amphora, namely cutting the caudal part of the fish from the rest of the body in order for them to fit inside the amphora.

The second fishbone assemblage identified at Dion came from the so-called House of Euboulos ${ }^{21}$. This was a luxurious house situated on the main street of the town, with mosaic floors, a central atrium, as well as a fountain in the large room next to it. One of the mosaics depicted sharks ${ }^{22}$. The owner's name is frequently recorded in relief on the lead water pipe, although more information on that person is lacking. The paved path adjacent to the house leads to the central square of the Agora. Fish remains from this context were first detected during

21. Pantermalis 1997, p. 48-49; Pantermalis 2000a, p. 212.

22. Vasileiadou 2011, p. 49, n. 142. 
excavation in 1980, lying inside large body sherds from five amphorae found one next to the other ${ }^{23}$. The assemblage was left in situ and was collected two years later. The anatomical range of this assemblage is more limited compared to the one from the House of the Hydraulis. It primarily constists of body elements, vertebrae and fins (spines, ribs, rays), as well as few neurocranial fragments and cranial bones (fig. 5, table 2). Archaeologists also mentioned the presence of fish scales, which have either not been recovered or did not survive during their exposure prior to retrieval ${ }^{24}$. The remains exhibited a relatively good state of preservation. The few cranial elements showed a high degree of fragmentation, probably due to their fragile nature. On the other hand, a significant number of vertebrae (40\% NISP) are partly or heavily fragmented. Among them, 9 vertebrae showed a specific pattern of fracturation.

Species identification of the assemblage from the House of Euboulos was based on the vertebral elements ${ }^{25}$. At least one Thunnus species, and possibly also an Eythunnus sp. have been identified ${ }^{26}$. Tunas are mostly oceanic species with an epipelagic to mid-water range $(>500 \mathrm{~m} \text { depth })^{27}$. Tunas generally prefer more oceanic habitats, with distributions depending on species and size. Their size, depending on the species, can exceed $1.60 \mathrm{~m}$ and $85 \mathrm{~kg}$. It is still too early to draw conclusions about the size of the tunas found in Dion, as a definite attribution to a species is pending. The positioning of the vertebrae by size ranges seems to suggest the presence of two fish, one smaller and one larger, of an estimated length of 40-60 and 80-100 cm, respectively, although more chunks could be present ${ }^{28}$.

Fish remains from the House of Euboulos are characterized by the unequal ratio of cranial/post-cranial representation (fig. 6). Even within the cranial region, only bones from the posterior skull and posterior cranial elements are preserved. This observation leads to the assumption of beheaded specimens, or alternatively of a severe post-depositional process having affected the more fragile cranial bones. However, questions

\section{Id., p. 49.}

24. Id. For comparison, see preserved fish scales on amphora fragments from Corinth (Zimmerman Munn 2003, fig. 12.5).

25. Fish vertebrae were identified to genus level, although neural and heamal spines, as well as pre- and postzygapophyses were barely preserved, thus making it more difficult to position the vertebrae.

26. Identification to the level of species was not possible at this level of study due to the close osteological similarities among different genera of Thunnus sp. (T. albacares, T. alalunga, T. thunnus and T. atlanticus), Starks 1910; de Sylva 1955; Godsil 1984.

27. Collette, Nauen 1983, p. 80.

28. Following the "Profils Rachidiens Globaux" method (PRG), Desse et al. 1989. arise when one takes into account the description of fish scales in the excavation reports. In this case, the presence of beheaded yet unscaled fish has to be considered. The remains from the House of Euboulos also comprised of a number of fragmented and/or cut vertebrae. Fragmentation patterns fall into several categories (fig. 7) ${ }^{29}$. Examination of the fragmented surface indicated that some of these fractures have probably occurred some time in the past, possibly when the bone was already dry. However, among fragmented vertebrae, a distinct pattern has been observed. Nine articulating vertebrae were split in a dorso-ventral direction, repeatedly in the middle of the vertebra, next to the centrum. Thorough examination of the fragmented surface under a Leica Wild M10 microscope by bone technology expert Dr. Rozalia Christidou confirmed that the fracture of these bones would have occurred while the bone was still fresh, presumably with a sharp knife. It is possible that these cuts occurred during filleting. Cutmarks are sometimes recorded on tuna bones; filleting can lead to bevel sectioning of the neural and haemal processes of the first abdominal vertebrae, halfway up the trunk, as well as to deep cuts on the caudal vertebrae ${ }^{30}$.

Summing up, there are several arguments indicating that the two assemblages from Dion can be identified as some sort of food stored for future consumption, rather than a traditional consumption refuse. The fact that these fish remains were found inside a container or in close connection to ceramic vessels might suggest that they represent stored fresh fish or a preserved fish product. This is particularly the case of the fish bones associated with the amphora from the House of the Hydraulis that represent whole or sub-whole larger fish of the same species. Similarly, the remains from the House of Euboulos cannot be considered stray kitchen refuse finds. The presence of a single fish family is significant. The articulating vertebrae and the presence of the back of the head also suggest whole or sub-whole specimens. Furthermore, in both assemblages size reconstruction revealed a rather limited range in body sizes, indicating deliberate size selection. However, an issue that still remains open is how these fish reached Dion, whether fresh or processed. In the following, it is worth examining the various possibilities, in the light of available evidence from ancient Aegean.

29. $1 / 2$ antero-posterior and $1 / 2$ dorso-ventrally; $1 / 2$ antero-posterior and $3 / 4$ dorso-ventrally; zygapophyses missing; diagonal anterior laterally; diagonal posterior dorso-ventrally; vertical dorso-ventrally; horizontal antero-posterior.

30. Bernal Casasola, Gonzalez 2008, p. 18 and references. 


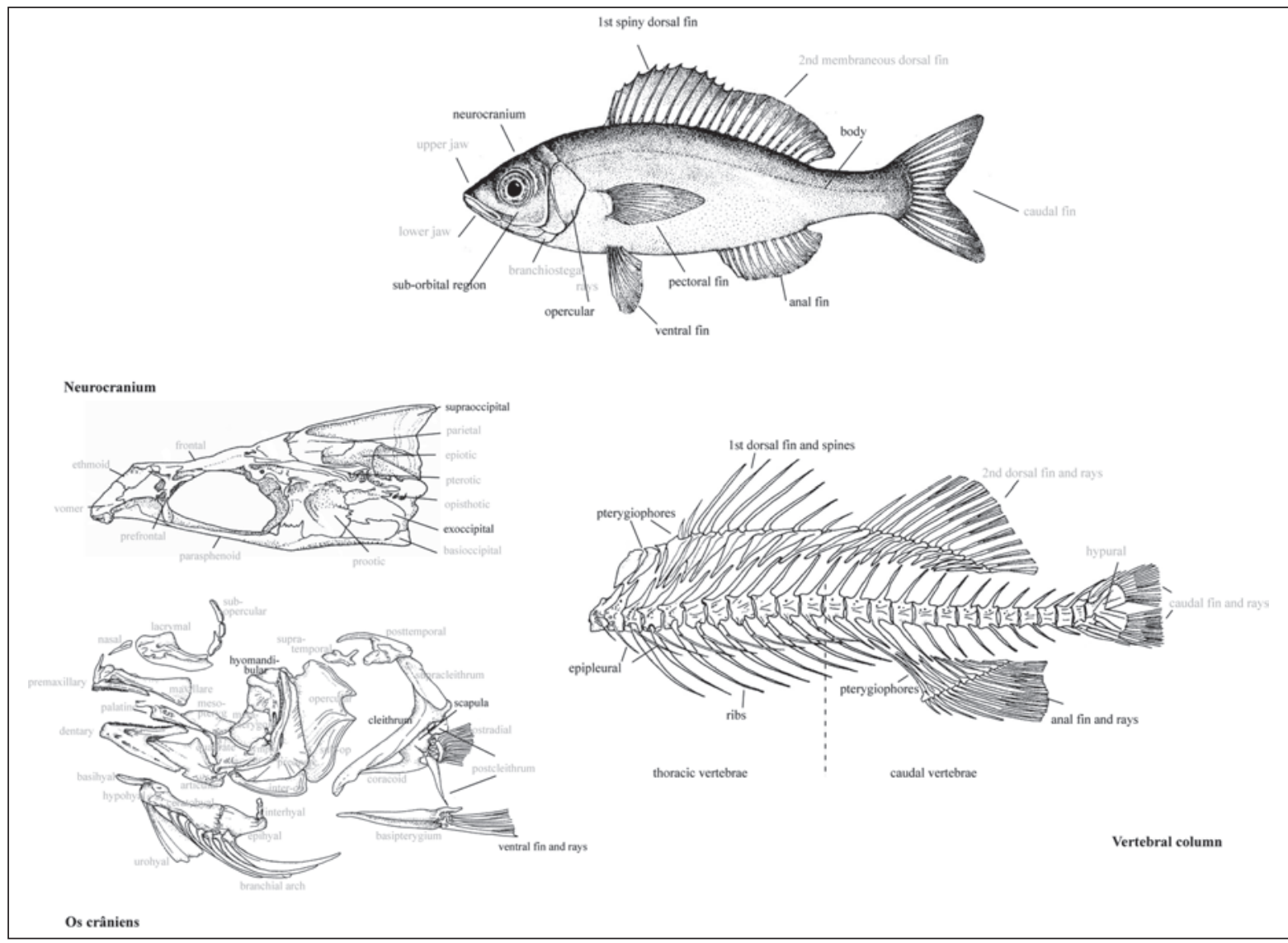

Fig. 5. External morphology and skeleton of a fish. In black letters the identified skeletal elements from the House of the Euboulos, in grey the missing ones (๑ T. Theodoropoulou).

\begin{tabular}{|l|l|c|}
\hline \multicolumn{2}{|l|}{ Skeletal part } & Total NISP \\
\hline Cranium & Neurocranium & 2 \\
& Opercularia & - \\
& Suspensorium & 13 \\
\hline Branchial skeleton & & - \\
\hline Body & Fins/ribs/rays & 103 \\
& Vertebral column & 90 \\
\hline Total NISP & $\mathbf{1 1 7}$ \\
\hline
\end{tabular}

Table 2. Skeletal representation of fishbones from the House of the Eubulus.

Fig. 6. Head and body part presence of little tunnies from the House of the Hydraulis (C) T. Theodoropoulou)

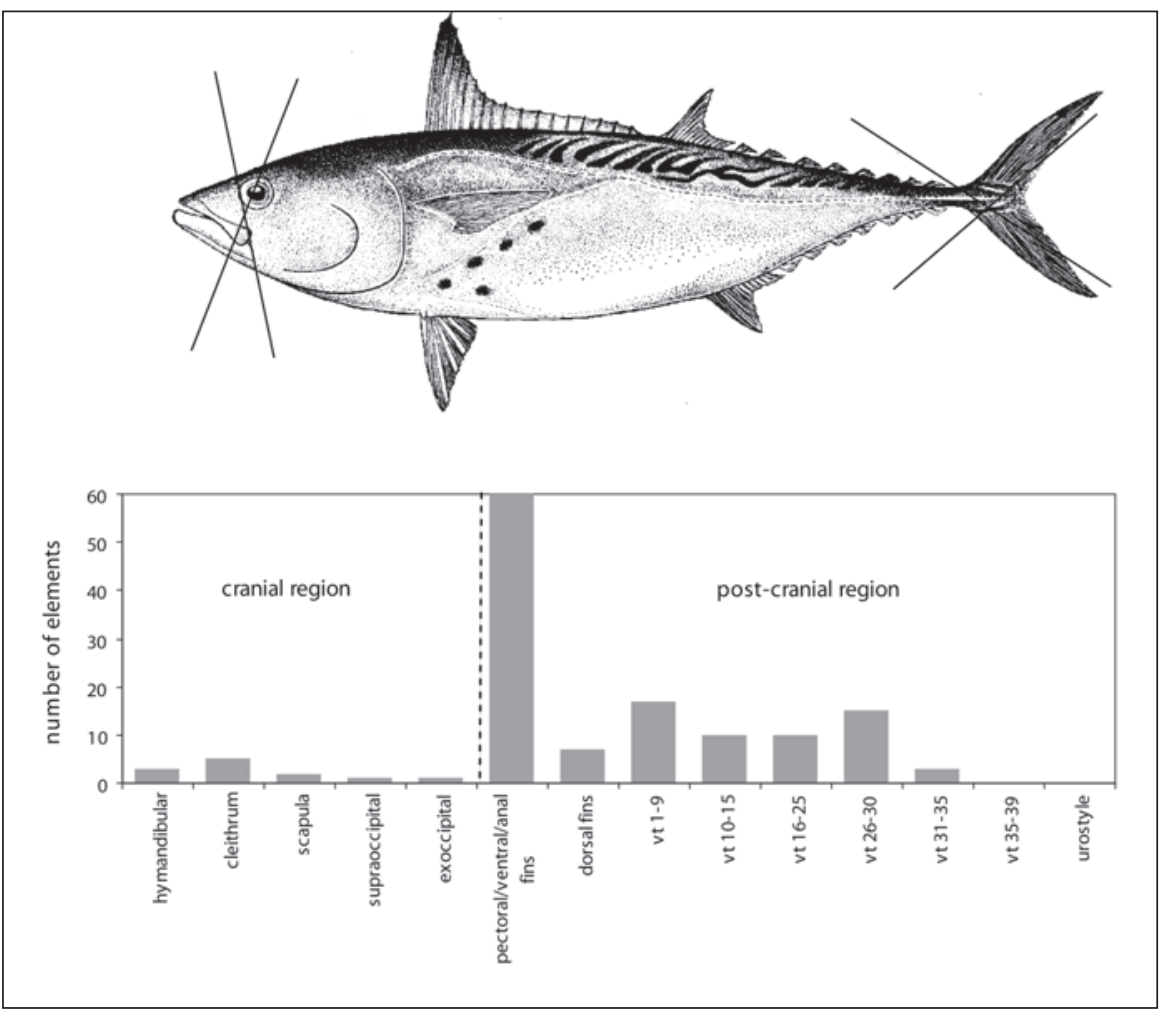




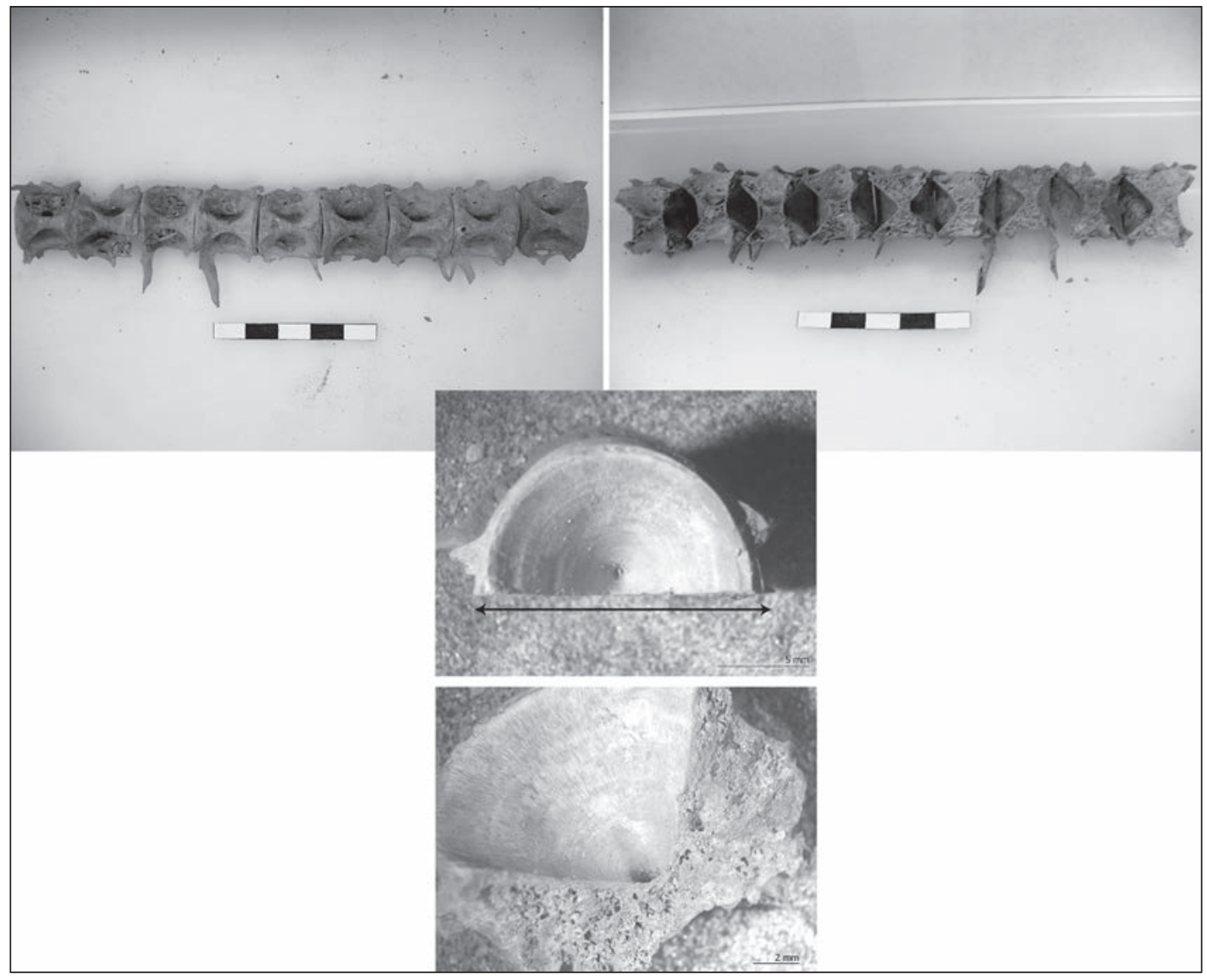

Fig. 7. Articulated Thunnus vertebrae from the House of Euboulos showing a distinct cutting pattern and stereoscopic views (5-8X) (๑ T. Theodoropoulou).

\section{Fresh vs. salted products in the Graeco-Roman world}

Fresh fish was always available in the Greek markets from the classical times down to the Roman period. Fish was a staple in Roman diet, and the Greek provinces would not have made exception to this rule. Among other evidence, two Latin inscriptions from the Roman Agora at Corinth refer to the selling of fresh meat and fish in the Tholos building ${ }^{31}$. Coming to the Roman town of Dion, the position of the House of Euboulos within the Agora boundaries and that of the House of the Hydraulis in close proximity to it, may indicate that the rich owners of these residences would have easy access to freshly marketed fish, in this case tunas from the Northern Aegean fish catches. The tradition of breeding fish or keeping live fish in fish-tanks was also known to the Greek provinces ${ }^{32}$. The close proximity of Dion

31. West 1931, p. 103-104, n. 125; Kent 1966, p. 127-128.

32. Crete (Chersonisos, Siteia, Ierapetra, Zakros), Kenchreiai near Corinth, Aegina, Curtis 1991, p. 116 and references. to the shore would favour transportation from the coast to the town on the day of capture. Several bronze fish hooks of different sizes and typologies found at Dion, as well as a net weaving needle, suggest that some citizens of Dion may have been actively involved in fishing activities ${ }^{33}$, and fishermen from this area had to contrib-

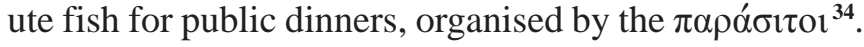
Transportation of fresh fish to the mainland is attested by ancient authors ${ }^{35}$, sometimes over long distances ${ }^{36}$. There are also examples of buyers travelling all the way

33. Vasileiadou 2011, p. 50, 199-200.

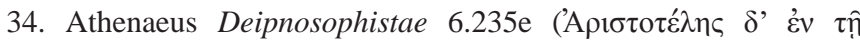

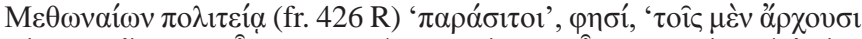

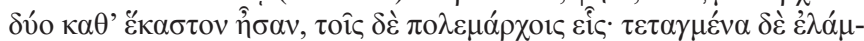

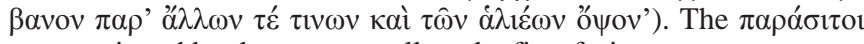
were assigned by the state to collect the first-fruits.

35. Pausanias Periegesis 8.5.8; Aristoteles Rhetoric 6.55; Strabo Geographica 14.2.21.

36. The case of eels from Lake Kopais (Boeotia) brought to Athens is often mentioned, Antiphanes fr. 191 (Kock); Aristophanes Acharnai 884, 894; Athenaeus Deipnosophistae (various passages), Mylona 2008, p. 76. 
to the coast for fresh fish ${ }^{37}$. On the other hand, fresh fish requires careful management and rapid consumption (usually within 1 to 3 days), as it spoils quickly in temperate areas, such as the Mediterranean ${ }^{38}$. For this reason, bigger fish were usually purchased in fillets or chunks. The rapid spoiling of fish might be avoided when whole fish are kept in sea water in jars, which might be the case of the whole fish kept inside the amphora in Dion.

However, preservation was a successful way to exploit large quantities of seasonal fish landings through transhipment of preserved fish and fish sauces to distant locations ${ }^{39}$. Processing with salt was the most common method for preserving staple foodstuffs in temperate areas of the ancient world. Archaeological finds from Corinth dated as early as the 5 th c. BC confirm references by Attic comedy writers mentioning trade and consumption of salted fish in the Athenian Agora ${ }^{40}$, which seems to have satisfied tastes more than supplementing a flourishing fresh-fish market. The tradition of preserved fish flourished particularly in the Roman period. However, available faunal evidence of such products in the Aegean part of the empire is much less abundant. In light of the Dion assemblages it is worth exploring various methods of preservation and trying to match them with the available faunal record.

The methods for processing fish have been extensively discussed in the literature ${ }^{41}$. Fish could be processed in two basic ways: a. pickling: the term includes all fish that were salted or kept in brine whole or in chunks, forming

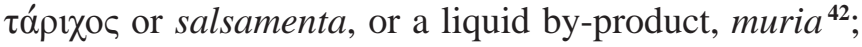
b. fish-sauce: the leftovers from larger fish (heads, entrails, blood) and/or small fry (anchovies, sardines) were left to macerate with salt and ferment, forming various liquids of various qualities and textures (garum, liquamen, allec). From a biological point of view, any fish, provided it has thick flesh and enough liquid, can be salted even without gutting or removal of the head ${ }^{43}$. Species of the Scombridae family are particularly suitable for salting, due to their high oil content which makes them prone to oxidation when exposed to the air ${ }^{44}$. Some fish were only gutted and packed with more salt than others, and for some products, the scales were

37. Athenaeus, Deipnosophistae 8.348b; Mylona 2008, p. 76.

38. In classical Athens fish fresh was not allowed to be kept over a longer period of time in water, Motsias 1982, p. 38.

39. Curtis 2001, p. 407.

40. Eupolis Marikas fr. 199; Athenaeus, Deipnosophistae 3.118e, $3.116 \mathrm{c}$.

41. Curtis 2001, p. 403-406, 413-415.

42. Id., p. 403.

43. Sternberg 2000, p. 148.

44. Pyke 1964, p. 75. left on the flesh ${ }^{45}$. Coming to the archaeo-ichthyological remains of these preparations, identification of the exact type of product, fish sauce (garum, liquamen, allec) or pickled fish (salsamenta) is not always very clear, and often remains completely invisible to specialists. Among the criteria that can be used to distinguish both types, N. Desse-Berset and J. Desse mention skeletal element representation, reconstructed body lengths and the anatomical position of the bones ${ }^{46}$. Small fish can be used in both fish sauce and salsamenta, although some elements help clearly distinguish between the two ${ }^{47}$. Desse-Berset and Desse conclude that, if the number of fish contained inside is relatively low and, if the fish identified are larger and their bones generally intact, in and articulated position and well preserved, the product would probably be salsamentum.

The final product received specific names (cybium, melandryum, trigonum) depending on the method of preparation, the degree of curing, the nature of the fish mentioned, or the fish part used in the case of bigger fish $^{48}$. Although these names were extensively used in Roman times, Curtis, among others, has noticed that the Romans did not always distinguish all these types to the same degree as the Greeks, and many terms are mere transliterations from the Greek ${ }^{49}$. A variety of Greek terms are mentioned in the Greek sources, distinguishing different species and ages of fish, shapes of cuts and anatomical parts, types and degree of processing and salting, texture and varieties of final products, which indicate a long tradition of these products in the Greek world ${ }^{50}$. The earliest faunal assemblage found in Corinth, if anything, confirms a tradition of consumption of such products by the Greeks. Based on faunal analysis, the products would consist of beheaded and unscaled fillets cut into $4-6 \mathrm{~cm}$ chunks. In light of these descriptions, these products could be identified as $\tau \alpha$ ápı๐ $\chi \varepsilon \varepsilon \pi 1 \delta \omega \tau o ́ v$ (salted fish with scales), as opposed to the $\tau \alpha$ á $\chi о \varsigma, \tau i \lambda \tau o ́ v$ (scaled salted fish) ${ }^{51}$. The mixed fish species, namely tuna and gilthead bream, would also give a special character to the product.

Turning to the assemblage from Dion, the generally complete or sub-complete body representation as well as the large size of the fish from both contexts, would

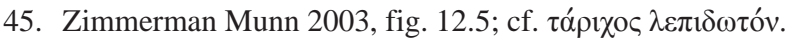

46. Desse-Berset, Desse 2000, p. 91.

47. For instance, a container with many small whole fish, particularly clupeids, like sardines and anchovies, whose bones are disarticulated and mixed up, probably would have held fish sauce, Desse-Berset, Desse 2000, p. 92.

48. de Saint-Denis 1947; Curtis 1991, p. 6-15.

49. Curtis 2001, p. 317, 403.

50. For a complete list, Curtis 1991, p. 6-8, n. 2.

51. Curtis 2001, p. 317. 
make it more plausible to identify salsamenta products rather fish sauce. Remains of salsamenta from inside amphorae usually show excellent preservation, as opposed to the fragile and damaged surface of garum remains due to the intense physico-chemical procedures (heating, decomposition, fermenting). Fishbones from both Dion contexts show a relatively good surface preservation. The Hydraulis context consisted of a few whole/sub-whole individuals. These could possibly be identified as $\theta v v v i ́ \delta \varepsilon c / \theta v v v i ́ \delta i \alpha$ (salted young tunnies). Whole specimens of salted fish, like mackerels, have been found in association with amphorae in the Roman world. Although Columella mentions whole fish, gutted and stacked into the vats, A. Morales and E. Roselló note that the presence of complete specimens of large-sized species, like tunas, presents a number of constraints, which are valid for the Dion material ${ }^{52}$. With respect to the little tunnies from the House of Hydraulis, "had they been processed as salsamenta, one wonders why their skulls and vertebrae were not removed, as these represented a substantial, non-edible fraction of the total weight of these animals" ${ }^{53}$. The texture of the products cannot either be further identified. These large-sized fish would be moist and soft if lightly salted, or dryer, rather tight and stretched, with a hard consistency, if salted for an extended period ${ }^{54}$. In the case of the Euboulos fish, the absence of the frontal part of the skull seems to resemble the method mentioned by N. Desse-Berset of removing the head or cutting-off the frontal part, which allows for the removal of the blood content and prevents the fish from rapid spoiling ${ }^{55}$. The transversely cut vertebrae may suggest that these are the remains of $\tau \varepsilon \mu \alpha$ x́ $\eta$ $\theta v v v i \delta \omega v$ (cuts of young tunnies), or similar products, such as $\tau \varepsilon \tau \rho \alpha ́ \gamma \omega v o v$ (square chunk) or kóßtov (cube chunk). If the excavation reports on the Eubulos context are right to mention the presence of scales, these cuts could be rather coarse looking and rougher to the touch ${ }^{56}$.

To sum up, in light of the zooarchaeological evidence from Greece, we are far from having a complete record of available salt-fish products that could match the list of such products compiled through literary sources. Smaller cuts of preserved fish, sparids and tunnies, could have circulated in the Greek markets as early as the 5th c. BC, while later Roman products could include larger cuts of young tunnies and whole tunas. Despite

52. Morales, Roselló 2008, p. 12.

53. Morales, Roselló are especially referring to individuals under $1 \mathrm{~kg}$, which is not the case of the Hydraulis material.

54. Curtis 2001, p. 415.

55. Desse-Berset 1993.

56. Curtis 2001, p. 415. the scarcity of zooarchaeological evidence, the occasional presence of such finds in the Aegean region raises a number of questions with respect to the organisation of production, transport and consumption of these products in the Greek East. In the following section, some of these issues are discussed in light of the faunal material presented above.

\section{Local delicacies vs. long-distance trade in fish products in the Graeco-Roman world}

Ancient authors identify places of production with respect to the preferred salsamenta and garum industries around the Mediterranean ${ }^{57}$. Ongoing archaeological research in the Western Mediterranean offers a growing list of areas that specialised in these productions. Evidence from the eastern part of the Mediterranean, on the other hand, is far less complete, with respect both to local places of production and to areas that engaged in trade with the Aegean region.

The earliest archaeological record of trade of fish products from other parts of the Mediterranean into the Aegean comes from 5th c. BC Corinth. Pottery analysis from the Punic Amphora Building suggests a flourishing trade of Punic fish-fillets and sauce amphorae to Corinth, and possibly to Kenchreiai, Athens (Kerameikos), Crete (Knossos) and Delos, where similar salted fish vessels have also been found ${ }^{58}$. The degree of analysis achieved thus far narrows the provenance to the wider Western Mediterranean, namely to North Africa or Southern Spain ${ }^{59}$. Future research may shed light on the exact provenance of these finds from Corinth. Remaining evidence is based on literary information deriving from a very precise part of the ancient world, that is ancient Athens ${ }^{60}$. Citing Curtis, "the athenian population apparently had an insatiable appetite for processed fish since literary sources show that salted fish came to Athens from as far away as Byzantium in the East and Spain and Sicily in the West" 61. Most salted fish imports to Athens described in the literary sources came from numerous locations around the Black Sea and were transhipped through Byzantium, a tradition that continued down to

57. Curtis 2001, p. 411; Curtis 2005, p. 36-38.

58. Curtis 1991, p. 118, n. 25 and references.

59. Maniatis et al., 1984.

60. For instance, in the 4th c. BC Phaselite merchands would bring jars of $\tau$ ápıðoc and Coan wine from Pontos to Athens, Demosthenes Contra Lacritum 31.8. Cf. most references in Athenaeus' work.

61. Curtis 1991, p. 114. 
Roman times ${ }^{62}$. However, in other instances, tuna slices were brought to Athens from Italy and Spain ${ }^{63}$.

Within this wide geographical framework of production sites for fish products, it is intriguing to attempt a hypothesis on the provenance of the fish products found at Dion. A better understanding of this issue could arise from the combined analysis of zooarchaeological and ceramic remains ${ }^{64}$. In the case of a foreign origin for the vessel and its contents of preserved fish from other parts of the Roman Empire, the finds from Dion would be expected to come from the Western Mediterranean ${ }^{65}$. On the other hand, the hypothesis of an Aegean salted fish product would be less easily identifiable on the basis of pottery identity unless it came from ascertained production sites ${ }^{66}$. At this point of research, in the absence of final pottery analysis from the site of Dion, it is difficult to attribute the Dion fish assemblages to either a local market or to a long-distance trade market, such as from a distant Roman province. In the following section, the local origin of production is explored with respect to both biogeographical criteria available for the Aegean and literary or other evidence suggesting such activities in this part of the Mediterranean.

Tuna species present in the Aegean are the bullet tuna or bonito (Auxis rochei), the little tunny (Euthynnus alletteratus), albacore (Thunnus alalunga) and the bluefin tuna (Thunnus thunus) ${ }^{67}$. Tuna fisheries are quite lucrative in some areas of the Aegean and at specific times of the year, namely during migration from the Black Sea to the Western Mediterranean and the Atlantic ${ }^{68}$. Among possible or ascertained areas of tuna exploitation in the Aegean during antiquity are the Argolid, Patra, Megara, Halai Aixonidae, Troizen, Karystos, Samos, Lesbos, the island of Kastelorizo near Rhodes, Cos, and Crete, as well as Minor Asia (Halicarnassos)

62. Nicostratus frs. 4, 5 (Edmonds), Antiphanes frs. 77, 181 (Edmonds). On the role of Pontic areas and Byzantium in transhipment, see Braund 1995. Polybios (Historiae 4.38.4, 31.25.5.) notes that salted fish was one of the major products that Pontic areas supplied both to the cities of Greece and to Rome.

63. Antiphanes fr. 77 (Edmonds), Nicostratus frs. 4, 5 (Edmonds), Eupolis fr. 186 (Edmonds), Theopompos fr. 51 (Edmonds),

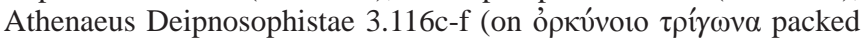
in jars brought by a Bruttian or a Campanian merchant, and on slices of Sicilian tunas).

64. For similar examples, Van Neer et al. 2005.

65. For a recent overview on usual types of amphorae associated with salsamenta and garum in the Western Mediterranean, see Delaval, Sternberg 2007 and Botte 2009, p. 105-168.

66. See below.

67. Papaconstantinou 1988, p. 134-135, 138-139.

68. Megalofonou 1991; Rose 1994, p. 96-97.

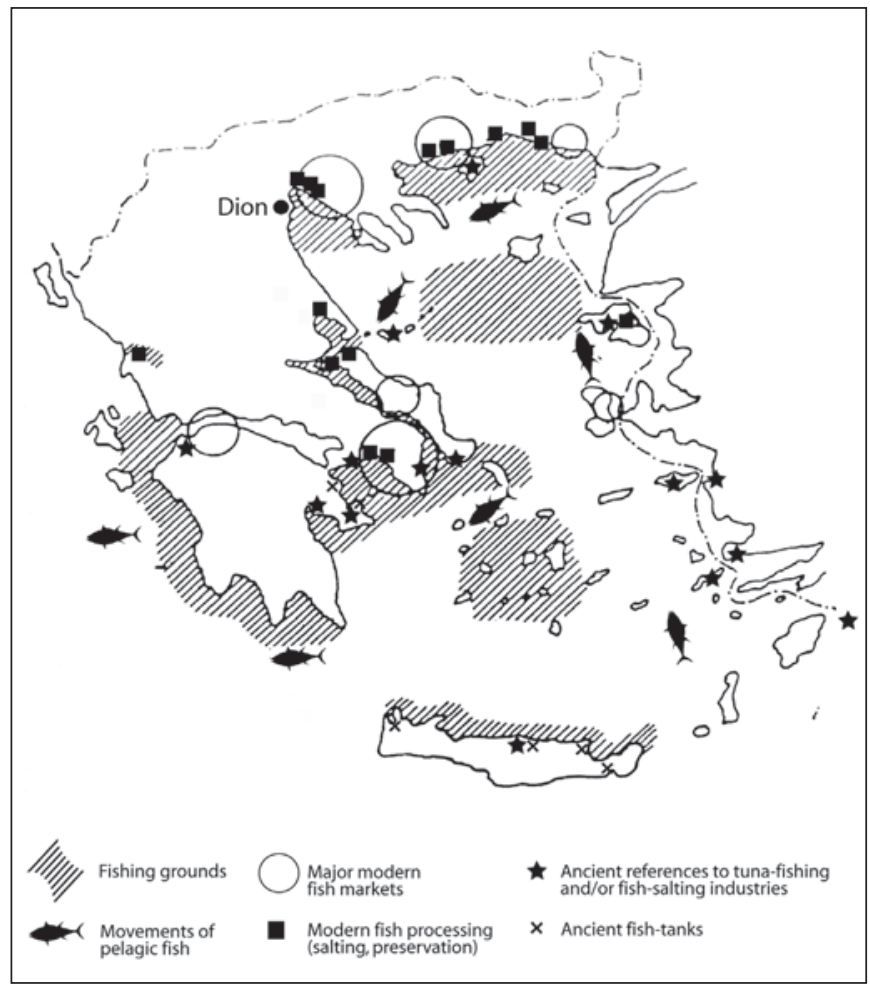

Fig. 8. Modern fishing grounds and movements of pelagic fish in the Aegean, markets and fish preservation locations, and locations of ancient tuna fisheries and fish-salting industries based on ancient sources (after loakimides 1980, p. 100, modified).

(fig. 8) ${ }^{69}$. Several areas in the Aegean were also known in antiquity for their salting factories ${ }^{70}$. Migratory fisheries have very specific seasonal constraints, to which man has always adapted his fishing strategies ${ }^{71}$. Some inscriptions offer insights into the organisation of these activities. For example, the well-known inscription from Troizen regulates the revenues from the exploitation of the tuna fishing grounds and the salt pans between the cities of Troizen and Arsinoe ${ }^{72}$. It is known from other parts of the Roman world, namely Asia Minor, that fishermen's guilds existed for the exploitation of this seasonal resource ${ }^{73}$. Another inscription from Cos provides a list of sacrificial obligations to Poseidon, among which the leasing of public watch-towers for observing migratory fish ${ }^{74}$. In another instance, merchants, such as Chairephilos of Athens, would purchase a portion of the

69. Curtis 1991, p. 113-115; id. 2001, p. 318; Corvisier 2007, p. 141-142.

70. Attica, Megaris, Peloponese, Central Greece, Macedonia, Thrace, Epirus, the Aegean islands and Crete, Carusi 2008, p. 45-98.

71. Sternberg 2002, p. 98.

72. IG 4(2)1, 163-146 BC.

73. Dumont 1976, p. $97-119$.

74. SIG [4]1000, 200-170 BC. 
catch in good years and provide the capital to process it ${ }^{75}$. The preserved fish could then be sold during late winter and early spring.

Narrowing down the geographical area closer to the town of Dion, to the Northern Aegean zone, combined data on ancient and modern tuna fisheries in the region do not refute the hypothesis of a local production of the fish found at Dion. Tuna fisheries are an important activity in the wider Northeastern Aegean, from the Sporades to the Chalkidiki peninsula ${ }^{76}$. Immature and adult individuals that have already spawned elsewhere during the summer arrive in the Sporades basin, usually at the end of August, and remain there in surface waters until the end of November ${ }^{77}$. Modern tuna catches often occur off the Chalkidiki peninsula. They consist mainly of Thunnus thunnus, as well as Thunnus alalunga and Eythunnus alletteratus $^{78}$. The average length of the catches is estimated to be $100-130 \mathrm{~cm}^{79}$. Some of these species are salted in autumn, when they are at more fleshy ${ }^{80}$.

Biogeographical patterns of migration of tuna fish through the Northern Aegean seem to fit well with the seasonality pattern reflected in both fish bone assemblages. The possible use of fish remains as a means of throwing light on seasonal exploitation of these resources has been extensively discussed in the archaeoichthyological literature ${ }^{\mathbf{8 1}}$. Reconstruction of seasonality is based on the observation that fish living in cold and temperate waters are affected by seasonal environmental changes (cold-warm season) which, in turn, influence calcification and growth rates, reflected in the growth rings in their skeletons. Usually, one year's growth is considered to be one groove and one ridge. Stained rings note the annual slowing down in fish growth ${ }^{82}$. Careful observation of growth rings in the studied assemblages was in several cases possible, thanks to the good preservation conditions of the centra of vertebrae. The study points to early/late autumn catches of fish. Had the Dion fish been captured off the coasts of the Thermaic gulf, Thasos or in the Sporades, they would have indeed belonged to the abundant late August-November catches in this region. If, on the other hand, the long-distance

75. Gallant 1985 p. 43.

76. Megalofonou 1990, p. 154.

77. Megalofonou 1991; Tselas 1991.

78. Kallianiotis et al. 2001, p. 2.

79. Id.

80. Diamantidis 2011, p. 155.

81. Casteel 1976; Wheeler, Jones 1989, p. 154-159; Desse, DesseBerset 1992; Desse et al. 2002.

82. Rodríguez-Maríni et al. 2006, figs. 1-3. trade hypothesis is put forward, the fish would belong to what Sternberg calls "thons de retour" ${ }^{33}$.

Ancient evidence from this region suggests that some fish-salting activities took place in the wider North Aegean area. Although the coastal waters off Dion are only mentioned by Athenaeus with respect to the fishing of squid ${ }^{84}$, other places in Northern Greece were actively involved in the exploitation of tuna fishing. The island of Thasos was one of the well-known places for pickled fish in Classical and Hellenistic times ${ }^{85}$. Another production site mentioned was Peparethos, in the Sporades ${ }^{86}$. Since Thasos and Peparethos traded in preserved fish products in the 5th-3rd c. BC to places as far as Egypt, it could be suggested that this lucrative industry continued down to Roman times. It seems that salteries also existed in the North Aegean, possibly as early as the Late Roman Empire ${ }^{87}$. The Lex Aemiliana (167 BC) records a prohibition of the import of salt and a regulation of the production in Pieria between the rivers Peneios and Axios in order to supply the Stovoi of Paeonia ${ }^{88}$. The alcaline lake X $\alpha \lambda \varepsilon \dot{\varepsilon} \sigma \rho \alpha$, on the banks of the Axios river, was known to produce «X X $\alpha \varepsilon \sigma \tau \rho \alpha i ́ o v$

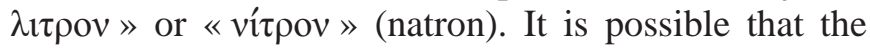
entire estuarine zone to the north of the Thermaic gulf, formed by the deltas of major rivers Axios, Aliakmon and Loudias, would create favourable conditions for salines ${ }^{89}$. Other known places of salt production in the Northern Aegean coast were located at Thessaloniki, possibly Akanthos (Chalkidike), as well as the lakes Vistonis and Plastiria in the Aegean Thrace ${ }^{\mathbf{9}}$.

To sum up, careful correlation of ancient sources and biological patterns do not exclude fishing and production of salted fish products in the wider Northern Aegean area. However, secure identification of the provenance of the Dion products is not possible in the absence of relevant pottery evidence. Despite the limitations on the identity of the finds from Dion, it is worthwhile examining the possible ways of procurement of these products by the citizens of the Roman town.

83. Sternberg 2002, p. 99.

84. Athenaeus, Deipnosophistae 7.326d.

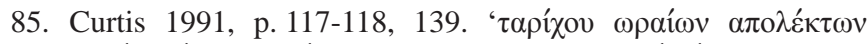

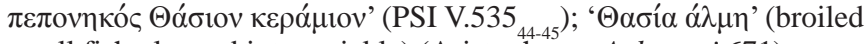
small fish plunged into a pickle) (Aristophanes Acharnai 671).

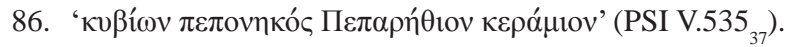

87. On the salines of Kitros in Pydna (W. Thermaic gulf), Poulter, Marki 1998 in Vasileiadou 2011, p. 52; Carusi 2008, p. 65.

88. Carusi 2008, p. 65; Vasileiadou 2011, p. 52, Titus Livius, $A b$ Urbe Condita 45.29.11-12.

89. Hammond 1972, p. 142-149, 160 in Carusi 2008, p. 65.

90. Carusi 2008, p. 66-67. 


\section{Selling salted fish in the Aegean markets}

Fish markets had a special place within the life of Greek and Roman agoras. Fresh and preserved fish were usually sold in two distinct areas, especially in the Roman times. Greek, like Roman texts, inform on special areas of the market or close to the market reserved for the sale of different types of fish ${ }^{91}$, as well as different sellers according to the type of cut and preservation ${ }^{92}$. According to Aristophanes and others ${ }^{93}$, salted fish was sold at the gates of Athens and in the Agora ${ }^{94}$. The famous Punic Amphora Building in Corith has provided evidence of a center for the distribution of Gaditean preserved fish to the Corinthians and beyond. The fish from Dion, whether a long-distance trade product or a local landing, would have arrived at the town either from the town's nearby port or from a fishing village close to the market; they might have also been purchased from the fishermen themselves in a nearby fishing village, following a Classical habit mentioned by ancient sources ${ }^{95}$. The proximity of both houses to the market of Dion suggests a more plausible provisioning from this area.

One final comment concerns the price of the acquired products. Evidence for fresh fish prices is scarce, but relevant information from Classical sources suggests that usually specific species and large-sized fish were more expensive than smaller coastal fish ${ }^{\mathbf{9}}$. Purchasing of fresh fish in these times, probably also in the Roman period, was linked to high status, affluence, and a cosmopolitan way of life ${ }^{97}$. Quoting Curtis, "fresh fish was for many Romans, and no doubt, for all poor Romans, like meat, an expensive food and, so, one not often eaten" ${ }^{98}$. Yet, it seems more likely that prices for fresh fish were also related to different quality and sized fish. Salted products, on the other hand, must have been affordable to people of all social classes according to Curtis, as prices for salted fish products would be less high than those

91. See, the 4th c. BC $\tau \alpha \rho \imath \chi 0 \pi \omega \lambda$ cíov on Delos, and in Roman times the forum piscatorium in Corinth, as well as a mentioning by

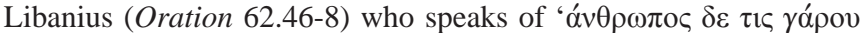

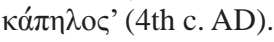

92. $\alpha{ }^{\prime} \lambda \mu \alpha 10 \pi \omega ́ \lambda \eta \varsigma=$ the seller of almi-a mixture of salt and water, $\dot{\omega} \alpha \iota \tilde{\omega}^{\prime} \lambda \eta \varsigma=$ the seller of high-quality salted fish (7th c. AD), $\tau \varepsilon \mu \alpha \chi 0 \pi \omega \dot{\lambda} \eta \varsigma=$ salted fillets, garopolis = the seller of garon (2th c. AD), $\tau \alpha \rho \iota \chi о л \rho \alpha ́ \tau \iota \sigma \sigma \alpha=$ the female seller of preserved fish (6th c. AD), Curtis 1991, p. 136, n. 121.

93. Cf. the $\tau \alpha \rho \iota \chi о \omega \dot{\lambda} \omega \omega v$ street, Curtis 1991, p. 136.

94. Cf. with Mana-Pascual A4 amphorae identified at Kerameikos.

95. Mylona 2008, p. 76.

96. For instance, large tunas and specific parts are higly prized in the Akraephnia fish price list.

97. Davidson 1993, p. 55; Wilkins 1993; Mylona 2008, p. 83.

98. Curtis 2001, p. 402. for fresh ones ${ }^{99}$. Yet, Curtis' comment mainly refers to fish sauce as a low quality foodstuff for providing cheap protein to the poor. Although generally salsamenta, especially whole fish, were usually meant for the rich and represented expensive, luxury products, they could also be cheaper depending on the salting process, the size and quantities, and, above all, the fish species ${ }^{100}$. As Corvisier notes quoting Hikesios and Pline, specific salted pieces of tuna, such as parts of the head and the belly, were more expensive at the fish market ${ }^{101}$. The late 3rd c. BC Akraiphnia fish price list offers some evidence ${ }^{102}$. Taste and fashion would also play a significant role in pricing. The final price of these products would also be subject to the modalities of transport from the nearby coast or from distant locations, as well as to their selling in a market connected to a nearby sanctuary.

Turning to the Dion case study, in the scenario of the two fish assemblages having been freshly caught from the neighbouring coasts, despite the proximity of procurement, their seasonal availability related to their significant size and quantities could have placed them in the higher price range in the local fish market. The quality and type of the transported goods would also define the final price. Finally, the distance covered to the town of Dion before these products rearched the market would also be reflected in the price. An amphora filled with whole tunas or little tunnies sent from Thasos would certainly represent a highly valued foodstuff, yet not as prized as a product from the western margins of the Roman Empire. Although these questions will probably remain unaswered, both the context of recovery and archaeoichthyological analysis seem to reinforce the idea of high-class buyers and consumers.

\section{Conclusions}

The recent archaeoichthyological analysis of two fish assemblages from the Roman town of Dion, Northern Greece, found in association with amphorae, has brought forward the role of salted fish products in the Greek world. The faunal study served as the basis for

99. Curtis 2001, p. 403; Corvisier 2007, p. 154-155. Around the time of the Dion assemblage (3rd c. AD) salsamenta were four-times cheaper than fresh fish, Corvisier 2007, p. 155.

100. According to Curtis 1991, p. 136, references to salted tunny

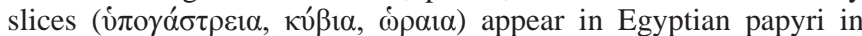
regard to provisions (often imports) for the upper classes.

101. Corvisier 2007, p. 154-155.

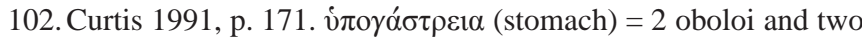
chalkoi, other portions $=1.5$ oboloi, quarters of young tunas $=1$ obolos, while one far Pontic fish could cost 300 drachmai. Salviat,Vatin 1971 ; Roesch 1974. 
an overview of the available literary and archaeological evidence of salted fish products and salting industries in the Aegean from Classical to Roman times. The paucity of evidence from this region comes in contrast to the detailed record from the Western Mediterranean. Thriving tuna fisheries and salted products played a major role in the Roman Empire's commerce and food industry, with evidence of long-distance trade all over the Mediterranean.

The case study presented can now be added to the hitherto scanty record from the Greek East. Species identification, skeletal part representation and size reconstructions allowed for a detailed description of the faunal contexts, consisting of whole or sub-whole specimens of large little tunnies and tunas, caught from late summer to late autumn. Although scanty examples of long-distance fish products travelling to the Aegean are known from Classical Corinth, it is not clear whether this is the case of Dion, as important information relating pottery associated with the fish assemblages to a local or distant origin is still lacking. On the other hand, the latter allowed us to test the hypothesis for a local
Aegean provenance for processed fish and to review available evidence of tuna fisheries and salting industries in Greece, and, more specifically, in Northern Aegean. Although the Aegean does not usually appear as a major area in that matter, tuna fisheries flourished in ancient Greece thanks to the seasonal migration of tuna shoals through the Aegean, and salting industries existed in several migratory fishing grounds across this region, including Northern Greece.

The fish assemblages from Dion offer a rare possibility for an insight into the everyday life of a Greek Roman town, thus contributing to the hitherto scarce zooarchaeological record of salted fish circulation and consumption in this part of the Empire. This paper points to the need for a reassessment of available literary and archaeological evidence with a special focus on newly excavated faunal material. Only by offering a « fresh » interdisciplinary eye on the « salted » Greek East riddle, will it be possible to connect the Aegean «fish-pond» to the well-documented network of fish industries of the Mediterranean in the Roman period.

\section{Bibliography}

Bernal Casasola, Arévalo Gonzalez 2007 : BERNAL CASASOLA (D.), ARÉVALO GONZALEZ (A.) - Baelo Claudia y sus haliéuticas: síntesis de las últimas actuaciones arqueológicas (2000-2004). In : Napoli (J.) (ed.), Ressources et activités maritimes des peuples de l'Antiquité, Actes du Colloque international de Boulogne-sur-Mer (12-14 mai 2005), Centre de recherche en histoire atlantique et littorale, Université du littoral Côte d'Opale, Dunkerque, 2007, p. 9-24.

Botte 2009 : BOTTE (E.) - Salaisons et sauces de poissons en Italie du sud et en Sicile durant l'Antiquité, Collection du Centre Jean Bérard 31, Archéologie de l'artisanat antique 1, Naples, 2009.

Braund 1995 : BRAUND (D.) - Fish from the Black Sea: classical Byzantium and the Greekness of trade. In : Wilkins (J.), Harvey (D.) and Dobson (M.) (eds.), Food in Antiquity, University of Exeter Press, Exeter, 1995, p. 162-170.

Carusi 2008 : CARUSI (C.) - Il sale nel mondo greco (VI a.C.-III d.C.) : luoghi di produzione, circolazione commerciale, regimi di sfruttamento nel contesto del Mediterraneo antico, Pragmateiai 15, Bari, 2008.

Casteel 1976 : CASTEEL (R.W.) - Fish remains in archaeology and paleoenvironmental studies, Academic Press, New York, 1976.

Collette, Nauen 1983 : COLLETTE (B.B.), NAUEN (C.E.) - Scombrids of the world: an annotated and illustrated catalogue of tunas, mackerels, bonitos and related species known to date, FAO Fisheries Synopsis 125, 2, Rome, 1983.
Corvisier 2007 : CORVISIER (J.-N.) - La pêche dans le monde grec. In : Debidour (M.) (ed.), Économies et sociétés dans la Grèce égéenne, 478-88 av. J.-C., Editions du Temps, Nantes, 2007, p. 129-159.

Curtis 1984: CURTIS (R.I.) - The salted fish Industry of Pompeii, Archaeology, 37, 6, 1984, p. 58-59, 74-75.

Curtis 1991 : CURTIS (R.I.) - Garum and salsamenta: production and commerce in materia medica, Studies in Ancient Medicine, Leiden, 1991.

Curtis 2001 : CURTIS (R.I.) - Ancient food technology, Leiden, 2001.

Curtis 2005 : CURTIS (R.I.) - Sources for production and trade of Greek and Roman processed fish. In : Bekker-Nielsen (T.) (ed.), Ancient fishing and fish processing in the Black Sea region, Black Sea Studies 2, 2, Aarhus University Press, Gylling, 2005, p. 31-46.

Davidson 1993 : DAVIDSON (J.) - Fish, sex and revolution in Athens, Classical Quaterly, 43, 1, p. 53-66.

Davidson 1997 : DAVIDSON (J.) - Courtesans and fishcakes. The consuming passions of Classical Athens, Fontana Press, London, 1997.

De Sylva 1955 : DE SYLVA (D.P.) - The osteology and phylogenetic relationships of the blackfin tuna, Thunnus atlanticus (Lesson), Bulletin of Marine Sciences of the Gulf and Caribbean, 5, 1, 1955, p. 1-41. 
Delaval, Sternberg 2007 : DELAVAL (E.), STERNBERG (M.) - Garum et pissalat : de la pêche à la table, mémoires d'une tradition, Catalogue d'exposition. Musée d'archéologie d'Antibes, Editions Snoeck, 2007.

Desse et al. 2002: DESSE (G.), DESSE (J.), DESSE-BERSET (N.) L'archéo-ichtyologie. In : Miskovsky (J.-C.) (ed.), Géologie de la Préhistoire : méthodes, techniques, applications, Paris, 2002, p. 815-822.

Desse, Desse-Berset 1992 : DESSE (J.), DESSE-BERSET (N.) - Âge et saison de mort des poissons : application à l'archéologie. In : Baglinière (J.-L.) et al. (eds.), Tissus durs et âge individuel des vertébrés, Colloque National Bondy (4-6 mars 1991), ORSTOM-INRA, Paris, 1992, p. 341-353.

Desse, Desse-Berset 1996 : DESSE (J.), DESSE-BERSET (N.) - On the boundaries of osteometry applied to fish, Archaeofauna, 5, 1996, p. 171-179.

Desse et al. 1989 : DESSE (J.), DESSE-BERSET (N.), ROCHETEAU (M.) - Les profils rachidiens globaux. Reconstitution de la taille des poissons et appréciation du nombre minimal d'individus à partir des pièces rachidiennes, Revue de Paléobiologie, 8, 1, 1989, p. 89-94.

Desse-Berset 1993 : DESSE-BERSET (N.) - Contenus d'amphores et surpêche ; l'exemple du Sud-Perduto. In : Desse (J.) et Audoin-Rouzeau (F.) (eds.), Exploitation des animaux sauvages à travers le temps (XIII Rencontres internationales d'archéologie et d'histoire d'Antibes, IV colloque international de l'homme et l'animal, 15-17 octobre 1992), Editions ADPCA, Juan-les-Pins, 1993, p. 341-346.

Desse-Berset, Desse 2000 : DESSE-BERSET (N.), DESSE (J.) - Salsamenta, garum et autres préparations de poisson. Ce qu'en disent les os, MEFRA, 112, 1, 2000, p. 73-97.

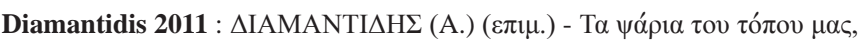
A $\theta$ ńva, 2011.

Dumont 1976 : DUMONT (J.C.) - La pêche du thon à Byzance à l'époque hellénistique, Revue de Études Anciennes, 78, 1976, p. 96-119.

Gallant 1985 : GALLANT (T.W.) - A fisherman's tale, Miscellanea Graeca, fasciculus 7, Gent, 1985.

Godsil 1984 : GODSIL (H.C.) - A descriptive study of certain tuna-like fishes, California Department of Fish Game, Fishery Bulletin, 97, 1984, p. 1-185.

Højte 2005 : HØJTE (J.M.) - The archaeological evidence for fish processing in the Black Sea. In : Bekker-Nielsen (T.) (ed.), Ancient fishing and fish processing in the Black Sea region, Black Sea Studies 2, 2, Aarhus University Press, Gylling, 2005, p. 133-160.

Kallianiotis et al. 2001 : KALLIANIOTIS (A.), KORRENTIOS (K.), ARGYRI (A.), KALLIANOTI (F.) - The Bluefin tuna fishery in the Eastern

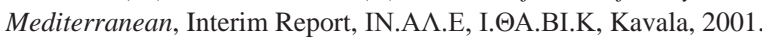

Kahraman, Oray 2001 : KAHRAMAN (A.E.), ORAY (I.K.) - The determination of age and growth parameters of atlantic little tunny Euthynnus alletteratus (Rafinesque, 1810) in Turkish waters, Col. Vol. Sci. Pap. ICCAT 52, 2, 2001, p. 719-732.

Kent 1966 : KENT (J.H.) - The inscriptions 1926-1950, Corinth 8(3), The American School of Classical Studies at Athens, Princeton, 1966.

Maniatis et al. 1984 : MANIATIS (Y.), JONES (R.E.), WHITBREAD (I.K.), KOSTIKAS (A.), SIMOPOULOS (A.), KARAKALOS (Ch.) and WILLIAMS II (C.K.) - Punic amphoras found in Corinth, Greece : an investigation of their origin and technology, Journal of Field Archaeology, 11, 1984, p. 207-222.
Megalofonou 1990 : MEGALOFONOU (P.) - Size distribution, lengthweight relationships, age and sex of albacore, Thunnus alalunga Bonn., in the Aegean Sea. In: Report of the GFCM-ICCAT Expert consultation on evaluation of stocks of large pelagic fish in the Mediterranean, 33, 1990, p. 154-162.

Morales, Roselló 2008 : MORALES (A.), ROSELLÓ (E.) - Iruna-Veleia (Alana, Spain): an overview of the fish remains from the Domus of Pompeia Valentina, Informe Tecnico LAZ-UAM 2008/1, 2008.

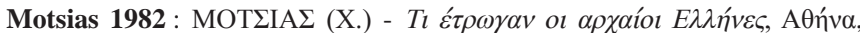
1982.

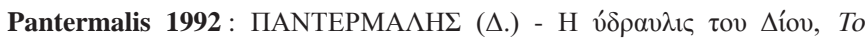

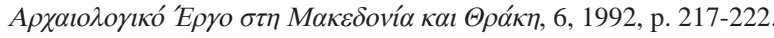

Pantermalis 1997 : PANTERMALIS (D.) - Dion: the archaeological site and the museum, Athens, 1997.

Pantermalis 2000a : PANTERMALIS (D.) - Discovering Dion, Athens, 2000 .

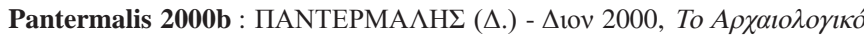

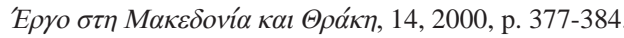

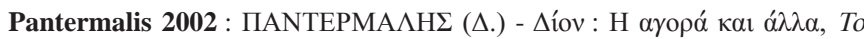

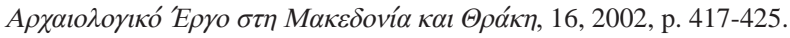

Papaconstantinou 1988 : PAPACONSTANTINOU (C.) - Faunae Graeciae. Check-List of Marine Fishes of Greece, National Centre for Marine Research and Hellenic Zoological Society, Athens, 1988.

Poulter, Marki 1998 : POULTER (A.G.), MARKI (E.) - Field survey at Louloudies: the discovery of a new Late Roman city in the Pieria, To

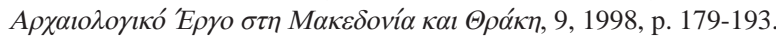

Pyke 1964 : PYKE (M.) - Food Science and Technology, Murray, London, 1964.

Rodríguez-Maríni et al. 2006: RODRÍGUEZ-MARÍNI (E.), OLAFSDOTTIR (D.), VALEIRAS (J.), RUIZ (M.), CHOSSONPAMPOULIE (V.), RODRÍGUEZ-CABELLO (C.) - Ageing comparison from vertebrae and spines of bluefin tuna (Thunnus thunnus) coming from the same specimen, Col. Vol. Sci. Pap. ICCAT, 59, 3, 2006, p. 868-876.

Roesch 1974: ROESCH (P.) - Sur le tarif des poissons d'Akraiphia, Zeitschrift für Papyrologie und Epigraphik, 14, 1974, p. 5-9.

Rose 1994 : ROSE (M.) - With line and glittering bronze hook: Fishing in the Aegean Bronze Age, PhD Dissertation, Indiana University, Ann Arbor, Bloomington, 1994.

Salviat, Vatin 1971 : SALVIAT (F.), VATIN (C.) - Le tarif des poissons d'Akraiphia. In : Salviat (F.) and Vatin (C.), Inscriptions de Grèce centrale, Paris, 1971, p. 95-109.

Saint-Denis 1974 : DE SAINT-DENIS (E.) - Le vocabulaire des animaux marins en latin classique, Paris, 1974.

Santos et al. 2006: SANTOS (M.N.), CANAS (A.), LINO (P.G.), MONTEIRO (C.C.) - Length-girth relationships for 30 marine fish species, Fisheries Research, 78, 2-3, 2006, p. 368-373.

Starks 1910 : STARKS (E.C.) - The osteology and mutual relationships of the fishes belonging to the family Scombrids, Journal of Morphology, 21, 1, 1910, p. 77-99. 
Sternberg 2000 : STERNBERG (M.) - Données sur les produits fabriqués dans une officine de Neapolis (Nabeul, Tunisie), MEFRA, 112-1, 2000, p. 135-153.

Sternberg 2002 : STERNBERG (M.) - Exploitation des mouvements migratoires et déplacement de populations piscicoles par l'Homme de l'âge du Fer à l'Antiquité. In : Gardeisen (A.) (ed.), Mouvements ou déplacements de populations animales en Méditerranée au cours de l'Holocène. Séminaire de recherche du thème 15 Archéologie de l'Animal (UMR 154-CNRS) (Lattes-Monpellier, 29 septembre 2000), BAR International Series 1017, 2002, p. 97-103.

Theodoropoulou 2011 : THEODOROPOULOU (T.) - Archaeoichthyological

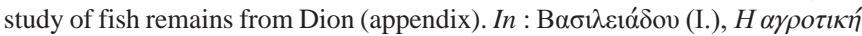

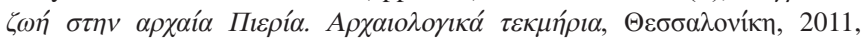
p. 301-321.

Tselas 1991: TSELAS (S.) - Review of National Fisheries (Greece). In : Report of the GFCM-ICCAT Expert Consultation on Evaluation of Stocks of Large Pelagic Fish in the Mediterranean, FAO Fisheries Report, 449, Rome, 1991, p. 3-4.

VanNeeretal.2005 :VANNEER(W.), WOUTERS(W.), RUTSCHOWSCAYA (M.-H.), DELATTRE (A.), DIXNEUF (D.), DESENDER (K.), POBLOME (J.) - Salted fish products from the Coptic monastery at Bawit, Egypt: evidence from the bones and texts. In : Hüster-Plogmann (H.) (ed.), The role of fish in ancient time. Proceedings of the 13th Meeting of the ICAZ Fish Remains Working Group (Basel/August 4th-9th October 2005), Verlag Marie Leidorf GmbH, 2005, p. 147-159.

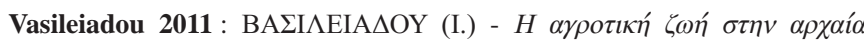

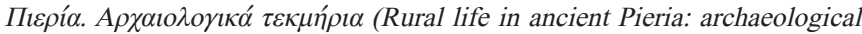

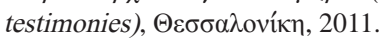

West 1931 : WEST (A.B.) - Corinth VIII, ii. Latin inscriptions 1896-1926, Harvard University Press, Massachusetts, 1931.

Wheeler, Jones 1989: WHEELER (A.), JONES (A.K.G.) - Fishes, Cambridge Manuals in Archaeology, Cambridge, 1989.

Wilkins 1993 : WILKINS (J.) - Social status and fish in Greece and Rome. In : V. Mars and G. Mars (eds.), Food, culture and history, London Food Seminar, London, 1993, p. 191-203.

Williams 1979 : WILLIAMS II (C.K.) - Corinth 1978 : Forum Southwest. Hesperia, 48, 2, 1979, p. 108-118.

Zimmerman Munn 2003 : ZIMMERMAN MUNN (M.-L.) - Corinthian trade with the Punic West in the Classical period. In : Bookidis (N.) (ed.), Corinth. Results of Excavations conducted by the American School of Classical Studies at Athens, Princeton, Princeton University Press, 2003, p. 195-217. 


\section{Fish products and their trade in Tauric Chersonesos/Byzantine Cherson: the development of a traditional craft from Antiquity to the Middle Ages}

\section{Martina Čechová}

\section{Introduction}

$\mathrm{T}$

Tauric Chersonesos was founded in the second half of the 5th c. BC as a colony of Herakleia Pontike, which was a colony of the Greek city of Megara on the southern shores of the Crimea; an outpost of the Classical world. Tauric Chersonesos, was, however, on the western side of the Crimean peninsula, and was established in order to increase Greek influence in this area. The centre of ancient Chersonesos was on the western side of the Qarantine Bay, west of Sevastopol Bay, a major Black Sea port with excellent natural harbouring facilities. Qarantine Bay had the advantage of being surrounded by sea from three sides, which was very important from a defensive point of view. The natural conditions around Chersonesos were very promising: there were large pastures, extensive arable lands and suitable conditions for fishing. The location also had potential as a trading hub. (see fig. 1 for location.)
Despite its distance from other centres of the ancient world and a location bordering barbarian territory, Chersonesos/Cherson was continually inhabited for almost two thousand years. It began as a Greek colony and then became a significant ally of the Roman empire. The Romans wanted to keep the North Pontic area peaceful, and so placed a garrison at Chersonesos. Later on the Black Sea area came under the influence of the Eastern Roman empire, or, as we call it nowadays, the Byzantine empire. Cherson's history of good relations with the super powers (Athens, Macedonia, the Roman Empire or the Bosporian Kingdom) and barbarian neighbours was due to skillful politics. Chersonesos thus survived the turbulent period of the $3^{\text {rd }} \mathrm{c}$. AD when many of the former Greek colonies of the Black Sea area were destroyed by barbarian raids. When Chersonesos became Byzantine, it remained important as the northernmost Byzantine outpost, protecting the empire from ouside enemies, and was known from this time as Cherson.

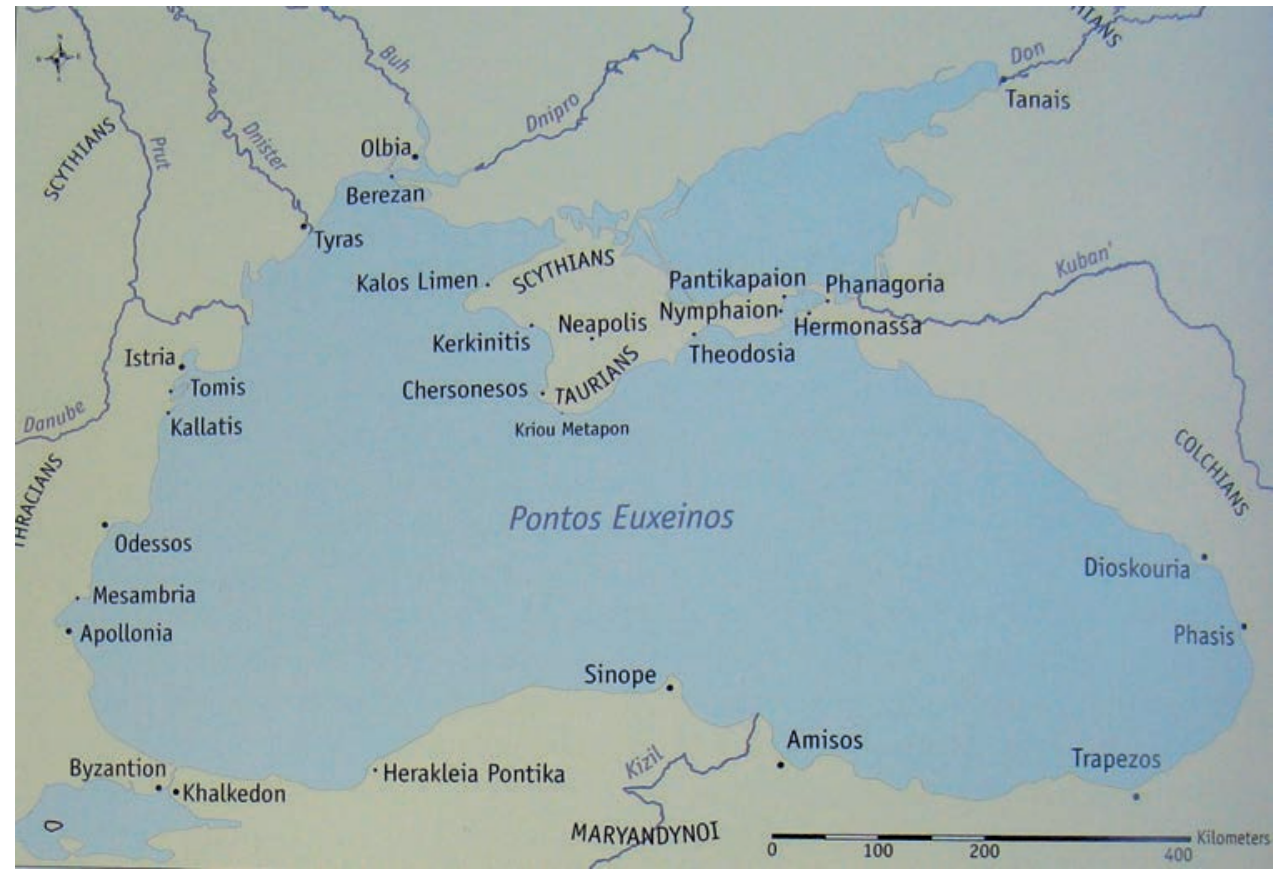

Fig. 1. Locational map of the study area (from Crimean Chersonesos 2003). 
Cherson was destroyed at the very end of the 13th c. by Mongolian hords and was finally abandoned after another attack about 100 years later. Even before its abandonment its importance had greatly diminished, since trade routes to Crimea led more to the east, to the Italian colonies of Sudak or Kaffa (Feodosija). The geographically strategical location of the Heracleian peninsula was not recognized again until the era of Empress Catherine the Great (1729-1796), when Russian naval bases were sought on the Black Sea. The city of Sevastopol was hence founded at a bay close to ancient Cherson. Fortunately, thanks to the decision to establish Sevastopol next to, and not over, the ruins, the ancient city was not affected by modern building activities. Cherson is therefore considered as an extremly suitable and important place for research, where all the aspects of ancient and medieval city life can be studied.

Archaeological excavations of Cherson began in 1827. Despite many difficulties mainly in the early years of excavation, many monuments from the city's long history have been preserved. The protected area covers 500 hectares; only one third has been excavated so far.

Ancient Chersonesos was built according to Greek architectonic rules for cities (the ancient building boom hit the city in the 3rd c. BC, when the walls, the theatre, the mint, temples, private houses and the agora were built and Chersonesos turned into a flourishing Hellenistic city). The rectangular plan of the streets was kept despite many reconstructions in the Middle Ages.

Besides its political significance, Cherson served as a trading centre where nomads could sell their products and vice versa. However, the economy of Cherson was based not only on its position as a trading crossroads; there were also various workshop industries that enabled Cherson to trade its own products, one of which was fish products.

\section{Fish industry at Cherson Natural conditions for fish processing}

Like any seaside town, Cherson was involved with fishing. However, at Cherson this evolved from simple fishing to an advanced industry. One reason for this was that the natural conditions for fishing were extremly favourable in the northern Black Sea because the Dniepr and Don rivers brought fresh water to the sea, which created good conditions for fish life in shallow coastal areas. ${ }^{1}$ Furthermore, there was an abundance of salt

1. Mylona 2008, p. 121. in the area, which was used not only as a commodity to sell but also as a preservative for fish processing. It was Strabo who described the salt beds in the vicinity of Cherson for the first time. ${ }^{2} \mathrm{He}$ wrote about a place 15 stadia from Cherson (approximately $6 \mathrm{~km}$ ) where salt was worked - in the north-western part of the Herakleian peninsula, where salt mining developed from Antiquity. Salt was a cheap but necessary commodity and trade in salt was one of the most important components of Cherson's economy in Antiquity and the Middle Ages alike. ${ }^{3}$ Salt was also an essential part of the fish production industry, since fish spoil extremly quickly if they are not preserved such as through smoking, drying, preserving or indeed salting. The annual amount of salt needed for fish processing in Cherson is estimated to be $8,00000 \mathrm{~kg} .{ }^{4}$

\section{Making garum, salting vats}

The fish sauce, garum, was a very popular foodstuff in Antiquity and also in the Middle Ages. The preparation of garum was described in a Roman cookbook by Apicius ${ }^{5}$ and also in Geoponica, a 10th c. volume containing advice on breeding domestic animals, veterinary medicine, viticulture, oleoculture and also salting meat and fish and the construction of salting facilities. ${ }^{6}$ Vats were constructed in Cherson for making garum and the remains represent the best evidence for the size of the fish production industry in Cherson, with over 100 vats so far having been recorded. Moreover, many objects such as fish bones, sinkstones, hooks or needles have been found in the houses in Cherson, providing evidence for this industry. ${ }^{7}$

The salting vats in question were first excavated at the end of the 19th c.; at this time they were considered to be granaries or water cisterns. Their true function as fish salting vats was revealed when the residues from the walls and bases of the vats were examined and fish remains (or even layers of garum, see below the example of the vat no. 91) were found. ${ }^{8}$

The average volume of Cherson's vats is $25-30$ cubic metres, usually $3 \mathrm{~m}$ or more in depth. In comparison

\footnotetext{
2. Strabo. VII, 4,7 .

3. Soročan 2005, p. 235.

4. Hojte 2005, p. 154.

5. Apicius, 1, 8 .

6. Geoponica. 20, XLVI.

7. Romančuk 2005, p. 99.

8. Id., p. 104.
} 
with the vats from other northern Black Sea towns like Tyritake, Cherson's are very large. In Tyritake there are 8 shallow vats situated close to each other; they were suitable for salting large fish. However, the large, deep vats at Cherson were designed for salting smaller fish and making garum. ${ }^{9}$ This suggestion is supported by evidence of anchovie bones in their bases. The shape of the vats varies; they were hewn in the rock or dug out of the earth. Their walls were covered by limestone bricks and cemented to be water-resistant, and the floors were covered with pieces of pottery, bricks or limestone plates and also cemented. Some of the bricks had stamps on them, which can be used for dating, such as from vat $\operatorname{nos} 60,83,84,86,96 .{ }^{10}$

Cherson's vats were not located in a closed district within the city but were connected to (private) houses and spread throughout the city, which is not what we would expect from the information in Geoponica. In many cases a store-room with large pithoi was found next to a vat. ${ }^{11}$ To quote one example, in the north-eastern part of Cherson, block XV-XVI (modern numbering, see fig. 2 , in red) in the yard there were two water tanks, wells and pits for pithoi, for storing the salted fish. Two deep rectangular vats (nos 75, 76, fig. 3 ) were situated in the eastern part of the house. This house was rebuilt from a Hellenistic house in the 1st c. AD. ${ }^{12}$. The first period of use for the vats dates back to the 1st-4th c. AD, thought to be connected with the presence of the Roman army in Cherson; the army protected the area, so trade and crafts flourished and the economy of Cherson and its vicinity prospered, especially in the 2 nd-3rd c. AD. Moreover, the soldiers needed food, and fish products were cheap and easy to make. This prosperous industry was, however, thought to be in decline in the 4th c. AD. ${ }^{13}$ Nonetheless, in 1958 a vat (no. 33, fig. 4) built (according to the archaeological finds) after the beginning of the 5th c. was excavated and E. G. Surov, a researcher from the Ural University and the then head of the excavations, argued that fish processing did not finish in the 4th c. but went on into the medieval period. ${ }^{14}$

\footnotetext{
9. Id., p. 102-103.

10. Id. 1972, p. 51; Id. 2005, p. 104, 107.

11. Hojte 2005, p. 152.

12. Romančuk 1973, p. 246-249; Id. 1977, p. 18-26; Crimean Chersonesos 2003, p. 86; Hojte 2005, p. 150.

13. Bělov 1963, p. 66-67.

14. Romančuk 2005, p. 105.
}

\section{The End of Antiquity and the Early Middle Ages}

When vat no. 33 was found, the theory that the fish industry was in decline in the 4th c. AD was reconsidered. More vats from the Middle Ages were excavated, and researchers admitted that the fish production industry successfully survived the transition between Antiquity and the Middle Ages. ${ }^{15}$ Although many of the vats were backfilled over time, new ones were built and the fish industry was not interrupted. The cause of the backfilling was building development within the city; there is no known reason to suppose there was any reduction in fish processing. For example, a large number of vats were backfilled during the reconstruction works that took place in Cherson at the turn of the 7 th c. ${ }^{16}$

Because of the methods of the early excavators it is not possible to establish when all the vats were built or used, however, a certain number of vats can be classified on the basis of stratigraphy, building techniques and archaelogical finds from the backfilling (mainly amphorae and other pottery fragments). Also coins, bronze and glass objects or bones have been found inside them. Some of the vats were filled in one event and the filling represents a closed set of artefacts. For example, vat nos 30-32 and 52, 55-56 were all backfilled at the beginning of the 7th c. and a basilica was built over them (today called Uvarovskaja after its excavator). ${ }^{17}$

The classification of vats (fig. 2), was made (where possible) mainly by A. Romančuk. Vat nos 70, 79, 86, $89,90,94,95$ were used up to the 6th c., vat nos 30-33, $52,56,63,68,92,97-100$ were used up until the turn of the 7th c. Vat nos 33, 34-41, 60-62, 83, 84, 86 were built in the 5th-7th c., while nos 74 and 75 were not backfilled earlier than in the mid-7th c. Vat nos 36-41 worked until the 8th-10th c. Vat nos 14, 34, 35, 47, 48, 93, 96 were used as late the 9th-10th c. Vat no. 91 was built in the 9th or 10th c. Essentially, out of all the datable vats, one third were used in the 6th-10th c. ${ }^{18}$ The theory of such a long and prosperous fish industry is confirmed by many archaeological finds, mainly coins and pottery fragments. Here are some examples, with dimensions given where available.

15. Bortoli, Kazanski 2002, p. 660.

16. Soročan 2005, p. 234-235. According to him, $19 \%$ out of 101 vats were backfilled at that time. Golofast 2007, p. 56.

17. Romančuk 1972, p. 45, 50.

18. Id. 2005, p. 108-109; Id. 1977, p. 20; Id. 1973, p. 247; Id. 1997, p. 70-71; Sazanov 2000, p. 123-149. 


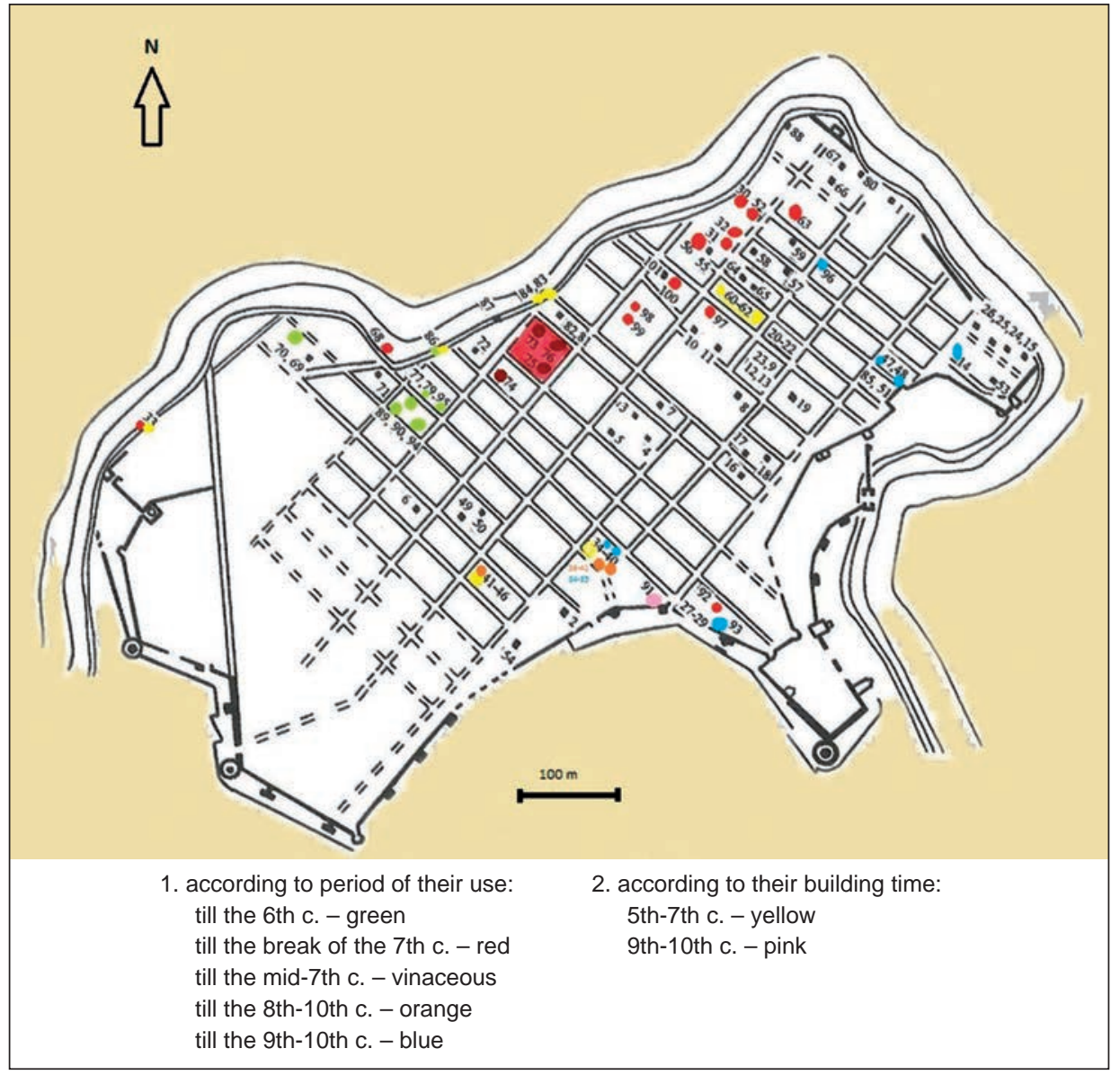

Fig. 2. Map of vats of Cherson, divided (where known). (Map after Romančuk 2005, colours are author's)

Vat no. 84 (base $2.65 \times 2.4 \mathrm{~m}$ )

The walls of the vat were damaged by the sea, however, the base remained intact and it is of great interest because of the pottery plinths that were used to build it (Fig. 5). 36 plinths were found there $(39 \times 35 \mathrm{~cm}$, $4-5 \mathrm{~cm}$ thick), and 23 had inscriptions that suggest dates between the 5 th- 7 th c. ${ }^{19}$

\section{Vat no. 63 (depth $15 \mathrm{~m}$ )}

This vat ${ }^{20}$ is $15 \mathrm{~m}$ deep and its filling is homogeneous. It consists of many amphorae and other pottery fragments (e. g. Hayes 27, Zeest 99, Late Amphora 1, Late Amphora 2, Carrote etc.). More precise dating of the backfilling was enabled by coins found in the filling. They were issued by Emperor Maurice (AD 582-602), so the backfilling of the vat was dated to the end of the 6 th to the beginning of the 7 th $\mathrm{c}$.

19. Beševliev 1964, p. 103.

20. Comprehensive information on this vat was given by A. Sazanov, see Sazanov 2000.
Vat no. $91(6.4-6.5 \mathrm{~m} \times 2.5-1.1 \mathrm{~m}$, depth $4.7 \mathrm{~m})$

The backfill consisted of two layers: a layer of fish remains at the bottom and backfill over this. The backfill material contained many fragments of amphorae with flat bases and rounded handles, attached just under the rim. Another amphora type is characterized by a piriform body and rounded handles connected above the low neck. This type dates to the 11th to 13 th c. ${ }^{21}$ Moreover, many fragments of Glazed Whiteware were found in the backfill. This type of pottery, in general characterized by open vessels that are incised or stamped on the inside, belongs to the standard ware of the middle Byzantine period; it was made from the 8th to the 12 th $\mathrm{c} .{ }^{22}$ Coins, that were found in the backfill (228 coins in total) came from the 9th-12th c. The latest are coins of Emperor Alexios I Comnenos (AD 1081-1118). Other than these finds, changes in architecture within Cherson provide

21. Jakobson 1950 , p. 104, ris. 53a, 53b, 54; Bakirtzis 2003, p. $80-81$, fig. 21.

22. Talbot-Rice 1930, p. 27-28; Dark 2001, p. 63; Vroom 2005, p. 77. 


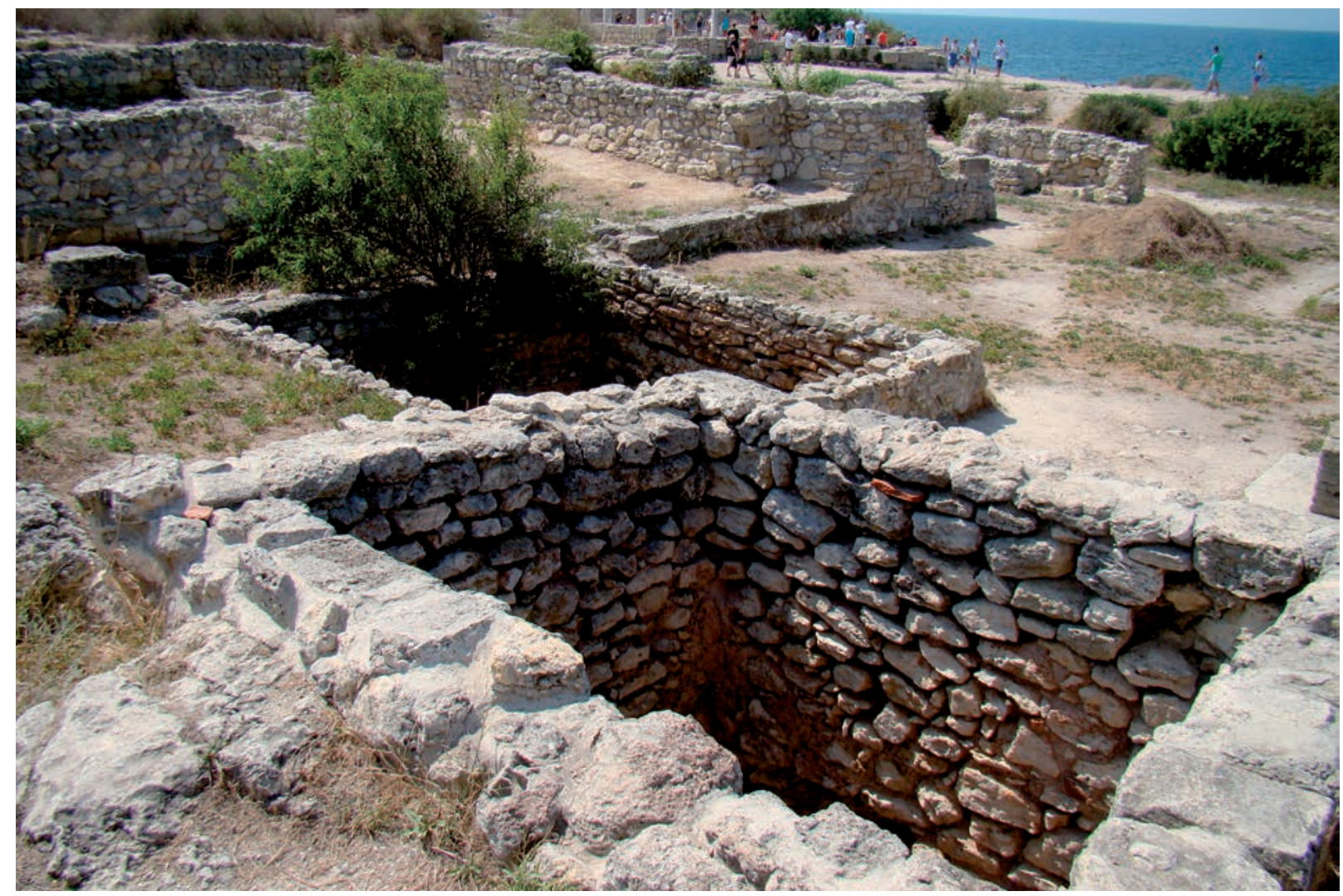

Fig. 3. Vats No. 75 and 76 (photo: Martina Čechová).

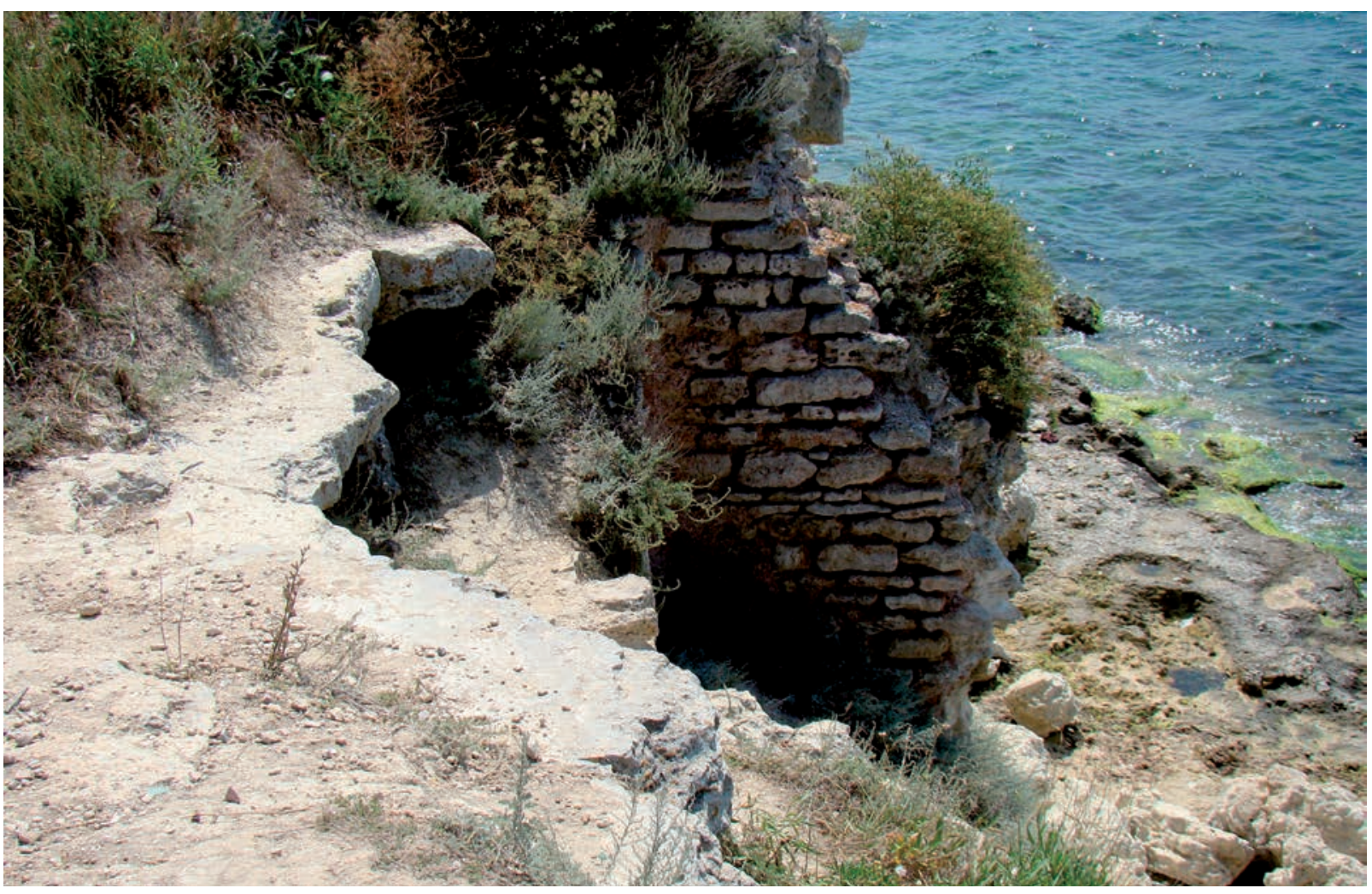

Fig. 4. Vats No. 33 (photo: Martina Čechová). 


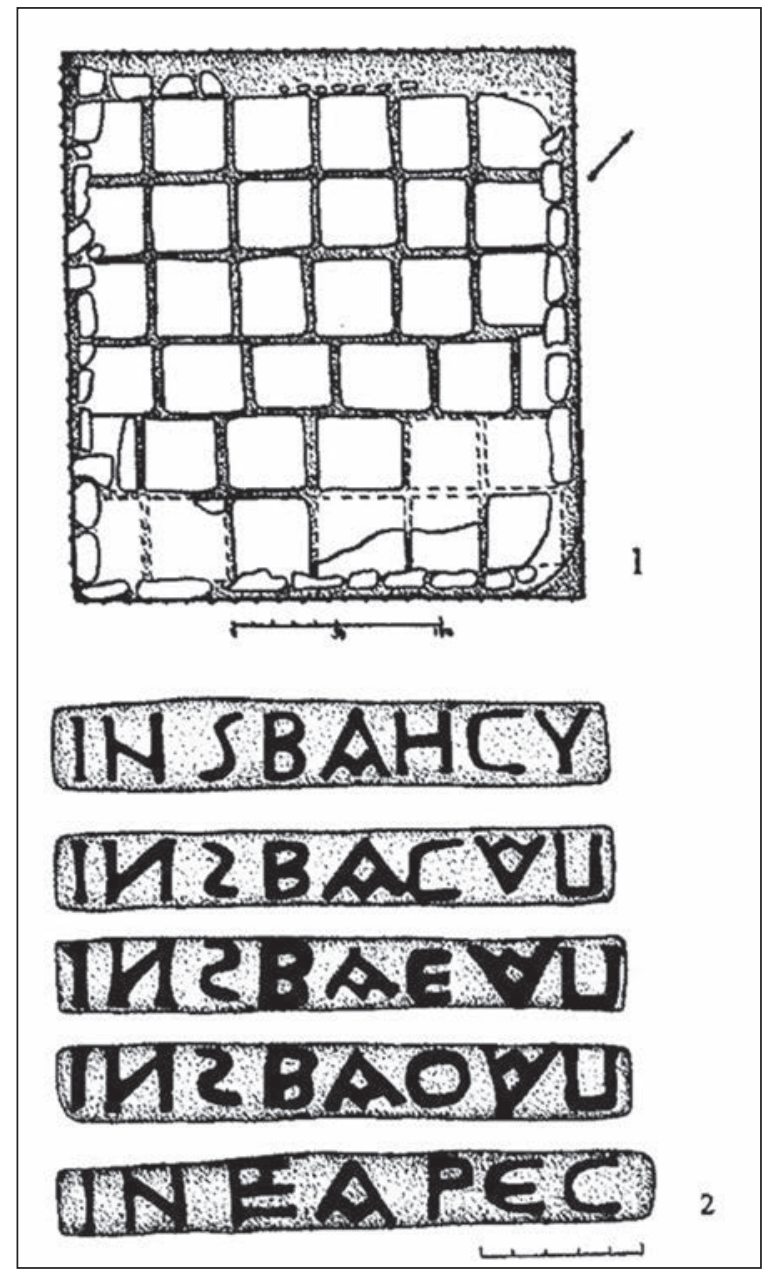

Fig. 5. Bottom of the vat no. 84 and brick stamps (after Romančuk 2005).

further chronological indications; according to the archaeological excavation the vat was built in the 9th or 10th c. and it was probably backfilled in the 11th or in the first half of the 12th c., when the defensive tower no. XIV, which is situated in the immedient vicinity, was being rebuilt. ${ }^{23}$

The archaeological finds confirm that fish processing continued in Cherson in the Middle Ages. The number of the vats that have been found so far indicates that the fish production industry must have been highly developed in Cherson for garum and salted fish and would have been intended not only for local consumption but also for trade. Indeed, it may have been an essential element of Cherson's economy as late as the 10th c. ${ }^{24}$ Estimates of $0.5 \mathrm{~kg}$ of garum per inhibitant per day have

23. Romančuk 1972, p. 46, 52; Id. 1977, p. 20; Id. 2005, p. 109. 24. Soročan 2005, p. 234; Romančuk 2005, p. 110; Vladimirov et al. 2004, p. 552. been suggested (but only one third of the city area has been excavated so far, so it was probably even more.) ${ }^{25}$

\section{Economy and Trade}

According to archaeological finds (mainly amphorae and other pottery), Cherson was a significant trading center in the first half of the 5th c. In following years the city turned into a strategical outpost of the Byzantine empire. The importance of the city for the empire increased from the end of the 5th c., confirmed in the 6th c. by the rebuilding of the city walls by Emperor Justinian. ${ }^{26}$ Building activity was supported by the Byzantine government until the turn of the $7 \mathrm{th} \mathrm{c}$. because Cherson was considered as strategically important. ${ }^{27}$ Cherson was also economically signficant thanks to the stable politicial situation in the Crimea at that time. The city belonged to the Eastern Mediterranean trade system and it represented the main Byzantine port in Crimea, for exportation and as an entrepot for redistribution. ${ }^{28}$ Byzantine support of Cherson was influenced by a need to control not only Cherson but also the Goths, living in the south-western inland of Crimea. Cherson also had contact with nomads, whose goods such as furs, leather or cattle were exported from Cherson to other Byzantine cities. ${ }^{29}$

\section{Transportation}

Liquid commodities such as wine, olive oil or garum were transported in amphorae. However, it is difficult to distinguish which types were used for Black Sea products. Shapes may have been selected according to the quality of the content, ${ }^{30}$ and were certainly defined by practical aspects. For instance dense liquids were transported in amphorae with broad rims; olive oil amphorae generally had a short neck and a globular body; wine amphorae often had a long neck etc. On this basis, amphorae for fish products should have a short conical neck and a broad mouth with a body shape widening towards the lower part with a hollow or full point. Generally, in the Mediterranean the amphorae that answer this description include e. g. types Dressel 7-11

25. Romančuk 2005, p. 109.

26. Procopius. III, 7, 10.

27. Golofast 2007, p. 57.

28. Borodin 1991, p. 173-190; Golofast 2007, p. cit., 57; Romančuk, Sazanov 1991, p. 47. Romančuk 2005, p. 108.

29. Vladimirov et al. 2004, p. 554.

30. Macrobius. 7. 12. 13-16. 
or 20 but also quite a lot of other types, depending on their place of production. ${ }^{31}$ Black Sea amphoras seem to be slightly larger and heavier but the shapes are similar.

The issue of Roman Black Sea fish amphorae was researched by A. Opait. According to him, the main amphora types include Zeest 75, Zeest 75-Similis, Zeest 85-Similis, Zeest 83 and 89, Fish table amphora 54. ${ }^{32}$

The early Byzantine amphora types follow their antic predecessors. They were called kufon or megarikon ${ }^{33}$ and served mainly to transport wine and oil, but unfortunately we have little information about fish amphorae types in the early Middle Ages. However, the fish production industry was obviously an essential element of the Cherson economy at this time, as outlined above through evidence of salting vats, so presumably there were amphorae for these products.

\section{Trade contacts}

According to the amphorae and other pottery finds from Cherson, trade was active from the beginning of the 6 th to the mid-7th centuries, peaking in the last third of the 6th century. ${ }^{34}$ There was trade with Constantinople (where fish was an essential element of the $\operatorname{diet}^{35}$ ), Antiochia, Gaza and Syro-Palestinian area, North Africa, Greece and Asia Minor and, of course, other Crimean and south Pontic settlements. ${ }^{36}$ Trade with the Mediterranean might not have been direct but may have been through Constantinople. ${ }^{37}$ However, finished craft products were imported to Cherson, in particular fine pottery produced in Asia Minor, Cyprus and North Africa. ${ }^{38}$

\section{Salt}

Salt, the indispansable stuff for the fish processing, was also exported for centuries. The salt trade was indicated in letters of Pope Martin, who was exiled to Cherson and died there in AD 655/6. These letters represent a very important source of knowledge about life in Cherson at that time, nonetheless, their reliability must be considered carefully, as they could have been influenced by the painful fate of the exile. ${ }^{39}$ The letters are full of complaints; among other things the Pope complained about the high price of food, mainly grain, which was bought from ships that were then loaded up with salt for export, ${ }^{40}$ supporting the idea of the continuity of the fish trade.

A note on salt mining can be found also in Constantine Porphyrogennetos' De Administrando Imperio, where the emperor (AD 913-959) writes about the area between the river Dnieper and the city of Cherson, that is made up of "marshes and harbours, in which the Chersonites work the salt". ${ }^{41}$ Also the AD 945 treaty between the Byzantine's and the Rus' preserved in the Russian Primary Chronicle says that the Russains were not allowed to do any harm to Cherson's fishermen if they met them in the Dnieper delta. ${ }^{42}$ So, salting fish and salt mining must have been a long-standing traditional and important craft in Cherson.

\section{Conclusion}

In conclusion, fish processing and salt mining were very important components of the economy of Roman and early and middle Byzantine Cherson. These industries continued without interruption from Roman times through to the early Middle Ages; according to various archaeological finds vats were built in the 5th-6th c. and continued until the 10th-11th c. The exportation of garum, salted fish and salt were a source of wealth for Cherson over many centuries and ensured its position as an important trading centre.

31. Ejstrud 2005, p. 171, 175.

32. Opait 2007, p. 101-121.

33. Bakirtzis 2003, p. 70.

34. Sazanov 2007, p. 803-815.

35. Shepard 2009, p. 426.

36. Sazanov 1991, p. 60-72.; Id. 2000, p. 123-149; Id. 2007, p. $803-809$.

37. Golofast 1990, p. 50-54.

38. Romančuk, Sazanov 1991, p. 47.

39. Romančuk 2008, p. 154.

40. Borodin 1991, p. 189.

41. Constantine Porphyrogenitus. 42, 120.

42. Primary Chronicle, year 6453 (945). 


\section{Bibliography}

\author{
Abbreviations \\ ADSV-Antičnaja Drevnost i Srednije Veka \\ BAR-British Archaeological Reports \\ LRCW-Late Roman Coarse Ware \\ MAIET-Materialy po Archeologii, Istorii i Etnografii Tavrii \\ Bakirtzis 2003 : BAKIRTZIS(Ch.) - Vyzantina tsoukalolagina, Athina 2003.
}

Bělov 1963 : BĚLOV (G. D.) - Iz istorii ekonomičeskoj zizni Chersonesa vo II-IV vv. n. e. In : Antičnyj gorod, Moscow, 1963, p. 66-67.

Beševliev 1964 : BEŠEVLIEV (V.) - Spätgriechische und spätlateinische Inschriften aus Bulgarien, Berlin, 1964, p. 103.

Borodin 1991 : BORODIN (O. P.) - Rimskij papa Martin I. i jevo pisma iz Kryma (statja, perevod, kommentarij). In : Karpov (S. P.) (ed.), Pričernomorje $v$ srednije veka, Moscow 1991, p. 173-190.

Bortoli, Kazanski 2002 : BORTOLI (A.), KAZANSKI (M.) - Kherson and its Region. In: Laiou (A. E.) (ed.), The Economic History of Byzantium: From the Seventh through the Fifteenth Century, Dumbarton Oaks Research Library and Collection, Washington, D. C. 2002, p. 659-665.

Crimean Chersonesos 2003 : Crimean Chersonesos, Institute of Classical Archaeology and the National Preserve of Tauric Chersonesos, 2003.

Dark 2001 : DARK (K.) - Byzantine Pottery, 2001.

Ejstrud 2005 : EJSTRUD (B.) - Size Matters: Estimating Trade of Wine, Oil and Fish-sauce from Amphorae in the First Century AD. In : BekkerNielsen (T.) (ed.), Ancient Fishing and Fish Processing in the Black Sea Region, Aarhus University Press, 2005.

Golofast 2007: GOLOFAST (L.) - Early Byzantine deposits from Chersonesos. In : Aibabin (A.), Ivakin (H.) (eds.), Kiev - Cherson Constantinople, 2007, p. 45-75.

Golofast 1990 : GOLOFAST (L. A.) - Amforiski iz raskopok rannevizantijskovo Chersona, ADSV, 27, 1990, p. 50-54.

Hojte 2005: HOJTE (J. M.) - The Archaeological Evidence for Fish Processing in the Black Sea Region. In : Bekker-Nielsen (T.) (ed.), Ancient Fishing and Fish Processing in the Black Sea Region, Aarhus University Press 2005, p. 133-161.

Jakobson 1950 : JAKOBSON (A. L.) - Srednevekovyj Chersones (XII$X I V v v$.), Moskva - Leningrad 1950.

Mylona 2008 : MYLONA (D.) - Fish-Eating in Greece from the Fifth Century B. C. to the Seventh Century A. D., BAR International Series 1754, 2008.

Opait 2007 : OPAIT (A.) - A Weighty Matter: Pontic Fish Amphorae. In : Gabrielsen (V.), Lund (J.) (eds.), The Black Sea in Antiquity. Regional and Interregional Economic Exchange, Aarhus University Press 2007, p. 101-121.
Romančuk 1972 : ROMANČUK (A. I.) - Novyje materialy o vremeni strojitelstva rybozasoločnych vat $\mathrm{v}$ Chersonese, $A D S V, 9,1972$, p. 45- 53.

Romančuk 1973 : ROMANČUK (A. I.) - Kompleks VII v. iz portovovo rajona Chersonesa, $A D S V, 10,1973$, p. 246-249.

Romančuk 1977: ROMANČUK (A. I.) - Plan rybozasoločnych vat Chersonesa, $A D S V$, 14, 1977, p. 18-26.

Romančuk 1997 : ROMANČUK (A. I.) - More kak faktor razvitija ekonomiky i kultury vizantijskovo Chersona, Meždunarodnaja konferencija «Vizantija i Krym» (Sevastopol, 6.-11. Ijunija 1997), p. 70-71.

Romančuk 2005: ROMANČUK (A. I.) - Studien zur Geschichte und Archäologie des Byzantinischen Cherson, Colloquia Pontica, 11, 2005.

Romančuk 2008: ROMANČUK (A. I.) - Issledovanija ChersonesaChersona. Raskopki. Gipotezy. Problemy, Jekatěrinburg 2008.

Romančuk, Sazanov 1991: ROMANČUK (A. I.), SAZANOV (A. V.) - Krasnolakovaja keramika rannevizantijskovo Chersona. Srednevekovyj Cherson: istoria, stratigrafia, nachodki, Sverdlovsk 1991.

Sazanov 1991 : SAZANOV (A. V.) - Amfornyj kompleks pervoj četvěrti VII v. n. e. iz severo-vostočnovo rajona Chersonesa, MAIET, II, 1991, p. 60-72.

Sazanov 2000 : SAZANOV (A. V.) - Les ensembles clos de Chersonèse de la fin du $\mathrm{VI}^{\mathrm{e}}$ au troisième quart du $\mathrm{VII}{ }^{\mathrm{e}}$ siècles: la chronologie de la céramique. In : Kazanski (M.), Soupalt (V.) (eds.), Les Sites Archéologiques en Crimée et au Caucase durant l'Antiquité tardive et le haut Moyen-Age, Leiden-BostonKöln, 2000, p. 123-149.

Sazanov 2007: SAZANOV (A. V.) - Les amphores orientales d'époque protobyzantine au nord de la mer Noire: chronologie et typologie. In: Bonifay (M.), Tréglia (J.-C.) (eds.), $L R C W 2$, BAR International Series 1662 , II, 2007, p. 803-815.

Shepard 2009 : SHEPARD (J.) - Mists and Portals: The Black Sea's North Coast. In: Mango (M.) (ed.), Byzantine Trade, 4th-12th centuries, 2009, p. 421-441.

Soročan 2005 : SOROČAN (S. B.) - Vizantijskij Cherson. Očerki istorii $i$ kultury (vtoraja polovina VI-pervaja polovina 10 vv.), Charkov, 2005.

Talbot-Rice 1930 : TALBOT-RICE (D.) - Byzantine Glazed Pottery, Oxford 1930.

Vladimirov et al. 2004 : VLADIMIROV (A. O.), ŽURAVLOV (D. V.), ZUBAR (V. M.), KRIŽICKIJ (S. D.), RUSJAJEVA (G. S.), RUSJAJEVA (M. V.), SKRŽINSKA (M. V.), SOROČAN (S. B.), CHRAPUNOV (M. I.) - Chersones Tavričeskij v seredině I v. do n.e. - VI v. n. e., Charkov 2004.

Vroom 2005 : VROOM (J.) - Byzantine to Modern Pottery in the Aegean, Biljeveld, 2005. 


\section{Conclusions}

\section{Emmanuel Botte, Victoria Leitch}

$\mathrm{T}$

The papers presented in this volume have made an important contribution to scholarship on the subject, summarized here from three perspectives. First, we look at methodological questions and what we can add to our knowledge of the fish products themselves; next, is an investigation of the workshops and analyses on the development and decline of fish production in the western Mediterranean; and finally evidence from the containers is assessed.

\section{Methodology: the contribution of experimental archaeology and scientific analysis of fish products}

Terminology presents one of the greatest problems when studying fish production in antiquity. There is a tendency to conflate - for lack of a better alternative the simple terms 'salted fish' and 'fish sauce'. As André Tchernia points out, this equates, in today's world, to study cod and nиос mam as homogeneous products, which they certainly are not. To move forward, we must search outside the written sources, which, for over half a century have dominated research on this subject.

There are three principal areas that will help progress studies. The first of these is experimental archeology. S. Grainger ${ }^{1}$ suggests that the ancients did not have an exact knowledge of the products they consumed and that this partly explains our confusion today. Grainger proposes that garum corresponds only to the product manufactured with the guts and blood of the fish, while Liquamen, the most common type, was made from the whole fish. C. Driard then looks at the nature of the goods. He undertook a set of experiments to detect the levels of salt used in the workshops of Gaul Lyonnaise.

1. We could regret that in her contribution, S. Grainger completely ignored the previous bibliography, especially the French one: P. Grimal, Th. Monod, Sur la véritable nature du garum, REA, 54, Fasc. 1-2, 1952, p. 27-38; C. Jardin, Garum et sauces de poisson de l'Antiquité, RStLig., XXVII, 1961, p. 70-96.
The second research area is the scientific analysis of fish remains. In Herculaneum, the discovery of a sewer composed of human and domestic waste enabled E. Rowan to demonstrate different modes of fish consumption in one neighbourhood of this coastal city. Her study illustrates the significant and varied consumption of fish (whole, in pieces, but also boiled, fried or as a sauce), whose species varied according to the seasons. A. Bardot's study is the first systematic investigation of the phenomenon of trade in oysters at a supra-provincial scale. The originality of the study lies in its illustration of different modes of transporting oysters, such as leaving the flesh in its shell, or trading the flesh only, which involved prior preparation using dry salt or cooking brine. T. Theodoropoulou then shows the magnitude of the potential that Greece has to offer in the study of fish consumption and it is hoped that further investigations will help to complete the picture.

The third methodological tool is chemical analysis. Unlike wine or oil in particular, chemical analyses for the identification of fish remains have not yet been sufficient to identify definite markers, but N. Garnier has found that sterols appear to be the best candidate so far. We must therefore further develop research in this direction in order to identify a common protocol.

\section{Production sites}

C. Driard's research, although dedicated to the operation of workshops in Brittany rather than their chronology, uses new and previous investigations to re-interpret their duration and functioning. The archaeology demonstrates that fish production was carried out in the second and third centuries only. Sardines (Sardina pilchardus) seem to be the most common remains found in the basins. However, the sardines were found in the basins after their final use, so we must be cautious about overstating their importance. I. Vaz Pinto, A. P. Magalhães and P. Brum offer a neat summary of the chronology at Tróia as well as its productive capacity, unmatched by any site throughout the Mediterranean. 
Evidence from the 25 visible workshops suggests three phases: the first workshops date to the beginning of the Tiberian period, which parallels the amphora workshops on the other bank of the Sado estuary. There is a break at the end of the second century with the abandonment and destruction of the workshops. In the third to the early fourth century, new, small workshops emerge, and new amphora types. A final expansion occurs in the fourth century, which is marked by the abandonment of the site during the first half of the fifth.

Between the Atlantic Ocean and the Mediterranean Sea, the site of Cadiz is undoubtedly one of the most enlightening, because it gives us an overview of production from Phoenician times to late antiquity. The industry began with small installations that remain little known today, but A. Saez Romero is able to demonstrate that there is a turning point in the scale of the workshops from the late second century BC, and then in the Augustan period more complex production sites were created.

Several papers focus on the southern shores of the Mediterranean. Many of the most important and wealthiest sites in Roman North Africa lay along its coast, sites which were also involved in major maritime trade across the Mediterranean. Oil, wine and grain were the main foodstuffs exported from the African shores, but evidence for a significant trade in fish products is now being recognized, largely on account of new scientific analyses. Four papers at the Fish and Ships workshop looked at evidence from North Africa, from regions that have not generally received much attention in the literature, particularly in connection with fish production and trade. The regions are Tipasa in Algeria, the lesser Syrtes (Gulf of Gabes), southern Tunisia, Cyrenaica in Libya and sites in the Libyan Sahara.

Fish production at Tipasa in Algeria has been known for decades, but T. Amraoui's new contribution draws attention to the evidence, giving it a chronological framework. There are circular and rectangular vats, but it is not known whether these different shapes represent a technological or chronological difference. It seems that fish production began in the 3rd century, probably winding down in the mid 4th and perhaps continuing into the 6th century. There is also a house, the Maison des Fresques, with dolia, in a late context, which could have been used for making fish sauce, as was known also in Pompeii. Looking at the size of the sites and the lack of amphora production, T. Amraoui deduces that fish production was probably for local consumption only, stored in barrels and re-used amphorae, though exportation cannot yet be ruled out.
The Gulf of Gabes, a bridge between Byzacena and Tripolitania, is clearly a productive region, but it requires more excavation and systematic survey, though the Franco-Tunisian coastline survey did highlight that fish production was very much part of its economic landscape. New research directed by A. Drine and E. Jerray has been trying to link amphora production with fish processing sites, to provide much needed information on the scale and market for fish products in the area. There is evidence for vats, probably for fish, and at least four ceramic kilns. The chronological information from the Gulf of Gabes is not very precise, but suggests activity in the late 1 st to 4th century, not only for fish production, but also for wine and oil.

Further east, the coastal region of Cyrenaica in Libya has recently been surveyed by M. Hesein. He pinpointed six sites with potential fish production facilities. The cape of Phycus seems the most likely, where there is evidence for industrial activity including remains of rectangular tanks. At Phycus itself, Aptouchou and Kainopolis there are rock-cut vats, however the shapes are more suggestive of storage for other products like wine, grain or water. Excavation and scientific analyses of the vat contents is needed to confirm the status and scale of fish production in this area. At the moment, the evidence suggests activity in the Roman period, but we lack a precise chronology and therefore how it fits in with other regions of North Africa and its trading partners. For instance, was fish production carried out differently in this area, using different types and shapes of vats, or was fish production fairly insignificant from a trading point of view, which would explain the lack of confirmed fish factories?

Finally, far from the Mediterranean, M. Čechová's paper on the site of Chersonesos in the Black Sea confirms that fish production was a major industry between Antiquity and the Middle Ages, which has important implications for the economy of the region.

\section{Containers}

Research on the types of container used for fish products is far from complete. A number of different methods of transportation and commercialization have been discussed in this volume, but more work needs to be done analyzing the contents of potential fish product containers and creating more secure typologies for the amphorae used to transport them. 
In North Africa there are many fish production sites, but conversely, few with associated amphora production sites. In some cases it is possible that fish production was for local consumption only, so amphorae may not have been needed. In other cases, for instance at Tipasa, this may simply be due to a lack of excavation, particularly in extra-mural areas where you would expect amphora production to be located.

In the Gulf of Gabes, the amphorae are principally Tripolitanian I and III and Dressel 2/4, which are generally associated with oil and wine. Survey around one site, Henchir Mdeina, found sherds of Africana IIA and Tripolitanian II, though no associated kiln site. In effect, the question of amphora types associated with fish production remains unanswered but there is great potential in future for scientific analyses to shed light on this question.

The question of production in Cyrenaica is still too little studied to draw any meaningful conclusions - for both fish production and its containers. The scale and chronology for fish production along the Cyrenaican coast thus remains uncertain and so far we cannot say if the local production was limited to local trade and/or for export.

Fish trade in the Libyan Sahara is discussed by V. Leitch, who finds that the evidence for fish products in the desert was rather thin. This could be for three reasons. First, that there was not much demand for it, secondly that it was too expensive to transport and thirdly that fish production along the Libyan coast may not have been on a large-scale, so it was rarely exported. Looking at scientific analyses of the Tripolitanian II amphora, heralded as a container for fish products, it seems, on closer investigation, that this is rather speculative and there is in fact very little evidence to support this designation, and instead this amphora type was probably for wine. Fish production is attested at Sabratha, but until further excavations and analyses have been undertaken, the size and importance of fish production all along the Libyan coast remains unknown.

Outside Africa, D. Djaoui, G. Piquès and E. Botte demonstrate that we must not simply focus on amphorae and that small ceramic containers could equally have been used for fish products, as occurred in central Italy. C. Nervi illustrates how many gaps there are in our knowledge of the Sardinian fishing industry - one of the largest islands in the Mediterranean. Her research so far points to the importation of fish products, but little is known about production on the island.

\section{Where we are now}

This volume hopes to have brought significant new insights into scholarship on fish production and trade, mainly during the Roman period. Nevertheless André Tchernia writes "La repartition de ces différents produits dans les différents types d'amphores, la typologie des installations selon l'objet de leur production ne sont pas des questions résolues". Further, some regions (such as Algeria, Libya, Greece and Sardinia) lack systematic research - excavation and survey - meaning that a broad overview of the state of the question is not yet possible. What these papers have achieved is to open up new and important questions, and to demonstrate how much variation there was in the productive landscape from east to west along the Mediterranean coast - probably due to a combination of fishing conditions, political evolutions and their impact on trading networks. 
Achevé d'imprimer en août 2014 par

l'imprimerie Sepec

à Peronnas

Dépôt légal : octobre 2014 